\title{
Literatura „ziemi obiecanej” Twórczość niemieckojęzycznych łodzian w XIX i na początku XX wieku
}


畒 


\author{
Monika Kucner
}

\title{
Literatura „ziemi obiecanej” Twórczość niemieckojęzycznych łodzian w XIX i na początku XX wieku
}

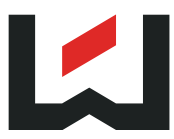

WYDAWNICTWO 
Monika Kucner - Uniwersytet Łódzki, Wydział Filologiczny, Katedra Literatury i Kultury Niemiec, Austrii i Szwajcarii, 90-114 Łódź, ul. Sienkiewicza 21

\author{
RECENZENT \\ Magdalena Sitarz \\ REDAKTOR WYDAWNICTWA UŁ \\ Iwona Gos \\ SKŁAD KOMPUTEROWY \\ Oficyna Wydawnicza Edytor.org \\ PROJEKT OKŁADKI \\ Witold Warzywoda
}

Publikacja została przygotowana do druku w ramach projektu przyznanego przez Polsko-Niemiecką Fundację na rzecz Nauki (PNFN). Nr projektu: 2011-19

(C) Copyright by Uniwersytet Łódzki, Łódź 2014

Wydane przez Wydawnictwo Uniwersytetu Łódzkiego

Wydanie I. W.06517.14.0.M

ISBN (wersja drukowana) 978-83-7969-098-5

ISBN (ebook) 978-83-7969-339-5 
Gabrysi i Radkowi 



\section{SPIS TREŚCI}

$\begin{array}{ll}\text { Wstęp } \quad 9 & 9\end{array}$

1. Kultura i oświata Łodzi $\quad 17$

1.1. Publiczność literacka $\quad 17$

$\begin{array}{ll}\text { 1.2. Organizacje i stowarzyszenia kulturalne } & 26\end{array}$

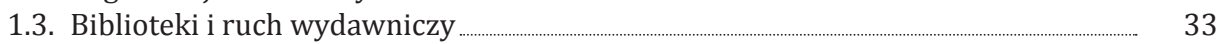

$\begin{array}{ll}\text { 1.4. Życie literackie Łodzi } & 38\end{array}$

1.5. Kościół jako ośrodek życia religijnego i kulturalnego $\quad 49$

$\begin{array}{ll}\text { 1.6. Teatr } & 51\end{array}$

1.7. Szkoła i działalność kół literackich dla młodzieży _... 53

2. Łódzka prasa i jej związki z literaturą $\quad 59$

2.1. Niemieckojęzyczna prasa Łodzi - uwagi ogólne $\quad 59$

$\begin{array}{ll}\text { 2.2. Etapy rozwoju prasy niemieckiej } & 65\end{array}$

2.3. Literatura na łamach prasy _... $\quad 85$

3. Literatura 93

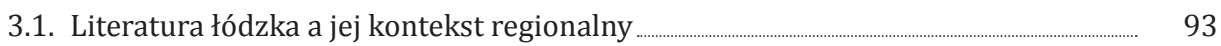

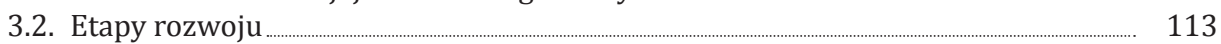

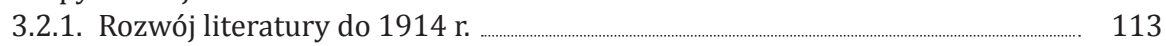

$\begin{array}{ll}\text { 3.2.2. Okres I wojny światowej ———. } & 121\end{array}$

3.2.3. Okres Drugiej Rzeczypospolitej _ـ_ 124

4. Łódź w latach Wielkiej Wojny — $\quad 127$

$\begin{array}{ll}\text { 4.1. Liryka antywojenna } & 127\end{array}$

$\begin{array}{lr}\text { 4.2. Literatura } w \text { kręgu propagandy } & 139\end{array}$

$\begin{array}{ll}\text { 4.3. Raport z wojennych miast } & 153\end{array}$

4.4. Łódź oczami niemieckiego okupanta _. 163

5. Inne przestrzenie łódzkiej poezji $\quad 169$

5.1. Zaangażowanie polityczne łódzkiej poezji — $\quad 169$

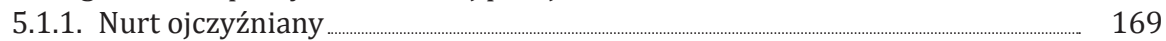

5.1.2. „Prosimy o dowody!” Wiersze zaangażowane Carla Heinricha Schultza _. . 179

5.2. W poszukiwaniu miłości i szczęścia $\quad 192$

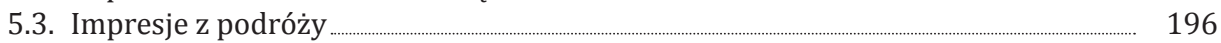

5.4. Okazją są jubileusze $\quad \ldots 199$

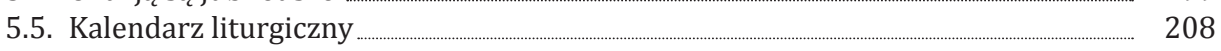

\begin{tabular}{ll} 
6. Lodzermensch i jego wizerunki literackie $\quad 215$ \\
\hline$\square \square$
\end{tabular}

6.1. Mit Lodzermenscha _ـ 215

6.2. Typy łódzkie według Berty Teplitzkiej i Heinricha Zimmermanna _.._ _ 220 
6.3. Lodzermensch w dowcipach Reinholda Piela $\quad 225$

6.4. Lodzermensch - zmiana paradygmatu? ——.. 232

7. Łódź - problematyka społeczna $\quad 245$

7.1. Łódź - miasto kontrastów . _ $\quad 245$

7.2. Łódź sentymentalna w twórczości Carla Heinricha Schultza _ـ_ 253

Zakończenie _ 269

Aneks _ $\quad 273$

Łódzkie sylwetki____.. 273

Fotografie __ 305

Bibliografia $\quad 315$

Indeks nazwisk $\quad 325$ 


\section{WSTĘP}

Korzystne warunki polityczno-gospodarcze na początku XIX w. przyciągnęły do Łodzi wielu osadników z krajów niemieckich, jak również w późniejszym okresie ludność polską i żydowską. W zaskakująco szybkim tempie rozwinęła się z małej, niewiele znaczącej miejscowości w wielkoprzemysłową metropolię, wokół której powstało wiele mitów, jak: „ziemia obiecana”, „Manchester Wschodu”, „złe miasto” czy „miasto Lodzermenschów”"1.

Łódź fascynowała swoją krótką, aczkolwiek intrygującą historią już od początku rozwoju przemysłowego. Pierwsze opracowania na temat jej dziejów powstały w połowie XIX w. W 1853 r. Oskar Flatt, miłośnik Łodzi fabrycznej, opublikował monografię, w której zawarł historyczny opis miasta, wzbogacając go o dane statystyczne oraz informacje gospodarcze ${ }^{2}$, natomiast w 1857 r. Wiktor Dłużniewski, nauczyciel i poeta, wydał wierszowaną gawędę pt. Paweł Łodzia Kubowicz ${ }^{3}$, nawiązującą do starych legend rolniczej Łodzi. Jednak dopiero po 1945 r. zaczęto prowadzić systematyczne i szeroko zakrojone badania poświęcone temu miastu ${ }^{4}$. Jedną z pierwszych powojennych prac jest publikacja Adama Ginsberta Łódź. Studium monograficzne ${ }^{5}$. Po niej pojawiły się kolejne, jak chociażby praca zbiorowa pod redakcją Edwarda Rosseta Łódź w latach 1945-19606, Gryzeldy Missalowej Studia nad powstaniem

1 Problematyką mitów Łodzi i ich obrazem w regionalnej literaturze zajmuje się najnowsza praca J. Fiszbak, Mity „ziemi obiecanej” w regionalnej literaturze Łodzi. Między grą wyobraźni, fikcją literacką a historiq, Łódź 2013.

2 O. Flatt, Opis miasta Łodzi pod względem historycznym, statystycznym i przemysłowym, Warszawa 1853.

${ }^{3}$ W. Dłużniewski, Paweł Łodzia Kubowicz, Łódź 1857.

${ }^{4} \mathrm{~W}$ okresie międzywojennym badania prowadzone były w ramach różnych towarzystw naukowych, jak np. Towarzystwa Przyjaciół Nauk czy Polskiego Towarzystwa Historycznego. Pierwsi badacze publikowali swoje wyniki na łamach m.in. „Roczników Oddziału Łódzkiego Polskiego Towarzystwa Historycznego” i „Roczników Łódzkich” wydawanych przez Archiwum Akt Dawnych miasta Łodzi (dalej: AADmŁ). Dość często publikacje na temat Łodzi i regionu ukazywały się na łamach lokalnych gazet codziennych. Por. Łódź - monografia miasta, red. S. Liszewski, Łódź 2009, s. 9-13.

${ }^{5}$ A. Ginsbert, Łódź. Studium monograficzne, Łódź 1962.

${ }^{6}$ Łódź w latach 1945-1960, red. E. Rosset, Łódź 1962. 
łódzkiego okręgu przemysłowego 1815-18707, Marka Kotera Geneza układu przestrzennego Łodzi przemysłowej ${ }^{8}$ oraz Anny Rynkowskiej Ulica Piotrkow$s k a^{9}$. Dalsze lata przyniosły również wiele publikacji z zakresu szeroko rozumianych dziejów miasta. Należą tu m.in.: Dzieje miasta Łodzi pod redakcją Ryszarda Rosina ${ }^{10}$, praca zbiorowa pod redakcją Haliny Mortimer-Szymczak Województwo miejskie łódzkie. Monografia. Zarys dziejów, obraz współczesny, perspektywy rozwoju ${ }^{11}$ oraz szereg publikacji Wiesława Pusia, w tym Dzieje Łodzi przemysłowej ${ }^{12}$, Rozwój przemysłu w Królestwie Polskim ${ }^{13}$, Żydzi w Łodzi w latach zaborów 1793-1914 ${ }^{14}$. Zainteresowanie historią miasta nie słabnie również obecnie. Świadczą o tym chociażby niezwykle cenne monografie, które ukazały się pod redakcją Wiesława Pusia, Marka Kotera, Mariusza Kuleszy i Stefana Pytlasa Wpływ wielonarodowego dziedzictwa kulturowego Łodzi na współczesne oblicze miasta ${ }^{15}$ oraz Stanisława Liszewskiego Łódź - monografia miasta ${ }^{16}$. Wśród wymienionych publikacji czytelnik znajdzie wiele informacji na temat kształtowania się tkanki miejskiej, rozwoju demograficznego ludności, struktury gospodarczej, warunków życia łodzian, życia społecznego oraz kulturalnego. Brak jest natomiast, i to dotyczy sporej części piśmiennictwa na temat historii miasta, odniesień do literatury niemieckojęzycznych łodzian ${ }^{17}$.

${ }^{7}$ G. Missalowa, Studia nad powstaniem łódzkiego okręgu przemysłowego 1815-1870, Łódź 1964.

${ }^{8}$ M. Koter, Geneza układu przestrzennego Łodzi przemysłowej, „Prace Geograficzne” 79/1969.

9 A. Rynkowska, Ulica Piotrkowska, Łódź 1970.

10 Łódź. Dzieje miasta, red. R. Rosin, t. 1: Do 1918 roku, red. B. Baranowski, J. Fijałek, Warszawa-Łódź 1980.

11 Województwo miejskie łódzkie. Monografia. Zarys dziejów, obraz współczesny, perspektywy rozwoju, red. H. Mortimer-Szymczak, Łódź 1981.

12 W. Puś, Dzieje Łodzi przemysłowej, Łódź 1987.

13 W. Puś, Rozwój przemysłu w Królestwie Polskim, Łódź 1997.

${ }^{14}$ W. Puś, Żydzi w Łodzi w latach zaborów 1793-1914, Łódź 1998.

15 W. Puś, M. Koter, M. Kulesza, S. Pytlas, Wpływ wielonarodowego dziedzictwa kulturowego Łodzi na współczesne oblicze miasta, Łódź 2005.

${ }^{16}$ Por. Łódź - monografia...

17 Badania na temat polskojęzycznej literatury oraz środowiska literackiego obejmują wiele publikacji i wykazują stan o wiele bardziej zaawansowany niż badania nad niemieckojęzyczną twórczością literacką. Jednymi z pionierskich opracowań naukowych na temat literatury dawnej Łodzi są publikacje Ludwika Stolarzewicza. Pierwsza z nich to Literatura Łodzi w ciagu jej istnienia: Szkic literacki i antologja, Łódź 1935, w której autor stara się opisać stan literatury w Łodzi od początków tworzenia się miasta przemysłowego do czasów jemu współczesnych. W kolejnej publikacji pt. Antologia 120 poetów. Wiersze na obchody i uroczystości, Łódź 1938, autor przedstawia twórczość pisarzy związanych z Łodzią. W pewnym sensie nawiązaniem do antologii Stolarzewicza może być publikacja Ziemowita Skibińskiego oraz Barbary Stelmaszczyk-Świontek, Kwiaty łódzkie. Antologia poezji o Łodzi z 1982 r., która w dużej mierze prezentuje dorobek pisarski łodzian. W latach 70. zainteresowaniem badaczy cieszy się pierwsza powieść Walerii Marrené-Morzkowskiej o mieście fabrycznym, o której pisze 
Pierwsze opracowania na ten temat pojawiły się w okresie międzywojennym w dorobku niemieckich badaczy Łodzi, tzw. Siedlungsforscher, do których należał m.in. Albert Breyer ${ }^{18}$. W 1931 r. autor ten w artykule zatytułowanym Neuerscheinungen im Deutschen Schrifttum Mittelpolens (1925-1930) [Nowości wydawnicze piśmiennictwa niemieckiego w Polsce środkowej (1925-1930)], który ukazał się w czasopiśmie „Deutsche Blätter in Polen”19, w dużej mierze nawiązywał do tzw. Heimatliteratur - literatury ojczyźnianej, gloryfikującej cnoty mieszkańców małej ojczyzny, której towarzyszyła ksenofobia i niechęć do innych krajów. Ten rodzaj literatury był bardzo popularny w okresie międzywojennym wśród ludności niemieckiej w Polsce. Miał on głównie na celu pobudzać związek Niemców, którzy pozostali w wyniku postanowień traktatowych po I wojnie światowej na terenach Polski, z macierzą. Literatura pełniła również rolę konsolidacyjną niemieckiego środowiska ${ }^{20}$. Oprócz artykułu Breyera z pewnością na uwagę zasługuje dość obszerna publikacja Karla Kurta Kleina pt. Literaturgeschichte des Deutschtums im Ausland [Historia literatury Niemców z zagranicy] ${ }^{21}$, w której autor w jednym

m.in. Helena Karwacka. Ta sama badaczka analizuje również twórczość Artura Glisczyńskiego, jako piewcy tego fabrycznego miasta. W kręgu zainteresowań znajduje się także twórczość Juliana Tuwima, która stała się przyczynkiem do napisania szkicu bibliograficzno-literackiego pt. Tuwimiana łódzkie, autorstwa W.A. Kempy. Również łódzka twórczość Wiktora Dłużniewskiego, nauczyciela i literata, była przedmiotem analiz naukowych m.in. Romana Kaczmarka, Wiktor Dłużniewski pierwszy piewca Łodzi, oraz kilku artykułów Anieli Kowalskiej, m.in. Debiut warszawski i debiut łódzki Wiktora Dłużniewskiego; Nieznany łódzki utwór o „ziemi obiecanej”; Wiktor Dłużniewski, autor „Wyprawy do Ameryki”. W latach 90. XX w. do zagadnień poezji łódzkiej wraca w swoich Opowieściach o dawnych poetach Łodzi Tadeusz Gicger. Polskojęzyczną literaturę Łodzi analizuje również w swych publikacjach Tadeusz Błażejewski. W roku 1989 pojawia się jego książka pt. Współczesna Łódź literacka. Słownik autorów. W 2005 r. publikuje on w tomie Wizerunek Łodzi w literaturze, kulturze i historii Niemiec i Austrii artykuł pt. Z dziejów Łodzi literackiej, w którym dokonuje krótkiej analizy polskojęzycznej literatury Łodzi przed i po II wojnie światowej. Istotną publikacją jest również praca pt. Łódź, która przeminęła w publicystyce i prozie (antologia), która ukazał się w Łodzi w 2008 r. pod redakcją Piotra Boczkowskiego. Książka jest zbiorem dawno zapomnianych utworów literackich o Łodzi, w tym m.in. Stanisława Łąpińskiego - Tkacz, Władysława Rowińskiego - Julka, Władysława Kosiakiewicza - Bawełna czy Artura Glisczyńskiego - Mańka. Najnowszym opracowaniem na temat łódzkiej literatury jest praca Jolanty Fiszbak, Mity „ziemi obiecanej” w regionalnej literaturze Łodzi. Między gra wyobraźni, fikcja literacka a historiq z 2013 r., w której autorka podejmuje dyskusję z utartymi wyobrażeniami o mieście.

18 Zob. aneks: Łódzkie sylwetki.

19 „Deutsche Blätter in Polen” - miesięcznik wydawany w Poznaniu od 1924 r. W latach 1924-1925 kierowany przez Hermanna Rauschninga, w 1926 r. przez tegoż samego oraz Viktora Kaudera i Martina Kage, natomiast w okresie 1927-1931 przez Paula Zöcklera. Na łamach tego czasopisma drukowano artykuły dotyczące historii niemieckiego osadnictwa, kultury i literatury Niemców w Polsce.

${ }^{20}$ Na temat Heimatliteratur zob. rozdział 5: Inne przestrzenie łódzkiej poezji.

${ }^{21}$ K.K. Klein, Literaturgeschichte des Deutschtums im Ausland. Schrifttum und Geistesleben der deutschen Volksgruppen im Ausland vom Mittelalter bis zur Gegenwart, Leipzig 1939, wyd. 2, 1977. 
z rozdziałów dokonuje pobieżnej charakterystyki twórczości literackiej Niemców z środkowej Polski, starając się przedstawić dorobek trzech pisarzy łóodzich: Sigismunda Banka, Juliana Willa oraz Philippa Kreutza ${ }^{22}$, związanych z nurtem Heimatliteratur.

Stan badań nad literaturą niemieckojęzyczną Łodzi i regionu zamyka się więc do 1939 r. w dwóch pracach o charakterze przyczynkowym, bez ambicji do syntetycznego opracowania. Są to prace niemieckich autorów. Po stronie polskiej natomiast brak jest recepcji naukowej tej literatury. Rok 1945 nie zmienia w sposób znaczący tego stanu rzeczy, tzn. publikacje, które powstały po tym czasie, nie wypełniają tej ważnej luki badawczej. O literaturze Niemców łódzkich piszą niemieccy historycy, głównie o hobbistycznym podejściu do zagadnienia, jak Otto Heike. W dwóch publikacjach - Das Deutschtum in Polen. 1918-1939 [Niemcy w Polsce 1918-1939]23 oraz Die deutsche Minderheit in Polen bis 1939 [Mniejszość niemiecka w Polsce do 1939] ${ }^{24}$ - autor nawiązuje, jedynie na marginesie swoich rozważań na temat historii miasta, do osiągnięć literackich tej grupy społecznej. Dużą słabością obydwu opracowań jest brak pogłębionych analiz literaturoznawczych, jak również duży wpływ wspomnianej już publikacji Kleina z 1939 r. Heike stara się powielać tezy stawiane przez tego autora, z których niesłusznie mogłoby wynikać, iż literatura łódzka zamyka się właśnie w kręgu Heimatliteratur ${ }^{25}$.

Również niewiele nowego do badań wnosi artykuł Renate Gerlach-Damaschke pt. Dichtung im Kontext der Geschichte. Zur Literatur der Deutschen in und aus Polen [Poezja w kontekście historycznym. 0 literaturze Niemców w Polsce i z Polski], który ukazał się w tomie Beiträge zur deutsch-polnischen Nachbarschaft. Festschrift für Richard Breyer [Artykuły na temat polsko-niemieckiego sąsiedztwa. Księga jubileuszowa poświęcona Richardowi Brayerowi] z 1992 r. $^{26}$ Autorka, podobnie jak jej poprzednicy Klein oraz Heike, redukuje twórczość literacką Niemców łódzkich do pisarzy wcześniej wymienianych: Juliana Willa oraz Sigismunda Banka. Podaje przykłady ich twórczości, nie dokonuje natomiast żadnych pogłębionych analiz czy interpretacji.

Z historycznego punktu widzenia cenny jest artykuł Wolfganga Kesslera dotyczący recepcji szeroko rozumianej literatury Niemców na obczyźnie

${ }^{22}$ Więcej na temat życia i twórczości tych pisarzy zob. aneks: Łódzkie sylwetki.

23 O. Heike, Das Deutschtum in Polen. 1918-1939, Bonn 1955.

${ }_{24}$ O. Heike, Die deutsche Minderheit in Polen bis 1939. Ihr Leben und Wirken kulturell, gesellschaftlich, politisch, Leverkusen 1985.

${ }^{25}$ Heike w swoim opracowaniu nieznacznie rozszerza krąg łódzkich pisarzy, wzbogacając go o kolejne nazwiska. Poza Bankeim, Willem oraz Kreutzem wymienia twórczość Edith Gellert, Augusta Utty, pastora Friedricha Metznera oraz Augusta Hermanna Müllera.

${ }^{26}$ R. Gerlach-Damaschke, Dichtung im Kontext der Geschichte. Zur Literatur der Deutschen in und aus Polen, [w:] Beiträge zur deutsch-polnischen Nachbarschaft, hrsg. v. C.J. Kenez, H. Neubach, J. Rogall, Berlin-Bonn 1992, s. 34-40. 
(Auslanddeutsche). Autor dokonuje w nim przeglądu najważniejszych stanowisk niemieckich badaczy literaturoznawców na temat tej twórczości ${ }^{27}$. Na tych kilku opracowaniach kończy się jednak naukowa recepcja omawianej literatury po stronie niemieckiej.

Zainteresowanie polskich badaczy literaturą Niemców łódzkich pojawiło się dość późno. Przez cały okres PRL-u nie pisano o dokonaniach literackich tej grupy społecznej. Dopiero w 2001 r. ukazał się artykuł Barbary Rateckiej Niemiecki pegaz $w$ Łodzi. Szkic o twórczości literackiej Niemców łódzkich ${ }^{28}$, w którym autorka zajmuje się szerzej tym zagadnieniem. Po nim nastąpiło kolejne omówienie tej samej badaczki pt. Obraz Łodzi w literaturze Niemców łódzkich ${ }^{29}$. Obydwa artykuły uzupełnia antologia niemieckojęzycznych tekstów o Łodzi pt. Lodz in der deutschsprachigen Literatur [Łódź w niemieckojęzycznej literaturze $]^{30}$. Polskojęzyczne prace wprawdzie rozszerzają stan wiedzy na temat twórczości literackiej, chociażby wprowadzając nowe nazwiska pisarzy, jak np. pastora Rudolfa Gundlacha czy Bruno Raymonda, to należy, jak podkreśla autorka artykułów, potraktować je jako przyczynek, wymagający szerzej zakrojonych badań w tym zakresie ${ }^{31}$. Na konieczność zbadania tejże literatury oraz odpowiedzenia na wiele nurtujących pytań, w szczególności w perspektywie porównawczej, wskazała również Joanna Jabłkowska, pisząc m.in.:

Es lohnt sich, die fiktionale Prosa zu analysieren, die keinen direkten autobiographischen und persönlichen Hintergrund hat, sondern - stilistisch zwar oft noch sehr einfach - ein Zeichennetz bildet, das sich eindeutig auf die Stadt Lodz beziehen lässt. Es ist zu fragen, ob sich in der polnischen und der deutschen literarischen Sprache ähnliche Symbole, Metaphern und eine ähnliche Ikonographie entwickelten ${ }^{32}$.

${ }^{27}$ W. Kessler, Doppelte Ausgrenzung. Zu Geschichte und Konzeption der „Auslanddeutschen Literatur", [w:] Literatur, Grenzen, Erinnerungsräume: Erkundungen des deutsch-polnisch-baltischen Ostseeraums als einer Literaturlandschaft, hrsg. v. B. Neumann, A. Talarczyk, D. Albrecht, Würzburg 2004.

${ }^{28}$ B. Ratecka, Niemiecki pegaz $w$ Łodzi. Szkic o twórczości literackiej Niemców łódzkich, [w:] Niemcy w dziejach Łodzi do 1945 roku, red. K.A. Kuczyński, B. Ratecka, Łódź 2001, s. 235-257.

${ }^{29}$ B. Ratecka, Obraz Łodzi w literaturze Niemców łódzkich, [w:] Wizerunek Łodzi w literaturze, kulturze i historii Niemiec i Austrii, materiały z konferencji, Łódź 2005.

${ }^{30}$ Lodz in der deutschsprachigen Literatur, hrsg. v. K.A. Kuczyński, E. Mehnert, B. Ratecka, Łódź 2005.

31 Por. B. Ratecka, Obraz...

32 J. Jabłkowska, „Das gelobte Land“ oder das Elend des Frühkapitalismus? „Heimatliteratur" aus und über Lodz, [w:] Lodz jenseits von Fabriken, Wildwest und Provinz. Kulturwissenschaftliche Studien über die Deutschen in und aus den polnischen Gebieten, hrsg. v. S. Dyroff, K. Radziszewska, I. Röskau-Rydel, München 2009, s. 62 [Warto analizować prozę fikcjonalną, która nie jest ani tekstem autobiograficznym, ani osobistym wspomnieniem, lecz - wprawdzie stylistycznie bardzo prosta - tworzy konglomerat cech, które jednoznacznie wskazują na Łódź. Warto zastanowić się, czy w języku polskim i niemieckim rozwinęła się podobna symbolika, metaforyka oraz wspólna ikonografia. Tłumaczenie Monika Kucner, dalej: M.K.]. 
Jak wynika z tych kilku przywołanych przeze mnie prac, badania nad literaturą Niemców łódzkich były prowadzone dość sporadycznie, brak wśród nich syntetycznych opracowań, dogłębnych analiz i interpretacji. Literatura była zawężana do nurtu Heimatdichtung, co daje oczywiście jej dość uproszczony obraz. W dotychczasowych pracach starano się przedstawić głównie twórczość Niemców łódzkich, a więc osób niemieckiego pochodzenia, którzy tworzyli w języku niemieckim. Nie uwzględniano natomiast faktu, iż społeczność ta po zasymilowaniu z polskością tworzyła także w języku polskim. Rzadko uwzględniano również twórczość autorów żydowskich, piszących po niemiecku, którzy poprzez ten język identyfikowali się z kulturą niemiecką. Dlatego niniejsza publikacja ma na celu przedstawienie, jak wskazuje jej podtytuł, „literatury niemieckojęzycznych łodzian”, a więc nie tylko Niemców łódzkich tworzących po niemiecku, lecz także po polsku. Uwzględnia ponadto autorów żydowskiego pochodzenia, którzy tworzyli w języku niemieckim. Dla potrzeb tej pracy będę stosowała określenie „literatura niemieckojęzycznych łodzian” wymiennie z pojęciem „literatura łódzka”.

We wstępie warto jeszcze raz podkreślić, że mamy do czynienia z materiałem nieeksplorowanym. Na przestrzeni wielu lat moich badań dotarłam do tekstów, które nigdy nie były cytowane oraz publikowane. Większość z nich zdobyłam dzięki kwerendzie archiwalnej i bibliotecznej, uzupełnionej o poszukiwania w prywatnych zbiorach, antykwariatach, na aukcjach internetowych czy nawet „pchlich targach”. Wiele tekstów odnalazłam w Bibliotece Uniwersytetu Łódzkiego, Wojewódzkiej i Miejskiej Bibliotece Publicznej im. Marszałka Józefa Piłsudskiego w Łodzi, Bibliotece Narodowej w Warszawie, Bibliotece Uniwersytetu Warszawskiego, Niemieckim Instytucie Historycznym w Warszawie, Bibliotece Raczyńskich w Poznaniu, Bibliotece Uniwersytetu im. Adama Mickiewicza w Poznaniu, Archiwum Państwowym w Łodzi, Archiwum Państwowym w Poznaniu, w Bibliotece Uniwersytetu Gdańskiego, Politisches Archiv des Auswärtigen Amtes w Berlinie, Deutsche Nationalbibliothek w Lipsku, Auslandsinstitut w Stuttgarcie, a także w Bibliotece Martina-Opitza w Herne, która w swoich zasobach posiada liczne zbiory z zakresu historii i kultury Niemców łódzkich.

W poszukiwaniach nieocenionym źródłem literatury była dla mnie łódzka prasa. Utwory literackie odnalazłam na łamach takich gazetach, jak: „Łodźer Anzeiger/Łódzkie Ogłoszenia”, „Lodzer Zeitung”, „Lodzer Tageblatt”, „Neue Lodzer Zeitung”, „Lodzer Volkszeitung”, „Deutsche Post” oraz „Freie Presse”. Oprócz wspomnianych gazet, cennym źródłem były również dodatki beletrystyczne, jak: „Illustrierte Sonntagsbeilage. Neue Lodzer Zeitung”, „Illustrierte Sonntagsbeilage zur Neuen Lodzer Zeitung”, „Illustriertes Sonntagsblatt. Beilage zur Neuen Lodzer Zeitung", ,Illustriertes Wochenblatt. Beilage zur Neuen Lodzer Zeitung”, „Die Welt im Bilde” oraz kalendarze: „Volksfreund-Kalender 
für Stadt und Land” i „Lodzer Informations- und Hauskalender”. Kwerendą zostało objętych ponad 4 tys. numerów wyżej wspomnianych gazet.

W przeprowadzonych badaniach uwzględniłam liczne formy prozatorskie, jak nowele, opowiadania, obrazki okolicznościowe, poza tym utwory dramatyczne i powieści - wyjątek stanowią powieści w odcinkach, publikowane na łamach suplementów kulturalnych. Nie były one w większości twórczością łódzką, lecz przedrukami z prasy zachodniej, głównie pruskiej, lub powieściami kupowanymi na zamówienie u różnych wydawców zagranicznych, dlatego zostały przeze mnie pominięte w pracy. Ważną część łódzkiej literatury, którą również uwzględniłam, jest poezja, w szczególności okazjonalna. Oprócz literatury fikcjonalnej analizie poddałam gatunki literatury niefikcjonalnej, jak felieton. Uwzględniłam również jako szczególny rodzaj twórczości literackiej kazania oraz dowcipy.

Niniejsza publikacja jest pierwszą tego rodzaju monografią, w związku z tym na pewno jeszcze niekompletną. Zebrany materiał pozwolił jednak na dokonanie oglądu całości, w tym: wyodrębnienie pisarzy charakterystycznych dla kręgu tej literatury, ustalenie chronologii jej rozwoju, przedstawienie najbardziej reprezentatywnych gatunków oraz motywów. Powyższe zagadnienia w sposób istotny wpłynęły na podział treści w niniejszej książce. Zdecydowałam się na początku pracy wprowadzić rozdział poświęcony rozwojowi kultury i oświaty. To właśnie one miały ogromny wpływ na kształtowanie się literatury w Łodzi oraz jej twórców. Ponieważ w XIX i na początku XX w. Łódź była w miastem wielokulturowym, toteż wspomniany kontekst pojawia się przy omawianiu tego zagadnienia. Dlatego opisuję nie tylko kulturę i oświatę niemiecką, ale również staram się zwracać uwagę na aspekty polskie i żydowskie. Odrębny rozdział poświęciłam prasie, bowiem to właśnie lokalne pisma były istotnym medium dla rozpowszechniania łódzkiej literatury.

W pracy starałam się podjąć istotną kwestię dotyczącą syntetycznego spojrzenia na tę twórczość. Szczególnie interesowało mnie pytanie, czy w Łodzi ukształtowała się specyficzna literatura, z której dałoby się wyłuskać określony zbiór tematów, motywów, poetyk, które można by określić mianem literatury regionalnej, tworzącej tożsamość tego miejsca, będącej wynikiem specyficznego działania oraz myślenia. Dlatego powyższym kwestiom poświęciłam kolejne rozdziały pracy, w których starałam się dokonać próby systematyzacji zebranego materiału. Uwzględniłam w nich rozważania na temat literatury regionalnej oraz wyszczególniłam etapy jej rozwoju.

Oprócz zagadnień związanych z problematyką regionu, w kontekście omawianej literatury, starałam się wyodrębnić tematykę najczęściej podejmowaną przez pisarzy, a więc, odpowiedzieć na pytania: jak widzieli Łódź? Czy postrzegali ją podobnie jak polscy pisarze? Czy posługiwali się tymi samymi 
motywami? Jak widzieli Lodzermenscha? Czy podobnie jak u wielu polskich pisarzy była to negatywnie nacechowana postać? I w końcu jak literatura reagowała na wielkie wydarzenia polityczne, jakimi były wybuchy I i II wojny światowej. Ponieważ istotną rolę w łódzkiej literaturze odgrywała poezja, gatunek szczególnie ulubiony przez niemieckojęzycznych pisarzy, poświęciłam temu zagadnieniu dość dużo miejsca, ukazując jej różne przestrzenie.

$\mathrm{Z}$ uwagi na fakt, iż w pracy mamy do czynienia z nieznaną literaturą oraz z materiałem trudno dostępnym dla czytelnika, wiele tekstów wydrukowano bowiem tylko raz w gazecie przed 1939 r. i już nigdy nie miały szansy ukazać się po raz kolejny, zdecydowałam się na wprowadzenie dość rozbudowanych przypisów wyjaśniających. Podobnie ma się rzecz z cytatami, pochodzącymi z utworów literackich. Ponieważ jest to materiał nieznany, wprowadzenie wielu cytatów w języku oryginału (tłumaczenia w przypisie) pozwoli lepiej zrozumieć charakter tych tekstów. Na solidną antologię zawierającą najciekawsze teksty literackie łódzkich pisarzy przyjdzie jeszcze czas.

Zakresem rozważań zostały objęte lata 1824-1939. Cezury wydają się klarowne, szczególnie z uwagi na fakt, iż data początkowa oznacza przybycie do Łodzi pierwszych osadników niemieckojęzycznych, datę końcową wyznacza wybuch II wojny światowej, która miała ogromny wpływ na twórczość literacką niemieckojęzycznych łodzian. Po tym czasie wielu z nich opuściło Polskę w wyniku niesprzyjającej sytuacji politycznej, przeniosło się do Niemiec, gdzie publikowali swoje utwory zazwyczaj na łamach tamtejszych czasopism ziomkowskich. Z uwagi na zastosowane w pracy ramy czasowe, literatura ta już nie została objęta badaniami.

Istotną część pracy stanowi aneks: Łódzkie sylwetki, który jest minileksykonem osób związanych z Łodzią. Wiele miejsca poświęciłam w nim niemieckojęzycznym autorom, jak również polskim i żydowskim pisarzom. Czytelnik znajdzie również informacje na temat lokalnych dziennikarzy i wydawców, związanych w różnoraki sposób z twórczością literacką tego miasta. Treści tam zawarte pozwalają zorientować się czytelnikowi, kim byli łódzcy autorzy. Leksykon zawiera sylwetki najważniejszych pisarzy i poetów, których życiorysy dało się ustalić. Do wielu z nich, mimo wielu prób, niestety nie dotarłam. Stąd minileksykonu, podobnie jak całej zaprezentowanej literatury, nie należy traktować jako zbioru zamkniętego, lecz wymagającego dalszych wnikliwych poszukiwań i badań.

Last but not least, pragnę serdecznie podziękować wszystkim osobom i instytucjom, które przyczyniły się do powstania tej publikacji. 


\section{KULTURA I OŚWIATA ŁODZI ${ }^{1}$}

\subsection{Publiczność literacka}

Warunkiem sine qua non istnienia literatury jest publiczność, która wywiera istotny wpływ na rozwój i upowszechnianie określonych konwencji, gatunków i stylów twórczości pisarskiej. Na kształtowanie publiczności literackiej oddziałuje wiele czynników, m.in. struktura danej społeczności, a także udział poszczególnych grup w tworzeniu i recepcji treści kulturalnych. Znacząca jest również rola czynników językowych i ideologicznych, warunkujących dokonywanie wyborów, oraz czynniki materialne, np. sposób rozpowszechniania dóbr kultury. Ogromną wartość ma też rozwój bibliotek, wysokość nakładów książek, ich cena, reklama, rozwój prasy i księgarstwa. Należy ponadto pamiętać, że jednym z ważnych elementów kształtowania się publiczności literackiej jest wolny czas, umożliwiający uczestnictwo w kulturze ${ }^{2}$.

Patrząc na Łódź przełomu XIX i XX w., należy zauważyć, iż miasto to przez długi czas nie zdołało wykształcić odbiorców dzieł literackich ani środowiska literackiego, choć rozwijało się w iście amerykańskim stylu.

Początki Łodzi jako miasta sięgają XV w., kiedy król Władysław Jagiełło nadał jej przywilej lokacyjny ${ }^{3}$. Przez wiele stuleci Łódź była małą, senną mieściną, w której dominujące źródło utrzymania stanowiło rolnictwo i handel. Sytuacja zmieniła się na początku XIX w., kiedy zaszły istotne zmiany w polityce gospodarczej Rosji i Królestwa Polskiego. U podstaw tej polityki legła potrzeba intensywnej industrializacji kraju, która mogła się dokonać jedynie dzięki stworzeniu dogodnych warunków polityczno-gospodarczych. W tym celu władze Królestwa Polskiego podjęły szereg decyzji sprzyjających

1 Treści zawarte w kolejnych podrozdziałach są wprowadzeniem do tematu „Kultura i oświata Łodzi do 1939 roku". Omówione zagadnienia stanowią jedynie tło rozważań dotyczących niemieckojęzycznej literatury Łodzi i jej rozwoju.

2 Pojęcie „publiczność literacka” przyjmuję za: M. Głowiński, Publiczność literacka, [w:] Słownik terminów literackich, red. J. Sławiński, Wrocław-Warszawa-Kraków 2002, s. 455-556.

${ }^{3}$ Por. K. Badziak, Zarys dziejów Łodzi do 1918 roku, [w:] Łódź - monografia miasta, red. S. Liszewski, Łódź 2009, s. 27-61. 
rozwojowi przemysłu włókienniczego na terenie kilku miast rządowych, w tym również Łodzi. Ważnym impulsem rozwoju były liczne przywileje oraz szeroko zakrojona akcja werbunkowa, którą wysłannicy rządowi prowadzili poza granicami Królestwa Polskiego, głównie w Saksonii, Nadrenii, Prusach (na Śląsku, na obszarze Wielkiego Księstwa Poznańskiego i Brandenburgii) oraz na terenie Czech. Kryzys, jaki dotknął przemysł włókienniczy w Europie na początku lat 20. XIX w., spowodował, że wielu majstrów tkackich zdecydowało się opuścić dotychczasowe miejsce zamieszkania i poszukać pracy w rozwijających się regionach ${ }^{4}$.

Przybywający do Łodzi osadnicy znajdowali zatrudnienie w nowo tworzonych warsztatach tkackich. Zazwyczaj nie posiadali kapitału, by móc inwestować pokaźne sumy w rozwijający się przemysł, dlatego ogromną rolę odgrywały bezzwrotne pożyczki, zagwarantowane przez rząd Królestwa Polskiego. Osadnicy otrzymywali również bezpłatne place pod zabudowę, zwolnienia z konieczności opłaty czynszów na sześć lat i korzystali z innych przywilejów umożliwiających rozwój lokalnej przedsiębiorczości ${ }^{5}$. Z biegiem lat niewielkie warsztaty tkackie przekształciły się w manufaktury obejmujące pełny cykl produkcyjny, tzn. przędzalnię, tkalnię i apreturę. Do lat 40. XIX w. przedstawicielami łódzkiego przemysłu byli głównie Niemcy. Jednym z pierwszych, który w 1824 r. przybył do Łodzi, był Christian Friedrich Wendisch ${ }^{6}$. Nie zdołał jednak, podobnie jak wielu innych osadników, takich jak Jan Traugott Lange ${ }^{7}$ czy Tytus Kopisch ${ }^{8}$, sprostać wyzwaniom i mimo udzielonych mu pożyczek i przyznania rozległej posiadłości nad rzeką Jasień, jego kariera przemysłowa poniosła klęskę. Przykładem sukcesu jest natomiast niemiecki fabrykant Ludwik Geyer ${ }^{9}$. Jako pierwszy zainstalował w 1839 r. w swojej fabryce maszynę parową do napędu 180 krosien ręcznych, a jego przedsiębiorstwo było $w$ Łodzi do początku lat 60. jednym z największych i najnowocześniejszych ${ }^{10}$. Obok Geyera wyrastały inne znamienite postaci łódzkiego przemysłu: Traugott Grohmann ${ }^{11}$, Robert Biedermann ${ }^{12}$, Edward

${ }^{4}$ Por. Łódź - monografia..., s. 116.

${ }^{5}$ Ibidem, s. 37-43.

${ }^{6}$ Por. K.P. Woźniak, Poczq̨tki osadnictwa niemieckiego w Łodzi, [w:] Niemcy łódzcy / Die Lodzer Deutschen, red. A. Machejek, Łódź 2005, s. 13.

${ }^{7}$ Ibidem, s. 14.

8 Ibidem.

9 Na temat działalności i życia Ludwika Geyera zob. http://www.lodz.ap.gov.pl/fab3. html [dostęp: 20.09.2013].

${ }^{10}$ K.P. Woźniak, Początki osadnictwa..., s. 17.

11 Por. S. Pytlas, Wielki rozwój przemysłu i jego twórcy 1865-1914, [w:] Niemcy łódzcy..., s. 25.

12 Na temat działalności i życia Roberta Ludwika Karola Biedermanna zob. W. Kużko, Biedermannowie: dzieje rodziny i fortuny 1730-1945, Łódź 2000, http://www.lodz.ap.gov.pl/fab1. php [dostęp: 20.09.2013]. 
Herbst $^{13}$, Juliusz Heinzel ${ }^{14}$ czy wreszcie ojciec łódzkiej bawełny, Karol Wilhelm Scheibler ${ }^{15}$. W 1865 r. stanowili oni warstwę dominującą wśród łódzkiej burżuazji przemysłowej. Ich sukcesy finansowe sprawiły, że od połowy XIX w. Łódź stała się miastem wielkoprzemysłowym i jednym z największych ośrodków włókienniczych w Królestwie Polskim. Pod koniec lat 70. XIX w. przedsiębiorstwo Scheiblera należało do największych w Królestwie Polskim, zaś od lat 80. do największych w Cesarstwie Rosyjskim ${ }^{16}$.

Znacznie później sukcesy w przemyśle zaczęli odnosić fabrykanci pochodzenia żydowskiego. Jednym z nich był Izrael Poznański ${ }^{17}$, którego przedsiębiorstwo, podobnie jak fabryka Scheiblera, osiągnęło znaczące wyniki. Wybuch I wojny światowej negatywnie odbił się na rozwoju gospodarczym miasta. Polityka władz okupacyjnych była dla łódzkiego przemysłu bezwzględna - fabryki zamknięto, a surowce i maszyny zarekwirowano. Łódzcy fabrykanci ponieśli olbrzymie straty, których już nigdy nie byli w stanie odrobić.

Rozkwit przemysłu miał ogromny wpływ na zmiany w strukturze demograficznej miasta. U progu rozwoju przemysłowego Łódź liczyła zaledwie 767 mieszkańców, z czego większość stanowiła ludność polska, zajmująca się przeważnie rolnictwem. Pozostała część mieszkańców to społeczność żydowska, trudniąca się handlem i rzemiosłem ${ }^{18}$. Sytuacja zmieniła się z chwilą, gdy Łódź stała się miastem fabrycznym, do którego napływali zagraniczni osadnicy. Znaczny przyrost ludności odnotowano już pod koniec lat 20. XIX w., kiedy założono osady Nowe Miasto oraz Łódka. Liczba ludności wzrosła wówczas do 5000. Kolejny dynamiczny rozwój odnotowano w latach 30 . i na początku 40. tego samego wieku. Łódź liczyła już ok. 20000 mieszkańców i stała się dla wielu przybyszów „ziemią obiecaną”, dającą wiele możliwości rozwoju ${ }^{19}$. W kolejnych latach wskutek załamania koniunktury gospodarczej oraz w wyniku epidemii chorób zakaźnych (głównie gruźlicy) dynamika wzrostu uległa spowolnieniu. Korzystnie na rozwój łódzkiej populacji wpłynęło uwłaszczenie chłopów w 1864 r. Od tego czasu aż do wybuchu I wojny światowej liczba ludności zwiększyła się prawie dwunastokrotnie - z 40319 do 477862.

${ }^{13}$ Na temat działalności i życia Edwarda Augusta Maurycego Herbsta zob. http://www. lodz.ap.gov.pl/fab5.html [dostęp: 20.09.2013].

14 Por. S. Pytlas, Wielki rozwój..., s. 28.

${ }_{15}$ Na temat działalności i życia Karola Wilhelma Scheiblera zob. http://www.lodz.ap.gov. pl/fab7.html [dostęp: 20.09.2013].

${ }_{16}$ Zob. S. Pytlas, Wielki rozwój..., s. 25.

17 Por. K. Badziak, Wielkość i upadek fortuny Poznańskich, [w:] Dzieje Żydów w Łodzi 18201944. Wybrane problemy, red. W. Puś, S. Liszewski, Łódź 1991, s. 79-113.

18 Por. J. Janczak, Ludność Łodzi przemysłowej 1820-1914, Łódź 1982, s. 40; M. Koter, M. Kulesza, W. Puś, S. Pytlas, Wpływ wielonarodowego dziedzictwa kulturowego na współczesne oblicze miasta, Łódź 2005, s. 12.

19 J. Janczak, Ludność..., s. 53. 
Okres I wojny światowej był dla stanu demograficznego miasta zdecydowanie niekorzystny, gdyż spowodował znaczne wyludnienie. W 1915 r., po przyłączeniu Bałut i Chojen, Łódź liczyła ok. 600000 mieszkańców, lecz pod koniec wojny pozostało $\mathrm{w}$ mieście zaledwie 430000 . W latach międzywojennych ponownie wzrósł wskaźnik przyrostu, nie osiągnął jednak takiej dynamiki, jaką odnotowała Łódź w XIX w. ${ }^{20}$ Przed wybuchem II wojny światowej liczba ludności wynosiła już $672000^{21}$.

Porównując rozwój demograficzny Łodzi w drugiej połowie XIX i na początku XX w. z rozwojem innych miast polskich i europejskich, należy zauważyć, iż był dynamiczniejszy niż w takich ośrodkach, jak Kraków, Warszawa, Poznań czy Gdańsk ${ }^{22}$ oraz wyprzedzał pod tym względem choćby Manchester czy Lyon ${ }^{23}$. Biorąc pod uwagę tę cechę rozwoju demograficznego Łodzi, a także uwzględniając prostą zależność, że koncentracja ludności, produkcji i konsumpcji przynosi korzystne efekty ekonomiczne (czyli korzyści dla aglomeracji), a także sprzyja rozwojowi kultury i gromadzeniu jej dóbr, należy zastanowić się, jak powyższe stwierdzenie przekłada się na warunki łódzkie, tzn. czy rzeczywiście wzrost demograficzny sprzyjał tu rozwojowi kultury, a co za tym idzie również literatury. Aby odpowiedzieć na to pytanie, warto przyjrzeć się strukturze narodowościowo-wyznaniowej i społeczno-zawodowej w tym czasie, gdyż będą one miały zasadniczy wpływ na rozwój kultury i literatury.

Jak już wspomniano, rozwój demograficzny Łodzi spowodowany był napływem ludności obcej z terenów Saksonii, Prus (Śląska, Wielkopolski), Czech i Moraw, co oczywiście nie pozostało bez wpływu na skład narodowościowy i wyznaniowy miasta ${ }^{24}$. U progu rozwoju przemysłowego Łódź

${ }^{20}$ Por. J. Janczak, Struktura społeczna ludności Łodzi w latach 1820-1918, [w:] Polacy. Niemcy. Żydzi w XIX-XX w. Sąsiedzi dalecy i bliscy, red. P. Samuś, Łódź 1997, s. 40-43; Łódź - monografia..., s. 276-277.

${ }^{21}$ Łódź - monografia..., s. 265.

22 Por. A. Ginsbert, Łódź. Studium monograficzne, Łódź 1962, s. 22.

${ }^{23}$ Ibidem, s. 23.

${ }^{24}$ Dokładne ustalenie składu narodowościowego oraz wyznaniowego społeczności łódzkiej w XIX i na początku XX w. jest trudnym zadaniem. Zwraca na to uwagę J. Janczak, pisząc m.in. „Trzeba jednak zdawać sobie sprawę z tego, że dochodzenie do statystyki narodowościowej w przeszłości jest dosyć skomplikowane i wzbudza kontrowersje. Chodzi przede wszystkim o niejasność i zmienność w czasie stosownych w przeszłości kryteriów klasyfikacji ludności. Już ten czynnik sprawia, że uzyskane liczby mogą być niedokładne i niezupełnie porównywalne. Do tego dochodzą wszystkie obiektywne trudności w dokładnym klasyfikowaniu zbiorowości liczącej najpierw dziesiątki tysięcy, a potem setki tysięcy jednostek. [...] Ogólnie trzeba stwierdzić, że do czasu spisu powszechnego w 1897 r., pierwszego spisu w Cesarstwie Rosyjskim spełniającego wymogi spisów nowoczesnych, niezależnie od terminologii stosowanej w urzędowych statystykach, klasyfikacja narodowościowa musi się opierać na klasyfikacji wyznaniowej. Ma ona jednak charakter szacunkowy o różnym stopniu dokładności. Tak więc bez obawy popełnienia błędu liczbę ludności wyznania mojżeszowego (starozakonnego) można w Łodzi utożsamiać z liczbą Żydów, wyznania prawosławnego z liczbą Rosjan, zaś ludność 
była ośrodkiem, w którym dominowała ludność chrześcijańska oraz mieszkańcy wyznania mojżeszowego. Do połowy XIX w. w statystykach wyróżniano te dwie główne religie, natomiast w drugiej połowie XIX w. pojawili się w mieście również wyznawcy prawosławia, herrnhuci (bracia morawscy), ewangelicy reformowani, muzułmanie, baptyści oraz mariawici. Pomimo tak wielkiego zróżnicowania religijnego w Łodzi przez cały okres jej rozwoju dominowały jednak tylko trzy wyznania: katolickie, ewangelickie i mojżeszowe. Ewangelicy stanowili w przybliżeniu 44\% ogółu mieszkańców. Niewiele mniejszy odsetek (43\%) to katolicy. Znacznie mniejszą grupą była ludność wyznania mojżeszowego (ok. 12-13\%). Z biegiem lat struktura wyznaniowa miasta ulegała zmianom, przeważnie na korzyść ludności wyznania mojżeszowego, a wiązało się to ze zniesieniem w ustawodawstwie w $1862 \mathrm{r}$. ograniczeń w stosunku do Żydów. Po 1862 r. zauważa się znaczny spadek ludności ewangelickiej - pod koniec XIX w. odnotowano w Łodzi już tylko 18\% ewangelików i w następnych latach nadal utrzymywała się tendencja spadkowa. Odsetek ludności katolickiej pozostawał natomiast na wysokim poziomie - $\mathrm{w}$ pierwszej połowie XX w. katolicy stanowili ponad połowę ogółu ludności. Niewielki odsetek wśród innych wyznań dotyczył braci morawskich - w 1859 r. żyło ich w Łodzi 171. Również niewielki procent ludności stanowili wyznawcy prawosławia, a ich odsetek wynosił na początku XIX w. 3\% ogółu mieszkańców. Niewielką rolę odgrywali przybyli z Prus Wschodnich baptyści, których liczbę szacuje się w 1904 r. na 1933 osoby. W latach 90. XIX w. przywędrowali do Łodzi wraz z armią rosyjską muzułmanie, których w 1911 r. było 333. Mniej więcej w tym samym czasie pojawili się mariawici, którzy założyli swój kościół najpierw przy ul. Franciszkańskiej, później przy ul. Podleśnej i ul. Nawrot. Ich liczbę szacuje się w Łodzi na 1860 osób ${ }^{25}$.

Ze strukturą wyznaniową ludności łódzkiej jest sprzężony skład narodowościowy, dlatego w oparciu o powyższe badania, jak również o wnioski innych badaczy można stwierdzić, iż ludność niemiecka tworzyła w pierwszej połowie lat 50. XIX w. środowisko bardzo liczne i zarazem dominujące nad pozostałymi narodowościami. Jednocześnie była to w owym czasie społeczność stosunkowo hermetyczna, co miało wpływ na kształtowanie się kultury i literatury tego środowiska ${ }^{26}$. Ludność polska to ok. 36\% mieszkańców, zaś żydowska

wyznań ewangelickich to w tym czasie w zasadzie Niemcy. Największych problemów nastręcza podział narodowościowy ludności wyznania rzymskokatolickiego". J. Janczak, Struktura..., s. 42. Dlatego biorąc pod uwagę powyższe stwierdzenie, przedstawione w rozdziale dane dotyczące zarówno składu narodowościowego, jak i wyznaniowego oraz struktury zawodowej Łodzi do 1939 r. będą miały charakter jedynie szacunkowy.

25 Por. A. Gałecki, Tolerancja, potrzeba naszych czasów, [w:] Łódź wielonarodowa i wielowyznaniowa a idea tolerancji, Łódź 1997, s. 9.

${ }^{26}$ Por. A. Matuchniak-Krasuska, Kultura regionalna, kultura w regionie, [w:] Wiedza, innowacyjność, przedsiębiorczość a rozwój regionów, red. A. Jewtuchowicz, Łódź 2005, s. 149-170; L. Stolarzewicz, Literatura Łodzi w ciagu jej istnienia. Szkic literacki i antologia, Łódź 1935; 
- ok. $20 \%{ }^{27}$, choć z czasem proporcje te uległy zmianie. W drugiej połowie XIX w. odnotowano przyrost ludności polskiej (m.in. w wyniku uwłaszczenia chłopów) oraz żydowskiej (wskutek nadania jej praw w 1862 r.), natomiast znaczny ubytek ludności niemieckiej: przed wybuchem I wojny światowej Niemców w Łodzi było już tylko $10 \%$. W tym samym czasie mieszkało tu ok. 30\% Żydów, zaś reszta to Polacy. W przededniu II wojny światowej 55\% mieszkańców miasta stanowili Polacy, 34,7\% Żydzi, zaś 10\% Niemcy ${ }^{28}$.

Równolegle z rozwojem przemysłu ulegała zmianie struktura społeczno-zawodowa. U progu rozwoju przemysłowego duży odsetek ludności zajmował się rolnictwem, a także rzemiosłem i handlem. Wśród mieszkańców byli również służący i wyrobnicy. Sytuacja zmieniła się radykalnie po przybyciu osadników zagranicznych. Większość spośród czynnych zawodowo osób pracowała w przemyśle i w różnych zawodach rzemieślniczych. Pod koniec lat 20. XIX w. było ich ponad $80 \%$. Znacznie mniej osób zatrudnionych było w handlu i rolnictwie (w przybliżeniu $8 \%{ }^{29}$ ). Niewielki odsetek ludności stanowili również nauczyciele, duchowni oraz urzędnicy, a więc osoby wykształcone, które mogły aktywnie uczestniczyć w życiu kulturalnym miasta i stać się odbiorcami literatury. W kolejnej fazie rozwoju Łodzi niemal nieprzerwanie na wysokim poziomie utrzymywała się liczba osób pracujących w przemyśle i rzemiośle, i wynosiła w przybliżeniu 58,2\%. Tendencję spadkową do $0,3 \%$ odnotowano natomiast wśród ludności zatrudnionej w rolnictwie. W spisach z 1897 r. wyodrębniono dwie nowe kategorie: rentierów $(3,3 \%)$ oraz pracowników komunikacji i łączności (1,8\%). Pracownicy handlu, banków, ubezpieczeń i gastronomii to $11 \%$ społeczności czynnej zawodowo, zaś służących i wyrobników było $21,8 \%$.

Przyglądając się strukturze społeczno-zawodowej kolejnych lat, należałoby zwrócić uwagę na następujące zjawiska: jak wynika z danych ze spisu powszechnego z 1921 r., liczba osób zatrudnionych w przemyśle pozostawała nadal wysoka i wynosiła 57,5\% ogółu ludności. Wysoki odsetek stanowiła również ludność zatrudniona w handlu oraz ubezpieczeniach $(19,1 \%)$. Działy wymagające wysoko kwalifikowanych pracowników, takie jak oświata, kultura, służba publiczna, lecznictwo i higiena, były w Łodzi mało popularne. Choć w okresie międzywojennym liczba ludności pracującej w tych dziedzi-

A. Barszczewska-Krupa, Rodowód oraz drogi rozwoju kultury i oświaty w Łodzi. Uwagi ogólne, [w:] Łódź. Dzieje miasta, red. R. Rosin, t. 1: Do roku 1918, red. B. Baranowski, J. Fijałek, ŁódźWarszawa 1980, s. 480-486.

27 K. Janczak, Struktura..., s. 44-47.

${ }^{28}$ A. Gałecki, Tolerancja ..., s. 9.

29 Dane pochodzą z Raportu prezesa Komisji Wojewódzkiej Mazowieckiej o stanie przemysłu włókienniczego w 1828 r.; „Rocznik Oddziału Łódzkiego Polskiego Towarzystwa Historycznego" 2/1929-1930, s. 183, 190; Archiwum Państwowe Łodzi, Akta m. Łodzi 3842, s. 286-287; Poczq̨tki rozwoju kapitalistycznego miasta Łodzi 1820-1864, oprac. A. Rynkowska, Warszawa 1960, s. 76-77; K. Janczak, Struktura ..., s. 49-67. 
nach wzrosła, wynosząc w służbie publicznej 3,6\%, w kulturze i oświacie $2,12 \%$, zaś w lecznictwie i higienie 2,5\%, to jednak największy odsetek (aż $70 \%)$ stanowiła ludność robotnicza ${ }^{30}$. Dużo mniejszy odsetek przypadał na drobnomieszczaństwo, czyli drobnych kupców i rzemieślników (18,6\%), inteligencję, czyli urzędników, nauczycieli, lekarzy i wolne zawody $(9,6 \%)$ oraz burżuazję, tj. przemysłowców i kupców $(2,1 \%)^{31}$. Przez cały okres industrializacji w Łodzi dominowała ludność zatrudniona w przemyśle. Byli to głównie rzemieślnicy, robotnicy, burżuazja i kupcy. Mniej osób pracowało w handlu oraz rolnictwie ${ }^{32}$. Praktycznie ludność pracująca w fabrykach nie posiadała większych kwalifikacji zawodowych i często nie potrafiła czytać ani pisać. Szacuje się, że na początku XX w. ponad połowa mieszkańców Łodzi to analfabeci ${ }^{33}$. Przedstawiciele wolnych zawodów: urzędnicy, nauczyciele czy lekarze, a więc osoby, które mogły stać się inicjatorami życia kulturalnego, stanowiły w całej łódzkiej populacji niewielki procent ludności czynnej zawodowo ${ }^{34}$. Przyjmuje się, że w latach 60. XIX w. inteligencja Łodzi tworzyła niecały procent ogólnej liczby mieszkańców ${ }^{35}$. W drugiej połowie XIX w. sytuacja nieco się zmieniła, gdy w Łodzi zaczęło przybywać polskich, niemieckich, żydowskich i rosyjskich nauczycieli. Zwiększyła się również liczba urzędników, techników i inżynierów. Pojawili się ponadto lekarze, farmaceuci, adwokaci oraz duchowni różnych wyznań. Pod koniec XIX w. wolne zawody reprezentowały niecałe $3 \%$ ludności miasta ${ }^{36}$. Choć inteligencji w Łodzi przybywało, była zbyt słaba, by nadawać ton życiu kulturalnemu miasta i sama poszukiwała raczej wsparcia materialnego i ideowego u innych warstw społeczeństwa. Niemiecka inteligencja wzorowała się w sposobie bycia na miejscowej burżuazji niemieckiej i również u niej szukała pomocy finansowej. Podobnie inteligencja żydowska znajdowała wzory do naśladowania i kapitał wśród burżuazji niemieckiej. Polscy inteligenci nie uzyskiwali takiego wsparcia jak Niemcy czy Żydzi i dlatego często opuszczali Łódź w poszukiwaniu lepszych warunków życia poza jej granicami ${ }^{37}$. Sytuację łódzkiej inteligencji opisał Stefan Gorski w książce Łódź spółczesna:

Świat adwokacki, lekarski, architekci, budowniczowie, nauczyciele - bezpośrednio zainteresowani są biegiem interesów łódzkich. Jedni mają akcje w danem przedsiębiorstwie, inni

30 Por. Łódź - monografia..., s. 269-271.

31 Ibidem, s. 270.

32 Ibidem.

33 Ibidem, s. 323.

34 Ibidem, s. 59-66.

35 Por. J. Janczak, Struktura..., s. 58.

36 Zob. M. Piestrzeniewicz, Rozrywka łodzian na przełomie XIX i XX wieku, Łódź 2010, s. 21. Dla porównania w tym samym czasie liczba inteligencji Warszawy nie była wiele wyższa. Miasto posiadało tylko $2 \%$ więcej ludności pracującej umysłowo.

37 Por. W. Puś, Dzieje Łodzi przemysłowej, Łódź 1987. 
„na spółkę” założyli drukarnię, ktoś znów próbuje szczęścia w grze „na zwyżkę” w placach... Słowem stosunki miejscowe stworzyły życie na wskroś odmienne, specjalne łódzkie ${ }^{38}$.

W życiu kulturalnym miasta przez długi czas decydującą rolę miała odegrać łódzka burżuazja pochodzenia niemieckiego i w mniejszym stopniu żydowskiego. Była w posiadaniu największego kapitału finansowego, który mógł stanowić istotne oparcie dla rozwoju kultury. Niestety, grupa ta skupiona była na własnych interesach i wykazywała niewielkie, niepoparte tradycjami mieszczańskimi potrzeby w zakresie literatury czy sztuki. Dlatego ostatecznie kultura, którą stworzyła miejscowa społeczność, była bardzo uboga ${ }^{39}$, natomiast rola inteligencji w jej tworzeniu była ograniczona. Niewielkie dochody, jakie przynosiła praca umysłowa, powodowały, że podejmowanie jakichkolwiek działań na płaszczyźnie publicznej stało się niepopularne. Istotną przeszkodą były także złe warunki bytowe tej grupy społecznej. Pogorszyły się one dodatkowo za sprawą kolejnych kryzysów w latach 1829-1834, 1844-1848, 1852$1854,1861-1864,1892,1905-1906$ i wskutek wybuchu I wojny światowej ${ }^{40}$.

Stagnacja przemysłu powodowała poważne ograniczenia w zarobkowaniu, a z czasem całkowite bezrobocie. Ceny żywności gwałtownie rosły, ludzie głodowali i zapadali na różne choroby. Zarobki również nie były wysokie i oscylowały w granicach 6-7 rb za 5 dni pracy. W chwili wybuchu powstania styczniowego znacznie spadły i wynosiły zaledwie 2 rb tygodniowo (dla porównania cena chleba wynosiła wówczas od 2,5 do 5,5 kop.). Również warunki mieszkaniowe były złe ${ }^{41}$. W wielu łódzkich dzielnicach, przede wszystkim w żydowskiej, panowało katastrofalne przeludnienie, prowadzące $\mathrm{w}$ konsekwencji do znacznego zanieczyszczenia i rozprzestrzeniania się chorób zakaźnych ${ }^{42}$. W jednoizbowych lokalach mieszkało ponad $50 \%$ ludności, w dwuizbowych 20,4\%, natomiast w trzyizbowych i większych $20,7 \%{ }^{43}$.

Z przeglądu struktury społeczno-zawodowej z perspektywy podziału na poszczególne skupiska narodowościowe wynika, iż ludność polska była grupą wiodącą wśród osób zatrudnionych w rolnictwie, przemyśle, rzemiośle, komunikacji, łączności, w grupie wyrobników oraz służby domowej. Ludność niemiecka dominowała w przemyśle, rzemiośle i w grupie rentierów, Żydzi natomiast $\mathrm{w}$ handlu, branży bankowej i ubezpieczeniach, Rosjanie zaś zajmowali stanowiska w aparacie administracyjnym i w oświacie. W latach rewolucji 1905/1907 r. ich liczebność sięgała ok. 3\% ogółu mieszkańców, nato-

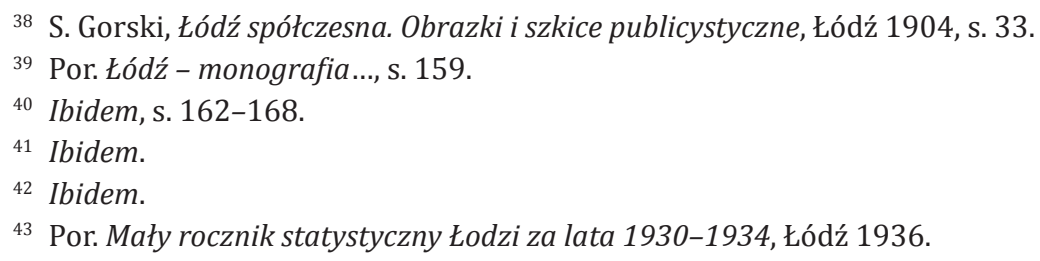


miast przed wybuchem I wojny światowej zaledwie $1 \%{ }^{44}$. Mimo iż stanowili niewielki procent społeczeństwa, wywierali znaczący wpływ na życie miasta, szczególnie w sferze politycznej.

Od lat 20. XIX w. do 1939 r. struktura demograficzna ludności Łodzi zarówno pod względem społeczno-zawodowym, jak i narodowościowym oraz wyznaniowym nie sprzyjała kształtowaniu publiczności literackiej. Odrębność kultur, religii i języków powodowała, że Polacy, Niemcy i Żydzi żyli zazwyczaj obok siebie, ale nie razem; dotyczy to w szczególności społeczności żydowskiej, która pozostawała w izolacji, choćby z uwagi na obowiązujący do lat 60. XIX w. zakaz osiedlania się w określonych dzielnicach miasta. Również społeczność polska była skupiona na własnych dążeniach w walce o polskość, dlatego wszelkie inicjatywy kulturalne miały służyć przede wszystkim zachowaniu polskiej tożsamości i tradycji, tak ważnych w okresie zaborów. Odrębność niemiecka z kolei miała swe źródło w wielkim przemyśle, którego twórcami byli niemieccy fabrykanci - to oni zajmowali wyższe stanowiska w fabrykach i stanowili uprzywilejowaną warstwę miejscowej społeczności. Do niemieckich fabrykantów należała również inicjatywa w dziedzinie kultury - nie wykazywali się jednak szczególnymi aspiracjami, dlatego podejmowane przez nich działania często realizowano jedynie na pokaz. Gros społeczeństwa stanowili robotnicy, a inteligencja, czy to polska czy zagraniczna, była zbyt słaba, by inicjować działania służące rozwojowi życia kulturalnego miasta, w tym także literatury. Dodatkowo negatywny wpływ miał wysoki poziom analfabetyzmu i złe warunki bytowe ludności. Sytuację kultury w XIX-wiecznej Łodzi, jak również znajomość kanonu literatury wśród łódzkiej burżuazji w dość znamienny sposób przedstawił Władysław Stanisław Reymont w Ziemi obiecanej. Jego bohaterowie wykazują się zupełną nieznajomością literatury: przykładowo najbogatszy łódzki bankier, Grosglik, za twórcę Ogniem i mieczem uznaje francuskiego pisarza Wiktora Hugo. Postacie Reymonta manifestują również niechęć do przeżyć estetycznych, jakich dostarczają wizyty w teatrze, który dla wielu Lodzermenschów reprezentowanych w powieści przez Karola Borowieckiego, Moryca Welta, Maxa Bauma i innych jest jedynie dobrym miejscem do robienia interesów ${ }^{45}$.

Brak wyedukowanych odbiorców kultury (w tym publiczności literackiej) powodował, iż współcześni Reymontowi postrzegali Łódź, podobnie jak on sam, jako kulturalną pustynię, w której największą wartość ma pieniądz, sukces i rosnące ceny bawełny, pozwalającej zarobić krocie. 0 kulturze Łodzi, a dokładniej o jej braku napisano wiele, a jednym z pierwszych, który to uczynił,

\footnotetext{
${ }^{44}$ Por. A. Gałecki, Łódź wielonarodowa i wielowyznaniowa a idea tolerancji, Łódź 1997.

45 Zob. W.S. Reymont, Ziemia obiecana, Łódź 1899.
} 
był Ludwik Stolarzewicz. Autor trafnie ujął to zjawisko w bardzo zwięzłych słowach:

W mieście, w którem „interes” był wszystkiem, w mieście, w którem wszystko kręciło się wokół pytania, czy bawełna spada, czy ceny idą w górę, gdzie sprzedać, dokąd wysłać towar, nie było wprost czasu na myśli o literaturze - nauce - sztuce! $!^{46}$

Należy jednak zauważyć, że z czasem inteligencji przybywało. Jej szeregi zasilali przede wszystkim inteligenci warszawscy, ale również galicyjscy, przybywający do Łodzi w celach zarobkowych. Należeli do nich m.in. Aleksander Bolesław Cyps, który przyjechał do Łodzi z Krakowa, czy Wiktor Czajewski, przebywający najpierw w Krakowie, następnie w Warszawie, w końcu osiadły na jakiś czas w Łodzi ${ }^{47}$. Na zagranicznych uczelniach doświadczenie zdobywała również społeczność niemiecka. Z czasem Niemcy łódzcy zaczęli powoływać do życia instytucje kształtujące rozwój miejscowej kultury. Łódź odwiedzali również wielcy pisarze, jak np. Alfred Döblin, który przyjechał tu w 1924 r., a swoje wspomnienia z podróży zawarł w książce Reise in Polen.

\subsection{Organizacje i stowarzyszenia kulturalne}

Kultury Łodzi przemysłowej nie ukształtował silny ośrodek lokalny. Na początku lat 20. XIX w. brakowało tu specyficznie lokalnych instytucji i wzorów zrodzonych na miejscu, zaimportowano je więc z zewnątrz wraz z przybyciem pierwszych zagranicznych osadników. Prawdopodobnie działo się tak również w innych ośrodkach uprzemysłowionych o podobnej skali, bowiem w każdym z nich magnesem przyciągającym ludzi z zewnątrz był właśnie przemysł. Do lat 20. XIX w. w Łodzi nie wykształcił się własny folklor miejski ani wiejski i brakowało poważniejszych instytucjonalnych oraz pozainstytucjonalnych inicjatyw kulturalnych. Osadnicy napływający do Łodzi pielęgnowali własne tradycje przywiezione $\mathrm{z}$ regionu, z którego pochodzili ${ }^{48}$. Były to najczęściej małe miasteczka, również nietętniące bogatym życiem kulturalnym. Duża część osób przybywających do Łodzi w ogóle pozbawiona była możliwości aktywnego uczestnictwa w kulturze, a fakt ten dotyczył głównie ludności wiejskiej, która nie potrafiła czytać ani pisać. Wielu z tych ludzi Łódź dała po raz pierwszy szansę uczestniczenia w kulturze, o ile oczywiście ujawnili wystarczająco silną motywację.

${ }^{46}$ L. Stolarzewicz, Literatura Łodzi..., s. 8.

${ }_{47}$ Zob. E. Pleszkun-Olejniczakowa, Instytucje literackie $w$ Łodzi międzywojennej i ich rola kulturotwórcza, Łódź 1996, s. 60.

${ }^{48}$ Por. Łódź - monografia..., s. 151; A. Barszczewska-Krupa, Rodowód ..., s. 480-485. 
Odrębność kulturowa każdej z przybyłych do Łodzi grup zapewne stanowiła przeszkodę w swobodnym przenikaniu tradycji i zwyczajów, a dodatkowo pogłębiana była restrykcyjną polityką zaborców. Wprowadzone przez carat po 1865 r. zakazy odbywania zgromadzeń, zebrań, zakładania partii politycznych i związków zawodowych, cenzura prasy i książek czy wreszcie brak samorządu powodowały, że do lat 80 . XIX w. instytucje kultury rozwijały się bardzo powoli, a podstawowe potrzeby kulturalne lokalnej społeczności zaspokajały zgromadzenia rzemieślnicze ${ }^{49}$. Mimo iż różnorodność kulturowa nie pomagała w przenikaniu wzorców, w Łodzi podejmowano jednak wspólne inicjatywy w dziedzinie kultury. Przykładem może być utworzenie w 1824 r. przez niemieckich osadników Lodzer Bürger-Schützengilde [Łódzkiego Towarzystwa Strzeleckiego ${ }^{50}$, którego członkami byli początkowo zarówno Polacy, jak i Niemcy. Z jego inicjatywy organizowano z okazji Zielonych Świątek, cieszące się wśród lokalnej społeczności dużą popularnością, konkursy strzeleckie o tytuł króla kurkowego. Oskar Flatt, autor pierwszego obszerniejszego opisu Łodzi, zamieścił w 1853 r. wzmiankę na temat inicjatyw podejmowanych przez Łódzkie Towarzystwo Strzeleckie:

Strzelanie do tarczy i wybór Króla Kurkowego odbywa się corocznie w drugi i trzeci dzień Zielonych Świątek. Jest to epoka ważna w całorocznym życiu mieszkańców Łodzi: cały ruch fabryczny jest wtedy w stagnacyi, każdy żyje tylko myślą o owem dziś i wysila głowę, aby tę doroczną epokę godnie uczcić i uświetnić. Bliższe i dalsze okolice Łodzi ślą jej na ten dzień licznych gości, a i Warszawa nie jednego tam liczy reprezentanta, który dla urozmaicenia Bielany na festyn Strzelecki zamienił ${ }^{51}$.

W późniejszych latach powstały kolejne stowarzyszenia i organizacje, nawiązujące do prężnie rozwijającego się w tym czasie na terenie Niemiec i Anglii

${ }^{49}$ Por. A. Barszczewska-Krupa, Rodowód...; A. Jewtuchowicz, A. Suliborski, Życie społeczne i kulturalne w Łodzi do 1918 roku, [w:] Łódź - monografia..., s. 150-168.

${ }^{50}$ Historia Bractw Strzeleckich czy też Kurkowych wywodzi się ze średniowiecza, kiedy miasta w myśl prawa magdeburskiego były zobowiązane do organizowania własnej obrony. Ponieważ wiele z nich nie stać było na utrzymywanie regularnego wojska, toteż miejscową ludność przyuczano do posługiwania się bronią. W tym celu bractwa organizowały turnieje służące doskonaleniu umiejętności strzeleckich. Najpierw strzelano z łuku, a następnie z kuszy do celu, który przypominał ptaka, a dokładniej koguta, po staropolsku „kura”. Bractwa cieszyły się ogromnym zaufaniem władców, nagradzających je licznymi przywilejami. Uroczystości strzeleckie były znaczącymi wydarzeniami kulturalnymi, odgrywającymi istotną rolę w życiu lokalnej społeczności. Pierwsze Bractwa Kurkowe powstawały w miastach niemieckich, w tym na Śląsku. Por. m.in. T.A. Jakubiak, Kurkowe bractwa strzeleckie w Wielkopolsce, Poznań 1986; Z. Humerczyk, Dzieje bractwa strzeleckiego w Grodzisku Wielkopolskim, 1646-1947 w zarysie, Grodzisk Wielkopolski 2000; J. Grochowska, Kurkowe Bractwo Strzeleckie w Wejherowie. Historia i współczesność, Wejherowo 2004; K. Jelonek-Litewka, Inwentarz akt Towarzystwa Strzeleckiego (Bractwa Kurkowego) w Krakowie z lat 1591-1939, Kraków 2005; Dawne Kurkowe Bractwa Strzeleckie w Chojnicach i na Pomorzu, red. K. Lemańczyk, Chojnice 2006.

51 O. Flatt, Opis miasta Łodzi pod względem historycznym, statystycznym i przemysłowym, Warszawa 1853, s. 145. 
ruchu turnerskiego. Były to Łódzkie Towarzystwo Cyklistów (1886) oraz Towarzystwo Cyklistów-Turystów(1895) ${ }^{52}$. Obie organizacje skupiały w swych szeregach niemieckojęzycznych miłośników jazdy na wielocypedach, a także miłośników piłki nożnej. Pod koniec XIX i na początku XX w. utworzono również inne towarzystwa sportowe, m.in. Stowarzyszenie Sportowe „Union”, Łódzkie Towarzystwo Gimnastyczne „Achilles”, Stowarzyszenie Sportowe „Newcastle” czy Klub Piłkarski „Victoria”, propagujący w Łodzi rozwój piłki nożnej. Do najbardziej ekskluzywnych klubów niemieckich należał w Łodzi założony w 1913 r. Laws-Tennis Klub, w którym uprawiano tenis ziemny i gimnastykę. Nieco inaczej rozwijała się kultura fizyczna wśród miejscowej społeczności polskiej. Pierwsze polskie stowarzyszenia sportowe zaczęły działać w mieście dopiero pod koniec lat 80. XIX w., kiedy powstał Konsulat Łódzki Warszawskiego Towarzystwa Cyklistów. Tworzenie kolejnych towarzystw o charakterze sportowym napotykało na opór władz guberni piotrkowskiej, które nie zezwoliły najpierw na utworzenie Towarzystwa Gimnastycznego Sokót, a następnie Towarzystwa Miłośników Gimnastyki. Dopiero w 1909 r. udało się zatwierdzić statut Towarzystwa Zwolenników Rozwoju Fizycznego, co otworzyło drogę do zabiegów o legalizację kolejnych towarzystw sportowych, których w okresie międzywojennym było już 81.

Najpóźniej zaczęły działać żydowskie stowarzyszenia sportowe. Pierwsze z nich to Łódzkie Towarzystwo Zwolenników Gry Szachowej, powstałe w 1897 r. Kolejnymi klubami były: Łódzkie Żydowskie Towarzystwo Gimnastyczno-Spor-

${ }^{52}$ Na początku XIX w. w wielu krajach europejskich zaczął prężnie rozwijać się tzw. ruch turnerski, czyli system obejmujący programy ćwiczeń fizycznych zarówno na potrzeby ogólnorozwojowe, jak i specjalizacji ruchowej. Służył usprawnieniu i wzmocnieniu organizmu oraz wspierał rozwój psychiki. Szczególne osiągnięcia wspieraniu ruchu turnerskiego miało państwo pruskie, zainteresowane rozwijaniem zdolności ruchowych swoich obywateli. Jednym z twórców tego ruchu był Friedrich Ludwig Jahn (1778-1852), który w 1811 r. w Hasenheide koło Berlina utworzył ośrodek będący centrum wychowania niemieckiej młodzieży w duchu starogermańskim. Młodzi ludzie ubrani w jednolite lniane stroje odbywali ćwiczenia dwa razy w tygodniu i odżywiali się jedynie chlebem i wodą. Nosili odznaki, na których wyryte były daty bitew w lasach teutoburskich, a także pierwszego i ostatniego turnieju rycerskiego, rozegranego w Niemczech. Surowe wychowanie miało być początkiem odrodzenia narodu niemieckiego, który zdaniem Jahna daleko odszedł od dawnych tradycji. Od młodych ludzi oczekiwano przede wszystkim gotowości do służby wojskowej w duchu dawnych tradycji rycerskich. Kontynuatorem idei turnerskiej był Adolph Spiess, który znacznie zmodyfikował oczekiwania wobec ruchu. Tradycję ćwiczeń fizycznych przejęto w okresie narodowego socjalizmu. Nie służyły już one tylko i wyłącznie ogólnemu rozwojowi, ale przede wszystkim kształtowały karność i poczucie porządku, co miał podkreślać militarny charakter gimnastyki. Z czasem ruch turnerski zaczął przybierać inne formy - inicjował tworzenie związków i klubów sportowych, będących dla zwykłej ludności bardzo popularną formą rozrywki. W klubach i stowarzyszeniach wartością nadrzędną nie był już rygor, lecz podnoszenie sprawności fizycznej. W tym celu tworzono liczne związki strzeleckie, szermiercze, myśliwskie, łyżwiarskie, lekkoatletyczne i inne. Por. M. Marcinkowski, A. Sokołowski, Aksjologiczne i funkcjonalne aspekty kultury fizycznej w wojsku, t. 7, Warszawa 2004. 
towe, Łódzkie Żydowskie Towarzystwo Sportowo-Gimnastyczne „1913”, Zwiqzek Żydowskich Towarzystw Gimnastyczno-Sportowych oraz Łódzkie Żydowskie Towarzystwo Gimnastyczno-Sportowe „Bar-Kochba”. W latach 20. XX w. zaczęły powstawać kolejne, jak np. utworzone w 1920 r. Żydowskie Stowarzyszenie Gimnastyczno-Sportowe "Hakoah” czy też zorganizowany w 1921 r. Żydowski Klub Sportowy „Achduth” lub powstałe w 1923 i 1924 r. Żydowskie Stowarzyszenie Sportowo-Gimnastyczne „Hasmonea” i Żydowski Klub Sportowy „Makabi”. Oprócz gimnastyki uprawiano również (podobnie jak w przypadku sportowców niemieckich i polskich) piłkę nożną i tenis stołowy oraz wiele innych dyscyplin sportowych ${ }^{53}$. W początkowym okresie współpraca polsko-niemiecka na niwie sportowej była możliwa w przypadku wspomnianego już Łódzkiego Towarzystwa Strzeleckiego, jednakże polityka władz rosyjskich doprowadziła do powstania organizacji stosunkowo hermetycznych pod względem narodowościowym. Kres tej polityce położyło utworzenie w 1910 r. Łódzkiej Ligi Sportowej, w ramach której doszło do współpracy polskich, niemieckich i żydowskich stowarzyszeń sportowych działających w Łodzi.

Poza towarzystwami sportowymi istotną rolę w krzewieniu kultury odegrała muzyka, a także najróżniejsze towarzystwa śpiewacze i chóry. W $1846 \mathrm{r}$. powołano do życia Łódzkie Męskie Towarzystwo Śpiewacze, które pełniło ważną rolę w życiu towarzyskim miasta. Jego członkowie dbali nie tylko o wysoki poziom artystyczny swoich występów, ale również chętnie prezentowali swe osiągnięcia poza granicami Łodzi. Pierwszym dyrygentem był nauczyciel Jan Franz. W 1864 r. odbyło się uroczyste poświęcenie sztandaru ${ }^{54}$. Pod batutą kolejnego dyrygenta, Augusta Heinricha, Towarzystwo zgromadziło wielu wybitnych śpiewaków i odnosiło spektakularne sukcesy. Po tym okresie nastąpił jednak zastój, a renomę stowarzyszenie odzyskało dopiero pod opieką Otto Heyera. Jednym z większych osiągnięć był występ w 1892 r. przed carem Aleksandrem III. Chór wystąpił ponownie przed kolejnym carem, Mikołajem II, gdy ten w 1901 r. przybył wraz z małżonką Aleksandrą Fiodorowną i następcą tronu Michałem Aleksandrowiczem do Tomaszowa na uroczystość poświęcenia cerkwi.

Niemiecką kulturę i tradycję pielęgnował również utworzony w $1856 \mathrm{r}$. Zwiqzek Śpiewaczy Katolików Niemieckich "Cecilie” oraz Męskie Kościelne Towarzystwo Śpiewacze działające przy kościele ewangelickim św. Trójcy,

53 Por. A. Bogusz, Dawna Łódź sportowa, Łódź 2007, s. 97-135.

54 „Łodzer Anzeiger/Łódzkie Ogłoszenia” odnotowały ten fakt 30 lipca (11 sierpnia) [daty podaję w oryginale zarówno według kalendarza juliańskiego, jak i gregoriańskiego, podwójne datowanie obowiązywało w zaborze rosyjskim do 1915 r.] 1864 r., pisząc m.in., iż po południu 15 sierpnia o godz. 16 odbędzie się w sali „Paradyżu” uroczyste poświęcenie sztandaru. Członkowie Towarzystwa muszą zgłosić się po bilety dla rodzin, bez których nie będzie można zostać wpuszczonym (s. 4). Podobne ogłoszenie ukazało się w kolejnym numerze pisma z 1/13 sierpnia 1864 r. W następnych numerach gazeta nie zamieściła już żadnych komentarzy na temat przebiegu uroczystości. 
cieszące się popularnością nie tylko w Łodzi, ale i poza jej granicami. Towarzystw śpiewaczych w Łodzi było wiele, choć należy nadmienić, że niełatwo było prowadzić działalność kulturalną w mieście, które nie uchodziło za kolebkę kultury ani polskiej, ani niemieckiej, ani jakiejkolwiek innej. Wiele stowarzyszeń borykało się z problemami finansowymi i trudnościami natury politycznej. Władze carskie do 1914 r. prowadziły w Łodzi restrykcyjną politykę kulturalną, stąd wiele stowarzyszeń często zamykano bądź znacznie ograniczano ich działalność z obawy przed separatystycznymi dążeniami narodowymi. Znaczny regres $\mathrm{w}$ funkcjonowaniu stowarzyszeń ujawnił się w Łodzi szczególnie po powstaniu styczniowym, gdy zakazano działalności wielu organizacji.

Istotną cezurą dla rozwoju kultury Łodzi była rewolucja 1905 r., kiedy uaktywniły się środowiska robotnicze i kręgi polskiej inteligencji. Dla Polaków impulsem do działania była walka o polskość i chęć stworzenia instytucji upowszechniających kulturę i język polski. W mieście, zdominowanym od wielu lat przez społeczność niemiecką, cel ten wydawał się dla polskiego środowiska absolutnym priorytetem ${ }^{55}$. W tym czasie powstało wiele organizacji dążących do podniesienia stanu wiedzy zawodowej i ogólnej wśród robotników, niezależnie od ich wyznania i narodowości. W 1905 r. powołano do życia m.in. Towarzystwo Krzewienia Oświaty (dalej: TKO), w ramach którego część łódzkiej inteligencji upowszechniała naukę pisania i czytania ${ }^{56}$, choć nie tylko - organizowano także spotkania artystyczne, zabawy, współpracowano z łódzkim teatrem i tworzono sieć wypożyczalni książek. TKO zainicjowało również szkolnictwo wyższe, jednak pomysł ten napotkał początkowo na ogromne trudności ze strony władz. Podobną działalność kulturalno-oświatową prowadziła Polska Macierz Szkolna (dalej: PMS), skupiająca głównie członków Narodowej Demokracji. PMS zakładała polskie szkoły, biblioteki i czytelnie, organizowała kursy czytania i pisania, koncerty i wieczory literackie, była także - podobnie jak TKO - inicjatorką powstania szkolnictwa wyższego $\mathrm{w}$ Łodzi. Zorganizowała Uniwersytet Ludowy PMS, prowadzący wykłady z literatury, historii, geografii i ekonomii ${ }^{57}$.

Niemieckojęzyczni łodzianie dostrzegali również potrzebę rozszerzania działalności oświatowej i tworzenia szkół z wykładowym językiem niemieckim. W tym celu w 1907 r. powołano Niemieckie Towarzystwo Szkolno-Oświatowe, Niemieckie Stowarzyszenie Szkół Realnych i Gimnazjalnych oraz Zwiqzzek Niemieckojęzycznych Majstrów i Robotników. Te trzy organizacje prowadziły szeroko zakrojoną akcję na rzecz tworzenia szkół z wykładowym językiem

\footnotetext{
55 Por. A. Jewtuchowicz, A. Suliborski, Życie społeczne..., s. 150-168.

${ }_{56}$ Zob A. Barszczewska-Krupa, Rodowód..., s. 480-485.

57 Por. K. Chańko, Społeczne stowarzyszenia oświatowo-kulturalne, [w:] Łódź. Dzieje miasta..., s. 526-532.
} 
niemieckim, organizowały także wieczorki literackie, spotkania teatralne oraz koncerty, zakładały biblioteki i czytelnie. Ich działalność kontynuowały m.in. powstały w 1917 r. Der Deutsche Lehrerseminar [Niemiecki Związek Nauczycieli] oraz Der Deutsche Kultur- und Wirtschaftsbund „Fortschritt” [Niemieckie Towarzystwo Kulturalno-Oświatowe „Postęp”], które prezentowały interesy niemieckich socjaldemokratów z Łodzi ${ }^{58}$.

$\mathrm{Z}$ uwagi na charakter działalności warto przyjrzeć się nieco bliżej jednej $\mathrm{z}$ tych organizacji, a mianowicie Deutscher Schul- und Bildungsverein [Niemieckie Towarzystwo Szkolno-Oświatowe, dalej: DSBV]. Powstało 31 stycznia 1907 r. z inicjatywy niemieckich łodzian, pragnących wspierać szeroko pojęte kształcenie ludności niemieckiej w Łodzi. Ogromną rolę w działalności związku odgrywali łódzcy przemysłowcy sponsorujący wiele jego przedsięwzięć. Do założycieli towarzystwa należeli m.in. Ernst Leonhardt, pierwszy przewodniczący związku, a także jego zastępcy Franz Schimmel i Louis Schweikert, następnie skarbnicy Ernst Wever, Leopold Kindermann oraz Gerhard A. Sebastian. W pracach związku uczestniczyli również Karl Weigelt, Rudolf Ziegler, Heinrich Zirkler i Alexis Drewing ${ }^{59}$. Najważniejszym celem stowarzyszenia było zorganizowanie niemieckiego szkolnictwa dla miejscowej młodzieży. Już w pierwszym okresie działalności organizacja zaczęła odnosić sukcesy. W 1906 r. przejęto protektorat nad pierwszym niemieckim gimnazjum, utworzonym przez Bogumiała Brauna z Warszawy. Rok później powołano Niemieckie Stowarzyszenie Szkół Gimnazjalnych i Realnych, które zainicjowało działalność czterech szkół elementarnych z wykładowym językiem niemieckim dla 1200 uczniów i zatrudniło 12 nauczycieli. Kilka lat później sytuacja zmieniła się diametralnie, ponieważ władze carskie ograniczyły prawo do wolności nauczania w języku ojczystym, wprowadzając obowiązek prowadzenia zajęć w języku rosyjskim ${ }^{60}$. Mimo to związek nie zaprzestał działalności - w 1910 r. zrzeszał 64 członków, rok później już 102. Największym osiągnięciem stowarzyszenia było przeniesienie z Warszawy

58 Świadczy o tym m.in. pismo niemieckiego Konsulatu z Łodzi do Auswärtiges Amt z 21 grudnia 1932 r. na temat działalności charytatywnej tej organizacji, w którym konsul Molly podkreśla, iż organizacja ma charakter narodowoniemiecki, występuje przeciwko polonizacji Niemców w Łodzi, a jej organ prasowy „Lodzer Zeitung” często publikuje artykuły skierowane przeciwko polonizacji szkół niemieckich. Por. AA Akten Deutschtum 1932-1935, Bd. 6, 7, Po6a, PA RAV Lodz 39.

59 Por. Der Deutsche Schul- und Bildungsverein zu Lodz. Erinnerungsschrift zum 50. Jahrestag seiner Gründung: 1907-1957, hrsg. v. H. Markgraf, F. Weigelt, Weinheim 1957.

${ }^{60} \mathrm{O}$ charakterze tej organizacji świadczą m.in. pisma niemieckiego Konsulatu z Łodzi (konsula Molly) do Auswärtiges Amt na temat jubileuszu z okazji 25-letniej działalności z 15 listopada 1932 r. oraz 21 grudnia 1932 r., por. Auswärtiges Amt: Akten Deutschtum 1932-1935, Bd. 6, 7, Po6a, PA RAV Lodz 39. Organizacja ta była również finansowo wspierana przez Auswärtiges Amt, por. pismo AA do Niemieckiego Konsulatu w Łodzi z 17 stycznia 1933 r. na temat subwencji; Auswärtiges Amt: Akten Deutschtum 1932-1935, Bd. 6, 7, Po6a, PA RAV Lodz 39. 
do Łodzi Niemieckiego Seminarium, które przez 25 lat działalności wykształciło wielu nauczycieli. Placówka kultywująca niemieckie ideały narodowe istniała do $1937 \mathrm{r}^{61}$

Oprócz tworzenia nowych szkół DSBV zajmowało się także prowadzeniem kursów dokształcających i wykładów, zakładaniem bibliotek oraz czytelni, podtrzymywaniem tradycji muzycznych, wspieraniem aktywności sportowej i innej działalności rozrywkowej wśród mniejszości niemieckiej nie tylko Łodzi, ale i całej Guberni Piotrkowskiej ${ }^{62}$. Szczególnie palącym problemem był niezadowalający poziom wykształcenia robotników niemieckiego pochodzenia, ponieważ wielu z nich ukończyło zaledwie kilka klas rosyjskiej szkoły elementarnej. Dlatego DSBV widziało ogromną potrzebę upowszechniania czytelnictwa wśród szerokich mas. 9 lutego 1910 r. otwarto bibliotekę i czytelnię, w której zgromadzono 2535 książek o wartości 3000 rb. Wiele pozycji zakupiło DSBV we własnym zakresie, część pochodziła z darów. Okazałą kolekcję, liczącą 220 tomów niemieckiej literatury, biblioteka otrzymała od Oskara Schweikerta. Oprócz książek gromadzono również prasę łódzką i berlińską ${ }^{63}$. Czytelników pozyskiwano ogłoszeniami w lokalnej prasie i rozpowszechnianiem informacji w fabrykach. W tym celu przygotowywano specjalne ulotki, przekonujące robotników do samokształcenia poprzez lekturę książek. Dla szerzenia czytelnictwa szczególnie zasłużyli się Oskar Daube, Alexis Drewing, Wilhelm Neumann, Gustaw Kühn oraz Peter Jahnke, tworząc z wielkim zaangażowaniem nowe działy biblioteki i zdobywając kolejne tomy ${ }^{64}$. Już $\mathrm{w}$ rok po rozpoczęciu działalności biblioteka liczyła 250 stałych czytelników.

$\mathrm{Z}$ czasem stało się jednak jasne, że sama biblioteka nie wystarczy do podniesienia poziomu wykształcenia wśród niemieckojęzycznych łodzian. Dlatego zdecydowano o powołaniu Komisji ds. Odczytów, której kierownictwo objął dr Albert Zielke. W prace Komisji zaangażowali się również Bruno Guthke, Karl Weigelt, Wilhelm Kamenz i Ferdinand Schmidt. Wykłady prowadzili niemieccy nauczyciele, tacy jak np. Gottlieb i August Raths, Eberhard Hentschel czy Ernst Gollnick. Ich działalność wspierali lokalni przemysłowcy, zezwalając na rozdawanie w swoich fabrykach ulotek informujących o odczytach. Także pracownicy DSBV osobiście odwiedzali fabryki i zachęcali robotników do podnoszenia poziomu wiedzy ${ }^{65}$. Sami wykładowcy nie posiadali jednak stosownego wykształcenia, by zapewnić wysoki poziom i efektywność edukacji, dlatego władze DSBV podjęły decyzję o sprowadzeniu fachowej pomocy z Niemiec. DSBV otrzymywało stamtąd gotowe referaty, odczytywane następnie przez miejscowych nauczycieli ${ }^{66}$. Z czasem, gdy stowarzyszenie nawiązało kontakty
61 Ibidem.
62 Ibidem.
63 Ibidem.
64 Ibidem.
65 Ibidem.
66 Ibidem. 
z podobnymi organizacjami w Niemczech, do Łodzi zaczęli osobiście przybywać świetni specjaliści z wykładami z różnych dziedzin. Odczyt wygłosił tu m.in. prof. Theodor Litt, wykładowca Instytutu Nauk o Wychowaniu Uniwersytetu w Bonn ${ }^{67}$. Oprócz aktywności oświatowej i wychowawczej DSBV zorganizowało także sekcję dramatyczną i muzyczną. Posiadając w mieście silnego konkurenta w postaci stałej sceny niemieckiej, pierwsza z nich nie odniosła większych sukcesów. Więcej szczęścia miała natomiast sekcja muzyczna, podzielona na instrumentalną i śpiewaczą. Obie grupy cieszyły się dużą popularnością wśród łódzkiej publiczności i prezentowały stosunkowo przyzwoity poziom artystyczny, co było zasługą doskonałych dyrygentów i kapelmistrzów.

I wojna światowa odbiła się negatywnie na aktywności DSBV. Brakowało zarówno nowych członków, jak i środków finansowych do prowadzenia działań statutowych. Dodatkową trudnością było powołanie innej organizacji o nazwie Deutscher Verein für Lodz und Umgebung [Niemiecki Związek dla Łodzi i Okolic] pod kierownictwem Adolfa Eichlera ${ }^{68}$, jednego z wielu łódzkich aktywistów propagujących - jak pisał Mirosław Cygański - ideologię narodowoniemiecką ${ }^{69}$. Nowa organizacja powstała 5 marca $1916 \mathrm{r}$. i w swoim statucie również definiowała cele związane z szerzeniem niemieckiej kultury i oświaty w Łodzi ${ }^{70}$.

\subsection{Biblioteki i ruch wydawniczy}

Jedną z najpowszechniejszych form uczestniczenia w kulturze jest czytelnictwo, a w jego rozwoju istotną rolę pełnią biblioteki oraz ruch wydawniczy. Pod koniec XIX w. nieznany przybysz z Warszawy w takich słowach wypowiedział się na ten temat:

Muzea, zbiory, biblioteki publiczne są to również instytucje nieznane tu wcale; w szalonym iście rozwoju swym Łódź złożyła cały zapas żywotnych swych sił w troskę około materialnego, a nie intelektualnego bytu ${ }^{71}$.

${ }^{67}$ Zob. aneks: Łódzkie sylwetki.

${ }^{68}$ Oprócz Adolfa Eichlera do grupy działaczy propagujących ideologię narodowoniemiecką należeli także Friedrich Flierl, Wilhelm Neumann, Robert Piel, Karol Grams, Ludwig Wolff, Henryk Zirkler, Ernst Leonhardt, Ludwik Schweikert, Henryk Bräutigam, Hans Weyrauch i Bruno Tugemann. Por. M. Cygański, Mniejszość niemiecka w Polsce w latach 1918-1939, Łódź 1962.

${ }^{69}$ Ibidem.

7025 lutego 1917 r. organizacja zmieniła nazwę na Deutscher Verein, Hauptsitz in Lodz [Niemiecki Związek. Siedziba w Łodzi].

71 Por. Przewodnik ilustrowany po Warszawie, Łodzi i okolicach fabrycznych, Warszawa 1897. 
U progu rozwoju przemysłowego Łódź posiadała niewielki księgozbiór znajdujących się przy pierwszej łódzkiej szkole elementarnej. Biblioteka miała zaledwie kilka polskich książek z zakresu metodyki nauczania, przeznaczonych dla miejscowych nauczycieli ${ }^{72}$. W pierwszych latach istnienia Łódź przemysłowa posiadała pojedyncze księgozbiory domowe, należące głównie do miejscowej inteligencji, jako że niemieccy osadnicy w swych bagażach przywozili modlitewniki, Biblię i literaturę niemieckojęzyczną ${ }^{73}$. Jak wynika z inwentarza majątków, sporządzonego w 1829 r., łódzki fabrykant Geyer przywiózł z sobą 58 egzemplarzy niemieckich publikacji ${ }^{74}$. Książki gromadzili również inni przemysłowcy. Christian Friedrich Wendisch pozostawił po sobie 18 egzemplarzy, zaś Juliusz Kunitzer miał ok. 200 tomów, głównie w języku niemieckim ${ }^{75}$. Pokaźne księgozbiory znalazły się również w posiadaniu innych przemysłowców, Karola Wilhelma Scheiblera czy Ludwika Grohmanna ${ }^{76}$. W ich domowych bibliotekach przeważała literatura piękna autorstwa Lessinga, Herdera, Puszkina czy Gogola ${ }^{77}$. Także społeczność żydowska gromadziła własne księgozbiory, obejmujące dzieła Moliera, Hugo, Goethego, Heinego, Dostojewskiego czy Kraszewskiego ${ }^{78}$. Potwierdza to fakt, że społeczności Łodzi nieobcy był nawyk sięgania po książki, bowiem księgozbiory domowe i samo ich istnienie należy rozumieć jako miernik częstotliwości kontaktów ze słowem pisanym i jako sygnał - niekiedy jeszcze nikły - potrzeby obcowania z literaturą. W wielu przypadkach książka była jednak zaledwie nieodzownym elementem dekoracyjnym willi, pałacu czy rezydencji i świadczyła nie tyle o oczytaniu jej właściciela, ile raczej o jego zamożności i prestiżu.

Łódzcy fabrykanci zaopatrywali się w książki za granicą, podczas pobytów na studiach. Kolekcję Biedermannów zapoczątkował Alfred Biedermann (1866-1936), nabywając woluminy w czasie studiów w Zurychu i Getyndze (obecnie zbiory rodziny znajdują się w zasobach Książnicy Łódzkiej). Inną możliwością kontaktu z książką, dostępną również dla mniej zamożnych łodzian, były księgarnie Ludwika Fiszera ${ }^{79}$, Cezarego Richtera ${ }^{80}$, S. Strakuna ${ }^{81}$,

${ }^{72}$ Por. J. Konieczna, Kultura książki polskiej w Łodzi przemysłowej 1820-1918, Łódź 2005, s. 17-28.

${ }^{73}$ Ibidem.

${ }^{74}$ Por. A. Kempa, Księgozbiory Niemców łódzkich, „Tygiel Kultury” 7-9/2005, http:// www.tygielkultury.eu/7_9_2005/aktual/24ram.htm [dostęp: 10.12.2013].

75 Ibidem.

${ }^{76}$ Por. S. Pytlas, Łódzka burżuazja..., s. 224-233.

77 Ibidem.

${ }^{78}$ Ibidem.

${ }^{79}$ Zob. aneks: Łódzkie sylwetki.

${ }^{80}$ Ibidem.

81 Ibidem. 
R. Horna ${ }^{82}$ czy Józefa Alfreda Straucha ${ }^{83}$, przy których organizowano wypożyczalnie ${ }^{84}$. Obejmowały one zazwyczaj księgozbiory wielojęzyczne z przewagą beletrystyki. Z zachowanego katalogu wypożyczalni książek Ludwika Fiszera mieszczącej się przy ul. Piotrkowskiej 48 wynika, iż w 1910 r. dział niemiecki liczył 1839 tytułów, obejmował zaś beletrystykę w języku oryginału i w przekładach. Część tego zbioru pochodziła przypuszczalnie z darów miejscowych Niemców lub z zakupów antykwarycznych, co potwierdzają o pięćdziesiąt i więcej lat wcześniejsze daty wydań książek (np. Der Mäuseturm am Goplo-See Bronikowskiego 1827, Han z Islandii 1833, Notre Dame de Paris 1836, RuyBlas 1839 Hugo czy Der Gelehrte Bulwera1835). W katalogu figurują przygodowe i awanturnicze powieści Coopera, Maya i obu Dumasów, dzieła Gerharda Hauptmanna, Maurycego Jokaia, Maksyma Gorkiego, Stanisława Przybyszewskiego, Józefa Ignacego Kraszewskiego Der Dichter und die Welt, Die Gräfin Cosel i Mirtala Elizy Orzeszkowej ${ }^{85}$.

Początkowo dostęp do księgozbiorów, oprócz zamożnych fabrykantów i nauczycieli, miała ucząca się młodzież. W 1868 r. niewielki księgozbiór (196 tytułów w 298 tomach) posiadała Szkoła Powiatowa Specjalna, znana wcześniej jako Szkoła Powiatowa Niemiecko-Rosyjska, a potem niemieckie gimnazjum realne. W 1911 r. biblioteka tego gimnazjum wykazywała na stanie 1500 tomów w języku niemieckim i 1037 tomów w języku rosyjskim ${ }^{86}$.

W miarę upowszechniania czytelnictwa zaczęły powstawać w Łodzi samodzielne biblioteki publiczne, takie jak Biblioteka Miejska oraz biblioteki przyfabryczne, z których największe funkcjonowały przy zakładach głównie niemieckich przedsiębiorców - K. Scheiblera, F. Leonhardta, J. Hirschberga i in. Książki niemieckojęzyczne znajdowały się również w zasobach Miejskiej Biblioteki Publicznej w Łodzi, którą aż do wybuchu wojny wzbogacały dary miejscowych Niemców. 29 kwietnia 1939 r. wprowadzono do jej inwentarza 522 dzieła w 822 tomach, pozostałe po zmarłej 18 lutego tego roku Matyldzie Grohmanowej. W niespełna miesiąc później Franciszka Enderowa ofiarowała Bibliotece 16 roczników czasopism i 19 tytułów książek w 22 woluminach ${ }^{87}$.

Liczba książek w różnego rodzaju księgozbiorach sukcesywnie wzrastała. I tak np. utworzona w 1898 r. Łódzka Wypożyczalnia Książek liczyła w 1911 r. ponad 11000 woluminów, wśród których nie brakowało książek

${ }^{82}$ Ibidem.

${ }^{83}$ Ibidem.

${ }^{84}$ Więcej na temat księgarstwa łódzkiego zob. J. Strzałkowski, Drukarnie i księgarnie w Łodzi do 1944 roku, Łódź 1999; J. Jaworska, Poczq̨tki księgarstwa w Łodzi, „Roczniki Biblioteczne” 1-2/1969; J. Krakowiak, Od Fiszera do „Pegaza”, Łódź 2005.

85 Por. A. Kempa, Księgozbiory...

${ }^{86}$ Ibidem.

${ }^{87}$ Ibidem. 
dla dzieci i beletrystyki, ale także publikacji o charakterze naukowym i popularnonaukowym. Większość bibliotek pobierała od czytelników miesięczne opłaty. W 1911 r. w bibliotece utworzonej pod patronatem PMS opłata czytelnicza wynosiła 5 kop. miesięcznie. Mimo iż była to suma stosunkowo niewielka, zadłużenie czytelników wynosiło ok. 200 rb $^{88}$.

Bogatymi księgozbiorami mogły się poszczycić łódzkie stowarzyszenia naukowe, kulturalno-oświatowe i zawodowe. Jedną z największych bibliotek związkowych powołano w 1890 r. pod patronatem Stowarzyszenia Wzajemnej Pomocy Pracowników Handlowych $m$. Łodzi. Jej księgozbiór obejmował początkowo 488 pozycji, głównie o charakterze ekonomicznym, ale już kilkanaście lat później biblioteka dysponowała ponad 6700 woluminami i oferowała oprócz literatury fachowej również ciekawą beletrystykę. W okresie rewolucji 1905 r. zainteresowanie czytelnictwem zaczęli przejawiać już nie tylko przedstawiciele inteligencji, lecz także robotnicy. $W$ związku $\mathrm{z}$ tym otwierano dla nich biblioteki przy najróżniejszych stowarzyszeniach i związkach. W wielu z nich część księgozbioru tworzyły książki fachowe oraz literatura propagandowa, podnosząca świadomość klasy robotniczej ${ }^{89}$. Obok polskich bibliotek zakładano również biblioteki robotnicze dla społeczności żydowskiej i niemieckiej. Powstałe w 1912 r. Stowarzyszenie Pracowników Handlowych Żydów Wzajemna Pomoc zorganizowało bibliotekę liczącą 1525 woluminów, natomiast niemiecki proletariat utworzył przy Gewerkschaft Evangelischer Textilarbeiter dość pokaźny księgozbiór, obejmujący głównie literaturę niemieckojęzyczną.

Własnymi bibliotekami dysponowały także stowarzyszenia zrzeszające łódzką inteligencję. Kilkaset tomów zgromadziły przykładowo biblioteki Łódzkiego Oddziału Polskiego Towarzystwa Esperantystów oraz Polskiego Towarzystwa Teatralnego. Niemiecka inteligencja skupiona wokół Stowarzyszenia Młodzieży Ewangelickiej również posiadała własną aczkolwiek niewielką bibliotekę, a w niej 74 książki o treści religijnej, naukowej i beletrystycznej oraz 13 tytułów prenumerowanych czasopism, m.in. „Kłosy”, „Dziennik Łódzki”, „Głosy Kościelne”, „Zeitschrift für die Textilindustrie”, „Der Bundesbote”, „Das Vereinsblatt für evangelisch-lutherische Jünglinge” czy „Sankt-Petersburger Herold”. O wiele większa była biblioteka utworzona przy Łódzkim Niemieckim Stowarzyszeniu Popierania Oświaty. Jej księgozbiór obejmował w 1918 r. ponad 4000 tomów ${ }^{90}$. Pod koniec 1929 r. instytucja ta posiadała 6823 woluminy w języku niemieckim i 419 zarejestrowanych czytelników. Biblioteką kierowali Piotr Jahnke i jego zastępczyni Olga Bayer, członkowie Stowarzyszenia Nauczycieli Niemieckich, które

\footnotetext{
88 Por. J. Konieczna, Biblioteki, [w:] Łódź. Dzieje miasta..., s. 562-570.

${ }^{89}$ Ibidem.

${ }^{90}$ Ibidem.
} 
w 1917 r. przejęło nadzór nad księgozbiorem Niemieckiego Stowarzyszenia Popierania Oświaty. W 1916 r. utworzono za zgodą władz okupacyjnych bibliotekę nacjonalistycznego Deutscher Verein [Stowarzyszenie Niemieckie], która w 1918 r. liczyła ponad 5000 tomów z zakresu beletrystyki, historii, geografii, pedagogiki i religii. W 1917 r. ze zbiorów bibliotecznych korzystało blisko 1100 czytelników, zarówno członków stowarzyszenia, jak i niezrzeszonych. Na potrzeby młodzieży stowarzyszenie zorganizowało odrębną bibliotekę. Pozycje z księgozbiorów opatrywano pieczęciami, takimi jak np. „Eigentum des Deutschen Vereins für Lodz und Umgegend” [Własność Związku Niemieckiego dla Łodzi i Okolic] lub „Bücherei der Deutschen zur Förderung von Schulbildung und allgemeiner Bildung in Lodz" [Biblioteka Niemców dla Wspierania Kształcenia Szkolnego i Ogólnego w Łodzi]. Stowarzyszenie miało dość duże zasługi w propagowaniu czytelnictwa, przykładowo organizując regularnie dni książki, w ramach których prezentowano odczyty lokalnych pisarzy. I tak 22 marca $1931 \mathrm{r}$. stowarzyszenie zorganizowało imprezę, podczas której wykłady wygłosili Sigismund Banek (na temat „Ducha książki”), Julian Will („Kobieta i książka”), Magdalena Schwarz („Kobieta w polskiej literaturze) i Heinrich Slapa („Książka jako dziedzictwo kultury") $)^{91}$.

Równie pokaźny księgozbiór posiadała inteligencja żydowska, skupiona wokół Towarzystwa Ibrijah, której biblioteka obejmowała ok. 2000 książek w języku hebrajskim.

W domach robotników książki pojawiły się na przełomie lat 80. i 90. XIX w., wraz z konsolidacją ruchu robotniczego, reprezentowanego przez Zwiq̨zek Robotników Polskich ${ }^{92}$. Ludność robotnicza najchętniej sięgała po druki o charakterze ideologicznym, coraz częściej kupowała również książki i czytała gazety. Duża liczba pozycji literatury wspomnieniowej potwierdza intelektualne ambicje łódzkiej społeczności robotniczej, w tym gotowość gromadzenia literatury ${ }^{93}$. Na początku XX w. wiele rodzin robotniczych posiadało mniejsze lub większe księgozbiory, w których przeważała literatura popularnonaukowa, pozwalająca zaspokoić wiedzę z danej dziedziny. Rzadziej była to literatura piękna, częściej natomiast znajdowały tu swoje miejsce różne czasopisma. W porównaniu z klasą robotniczą inteligencja łódzka nie wypadała lepiej. Także i te kręgi rzadko kupowały książki, a jeśli już to przeważnie o charakterze popularnym ${ }^{94}$.

91 Tag des Buches, ADMuW (Archiv der Deutschen aus Mittelpolen und Wolhynien), sygn. A1cV, nr 615.

92 J. Krajewska, Czytelnictwo wśród robotników w Królestwie Polskim 1870-1914, Warszawa 1979.

${ }^{93}$ L. Rudnicki, Odrodzenie, Warszawa 1920; Stare i nowe, Warszawa 1949-1950; J. Jeremski, Bratobójcy, Warszawa (b.r.w.); Ludzie z parteru, Warszawa 1936.

${ }^{94}$ Por. J. Konieczna, Biblioteki..., s. 562-570. 
Zainteresowanie książką w społeczeństwie łódzkim wciąż rosło. Posiadanie własnego zbioru literatury upowszechniło się szczególnie wśród niemieckojęzycznych osadników drugiego i trzeciego pokolenia, ponieważ byli to już ludzie wykształceni i zainteresowani kulturą. Poza tym studia odbywane w zagranicznych uczelniach obligowały do zapoznania się z najnowszym kanonem literatury światowej.

Biblioteki powstawały również przy parafiach, np. w Radogoszczu. Tam księgozbiorem opiekował się pastor Karol Serini. W 1922 r. utworzono książnicę przy kościele ewangelicko-augsburskim św. Jana Ewangelisty przy ul. Sienkiewicza 60.

Okres wojenny miał zdecydowanie negatywny wpływ na rozwój bibliotek. We wrześniu 1939 r. po zajęciu Łodzi przez wojska niemieckie władze okupacyjne przystąpiły do likwidacji polskich bibliotek publicznych, oświatowych i prywatnych. Większość książek wywieziono na przemiał do papierni w Pabianicach, część spalono w rowach przeciwczołgowych, natomiast zbiory Miejskiej Biblioteki Publicznej przeniesiono z dotychczasowej siedziby przy ul. Andrzeja 14 (obecnie Miejska Biblioteka Publiczna Łódź-Śródmieście) do lokalu przy ul. Gdańskiej. Zadanie zorganizowania niemieckiej sieci bibliotek publicznych otrzymał Sigismund Banek, poeta i szef Niemieckiego Stowarzyszenia Popierania Oświaty w Łodzi, zaś w czasie okupacji przywódca łódzkiej Kreisgruppe Heimatbund. Mianowano go kierownikiem Stadtbücherei Litzmannstadt. Niemieckiej Bibliotece Miejskiej, posiadającej pod koniec okupacji wraz z siedmioma filiami ponad 50000 woluminów, przydzielono lokal na parterze w gmachu „Pod Gutenbergiem” przy ul. Piotrkowskiej 86. Książki, częściowo przejęte ze zlikwidowanych bibliotek niemieckich stowarzyszeń kulturalnych i szkół oraz dubletów Staats- und Universitätsbibliothek w Poznaniu, zgrupowano według podstawowych działów, tworząc zbiory, takie jak Pädagogische Bücherei, Musikbücherei, Wissenschaftliche Bücherei i in.

Po zakończeniu działań wojennych znaczna część zasobów bibliotecznych Litzmannstadt trafiła do Miejskiej Biblioteki Publicznej i została wykorzystana do stworzenia wyodrębnionych działów Biblioteki (Zbiorów Muzycznych i Pracowni Regionalnej).

\section{4. Życie literackie Łodzi}

Środowisko literackie stanowi dla rozwoju kulturalnego danego miejsca element niezwykle istotny. Jednak warunki, w jakich wyrastała Łódź przemysłowa, jak już to zostało wcześniej wspomniano, nie sprzyjały rozwojowi intelektualnemu i kulturalnemu. Ludwik Stolarzewicz tak rozpoczyna swoje rozważania na temat literatury w tym mieście: 
Łódź - drugie co do ilości mieszkańców miasto w Polsce - jedno z ostatnich... jeżeli chodzi o życie literacko-naukowe. Łódź - Manchester polski! Łódź - miasto pracy - ośrodek polskiego przemysłu włókienniczego - miasto bez tradycji i przeszłości historycznej. Czyżby więc można w niej mówić o jakiejś pracy umysłowej? Czyż możliwa w niej jakaś atmosfera dla poety-powieściopisarza? ${ }^{95}$

Autor rozprawy słusznie stawia pytania o przyjazną ludziom pióra atmosferę i tradycje, których na początku XIX w. w Łodzi nie było. Zapewne w porównaniu z takimi ośrodkami, jak Kraków czy Warszawa, Łódź była kulturalną prowincją, nieposiadającą historii i atmosfery sprzyjającej rozwojowi środowiska literackiego. Ogromny wpływ na taki stan rzeczy miała struktura społeczna miasta. Do lat 20. XIX w. Łódź posiadała wprawdzie status miasta, nie zdołała jednak wykształcić struktur społecznych, stymulujących rozwój kultury. Do tego czasu inteligencję Łodzi reprezentowała niewielka grupa ludzi: nauczyciel, ksiądz oraz burmistrz. Brak było intelektualistów, którzy staliby się inicjatorami życia kulturalnego. Sytuacja zmieniła się nieco z chwilą przybycia pierwszych niemieckich osadników, choć fakt ten nie oznacza jeszcze dużego ożywienia życia kulturalnego. Przybywający do Łodzi zagraniczni osadnicy zainteresowani byli głównie poprawianiem warunków własnej egzystencji materialnej, rekrutując się przeważnie spośród niezamożnych tkaczy i rzemieślników o ograniczonej potrzebie uczestniczenia w życiu kulturalnym. Również Polacy, napływający z okolicznych miast i wsi, byli przeważnie chłopami, którzy po uwłaszczeniu poszukiwali pracy.

Aktywność inteligencji w dziedzinie kultury była zatem bardzo ograniczona i w Łodzi istniało niewiele grup artystycznych, literackich oraz innych środowisk twórczych. Jednym z prężniej działających środowisk byli łódzcy dziennikarze i pastorzy. Znaczny przyrost polskiej inteligencji odnotowano tuż przed wybuchem I wojny światowej i był on zapewne związany z rosnącą świadomością narodową Polaków. Wraz ze zwiększającą się liczbą kręgów inteligenckich budziła się potrzeba uczestniczenia $\mathrm{w}$ różnego rodzaju aktywnościach kulturalnych i inicjowania różnorodnych przedsięwzięć. Najliczniejszą grupę stanowili $\mathrm{w}$ Łodzi muzycy, zapewne $\mathrm{z}$ uwagi na istnienie powstających tu na przestrzeni wielu lat towarzystw śpiewaczych i muzycznych $^{96}$. Drugim co do wielkości było środowisko artystów dramatycznych, rewiowych i reżyserów. Niewielu było w Łodzi natomiast przedstawicieli sztuk pięknych, a więc malarstwa i rzeźby, zaś najmniej liczną grupę stanowili pisarze. Wielu z nich było artystami-amatorami, nieposiadającymi odpowiedniego wykształcenia. Charakterystyczny dla rozwoju kultury Łodzi był również fakt, iż środowisko artystyczne, w tym także literackie, tworzyła inteligencja

\footnotetext{
95 L. Stolarzewicz, Literatura Łodzi..., s. 7.

${ }_{96}$ Por. A. Pellowski, Kultura muzyczna Łodzi do roku 1918, Łódź 1994.
} 
napływowa. Duże zasługi dla rozwoju kultury mieli przybywający z Warszawy pisarze, dziennikarze i nauczyciele, stający się motorem wszelkich poczynań kulturalno-artystycznych. Wielu z nich pracowało tu w charakterze korespondentów warszawskich gazet, takich jak „Kurier Warszawski”, „Kurier Codzienny”, „Gazeta Polska”, „Gazeta Warszawska”, „Słowo” czy „Wiek”. Z Warszawy przybył do Łodzi m.in. Oskar Flatt. Zafascynowany miastem poświęcił mu pierwszą monografię, którą można uznać za początek łódzkiego piśmiennictwa ${ }^{97}$.

Do lat 80. XIX w. życie literackie w Łodzi praktycznie się nie rozwijało. Dopiero stworzenie przez Henryka Elzenberga (1849-1899), prawnika i absolwenta Szkoły Głównej, „Dziennika Łódzkiego”98 spowodowało pewne ożywienie. Z gazetą współpracowali m.in.: Eliza Orzeszkowa, Maria Szeliga ${ }^{99}$, Waleria Marrené-Morzkowska ${ }^{100}$, Łucjan Kościelecki ${ }^{101}$, Karol Łaganowski ${ }^{102}$ i Antoni Mieszkowski ${ }^{103}$. Przyglądając się bliżej biografiom tych osób, można stwierdzić, że między Łodzią i Warszawą rozwinęła się swego rodzaju literacka współpraca, z której Łódź czerpała wiele korzyści. Twórczość literacka prezentowana na łamach „Dziennika Łódzkiego” obejmowała głównie felietony, krótkie opowiadania, reportaże, niekiedy powieści w odcinkach oraz poezję użytkową. W latach 90. ubiegłego wieku w łódzkich gazetach drukowano utwory Artura Glisczyńskiego ${ }^{104}$, jedynie przez dość krótki okres swego życia związanego z Łodzią, a następnie mieszkającego w Warszawie. Tam stworzył utwory m.in. poświęcone Łodzi: Z mroku i dymu, Tragedie miejskie, Obrazki. Łódź powoli stawała się również tematem powieści. Na łamach „Biesiady Lite-

97 Por. H. Karwacka, Opis miasta Łodzi Oskara Flatta początkiem piśmiennictwa przemysłowego miasta, „Prace Polonistyczne”1976, ser. XXXII, s. 249-264.

98 „Dziennik Łódzki” był pismem łódzkiej inteligencji. Kontynuował program warszawskiego pozytywizmu i szerzył kulturę polską w wielonarodowym środowisku łódzkim. W sferze społecznej pismo cechowało się umiarkowaniem, ale podejmowało też krytykę stosunków narodowościowych i wypowiadało się w obronie robotników. Jego założycielem był wspomniany Henryk Elzenberg, wydawcą zaś Stefan Kossuth, a redaktorem odpowiedzialnym Zdzisław Kułakowski. Pierwszy numer ukazał się 6 stycznia 1884 r. Gazeta wychodziła do 1892 r. W 1919 r. próbowano wznowić druk, jednak bez powodzenia. Kolejne próby podjęto w latach 1931-1932. Pismo ukazywało się najpierw pod nazwą „Dziennik Łódzki - Niezależne Pismo Poranne”, a następnie jako „Ilustrowany Dziennik Łódzki“, którego redaktorem odpowiedzialnym był Józef Przybylski. Po 1945 r. gazeta należała do koncernu RSW Prasa-Książka-Ruch, a w 2000 r. połączono ją z dziennikiem „Wiadomości Dnia”. Od 2007 r. ukazuje się pod nazwą „Polska Dziennik Łódzki”. Por. J. Walicki, „Dziennik Łódzki” - Nasze 115-lecie, Łódź 1999.

${ }_{99}$ Zob. aneks: Łódzkie sylwetki.

${ }^{100}$ Ibidem.

101 Ibidem.

102 Ibidem.

${ }^{103}$ Ibidem.

104 Ibidem. 
rackiej”105 opublikowano w 1890 r. w odcinkach niecieszącą się zbyt wielkim uznaniem czytelników i krytyki literackiej powieść Walerii Marrené-Morzkowskiej Wśród kqkolu ${ }^{106}$. Opisowi Łodzi poświęcili swe utwory dwaj inni pisarze, Wincenty Kosiakiewicz ${ }^{107}$, autor powieści Bawełna ${ }^{108}$, oraz Władysław Stanisław Reymont, który akcję jedynej znanej powieści o Łodzi pt. Ziemia obiecana $^{109}$ umieścił właśnie w tym mieście.

Środowisko artystyczne i kultura Łodzi czerpią wiele korzyści z działalności Wiktora Czajewskiego ${ }^{110}$. Wokół niego i jego pisma „Rozwój” życie artystyczno-literackie zaczęło nabierać żywszych kolorów. Czajewski zadbał też o działalność wydawniczą, publikując teksty dotyczące m.in. dziejów Polski, polskiej literatury i teatru. Na łamach „Rozwoju” propagował kult idei pozytywistycznych, a jako swych ulubionych pisarzy popularyzował Bolesława Prusa i Henryka Sienkiewicza. Jego gazeta informowała o różnorodnych imprezach o charakterze kulturalnym, a więc o rocznicach i jubileuszach, a także organizowała konkursy literackie. Z inicjatywy Czajewskiego zorganizowano m.in. konkurs dramatyczny im. Henryka Sienkiewicza oraz konkurs nowelistyczny im. Bolesława Prusa. $\mathrm{Z}$ redakcją gazety współpracowali m.in. Zygmunt Bartkiewicz ${ }^{111}$, autor zbioru Złe miasto $^{112}$, Bolesław Gorczyński ${ }^{113}$, Artur Glisczyńskii ${ }^{114}$, Władysław Rowiński ${ }^{115}$,

105 „Biesiada Literacka” to ilustrowany tygodnik literacki i polityczny, wydawany w latach 1867-1917 pod redakcją W.J. Maleszewskiego i M. Synoradzkiego. Drukowano w nim teksty m.in. P. Chmielowskiego, J.I. Kraszewskiego, H. Sienkiewicza, B. Prusa, M. Rodziewiczówny, J. Kaden-Bandrowskiego.

106 Powieść W. Marrené-Morzkowskiej Wśród kq̨kolu ukazywała się na łamach „Biesiady Literackiej" w 1890 r. Por. Łódź, która przeminęła w publicystyce i prozie, red. P. Boczkowski, Łódź 2008.

107 Zob. aneks: Łódzkie sylwetki.

108 W. Kosiakiewicz, Bawełna, Petersburg 1895.

109 W.S. Reymont, Ziemia... Powieść ukazywała się początkowo w odcinkach na łamach łódzkiego „Kuriera Codziennego”.

110 Zob. aneks: Łódzkie sylwetki.

111 Ibidem.

112 Publikacja wydana po raz pierwszy w 1911 r. była zbiorem szkiców autora na temat Łodzi pogrążonej w porewolucyjnym zamęcie po wydarzeniach 1905 r. Pracę kilkakrotnie wznawiano (najpierw dwa razy za życia autora, w 1918 i 1930 r., oraz w Bibliotece „Tygla Kultury" w 2001 r.). Pisząc swą książkę początkowo w formie cyklu reportaży ukazujących się regularnie w warszawskim tygodniku „Świat”, Bartkiewicz wskazywał przede wszystkim na ogromne zróżnicowanie społeczne mieszkańców Łodzi - z jednej strony istniała najbogatsza klasa składająca się z przemysłowców, fabrykantów i kupców, z drugiej żyjąca w nędzy i wyzysku najbiedniejsza warstwa robotników. Taki obraz Łodzi m.in. za sprawą Bartkiewicza zapisał się w polskiej literaturze, zaś Łódź zyskała obok miana „ziemi obiecanej” także określenie „złe miasto”.

113 Zob. aneks: Łódzkie sylwetki.

114 Ibidem.

115 Ibidem. 
Władysław Ratyński ${ }^{116}$, Mieczysław Herz ${ }^{117}$ oraz Stanisław Łąpiński ${ }^{118}$. Do wybuchu I wojny światowej środowisko łódzkich literatów skupiało się głównie wokół gazet, tam bowiem mogli publikować swą twórczość. Również w okresie wojny większość z nich była związana z prasą. Na łamach „Gazety Łódzkiej”119 publikowano dość regularnie poezję łódzkich twórców: Aleksego Rżewskiego ${ }^{120}$, Mieczysława Brauna ${ }^{121}$, Aleksandra Kraśniańskiego ${ }^{122}$ i Juliana Tuwima. W latach powojennych zamieszczano $\mathrm{w}$ gazetach utwory kolejnych literatów, takich jak Maria Przedborska ${ }^{123}$, Mieczysław Jastrun, Witold Wandurski ${ }^{124}$, Zofia Jabłońska czy Halina Stawarska. Lokalni autorzy zabiegali o stworzenie pisma kulturalno-literackiego, jednak wysiłki okazywały się najczęściej bezowocne, ponieważ tego rodzaju czasopisma zazwyczaj nie budziły zainteresowania czytelników. W okresie międzywojennym również Łódzki Klub Literacki ${ }^{125}$ zabiegał o wydanie regionalnego periodyku „Prądy”126. Wszystkie te próby nie powiodły się i Łódź w okresie międzywojennym nadal pozostawała bez poważnego czasopisma artystyczno-literackiego. Również pod koniec lat 30. XX w. wszystkie pisma literackie miały charakter efemerydalny: w 1936 r. zaczęto wydawać „Budowę"127,

${ }^{116}$ Ibidem.

117 Ibidem.

118 Ibidem.

119 „Gazeta Łódzka” ukazywała się od 1 lutego 1912 do 1915 r. i zyskała dużą popularność wśród mieszkańców Łodzi. Wydawcą i drukarzem był Jan Grodek.

120 Zob. aneks: Łódzkie sylwetki.

121 Ibidem.

122 Ibidem.

123 Ibidem.

124 Ibidem.

125 Łódzki Klub Literacki powołano do życia 26 lutego 1931 r., a jego prezesem został Marian Piechal. Po kilku tygodniach, 12 kwietnia, w Instytucie Propagandy Sztuki w parku Sienkiewicza odbyło się posiedzenie organizacyjne Klubu i wieczór inauguracyjny „Prądów”, nowego czasopisma literackiego Łodzi. Por. A. Kempa, Zjazd, którego nie było, „Tygiel Kultury”, 7-9/2009; E. Pleszkun-Olejniczakowa, Czasopisma kulturalne w Łodzi. Dwudziestolecie międzywojenne, „Tygiel Kultury” 4/1996, s. 75-78.

126 „Prądy” - czasopismo literackie. Pierwszy numer, opatrzony podtytułem „Regionalne czasopismo Łódzkiego Klubu Literackiego”, ukazał się w marcu 1931 r., następne dwa numery wyszły w maju i w listopadzie, zaś numer czwarty i zarazem ostatni wydano w marcu następnego roku. Mimo przymiotnika „regionalne” pismo wybiegało tematycznie daleko poza ramy regionalizmu. Pisywali do „Prądów” nie tylko łodzianie, ale i pisarze, często awangardowi, spoza Łodzi. Por. E. Pleszkun-Olejniczakowa, Czasopisma ..., s. 75-78.

127 „Budowa” - czasopismo literacko-artystyczne, utworzone w 1936 r. przez Kazimierza Sowińskiego. Miało charakter efemerydalny i doczekało się zaledwie trzech numerów: pierwszy ukazał się w styczniu, drugi w marcu, trzeci w czerwcu 1936 r. Publikowali tu obok łodzian: Rafała Lena, Mariana Piechala, Kazimierza Sowińskiego, Grzegorza Timofiejewa i Władysława Strzemińskiego, także: Jan Brzękowski i Jan Kurek (obaj związani z awangardą krakowską), Józef Czechowicz (z awangardy lubelskiej) oraz postaci zasłużone dla łódzkiej kultury i oświaty. Ibidem. 
dwa lata później „Kulturę Łodzi”128, następnie „Odnowę"129, „Osnowy Literac-

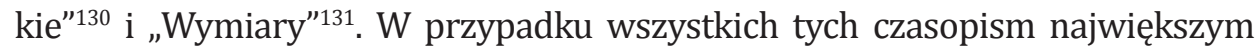
problemem był brak solidnych funduszy dla zapewnienia im dalszej egzystencji na rynku prasowym.

W okresie międzywojennym środowisko łódzkich literatów z oczywistych względów nie należało do przodujących, zaś tworzący tu ludzie pióra rzadko dotrzymywali kroku najnowszym trendom pojawiającym się $\mathrm{w}$ literaturze narodowej. Nawet przybywający do Łodzi przedstawiciele inteligencji galicyjskiej, jak przykładowo Aleksander Bolesław Cyps, wykazywali anachroniczne gusta literackie (Cyps odwoływał się w swoich tekstach do epoki Młodej Polski). Brakowało zatem jakichkolwiek wybitnych autorów, których dzieła czytano by także poza granicami Łodzi.

Typową cechą tego środowiska był jego robotniczy charakter, ponieważ wielu pisarzy było niezmiernie wyczulonych na krzywdę proletariatu i kapitalistyczny wyzysk. Do takich pisarzy robotniczych można zaliczyć Lucjana Rudnickiego ${ }^{132}$, Władysława Pawlaka ${ }^{133}$ i Antoniego Kasprowicza. Niewątpliwie jednak środowisko łódzkich literatów, niemające w tym czasie sobie podobnego, było na swój sposób unikalne. Większość łódzkich autorów nie utrzymywała się z pisarstwa, lecz pracowała jako nauczyciele, adwokaci czy

128 „Kultura Łodzi” - czasopismo poświęcone życiu literackiemu miasta, redagowane i wydawane przez Ludwika Stolarzewicza, ukazywało się od lutego do czerwca 1938 r. Łącznie wydano pięć numerów, w których dokonano szczegółowego przeglądu stanu i rozwoju poszczególnych dziedzin życia kulturalnego Łodzi, a także poinformowano o perspektywach rozwoju kultury literackiej miasta. Pismo potwierdzało już wyraźnie świadomość istnienia życia literackiego Łodzi. W skład komitetu redakcyjnego wchodzili poza Stolarzewiczem: Jan Augustyniak, Henryk Dzienisiewicz, Alojzy Jamroz, Antoni Kasprowicz, Marian Piechal i Bohdan Pawłowicz. Ibidem.

129 „Odnowa” - pismo poświęcone literaturze i kulturze (od grudnia 1938 do stycznia 1939 r. ukazały się zaledwie dwa numery), redagowane przez Mariana Piechala. Publikowano w nim wiersze, kronikę kulturalno-oświatową z uwzględnieniem teatru, sztuk plastycznych, muzyki, radia oraz przeglądy i recenzje artykułów prasowych i książek.

130 „Osnowy Literackie” - czasopismo redagowane przez Krystynę Chruścielską, wydawane przez Mariana Adamczyka-Zarembę. Od maja 1938 do marca 1939 r. wyszło sześć numerów. Pismo miało charakter lokalny i nie podejmowało prób nawiązania kontaktów z twórcami pozałódzkimi. Ibidem

131 „Wymiary” były pismem najbardziej znaczącym w życiu literackim miasta. Redakcją zajmowali się Tadeusz Sarnecki i Grzegorz Timofiejew. Gazeta ukazywała się ponad rok; ostatni, dwunasty numer wyszedł z datą czerwiec-lipiec 1939 r. „Wymiary” nawiązywały treścią i formą do „Prądów”, a pośrednio także do „Meteora”. Pismu o stosunkowo dużym jak na ówczesne warunki nakładzie (10 000 egzemplarzy) starano się nadać charakter ogólnopolski; było ono związane z demokratyczną myślą ówczesnej lewicującej inteligencji. Z „Wymiarami” utrzymywali kontakt wybitni twórcy, krytycy i naukowcy, także spoza Łodzi. Ibidem.

${ }^{132}$ Zob. aneks: Łódzkie sylwetki.

133 Ibidem. 
dziennikarze. Z pracy literackiej nie mogliby utrzymać rodzin, stąd zapewne tak duże zainteresowania tematyką społeczną i biedą. Tak więc mało profesjonalny charakter łódzkiego środowiska literackiego miał również wpływ na poziom artystyczny tekstów. Już współcześni badacze łódzkiej literatury, jak np. Ludwik Stolarzewicz ${ }^{134}$, wypominał łódzkim pisarzom ich literacką miernotę ${ }^{135}$. Dość późno pojawiła się w Łodzi twórczość dramatyczna, a wśród niewielkiego grona jej autorów należy wymienić Ludwika Stolarzewicza, Witolda Wandurskiego i Walerię Nahurską.

Podobnie jak miało to miejsce w przypadku konsolidowania życia literackiego wokół jakiegoś periodyku, próby utworzenia grupy artystyczno-literackiej również przez wiele lat napotykały na liczne trudności. W okresie międzywojennym „Tygodnik Łódzki” ${ }^{36}$, pismo o ambicjach literackich, podjęło nieudany wysiłek zintegrowania dość wątłego środowiska literackiego. Podobny los spotkał twórców, którzy w 1922 r. zainicjowali powstanie grupy Srebrny Wóz. Wśród jej założycieli znaleźli się Karol Hiller ${ }^{137}$ i Witold Wandurski. Inicjatywa miała posłużyć scaleniu środowiska artystycznego miasta, a więc pisarzy, plastyków, aktorów i reżyserów teatralnych. Do ugrupowania przystąpili m.in. twórcy byłego stowarzyszenia żydowskiej awangardy Jung Idysz - Natan Szpigel i Marek Szwarc, a także Artur Szyk i Maurycy Trębacz. W jej szeregi wstąpili też pisarze Józef Wittlin i Mieczysław Braun oraz świetnie zapowiadający się reżyser teatralny Józef Mayen. Inicjatywa nie otrzymała wsparcia od władz miasta ani od łódzkiego kapitału, więc grupa szybko zawiesiła działalność.

Na przełomie lat 1926/1927 zawiązała się w Łodzi kolejna grupa artystyczna o nazwie Start, której wiceprezesem został Karol Hiller. Brał udział w pierwszej wystawie stowarzyszenia, w którym większość członków stanowili artyści żydowscy, m.in. Samuel Finkelstein, Izaak Hirszberg, Ignacy Hirszfang, Izrael Lejzerowicz, Dora Rawska-Kon, Dawid Rozenberg, Roman Rozental, Regina Szenbrunowa, Natan Szpigel, Abraham Weinbaum i Ruth Weinsteinówna. Podczas pierwszej publicznej prezentacji obrazy Hillera wzbudziły zainteresowanie krytyków podkreślających, że artysta przekracza ramy realizmu i wchodzi w sferę metafizyki. Stanowiło to zachętę do przygotowania kolejnej prezentacji. Wkrótce do stowarzyszenia wstąpili również tacy artyści, jak Konstanty Mickiewicz, Zenobiusz Poduszko, a nawet Władysław Strzemiński. W 1933 r. Hiller stanął także na czele komitetu redakcyjnego czasopisma „Forma”, oficjalnie organu związku, lecz de facto nowoczesnego forum wymiany poglądów na sztukę. Bardzo wysoki poziom czasopisma,

134 Ibidem.

135 Por. L. Stolarzewicz, Literatura...

136 „Tygodnik Łódzki” - czasopismo społeczno-literackie, którego wydawcą i redaktorem naczelnym byli Adam Kowalczewski-Siedlecki oraz Lucjan Dąbrowski. Dział literacki prowadził Aleksander Bolesław Cyps, zaś dział felietonu Andrzej Nullus.

137 Zob. aneks: Łódzkie sylwetki. 
którego ostatni numer wydany w 1939 r. zniszczyli Niemcy, może do dziś stanowić wzór dla periodyków poświęconych sztuce.

Na uwagę zasługują również dwie inne grupy literackie, związane z Łodzią. Pierwsza z nich to Skamander ${ }^{138}$, który w 1918 r. próbował wydawać pismo „Tańczący Ogień" ${ }^{139}$, druga zaś to Meteor ${ }^{140}$, związany nie tylko z Łodzią, ale również z Warszawą. Założycielami Meteora w 1928 r. byli Marian Piechal, Grzegorz Timofiejew i Kazimierz Sowiński, absolwenci Miejskiego Gimnazjum Męskiego w Łodzi. Do grupy dołączyli również Włodzimierz Słobodnik, Roman Kołoniecki, Świętopełk Karpiński, Stefan Flukowski, Rafał Len, Tadeusz Horzelski i Jan Ostaszewski. Oprócz własnego czasopisma zatytułowanego „Meteor" członkowie ugrupowania redagowali w latach 1929-1930 dodatek literacki „Głosu Polskiego” o nazwie „Z twórczości poetów grupy Meteor”141. Byli inicjatorami serii wydawniczej Biblioteka Meteora, w ramach której drukowano wiele utworów, m.in. Piechala Krzyk z miasta ${ }^{142}$ (1929), Sowińskiego Gwiazdy na strychu ${ }^{143}$ (1930) i Timofiejewa Nie ma mnie $w$ domu ${ }^{144}$ (1930). Członkowie ugrupowania organizowali w Łodzi i w Warszawie spotkania autorskie i wieczory dyskusyjne, czerpiąc inspiracje z poetyki awangardy krakowskiej, której cechą był silny indywidualizm. Często podejmowali także problematykę społeczną i proletariacką, nie stronili również od rozważań egzystencjalnych. W swej twórczości nawiązywali do pisarstwa Cypriana Kamila Norwida i Stanisława Brzozowskiego. Grupa Meteor działała prawie dwa lata. W 1930 r. część członków, m.in. Piechal, Flukowski, Słobodnik, Bieńkowski i Karpiński, zasiliła szeregi innego ugrupowania literackiego, Kwadryga ${ }^{145}$,

138 Por. m.in. W. Appel, Meandry Skamandrytów, Toruń 2011; H. Faryna-Paszkiewicz, Opium życia. Niezwykła historia Marii Morskiej, muzy skamandrytów, Warszawa 2008; Z. Mokranowska, Prozy poetów kręgu "Skamandra” wobec tradycji elitarnych i popularnych form kultury, Katowice 2003, Skamander, [w:] G. Gazda, Słownik europejskich kierunków i grup literackich XX w., Warszawa 2000, s. 577-580.

139 „Tańczący Ogień. Dla Sztuki i Wszystkiego, Co z Nią Związane” - w sumie w 1920 r. ukazał się jeden numer tego czasopisma, którego wydawcą był Mieczysław Pawłowicki, a redaktorem Stefan Płochocki. W czasopiśmie publikowali m.in. Mieczysław Braun, Aleksander Kraśniański, Julian Tuwim, Kazimierz Wierzyński, Antoni Słonimski i Jan Lechoń. Jak twierdzi Elżbieta Pleszkun-Olejniczakowa, wpływ tej gazety na łódzką kulturę literacką był znikomy. Por. Elżbieta Pleszkun-Olejniczakowa, Czasopisma ..., http://www.tygielkultury.eu/1_3_2005/ aktual/9ram.htm [dostęp: 12.12.2013].

${ }^{140}$ Por. T. Błażejewski, Meteor. Pierwsza grupa poetycka, „Poezja” 3/1973; M. Piechal, Dwudziestolecie Meteora. Pierwsza w dziejach Łodzi grupa poetycka, „Robotnik” 159/1948.

141 Por. G. Gazda, Słownik...

${ }_{142}$ M. Piechal, Krzyk z miasta, Łódź 1929.

${ }^{143}$ K. Sowiński, Gwiazdy na strychu, Łódź 1930.

${ }^{144}$ G. Timofiejew, Nie ma mnie w domu, Łódź 1930.

${ }^{145}$ Kwadryga - warszawska grupa literacka skupiająca wielu młodych poetów lat 30. XX w. Jej członkami byli m.in. Mieczysław Bibrowski (1908-2000), Stanisław Ciesielczuk (1906-1945), Stanisław Ryszard Dobrowolski (1907-1985), Stefan Flukowski (1902-1972), 
a Timofiejew w 1931 r. zaczął wydawać w Łodzi czasopismo „Prądy”"146, na którego łamach publikowali Paweł Hulka-Laskowski, Zofia Nałkowska, Józef Wittlin, Jan Nepomucen Miller, Julian Tuwim, a także Marian Piechal i Rafał Len, byli członkowie Meteora.

Również w przypadku literatów żydowskich i niemieckojęzycznych, z których większość była nauczycielami, lekarzami, adwokatami lub dziennikarzami, niechętnie podejmującymi ważkie polemiki i dyskusje, sytuacja wyglądała bardzo podobnie. Tu także brakowało ugrupowań, które nadawałyby ton środowisku literackiemu. Wielu żydowskich pisarzy współpracowało z miejscową prasą wydawaną w języku jidysz lub hebrajskim. Warto wymienić takich pisarzy, jak Jeszajahu Szpigel ${ }^{147}$, Symcha-Bunim Szajewicz ${ }^{148}$, Miriam Ulinower ${ }^{149}$, Izrael Rabon ${ }^{150}$, Józef Zelikowicz ${ }^{151}$ czy Abraham Joachimowicz ${ }^{152}$. W okresie międzywojennym należy odnotować fakt pojawienia się w środowisku żydowskim grupy literacko-artystycznej Jung Idysz ${ }^{153}$, założonej przez poetę i grafika Mojżesza Brodersona ${ }^{154}$. Członków grupy, określanych często mianem przedstawicieli żydowskiego ekspresjonizmu (m.in. Jankiela Adlera ${ }^{155}$, Henryka Barczyńskiego ${ }^{156}$, Dinę Matus ${ }^{157}$, Marka Szwarca ${ }^{158}$, Zofię Gutentag ${ }^{159}$, Henryka Berlewi ${ }^{160}$, Idę Brauner ${ }^{161}$ czy Wincentego Braunera ${ }^{162}$ ) fascynowały irracjonalne kierunki filozofii i mistycyzm chasydzki. Swoimi poglądami próbowali nawiązać do powstałej w tym czasie europejskiej sztuki awangardowej.

Aleksander Maliszewski (1901-1978), Marian Piechal (1905-1989), Nina Rydzewska (19021957), Władysław Sebyła (1902-1940), Włodzimierz Słobodnik (1900-1991), Lucjan Szenwald (1909-1944), Zbigniew Uniłowski (1909-1937) i Wiesław Wernic (1906-1986).

146 „Prądy” - czasopismo Łódzkiego Klubu Literackiego. Redaktorem był Grzegorz Timofiejew. Ukazywało się w latach 1931-1932.

147 Zob. aneks: Łódzkie sylwetki.

148 Ibidem.

149 Ibidem.

${ }^{150}$ Ibidem.

151 Ibidem.

152 Ibidem.

153 Por. J. Malinowski, Grupa Jung Idysz i żydowskie środowisko „Nowej Sztuki” w Polsce 1918-1923, Warszawa 1987, s. 5-26.

154 Zob. aneks: Łódzkie sylwetki.

155 Ibidem.

156 Ibidem.

157 Ibidem.

158 Ibidem.

159 Ibidem.

160 Ibidem.

161 Ibidem.

162 Ibidem. 
Grupę awangardową tworzyli w Łodzi także artyści zainspirowani malarstwem Władysława Strzemińskiego. Grupa przyjęła nazwę „a.r.” i skupiała wokół siebie takich artystów i grafików, jak Katarzyna Kobro, Henryk Stażewski czy Karol Hiller. Ważnym elementem tutejszego życia literackiego i artystycznego było ustanowienie przez władze miasta w 1926 r. Nagrody Literackiej m. Łodzi, przemianowanej następnie na Nagrodę m. Łodzi dla Literatury Pięknej, Nauki i Sztuk Plastycznych. Jej laureatami zostali m.in.: Julian Tuwim, Zofia Nałkowska, Władysław Strzemiński i Andrzej Strug ${ }^{163}$.

Przez cały okres rozwoju niemieckiej literatury niemieckojęzyczne kręgi literackie Łodzi były bardzo słabym środowiskiem. Tak jak miało to miejsce w przypadku innych grup narodowościowych, twórczością literacką zajmowali się tu dziennikarze, nauczyciele, adwokaci, lekarze i uczniowie. Brakowało ludzi pióra, którzy mogliby świadomie i celowo kreować środowisko. W tym miejscu na podkreślenie zasługuje fakt, że obraz inteligencji niemieckiej, która mogłaby pełnić przewodnią rolę w kształtowaniu środowiska, przedstawiał się bardzo mizernie. Po pierwsze była to grupa nieliczna, a poza tym od wielu lat zapatrzona w łódzką, niemiecką burżuazję przemysłową jako wzór do naśladowania. Przejmowała nie tylko jej styl życia, sposób ubierania się czy zachowania w domu i na ulicy, ale także to, co niekoniecznie winno napawać dumą - brak zamiłowania do literatury i wszelkich wytworów kultury. W okresie międzywojennym wzorem dla części spolonizowanych Niemców i Żydów była mieszczańska kultura niemiecka, adaptowana do polskich warunków.

Ważną rolę w kształtowaniu niemieckojęzycznego środowiska literackiego odegrali w pierwszej kolejności dziennikarze i wydawcy. Jednym z nich był Johann Petersilge ${ }^{164}$, który na łamach swojej pierwszej gazety zaczął publikować artykuły o charakterze kulturalnym. Niemałe zasługi przypadły w udziale również kolejnym wydawcom i dziennikarzom, takim jak Aleksander Milker ${ }^{165}$ czy Alexis Drewing ${ }^{166}$. W swojej gazecie „Neue Lodzer Zeitung" ${ }^{\prime 167}$ Drewing publikował wiersze i opowiadania, dbał również o poziom literacki dodatków prasowych i dobór materiału literackiego. Niewątpliwie miał świadomość, że dla utrzymania tytułu musi proponować jego czytelnikom poziom adekwatny do ich potencjału intelektualnego. Tak więc w początkowej fazie rozwoju środowiska literackiego Łodzi dziennikarze stawali się literatami. Także później istniał dość ścisły związek między zawodem

163 Por. A. Turowski, Konstruktywizm polski: próba rekonstrukcji nurtu 1921-1934, Wrocław 1981; idem, Budowniczowie świata. Z dziejów radykalnego modernizmu, Kraków 2000.

164 Zob. aneks: Łódzkie sylwetki.

165 Ibidem.

166 Ibidem.

167 Zob. rozdział 2: Łódzka prasa i jej związki z literaturą. 
dziennikarza i pisarza, bo niejeden literat trudnił się z przyczyn finansowych dziennikarstwem.

Lokalne gazety starały się rozbudzać intelektualnie łódzkich czytelników, organizując przykładowo konkursy literackie, cieszące się wśród niemieckojęzycznych łodzian wielką popularnością. Pierwszymi literatami niemieckojęzycznymi, którzy wiele uczynili dla środowiska, były osoby duchowne. To one na stałe zapisały się do historii miasta jako współtwórcy niemieckojęzycznego środowiska literackiego Łodzi. Należeli do nich pastorzy Friedrich Metzner $^{168}$, August Hermann Müller ${ }^{169}$ i Philipp Kreutz ${ }^{170}$. Wiele uroczystości, ważnych z perspektywy lokalnej społeczności niemieckiej, zyskało oprawę literacką w postaci wiersza czy pieśni autorstwa tychże duchownych poetów. Stosunkowo duże zainteresowanie literaturą wśród pastorów ewangelickich wynikało przede wszystkim z ich solidnego wykształcenia oraz zainteresowań kulturowych, głębszych niż w przypadku duchownych katolickich. Starsi duszpasterze ewangeliccy zazwyczaj zdobywali dyplomy na niemieckich uniwersytetach, młodsi natomiast często byli absolwentami Wydziału Teologii Ewangelickiej Uniwersytetu Warszawskiego. Posiadali doskonałą orientację nie tylko w literaturze teologicznej, ale również pięknej, a wielu z nich po ukończeniu studiów zajmowało się dodatkowo filozofią, teologią lub historią literatury.

W niemieckojęzycznym środowisku literackim Łodzi dość znaczną grupę stanowili pisarze żydowskiego pochodzenia, tworzący w języku polskim lub niemieckim. Należał do nich m.in. publicysta, literat i krytyk związany także z teatrem niemieckim, Heinrich Zimmermann ${ }^{171}$, inicjator poświęconego sprawom kultury i literatury pisma „Freie Bühne”"172. Mimo ostatecznego niepowodzenia przedsięwzięcia pomysł ten zasługuje na wzmiankę, gdyż miał na celu ożywienie lokalnego życia literackiego. Do pisarzy żydowskiego pochodzenia, tworzących w języku niemieckim, zalicza się również Bertę Teplitzką ${ }^{173}$, autorkę zbioru felietonów Lodzer Typen ${ }^{174}$, której twórczość - podobnie jak w przypadku Zimmermanna - będzie przedmiotem analizy niniejszej rozprawy ${ }^{175}$.

\footnotetext{
168 Zob. aneks: Łódzkie sylwetki.

169 Ibidem.

170 Ibidem.

171 Ibidem.

172 „Freie Bühne. Monatsblätter für Literatur und dramatische Kunst” - czasopismo literackie o charakterze efemerydalnym, redagowane przez Heinricha Zimmermanna. W $1919 \mathrm{r}$. ukazały się zaledwie dwa numery.

173 Zob. aneks: Łódzkie sylwetki.

174 Por. Berta Teplitzka. Portrety łódzkie, oprac. M. Półrola, Łódź 2007.

175 Ibidem.
} 
Należy podkreślić, że środowisko łódzkie nie wykształciło ważniejszych instytucji literackich czy pism, które prowadziłyby polemikę z aktualnymi tendencjami w literaturze polskiej czy światowej. Wiadomo jednak, że niemieckojęzyczni pisarze z Łodzi chętnie uczestniczyli w życiu literackim Berlina, dokąd wyjeżdżali na odczyty i wykłady, które wzbogacały ich wiedzę na temat współczesnych tendencji w literaturze. Wielu z nich już w okresie dwudziestolecia międzywojennego i wcześniej kształciło się na międzynarodowych uczelniach i zdobywało wiedzę z zakresu literatury i innych dyscyplin naukowych.

Cechą łódzkiego środowiska literackiego jest duży stopień anonimowości, ponieważ wielu autorów nie podpisywało się w gazetach własnym nazwiskiem - była to wówczas dość powszechna praktyka. Również gazety nie dbały o to, by regularnie zamieszczać życiorysy łódzkich autorów, których twórczość ma swoją wartość i stanowi ważną część łódzkiej produkcji literackiej. Stąd dogłębne analizy tego środowiska wymagają jeszcze wielu badań.

\subsection{Kościół jako ośrodek życia religijnego i kulturalnego}

Pod koniec XIX i na początku XX w. kościół stał się ważnym ośrodkiem nie tylko życia religijnego, ale również kulturalnego. Do końca XVIII w. ludność Łodzi reprezentowała w znacznej większości wyznanie katolickie, a proboszcz był osobą dominującą w lokalnej wspólnocie parafialnej. Sytuacja zmieniła się z chwilą przybycia pierwszych osadników niemieckojęzycznych, w przeważającej mierze protestantów. Wśród nowej, napływającej ludności niemieckiej bywali jednak także katolicy oraz przedstawiciele wyznania mojżeszowego. Dość znaczną część społeczeństwa łódzkiego stanowili też wyznawcy prawosławia, zaś relatywnie nieliczną grekokatolicy i muzułmanie. Oprócz duchownych świeckich na terenie Łodzi działali również bracia zakonni, zgrupowani w klasztorach franciszkanów, salezjanów, bonifratrów, jezuitów i bernardynów. W porównaniu z innym miastami regionu łódzkie duchowieństwo charakteryzowało się stosunkowo wysokim poziomem intelektualnym.

W Łodzi służba duszpasterska nie była łatwym zadaniem, gdyż księża katoliccy często musieli rywalizować z pastorami ewangelickimi i organizacjami komunistycznymi. Dlatego poza posługą liturgiczną kościoły prowadziły również działalność w innych sferach życia. Miejscowi pastorzy ewangeliccy oraz księża katoliccy angażowali się zwłaszcza na rzecz rozwoju kultury i oświaty. K. Mikinas, kantor miejscowej parafii św. Trójcy, stanął na czele powstałej w 1825 r. Ewangelickiej Szkoły Elementarnej, zaś w 1829 r. utworzono 
Katolicko-Ewangelicką Szkołę Elementarną. Kuratorem szkoły ewangelickiej był pastor Friedrich Gottlob Metzner, natomiast szkoły katolickiej ksiądz Józef Krieger.

Kościoły były także ośrodkiem życia muzycznego. W 1856 r. powstał pierwszy niemiecki chór katolickiego Stowarzyszenia Śpiewu Kościelnego „Cecylia", występujący w kościele parafialnym pw. Wniebowzięcia Najświętszej Marii Panny na Starym Mieście i w kościele pw. Podwyższenia Świętego Krzyża. Przy obu kościołach działały także inne chóry, m.in. niemieckie Gloria i Hieronymus, zaś z czasem niemal każda łódzka parafia szczyciła się własnym, niekoniecznie tylko jednym chórem ${ }^{176}$.

Łódzkie duchowieństwo działało też dość prężnie na rzecz łódzkiej społeczności robotniczej. Księża inicjowali m.in. chrześcijański ruch robotniczy i zakładali bractwa religijne (np. bractwo przy kościele św. Józefa) ${ }^{177}$, prowadzili również intensywną działalność społeczną. W osobach duchownych wielu robotników upatrywało obrońców swej klasy przed wyzyskiem fabrykantów. Ks. Wincenty Tymieniecki był m.in. inicjatorem powołania Resursy Rzemieślniczej prowadzącej żłobek, szkołę dla głuchoniemych i inne instytucje społeczne. W obrębie danej parafii wydawano także różnego rodzaju pisma. Przykładowo w latach 20. XX w. ks. Antoni Potempa wydawał tygodnik „Die Sonntagsglocke. Das Wochenblatt der deutschen Katholiken in Polen”, w którym publikowano kazania, artykuły hagiograficzne, fragmenty listów pasterskich, życiorysy, a także informowano o życiu parafii ${ }^{178}$.

Księża brali również czynny udział w życiu literackim i naukowym miasta, jak miało to miejsce w przypadku ks. Antoniego Roszkowskiego czy ks. Władysłwa Grzelaka. W życiu literackim Łodzi znaczącą rolę odegrał np. ks. Antoni Szendlerowski, w latach 1901-1905 wikariusz kościoła pw. św. Krzyża. Jego twórczość pozostawała pod dużym wpływem autorów młodopolskich, m.in. Stanisława Przybyszewskiego. Szendlerowski był autorem takich utworów dramatycznych, jak Maria z Magdali, Samson czy Paraklet ${ }^{179}$.

Także pastorzy ewangeliccy parali się pisarstwem, wydając (np. pastor Rudolf Gundlach oraz pastor Wilhelm Angerstein) śpiewniki kościelne i zajmowali się twórczością liryczną (np. Philipp Kreutz czy August H. Müller). Prowadzili także intensywną działalność wydawniczą. Przykładowo pastor Wilhelm Angerstein i Julius Dietrich byli autorami opracowań historycznych, poświęconych wyznaniom i kościołom. Inni duchowni ewangeliccy wydawali

176 Por. M. Budziarek, Łódzki bedeker wyznaniowy, Łódź 1998.

177 Por. W. Kaszubina, Bibliografia prasy łódzkiej 1863-1944, Warszawa 1967.

178 Por. Bibliografia czasopism religijnych w Polsce 1918-1944, oprac. Z. Zieliński, Lublin 1981.

179 Por. A. Hutnikiewicz, Młoda Polska, Warszawa 2000. 
teksty z zakresu teologii pasterskiej. W tym kontekście należy szczególnie podkreślić zasługi pastora Paula Althausa, wspomnianego wcześniej Wilhelma Angersteina oraz Augusta Gerhardta.

\subsection{Teatr}

Początki teatru w Łodzi sięgają lat 40 . XIX w. ${ }^{180} \mathrm{~W}$ tym czasie zaczęły przybywać do miasta wędrowne trupy teatralne, których występy przyciągały wielonarodową publiczność. Jedno z pierwszych przedstawień w wykonaniu Ignacego Marzantowicza odbyło się 6 stycznia 1844 r. Łódzką publiczność bawiły też wędrowne trupy Feliksa Pietrzykowskiego, Wincentego Raszewskiego, Józefa Barańskiego i Juliusza Pfeiffera. Większość zespołów przebywała w Łodzi dość krótko, bo zaledwie kilka tygodni, po czym opuszczała miasto, nierzadko z długami. Prezentowane sztuki teatralne miały zadowolić gusta łódzkiej publiczności, składającej się w przeważającej części z urzędników, fabrykantów i rzemieślników, a więc społeczności o stosunkowo niskiej świadomości kulturowej. W Łodzi grywano głównie farsy, operetki, komedie i wodewile. Mimo braku wyrobionych widzów miejscowi miłośnicy sceny teatralnej pragnęli częściej z nią obcować. W 1866 r. oczekiwaniu temu wyszedł naprzeciw Fryderyk Sellin, organizując scenę teatralną w dawnym budynku stajni wojskowej przy ul. Konstantynowskiej 16. Początkowo zamierzał wystawiać tam naprzemiennie sztuki polskie i niemieckie, jednak wbrew wcześniejszym deklaracjom przez kolejnych dwanaście lat prezentował przeważnie repertuar polskojęzyczny. Niemal w tym samym czasie społeczność niemiecka podjęła ważną próbę utworzenia stałej sceny niemieckiej. W 1867 r. właściciel hotelu i teatru „Paradyz”, August Hentschel, otworzył pierwszy stały teatr niemiecki, angażując aktorów z Hamburga, Halle, Wrocławia, Bydgoszczy i Krakowa. Dla sceny polskiej była to poważna konkurencja, gdyż w latach 60. nie myślano jeszcze o dzieleniu publiczności i dlatego na wieść o stałych występach aktorów niemieckich wykonawcy polscy ustąpili. Zanim powstała stała scena polska, 2 października 1877 r. odbyła się przy ul. Piotrkowskiej 67 podniosła uroczystość inauguracji działalności nowego teatru, który stanął w podwórzu hotelu „Victoria”. Jedno z pierwszych

${ }^{180} 0$ teatrze w Łodzi powstało wiele prac naukowych, dlatego ograniczę się do syntetycznego omówienia tego zagadnienia. Najważniejsze z publikacji wyszły spod pióra Anny Kuligowskiej-Korzeniewskiej, Małgorzaty Leyko oraz Karoliny Prykowskiej-Michalak. Por. m.in. A. Kuligowska-Korzeniewska, Trudne poczq̨tki. Teatr łódzki w latach 1844-1863, Wrocław 1976; eadem, Sto lat stałej sceny polskiej w Łodzi 1888-1988, Łódź 1993; eadem, Scena obiecana. Teatr polski w Łodzi 1844-1918, Łódź 1995; Łódzkie sceny żydowskie. Studia i materiały, red. M. Leyko, Łódź 2000; Teatr niemiecki w Polsce. XVIII-XX wiek, red. K. Prykowska-Michalak, Łódź 2008. 
przedstawień dał tu wraz ze swoją trupą Józef Teksel ${ }^{181}$. Teatr „Victoria” wystawiał sztuki dla publiczności zarówno polskiej, jak i niemieckiej, często goszcząc na widowni także inteligencję żydowską. W teatrze grywano repertuar polsko- i niemieckojęzyczny, dramatyczny i muzyczny; prezentowano np. Wesele Figara, Czarodziejski Flet W.A. Mozarta, Trubadura G. Verdiego oraz Tannhäusera R. Wagnera.

Stała scena polska powstała ponad dwadzieścia lat później, a jej inauguracja odbyła się 6 października 1888 r. Inicjatorem był Lucjan Kościelecki, który wystawił tego dnia komedię Kazimierza Zalewskiego Małżeństwo Apfel. Wsparcia finansowego udzieliła miejscowa burżuazja w osobach M. Poznańskiego, E. Herbsta, M. Herza, S. Silbersteina, L. Golca oraz A. Stamirowskiego. Mimo materialnego wsparcia ze strony fabrykantów teatr przez wiele lat zmagał się z problemami finansowymi, wskutek czego nieustannie zmieniali się jego dyrektorzy ${ }^{182}$. Scena polska nie mogła istnieć bez stałego wsparcia instytucji nadrzędnej i dlatego w 1903 r. powołano Polskie Towarzystwo Teatralne, zajmujące się zbieraniem składek społecznych na utrzymanie teatru w Łodzi. Członkami towarzystwa byli potomkowie niemieckich i żydowskich osadników: M. Poznański, E. Geyer, K. Schweikert, J. Rappaport, D. Lande i Z. Weinreb. Wielką estymą w środowisku teatralnym cieszył się wybitny reżyser, aktor i dyrektor polskiej sceny teatralnej, Aleksander Zelwerowicz, którego repertuar mógł zadowolić nawet bardzo wymagającą publiczność. Wystawiał m.in. sztuki Wyspiańskiego, Słowackiego, Krasińskiego, Mickiewicza, Asza i Nowaczyńskiego.

W tym samym czasie scena niemiecka wzbogaciła się o budynek teatru „Thalia”, który powstał w 1882 r. przy ul. Dzielnej 18 (obecnie ul. Narutowicza). Świetności przysporzył mu Albert Rosenthal, który w 1890 r. objął dyrekcję sceny i prowadził ją przez dziewiętnaście lat aż do swojej śmierci. Angażował najwybitniejszych aktorów niemieckich, takich jak Adalbert Matkowsky czy Friedrich Mitterwuryer, a repertuar i poziom artystyczny cieszyły się dużym uznaniem publiczności. Również kolejni dyrektorzy, Adolf Klein i Walter Wassermann, odnosili znaczące sukcesy. Podobnie jak scena polska, również teatr niemiecki często borykał się z trudnościami finansowymi i wciąż musiał pozyskiwać subwencje na swą działalność.

W życiu teatralnym aktywnie uczestniczyli nie tylko widzowie niemieccy i polscy; na przedstawieniach $\mathrm{w}$ języku polskim i niemieckim bywała również społeczność żydowska. W latach 80. do Łodzi coraz częściej docierały profesjonalne trupy żydowskie. Z żargonową operetką przyjechał Abraham Goldfaden, ojciec teatru żydowskiego. Poza tym w mieście gościli Jakub Adler, Abraham Izaak Tancman i Józef Wajnsztok. Pierwsza stała sce-

${ }^{181}$ Zob. aneks: Łódzkie sylwetki.

182 Por. m.in. W.L. Karwacki, Teatr dla robotników przed 1914 r., [w:] Polska klasa robotnicza, t. 7, Warszawa 1976, s. 176-187; A. Kuligowska-Korzeniewska, Scena obiecana ..., s. 102-105. 
na żydowska powstała w 1905 r., zaś drugi stały teatr żydowski w $1912 \mathrm{r}$. Obie sceny proponowały bardzo urozmaicony repertuar - grywano sztuki żydowskie, polskie, niemieckie, rosyjskie i francuskie. Działalność teatru żydowskiego wydatnie wsparło utworzone w 1907 r. Żydowskie Towarzystwo Dramatyczne „Kunst”.

Po I wojnie światowej łódzkie życie teatralne rozwijało się coraz intensywniej. Polska scena przyciągnęła wielu znamienitych artystów, takich jak Karol Adwentowicz (który w latach 1929-1930 kierował tutejszym Teatrem Miejskim), Stanisława Wysocka (kierowała Teatrem Miejskim w sezonie 1932/1933), reżyserów Edmunda Wiercińskiego i Leona Schillera. Choć teatr żydowski wciąż borykał się z brakiem subwencji, wykształcił w okresie międzywojennym nowe formy sceniczne, wywodzące się z tradycji awangardy literacko-malarskiej.

O ile dla scen polskiej i żydowskiej okres międzywojenny był owocny i obfitował w różnorodne inicjatywy, o tyle dla teatru niemieckiego okazał się niesprzyjający. W 1921 r. spłonął budynek „Thalii”, a wcześniej rozwiązał się zespół Waltera Wassermanna. Mimo to scena niemiecka próbowała się odrodzić; w 1919 r. z inicjatywy dziennikarza i krytyka teatralnego Heinricha Zimmermanna powołano do życia teatr amatorski o nazwie „Freie Bühne”, zaś w latach 1923-1925 amatorską działalność prowadziło towarzystwo Thalia. „Freie Bühne” istniała bardzo krótko, bo zaledwie do 1920 r. W repertuarze miała m.in. sztuki Maxa Halbego i Fiodora Dostojewskiego. W okresie międzywojennym spektakle teatralne prezentowali również uczniowie Łódzkiego Gimnazjum Niemieckiego, którzy wystawili m.in. komedie Otto Ernsta oraz utwór Michaela Schmita, rektora gimnazjum, a ponadto adaptacje Schillera i Goethego. Amatorskie przedstawienia teatralne organizowały także najróżniejsze stowarzyszenia, związki wyznaniowe i bractwa ${ }^{183}$. Sceny działały aż do wybuchu II wojny światowej, potem teatr w Łodzi stał się narzędziem propagandy ideologii nazistowskiej.

\subsection{Szkoła i działalność kół literackich dla młodzieży}

Pod koniec lat 20. XIX w. w Łodzi istniały dwie szkoły elementarne, do których uczęszczały polskie dzieci. Z chwilą przybycia niemieckojęzycznych osadników palącą potrzebą stała się organizacja oświaty, tym bardziej

183 Por. K. Prykowska-Michalak, Teatr niemiecki w Łodzi. Sceny. Wykonawcy. Repertuar 1867-1939, Łódź 2005, s. 135-140. 
że analfabetyzm wśród łodzian wynosił wówczas ok. 90\% ${ }^{184}$. W tym celu w 1834 r. utworzono na Starym Mieście szkołę ewangelicką, którą kierował pastor Friedrich Metzner. Oprócz publicznego szkolnictwa rządowego tworzono też szkoły prywatne, do których uczęszczały dzieci bogatszych łodzian. W 1845 r. przeniesiono z Warszawy do Łodzi Szkołę Powiatową Realną Niemiecko-Rosyjską, do której chodziły dzieci polskie i niemieckie ze średnio zamożnych rodzin mieszczańskich, wśród nich latorośle wybitnych łódzkich przemysłowców, takich jak Karol Anstadt czy Izrael Poznański. Lata 60. XIX w. przyniosły dalszy rozwój łódzkiego szkolnictwa. Łódź posiadała już 5 szkół elementarnych katolickich i 4 ewangelickie. W późniejszym okresie dynamicznemu przyrostowi ludności nie towarzyszył już proporcjonalny wzrost liczby szkół. W 1883 r. działało na terenie Łodzi zaledwie 16 szkół elementarnych, natomiast w latach 90. - 24.

Również społeczność wyznania mojżeszowego zakładała własne szkoły elementarne. W 1865 r. z inicjatywy Hermana Konstadta, Jakuba Dobranickiego, Lejzera Bergera i Henocha Goldberga powstała elementarna szkoła państwowa dla dzieci żydowskich. Do wybuchu I wojny światowej na terenie Łodzi funkcjonowało 12 takich placówek ${ }^{185}$.

Szkoły powstające na terenie Łodzi w XIX w., szczególnie w okresie między powstaniami, miały zgodnie z wizją władz carskich realizować politykę rusyfikacji. Obok rosyjskiego językiem wykładowym miał być niemiecki, jednak w rzeczywistości posługiwano się również językiem polskim ${ }^{186}$. Wykładowcami języka polskiego byli Hieronim Dzieszuk oraz literat Wiktor Dłużniewski. Wybuch powstania styczniowego wpłynął na intensyfikację procesu rusyfikacji polskiego szkolnictwa. Otwarta w 1869 r. Łódzka Wyższa Szkoła Rzemieślnicza, wzorowana na podobnej w Chemnitz, realizowała program nauczania według standardów wyznaczonych przez władze carskie ${ }^{187}$. Nauczanie odbywało się w języku rosyjskim - w tym celu sprowadzono rosyjski personel pedagogiczny i podręczniki. Szkoła przygotowywała absolwentów do pracy na stanowiskach majstra i technika, umożliwiała również podjęcie nauki na wyższych uczelniach technicznych za granicą. Program obejmował kształcenie z zakresu farbiarstwa, mechaniki, chemii i włókiennictwa. Później profil szkoły wzbogacono i przemianowano ją na Szkołę Rękodzielniczo-Przemysłową, która - podobnie jak jej poprzedniczka - cieszyła się wśród łódzkiej młodzieży dużym zainteresowaniem. W trosce o rozwój gospodar-

184 Por. E. Podgórska, Szkolnictwo elementarne w okresie międzypowstaniowym, [w:] Łódź. Dzieje miasta..., s. 508-525.

185 Por. W. Puś, Żydzi w Łodzi w latach zaborów 1793-1914, Łódź 1998, s. 146-151.

186 Ibidem.

187 Por. W Puś, Udział w życiu oświatowym i kulturalnym miasta, [w:] M. Koter, M. Kulesza, W. Puś, S. Pytlas, Wpływ..., s. 77-108. 
czy aglomeracji łódzkiej organizowano pod koniec XIX w. oprócz szkół o profilu przemysłowym także szkolnictwo o charakterze handlowym i kupieckim. W 1897 r. powołano do życia szkołę kupiecką Z. Gecena, zaś w 1898 r. Zgromadzenie Kupców zorganizowało siedmioklasową szkołę handlową ${ }^{188}$.

Od początku lat 70. XIX w. również społeczność żydowska angażowała się w zakładanie szkół zawodowych. Pierwsza Talmud Tora powstała w $1873 \mathrm{r}$. z inicjatywy rabina Eliasza Chaima Majzela. Kolejne szkoły otwarto w 1894 i $1901 \mathrm{r}^{189}$

Ogromny wpływ na rozwój łódzkiego szkolnictwa miała rewolucja $1905 \mathrm{r}$. W tym czasie doszło do ostrej walki na rzecz krzewienia polskiej oświaty. Łódzka inteligencja zaangażowała się w batalię o wprowadzenie do szkół wykładowego języka polskiego, a także inicjowała otwieranie nowych placówek oświatowych. W 1906 r. z inicjatywy żydowskiego przemysłowca Stanisława Silbersteina powstało Towarzystwo Oświatowe im. Elizy Orzeszkowej. Również społeczność niemiecka organizowała własne szkoły niemieckojęzyczne. Z inicjatywy społecznej utworzono w 1906 r. instytucję o wielkim znaczeniu dla kształcenia na poziomie średnim, a mianowicie Łódzkie Gimnazjum Niemieckie (Lodzer Deutsches Gymnasium, dalej: LDG). Żydowskie szkolnictwo średnie wykształciło się w porównaniu z polskim i niemieckim stosunkowo późno. W 1912 r. z inicjatywy kaznodziei M. Braudego społeczność żydowska powołała do życia Towarzystwo Żydowskich Szkół Średnich. Poza szkołami średnimi tworzono w Łodzi również prywatne pensje żeńskie. Do najbardziej znanych należały pensje dla dziewcząt M. Raubal, T. Schmidt, A. Berlach, J. Jezierskiej, S. Wehser oraz M. Niewęgłowskiej.

Po I wojnie światowej system oświaty nadal się rozrastał.W 1919 r. obowiązkiem nauczania objęto już 38500 dzieci. W 1938 r. istniało w Łodzi 199 szkół podstawowych, w których uczyło się 84300 uczniów, natomiast do szkół średnich uczęszczało mniej więcej w tym samym czasie 10300 młodzieży ${ }^{190}$.

Szkolnictwo wyższe w Łodzi długo nie mogło się zadomowić, a wiele cennych inicjatyw nigdy nie doczekało się realizacji. Planowano utworzyć w mieście uczelnię o profilu medycznym oraz handlowym, jednak planów tych nigdy nie zrealizowano. Dopiero w 1921 r. powołano jedną z pierwszych palcówek o charakterze wyższej uczelni. Był to Instytut Nauczycielski, kierowany przez Tadeusza Czapczyńskiego. Zadaniem tej placówki było kształcenie nauczycieli na potrzeby gimnazjów i seminariów nauczycielskich. W tym samym roku zakończoną powodzeniem inicjatywę powołania Wyższego Seminarium Duchownego podjął ks. Wincenty Tymieniecki (placówka działa do dziś). W 1925 r. zgłoszono kolejną inicjatywę i powołano Wyższą Szkołę

\footnotetext{
188 Ibidem.

189 Por. W. Puś, Żydzi w Łodzi..., s. 151-153.

190 Ibidem.
} 
Nauk Społecznych i Ekonomicznych, zaś cztery lata później powstał w Łodzi Oddział Łódzkiej Wolnej Wszechnicy Polskiej, kształcący przed wybuchem wojny 1000 słuchaczy ${ }^{191}$.

Niemieckojęzyczne szkoły w Łodzi oferowały uczniom bogaty wachlarz aktywności kulturalnych, ponieważ to właśnie na placówkach oświaty spoczywał główny ciężar przygotowania wykształconego społeczeństwa do uczestnictwa w kulturze, do czytania literatury i jej tworzenia, a więc do czynnego i biernego brania udziału w życiu literackim. W życiu literackim notabene na miarę czasów i według ówczesnych wyobrażeń, co de facto oznaczało - na przeciętnym, czyli niezbyt wysokim poziomie.

W programach szkolnych uwzględniano lekcje literatury. Niemieckich uczniów zapoznawano nie tylko z wybranymi fragmentami utworów polskich, niemieckich czy rosyjskich klasyków, ale także z kompletnymi dziełami. Z pewnością można tu mówić o szkolnej edukacji literackiej, polegającej na przygotowaniu do własnej twórczości i recepcji twórczości cudzej oraz - co bardzo ważne - na docenianiu roli literatury w życiu jednostki i społeczeństwa. Wspomnienia Karla Dedeciusa czy Gerdy Leber-Hagenau potwierdzają, iż tamte lata wykształciły specyficzną atmosferę, niezwykle przychylną obcowaniu z literaturą ${ }^{192}$.

Pod tym względem przodowało Łódzkie Gimnazjum Niemieckie. W 1915 r. powołano stowarzyszenie Integer vitae, zainicjowane przez nauczyciela języka niemieckiego, dra Oskara E. Grünthera. Przewodniczącym towarzystwa został E. Friedenberg, a jego zastępcą C. Neumann. Celem stowarzyszenia było kształcenie literacko-kulturowe młodych ludzi, przede wszystkim uczniów przedostatniej i ostatniej klasy gimnazjalnej. W ramach stowarzyszenia działały dwie sekcje: literacka i muzyczna. Członkowie sekcji literackiej recytowali wiersze niemieckich klasyków i wystawiali sztuki teatralne, zaś w sekcji muzycznej ćwiczono grę na różnych instrumentach i w różnych konfiguracjach (duety, tria oraz kwartety), a w końcu utworzono niewielką orkiestrę kameralną. Spotkania sekcji odbywały się raz na dwa tygodnie, w soboty po południu ${ }^{193}$. Grupy działały nie tylko dla własnej przyjemności - ich twórczość uświetniała wiele szkolnych uroczystości. Szczególną popularnością cieszyła się grupa teatralna, która przygotowała m.in. przedstawienia Alt-Heidelberg oraz Kolberg w reżyserii Oswalda Hessego. Oba zaprezentowano później także szerszej publiczności w sali Męskiego Towarzystwa Śpiewaczego. Kolejnym udanym przedsięwzięciem był spektakl o życiu Fryderyka II Der junge Fritz [Młody Fritz], wystawiony w kwietniu

191 Ibidem.

192 Por. Gdzie sq Niemcy z tamtych lat - wspomnienia łódzkich Niemców/Sag mir, wo die Deutschen sind - Erinnerungen Lodzer Deutschen, red. K. Radziszewska, Łódź 1999.

193 Por. Der deutsche Schul- und Bildungsverein... 
1918 r. na scenie teatru niemieckiego w Łodzi. Przedstawienie stanowiło oprawę artystyczną uroczystości z okazji przybycia do Łodzi Generalnego Gubernatora von Beselera. W jego przygotowaniu pomagali profesjonalni aktorzy oraz Adela Hartwig-Wassermann, żona dyrektora Waltera Wassemanna. Stowarzyszenie przetrwało do $1920 \mathrm{r}^{194}$

Także później niemieccy uczniowie nadal chętnie pogłębiali swoje zainteresowania literackie i muzyczne, kontynuując różnorodną działalność artystyczną. W tym celu powołano inne stowarzyszenie o nazwie Schillerkreis ${ }^{195}$, skupiające także uczniów gimnazjalnych i nauczycieli języka niemieckiego. Młodzi ludzie dążyli do realizacji celów idealistycznych, zgłębiając życie i twórczość Friedricha Schillera. Czytali listy, biografię i dzienniki Schillera, wspólnie studiowali, analizowali i interpretowali jego dzieła. Wielu z nich podejmowało pierwsze próby literackie, w których widoczne były inspiracje weimarską klasyką. W ogóle należy podkreślić, iż klasycy weimarscy, należeli do podstawowego kanonu lektur szkolnych. Na lekcjach omawiano ballady Schillera i Goethego, ich dramaty Die Jungfrau von Orleans, Wilhelm Tell, Wallensteins Lager, Maria Stuart, Don Carlos, Die Jungfrau von Orléans, Götz von Berlichingen, Iphigenie auf Tauris, Torquato Tasso ${ }^{196}$. Czytano również Uhlanda oraz Lessinga, jednakże poświęcano im o wiele mniej miejsca. Do stowarzyszenia należało wielu nauczycieli, np. Else Strobelt, Magdalene Schwarz, Oskar Eugen Günther czy Leo Müller. Na spotkaniach, odbywających się raz w tygodniu, dyskutowano na tematy literackie, ale również podejmowano próby tworzenia własnej literatury. Raz w miesiącu efekty wspólnej pracy prezentowano szerszej publiczności, przy czym coraz lepsza orientacja młodych ludzi w sprawach literatury i kultury wzbudzała uznanie. Schillerkreis dzielił się ponadto na kółka skupiające uczniów danej klasy; co tydzień organizowano zebrania klasowe, raz w miesiącu zwoływano zebranie wszystkich kółek, natomiast raz w roku odbywało się walne zebranie podsumowujące całoroczną działalność. Członkami stowarzyszenia Schillerkreis mogli być uczniowie najstarszej, czwartej klasy gimnazjum ${ }^{197}$. Istniała także filia stowarzyszenia w Niemieckim Gimnazjum Żeńskim, skupiająca nie tylko najstarsze roczniki, ale również młodsze grupy uczniów. Twórczość niemieckich uczniów z Łodzi i ich pierwsze próby literackie prezentowano wielokrotnie na konkursach

194 Ibidem.

195 Por. AdaMuW (Archiv der Deutschen aus Mittelpolen und Wolhynien): Satzungen des Schillerkreises, sygn. A1CIV, nr 584.

196 Por. Jahresbericht des Zgierzer Deutschen Real-Gymnasiums für Knaben und Mädchen über das Schuljahr 1924-1925, Politisches Archiv des Auswärtigen Amtes, Akten Schulwesen 1925-1927, sygn. 49.

197 Członkowie stowarzyszenia wnosili miesięczne opłaty w wysokości 0,50 zł. Każde spóźnienie na zebranie kosztowało ucznia 0,25 zł, natomiast wpisowe wynosiło 2 zł. Por. ADMuW: Satzungen des Schillerkreises, sygn. A1CIV, nr 584. 
w Niemczech oraz w lokalnej prasie. Działalność literacką prowadziło też powołane w 1917 r. ${ }^{198}$ Stowarzyszenie Niemieckiego Nauczycielstwa, którego celem była konsolidacja niemieckich pedagogów, doskonalenie zawodowe, podnoszenie poziomu edukacji i krzewienie oświaty. Dbano także o rozwój życia towarzyskiego, podejmując szereg różnorodnych aktywności, takich jak np. organizacja wieczorów literackich. Jednym z nich była impreza urządzona 31 stycznia 1928 r. w sali Gimnazjum Niemieckiego, przebiegająca pod hasłem „Śmiejmy się!”. Gościem honorowym i jednocześnie wspaniałym recytatorem wesołych wierszy i ballad Goethego i Münchhausena, zabawnych wierszy o winie, kobietach i mężczyznach, był Willi Damaschke z Bydgoszczy ${ }^{199}$.

Rozwój instytucji kulturalnych postępował w Łodzi na miarę potrzeb lokalnej społeczności, przy czym potrzeby te nie były zbyt wygórowane. Społeczność łódzką stanowili w głównej mierze robotnicy i pracownicy fabryk, którzy przybyli tu z odległych wsi i miasteczek. Dlatego kultura, którą tworzyli, często nawiązywała do rodzimych tradycji i zwyczajów. Chętnie powoływano instytucje i związki o charakterze turnerskim, towarzystwa śpiewacze i szkolno-oświatowe. Łodzianie byli również twórcami teatru jako miejsca, w którym prezentowano także ambitniejsze i trudniejsze sztuki. Niemieckojęzyczni łodzianie nie zdołali doprowadzić do powołania organizacji, która zgromadziłyby twórców, krytyków i odbiorców literatury i poświęciła się działalności literackiej. Wśród nielicznych ludzi pióra znaleźli się dziennikarze, adwokaci, nauczyciele, uczniowie szkół gimnazjalnych, lekarze i działacze polityczni. Ci ostatni na początku XX w. i w okresie międzywojennym wspierali w Łodzi niemiecką kulturę, silnie związaną z nurtem propagującym ideologię narodowoniemiecką, co oczywiście nie pozostało bez wpływu na kształt tworzonej przez nich literatury ${ }^{200}$.

198 Por. Statut Stowarzyszenia Niemieckiego Nauczycielstwa w Łodzi, ADMuW, sygn. A1CIII, nr 415.

199 Por. ADMuW, sygn. A1CIII, nr 415.

200 Szerzej na temat Heimatdichtung w rozdziale 5: Inne przestrzenie łódzkiej poezji. 


\section{2. ŁÓDZKA PRASA I JEJ ZWIĄZKI Z LITERATURĄ}

\subsection{Niemieckojęzyczna prasa Łodzi - uwagi ogólne}

W kontekście rozwoju regionalnej literatury łódzkiej istotna rola przypadła miejscowym gazetom niemieckim. To właśnie ich lektura bywała dla zwykłych, przeciętnych łodzian początkowo niemal wyłącznym źródłem kontaktu z literaturą. Prasa odegrała zatem w życiu kulturalnym miasta zasadniczą rolę, a na jej rozwój w XIX i w pierwszej połowie XX w. wpłynęło wiele czynników pośrednich, tzn. politycznych, społeczno-kulturowych i ekonomicznych, oraz bezpośrednich - ustawodawstwo prasowe i warunki techniczne, związane z drukiem i rozpowszechnianiem gazet. Mimo iż Łódź była na przełomie wieków miastem rozwijającym się w iście amerykańskim tempie, na pierwszą lokalną gazetę przyszło jej długo czekać. Pojawiła się dopiero w latach 60 . XIX w., kiedy miasto liczyło już ponad 40000 mieszkańców. Był to polsko-niemiecki tytuł „Łodźer Anzeiger/Łódzkie Ogłoszenia”, wydawany przez Johanna Petersilgego ${ }^{1}$. Pismo miało charakter głównie informacyjny i prezentowało przedruki rozporządzeń władz lokalnych na okoliczność wybuchu powstania styczniowego oraz wynikających stąd ograniczeń dla ludności. Istniało wiele przyczyn, dla których gazeta nie cieszyła się zbyt dużą popularnością. Z jednej strony nie zachęcała ówczesnego czytelnika do lektury z uwagi na rodzaj zamieszczanych w niej informacji (głównie rozporządzeń władz lokalnych), a także sposób przekazu i brak ciekawej szaty graficznej. Z drugiej strony nie należy zapominać, iż w tym czasie dużą część łódzkiego społeczeństwa stanowili analfabeci, stąd potencjalnych czytelników gazet nie mogło być zbyt

${ }^{1}$ Gazeta „Łodźer Anzeiger/Łódzkie Ogłoszenia” od numeru 46 z 19./31.05.1864 r. zmieniła nazwę na „Łodzer Anzeiger/Łódzkie Ogłoszenia”, natomiast nigdy nie nazywała się „Łódzkie Ogłoszenia - Lodzer Anzeiger", jak pisze wielu badaczy Łodzi. Dlatego w pracy będę posługiwała się do numeru 46 tytułem „Łodźer Anzeiger/Łódzkie Ogłoszenia”, a później „Łodzer Anzeiger/Łódzkie Ogłoszenia”. 
wielu. Taki stan utrzymywał się dość długo, gdyż - jak wykazują statystyki z 1931 r. - co trzeci mieszkaniec miasta w tym czasie był analfabetą lub półanalfabetą ${ }^{2}$. Gazeta nie przetrwała długo, a jej wydawca, Johann Petersilge, w 1865 r. otworzył w jej miejsce kolejną o nazwie „Lodzer Zeitung”. Ten tytuł miał niebawem zdobyć popularność i zyskać sympatię wielu łodzian.

Mimo trudnych warunków łódzka prasa rozwijała się, a wielonarodowy charakter miasta kształtował w istotny sposób jej profil. Aby w klarowny sposób przedstawić rozwój łódzkiej prasy, przyjęłam kryterium językowe jako podstawowy wyróżnik jej podziału. W dalszej części rozdziału zastosowałam kryteria ustalone przez znanego prasoznawcę Walerego Pisarka, który także uznaje kryterium językowe za istotne dla charakterystyki prasy w ogóle ${ }^{3}$. Posłużyłam się poza tym kryterium częstotliwości ukazywania się gazet oraz - jako najważniejsze kryterium klasyfikacji czasopism - ofertą tematyczną. Pozostałe kryteria, takie jak np. zasięg, typ właściciela-dysponenta, status prawny, ideologia, publiczność, poziom intelektualny czy funkcja społeczna, zostaną omówione przy okazji charakterystyki poszczególnych pism, by z jednej strony uniknąć powtarzania pewnych treści, z drugiej zaś zachować przejrzystość wywodów.

Na podstawie dotychczasowych badań Wiesławy Kaszubiny można przyjąć, iż w okresie 1863-1944 ukazały się w Łodzi 834 pisma o różnym charakterze, z różnych dziedzin i $\mathrm{w}$ różnych językach ${ }^{4}$. Najwięcej pism wydawano w języku polskim, zaś drugie miejsce pod względem liczby tytułów zajmowały gazety niemieckie. W omawianym okresie było ich $110^{5}$, w języku jidysz

${ }^{2}$ Por. J. Tynecki, Łódzki rynek prasowy $w$ dwudziestoleciu międzywojennym, „Prace Polonistyczne" 1983, ser. XXXIX.

${ }^{3}$ Więcej na temat klasyfikacji druków prasowych zob. W. Pisarek, Słownik terminologii medialnej, Kraków 2006.

${ }^{4}$ Badania przeprowadzone w latach 60. XX w. przez Wiesławę Kaszubinę nie są kompletne. Niestety dotychczas nikt inny nie podjął kolejnej próby weryfikacji stanu łódzkiej prasy, obejmującej m.in. wysokość nakładów czy liczbę tytułów. Kaszubina pozostaje na razie jedyną badaczką, która zajęła się tym dość trudnym zagadnieniem. Jak sama przyznaje, praca nie była łatwa, bowiem stan archiwaliów nie jest dobry, a rozproszenie materiału znacznie utrudnia prowadzenie badań. Gazet wymienionych w opracowaniu Kaszubiny nie należy traktować jako zbioru zamkniętego, ponieważ jego autorka nie uwzględniła wszystkich pism w tym kalendarzy, sprawozdań i jednodniówek. Opierając się na jej badaniach i uzupełniając je dodatkowo o prace innych autorów, takich jak np. Andrzej Paczkowski, Tadeusz Kowalak, Karol Kaschnitz, i informacje znajdujące się w Małym roczniku statystycznym, można szacunkowo zrekonstruować obraz łódzkiej prasy w omawianym okresie, choć należy również wskazać na pewne niedostatki wynikające w wielu przypadkach z braku danych źródłowych.

${ }^{5}$ Wśród wielu gazet niemieckojęzycznych do najważniejszych można zaliczyć takie dzienniki i tygodniki, jak: „Łodźer Anzeiger/Łódzkie Ogłoszenia”, ,Lodzer Tageblatt”, „Neue Lodzer Zeitung”, „Freie Presse”, „Deutsche Lodzer Zeitung”, „Lodzer Volkszeitung”, „Der Deutsche Weg”, „Der Deutsche Wegweiser”, „Deutsche Post”, „Der Friedensbote”, „Lodzer Textilmarkt”. Dokładniejsze informacje na temat wymienionych gazet można znaleźć w kolejnych rozdziałach omawiających stan prasy łódzkiej. 
$91^{6}$, w hebrajskim $23^{7}$, rosyjskim $14^{8}$, czeskim $1^{9}$, litewskim $1^{10}$, ukraińskim $1^{11}$, francuskim $1^{12}$ oraz 1 gazeta w języku esperanto ${ }^{13}$, pozostałe pisma ukazywały się w języku polskim. Oprócz pism jednolitych językowo pojawiały się na łódzkim rynku prasowym gazety dwu- i trzyjęzyczne, np. „Herold. Rynek Włókienniczy. Textilmarkt"14 (organ polskiego przemysłu włókienniczego, wydawany w języku polskim i niemieckim) oraz „Textile Journal” ${ }^{15}$, wydawany w języku polskim, niemieckim i rosyjskim. Takich gazet było jednak w Łodzi niewiele i tworzyły jedynie mało znaczący margines ${ }^{16}$. W sumie

${ }^{6}$ Z ważniejszych tytułów prasowych w języku jidysz warto odnotować „Łodzier Togbłat” i „Łodzier Fołksbłat”.

${ }^{7} \mathrm{~W}$ języku hebrajskim ukazywały się w większości pisma cotygodniowe oraz comiesięczne, np. miesięczniki „Beet Jakov”, „Hamadrich”, „Hakedem” oraz dwutygodnik „Cifririm”.

${ }^{8}$ W połowie lat 90. XIX w. zaczęła wychodzić rosyjska gazeta o nazwie „Łodzinskij Listok", niezmiernie lojalna wobec władz carskich, stąd można ją określić mianem półoficjalnego organu carskiego. Większość tekstu zajmowały ogłoszenia carskich władz, przedrukowywane z gazet rosyjskich. Mniejsze znaczenie dla miejscowego rynku prasowego miały dwie kolejne rosyjskie gazety: „Łodzinskij Listok Objawlenij” (ukazywał się w latach 1900-1902) oraz „Łodzinskaja Gazieta Objawlenij”. Ta ostatnia wychodziła jeszcze krócej, bo tylko przez pół roku 1892. Dopiero przed wybuchem I wojny światowej pojawiły się dwa ważniejsze pisma o ambicjach społeczno-literackich. Jednym z nich była „Łodzinskaja Mysl” z 1910 r. oraz „Łodzinskaja Żyzń”, która ukazywała się w latach 1911-1912. Pod koniec XIX w. podjęto również próbę wydania pierwszego rosyjskiego dwutygodnika oraz miesięcznika. W 1898 r. Leopold Zoner zaczął wydawać „Żurnał Tiechnołogii, Promyszlennosti i Torgowli”, a w latach 1907-1908 wychodził miesięcznik „Bumaga i Gałantierejno-piszczebumażnyje Prinadleżnosti”. Wśród czasopism o charakterze kulturalnym należy wymienić wydawaną w 1912 r. gazetę „Gołos Łodzi i Łodzinskij Kommersant". Por. W. Kaszubina, Bibliografia prasy łódzkiej 1863-1944, Warszawa 1967, s. 75 oraz badania własne.

9 "Cesko Ruske Listy” to miesięcznik, który ukazywał się w 1907 r. Ibidem, s. 30.

10 Jedyną gazetą ukazującą się w języku litewskim był „Marijavitas”, pismo o charakterze efemerydalnym, które pojawiło się na łódzkim rynku prasowym w 1909 r. Ibidem, s. 135.

11 „Pislanec Pravdy. Casopys prysvjacenyj posyrennju chrisyjanskoi dumky“ - gazeta baptystów, ukazała się w 1927 r., wydawcą i redaktorem odpowiedzialnym był Włodzimierz Gutsze. Drukowano ją w drukarni Kompas przy ul. Sienkiewicza 53 w Łodzi.

12 Jedyną gazetą w języku francuskim, która ukazywała się w Łodzi w 1913 r., był ilustrowany dwutygodnik „Le Francais”. Ibidem, s. 54.

13 Jedyną w Łodzi gazetą ukazującą się w języku esperanto był biuletyn łódzkiej młodzieży esperanckiej „Juna Penso”, który ukazał się w 1909 r.

14 „Herold. Rynek Włókienniczy. Textilmarkt” - organ polskiego przemysłu włókienniczego, którego pierwszy numer ukazał się 1 września 1927 r. Pismo wychodziło do 1932 r., następnie zmieniło nazwę na „Łódzki Rynek Włókienniczy. Lodzer Textilmarkt”. Jego wydawcą i redaktorem był Alfred Tögel. Pojedyncze numery dostępne w ADMuW, sygn. Bk1II 2481.

${ }^{15}$ Gazeta dostępna z oryginalną wkładką, zawierającą próbkę materiałów w kolorze błękitu kadziowego, które wytworzyła rosyjska fabryka farb anilinowych Leopolda Cassella, w ADMiW, sygn. Bk1 III 6183.

${ }^{16}$ Jak wynika z analizy bibliografii prasy łódzkiej, przeprowadzonej w oparciu o spis sporządzony przez W. Kaszubinę, pism dwu- i trzyjęzycznych było w Łodzi trzynaście. 
pisma obcojęzyczne stanowiły w okresie 1863-1944 ok. 29\% ogółu ukazujących się tytułów, z czego 13\% to pisma niemieckojęzyczne. Z uwagi na charakter pracy warto skoncentrować się na zwięzłej charakterystyce właśnie tej prasy jako ważnego źródła popularyzacji niemieckiej literatury ${ }^{17}$.

${ }_{17}$ Ponieważ celem niniejszej pracy nie jest przedstawienie rozwoju prasy łódzkiej w sposób kompletny, tzn. całego jej wielonarodowego charakteru, należy zwrócić uwagę na stosunkowo obszerny, choć nie do końca wyczerpujący stan badań zagadnienia. Pierwsze próby usystematyzowania łódzkiej prasy podjęto w okresie międzywojennym. Powstały wówczas publikacje O. Tögela, Deutsches Zeitungswesen in Lodz (1926), K. Kaschnitza, Prasa niemiecka w Polsce, „Biblioteka Spraw Narodowościowych” 13/1933 oraz Z. Stolińskiego, Die deutsche Minderheit in Polen, Warszawa 1928. Na ich podstawie można wyciągnąć ogólniejsze wnioski o stanie prasy. Szeroko zakrojone i systematyczne badania problemu podjęto dopiero w okresie powojennym. Ukazały się wtedy liczne publikacje W. Kaszubiny: Bibliografia prasy łódzkiej 1863-1944, Warszawa 1967; Najstarsze łódzkie czasopisma kulturalno-literackie. Szkic historyczno-bibliograficzny, „Prace Polonistyczne” 1969, ser. XXV, s. 115-140. Interesujący materiał źródłowy zawierają również artykuły J. Jaworskiej: Goniec Łódzki (1898-1906) wobec rosyjskiej cenzury, „Roczniki Biblioteczne” 1966, R. 10, s. 363393; Początki księgarstwa w Łodzi, „Roczniki Biblioteczne” 1-2/1969, R. 13, s. 117-137; Łódzkie wydawnictwa popularne (przed 1918 r.), „Roczniki Biblioteczne” 1-2/1971, R. 15, s. 57-79; Zakłady drukarsko-litograficzne J. Petersilgego w Łodzi (1860-1915), „Roczniki Biblioteczne" 3-4/1972, R. 16, s. 521-534; Cenzura carska w Łodzi przed pierwszq wojnq światowa, „Roczniki Biblioteczne” 1-2/1973, R. 17, s. 121-156; Literatura piękna w dorobku łódzkich wydawców (do 1918 r.), „Zeszyty Naukowe Uniwersytetu Łódzkiego. Nauki Humanistyczno-Społeczne" 26/1977, s. 45-66; Wydawnictwa łódzkie w latach 1868-1918. Szkic historyczno-statystyczny, „Roczniki Biblioteczne” 3-4/1978, R. 22, s. 479-510. Poza tym trzeba wspomnieć publikację W. Władyki, Prasa codzienna w Polsce 1918-1939. Charakterystyka statystyczna, „Rocznik Historii Czasopiśmiennictwa Polskiego” 13(2)/1974, s. 137-155. Istotne informacje na temat prasy łódzkiej okresu międzywojennego zawierają następujące publikacje: T. Kowalaka, Prasa niemiecka w Polsce 1918-1939, Warszawa 1971; J. Tyneckiego, Łódzki rynek prasowy w dwudziestoleciu międzywojennym, „Prace Polonistyczne” 39/1983, s. 259-284; A. Paczkowskiego, Prasa polska w latach 1918-1939, Warszawa 1980; J. Łojka, J. Myślińskiego, W. Władyki, Dzieje prasy polskiej, Warszawa 1988. Z nowszych publikacji, które ukazały się po 1990 r., należy wymienić prace L. Olejnika, Z dziejów prasy łódzkiej „Kurier Łódzki” i „Echo”. Wydawnictwa Jana Stypułkowskiego 1919-1939, „Acta Universitatis Lodzeinsis. Folia Historica" 52/1995, s. 143-162; M. Kucner, Prasa niemiecka $w$ Łodzi 18631939, [w:] Niemcy w dziejach Łodzi do 1945 roku, red. K.A. Kuczyński, B. Ratecka, Łódź 2001; Z dziejów politycznej prasy mniejszości niemieckiej w Łodzi, „Zeszyty Naukowe PWSZ we Włocławku" 2/2004, s. 147-151; Gazety niemieckie do 1939 roku / Deutsche Zeitungen bis 1939, [w:] Niemcy łódzcy, red. A. Machejek, Łódź 2005, s. 75-78; Prasa niemiecka w Łodzi w okresie międzywojennym, [w:] Wizerunek Łodzi w literaturze, kulturze i historii Niemiec i Austrii. Materiały z konferencji, Łódź 2005, s. 161-180; Deutsche Presselandschaft der Zwischenkriegszeit in Lodz, „Acta Universitatis Lodziensis, Folia Germanica” 5/2009, s. 285-301; Lodz in den feuilletonistischen Texten von Carl Heinrich Schultz (1882-1940), [w:] Lodz jenseits von „Fabriken, Wildwest und Provinz", hrsg. v. S. Dyroff, K. Radziszewska, I. Röskau-Rydel, München 2009, s. 73-93; Politische Presse und das politische Leben der deutschen Minderheit bis 1939, [w:] Studia i szkice dedykowane Julianowi Baranowskiemu, red. E. Wiatr, P. Zawilski, Łódź 
Odwołując się do danych statystycznych dotyczących pism niemieckojęzycznych w Łodzi, należy sięgnąć do badań Tadeusza Kowalaka, które niestety dotyczą jedynie okresu międzywojennego. Dlatego obraz prasy pod względem statystycznym od chwili ukazania się pierwszej łódzkiej gazety jest niekompletny. Jednakże warto przywołać źródła oraz istniejące dane. Według Kowalaka, w 1924 r. 17\% ogółu łódzkiej prasy stanowiły czasopisma niemieckie, natomiast $70 \%$ polskie. W $1932 \mathrm{r}$. autor zauważa wzrost udziału pism niemieckich do $27 \%$ i spadek polskich do 54\%; z kolei w 1935 r. odnotowuje niewielki spadek pism niemieckich (do 25\%) i wzrost polskich (do 62\%) ${ }^{18}$. W porównaniu do innych wielkich ośrodków prasowych, wydających w tym okresie prasę niemieckojęzyczną, takich jak Bydgoszcz, Poznań czy Katowice, Łódź była silnym niemieckojęzycznym centrum prasowym, a wyprzedzała ją jedynie Bydgoszcz, w której nakład prasy w omawianym okresie utrzymywał się niemal na stałym poziomie, pokrywając ponad jedną trzecią całego rynku gazet (1924 r. - 33\%, 1932 r. - 37\%, 1935 r. - 37\%). Najmniej gazet niemieckojęzycznych miał w tym czasie, według obliczeń Kowalaka, Poznań (1924 r. - 11\%, 1932 r. - 11\%, 1935 r. - 10\%) ${ }^{19}$. Częściowo odmiennych danych dostarcza praca Karola Kaschnitza. Według niego, w 1932 r. społeczność niemiecka w Polsce dysponowała łącznie 106 tytułami. Autor nie podaje jednak, jaki odsetek stanowiły one wobec ogółu ukazującej się w tym czasie prasy ${ }^{20}$.

Prasa niemieckojęzyczna w Łodzi zyskała z czasem wielu czytelników. Czytywali ją nie tylko miejscowi Niemcy, ale również Polacy i Żydzi ${ }^{21}$. Także w redakcjach wielu gazet zasiadali przedstawiciele różnych nacji, jak w przypadku polskojęzycznego „Przeglądu Handlowo-Przemysłowego”, którego redaktorem i wydawcą był niemiecki dziennikarz i pisarz Carl Heinrich Schultz ${ }^{22}$.

O różnorodności łódzkiej prasy przesądził nie tylko jej wielonarodowy charakter, nadający jej typowe cechy - łódzka prasa była zróżnicowana również pod względem częstotliwości ukazywania się. Biorąc pod uwagę to czysto formalne kryterium, należy stwierdzić, że wśród niemieckojęzycznych

2010, s. 56-68. Interesujących wniosków dostarczają również następujące prace: A. Ochocki, Reporter przed konfesjonałem, czyli jak się w Łodzi przed wojna robiło gazetę, Łódź 2004; D. Lakeberg, Die deutsche Minderheitenpresse in Polen 1918-1939 und ihr Polen- und Judenbild, Frankfurt/Main i in. 2010, J. Mikosz, Dodatki kulturalne do gazet dwudziestolecia międzywojennego, Łódź 2007 i „Dziennik Łódzki” - tradycja i współczesność, Łódź 2006 oraz M. Hrycka, Tematyka żydowska na łamach polskojęzycznych dzienników łódzkich okresu międzywojennego, Łódź 2012 (maszynopis pracy doktorskiej udostępniony przez prof. Barbarę Bogołębską).

18 Por. T. Kowalak, Prasa niemiecka..., s. 372, tabela 4.

${ }^{19}$ Ibidem.

${ }^{20}$ Por. K. Kaschnitz, Prasa niemiecka...

${ }^{21}$ Popularną gazetą czytaną przez wielu łodzian była „Lodzer Zeitung”, ukazująca się od 1865 do 1915 r. Więcej na temat tej gazety zob. kolejne rozdziały pracy.

22 Por. W. Kaszubina, Bibliografia..., s. 173. 
gazet były dzienniki wychodzące co najmniej dwa razy w tygodniu oraz czasopisma publikowane nie częściej niż raz w tygodniu i nie rzadziej niż raz w roku ${ }^{23}$. W latach 1863-1944 ukazało się w Łodzi 15 niemieckojęzycznych dzienników, 28 tygodników, 22 miesięczniki, 7 dwutygodników, 1 dwumiesięcznik, 2 kwartalniki i 1 rocznik. Resztę stanowiły pisma, które były jedynie efemerydami ${ }^{24}$. W odniesieniu do całego kraju danych dostarcza ponownie Tadeusz Kowalak. Według niego, w latach 1919-1939 w Polsce wychodziło 18-32 dzienników o charakterze politycznym, pism ukazujących się 2-4 razy w tygodniu było od 120 w 1919 r. do 11 w 1939 r., natomiast liczba tygodników wahała się między 6 i 14. Dla prasy gospodarczej liczby są znacznie niższe - tygodników w tym okresie było 5-15, dwutygodników 1-3, miesięczników 2-7. Podobnie niskie wartości odnosiły się do prasy o profilu zawodowym i religijnym. W przypadku pierwszej grupy dwutygodników było $5-11$, miesięczników 2-3; wśród tytułów religijnych odnotowano 3-11 tygodników, dwutygodników 1-5, miesięczników 4-14. Najmniej ukazywało się w Polsce niemieckojęzycznej prasy kulturalno-oświatowej. W latach 1919-1939 wychodziło 1-3 tygodników oraz 1-8 dwutygodników ${ }^{25}$.

Z przytoczonych danych wynika, iż najbardziej popularnymi pismami były w skali kraju gazety codzienne oraz tygodniki i dwutygodniki, mniejszą popularnością cieszyły się natomiast miesięczniki. W przypadku Łodzi mamy do czynienia z dużą popularnością tygodników i dwutygodników, które najprawdopodobniej ze względu na przemysłowy charakter miasta dostarczały czytelnikom przede wszystkim wiedzy fachowej, będąc zarazem ważnym medium opiniotwórczym. Jeśli jednak wziąć pod uwagę nakłady prasy, to daje się zauważyć, że dzienniki wydawano w większej liczbie egzemplarzy niż inne czasopisma. Dla przykładu nakład "Neue Lodzer Zeitung” wynosił od 10000 do 18 000, „Freie Presse” do 15 000, zaś „Deutsche Lodzer Zeitung” nawet do 34000 egzemplarzy. W odniesieniu do tygodników i dwutygodników sytuacja wygląda inaczej, bowiem w tym przypadku mamy do czynienia z niższymi nakładami („Der Kinderfreund” od 2400 do 4000 egzemplarzy, „Der Hausfreund” 1600) ${ }^{26}$.

${ }^{23}$ Jak zauważa W. Pisarek, podział ten nie jest do końca zgodny z międzynarodowym, standardowym systemem klasyfikacji druków periodycznych, dla których istotnym kryterium jest podział na gazety o treści ogólnej (czyli poświęcone wiadomościom o charakterze publicznym, międzynarodowym i politycznym) oraz czasopisma (o tematyce innej niż obowiązująca dla wcześniej wspomnianych gazet ogólnych). W dalszej kolejności gazety ogólne dzieli się na ukazujące się co najmniej cztery razy w tygodniu oraz nie częściej niż trzy razy w tygodniu.

${ }^{24}$ Dokonałam analizy na podstawie pracy W. Kaszubiny, Bibliografia...

25 Ta dość duża rozpiętość dotycząca liczby ukazujących się gazet wynika z braku rzetelnych badań na ten temat. Por. T. Kowalak, Prasa niemiecka..., s. 372, tabela 4.

${ }^{26} \mathrm{~W}$ przypadku nakładów prasy należy podkreślić, iż są one podawane w przybliżeniu. Z uwagi na brak dokładnych danych dotyczących stanu prasy w Łodzi od chwili jej powstania do wybuchu II wojny światowej trudno przedstawić jej rozwój w ujęciu statystycznym. Jak 
Biorąc pod uwagę kolejne istotne kryterium klasyfikacji czasopism, jakim jest tematyka, można wyróżnić wśród łódzkich gazet pisma ogólnoinformacyjne, społeczno-kulturalne i fachowe ${ }^{27}$. W okresie międzywojennym największą grupę stanowiły tytuły ogólnoinformacyjne i jest to zjawisko charakterystyczne dla ogółu niemieckojęzycznych gazet ukazujących się w tym czasie w Polsce ${ }^{28}$. Jak podaje Andrzej Paczkowski, pisma polityczne stanowiły ok. 50\% wszystkich wydawnictw w języku niemieckim. Miały na ogół jasno sprecyzowany profil i były organami prasowymi partii politycznych. Znajdowały się wśród nich pisma o charakterze ugodowym, nacjonalistycznym i socjalistycznym ${ }^{29}$. Nie dysponujemy jednak podobnymi ustaleniami w odniesieniu do okresów wcześniejszych. Na podstawie analiz Wiesławy Kaszubiny i Karola Kaschnitza można założyć, iż sytuacja w poprzednich okresach wyglądała bardzo podobnie. Przed 1918 r. trzon prasy niemieckojęzycznej stanowiły także pisma ogólnoinformacyjne, takie jak „Łodźer Anzeiger/Łódzkie Ogłoszenia”, „Lodzer Tageblatt”, „Neue Lodzer Zeitung” i „Lodzer Rundschau", natomiast prasę fachową reprezentowały takie tytuły, jak „Evangelisch-Lutherisches Kirchenblatt”, „Unsere Kirche”, „Der Hausfreund” i „Lodzer Textilmarkt”, z których wszystkie miały znacznie niższe nakłady niż prasa ogólnoinformacyjna.

\subsection{Etapy rozwoju prasy niemieckiej}

Dla łódzkiego rynku prasowego istotny jest przebieg rozwoju niemieckiej prasy, który należy rozpatrywać w kilku okresach: pierwszy dotyczy lat 1863-1914, drugi obejmuje I wojnę światową, trzeci lata międzywojenne.

\footnotetext{
pisze Andrzej Paczkowski, oficjalne dane odnoszące się stanu ilościowego prasy polskiej zaczęto opracowywać dopiero od 1924-1925 r. Statystykę prasy prowadził początkowo Wydział Prasowy Ministerstwa Spraw Wewnętrznych, od 1929 r. Instytut Bibliograficzny Biblioteki Narodowej w Warszawie. Przed wspomnianym okresem rejestracji czasopism dokonywały oficjalne agendy na podstawie niepełnej bazy faktograficznej, przy zastosowaniu niedoskonałych kryteriów rejestracji. Stąd wszystkie dane na temat stanu prasy przed 1924 r. mogą być jedynie hipotetyczne. W wielu przypadkach dane o nakładach dodatkowo zawyżano, gdyż umieszczano je w informatorach firm ogłoszeniowych. Dość dokładne informacje na temat łódzkiej prasy znajdują się jedynie w materiałach Wydziału Bezpieczeństwa Urzędu Wojewódzkiego Łódzkiego z lat 1937-1938. Dane według: W. Kaszubina, Bibliografia...

27 W. Pisarek, Słownik...

28 T. Kowalak, Prasa niemiecka...

29 A. Paczkowski, Prasa polska...
} 


\section{$1863-1914$}

W okresie od powstania styczniowego do wybuchu I wojny światowej łódzkie gazety rozwijały się $\mathrm{w}$ cieniu rosyjskiej cenzury. Wszystkie podlegały rosyjskiej cenzurze prewencyjnej, obowiązującej w całym Królestwie Polskim ${ }^{30}$. W tym celu utworzono w Warszawie instytucje odpowiedzialne za egzekwowanie ustawy. Do 1869 r. istniały dwie placówki zajmujące się kontrolą wydawnictw. Pierwszą z nich był Komitet Cenzury, drugą - Oddział Prasy Periodycznej. Po 1869 r. powstał jeden wspólny urząd, który zajmował się kontrolą wydawnictw. Był to Warszawski Komitet Cenzury, podporządkowany Głównemu Urzędowi ds. Prasowych w Petersburgu. Ocenie władz cenzorskich podlegały wydawnictwa zwarte i periodyczne, drukowane w Warszawie i w miastach prowincjonalnych Królestwa Polskiego. W przypadku niezastosowania się do wytycznych władz cenzorskich wobec wydawnictw stosowano liczne represje. Cenzor mógł nałożyć karę pieniężną, wydać zakaz drukowania gazety lub pewnych rubryk, a nawet zastosować karę więzienia. Odpowiedzialność za cenzurę łódzkich wydawnictw sprawowali kolejno: naczelnik wojenny Aleksander von Broemsen (we współpracy z policmajstrem Kalińskim), następnie naczelnik powiatu kapitan Szirnau, inspektor Łódzkiej Szkoły Rzemiosł G. Anapow, nauczyciel K. Schmidt oraz pułkownik Andrejew. 0 ile gazety niemieckie $\mathrm{w}$ Łodzi przez dłuższy okres cenzurowane były w mieście przez tutejsze władze, o tyle cenzurę gazet polskojęzycznych - z nie do końca zbadanych przyczyn - przejął Warszawski Komitet Cenzury ${ }^{31}$.

Podczas obowiązywania cenzury łódzcy Niemcy cieszyli się mimo wszystko większą swobodą prasową niż społeczność polska, co wynikało głównie z faktu, że niemieccy fabrykanci starali się zachować lojalność wobec carskich władz. Polacy natomiast - w przeważającej części robotnicy - byli $\mathrm{z}$ uwagi na dążenia patriotyczne niechętni Rosjanom ${ }^{32}$.

Charakterystyczna dla pierwszej fazy rozwoju prasy jest niewielka liczba tytułów ${ }^{33}$. Prasa znajdowała się wówczas w początkowym okresie rozwoju,

30 Por. J. Jaworska, Cenzura carska w Łodzi przed pierwszq wojnq światowq, , ,Roczniki Biblioteczne" 1-2/1973, R. 17.

31 Ibidem, s. 121-156.

32 Ibidem.

${ }^{33}$ Informacje na temat chronologii rozwoju prasy, jak również jej charakterystykę w kolejnych okresach opracowałam na podstawie następujących gazet niemieckojęzycznych: „Łodźer Anzeiger/Łódzkie Ogłoszenia” 1863-1864; „Lodzer Volkszeitung”; „Deutsche Lodzer Zeitung” 1915-1918; „Lodzer Zeitung” 1865-1915; „Lodzer Tageblatt”; „Neue Lodzer Zeitung”; „Deutsche Post” 1-27/1915, 1-53/1916, 1-52/1917, 1-44/1918; „Freie Presse” 1927-1939; „Der Deutsche Weg” 1935-1939; „Der Deutsche Wegweiser” 1938-1939; „Deutsche Post” 1915-1918; „Der Volksfreund” 1918; które ukazywały się w omawianym czasie. Ponieważ zagadnienie to nie jest tematem kluczowym dla rozważań na temat literatury, wnioski przedstawiono w sposób syntetyczny. 
czytelników było jeszcze niewielu, robotnicy i chłopi, którzy przybyli do miasta, nie potrafili czytać, a co za tym idzie nie mieli wyrobionych nawyków czytelniczych. Dlatego objętość pierwszych pism rzadko przekraczała cztery strony, co mimo wszystko nie umniejsza roli, jaką ówczesne pisma miały do spełnienia, bowiem oprócz funkcji informacyjnej starały się wypełniać także zadanie opinio- i kulturotwórcze. Za pomocą łatwych, nieskomplikowanych tekstów wprowadzały swoich czytelników w świat sztuki i literatury. Często redakcje poszukiwały materiału do przedruku w prasie europejskiej (głównie pruskiej), a zwyczaj ten praktykowano w wielu krajach europejskich od XVIII w. ${ }^{34} \mathrm{~W}$ większości gazet europejskich dominowała informacja $\mathrm{w}$ postaci wiadomości publikowanych $\mathrm{w}$ tzw. gazetach międzynarodowych, wydawanych w języku francuskim i niemieckim, przeznaczonych do rozpowszechniania w całej Europie ${ }^{35}$. Zazwyczaj wiadomości przedrukowywane w takich gazetach stanowiły aż 3/4 objętości pisma, dlatego na część lokalną pozostawało niewiele miejsca. Podobnie rzecz się miała z pierwszymi łódzkimi gazetami niemieckojęzycznymi, w których drukowano powieści w odcinkach i informacje z zagranicy, czerpiąc je z innych pruskich czasopism. Zapewne miało to ogromne znaczenie praktyczne, ponieważ pod koniec XIX w. redakcje nie posiadały jeszcze wystarczającego zaplecza $w$ postaci doświadczonej kadry dziennikarskiej i możliwości technicznych. W ogóle początkowy okres rozwoju niemieckojęzycznej prasy charakteryzował się trudnymi warunkami społeczno-gospodarczymi, dlatego gazety często upadały z braku pieniędzy i czytelników.

W początkowym okresie dużą część gazet stanowiła prasa ogólnoinformacyjna, w której ważnym elementem były zarządzenia carskich władz. Pierwsze pisma nie były organami partii, ponieważ zaborca na to nie zezwalał ${ }^{36}$, a i świadomość polityczna nie była jeszcze zbyt wysoka. Pisma szanowały i przestrzegały zasad tolerancji w stosunku do wszystkich obywateli miasta i starały się unikać konfliktów na tle narodowościowym. Odbiorcami niemieckich gazet była nie tylko ludność niemieckojęzyczna, ale również polska i żydowska, dlatego ewentualne podsycanie konfliktów między tymi grupami nie przysporzyłoby gazecie czytelników. Pierwsza polsko-niemiecka gazeta to wcześniej wspomniana „Łodźer Anzeiger/Łódzkie Ogłoszenia”, powstała 2 grudnia 1863 r. z inicjatywy Johanna Petersilgego, któremu sprzyjały władze rosyjskie, chcąc zyskać w nowo utworzonym piśmie istotny organ prasowy na okoliczność wprowadzenia stanu wyjątkowego po wybuchu powstania

${ }^{34}$ J. Łojek, J. Myśliński, W. Władyka, Dzieje prasy..., s. 16-17.

35 Gazety międzynarodowe w języku francuskim oraz niemieckim wydawano w Holandii i w zachodnich państwach Rzeszy Niemieckiej. Było ich - jak piszą Łojek, Myśliński, Władyka - ok. 20 (ibidem, s. 17).

${ }^{36}$ Ibidem. 
styczniowego. Pismo miało charakter urzędowy, jednak oprócz zarządzeń władz lokalnych i drobnych ogłoszeń miejscowych przedsiębiorców, gazeta od numeru 33 zamieszczała w kolumnie felietonowej krótkie utwory literackie, powieści w odcinkach i felietony właściwe. Wydawca chciał tym samym przełamać monotonię i uatrakcyjnić tytuł w celu pozyskania kolejnych abonentó $w^{37}$. W sumie Petersilge opublikował felietony w 34 spośród 135 numerów gazety ${ }^{38}$. Oferta felietonowa dla polskiego i niemieckiego czytelnika była zróżnicowana. W polskiej kolumnie zamieszczano teksty odwołujące się do nowinek z dziedziny techniki, astronomii, biologii i fizyki, minicykle historyczne i teksty beletrystyczne. Felietony te były pisane prostym, niewyszukanym językiem, gdyż miały z jednej strony bawić, z drugiej zaś pełnić funkcję edukacyjną. Uwagę czytelnika miały przyciągać już same tytuły, takie jak np. Zastosowanie prawa ciężkości gatunkowej do użytku praktycznego ${ }^{39}$, $O$ meteorach powietrznych ${ }^{40}$, Barometry i ciepłomierze naturalne ${ }^{41}$ czy $W y$ nalazek balonó $w^{42}$. Wiele $\mathrm{z}$ tych tekstów naszpikowanych było informacjami quasi-naukowymi, uzupełnianymi datami, faktami, nazwiskami wynalazców, konstruktorów etc. Charakteryzowały się stylem sprawozdawczym, pozbawionym literackiej finezji, lecz mimo to stanowiły z pewnością swoistą atrakcję i przeciwwagę dla oficjalnych informacji urzędowych.

Niemiecka kolumna felietonowa zaoferowała swoim czytelnikom jeden reportaż z uroczystości strzeleckiej, urządzonej w Łodzi z okazji Zielonych Świątek ${ }^{43}$ oraz trzy powieści w odcinkach. Pierwsza, zatytułowana Morgenständchen ${ }^{44}$, ukazała się w 33. numerze gazety i jest zabawną historyjką o domorosłych trubadurach, którzy - przekonani o swoim muzycznym talencie

${ }^{37}$ Por. M. Kucner, Felieton w prasie łódzkiej w XIX w., „Acta Universitatis Lodziensis. Folia Germanica" 7/2011, s. 153-166.

${ }^{38}$ Informacje przygotowałam na podstawie następujących numerów „Łodźer Anzeiger/Łódzkie Ogłoszenia": 33/1864.04.26, 34/1864.04.28, 35/1864.04.30, 36/1864.05.03, 37/1864.05.07,41/1864.05.14,44/1864.05.24,45/1864.05.28, 48/1864.06.04, 49/1864.06.07, 52/1864.06.14, 53/1864.06.16, 63/1864.07.09, 66/1864.07.16, 67/1864.07.19, 68/1864.07.21, 69/1864.07.23, 70/1864.07.26, 73/1864.08.02, 75/1864.08.06, 80/1864.08.18, 81/1864.08.20, 82/1864.08.23, 83/1864.08.25, 84/1864.08.27, 85/1864.08.30, 86/1864.09.01, 88/1864.09.06, 89/1864.09.10, 94/1864.09.22, 95/1864.09.24, 99/1864.10.04, 100/1864.10.06, 101/ 1864.10.08.

${ }^{39}$ Zastosowanie prawa ciężkości gatunkowej do użytku praktycznego, „Łodzer Anzeiger/ Łódzkie Ogłoszenia" 69/1864.07.23, 70/1864.07.26.

${ }^{40} O$ meteorach powietrznych, „Łodzer Anzeiger/Łódzkie Ogłoszenia” 84/1864.08.27, 85/1864.08.30, 86/1864.09.01.

${ }^{41}$ Barometryiciepłomierzenaturalne, „Łodzer Anzeiger/Łódzkie Ogłoszenia” 49/1864.06.07.

${ }^{42}$ Wynalazek balonów, „Łodzer Anzeiger/Łódzkie Ogłoszenia” 100/1864.10.06, 101/1864.10.08.

43 Das Schützen-Fest in Lodz, „Łodźer Anzeiger/Łódzkie Ogłoszenia” 44/1864.05.24.

${ }^{44}$ Morgenständchen, „Łodźer Anzeiger/Łódzkie Ogłoszenia” 33/1864.04.26. 
- chodzą od domu do domu i wyśpiewują pod oknami serenady. Kolejna powieść Der Stellvertreter ${ }^{45}$ ukazała się w 10 odcinkach, natomiast trzecia Wenn die Binde fälltt obejmowała 21 odcinków ${ }^{46}$. Wszystkie wspomniane teksty są bardzo typowe dla popularnego obiegu literatury, lub - jak to określa tradycja niemiecka - tzw. Trivialliteratur. Były one skierowane do masowego odbiorcy, który nie miał zbyt wygórowanych wymagań intelektualnych. Dominującym tematem było życie obyczajowe współczesnego mieszczaństwa. Powieści w odcinkach powielały schematy, często pojawiające się $\mathrm{w}$ innych tego rodzaju opowieściach. Opisywały przykładowo życie małżeńskie w rodzinie burżuazyjnej, awanse społeczne lub konflikty miłosne. Częstym tematem stawały się kłopoty materialne, sensacje, procesy sądowe, egzotyczne podróże, obrazki z życia oficerów, marynarzy, detektywistyczne zagadki etc. Niemieckie powieści drukowane na łamach „Łodźer Anzeiger” również epatowały podobnymi, schematycznymi motywami. Pierwsza z nich, Der Stellvertreter ${ }^{47}$, opisuje typowy przykład awansu społecznego bohaterki, córki dzierżawcy majątku. Już na początku opowieści ujawniają się braki w wykształceniu bohaterki. Nadrabia ona te zaległości, gdy poznaje młodego lorda E., który wprowadza ją na salony i w końcu poślubia. Jako typowy przykład często powielanego stereotypu kariery „Kopciuszka” także i ta historia dobrze się kończy. Innym przykładem schematycznego ujęcia fabuły jest powieść Wenn die Binde fälltt ${ }^{48}$, opowiadająca o nieszczęśliwej miłości bohatera zakochanego w kobiecie, która obdarza uczuciem innego mężczyznę. Typowe dla tej literatury jest umieszczanie bohaterów w idyllicznych krajobrazach, w tym przypadku nad Jeziorem Genewskim. Tłem miłosnych perypetii staje się dodatkowo wojna rozdzielająca oboje zakochanych. Mimo oferty felietonowej, a tym samym uatrakcyjnienia zawartości gazety, Petersilge zaprzestał wydawania „Łodźer Anzeiger” i 1 stycznia 1865 r. wprowadził na rynek „Lodzer Zeitung". Gazeta ukazywała się trzy razy w tygodniu, a od 1 czerwca $1881 \mathrm{r}$. codziennie. Do współpacowników należeli m.in. August Thiele ${ }^{49}$, Leopold

${ }^{45}$ DerStellvertreter,„,Łodźer Anzeiger/Łódzkie Ogłoszenia” 34/1864.04.28,35/1864.04.30, 36/1864.05.03, 37/1864.05.07,41/1864.05.14, 48/1864.06.04,49/1864.06.07,52/1864.06.14, 53/1864.06.16, 63/1864.07.09.

${ }^{46}$ Wenn die Binde fällt, „Łodzer Anzeiger/Łódzkie Ogłoszenia” 66/1864.07.16, 67/1864.07.19, 68/1864.07.21,69/1864.07.23,70/1864.07.26, 73/1864.08.02, 75/1864.08.06, 80/1864.08.18, 81/1864.08.20, 82/1864.08.23, 83/1864.08.25, 84/1864.08.27, 85/1864.08.30, 86/1864.09.01, 88/1864.09.06, 89/1864.09.10, 94/1864.09.22, 95/1864.09.24, 99/1864.10.04, 100/1864.10.06, 101/1864.10.08.

${ }^{47}$ Der Stellvertreter...

${ }^{48}$ Wenn die Binde...

49 Zob. aneks: Łódzkie sylwetki. 
Zoner $^{50}$, Aleksander Milker ${ }^{51}$, Alexis Drewing ${ }^{52}$, Karl Wilkens ${ }^{53}$, Maks Warrikow $^{54}$ i Karl Schmidt ${ }^{55}$. Po śmierci założyciela Johanna Petersilgego pismem kierowali Roman Petersilge, Michael Petersilge, Woldemar Petersilge i Demetrius Petersilge. W latach 1904-1909 gazeta wychodziła dwa razy dziennie (jako Morgen- i Abendausgabe). Wraz z pismem ukazywały się liczne dodatki: w latach 1901-1914 „Weihnachtsbeilage der Lodzer Zeitung”, „Tägliche Unterhaltungsbeilage der Lodzer Zeitung”, w 1903 r. „Osterbeilage der Lodzer Zeitung”, zaś od 1913 do 1914 r. „Humoristische Beilage” i „Sonntagsbeilage". Dwuszpaltowym układem treści pismo początkowo przypominało swoją poprzedniczkę, „Łodźer Anzeiger/Łódzkie Ogłoszenia”. Na pierwszej stronie znajdowały się ogłoszenia łódzkiego magistratu w języku polskim i niemieckim (od 1866 r. zrezygnowano z języka polskiego i zamieszczano ogłoszenia po niemiecku i rosyjsku) ${ }^{56}$. Na pierwszej stronie figurowała rubryka Politische Rundschau [Przegląd polityczny], na drugiej znajdowały się Neueste Nachrichten [Najnowsze wiadomości] ze świata polityki, w późniejszym okresie zmienione na rubrykę Telegramme [Telegramy]. Dalej widniała rubryka Verschiedene Mitteilungen [Doniesienia różne], w których w skrócie informowano o doniesieniach prasy zagranicznej. Z czasem zawartość tej rubryki wypełniano bardzo krótkim tekstem literackim i zmieniono jej nazwę na Vermischtes [Różne]. Czwartą i ostatnią stronę rezerwowano dla ogłoszeń prywatnych. Taki układ gazety nie był zbyt interesujący, a treści najczęściej okazywały się dość monotonne - przeważały doniesienia polityczne, ale brakowało szpalt poświęconych sprawom lokalnym. Również ukazujący się początkowo dodatek nie miał interesującej zawartości, ponieważ także dominowały w nim drobne ogłoszenia i mało interesujące teksty literackie (najczęściej przedruki z prasy niemieckiej) ${ }^{57}$. Sytuacja zmieniła się po 1881 r., kiedy gazeta zaczęła ukazywać się codziennie. Zmieniono znacząco układ pisma i wprowadzono nowe treści. Oprócz informacji politycznych, przekazywanych w dwóch rubrykach (Inland [Kraj] oraz Ausland [Zagranica]), na pierwszej stronie zamieszczono kolumnę felietonową, w której drukowano powieść w odcinkach. Na drugiej, w rubryce Lokales [Wiadomości lokalne] zaczęto drukować lokalne aktualności (m.in. informacje kulturalne z Łodzi) oraz rozbudowano rubrykę Vermischtes [Różne]. Trzecią stronę wypełniała

\footnotetext{
50 Ibidem.

51 Ibidem.

${ }^{52}$ Ibidem.

53 Ibidem.

54 Ibidem.

55 Ibidem.

56 Przykładowo rosyjskie obwieszczenia zamieszczone m.in. w „Lodzer Zeitung” 7/1870.11.19, s. 1, 7/1878.12.19.

57 Por. Beilage zur „Lodzer Zeitung” 145/1878.12.7./19.
} 
Kleine Chronik [Mała kronika] z doniesieniami o treści społeczno-politycznej, po niej zaś następowały Neueste Nachrichten [Najnowsze wiadomości]. Ważną część doniesień stanowiła rubryka Industrie, Handel und Verkehr [Przemysł, handel, ruch], adresowana do lokalnych fabrykantów, poszukujących najnowszych wieści ze świata handlu i przemysłu. Czwarta strona tradycyjnie przeznaczona była na ogłoszenia i reklamę $e^{58}$. $\mathrm{Z}$ czasem gazeta przechodziła kolejne przeobrażenia, które ją jeszcze bardziej unowocześniały. Rubryka z pierwszej strony, gdzie było miejsce dla powieści w odcinkach, otrzymała nazwę Kleines Feuilleton [Mały felieton]. Coraz częściej przenoszono ją na drugą stronę, gdyż napięta sytuacja społeczno-polityczna w przeddzień wybuchu I wojny wymagała innego rodzaju informacji. Unowocześniono również rubrykę Lokales, w której wydzielono specjalny dział informujący o wydarzeniach ze świata teatru, sztuki i nauki: Theater, Kunst und Wissenschaft [Teatr, sztuka i nauka]. Gazeta cieszyła się dużą popularnością wśród łodzian, którzy nazywali ją „lodzerką”. Niestety, rok po zajęciu Łodzi, Niemcy zamknęli redakcję, ponieważ - jak pisał Karol Kaschnitz - przyjęła stanowisko sprzeczne z „polityką i celami wojennymi Rzeszy”. Redaktor naczelny „Lodzer Zeitung", syn Petersilgego, został internowany do Niemiec, a drukarnię przejęły władze niemieckie ${ }^{59}$.

Na początku lat 80. XIX w. pojawiła się na rynku prasowym kolejna łódzka gazeta codzienna „Lodzer Tageblatt”, wydawana przez Leopolda Zonera. Popularnością jednak nie dorównywała „Lodzer Zeitung”, dlatego została zakupiona przez założycieli nowo powstającego kolejnego niemieckiego dziennika "Neue Lodzer Zeitung. Handels- und Industrieblatt”. Tę ostatnią gazetę założono w 1902 r. Uważana była w mieście za pismo ugodowe, stroniące od wszelkich konfliktów narodowościowych. W czasie rewolucji $1905 \mathrm{r}$. gazeta była organem pierwszej politycznej partii mniejszości niemieckiej w Królestwie Polskim (Konstitutional-Liberale Partei Deutschsprechender), reprezentującej liberalny program i dążącej do porozumienia między Polakami i Niemcami. Od 1910 r. „Neue Lodzer Zeitung. Handels- und Industrieblatt” zmieniła nazwę na „Neue Lodzer Zeitung” i odtąd wychodziła dwa razy dziennie. Redakcja mieściła się przy ul. Piotrkowskiej 15. Gazeta oferowała różne dodatki: „Illustrierte Sonntags-Beilage”, „Illustriertes Sonntagsblatt”, „Illustriertes Wochenblatt”, „Lodzer Frauen Zeitung” oraz „Welt im Bild”. Od 1910 r. ukazywał się co rok „Lodzer Informations- und Hauskalender”, zawierający artykuły poświęcone historii i kultury Łodzi. Wobec groźby wybuchu

${ }^{58}$ Opracowałam na podstawie: „Lodzer Zeitung”: 1865, 61/1870, 127/1878, 145/1886, 56, 67, 76, 82, 126/1887, 86/1888, 289/1889, 159, 253/1890, 29, 34, 46, 62, 94, 96, 98, $126,141 / 1891,121,130,145,210,238,248,266 / 1892,18,45,107,126,128,204 / 1894$, 247/1895, 6, 9/1896, 47, 55-70, 72-74, 79-83, 94, 103/1905, 192, 197, 227/1908, 87/1909, 61-63, 124-125, 192, 193/1910, 131/1911, 68, 412-572/1914.

59 Por. K. Kaschnitz, Prasa niemiecka... 
pierwszej wojny światowej gazeta zachowała swój propolski charakter i trzeba zauważyć, że była bardziej antyniemiecka niż inne polskie i rosyjskie czasopisma w Polsce. Cieszyła się ogromnym zainteresowaniem łódzkich czytelników. Jej dwaj redaktorzy, Aleksander Milker oraz Alexis Drewing, dokładali wszelkich starań, aby była redagowana na dobrym poziomie, a informacje szybko docierały do czytelników. Z tego względu wprowadzono stałe rubryki oraz wydanie poranne i wieczorne. Zasadniczą część informacyjną, składającą się z wiadomości ze świata i z kraju oraz informacji lokalnych, uzupełniono o część felietonową, w której ukazywała się zazwyczaj powieść w odcinkach. Poza tymi niezmiennymi elementami gazeta zawierała także dział ogłoszeń i reklam, umieszczanych tradycyjnie na ostatniej stronie.

Obok ugodowej prasy ogólnoinformacyjnej do 1914 r. ukazywały się pisma prezentujące poglądy łódzkich socjalistów. Znaczna część czytelników tej prasy to niemieccy robotnicy zatrudnieni w łódzkich fabrykach. Pierwsze pismo pojawiło się wraz z wybuchem rewolucji $1905 \mathrm{r}$. Był to organ najpierw PPS, później PPS-Lewicy o nazwie „Der Deutsche Arbeiter in Polen”, redagowany przez Jakuba Raaba. W 1906 r. pojawił się organ Socjaldemokracji Królestwa Polskiego i Litwy - „Vorwärts”. Przez wiele lat socjaliści reprezentowani byli przez te dwa pisma.

Wśród prasy ogólnoinformacyjnej, obok ugodowych pism oraz gazet prezentujących poglądy łódzkich socjalistów, ukazywały się gazety, które W swojej treści prezentowały ideologię narodowoniemiecką ${ }^{60}$. Na początku XX w. w Łodzi uległy zmianie warunki społeczno-polityczne, co miało istotne znaczenie dla prasy codziennej. W wielu łódzkich gazetach pojawiły się artykuły o tendencjach nacjonalistycznych, a ich propagatorami byli znani niemieccy działacze, tacy jak Wilhelm Neumann, Fryderyk Flierl oraz Adolf Eichler ${ }^{61}$. Ten rodzaj prasy miał do spełnienia określone zadanie, mianowicie „ochronę poczucia narodowoniemieckiego oraz utrzymanie kulturalnej

${ }^{60}$ W XIX w. w Niemczech mamy do czynienia z dążeniami do zjednoczenia, sięgającymi po postulaty odwołujące się do wspólnego języka, zmitologizowanego obszaru „Germanii” (Kulturnation). Wykorzystywano przy tym ukształtowany w procesie dziejowym etnos (rozumiany jako grupa ludzka wykazująca odrębność języka i kultury oraz posiadająca świadomość tej odrębności), jak również dyktat ideologii narodowej. Po 1933 r. wśród mniejszości niemieckiej w Polsce ujawnia się proces radykalizacji życia politycznego. Stosunek do narodowych socjalistów był pozytywny, a w niektórych przypadkach nawet entuzjastyczny. W zasięgu oddziaływania hitlerowskiej polityki mniejszościowej, zakładającej wspólnotę narodową Niemców niezależnie od miejsca zamieszkania, znajdowali się nie tylko Niemcy ze Śląska, Pomorza czy Wielkopolski, ale również z Polski Centralnej. Por. P. Kacprzak, Niemiecka mniejszość narodowa w Polsce w latach 1919-1939, „Studia Lubuskie” 3/2007, s. 145-158; I. Eser, J. Kochanowski, Losy Niemców w Polsce Centralnej w latach 1945-1950 na przykładzie województw łódzkiego, warszawskiego i krakowskiego (powiat Biała), [w:] Niemcy w Polsce 1945-1950.Wybór dokumentów, red. W. Borodzieja, H. Lemberga, t. 2, Warszawa 2000.

${ }^{61}$ Zob. aneks: Łódzkie sylwetki. 
łączności Niemców miejscowych z macierzą" - jak pisał Karol Kaschnitz ${ }^{62}$. W 1911 r. łódzcy Niemcy utworzyli pod nazwą „Lodzer Rundschau” pismo o charakterze narodowym, stojące w opozycji do ugodowej „Neue Lodzer Zeitung". Gazeta ukazywała się dwa razy w tygodniu w łódzkim Verlags-Gesellschaft z siedzibą przy ul. Piotrkowskiej 100. Wraz z czasopismem drukowano kilka dodatków: „Handelsblatt”, „Unterhaltungsbeilage”, „Wissen und Kunst”, „Frauen Rundschau”, „Jugend Zeitung” i „Illustriertes Familienblatt”. Mimo tak bogatych propozycji ze strony redakcji gazeta ukazywała się zaledwie przez piętnaście miesięcy do $1913 \mathrm{r}$. Została zamknięta z powodu artykułu poświęconego 300. rocznicy rodu Romanowów, w którym podkreślono niemieckie pochodzenie carskiej rodziny. Na terenie Łodzi ideologię bliską „Lodzer Rundschau” propagowały również dwa inne pisma niemieckie: „Monatsblätter für die Deutschen in Russland” oraz „Geistiges Leben”63. Gazety te nie odniosły większego sukcesu i szybko przestały się ukazywać. W pierwszej fazie rozwoju prasy ludność niemiecka bardziej sympatyzowała z pismami liberalnymi, jednak wybuch I wojny światowej i okupacja niemiecka w Łodzi zmieniły ten stan rzeczy.

W początkowym okresie rozwoju oprócz pism o charakterze ogólnoinformacyjnym ukazywała się prasa kościelna (parafialna). Wydawana była przez parafie wyznania rzymskokatolickiego i luterańskiego. Obejmowała swym zasięgiem przeważnie obszar jednej parafii, choć zdarzały się tytuły wydawane wspólnie przez dwie lub nawet trzy parafie. Żywotność większości tych pism była nietrwała, ale zdarzały się periodyki, wychodzące przez wiele lat. Pierwszą gazetą o charakterze religijnym był w Łodzi „Evangelisch-Lutherisches Kirchenblatt", wydawany przez pastora Wilhelma P. Angersteina $^{64}$. Pismo zaczęło wychodzić w $1884 \mathrm{r}$. dwa razy w miesiącu i wraz z dodatkiem „Missionsbeiblatt” ukazywało się do $1914 \mathrm{r}$. Kolejną gazetą o tematyce religijnej był wydawany od 1906 r. tygodnik ewangelicko-luterańskiego kościoła warszawskiego okręgu konsystorskiego „Unsere Kirche”, redagowany przez pastora Paula Hadriana.

W omawianym okresie zaczyna pojawiać się także prasa gospodarcza i pisma związków zawodowych. Na początku XX w. Łódź, będąca już wówczas centrum przemysłowym Polski, otrzymała fachowe czasopismo o tematyce

${ }^{62}$ K. Kaschnitz, Prasa niemiecka...

${ }^{63}$ Pojedyncze numery gazety znajdują się w Bibliotece Uniwersytetu Łódzkiego: 1-2, 4-12/1912, 1, 3, 4, 7, 8, 12/1913, a także w Bibliotece im. J. Piłsudskiego w Łodzi: 1913, 1912.

${ }^{64}$ Biblioteka UŁ posiada następujące roczniki tej gazety: 1-8, 10-19, 21-24/1886, 1-24/1888,5, 16, 21-32/1890, 6/1891, 24/1892 1-24/1893, 1-24/1894, 1-24/1895, 1-24/1896, 2, 5, 12, 17-19, 23/1898, 6, 21/1899, 13-24/1900, 1-24/1902, 15/1903. W zasobach Biblioteki im. J. Piłsudskiego znajdują się roczniki: 1909-1911, 1902-1908, 1896-1897, w Archiwum Państwowym w Łodzi: 1904-1908, 1909, 1910, 1911, 1913, 1914. 
ekonomicznej. W 1910 r. powstał dwutygodnik „Lodzer Textilmarkt”, organ Zwiq̨zku Przemysłowców Łódzkich, wydawany przez Wilhelma Neumanna i Bruno Tugemanna. Gazeta przestała się ukazywać w 1914 r. Wraz z czasopismem wychodziły dodatki „Beiblätter Woll- und Baumwollberichte” oraz „Kursberichte”.

Charakterystyczne dla początkowego okresu rozwoju czasopism jest w zasadzie brak pism o profilu kulturalnym. Ich rolę przejęły suplementy, czyli dodatki beletrystyczne, które zaczęto regularnie drukować pod koniec XIX w. Zamieszczano w nich powieści, opowiadania, a także wiadomości z życia kulturalnego, społecznego i religijnego. Dodatki te okazały się stałym elementem takich gazet, jak „Neue Lodzer Zeitung. Handels- und Industrieblatt”, „Lodzer Zeitung” oraz „Lodzer Tageblatt”. Swoje miejsce w gazecie znalazły również szarady i dowcipy ${ }^{65}$.

\section{Okres I wojny światowej}

W czasie I wojny światowej prasa pełniła nieco inną funkcję niż w latach wcześniejszych. Z chwilą wkroczenia wojsk niemieckich do Łodzi liczbę tytułów zredukowano, a wobec pism o charakterze prorosyjskim zastosowano ostre represje. Wprowadzono wojenną cenzurę prewencyjną, reglamentację papieru i przyborów drukarskich oraz ograniczono kolportaż. Regres na rynku prasowym spowodowały dodatkowo takie czynniki, jak zniszczenia wojenne i zubożenie ludności ${ }^{66}$. Zamknięto m.in. lubianą przez łodzian „Lodzer Zeitung", a na miejsce likwidowanych gazet tworzono pisma okupacyjne. Wraz z pojawieniem się na rynku gazet okupacyjnych, prasa zyskała na ideowości - ukazujące się na rynku prasowym tytuły coraz częściej prezentowały poglądy narodowoniemieckie. Uwypuklano w nich niemiecki charakter Łodzi, niemiecką kulturę i zagrzewano do walki z wrogiem. Relacje wojenne zdominowały nie tylko gazety narodowoniemieckie, ale także wszystkie łódzkie druki prasowe zarówno w części informacyjnej, jak i publicystycznej oraz publicystyczno-literackiej. Doniesienia z pól bitewnych ilustrowano licznymi fotografiami, rycinami i planami sytuacyjnymi. Dość często pojawiały się też reportaże, wspomnienia i dzienniki, dla których tłem była wojna ${ }^{67}$.

${ }^{65}$ Por. „Sonntags-Beilage Neue Lodzer Zeitung” 1-41, 43-46/1906, 1-52/1907, 19061907; 1-52/53/1908; 1-51/52/1909; 1908-1909; 24, 52/1910; 1-52/1911; 1-51/1912; $9-10,15,25,36,39,42,44,51 / 52 / 1913$.

${ }^{66}$ Ibidem.

${ }^{67}$ Wnioski opracowano na podstawie analizy następujących gazet: „Deutsche Lodzer Zeitung" 6-165/1915, 12-14, 16-19, 23, 26-34, 41-47, 55-60, 68-74, 77-79, 83-89, 93, 95-102, 110-117, 124-126, 128-130, 138-144, 152-158, 39, 81, 90, 136, 173-321,178-179, 181-186, 191, 192, 194-200, 208-212, 214-234, 237-241, 243-244, 245, 246-249, 251-273, 275-285, 287-289, 292, 298-310, 312-317, 319-320/1915, 1-361/1916, 1-360 /1917; 1-178/1918; „Deutsche Post” 2-27/1915, 153/1916, 1-51/1917, 2-43/1918. 
Jedną z pierwszych gazet, jakie założyły niemieckie władze okupacyjne wraz z nacjonalistą Georgiem Cleinowem ${ }^{68}$ na czele, był wcześniej wspomniany dziennik „Deutsche Lodzer Zeitung”. Pismo wychodziło od lutego 1915 r., a jego redakcja mieściła się przy ul. Piotrkowskiej 85. Z gazetą współpracowali Hans Kriese (odpowiedzialny za wiadomości lokalne), Ludwig Schrickel (zajmujący się polityką i felietonem), Alois Balle (redagował wiadomości handlowe) i Hans Franke (ogłoszenia). Wraz z zakończeniem okupacji niemieckiej pismo przestało się ukazywać i tym samym niemieckich nacjonalistów pozbawiono ważnego organu prasowego. 27 lipca 1916 r. obok „Deutsche Lodzer Zeitung” utworzono tygodnik „Deutsche Post”, organ prasowy stowarzyszenia Deutscher Verein. Redakcja gazety mieściła się najpierw przy ul. Pańskiej 87, później przy ul. Piotrkowskiej 15 i 152. Utworzenie „Deutsche Post" było dla części łódzkich Niemców ważnym wydarzeniem. Podczas okupacji ludność przybyła z Rzeszy traktowała ich jak Rosjan albo Polaków. Zadaniem gazety założonej przez A. Eichlera było przekonanie niemieckiego okupanta w ciągu trzech lat działalności redakcji o istnieniu lokalnej mniejszości niemieckiej i jej osiągnięciach kulturalnych, a także zadbanie o rozwój życia towarzyskiego i zacieśnienie więzi społecznych wśród mniejszości niemieckiej przy własnym, wrogim nastawieniu do społeczeństwa polskiego.

W czasie I wojny wśród niemieckich gazet dominowała prasa ogólnoinformacyjna o charakterze narodowoniemieckim. Wprawdzie nadal ukazywała się ugodowa „Neue Lodzer Zeitung”, która była pod bacznym okiem niemieckiego okupanta.

\section{Okres międzywojenny}

W okresie międzywojennym niemieckie czasopiśmiennictwo rozwijało się prężnie i prezentowało bogatą gamę poglądów ideowych ${ }^{69}$. Wiele gazet deklarowało przynależność i poparcie dla partii lub związku, reprezentując na swych łamach konkretne idee polityczne. W tym okresie wychodziły w Łodzi dzienniki o charakterze liberalnym, komunistycznym, socjalistycznym i nacjonalistycznym, niestroniące od krytyki wobec swoich adwersarzy ${ }^{70}$. Dlatego łódzki rynek prasowy stał się miejscem tarć politycznych i poważnych polemik koncentrujących się wokół haseł istotnych dla lokalnej społeczności.

68 Zob. aneks: Łódzkie sylwetki.

${ }^{69}$ Prawną sytuację prasy dla okresu międzywojennego regulowała Konstytucja RP z 21 marca 1921 r. oraz przepisy szczegółowe, odziedziczone po zaborze rosyjskim, obowiązujące poza okresem 1927-1930 aż do 1938 r. Od 1927 do 1930 r. obowiązywały rozporządzenia o prawie prasowym i rozpowszechnianiu nieprawdziwych wiadomości, wydane po przewrocie majowym przez prezydenta. W 1938 r. wprowadzono dekret prasowy (tzw. kagańcowy), na mocy którego zarządzono reglamentację prasy.

${ }^{70}$ Por. M. Kucner, Prasa niemiecka... 
Jednym z nich była walka o dominację polityczną i ideową nad mniejszością niemiecką w Łodzi. Pojawienie się w 1938 r. tygodnika „Der Deutsche Wegweiser"71 wydobyło na światło dzienne polemiki zwolenników i przeciwników ideologii narodowosocjalistycznej ${ }^{72}$. Dzięki prasie popularność zyskali tacy publicyści, jak Carl Heinrich Schultz ${ }^{73}$ czy Aleksander Hoefig ${ }^{74}$, opowiadający się przeciw polityce zagranicznej Hitlera. Niezależnie od różnic politycznych istniały kwestie w pewnym sensie jednoczące strony polemizujące. Jednym z takich zagadnień była sprawa niemieckiego szkolnictwa w Polsce i tendencji polskiego rządu do jego ograniczania ${ }^{75}$. Gazeta była organem Vereinigung der Deutschen in Polen (dalej: VDP), związku opowiadającego się za utrzymaniem przyjaznych stosunków między Polakami i Niemcami, który w obliczu kolejnych żądań Hitlera wobec Polski zachował się bardzo lojalnie, opowiadając się przeciw polityce Trzeciej Rzeszy. Zarówno współpracowników gazety, jak i członków związku łódzcy aktywiści, zwolennicy ideologii narodowosocjalistycznej, nazywali „renegatami”. Natychmiast po wkroczeniu wojsk niemieckich do Łodzi w 1939 r. aresztowano ich i wywieziono do obozów ${ }^{76}$.

Wśród prasy nadal dominowały gazety ogólnoinformacyjne. W miejsce okupacyjnej „Deutsche Lodzer Zeitung” pojawił się w 1918 r. dziennik „Lodzer Freie Presse”, główny organ obozu narodowoniemieckiego ${ }^{77}$. Gazetę redagowali m.in. Hans Kriese i Adolf Kargel, byli redaktorzy „Deutsche Lodzer

71 Por. „Der Deutsche Wegweiser” 1938, 1939, dostępny w Archiwum Państwowym w Łodzi, sygn. PŁ59.

72 „Der Deutsche Wegweiser” prowadził na swych łamach polemikę z narodowosocjalistycznym pismem „Der Deutsche Weg”. Kilka artykułów ukazujących spolaryzowane stanowiska to: Unsere Einstellung und „Der Deutsche Weg!”, „Der Deutsche Wegweiser”, 17.04.1938; Worte an das deutsche Volk!, „Der Deutsche Wegweiser”, 3.04.1938; Der Staat und wir, „Der Deutsche Wegweiser”, 6.03.1938, Untergang oder Aufstieg?, „Der Deutsche Wegweiser”, 13.03.1938, Doppeltes Maß, „Der Deutsche Wegweiser”, 27.03.1938.

${ }^{73}$ Zob. aneks: Łódzkie sylwetki.

${ }^{74}$ Ibidem.

75 Por. O. Heike, Das Deutschtum in Polen 1918-1939, Bonn 1955.

76 Zob. Literackie i nieliterackie obrazy miasta. Łódź przełomu wieków oczami niemieckojęzycznego autora Carla Heinricha Schultza / Nicht nur literarische Bilder einer Stadt. Lodz in den Augen eines deutschsprachigen Autors Carl Heinrich Schultz, red. M. Kucner, Łódź 2011.

77 Gazeta przez niemal cały czas prezentowała linię zgodną z polityką rządu niemieckiego, jednakże były wyjątki, kiedy pismo opublikowało dwa artykuły (Vom Regen unter die Traufe oraz Deutschlands Schrei nach Freiheit, „Freie Presse”, 31.08.1929), które spowodowały interwencję Ministerstwa Spraw Zagranicznych w Berlinie - pismo szefa Wydziału Prasowego Ministerstwa Spraw Zagranicznych w Berlinie V.L.R. Kaufmanna z 22 października 1922 r. do konsula łódzkiego Ericha von Luckwalda, w którym zapytuje, czy konsul nie zwróciłby uwagi gazecie na ten niestosowny fakt. Jak wynika z kolejnego pisma konsul von Luckwald poprosił o wyjaśnienia redaktora Kargela, który tłumaczył się, iż oba artykuły przez nieuwagę trafiły do druku, jeden z nich to przedruk z „Telegraphen Union”, a drugi z „Telegraphische Nachrichten". Luckwald wskazuje poza tym, iż w numerach 9, 15, 19 i 20 ukazało się wiele artykułów, które prezentują linię polityczną rządu niemieckiego. 
Zeitung”. Redakcja „Lodzer Freie Presse” miała siedzibę przy ul. Piotrkowskiej 86. Wraz z gazetą ukazywały się dwa dodatki: „Die Zeit im Bild” i „Textilmarkt”. Pismo było wydawane przez Towarzystwo Wydawnicze "Libertas"78, którego dyrektorem został znany niemiecki nacjonalista Eduard von Behrens $^{79}$.Ze względu na polityczny charakter gazety często ingerowała cenzura, redakcja zamieszczała bowiem w poszczególnych numerach artykuły ostro krytykujące stosunki wewnętrzne i politykę zagraniczną Polski. Bardzo dużo miejsca poświęcano również uciskowi i krzywdzie mniejszości niemieckiej w Polsce, przeciwstawiając ten fakt dobremu traktowaniu mniejszości polskiej w Niemczech, co nie odpowiadało prawdzie ${ }^{80}$. Po raz pierwszy władze polskie zamknęły gazetę 16 października 1919 r. Pismo dość dobrze radziło sobie z wszelkimi zakazami i ukazywało się w formie jednodniówek o tytułach „Neue Presse”, „Tages-Presse”, „Die Presse” i „Morgen-Presse”. 8 listopada tego samego roku gazeta ponownie wyszła jako „Lodzer Freie Presse”. W kwietniu 1923 r. druk dziennika po raz kolejny zawieszono, przez trzy tygodnie wychodził jako „Der Volksfreund”, chociaż istniała już gazeta o takim samym tytule. Od 1923 do 1939 r. „Lodzer Freie Presse” używała nazwy „Freie Presse". W niedzielę palmową $1933 \mathrm{r}$. tłum jej przeciwników szturmem wtargnął do redakcji, wydawnictwa i drukarni, demolując wszystkie pomieszczenia. Pismo nie potrzebowało jednak zbyt wiele czasu, aby ponownie zacząć się ukazywać, a z pomocą przyszła inna niemiecka gazeta, „Lodzer Volkszeitung”, udostępniając „Freie Presse” własne pomieszczenia. W 1937 r. gazeta znów ściągnęła na siebie falę niezadowolenia, kiedy wypowiedziała się przeciw polskiemu przewodnictwu kościoła ewangelicko-augsburskiego ${ }^{81}$. Władze polskie zamknęły pismo tym razem pod pretekstem niespełniania przepisów bezpieczeństwa i higieny pracy. Przez trzy miesiące gazeta wychodziła w wydawnictwie Concordia w Poznaniu, ponieważ żaden inny organ prasowy nie chciał już udostępnić „Freie Presse” swoich pomieszczeń dla wznowienia druku. Krótko przed wybuchem wojny wydawnictwo zatrudniło uzbrojonych funkcjonariuszy ochrony, dzięki czemu kolejne numery mogły wychodzić regularnie. Koniec „Freie Presse” miał przypaść na 1 września 1939 r., kiedy zamknięto wydawnictwo, redakcję i drukarnię, a redaktora A. Karegla aresztowano i wywieziono na Wschód ${ }^{82}$. Wehrmacht uwolnił aresztowanych i po dziesięciu dniach gazeta ponownie zaczęła wychodzić. We wrześniu 1939 r.

${ }^{78}$ Libertas - niemieckie towarzystwo wydawnicze. Działało w Łodzi w latach 1918-1944, drukowało m.in. nacjonalistyczną „Freie Presse” oraz „Litzmannstädter Zeitung”. Siedziba mieściła się przy ul. Piotrkowskiej 86 w kamienicy „Pod Gutenbergiem”, która wcześniej należała do Johanna Petersilgego.

79 Zob. aneks „Łódzkie sylwetki”.

80 [b.a.], Polacy w Niemczech, „Lodzer Freie Presse”, 22.03.1923.

81 0. Heike, Das Deutschtum ..., s. 167.

82 Wraz z Adolfem Kargelem wywieziono dyrektora wydawnictwa Libertas, Bertholda Bergmanna i redaktorów Horsta Markgrafa i Alfreda Nasarskiego. 
ukazała się jako „Deutsche Lodzer Zeitung”, dwa miesiące później jako „Lodzer Zeitung”, a od kwietnia 1940 r. jako „Litzmannstädter Zeitung” w oficynie Libertas. Działem polityki zajmował się Hugo Wieczorek, sztuką i gospodarką Horst Markgraf, a nad wszystkim czuwał przedstawiciel Berlina, Max Ludwig. Jako dodatki do „Freie Presse“ wychodziły „Illustrierte Beilage zur Freien Presse”, „Zeit im Bild”, „Sonntagsbeilage”, „Freie Stunden”, „Frauenbeilage” i „Unterhaltungsbeiblatt”, zapewniający czytelnikom stałą rozrywkę. Ważnym organem opiniotwórczym również w środowisku niemieckich nacjonalistów był organ Niemieckiego Zwiq̨zku Narodowego o nazwie „Der Deutsche Weg”, ukazujący się od 1935 r. Redaktorem pisma był Kurt Rapke, polityką zajmował się August Utta ${ }^{83}$, a sportem i felietonem Edmund Nasarski ${ }^{84}$. Gazeta powstała z dodatku do „Freie Presse” i przestała wychodzić 9 lipca $1939 \mathrm{r}$. w wyniku licznych represji ze strony władz polskich. W okresie od 1 kwietnia do 7 lipca 1939 r., w fazie zaostrzenia stosunków polsko-niemieckich, pismo nie unikało drażliwych artykułów gloryfikujących działalność Hitlera ${ }^{85}$. W tym czasie gazeta została siedmiokrotnie skonfiskowana i ostro potępiona przez polską opinię publiczną. Zarówno „Freie Presse”, jak i „Der Deutsche Weg" pisały z wielką arogancją o niemieckich pastorach współpracujących ze zwierzchnictwem kościoła ewangelicko-augsburskiego w Polsce. Wiele takich artykułów wyszło spod pióra Theodora Bierschenka, który niejednokrotnie zarzucał duchownym zdradę Niemiec ${ }^{86}$. Obok „Freie Presse” i „Der Deutsche Weg” 22 grudnia 1918 r. powstała jeszcze inna gazeta ogólnoinformacyjna o tendencjach nacjonalistycznych, „Der Volksfreund”. Początkowo jej wydawcą był Gustaw Ewald, później Ludwig87, Otto Wolff i Albert Breyer. Pismo ukazywało się co tydzień w nacjonalistycznej oficynie Libertas. Dodatki wychodzące wraz z gazetą to dwutygodnik „Der Landwirt”, „Aus Zeit und Leben”, „Illustrierte Monatsbeilage” i „Onkel Franz” (ilustrowany dodatek dla młodzieży). Tygodnik zamieszczał artykuły na temat polityki wewnętrznej państwa polskiego, interesując się zwłaszcza sytuacją mniejszości niemieckiej w Polsce. Często można było tu również znaleźć teksty o sytuacji kościoła ewangelicko-augsburskiego w Polsce, a także o działalności Deutscher Verein i niemieckich szkół.

Oprócz nacjonalistycznych pism w okresie międzywojennym nadal ukazywała się ugodowa „Neue Lodzer Zeitung”. Gazeta pozytywnie odnosiła się

${ }^{83}$ Zob. aneks: Łódzkie sylwetki.

${ }^{84}$ Ibidem.

85 W „Der Deutsche Weg” 12/1938 ukazał się artykuł Der Anschluss vollzogen. Ein Volk, ein Reich, ein Führer, w którym entuzjastycznie odniesiono się do niemieckiej ekspansji w Austrii i Sudetach.

${ }^{86}$ Artykuły na ten temat ukazały się w „Der Deutsche Wegweiser” 12 i 26 marca 1939 r.

87 Zob. aneks: Łódzkie sylwetki. 
do odradzającej się państwowości polskiej. Po utworzeniu organizacji pod nazwą Deutscher Kultur- und Wirtschaftsbund in Polen [Niemiecki Związek Kulturalno-Gospodarczy w Polsce, dalej: DKuWB], reprezentującej ugodową linię polityczną, stała się jej organem prasowym. Jednak nie zawsze konsekwentnie utrzymała ugodowy charakter. W latach 1936-1939 stała się organem Jungdeutsche Partei ${ }^{88}$. Pod wpływem apelu tygodnika „Der Deutsche Wegweiser" wiosną 1939 r. powróciła jednak do propolskiego charakteru, aczkolwiek nie na długo, gdyż w tym samym roku niemieckie władze okupacyjne zamknęły gazetę ${ }^{89}$.

Kiedy w latach 20. powstała w Łodzi pierwsza niemiecka partia socjalistyczna Deutsche Arbeitspartei Polens (dalej: DAP), na której czele stali tacy działacze, jak Emil Zerbe ${ }^{90}$, Armin Zerbe ${ }^{91}$, Artur Kronigg ${ }^{92}$ i Oskar Seidler ${ }^{93}$, wyszedł nowy tygodnik „Der Arbeiter”, a 28 października 1923 r. zaczęła ukazywać się „Lodzer Volkszeitung”94, redagowana przez Ludwiga Kuka i Armina Zerbe. W skład redakcji weszli również Otto Heike, Aleksander Hoefig oraz Richard Zerbe ${ }^{95}$. Początkowo gazeta wydawana była raz w tygodniu, od 4 maja 1924 r. dwa razy, od 30 października 1924 trzy razy, a od 1 września 1925 r. codziennie. Wysokość jej nakładu wynosiła 3000 egzemplarzy. Reprezentowała przede wszystkim poglądy niemieckojęzycznych robotników ${ }^{96}$. Gazeta stała w politycznej opozycji wobec dzienników nacjonalistycznych i ugodowych. Zamieszczano w niej liczne artykuły demaskujące prawdziwy charakter Trzeciej Rzeszy, ostrzegano także przed hitleryzmem i wynikającymi

${ }^{88}$ Wraz z „Neue Lodzer Zeitung” zaczął ukazywać się służący celom propagandowym dodatek niedzielny „Deutsche Erneuerung”. Redakcję pisma w latach 1934-1939 tworzyli Max Schmeller, Hans Kriese i Emil Otto Schütz.

${ }^{89}$ Informacje na temat „Neue Lodzer Zeitung” przygotowano na podstawie: W. Kaszubina, Bibliografia..., J. Jaworska, Początki księgarstwa...

${ }_{90}$ Zob. aneks: Łódzkie sylwetki.

${ }^{91}$ Ibidem.

${ }^{92}$ Ibidem.

${ }^{93}$ Ibidem.

94 Informacje na temat czasopism opracowałam na podstawie materiałów znalezionych w Politisches Archiv Berlin, sygn. RAV Lodz 64, Presse oraz AA Akten Deutschtum 19321935, Bd. 6, 7, Po6a, PA RAV Lodz 39, z których można wnioskować, iż „Lodzer Volkszeitung” do 1933 r. prezentowała politykę zgodną z linią polityczną rządu niemieckiego, występując m.in. przeciwko polonizacji niemieckich szkół, jednak, jak wynika z pisma niemieckiego Konsulatu w Łodzi do Deutsche Gesandtschaft w Warszawie z 22 marca 1933 r. od chwili wyborów w Niemczech gazeta miała występować przeciwko tej linii politycznej, publikując przedruki z zakazanej socjaldemokratycznej gazety „Vorwaerts” (chodzi o artykuły redaktora Stampfera). Por. AA Akten Deutschtum 1932-1935, Bd. 6, 7, Po6a, PA RAV Lodz 39.

95 Por. Sprawozdanie na temat działalności „Lodzer Zeitung”, Politisches Archiv Berlin, Presse, sygn. RAV Lodz 64.

${ }^{6}$ Według danych przesyłanych do konsulatu niemieckiego w Łodzi już dwa miesiące od ukazania się pierwszego numeru gazeta posiadała nakład w wysokości 2000 egzemplarzy. 
z niego zagrożeniami zarówno dla narodu niemieckiego, jak i polskiego ${ }^{97}$. Często ujawniano antypolskie nastawienie, dlatego władze polskie konfiskowały niektóre numery ${ }^{98}$. Od 20 czerwca 1935 r. do września 1939 r. gazeta ukazywała się pod nazwą „Volkszeitung”. Pismo utrzymywało się głównie z opłat abonamentowych oraz reklamy, którą zamieszczał m.in. łódzki magistrat ${ }^{99}$.

Obok trzech wielkich nurtów politycznych, dominujących w prasie ogólnoinformacyjnej, ukazywała się jako czwarta prasa niemieckich komunistów, choć w porównaniu z innymi zarówno jej nakład, jak i liczba tytułów były znacznie mniejsze. Wśród mniejszości niemieckiej w okręgu łódzkim w latach 1928-1930 aktywnie działała Kommunistische Partei Polens (dalej: KPP). Głównym jej celem była walka z niemieckim nacjonalizmem, kapitalizmem i sanacją, a organem prasowym gazeta „Der Kämpfer”, redagowana przez A. Capfa, W. i J. Dillnerów, E. Seiferta i R. Grünberga. Pismo wychodziło w niewysokim nakładzie i w latach 1932-1933 ukazało się zaledwie kilka numerów o objętości kilkunastu stron. Do pisma dołączano także liczne ulotki i odezwy. $\mathrm{Z}$ uwagi na prowadzone przez KPP akcje przeciw łódzkim nazistom ${ }^{100}$ gazeta (ale również łódzka KPP) nie ustrzegła się represji ze strony władz polskich, które aresztowały jej przywódców i zamknęły redakcję pisma.

Obok gazet o charakterze ogólnoinformacyjnym w okresie międzywojennym zaczęły ukazywać się w Łodzi pierwsze pisma o profilu kulturalnym. Ponieważ jednak miasto nie było ważnym ośrodkiem kultury, nie przyciągało swym przemysłowym charakterem intelektualistów. Niemieckojęzyczna prasa kulturalna wprawdzie istniała, ale miała charakter efemerydalny. Redagowana przez Heinricha Zimmermanna niemieckojęzyczna „Freie Bühne”101, która stawiała sobie za cel zachowanie więzi kulturowych między czytelnikami i kształtowanie wzorców, wyszła w zaledwie dwóch numerach. Autor, sam żywo zainteresowany sprawami łódzkiego teatru, zamieszczał tu swoje artykuły poświęcone temu zagadnieniu, a także teksty łódzkich i zagranicznych pisarzy. W pierwszym numerze znalazły się artykuły na temat niemieckiego teatru w Łodzi ${ }^{102}$ oraz sztuki aktorskiej Iry Aldridgea, który zmarł w mieście w 1867 r., zanim zagrał z lokalnym zespołem teatralnym Otella ${ }^{103}$. W pierw-

${ }_{97}$ Por. M. Cygański, Mniejszość niemiecka w Polsce w latach 1918-1939, Łódź 1961.

98 „Lodzer Volkszeitung” została skonfiskowana m.in. za artykuły: Drugi akt w procesie centrolewu (9.02.1933), Cała Łódź strajkującym włókniarzom (22.03.1933), Niezwykle ciężkie starcia na pogrzebie ofiar widzewskich wypadków (1.04.1933).

99 Por. Bericht über den finanziellen Stand der „Lodzer Volkszeitung” z 3.10.1930, Politisches Archiv des Auswärtigen Amtes, Presse, sygn. RAV Lodz 64.

100 M. Cygański, Mniejszość niemiecka..., s. 83.

101 Pierwszy numer gazety (1919) znajduje się w Bibliotece im. J. Piłsudskiego w Łodzi, natomiast dwa kompletne w ADMuW, sygn. ADMZ 0014.

102 H.Z., Geschichte des deutschen Theaters in Lodz, „Freie Bühne” 1/1919, s. 20-23.

${ }_{103}$ Więcej na temat twórczości Iry Aldrigea zob. K. Kujawińska-Courtney, Ira Aldridge (1807-1867). Dzieje pierwszego czarnoskórego tragika szekspirowskiego, Łódź 2009. 
szym numerze z 1919 r. Zimmermann zamieścił ponadto fragmenty utworu Fritza Mauthnera Aus dem Märchenbuch der Wahrheit i tekst Franza Theodora Csokora Zum Drama unserer Zeit, charakteryzujący istotę współczesnego dramatu niemieckiego. Interesujący jest przy tym fakt, iż Zimmermann stworzył dla niemieckojęzycznych poetów odrębną rubrykę pt. Unsere Dichter, w której publikował krótkie notatki o ich życiu i twórczości oraz utwory znanych autorów, jak np. cienionego w Niemczech Richarda Dehmela. W pierwszym numerze pisma znalazło się również miejsce dla lokalnych poetów, takich jak Wally Triebe i jego wiersza In der Heide. Gazeta informowała ponadto o repertuarze lokalnych teatrów i zamieszczała sprawozdania z wygłaszanych w Łodzi odczytów na tematy kultury i literatury. Wśród prelegentów byli m.in. Cesar Jelenta (odczyt na temat Dicher der Sünde und des Verbrechens) oraz Stanisław Przybyszewski (Über den Tod). Redakcja zaproponowała swoim czytelnikom opłatę abonamentową w wysokości 8 marek miesięcznie, uprawniającą do dwóch darmowych przedstawień teatralnych i 50\% zniżki na wieczorki poetyckie i wykłady. W październiku zaoferowano czytelnikom dwa przedstawienia: Raskolnikow Dostojewskiego i Verlorene Ehre Heinricha Bohrmann-Riegena. Pierwszy wieczór poetycki poświęcono twórczości Goethego, a w programie figurowały wykłady, recytacje i pieśni. Pierwszy wykład na temat Die Liebe im Drama ${ }^{104}$ wygłosił sam Heinrich Zimmermann. W drugim numerze gazety Zimmermann opublikował krótką, przetłumaczoną przez Eliezera Lejba Treistmana (do 1929 r. naczelnego rabina Łodzi) ${ }^{105}$, historię autorstwa Solomona Blumgartena (Yehoash, 1870-1927) Ali Hasan. Eine orientalische Geschichte oraz utwór austriackiego pisarza Petera Altenberga Ganz kleine Sachen. W numerze znalazło się też miejsce dla twórczości Goethego i jego stanowiska wobec polskiej literatury. Autor artykułu powoływał się przy tym na spotkanie Goethego z Andrzejem Edwardem Koźmianen, do którego doszło w 1830 r. w Weimarze. Na łamach swojego pisma Zimmermann zamieszczał również wiersze własnego autorstwa. I tak w drugim numerze opublikował trzy z nich: Es regnet, Form und Inhalt oraz Leben ${ }^{106}$. Mimo interesującego profilu po dwóch numerach gazetę zamknięto, najprawdopodobniej z powodu braku czytelników.

We wrześniu 1931 r. pojawił się w Łodzi ukazujący się do 1934 r. miesięcznik kulturalny „Der Runde Tisch”, organ Łódzkiego Chóru Męskiego. Jego redaktorami byli Alfred Boksleitner i Horst E. Markgraf, a wydawcą nacjonalistyczna oficyna Libertas. W tym samym wydawnictwie wyszło w $1932 \mathrm{r}$. poświęcone sztuce, literaturze, sprawom narodowym i ojczyźnie czasopismo „Jungvolk”, redagowane przez Artura H. Lobuscha. Wśród innych tytułów

104 Por. „Freie Bühne” 1/1919.

105 Yehoash, Ali Hasan. Eine orientalische Geschichte, „Freie Bühne” 2/1919 [b.s.].

106 Por. „Freie Bühne” 2/1919. 
warto też wspomnieć o gazetach przeznaczonych dla niemieckiego szkolnictwa. W 1918 r. wydawano „Unsere Schule”, miesięcznik dla szkolnictwa niemieckiego w Polsce, redagowany przez Heinricha Thiema. Podobny charakter miała inna łódzka gazeta, „Der Deutsche Lehrer in Polen”, miesięcznik adresowany do całego szkolnictwa polsko-niemieckiego i jednocześnie organ Niemieckich Nauczycieli przy DKuWB. Gazeta ukazywała się w latach 1934-1935 pod redakcją Alfreda Rennerta jako dodatek do „Deutscher Volksbote"107.

Podobnie jak w dwóch poprzednich okresach ważnym czynnikiem kształtowania świadomości artystycznej, historycznej, kulturowej i literackiej były dodatki kulturalne do gazet codziennych. $\mathrm{W}$ okresie międzywojennym ukazywały się dodatki do "Neue Lodzer Zeitung” „Illustrierte Sonntagsbeilage”, „Illustriertes Sonntagsblatt. Beilage zur Neuen Lodzer Zeitung”, „Illustriertes Wochenblatt. Beilage zur Neuen Lodzer Zeitung” oraz do „Die Welt im Bild. Sonntagsbeilage zur Neuen Lodzer Zeitung".

Obok artykułów o treści historycznej, obyczajowej i kulturalnej w dodatkach zamieszczano też atrakcyjne utwory literackie w postaci nowel, opowiadań, wierszy i powieści w odcinkach. Właśnie one stwarzały szansę dla intensywnego rozwoju sztuki ilustracyjnej, inicjując publikacje reportaży, a wraz z nimi fotografii z miejsca wydarzeń, które stały się nieodłącznym elementem gazety i zapełniały mniej więcej połowę wydania; drugą połowę przeznaczano tradycyjnie na druk powieści, opowiadań, wierszy i artykułów o tematyce kulturalnej. Również okładka zmieniła się w sposób diametralny. „Welt im Bild” zawsze przedstawiał jakąś fotografię ilustrującą intrygujące wydarzenie, które miało rozbudzić ciekawość czytelnika i zachęcić do lektury dalszych stron. Na okładkach pojawiały się zeppeliny, samoloty, zdjęcia z katastrof czy wojen, a także urodziwe kobiety ${ }^{108}$. Gazeta szła z duchem czasu i starała się nadążać za rozwojem współczesnego świata. Była to znacząca nowość, bowiem wcześniej dodatki zaczynały pierwszą stronę od tekstu literackiego. Jak już wspomniano, z niektórych dodatków (np. „Welt im Bild”)

107 Gazeta „Deutscher Volksbote” była organem prasowym Deutscher Kultur- und Wirtschaftsbund. Władze niemieckie, w tym niemiecki Konsulat w Łodzi oraz Auswärtiges Amt, miały sporo kłopotów z pismem w okresie międzywojennym. Podobnie jak organizacja, której była organem, stały na czele porozumienia między Polakami a Niemcami, co w tym czasie było niewygodne dla polityki mniejszościowej w Rzeszy, wszelkie dążenia asymilacyjne były źle widziane przez zwolenników polityki Hitlera. Zarówno gazetę, jak i DKuWB określano jako pseudoniemieckie, renegackie, niemające nic wspólnego z niemieckością, „Deutscher Volksbote" nazywano również polskim pismem propagandowym. Por. pismo niemieckiego Konsulatu w Łodzi z 19 września 1932 r., jak również pismo Reichsministerium für Volksauklärung und Propaganda do Präsidenten Reichsschriftkammer z 8 czerwca 1935 r., AA Akten Deutschtum 1932-1935, Bd. 6, 7, Po6a, PA RAV Lodz 39.

108 Por. okładki czasopisma z 12.09.1937, 9.02.1936, 28.07.1936, 25.03.1928, 5.05.1928, 19.08.1928, 6.10.1936, 29.05.1932, 10.06.1932, 12.11.1933, 13/1925, 22/1924. 
znikły na stałe informacje o lokalnych inicjatywach kulturalnych, tak chętnie zamieszczane w poprzednich latach, zastąpiły je natomiast wiadomości kulturalne ze świata. Można zatem wnioskować, że czytelnik oczekiwał nie tylko wieści lokalnych, gdyż te już mu nie wystarczały - chciał wiedzieć więcej i poszerzać swoje horyzonty o informacje kulturalne z całego świata.

Istotna rola w rozwoju kultury przypadła również łódzkim kalendarzom, które cieszyły się dużą popularnością wśród niemieckojęzycznych łodzian, spełniając - podobnie jak suplementy kulturalne - funkcję ludyczną. Do ich nabywania i lektury zachęcała bogata szata graficzna, liczne fotografie oraz artykuły dotyczące historii i kultury Łodzi i regionu ${ }^{109}$.

Okres międzywojenny charakteryzuje się rozwojem prasy innej niż ogólnoinformacyjna. Pojawiły się czasopisma kościelne, związków zawodowych, fachowe i naukowe, a także dziecięce i młodzieżowe.

W 1920 r. zaczął się ukazywać tygodnik religijny „Der Friedensbote”110, przygotowywany przez pastora Juliusa Dietricha. Była to gazeta nie tylko o charakterze religijnym, gdyż w wielu artykułach pojawiały się także treści polityczne. Przez cały 1939 r. pismo dawało wyraz nadziei na poprawę stosunków polsko-niemieckich, a tym samym uniknięcie konfliktu zbrojnego ${ }^{111}$. Czasopismo wydawało dodatki: „Jugendruf”, „Illustrierte Beilage”, „Kelle und Schwert”, "Wolhynische Beilage” i "Lobet den Herrn mit Posaunen” (organ ewangelicko-luterańskiego Towarzystwa Puzonistów w Polsce) oraz „Unser Landmann". Było to najpopularniejsze niemieckie pismo religijne dla ewangelików, które w obliczu perspektywy wybuchu wojny zajęło przychylne stanowisko wobec Polski ${ }^{112}$. W latach 1921-1922 ukazywał się pod redakcją pastora S. Michaelisa i O. Friese tygodnik „Evangelisches Wochenblatt”, oferujący jednak treści nie tyle religijne, ile raczej gospodarcze. Był organem Zwiq̨zku Rewizyjnego Spółdzielni Ewangelickich, zlikwidowanego w 1922 r. W latach 1926-1927 ukazywał się miesięcznik „Weg und Ziel” - pismo niemieckiej konferencji pastorów kościoła ewangelicko-augsburskiego w Polsce. Jego wydawcą był pastor A. Doberstein, przeciwnik biskupa Burschego. „Weg und Ziel” powstał z funduszy zgromadzonych przez Deutsche Stiftung przy protekcji niemieckiego konsulatu w Łodzi. Gazeta nie cieszyła się jednak powodzeniem, dlatego po roku działalności przestała się ukazywać. W opozycji do miesięcznika „Weg und Ziel” pozostała wydawana od 1933 r. w nacjonalistycznym wydawnictwie Libertas gazeta „Neue Evangelische Kirchenzeitung", występująca aż do wybuchu II wojny światowej przeciwko konferencji

109 Powyższe informacje opracowano na podstawie: „Lodzer Informations- und Haus-Kalender" 1911, 1912, 1918, 1919.

110 Pojedyncze numery gazety dostępne w Bibliotece UŁ: 1-52/1927, 49/1938 oraz ADMuW, sygn. Bk II 5377.

111 „Der Friedensbote” 36/1939.

112 T. Kowalak, Prasa niemiecka..., s. 348. 
pastorów ewangelicko-augsburskich w Polsce ${ }^{113}$. W 1925 r. powstał tygodnik chrześcijański „Die Wahrheit”, na którego czele stanęła nauczycielka Marta Foth. Pismo nie utrzymało się jednak zbyt długo na rynku i zawiesiło działalność po wydaniu zaledwie trzech numerów.

Łódzki ośrodek prasy religijnej prowadził ponadto ożywioną działalność wydawniczą dla dzieci i młodzieży, której celem było przeciwdziałanie polonizacji niemieckiej młodzieży chrześcijańskiej i pielęgnowanie odrębności kulturowej i religijnej. W 1929 r. zaczął ukazywać się miesięcznik „Jugendruf", organ ewangelicko-luterańskiej młodzieży w Polsce. Redaktorem pisma był pastor Gustav Schendler, współpracujący z innymi niemieckimi pastorami, jak np. A. Ackermannem. W okresie 1921-1939 ukazywało się dwa razy w miesiącu, jako dodatek do „Der Friedensbote”, pismo „Der Kinderfreund" pod redakcją pastora Juliusa Dietricha. Również młodzież zboru baptystów miała swój organ prasowy, a był nim wydawany w latach 1927-1939 miesięcznik Młodzieży Zboru Baptystów Polsce o nazwie "Jugendwarte”, redagowany przez A. Wenskego, oraz wydawane także przez niego czasopismo dla młodzieży chrześcijańskiej „Praktischer Vereinsleiter. Zeitschrift für Christliche Jugendführung".

W omawianym okresie rozwijała się w Łodzi również prasa gospodarcza i związków zawodowych. W 1924 r. pojawiła się gazeta pod redakcją A. Tögela, „Herold mit Textilmarkt”, nietypowa mieszanka treści politycznych, gospodarczych i literackich. W pierwszej części pisma zamieszczano artykuły polityczne i literackie, $\mathrm{w}$ drugiej zaś teksty poświęcone informacjom o charakterze przemysłowym i handlowym. Od 14. numeru ukazywał się podtytuł w języku polskim i niemieckim „Illustrierte Halbmonatsschrift für Politik und Handel”. Od 10 grudnia 1924 r. w podtytule widniała nazwa „Herold. Textilmarkt. Illustrierte Halbmonatsschrift für Handel und Industrie". Redaktorem pisma był A. Berendt. Inną gazetą o podobnym profilu była „Lodzer Herold” poświęcona nie tylko gospodarce i polityce, ale również nauce i rozrywce. Ukazywała się codziennie w latach 1932-1933, a jej wydawcami byli A. Schmidt i H. Arndt. Gazeta oferowała liczne dodatki informujące o nowinkach z zakresu rolnictwa, zabawiała rozrywką i była bogato ilustrowana. W latach 19271931 co dwa tygodnie wydawano redagowane przez J. Wintera i J. Kurzweila czasopismo fachowe przemysłu włókienniczego „Textil Revue”. Gazeta była do nabycia nie tylko na terenie Łodzi, ale również w Czechosłowacji i w krajach nadbałtyckich. Niektóre czasopisma gospodarcze wychodzące w Łodzi były adresowane do ludności wiejskiej, jak przykładowo tygodnik „Der Landbote”, organ niemieckiej ludności wsi, redagowany przez Armina Zerbe, działacza Niemieckiej Partii Socjalistycznej. Dowodzi to faktu, że niemieccy socjaliści próbowali pozyskiwać sympatyków także wśród ludności wiejskiej.

113 „Neue Evangelische Kirchenzeitung” 8/1939. 
Z chwilą podjęcia decyzji o zamieszczaniu w gazecie tekstów o tematyce narodowościowej redakcja naraziła się na represje ze strony polskich władz, stąd pismo wychodziło jedynie do stycznia $1930 \mathrm{r}^{114} \mathrm{~W}$ latach 1919-1939 ukazywał się tygodnik i dwutygodnik „Unser Landmann”, redagowany przez 0. Göhringa. Pismo, będące organem Łódzkiego Zwiq̨zku Spółek Niemieckich w Polsce, oferowało wiadomości gospodarcze i urzędowe. W 1922 r. pojawił się w mieście jedyny numer miesięcznika „Monatsblatt des Christlichen Commis Vereins zu Gegenseitiger Unterstützung", organ Chrześcijańskiego Zwiq̨zku Pracowników Handlowych, natomiast w latach 1928-1929 ukazywał się miesięcznik „Der Textilarbeiter”, organ Zwiq̨zku Robotników i Robotnic Polskiego Przemysłu Włókienniczego. Gazetę wznowiono w 1937 r. i wydawano do 1939 r. Była niemiecką wersją polskiego „Włókniarza” i zarazem przykładem dobrej współpracy polskich i niemieckich socjalistów, jako że redaktorami pisma byli zarówno Polacy, jak i Niemcy: E. Zerbe (redaktor „Lodzer Volkszeitung"), A. Łukasek, O. Dittbrenner, A. Walczak i A. Szczerkowski.

W okresie między dwiema wojnami niemieckie wydawnictwa prasowe w Łodzi stawiały sobie ambitne cele. Wśród cenionych i szanowanych tytułów trudno by szukać pism brukowych, nastawionych wyłącznie na sensację i aktualne plotki z życia osób publicznych, jak to było w przypadku polskojęzycznej „Republiki” czy „Expressu Wieczornego Ilustrowanego”115.

\subsection{Literatura na łamach prasy}

W drugiej połowie XIX i na początku XX w. niemieckojęzyczna prasa w Łodzi przejęła ważną rolę kulturotwórczą. Począwszy od pierwszej dwujęzycznej gazety niemiecko-polskiej „Łodźer Anzeiger/Łódzkie Ogłoszenia” (a dokładniej od numeru 33, w którym ukazało się w kolumnie felietonowej krótkie opowiadanie Das Morgenständchen ${ }^{116}$ ), na łamach tej prasy pojawiały się - najpierw nieregularnie, później na stałe - teksty literackie i publicystyczno-literackie, a wśród preferowanych gatunków prym wiodła zdecydowanie literatura popularna. Teksty takie zamieszczano w gazetach z różnych powodów. Dobór propozycji miał związek przede wszystkim z napływem do miasta

114 Gazetę skonfiskowano z powodu dwóch artykułów: Deutsche Lieder strafbar (8.12.1929) i Presseprozess in Kattowitz (29.12.1929).

115 Informacje na temat prasy w okresie międzywojennej opracowałam na podstawie: „Freie Presse” 278-284, 286-288/1924; 5-7,10-13, 17-21, 215-221, 223-230, 232-239/1925; 194-242, 244-251/1926; 27, 29-31, 33-37,40-41, 43-51, 53-90, 108/1930; 203, 277, 289/1934; 140, 185/1935; 1-366/1936; 3-171/1937; 182-273, 274-365/1938, 1-354/1939; „Neue Lodzer Zeitung” 1919-1938; „Lodzer Volkszeitung” 1926-1931, 1933-1934.

116 [b.a.], Das Morgenständchen, „Łodźer Anzeiger/Łódzkie Ogłoszenia” 33/1864.04.26. 
ludności wiejskiej. Rzeczą oczywistą wydaje się fakt, iż mieszkańcy wsi, pozbawieni w nowym otoczeniu form kultury, jakie towarzyszyły im w tradycyjnym środowisku, zaczęli poszukiwać innych możliwości. Nie można było liczyć na to, że wywodzący się z kręgów wiejskich nowi mieszkańcy miasta wykażą zainteresowanie kulturą wysoką. W naturalny sposób sięgali po ofertę najprostszą, najbardziej dopasowaną do ich potrzeb. Dla ludności wiejskiej było to częstokroć pierwsze zetknięcie z wytworami sztuki słowa, ponieważ brak umiejętności czytania i pisania z góry skutecznie wykluczał aktywne uczestnictwo w ofercie kulturalnej. W pierwszej kolejności zainteresowanie budziły zatem najprostsze formy, najłatwiej przyswajalne, nienużące i niezmuszające do intelektualnego wysiłku, bowiem nie sposób było wymagać od robotników skomplikowanej aktywności kulturalnej po wielogodzinnej pracy w fabryce. Literatura konsumowana przez robotników była w swoim przekazie prosta i pozwalała na stopniowe oswojenie z konwencjami literackimi, kierując $w$ wielu przypadkach w późniejszym czasie uwagę na inny rodzaj bardziej skomplikowanych tekstów literackich, by w ostateczności wykształcić zainteresowanie literaturą piękną.

Dlatego w prasie drukowano teksty łatwe, które miały przede wszystkim bawić, a niekiedy też uczyć. Z tego względu redakcje dobierały pozycje, których twórcami byli autorzy drugo- lub trzeciorzędni. Należeli do nich: Else Krafft $^{117}$, Paul Blitz ${ }^{118}$, Ida Bock ${ }^{119}$, Reinhold Ortmann ${ }^{120}$, Roda Roda ${ }^{121}$, Käte Lubowski ${ }^{122}$, Oscar Blumenthal ${ }^{123}$, Lenelotte Winfeld ${ }^{124}$, Mite Kremnitz ${ }^{125}$, Fritz Skowronnek ${ }^{126}$, Karl Federn ${ }^{127}$, Alfred Bock ${ }^{128}$, Ewald Gerhard Seeliger ${ }^{129}$, Paul Aleksander Schettler ${ }^{130}$, Klara Blüthgen ${ }^{131}$, Otto Elster ${ }^{132}$, Friedrich Thieme ${ }^{133}$ czy Adolf Thiele ${ }^{134}$. Na łamach łódzkich dodatków beletrystycznych publiko-

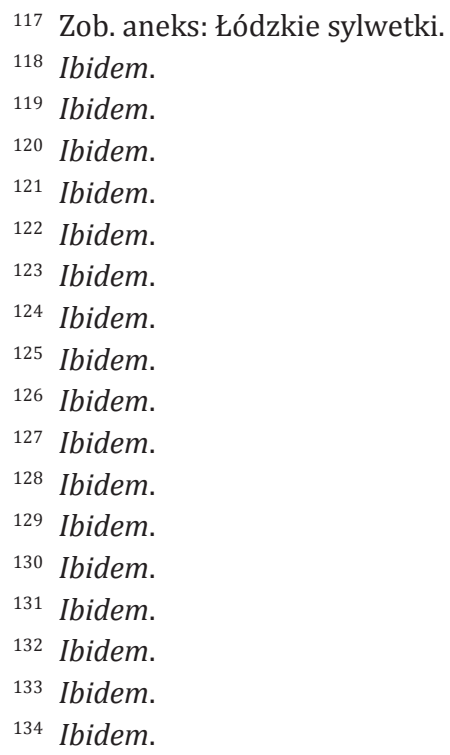


wano również dzieła Wilhelma Bölschego, który w wielu swoich tekstach propagował teorię Charlsa Darwina i Ernsta Haeckela ${ }^{135}$. Temu ostatniemu „Illustrierte Sonntagsbeilage” poświęciła obszerny artykuł w 60. rocznicę uzyskania przez niego stopnia doktora ${ }^{136}$. W łódzkich dodatkach drukowano również humoreski publicysty i pisarza, w czasach wilhelmińskich także popularnego dziennikarza Telesfora Szafrańskiego (pseud. Teo von Torn). W krótkich, zabawnych tekstach poświęcił dużo miejsca członkom cesarskiego korpusu oficerskiego, czyniąc motywem przewodnim ich miłosne perypetie, ale także ludzkie słabości ${ }^{137}$.

Teksty literatury „wysokiej” zamieszczano w prasie sporadycznie ${ }^{138}$, częściej proponując w zamian egzemplifikacji omówienie twórczości wielkich pisarzy i poetów. W taki właśnie sposób prezentowano m.in. twórczość Schillera, Mickiewicza, Słowackiego i Tołstoja. Szczególne miejsce wśród tych pisarzy zajmował Goethe. Łódź wraz ze swoimi niemieckojęzycznymi mieszkańcami szczególnie uroczyście obchodziła 100. rocznicę jego śmierci. W tym celu Auswärtiges Amt wydało wszystkim przedstawicielstwom zagranicznym instrukcję na tę okolicznośćc ${ }^{139}$. Niemcy łódzcy bardzo poważnie potraktowali jubileusz. Wszystkie niemieckie gazety informowały o tym fakcie z wszelkimi szczegółami. 20 marca 1932 r. redakcja „Freie Presse” wydała dodatek literacki poświęcony w całości życiu i twórczości pisarza. Zamieszczono m.in. wiersze okolicznościowe lokalnych autorów, m.in. Sigismunda Banka, cytaty z dzieł, Torquatto Tasso i Fausta, zdjęcia i opis Weimaru ${ }^{140}$.

Częściej natomiast publikowano literaturę takich autorów, jak Maksym Gorki $^{141}$, Antoni Czechow ${ }^{142}$, Michaił Lermontow ${ }^{143}$, Eliza Orzeszkowa, Maria

135 „Illustrierte Sonntagsbeilage” opublikowała framgent jego dzieła Entwicklungsgeschichte der Natur, 2 Bde., 1894-1896, pt. Das Ziel des Columbus, 5.02.1917.

${ }^{136}$ Por. Th. Abel, Ernst Haeckel, „Illustrierte Sonntagsbeilage”, 11.03.1917.

137 Zob. aneks: Łódzkie sylwetki.

138 „Illustrierte Sonntagsbeilage. Neue Lodzer Zeitung. Handels- und Industrieblatt”, 13./26.10.1902, zamieściła m.in. wiersz Anette von Droste-Hülshof pt. Die Unbesungenen.

139 Por. pismo AA do wszystkich misji i przedstawicielstw dyplomatycznych z 22 grudnia 1932 r., AA Akten Deutschtum 1932-1935, Bd. 6, 7, Po6a, PA RAV Lodz 39.

140 Por. „Sonderblatt zu Nr. 80 der Freien Presse”, Archiv der Deutschen aus Mittelpolen und Wolhynien, sygn. BK 1I, nr 448. Również bardzo uroczyście obchodziły rocznicę niemieckie stowarzyszenia, jak np. niemiecki Postęp, który zorganizował cały cykl wydarzeń z tym związanych. Por. AA Akten Deutschtum 1932-1935, Bd. 6, 7, Po6a, PA RAV Lodz 39.

141 „Illustrierte Sonntagsbeilage. Neue Lodzer Zeitung. Handels- und Industrieblatt”, 28.04/11.05, 11./24.05.1903, zamieściła Maksyma Gorkiego Die Geschichte mit den silbernen Buchlammern.

142 A. Czechow, Waka möchte schlafen, „Illustrierte Sonntagsbeilage. Neue Lodzer Zeitung”, 14/1.05.1911, Der böse Bube, „Illustrierte Sonntagsbeilage. Neue Lodzer Zeitung. Handels- und Industrieblatt", 16./29.01.1905.

${ }^{143}$ M. Lermontow, Der Traum, tłum. J. Williams, „Illustrierte Sonntagsbeilage. Neue Lodzer Zeitung. Handels und Industrieblatt" 1902. 
Konopnicka ${ }^{144}$, Bolesław Prus ${ }^{145}$, Henryk Sienkiewicz ${ }^{146}$, Guy de Maupassant ${ }^{147}$ czy Arthur Schnitzler ${ }^{148}$ i Stanisław Przybyszewski ${ }^{149}$. Ich teksty drukowano w odcinkach zarówno w prasie codziennej, jak i w dodatkach beletrystycznych. W kwestii popularyzacji właśnie tych autorów gazety łódzkie nie różniły się od innych, wydawanych w tym czasie pism polskich czy europejskich, bowiem przyczyny, jakimi kierowała się redakcja zamieszczając te właśnie teksty, były podobne. Jeśli chodzi o twórczość Guy de Maupassanta, należy podkreślić, iż był to autor bardzo popularny pod koniec XIX w. nie tylko w Polsce. Publikował na łamach wielu paryskich dzienników (np. „Le Figaro” czy „Le Gaulois”). Dużą popularnością cieszyły się teksty, w których przeważała tematyka społeczno-obyczajowa z elementami fantastyki i sensacji. Publikacje takie służyły z jednej strony rozrywce, z drugiej niepozbawione były wysokich wartości literackich. Podobnie ma się rzecz z tekstami Czechowa, którego intensywniejsza recepcja wśród czytelników polskich nastąpiła dość późno ${ }^{150}$. Połączenie w przypadku obu tych autorów wysokich wartości literackich z funkcją ludyczną spowodowało, że zaliczali się do pisarzy najchętniej czytanych przez łódzkich nabywców gazet.

Inną kwestią jest natomiast przedrukowywanie w gazetach utworów nowelistycznych pisarzy polskich. Najchętniej sięgano do tekstów łączących w podejmowanej tematyce wartości artystyczne i oddziaływanie społeczne. Dlatego chętnie tłumaczono na niemiecki Konopnicką, Prusa i Orzeszkową. Ich nowelistyka poruszała zagadnienia społeczne, z którymi mógł utożsamiać się współczesny czytelnik, cieszyła się zatem dość dużą popularnością. Oprócz wspomnianych pisarzy publikowano również takich autorów, jak Marian Gawalewicz. W „Illustrierte Sonntagsbeilage. Neue Lodzer Zeitung. Handels- und Indusrieblatt" zaprezentowano w 1904 i 1905 r. jego powieść Ćma.

${ }^{144}$ Wiersze Marii Konopnickiej w tłumaczeniu Otto Hansera wydrukowała „Illustrierte Sonntagsbeilage. Neue Lodzer Zeitung. Handels- und Industrieblatt”, 3./16.12.1902.

145 Por. B. Prus, Sie liebt mich - sie liebt mich nicht..., „Illustrierte Sonntagsbeilage. Neue Lodzer Zeitung. Handels und Industrieblatt”; Staś, „Illustrierte Sonntagsbeilage. Neue Lodzer Zeitung", 10./23.06.1912.

${ }^{146}$ Dodatek zamieścił trzy teksty Henryka Sienkiewicza: Janko, der Musikant, „Illustrierte Sonntagsbeilage zur Neuen Lodzer Zeitung”, 10.12.1916; Sei gesegnet, „Illustrierte Sonntagsbeilage zur Neuen Lodzer Zeitung", 17.12.1916; Der letzte seines Stammes. Eine Geschichte aus Texas, übers. v. F. Helmy, „Illustrierte Sonntagsbeilage Neue Lodzer Zeitung”, 12.02/20.01.1911.

147 G. de Maupassant, Das Alter, „Illustrierte Sonntagsbeilage. Neue Lodzer Zeitung. Handels- und Industrieblatt", 14./27.09.1903.

148 A. Schnitzler, Der Ehrentag, „Illustrierte Sonntagsbeilage. Neue Lodzer Zeitung. Handels- und Industrieblatt", 9./22.03.1903.

149 Redakcja „Illustrierte Sonntagsbeilage. Neue Lodzer Zeitung. Handels- und Industrieblatt" zamieściła w 1903 r. fragmenty Stanisława Przybyszewskiego pt. In diesem Erdenthal der Tränen (31.03/13.04.1913, 13./26.04.1903, 20.04/3.05.1903).

${ }^{150}$ Por. O.S. Czernik, Proza artystyczna a prasa codzienna 1918-1926, Wrocław 1982. 
Stosunkowo duże zainteresowanie przywiązywano w prasie do powieści w odcinkach. Ich autorami byli popularni w tym czasie twórcy zagraniczni, których teksty masowo drukowała prasa europejska. Łódzkie redakcje zamieszczały je regularnie $\mathrm{w}$ dziale felietonu gazety codziennej oraz $\mathrm{w}$ dodatkach beletrystycznych. Tematyka powieści oscylowała wokół zagadnień społecznych i sentymentalno-obyczajowych, związanych z życiem burżuazji i drobnomieszczaństwa, przedstawiając zwłaszcza konflikty rodzinne. Ofertę urozmaicały ponadto popularne wówczas powieści przygodowe, kryminalne i opowieści grozy, upowszechniane przez gazety niemieckie jako literatura modna, łatwa i dostępna dla szerokiej publiczności.

W dodatkach przekazywano również wiele informacji na temat kultury Łodzi ${ }^{151}$. Dużo miejsca poświęcano łódzkiej scenie teatralnej, przedstawiając portrety jej aktualnych dyrektorów, prezentując łódzkich aktorów czy też zamieszczając krytykę wystawianych przedstawień. Obok teatru dodatki zamieszczały wiele informacji na temat sztuk pięknych. Prezentowano malarzy i rzeźbiarzy, nie tylko zresztą łódzkich, ale i zagranicznych. Ponadto przedstawiano sylwetki pisarzy i poetów różnej proweniencji, obcych i rodzimych. Dużą popularnością wśród czytelników cieszyły się artykuły z okazji jubileuszy, opisujące działalność łódzkich instytucji dobroczynnych, kościelnych i oświatowych. Wśród tego rodzaju tekstów na uwagę zasługują portrety zwane inaczej sylwetkami ${ }^{152}$, w których w poetyce wspomnieniowej opisywano zasłużonych dla miasta luminarzy przemysłu, kultury i oświaty. Niemal w każdym dodatku beletrystycznym znajdziemy przykłady takich tekstów. Wiele z nich poświęcono Scheiblerom, Herbstom, Heinzlom, Grohmannom czy Kindermannom, ale nie zapominano też o mniej znanych łodzianach. Przykładowo „Illustrierte Sonntagsbeilage Neue Lodzer Zeitung” zamieściła w wydaniu z 12 lutego (20 stycznia) 1911 r. portret łódzkiego fabrykanta Ernsta Goeldnera, zaś 5 marca (20 lutego) 1911 r. sylwetkę Adolfa Otto. Tego samego dnia gazeta opublikowała obszerny artykuł na temat twórczości Leopolda Pilichowskiego. Bardzo często redakcje publikowały po kilka portretów naraz. 19 lutego (6 marca) 1911 r. dodatek poświęcono łódzkim artystom (m.in. Karolowi Ende), zaś w 1912 r. zamieszczono artykuł na temat Henryka Siemiradzkiego w 10. rocznicę śmierci. Łódzcy przemysłowcy, nauczyciele, aktorzy byli opisywani również z okazji śmierci. Tradycja zamieszczania na

${ }^{151}$ Informacje opracowano na podstawie: „Die Welt im Bilde. Sonntagsbeilage zur Neuen Lodzer Zeitung" 45-52/1927, 1-53/1928, 1-52/1929, 1-52/1930, 1-52/1931, 1930, 1-52/1931/1932, 1-53/1933, 2, 3, 32-41, 51/1935, 1-52/1936, 1-52/1937, 2, 7, 49/1938, 16/1939; „Illustriertes Wochenblatt”: 10, 24, 31-36, 46-52/1925, 30-39/1924; „Illustriertes Wochenblatt. Beilage zur Neuen Lodzer Zeitung" 2, 9-11, 13, 14, 18-23, 30, 32, 33, 35, 3739/1924, 13/1925.

152 Więcej na temat sylwetki prasowej zob. M. Wojtak, Gatunki prasowe, Lublin 2004, s. $120-165$. 
łamach prasy niemieckojęzycznej portretów z tej okazji została zaczerpnięta z kręgów protestanckich. Nachruf - bo tak w języku niemieckim określa się portret-informację z okazji śmierci - stanowi swego rodzaju pożegnanie z osobą zmarłą. Obowiązkowym elementem takiego portretu było najczęściej dołączane do artykułu zdjęcia zmarłego. Łódzkie portrety miały formę zbeletryzowanych biografii z elementami fikcji. Ich cechą było opiniowanie, interpretacja, różnorodne formy wartościowania, a także zdobnictwa stylistycznego. Zazwyczaj sylwetki charakteryzowano według pewnego schematu. W przypadku sylwetki-wspomnienia pierwszy akapit informował o śmierci, był więc redagowany zgodnie z zasadą odwróconej piramidy (w pierwszej kolejności najważniejsza informacja). W kolejnych akapitach przedstawiano informacje o życiu osoby zmarłej, podając często szczegóły na temat wykształcenia, miejsca urodzin, przebiegu działalności zawodowej. Rzadko pojawiały się jakiekolwiek daty. Unikano stylistyki typowego biogramu, choć nie zawsze. Ważną częścią były akapity wartościujące, a więc informacje o przymiotach charakteru zmarłej osoby i jej zasługach. Za przykład może posłużyć sylwetka-wspomnienie o pastorze Gundlachu. Aleksander Milker tak opisywał tę postać: „Pastor Gundlach nie żyje. Odszedł nie tylko duszpasterz, pastor, lecz również człowiek czynu, niestrudzony obrońca prawdy, szlachetności i dobroci"153. Często teksty opisujące osobę zmarłą nawiązywały do panegiryków, wyrażając przesadny zachwyt dla zasług, niejednokrotnie o charakterze pochlebstwa. Kolejność informacji na temat danej osoby nie była stała. Najczęściej tekst sylwetki kończył się przedstawieniem istotnych osiągnięć i zasług zmarłego dla łódzkiej społeczności. Struktura sylwetki była więc w pewnym stopniu spetryfikowana. Aspekt pragmatyczny obejmował zbiór stałych intencji, począwszy od poinformowania o śmierci poprzez informacje na temat życia aż do uwypukleniu zasług dla lokalnej społeczności. Na końcu najczęściej wyrażano nadzieję, że pamięć po zmarłym będzie trwać i okazywano wdzięczność za jego zasługi. Należy podkreślić, iż najbardziej rozbudowana była właśnie ostatnia część, informująca o zasługach.

Ważną częścią niemieckich gazet była liryka, w tym przede wszystkim wiersze okazjonalne, o której będzie szerzej mowa w następnych częściach książki. Poezja pojawiła się w prasie wraz z dodatkami beletrystycznymi do „Lodzer Zeitung”, a największy rozkwit przeżyła w okresie I wojny światowej i międzywojniu. Przez wiele lat liryka niemieckojęzycznych łodzian była rozproszona i nie posiadała stałych rubryk, choć podejmowano w tym kierunku wiele starań. I tak np. 9 września 1917 r. „Illustrierte Sonntagsbeilage zur Neuen Lodzer Zeitung" zaproponowała swoim czytelnikom rubrykę Unsere Dichter [Nasi poeci], w której zamierzano prezentować twórczość

${ }^{153}$ A. Milker, Konsistorialrat Pastor Rudolf Gundlach, „Illustriertes Sonntagsblatt. Beilage zur Neuen Lodzer Zeitung” 23/1922.10.15, s. 4. 
lokalnych poetów. W numerze 37 tejże gazety ukazały się wiersze Roberta Bräutigama $^{154}$, Theodora Abela ${ }^{155}$, Eduarda Habermanna ${ }^{156}$, Heinricha Zimmermanna ${ }^{157}$, Irmy Teichmann ${ }^{158}$ i Wilhelma Jessa ${ }^{159}$. Rubrykę zamieszczono ponownie w numerach 3 i 17 w 1918 r. Niestety, redakcja nie dotrzymała słowa i nie kontynuowała tej tradycji, choć zawsze starała się umieścić gdzieś w środku gazety, między tekstami nowel czy opowiadań, jakiś krótki wiersz. Niektóre redakcje (np. „Der Deutsche Wegweiser”) zapewniły wierszom stałe rubryki, w których zamieszczano je okazjonalne, często w nawiązaniu do aktualnych wydarzeń w kraju i za granicą ${ }^{160}$.

Niemieckojęzyczna prasa rozwijała się w Łodzi w szczególnych warunkach społeczno-politycznych. Z jednej strony towarzyszyła jej cenzura rosyjska, z drugiej brak czytelników wynikający z wysokiego poziomu analfabetyzmu oraz struktury tutejszego społeczeństwa, w którym przeważały osoby bez nawyków czytelniczych. Jednakże mimo tych przeciwności przybywało w Łodzi gazet. Najwięcej wychodziło tu dzienników ogólnoinformacyjnych, które były zazwyczaj organami partii i organizacji o charakterze ugodowym, komunistycznym, socjalistycznym i nacjonalistycznym; na kolejnym miejscu pod względem liczby tytułów plasowały się pisma społeczno-kulturalne i fachowe.

Literatura była obecna przede wszystkim $\mathrm{w}$ dodatkach beletrystycznych do gazet codziennych i w dziennikach. Czasopisma o charakterze społecznokulturalnym stanowiły niewielki margines wszystkich gazet niemieckojęzycznych i często ukazywały się zaledwie w jednym lub kilku numerach. Utwory literackie, zamieszczane na łamach prasy, były dostosowane do poziomu wykształcenia lokalnego czytelnika. Oferowano przede wszystkim literaturę popularną, rzadziej ambitniejsze teksty, choć również takie drukowano. Gatunki, które najchętniej zamieszczała prasa, to opowiadania, nowele, sylwetki, wiersze oraz powieści w odcinkach. Stałe miejsce na łamach wielu pism znalazł także felieton jako gatunek z pogranicza literatury i publicystyki.

${ }^{154}$ Zob. aneks: Łódzkie sylwetki.

155 Ibidem.

156 Ibidem.

157 Ibidem.

158 Ibidem.

159 Ibidem.

160 Por. „Der Deutsche Wegweiser” 1938, 1939, Archiwum Państwowym w Łodzi, sygn. PŁ59. 



\section{LITERATURA}

\subsection{Literatura łódzka a jej kontekst regionalny}

Materiał zebrany do poniższych rozważań sytuuje się w obrębie zjawisk określanych w badaniach teoretycznoliterackich jako tzw. Heimatliteratur - literatura ojczyźniana lub małoojczyźnianaㄹ, literatura pogranicza, literatura regionalna, literatura regionu lub regionalizm literacki. $\mathrm{W}$ toku dalszych analiz należałoby naświetlić problematykę związaną zarówno z przytoczonymi pojęciami, jak również ich rozwój historyczny. Pomoże to lepiej zrozumieć specyfikę omawianej literatury łódzkiej.

Podstawowym elementem rozważań na temat literatury ojczyźnianej jest bez wątpienia pojęcie Heimat. Niemieckojęzyczny autor i łódzki dziennikarz Carl Heinrich Schultz (1882-1940), do którego twórczości jeszcze się odwołam w dalszych rozdziałach pracy, tak pisał o Polsce jako swym kraju ojczystym:

Einst kamen unsere Ahnen her,

aus vielen deutschen Gauen,

dort war das Leben ihnen schwer,

sie wollten neu es bauen.

Sie gingen in das Polenland

und schufen neues Leben,

sie fanden neues Vaterland,

dem sie sich ganz ergeben.

Wir sind durch Schicksal festgebannt

an Polen, unser Heimatland ${ }^{2}$.

W przekładzie polskim tekst pieśni brzmi następująco:

Przodkowie nasi ongiś tu ściągali

z rozlicznych stron, z niemieckich krain,

1 Termin „literatura małoojczyźniana” jako polski ekwiwalent niemieckiego określenia Heimatliteratur zaproponowali Cz. Karolak, W. Kunicki, H. Orłowski, Dzieje kultury niemieckiej, Warszawa 2006, s. 403.

2 C.H. Schultz, Lied der Polendeutschen, „Der Deutsche Wegweiser”, 6.11.1938, s. 1. 
tam z trudem koniec z końcem wiązali,
tu zacząć wszystko od nowa zamierzali.
Przybyli zatem do polskiej krainy
życie budując od podwalin,
tutaj znaleźli drugą ojczyznę,
której swe serca bez reszty oddali.
To los tak chciał i żyć nam przyszło
na polskiej ziemi, w nowej ojczyźnie

W swoim wierszu autor nieprzypadkowo użył dwóch terminów: Vaterland i Heimatland, funkcjonujących w języku niemieckim jako określenie ojczyzny. Istnieje jednak różnica semantyczna między obu pojęciami. Pierwsze z nich Vaterland (lat. patria) oznacza ojczyznę ideologiczną, wspólne terytorium narodowe, z którym łączą się uczucia patriotyczne. Etymologicznie słowo to oznacza „kraj ojca”4. Pojęcie Vaterland wydaje się dość jednoznaczne i dla niniejszej pracy nie wymaga szerszej dyskusji, choć przyjdzie się jeszcze do niego odwołać, analizując definicję we wczesnych leksykonach niemieckich. Termin Heimat wymaga natomiast głębszej refleksji ${ }^{5}$.

Słowo Heimat wydaje się dość problematyczne zarówno dla polskiej historiografii, jak również dziejopisarstwa innych państw europejskich, które w swoich narodowych językach nie posiadają ekwiwalentu tego terminu. Na język francuski należałoby je przetłumaczyć jako pays natal/le pays/la petite patrie, $\mathrm{w}$ języku angielskim zaś to home/homeland lub homecountry. $\mathrm{W}$ języku polskim zwykło się tłumaczyć słowo Heimat jako „ziemię ojczystą/ojczyznę lokalną” lub „małą ojczyznę”. Z pewnością można znaleźć więcej takich określeń, chociażby „kraj rodzinny” czy „kraj ojczysty”, ale nie o to chodzi, ponieważ żaden $\mathrm{z}$ tych terminów nie oddaje w pełni sensu znaczenia niemieckiego Heimat. Odnosi się ono bowiem zarówno do sfery czysto materialnej (czyli do danego regionu, jego historii, kultury, otoczenia przyrodniczego, architektonicznego i socjalnego), jak i sfery duchowej, czyli pewnego rodzaju więzi emocjonalnej łączącej człowieka z danym regionem.

Większość wczesnych prac naukowych, głównie leksykonów, odnosi pojęcie Heimat do pierwszego aspektu znaczeniowego, czyli do sensu materialnego. W języku staro-wysoko-niemieckim słowo Heimat (haimoti) oraz

3 Tłumaczenie Małgorzata Półrola, [w:] Literackie i nieliterackie obrazy miasta. Łódź przełomu wieków oczami niemieckojęzycznego autora - Carla Heinricha Schultza / Nicht nur literarische Bilder einer Stadt. Lodz in den Augen eines deutschsprachigen Autors - Carl Heinrich Schultz, red. M. Kucner, Łódź 2011, s. 44.

${ }^{4}$ Vaterland, [w:] Deutsches Wörterbuch von Jacob und Wilhelm Grimm, 16 Bde, 32 Teilbänden, Leipzig 1854-1961, Leipzig 1971, http://woerterbuchnetz.de/DWB/?sigle=DWB\&mode=Vernetzung\&lemid=GV00089 [dostęp: 10.12.2013].

${ }^{5} \mathrm{~W}$ niniejszym rozdziale będę używać pojęcia Heimat wymiennie z takimi polskimi ekwiwalentami, jak: „mała ojczyzna”, „ziemia ojczysta”, „ziemia rodzinna”, „kraj ojczysty”, „region ojczysty/rodzinny". 
w średnio-wysoko-niemieckim (heimote) oznaczało dom rodzinny i zagrodę chłopską ${ }^{6}$, można by je zatem porównać z polskim terminem „ojcowizna", oznaczającym właśnie ziemię, dom rodzinny, majątek odziedziczony po ojcu․ W późniejszym okresie zakres znaczeniowy tego pojęcia rozszerzył się o strony rodzinne w odniesieniu do miejscowości ojczystej oraz kraju ${ }^{8}$. Pierwsze niemieckie słowniki nie podają wyjaśnienia słowa Heimat. W obszernej pracy Ausführliche Arbeit von der Teutschen HaubtSprache z 1663 r., cennym kompendium wiedzy z zakresu języka niemieckiego, autor wymienia wprawdzie słowo Heimat, ale jedynie w kontekście słowotwórczym. Jego sens znaczeniowy zostaje pominięty ${ }^{9}$. Po raz pierwszy pojęcie Heimat znalazło się w słowniku Johanna Christopha Adelunga z 1796 r. Czytamy tam, iż oznacza ono „miejsce, kraj, w którym ktoś jest u siebie, w którym się urodził” [der Ort, das Land, wo jemand daheim ist, d. i. sein Geburtsort $]^{10}$. Dla odróżnienia Adelung podaje również wspomniany wcześniej termin Vaterland, który oznaczał tyle, co:

[...] eigentlich das Land des Vaters oder dasjenige Land, in welchem der Vater einheimisch ist oder gewesen, d.i. dasjenige Land, in welchem jemand geboren oder erzogen worden. In seinem Vaterland sterben. Die Liebe zum Vaterlande. In weiterer Bedeutung pflegt man auch zuweilen dasjenige Land, welchem man als Einwohner einverleibet ist, in welchem man den Schutz und die Wohltaten eines ordentlichen Bürgers genießt, sein Vaterland zu nennen ${ }^{11}$.

W obu definicjach zarysowuje się wyraźna różnica między tymi terminami. W przypadku słowa Vaterland wyłania się znaczenie ojczyzny ideologicznej i historycznej, jeśli zaś chodzi o pojęcie Heimat, to używa się go w odniesieniu

${ }^{6}$ Heimat, [w:] Deutsches Wörterbuch...

7 Por. S.B. Linde, Słownik języka polskiego, t. 2, cz. 1: M-O, Warszawa 1809; R. Traba, Wschodniopruskość. Tożsamość regionalna i narodowa w kulturze politycznej Niemiec, Warszawa 2005.

${ }^{8}$ Por. U. Leuschner, Heimweh. Wie die Entfremdung von der Heimat zum Problem wurde. Die „nostalgia“ im Wandel des wissenschaftlichen Zeitgeistes, [w:] idem, Sehn-Sucht. 26 Essays zur Dialektik von Nostalgie, 2003, s. 18.

9 J.G. Schottelius, Ausführliche Arbeit von der teutschen Haubtsprache, Braunschweig 1663, s. 636-637, http://diglib.hab.de/wdb.php?dir=drucke/ko-306 [dostęp: 10.12.2013].

10 J.Ch. Adelung, Grammatisch-kritisches Wörterbuch der hochdeutschen Mundart mit beständiger Vergleichung der übrigen Mundarten, besonders aber des Oberdeutschen. Zweyter Theil: F-L, Wien 1808, s. 1077, http://www.ub.uni-bielefeld.de/diglib/adelung/grammati/ [dostęp: 10.12.2013].

11 Ibidem, Vierter Theil: Seb-Z, s. 978 [właściwie ziemia ojca albo kraj, w którym ojciec jest lub był tubylcem, tzn. kraj, w którym ktoś się urodził lub dorastał. Umrzeć w kraju ojczystym. Miłość do ojczystego kraju. W szerszym znaczeniu zwykło się określać tym mianem również kraj, do którego jest się przypisanym jako jego mieszkaniec, w którym korzysta się z opieki i praw, przysługujących porządnemu obywatelowi. Tłumaczenie M.K.]. 
do małej ojczyzny, stron rodzinnych, kraju dzieciństwa. Podobna definicja pojęcia Heimat znajduje się w Gesamt-Wörterbuch der Deutschen Sprache Jakoba Heinricha Kaltschmidta z 1834 r. Według słownika, słowo to oznacza dom ojca (niem. Vaterhaus), miejsce urodzenia (niem. Geburtsort) oraz miejsce, w którym człowiek przebywa prawomocnie jako członek obywatelskiej wspólnoty prawnej (niem. Ort des bürgerlichen Rechtsverbandes) ${ }^{12}$. W takim znaczeniu, czyli jako termin prawniczy, słowo Heimat funkcjonowało do pierwszej połowy XIX w. i oznaczało prawo człowieka do przebywania w danej gminie oraz korzystanie ze wszystkich należnych mu przywilejów i praw ${ }^{13}$. Znacznie bardziej rozbudowaną definicję przynosi słownik Jakuba i Wilhelma Grimmów z 1877 r., podający jako podstawowe określenie, iż Heimat oznacza kraj albo krainę, miejsce urodzenia, dom rodziców, zagrodę albo miejsce stałego pobytu. Oprócz powyższych znaczeń słownik odnotowuje również inne: Heimat dla chrześcijanina jest królestwem niebieskim w przeciwieństwie do ziemi będącej dla wierzącego światem obcym, w którym jest tylko gościem ${ }^{14}$.

W powyższej definicji należy zwrócić uwagę na dwa aspekty. Po pierwsze, autorzy odwołują się do znaczenia teologicznego, po drugie, w definicji zauważa się, iż Heimat zaczyna oznaczać nie tylko miejsce urodzenia, ale również miejsce stałego pobytu człowieka, a więc miejsce wyboru, jakiego może dokonać, poszukując swojej małej ojczyzny. Brak jednak w słowniku braci Grimm rozumienia słowa Heimat w kategoriach państwowych. Rozważając różne jego znaczenia, należy dodatkowo podkreślić fakt, iż łączy się ono z takimi pojęciami, jak Fremde (obczyzna) oraz Heimweh (tęsknota za krajem). Zarówno obczyzna, jak i tęsknota za krajem ojczystym mają związek z sytuacją społeczno-polityczną i kulturową XIX w. Był to okres rewolucji przemysłowej, której skutki ujawniły się na wielu płaszczyznach. Urbanizacja spowodowała migrację ludności ze wsi do miast i z tego względu społeczeństwa zmieniły strukturą z agrarnej na przemysłową; tak narodził się proletariat; doszło do masowych wędrówek ludności. Opuszczenie ojczystego kraju spowodowało konfrontację z elementami obcymi, ale również tęsknotę za kra-

12 J.H. Kaltschmidt, Kurzgefasstes vollständiges stamm- und sinnverwandtschaftliches Gesamt-Wörterbuch der Deutschen Sprache aus allen ihren Mundarten und mit allen Fremdwörtern. Ein Hausschatz der Muttersprache für alle Stände des Deutschen Volkes worin außer allen einfachen und zusammengesetzten Wörtern der hochdeutschen Sprache, auch alle derselben fehlenden Wörter der norddeutschen, d.h. der westphälischen, bremischen, schwäbischen, hamburgischen, holsteinischen, ditmarsischen, mecklenburgischen, pommerschen, lief- und ebstländlischen, und die Wörter der süddeutschen, d.h. der bayerischen, schwäbischen, schweizerischen und österreichischen Mundarten in schriftgerechter Schreibart verzeichnet und erklärt sind, Leipzig 1834, s. 389.

13 Por. Grenze und Staat: Paßwesen, Staatsbürgerschaft, Heimatrecht und Fremdengesetzgebung in der österreichischen Monarchie 1750-1867, hrsg. v. W. Heindl, E. Saurer, H. Burger, H. Wendelin, Wien-Köln-Weimar 2000.

${ }_{14}$ Deutsches Wörterbuch von J. Grimm und W. Grimm, 4 Bde, 2 Abtheilung: H. I. J, hrsg. v. M. Heyne, Leipzig 1877, s. 864-866. 
jem przodków. W Bilder-Conversations-Lexikon für das Deutsche Volk z 1838 r. na pierwszy plan wysuwa się właśnie kwestia tęsknoty za ojczyzną, która jest niejako „stanem chorobowym” (niem. krankhafter Zustand) w XIX w.:

Heimat nennt man das Land, wo man geboren ist. Jeder Mensch fühlt in seiner Brust ein mächtiges Gefühl, welches ihn zu dem Lande hinzieht, in welchem er seine Kindheit und Jugendzeit verlebte. Dieses Gefühl ist bei einzelnem Menschen und unter einzelnen Völkern, namentlich Gebirgsbewohnern, zuweilen so stark, dass aus der unbefriedigten Sehnsucht nach dem theuren Heimatslande ein krankhafter Zustand entsteht, den man Heimweh nennt ${ }^{15}$.

O ile do połowy XIX w. pojęcia Heimat używano głównie w kontekście społeczno-prawnym i oznaczało ono prawo do rodzinnej ziemi, to w drugiej połowie XIX w. należy je rozpatrywać w kontekście wspólnoty lokalnej i narodowej, symbolicznej i realnej, próbującej stworzyć narodową jednośćc ${ }^{16}$. Również w późniejszym okresie wskazuje się na wewnętrzną wspólnotę społeczną, która tworzy Heimat ${ }^{17}$. Dla Oswalda Spenglera jest ona nie tylko jednością języka, kultury, klimatu i historii, ale również czymś więcej - ideą ${ }^{18}$. Po II wojnie światowej pojęcie Heimat nabrało innego znaczenia. W NRD wykorzystała je do swych celów ideologia marksistowska, w RFN natomiast ideologia ruchów ekologicznych. W latach 70. najbardziej kompleksowo opisała pojęcie Heimat Ina Maria Greverus, opierając swe badania na antropologicznych koncepcjach Edmunda Husserla, Wilhelma Brepohla, Paula Leyhausena i Jakoba von Uexkülla. Na podstawie jej rozważań można przyjąć, że termin ten określa pewnego rodzaju środowisko (niem. Umwelt), w którym dana jednostka funkcjonuje, jest przez nie akceptowana i sama je akceptuje ${ }^{19}$. Tak rozumiane pojęcie Heimat wskazuje na jego aspekt emocjonalny. Autorka kompleksowo ujmuje problem więzi regionalnej, przedstawiając Heimat jako obszar socjokulturowy, zaspokajający potrzebę poczucia bezpieczeństwa jednostki, jej tożsamości i aktywności. W rozprawie Der territoriale Mensch. Ein literaturanthropologischer Versuch zum Heimatphänomen Greverus pisze:

${ }^{15}$ Bilder-Conversations-Lexikon für das deutsche Volk. Ein Handbuch zur Verbreitung gemeinnütziger Kenntnisse und zur Unterhaltung in vier Bänden, 2. Bd: $F-L, 368$ Abbildungen, 11 Landkarten, Leipzig 1838, s. 360-361 [Pojęciem mała ojczyzna określa się kraj, w którym człowiek się urodził. Każdy człowiek nosi w swym sercu potężne uczucie, przyciągające go do kraju, w którym spędził dzieciństwo i młodość. Uczucie to bywa u każdego człowieka z osobna i u poszczególnych narodów, szczególnie wśród mieszkańców gór, niekiedy tak silne, że poczucie niezaspokojonej tęsknoty za ukochanym ojczystym krajem rodzi stan chorobowy, nazywany tęsknotą za ojczyzną. Tłumaczenie M.K.].

16 Por. R. Traba, Wschodniopruskość, Olsztyn 2007.

17 Zob. K. Stavenhagen, Heimat als Lebenssinn, Göttingen 1948.

18 Por. O. Spengler, Untergang des Abendlandes, Bd. 1, München 1963.

19 I.M. Greverus, Der territoriale Mensch. Ein literaturanthropologischer Versuch zum Heimatphänomen, Frankfurt/Main 1972, s. 25. 
Das Territorium als ein konkreter und selbst geschaffener Raumausschnitt mit fließenden Grenzen ist also gewissermaßen die conditio sine qua non zum Anlauf der Territorialität, die die Bedürfnisse Sicherheit, stimulierende Aktivität und Identifikation befriedigt ${ }^{20}$.

Jak wynika z przytoczonego cytatu, Greverus posługuje się pojęciem terytorium, którego używa wymiennie z określeniem Heimat. Wzbogaca ponadto dotychczasowe definicje o komponent aktywności, wychodząc z założenia, że człowiek jest istotą działającą w danym obszarze socjokulturowym. Aktywność to czynnik niezbędny do wytworzenia poczucia przynależności do Heimat. Pojęcie to stanowi dla Greverus „räumliche und soziale Nähe, Tradition und Einfügung in eine kulturelle Ordnung und affektive Bindung an die raumzeitliche, alltagsweltliche Orientierung einer Gruppe”21, tzn. „terytorialną i społeczną bliskość, tradycję oraz dostosowanie do porządku kulturowego i afektywny związek z czasoprzestrzenną, codzienną orientacją danej grupy ${ }^{22}$. „Heimat - pisze w innym miejscu Greverus - wären dann solche Räume, in denen die Bedürfnisse der Menschen - eines einzelnen - qualitativ am meisten befriedigt werden können"23. [Małą ojczyzną byłyby zatem przestrzenie, w których potrzeby każdego człowieka mogą zostać najlepiej zaspokojone ${ }^{24}$. Dla Greverus pojęcie Heimat to także miejsce „höchster Verhaltenssicherheit, der Raum, in dem die Ich-Umwelt-Beziehung funktioniert"25. [Największego poczucia bezpieczeństwa, przestrzeń, w której funkcjonuje stosunek ja - otoczenie] ${ }^{26}$. W tym kontekście Heimat jest przestrzenią, w której jednostka odczuwa największą satysfakcję (niem. Satisfaktionsraum) i to od niej zależy, jakie miejsce stanie się dla niej Heimat:

Der Identifikationsraum kann Familie sein, kann eine Altersgruppe sein, ein Dorf, eine Stadt, eine Landschaft oder das ,Vaterland'. Eine Untersuchung des Identifikationsraumes ,Heimat' darf also weder von räumlichen noch sozialen Gebilden, noch von bestimmten kulturellen Objektivationen ausgehen, sondern sie muß das erlebende Subjekt als Ausgangspunkt nehmen ${ }^{27}$.

${ }^{20}$ Ibidem [Terytorium jako konkretny i samodzielnie stworzony fragment przestrzeni z płynnymi granicami jest więc niejako conditio sine qua non dla terytorialności, zaspokajającej potrzebę bezpieczeństwa, stymulującej aktywności i identyfikacji. Tłumaczenie M.K.].

${ }^{21}$ I.M. Greverus, Auf der Suche nach Heimat, München 1979, s. 19.

22 Tłumaczenie M.K.

${ }^{23}$ Ibidem, s. 16.

${ }^{24}$ Tłumaczenie M.K.

25 I.M. Greverus, Der territoriale Mensch..., s. 43.

26 Tłumaczenie M.K.

27 Ibidem, s. 42 [Miejscem identyfikacji może być rodzina, grupa rówieśnicza, wieś, miasto, krajobraz albo „ziemia ojców”. Badanie zakresu identyfikacji pojęcia „Heimat” nie może więc wychodzić ani od struktur przestrzennych, społecznych, ani konkretnych obiektywnych czynników kulturowych, lecz punktem wyjścia musi być jednostka z jej emocjami. Tłumaczenie M.K.]. 
Dla Greverus staje się oczywiste, że każdy człowiek potrzebuje miejsca, w którym może czuć się bezpieczny, z którym się identyfikuje i w którym aktywnie działa, bowiem te trzy czynniki sprawiają, że może tu rozwinąć poczucie własnej tożsamości. Natomiast w przypadku utraty ojczyzny jednostka odczuwa tęsknotę za nią, spowodowaną niemożnością przystosowania do nowych warunków ${ }^{28}$. W dalszych rozważaniach Greverus podaje ciekawą zależność między powodem opuszczenia ojczyzny i stosunkiem do nowej. Autorka stwierdza, że jeśli powodem opuszczenia starej ojczyzny są kwestie materialne, to istnieje niebezpieczeństwo, że jednostka będzie mieć problemy z przystosowaniem się do nowej ojczyzny i jej zaakceptowaniem ${ }^{29}$. To stwierdzenie Greverus będzie miało znaczenie dla dalszego toku rozważań o literaturze niemieckojęzycznej Łodzi, o którym będzie mowa w kolejnych rozdziałach pracy.

Obok Greverus kompleksowe badania na temat Heimat prowadziła Andrea Bastian, która podeszła do problemu wielopłaszczyznowo ${ }^{30}$. W książce Der Heimat-Begriff. Eine begriffsgeschichtliche Untersuchung in verschiedenen Funktionsbereichen der deutschen Sprache autorka definiuje pojęcie z perspektywy terytorium (podobnie jak Greverus) oraz w kategoriach socjologicznych. Dla Bastian Heimat to „[...] Raum i. S. von Wohnraum oder Landschaft" [przestrzeń w sensie przestrzeni mieszkalnej lub krajobrazu] ${ }^{31}$. Natomiast w przypadku kategorii socjologicznej autorka podkreśla: „Die ,soziale Kategorie' wird durch den Terminus ,Gemeinschaft' definiert und umfasst auch gemeinschaftsstiftende bzw. gemeinschaftserhaltende Aspekte wie z. B. Traditionen, Bräuche und Rituale“. [„Kategoria społeczna” jest definiowana z perspektywy terminu „wspólnota” i obejmuje także czynniki, które tworzą bądź podtrzymują wspólnotę, jak np. tradycje, obyczaje i rytuały] ${ }^{32}$. Obie definicje pojęcia Heimat, zarówno w kontekście terytorialnym, jak i socjologicznym, muszą ze sobą współgrać. Bastian stwierdza:

Folglich können das räumliche Element der Territorialität und die sozialen Elemente gemeinschaftlicher Verbundenheit nicht als getrennt voneinander existierende Faktoren betrachtet werden. [...] zu einer sozialen, gemeinschaftlichen Daseinsführung benötigt das Individuum einen konkreten (Lebens-) Raum ${ }^{33}$.

28 Ibidem, s. 34.

29 Ibidem, s. 64.

${ }^{30}$ Por. A. Bastian, Der Heimat-Begriff. Eine begriffsgeschichtliche Untersuchung in verschiedenen Funktionsbereichen der deutschen Sprache, Tübingen 1995.

${ }^{31}$ Ibidem, s. 25. Tłumaczenie M.K.

32 Ibidem.

33 A. Bastian, Der Heimat-Begriff..., s. 71-72 [Zatem przestrzennego elementu terytorialności oraz społecznych elementów więzi wspólnotowej nie można traktować jako czynników istniejących niezależnie od siebie. [...] do urzeczywistnienia społecznego i wspólnotowego bytu jednostka potrzebuje konkretnej (życiowej) przestrzeni. Tłumaczenie M.K.]. 
Poza elementami społecznymi i terytorialnymi pojęcia Heimat Bastian wymienia jeszcze czynniki emocjonalne, takie jak poczucie bezpieczeństwa, uznanie, zaufanie, a więc elementy wywoływane emocjami związanymi z ojczyzną. Należą do nich: dom rodzinny, język, zapach, smak, pieśni, obrazy przedmiotów lub osób. Natomiast wśród czynników wzmacniających uczucia związane z ojczyzną autorka wskazuje na tradycję i obyczaje ${ }^{34}$.

Choć Bastian znacznie rozbudowała pojęcie Heimat, istnieją jeszcze inne perspektywy. Heimat można rozważać z punktu widzenia miejsca utopijnego, które powstaje z doświadczenia utraty ojczyzny. W tym kontekście wypowiadali się m.in. Jean Améry oraz Bernhard Schlink, który stwierdził: „So sehr Heimat auf Orte bezogen ist, Geburts- und Kindheitsorte, Orte des Glücks, Orte, an denen man lebt, wohnt, arbeitet, Familie und Freunde hat - letztlich hat sie weder einen Ort, noch ist sie einer. Heimat ist Nichtort. Heimat ist Utopie"35. [Niezależnie od tego, jak bardzo pojęcie małej ojczyzny sprowadza się do miejsc takich jak miejsce urodzenia, miejsce lat dzieciństwa, miejsce szczęśliwe, miejsce, w których się żyje, mieszka, pracuje, gdzie ma się przyjaciół, rodzinę - ostatecznie mała ojczyzna ani nie ma miejsca, ani sama nie jest miejscem. Mała ojczyzna jest nie-miejscem, mała ojczyzna jest utopią ${ }^{36}$. W innym fragmencie autor przytoczonych słów stwierdza: „Die Heimaterfahrungen werden gemacht, wenn das, was Heimat jeweils ist, fehlt oder für etwas steht, das fehlt"37. [0jczyzny doświadcza się wtedy, gdy zabraknie tego, czym ona jest, lub tego, co ją stanowi $]^{38}$.

Powyższe cytaty dobrze ilustrują rozważania Schlinka na temat Heimat jako utopii. Kwintesencją małej ojczyzny jest tęsknota za nią, wywoływana np. reminiscencjami: „Die Erinnerungen machen den Ort zur Heimat, die Erinnerungen an Vergangenes und Verlorenes, oder auch die Sehnsucht nach dem, was vergangen und verloren ist" ${ }^{\prime 39}$. [Wspomnienia czynią z danego miejsca małą ojczyznę, wspomnienia rzeczy minionych i utraconych, albo też tęsknota za tym, co minęło i tym, co utracone ${ }^{40}$. W podobnym tonie wypowiada się również Jean Améry, żydowski intelektualista, który sam doświadczył utraty ojczyzny. Wskazuje na pozytywne aspekty takiego doświadczenia, podkreślając m.in.: „[...] daß ich mir auch der Bereicherung und Chancen, welche die Heimatlosigkeit uns bot, wohl bewußt bin. Die Öffnung auf die

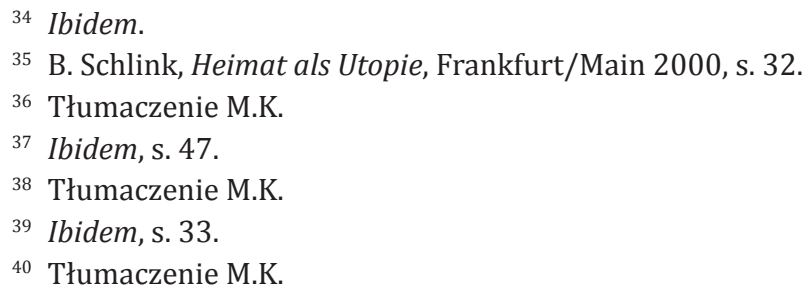


Welt hin, die die Emigration uns gab - ich weiß sie zu schätzen"41. [...że jestem w pełni świadom zysku i szans, jakie dał nam brak ojczyzny. Doceniam otwarcie na świat, które przyniosła nam emigracja] $]^{42}$.

Pojęcie Heimat jest zatem określeniem o szerokim zakresie znaczeniowym, którego ewolucja semantyczna dokonywała się na przestrzeni wielu stuleci. Zapewne badania ostatnich lat pozwoliły spojrzeć na nie z wielu nowych perspektyw i zwróciły uwagę na jego złożoność. Najlepiej ilustrują ten problem słowa Ernsta Blocha: „Heimat ist der Ort, wo noch niemand gewesen ist" $^{43}$. [Ojczyzna to miejsce, w którym nikt jeszcze nie był] ${ }^{44}$.

Obecnie słowo Heimat zastąpiono pojęciem „region”, które nie jest już nacechowane ideologicznie, ale podobnie jak Heimat również nie jest pojęciem jednoznacznym. Zjawiskami regionalizmu w literaturze zajmuje się Norbert Mecklenburg, który definiuje je w następujący sposób:

Politischer und literarischer Regionalismus sind nicht dasselbe, auch nicht zwei Seiten ein und derselben Sache. Aber sie sind miteinender verflochten. Der Begriff Regionalismus entspringt der politischen, nicht der Literaturgeschichte. Er bezeichnet seit dem 19. Jahrhundert autonomistische Bewegungen in verschiedenen unter staatlicher Zentralisierung leidenden Regionen europäischer Länder. Diese Bewegungen sind insofern immer auch literarische, als sie einmal regionale Kultur und Literatur erhalten und fördern wollen, zum anderen selbst mit publizistisch-literarischen Mitteln operieren, um Öffentlichkeit herzustellen. Sprache und Literatur sind damit von Anfang an zugleich Objekt und Instrument von politischem Regionalismus, regionale, oft volkstümliche Literatur - Objekt, regionalistische, oft kritische Literatur - Instrument. Die regionalistische kann sich der regionalen bedienen. Literarischer Regionalismus in diesem Sinn wäre dem politischen immer unter-, zumindest zugeordnet ${ }^{45}$.

41 J. Amery, Wieviel Heimat braucht der Mensch, [w:] Jenseits von Schuld und Sühne. Bewältigungsversuche eines Überweltigten, Stuttgart 1977, s. 80.

42 Tłumaczenie M.K.

${ }^{43}$ E. Bloch, Das Prinzip Hoffnung, Bd. 3, Frankfurt/Main 1970, s. 1628.

${ }_{44}$ Tłumaczenie M.K.

${ }^{45}$ N. Mecklenburg, Regionalismus und Literatur. Kritische Fragmente, „Basis” 9/1979, s. 9 [Regionalizm polityczny i literacki nie oznaczają tego samego, nie są również dwiema stronami tego samego medalu, są jednak ze sobą powiązane. Pojęcie regionalizmu ma rodowód polityczny, nie historycznoliteracki. Począwszy od XIX w. oznacza autonomiczne dążenia regionów na terytorium państw europejskich, cierpiących wskutek procesów państwowocentralistycznych. Dążenia te realizują się więc zawsze także w literackich, ponieważ z jednej strony pragną zachowania i rozwoju regionalnej kultury i literatury, z drugiej natomiast operują nawet środkami publicystyczno-literackimi, aby stworzyć audytorium. Język i literatura są więc od początku przedmiotem, a zarazem narzędziem regionalizmu politycznego; literatura regionalna, często ludowa - staje się obiektem; literatura regionalistyczna, często krytyczna - instrumentem. Literatura regionalistyczna może posługiwać się literaturą regionalną. W tym sensie regionalizm literacki byłby zawsze podporządkowany albo przynajmniej przyporządkowany politycznemu. Tłumaczenie M.K.]. 
W swojej definicji Mecklenburg wskazuje, po pierwsze, na przyporządkowanie regionalizmu literackiego do sfery politycznej z uwagi na fakt, że literatura jest jednocześnie obiektem i instrumentem regionalizmu politycznego. Cechą immanentną literatury regionalnej jest jej terytorialność, jest ona bowiem przyporządkowana do jakiegoś obszaru w ramach danego państwa lub do terytorium obejmującego obszary składowe kilku państw. Jako literatura regionalna nie musi być w swej wymowie konserwatywna. Raczej wskazuje się na jej progresywność oraz krytyczny stosunek do rzeczywistości $^{46}$. Nie musi również podejmować tematyki stricte regionalnej. Zwrócił na to uwagę Jürgen Hein, pisząc, że literatura regionu obejmuje całość tekstów pod względem tematycznym, strukturalnym i typologicznym ${ }^{47}$. Kolejne jej cechy to „Sprachlandschaften, politische und konfessionelle Territorien, materielle und geistige Produktionsverhältnisse, kulturelle Zentren, Kommunikationswege und -grenzen ${ }^{48}$. [Krajobrazy językowe, terytoria polityczne i wyznaniowe, stosunki produkcyjne materialne i duchowe, centra kulturowe, drogi i granice komunikacji ${ }^{49}$. Takie podejście do literatury otwiera wiele możliwości metodologicznych, pozwala ją bowiem analizować z perspektywy kulturoznawczej, socjologicznej, historycznej, politologicznej i geograficznej. Mecklenburg wyszedł z założenia, że analizować i oceniać można tę literaturę z perspektywy, „[der] poetischen Überhöhung der Region” [poetyckiego zawyżenia oceny regionu $]^{50}$. Oznacza to, że coś, co jest pojedyncze, może nabrać szczególnej wartości, jeśli odniesie się do tego, co szersze i kompleksowe. Co to znaczy w odniesieniu do literatury i jej badania? Pozwala odpowiedzieć na wiele pytań, np. jak mniejszość pokazywana jest na tle całego społeczeństwa, jaki tworzy świat (mikrokosmos) wobec pozostałej części społeczeństwa, jak wyglądał proces rozwoju języka czy religii tej mniejszości ${ }^{51} \mathrm{Z}$ tego względu literatura nie podlega interpretacji sama z siebie; należy ją pojmować kompleksowo i odkrywać jej zależność od innych, otaczających ją literatur. Takie rozumienie literatury regionalnej spowodowało inne po-

${ }^{46}$ Por. N. Mecklenburg, Erzählte Provinz. Regionalismus und Moderne im Roman, Königstein/Taunus 1982.

${ }^{47}$ J. Hein, Regionalliteratur, „Soltauer Schriften” 6/1998, s. 22-32.

48 N. Mecklenburg, Stammesbiologie oder Kulturraumforschung? Kontroverse Ansätze zur Analyse regionaler Dimensionen der deutschen Literatur, [w:] Kontroversen, alte und neue. Akten des VII. Internationalen Germenisten-Kongresses Göttingen 1985, Bd. 10: Vier deutsche Literaturen - Literatur seit 1945 - nur die alten Modelle? - Medium Film - das Ende der Literatur?, hrsg. v. K. Pestalozzi, A. von Bormann, Th. Koebner, Tübingen 1986, s. 3.

49 Tłumaczenie M.K.

${ }^{50}$ N. Mecklenburg, Rettung des Besonderen, Konzepte für die Analyse und Bewertung regionaler Literatur, [w:] Kolloquium zur literarischen Kultur der deutschsprachigen Bevölkerungsgruppen im Ausland, Flensburg 1984, s. 186.

51 Ibidem, s. 190. 
dejście do niemieckojęzycznego piśmiennictwa ukazującego się za granicą, przez wiele lat stygmatyzowanego przez znawców tematu jako twórczość prowincjonalna o nikłych wartościach estetycznych. Badania Meckelnburga sprawiły, że uprawnione jest również badanie literatury regionalnej pod względem jej wartości estetycznych.

Na zakończenie warto podkreślić, że postrzeganie literatury ojczyźnianej zarówno przez samych pisarzy, jak i teoretyków, szczególnie do lat 70. XX w., jest dość stereotypowe, tzn. dla większości z nich punktem odniesienia jest prowincja, wieś, wiejska okolica lub krajobraz wiejski przedstawiany zazwyczaj w sposób idealistyczny. Zmianę w postrzeganiu literatury ojczyźnianej przynoszą badania prowadzone przez niemieckich teoretyków, takich jak Mecklenburg czy Hain. Pojęcie Heimat jest zastępowane określeniem „region”, które nie jest już nacechowane ideologicznie. Literatura regionalna nie ogranicza się tylko do tekstów o regionie, lecz porusza także wszelkie inne tematy, ważne z perspektywy regionu. Zmienia się również podejście badawcze do literatury, otwierając perspektywę interdyscyplinarną, a więc uwzględniając aspekty kulturoznawcze, socjologiczne i historyczne. Produktywne może tu być dopiero odniesienie do warunków, w jakich powstawała oraz otaczających ją innych literatur.

Powyższe rozważania na temat pojęcia Heimat mają swoje odniesienie do literatury określanej jako ojczyźniana, małoojczyźniana, literatura małych ojczyzn czy - w szerszym znaczeniu - jako literatura regionalna. Ten rodzaj twórczości można by nazwać w bardzo ogólnym ujęciu „sztuką wyrażającą afirmację stron ojczystych oraz jej mieszkańców". Tak sformułowana definicja byłaby jednak zbytnim uproszczeniem, bowiem mianem literatury ojczyźnianej można by wówczas określić wszelkie utwory powstałe na przestrzeni wielu epok - począwszy od Teokryta, a na niemieckich Heimatdichter (autorach nurtu literatury ojczyźnianej) kończąc - które przedstawiały apoteozę małej ojczyzny. Już od najwcześniejszych czasów synonimem małej ojczyzny była wieś, której poświęcano obszerne opisy przyrody i stosunków społecznych.

Na gruncie tych utworów zaczyna pojawiać się na przełomie XIX i XX w. sztuka oraz literatura, której kwintesencją jest nie tylko afirmacja i idylliczne przedstawianie życia wsi i jej mieszkańców, lecz także propagowanie ideologii politycznej. Dużą rolę odgrywają w tym procesie dwa czasopisma propagujące idee sztuki ojczyźnianej: „Heimat” i „Deutsche Heimat”. Do ważniejszych przedstawicieli tego ruchu należeli m.in. Julius Langbehn, Heinrich Sohnrey, Carl Muth, Friedrich Lienhard oraz historyk literatury Adolf Bartels, propagujący piśmiennictwo o charakterze antysemickim i volkistowskim. Ruch ojczyźniany narodził się jako protest przeciw naturalizmowi i modernizmowi, a także z poczucia zagrożenia jedności narodowej i niemieckiej kultury. Jak pisał Ernst Wachler, niemiecki pisarz i publicysta, który propagował antysemityzm oparty na zasadach rasowo-biologicznych: 
Wir verlangen eine machtvolle Volkskunst für die Nation; voll Unerschrockenheit, Glut und Größe, mit würdigen Gegenständen, getragen von der Eigenart unserer Gaue, auf dem Boden unserer Landschaften, von der Kühnheit echten Deutschtums durchlodert ${ }^{52}$.

Sztuka ojczyźniana była związana z ideologią volkistowską (niem. völkisch oznacza „substancję narodową/żywioł narodowy”) ${ }^{53}$. Charakterystyczne dla niej wartości to ujęcie narodu w kategoriach mistycyzmu, kult natury, negowanie naukowości i podkreślanie znaczenia intuicji, fascynacja legendami i germańskimi wojownikami, bezpośrednie doświadczenie Boga, głoszenie wyższości rasy aryjskiej i antysemityzm. Ideologia volkistowska znalazła odbicie zarówno w sztuce, jak i w literaturze. W obliczu politycznego rozbicia kraju jej celem stała się konsolidacja narodu niemieckiego. Podobnie jak cała sztuka tego nurtu, literatura ojczyźniana pozostawała w opozycji do rozwijającego się modernizmu. Świat kreowany przez tę literaturę był spolaryzowany, tzn. miasto będące synonimem niechcianej cywilizacji przeciwstawiano wsi jako ostoi natury i moralności. Zdrowy mieszkaniec wsi był antytezą chorego mieszkańca miasta lub intelektualisty.

Zwolennicy literatury i ruchu ojczyźnianego często zwracali uwagę na motyw uzdrowienia narodu niemieckiego. Wspomniany już Wachler, postulujący w swych założeniach teoretycznych sanację narodu, pisał:

Die Mittel, die die Gesundheit, Schönheit und Kraft der Deutschen aufs höchste steigern, können nur bestehen in der Reinigung des Volkstums, der Ausscheidung oder der Aufsaugung des Fremden, Vernichtung des Entarteten ${ }^{54}$.

Z czasem w literaturze ojczyźnianej zaczęła przeważać argumentacja rasistowska, z której rozwinęła się literatura „krwi i ziemi” (Blut- und Bodenliteratur, w skrócie nazywana Blubo-Literatur). Anna Bramwell pisze:

,Blut und Boden' gehört zu den düsteren und tragischen Mythen, die die deutsche Geschichte der letzten zweihundert Jahre durchziehen. Düster deshalb, weil die ,Blut und Boden'-Ideologie mit den schrecklichsten Verbrechen der Nationalsozialisten verbunden ist. Und tragisch, weil es ein machtvolles soziales und nationalistisches Ideal war, das möglicherweise zum Kern der Konflikte des 20. Jahrhunderts zu rechnen ist und sicher-

${ }^{52}$ E. Wachler, za: K. Rossbacher, Heimatkunstbewegung und Heimatroman. Zu einer Literatursoziologie der Jahrhundertwende, Stuttgart 1975, s. 28 [Żądamy potężnej sztuki dla ludu; odważnej, żarliwej i wielkiej, o godnej treści, nacechowanej charakterem naszych stron, wyrosłej na gruncie naszych krajobrazów, przepojonej prawdziwym niemieckim duchem. Tłumaczenie M.K.].

53 Por. Cz. Karolak, W. Kunicki, H. Orłowski, Dzieje kultury..., s. 439-440.

${ }^{54}$ E. Wachler, za: K. Rossbacher, Heimatkunstbewegung und Heimatroman..., s. 56 [Drogą do osiągnięcia zdrowia, piękna i siły może być dla Niemców tylko oczyszczenie narodu, wyeliminowanie albo wchłonięcie wszystkiego, co obce i zniszczenie wszystkiego, co zdegenerowane. Tłumaczenie M.K.]. 
lich ein Faktor in vielen Konflikten der Gegenwart bleibt. Zwischen den Kriegen betrieben die Nachfolgerstaaten eine nationalistische Politik der Enteignung von Grund und Boden an allen, die nicht das richtige ,Blut' hatten ${ }^{55}$.

Ideologia „krwi i ziemi” pojawiła się wraz z pierwszymi teoriami rasistowskimi. Jej głównym propagatorem był Richard Walter Darré, według którego chłopstwo to ostoją niemieckiego społeczeństwa i w przeciwieństwie do mieszczaństwa może odrodzić niemiecki naród i nordycką rasę ${ }^{56}$. Istotą teorii „krwi i ziemi” była czysta gatunkowo rolnicza rasa przewodnia, dlatego bohaterami autorów tej literatury, takich jak Gerharda Schumanna, Josefa Berens-Totenohla, Heinricha Anackera, Herberta Böhme czy Heryberta Menzela, stali się chłopi, osiedleńcy i najemcy ziemscy jako antyteza skorumpowanego kapitalizmu. Utwory ojczyźniane zawierały schematyczne, powtarzające się elementy, do których należą dłuższe opisy wiejskich krajobrazów, chłopskich zagród, brak analizy psychologicznej i kumulacji wydarzeń. W utworach tych poszukiwano m.in. heroizmu, germańskiej krwi czy niczym nieskażonej „rodzimości”. Inną formą literatury, związaną ideologicznie z Trzecią Rzeszą, była tzw. Grenzlandliteratur. Ona również odwoływała się do teorii rasistowskich, była jednak - w porównaniu z Blut-und-Boden-Literatur - bardziej podatna na ideologiczne manipulacje, częściej głosiła też idee szowinistyczne. Uprawiali ją głównie mieszkańcy wschodnich rubieży Rzeszy, a więc Prus, Śląska, Pomorza, reprezentującej tzw. „kompleks Wschodu”, spowodowany polityczną niepewnością ludności pochodzenia niemieckiego, zamieszkującej te tereny. Poczucie niepewności wypływało głównie z wydarzeń politycznych - zmiany granic i plebiscytów. Mieszkająca na tych terenach ludność pochodzenia niemieckiego musiała w większym stopniu niż ludność rdzennie niemiecka z Rzeszy manifestować swój związek z macierzą i częściej epatować wrogim stosunkiem do obcych. Pisarze tworzący w tej tradycji mieli do spełnienia dwa zadania: po pierwsze byli duchowym bastionem w walce przeciw obcej politycznie, kulturowo i etnicznie ludności; po drugie utrzymywali Niemców poza granicami macierzy w stanie gotowości do podjęcia walki o zachowanie niemczyzny

55 A. Bramwell, Blut und Boden, [w:] Deutsche Erinnerungsorte, Bd. 3, München 2003, s. 380 [Teoria "krwi i ziemi” należy do najbardziej mrocznych i tragicznych mitów towarzyszących historii niemieckiej na przestrzeni ostatnich dwustu lat. Mrocznych - ponieważ ideologia krwi i ziemi wiąże się z najokrutniejszymi zbrodniami narodowych socjalistów. Tragicznych, ponieważ była potężnym ideałem społecznym i nacjonalistycznym, który najpewniej stał się zarzewiem konfliktów w XX w. i z pewnością nadal jest istotnym czynnikiem wielu współczesnych konfliktów. W okresie między wojnami państwa uprawiały nacjonalistyczną politykę pozbawiania ziemi wszystkich, w których żyłach płynęła nieodpowiednia „krew”. Tłumaczenie M.K.].

56 Por. R.W. Darré, Das Bauerntum als Lebensquell der nordischen Rasse, München 1928; idem, Um Blut und Boden, München 1929; idem, Neuadel aus Blut und Boden, München 1930. 
na danym terenie. W tym sensie Grenzlandliteratur oddzielała to, co swojskie, od tego, co obce ${ }^{57}$.

Po II wojnie światowej literatura ojczyźniana w NRD zaanektowała ten gatunek dla celów ideologicznych, tworząc tzw. Dorfroman (powieść wiejską), w której propagowano idee socjalizmu. W RFN natomiast rozwinęła się w dwóch kierunkach - utrata ojczyzny spowodowana zmianą granic wpłynęła na powstanie literatury reminiscencji i nostalgii - literaturę małych ojczyzn. Obok niej literaturę wspomnieniową reprezentują autorzy związani z organizacjami ziomkowskimi, którzy nawiązując do stylistyki dawnej Grenzlanddichtung, w demagogiczny sposób piszą o utracie swojej małej ojczyzny. Drugi nurt w ramach literatury ojczyźnianej to zdecydowane odrzucenie dotychczasowego kanonu literatury „krwi i ziemi” oraz Grenzlandliteratur. Ten trend prezentował apoteozę krajobrazu lat dzieciństwa i młodości, mit ojczyzny utraconej bez kontekstów ideologicznych, charakterystycznych dla Grenzlanddichtung.

W przypadku literatury niemieckojęzycznych łodzian trudno odpowiedzieć jednoznacznie na pytanie, czy utwory powstające na przełomie XIX i XX w. należały do literatury regionalnej. Nie wszystkie z nich prezentują charakterystyczny dla łódzkiego regionu koloryt, mentalność czy język, w wielu nie ma nawet jasnych odwołań do konkretnego miejsca - Łodzi. Istnieje niewiele tekstów egzemplifikujących język powstały w tym regionie, tzw. Lodzerdeutsch. Można zatem stwierdzić, iż autorzy starali się nadać swoim utworom uniwersalny charakter. Ten swoisty brak jasno wykształconej literatury regionalnej mógł mieć wielorakie przyczyny. Jedną z nich jest brak więzi, jaka nawiązuje się między człowiekiem i danym terytorium. Istnieje w tym względzie dość prosta zależność: im mocniejsze więzi z regionem, tym pełniejsza aktywność również w sferze kulturowej. Podstawą więzi z regionem są jednak wspólne dzieje i wspólne wartości, których w przypadku Łodzi zabrakło w początkowej fazie osadnictwa. Charakterystyczne dla Łodzi jest zatem dość późne zainteresowanie ludności literaturą zarówno z perspektywy czytelniczej, jak i twórczej. Przyczyn tego stanu rzeczy można doszukiwać się wielu. Po pierwsze, struktura ludności nie sprzyjała podejmowaniu jakichkolwiek inicjatyw kulturalnych - do Łodzi przybywali głównie tkacze, sukiennicy i rzemieślnicy, ludzie bez gruntowniejszego wykształcenia, posiadający jednak wiedzę techniczną. Na miejscu zastali również specyficzne środowisko - głównie zubożałą szlachtę i rzemieślników bez większych ambicji kulturowych. Brak inteligencji, a przede wszystkim mieszczaństwa, negatywnie wpływał na rozwój kultury. Ponieważ nie istniały miejscowe wzorce kul-

57 Por. H. Orłowski, Grenzlandliteratur. Zur Karriere eines Begriffs und Phänomens, [w:] Heimat und Heimatliteratur in Vergangenheit und Gegenwart, hrsg. v. H. Orłowski, Poznań 1993, s. 9-18. 
turowe, ludność pielęgnowała tradycje miejsc, z których przybyła ${ }^{58}$. Na początku lat 20. XIX w. społeczność niemieckojęzyczna miasta założyła na wzór niemiecki Łódzkie Towarzystwo Strzeleckie (niem. Lodzer Bürgerschützengil$d e$ ), skupiające przedstawicieli zarówno niemieckiej, jak i polskiej inteligencji, rzemieślników i fabrykantów. Taka sytuacja nie sprzyjała postrzeganiu Łodzi jako nowej ojczyzny i wytworzeniu specjalnej więzi.

Dodatkowym czynnikiem negatywnie wpływającym na budowanie szczególnych relacji z nową ojczyzną był czynnik finansowy jako przyczyna, za której sprawą ludność ta znalazła się w Łodzi. Badania przeprowadzone przez Greverus wykazały, że jeśli czynnik materialny jest głównym powodem opuszczenia własnej ojczyzny, to stanowi poważną przeszkodę w procesie adaptacji do nowego środowiska. Biorąc pod uwagę tę prawidłowość, należy stwierdzić, iż przywiązanie ludności niemieckojęzycznej do starej ojczyzny, do Heimat, było - przynajmniej na początku osadnictwa - bardzo silne. Idąc za tokiem rozumowania Greverus, można przypuszczać, iż pierwsi niemieccy osadnicy mogli mieć jedynie ograniczone poczucie bezpieczeństwa, wynikające z sytuacji społeczno-gospodarczej i politycznej na terenach polskich pod zaborem rosyjskim. Choć władze Królestwa Polskiego stworzyły przybyszom dość dobre warunki rozwoju własnej przedsiębiorczości, nadając im w tym celu liczne przywileje, zapewniając ulgi i wsparcie finansowe, to jednak wśród pierwszych fabrykantów liczne były przypadki bankructw i materialnego zubożenia. Brak stabilizacji spowodowany był polityką gospodarczą Rosji, która nakładała bądź zdejmowała cła na łódzkie wyroby bawełniane i w dużej mierze od tego właśnie uzależniała powodzenie łódzkiego handlu.

Aktywność kulturowa niemieckojęzycznych łodzian zaczęła się uwydatniać dopiero $\mathrm{w}$ drugiej połowie XIX w., kiedy powstał niemiecki teatr i założono pierwszą niemieckojęzyczną gazetę, tłumaczoną również na język polski. Można wnioskować, iż społeczność niemiecka w Łodzi przez dłuższy czas nie wykształciła więzi z nową ojczyzną. Choć w drugiej połowie XIX i na początku XX w. w ówczesnej prasie wiele pisano o tym, że ludność niemiecka nadaje ton życiu Łodzi, to jednak należy zauważyć, iż kultura niemiecka nie doczekała się tu wybitnych muzyków, kompozytorów, malarzy czy literatów, którzy podnieśliby miasto na wyżyny niemieckiej tradycji kulturowej. Ludność niemieckojęzyczna prawdopodobnie odczuwała bardzo silny związek ze starą ojczyzną. Nie bez znaczenia był również fakt, iż Polska centralna znajdowała się w tym czasie pod zaborem rosyjskim, a rzeczywistość zaborów nie pozwalała na rozwinięcie pełnej aktywności w różnych dziedzinach, w tym kulturowej. Zaborca ustanowił bowiem sztywne zasady, ograniczające

58 Por. A. Barszczewska-Krupa, Rodowód oraz drogi rozwoju kultury i oświaty $w$ Łodzi. Uwagi ogólne, [w:] Łódź. Dzieje miasta, t. 1: Do roku 1918, red. B. Baranowski, J. Fijałek, ŁódźWarszawa 1980, s. 480-485. 
swobodę działania wielokulturowego społeczeństwa. Aktywność jednostek, które mogły odegrać rolę kulturotwórczą, była więc z góry zawężona. W drugiej połowie XIX w. mimo dość trudnych warunków do rozwoju kultury społeczność niemiecka zaczęła się interesować słowem pisanym i sama tworzyć literaturę. W tym czasie pojawiają się pierwsze teksty potwierdzające zainteresowanie ludności niemieckojęzycznej lokalnym kolorytem. Znaczna ich część zamieszczana jest w miejscowej prasie, choć jej autorzy często pozostają anonimowi.

Na podstawie aktualnego stanu badań na temat literatury niemieckojęzycznych łodzian do 1939 r. można stwierdzić, iż w ciągu kilkudziesięciu lat rozwoju miasta nie rozwinęła się w nim literatura, która nosiłaby typowe cechy „ojczyźnianej” (Heimatliteratur). Brak wśród niemieckojęzycznych utworów tekstów idealizujących życie wsi i jej mieszkańców jako alternatywę dla nowoczesnej cywilizacji przemysłowej. Nie oznacza to jednak, że niemieckojęzyczni łodzianie postrzegali tę cywilizację bezkrytycznie - przeciwnie - miasto przedstawiano jako miejsce upadku norm społecznych i moralnych, i co najważniejsze - nie znajdowano alternatywy dla miejskiego życia. Wieś lub małe miasto traktowano jako anachronizm i miejsce, w którym żyła zubożała szlachta. Autorzy zazwyczaj nie poświęcali wiele uwagi opisom krajobrazu, skupiając się częściej na postawach moralnych bohaterów (a niekiedy całych zbiorowości), ukazując ich deprawację czy zakłamanie. Postawy bohaterów licznych opowiadań determinują popędy biologiczne i instynkty, nie zaś odczuwane emocje, co mogłoby świadczyć w pewnym sensie o podobieństwie tych tekstów do literatury okresu naturalizmu.

Dość dobrze rozwinęła się w Łodzi Heimatliteratur o charakterze volkistowskim. Jej rozwój ma swoje uzasadnienie w sytuacji społeczno-politycznej, w szczególności zaś w konfliktach nasilających się pod koniec XIX i na początku XX w.

Druga połowa XIX w. to początek procesu polaryzacji społecznej w Łodzi. W wieloetnicznym społeczeństwie ważna była świadomość narodowa, ale jeszcze ważniejsze okazały się podziały klasowe. Coraz wyraźniej ujawniał się podział na klasę robotniczą (bardzo mocno zasilaną przez chłopów szczególnie po uwłaszczeniu), warstwę inteligencji i burżuazji oraz drobnomieszczaństwo. Każda z tych grup zaczynała dostrzegać własną rolę w miejscowej społeczności. Duży wpływ na taki stan rzeczy miały rewolucja $1905 \mathrm{r}$. i wybuch I wojny światowej. Oprócz tych wydarzeń nie bez znaczenia pozostawała też polityka władz carskich faworyzująca ludność niemieckojęzyczną, co w konsekwencji rodziło silną świadomość podziałów narodowych w łódzkim społeczeństwie. Pod koniec XIX w. w inicjatywach społeczno-kulturowych wyraźnie rysują się tendencje do umacniania polskości w mieście. Szczególną rolę na rzecz wspierania polskiej kultury i tradycji odegrała 
miejscowa prasa, skupiająca łódzką inteligencję zasilaną przez grupę warszawską. Licznie podejmowane inicjatywy i publikacje prasowe miały służyć ożywieniu życie kulturalnego miasta. Również wśród części społeczeństwa niemieckiego w Łodzi coraz wyraźniejsze stawały się dążenia do zachowania niemieckiej odrębności kulturowej, a tym samym przeciwstawianie się polonizacji lub naciskom asymilacyjnym. Nie bez znaczenia była też sytuacja w Niemczech, a dokładniej dążenia nacjonalistyczne różnych aktywistów do scalenia całego narodu niemieckiego, czyli wzbudzenia poczucia jedności Niemców żyjących poza granicami państwa niemieckiego. Na początku XX w. także w Łodzi uaktywniają się działacze, m.in. Adolf Eichler, który angażuje się na rzecz wzmacniania pozycji niemczyzny w Polsce ${ }^{59}$. W takiej sytuacji politycznej również literatura zaczyna nasiąkać ideami propagowanymi przez miejscowych aktywistów. Zagadnienie łódzkiej literatury aż do wybuchu II wojny światowej można rozważać w kontekście literatury ojczyźnianej, choć z pewnymi zastrzeżeniami. Przed wybuchem II wojny nie stwierdza się istnienia w mieście twórczości, która nosiłaby cechy typowej Heimatdichtung, natomiast po odzyskaniu przez Polskę niepodległości po I wojnie światowej w literaturze łódzkiej widoczne stają się tendencje do podkreślania wyjątkowego powiązania niemczyzny łódzkiej z macierzą. Na czoło wysuwa się tu twórczość liryczna takich poetów, jak Sigismund Banek, Julian Will, pastor Philipp Kreutz, August Utta czy Edith Maltzahn ${ }^{60}$. Trzech pierwszych (Banka, Kreutza i Willa) wymienia przesiąknięta duchem narodowego socjalizmu Literaturgeschichte des Deutschtums im Ausland [Historia niemieckojęzycznej literatury poza granicami] autorstwa Karla Kurta Kleina z 1939 r. $^{61}$ Autor określa tych pisarzy mianem „Männer der tätigen Volkstumsarbeit ${ }^{62}$,, a odwołując się do słów Alfreda Karasek-Langera, podkreśla niezwykle ważny związek literatury z pracą na rzecz zachowania niemieckiej tożsamości:

Der Deutschtumsführer wird aus der Fülle der ihn umdrängenden Aufgaben heraus sehr oft zum Dichter, der Dichter aber, nach dem tieferen Sinn seiner Werke suchend, meist auch zum Deutschtumsführer. So sehen wir eine starke Wechselbeziehung zwischen Dichtung und Volkstumsarbeit $[\ldots]^{63}$.

59 M. Cygański, Mniejszość niemiecka w Polsce 1918-1939, Łódź 1962.

${ }^{60}$ Więcej na temat ich twórczości w rozdziale 5.1.1: Nurt ojczyźniany.

${ }^{61}$ K.K. Klein, Literaturgeschichte des Deutschtums im Ausland, Leipzig 1939, s. 368. Na temat historii niemieckojęzycznej literatury poza granicami Rzeszy por. W. Kessler, Doppelte Ausgrenzung. Zu Geschichte und Konzeption der "auslanddeutschen Literatur", [w:] Literatur - Grenzen - Erinnerungsräume, Würzburg 2004, s. 261-282.

${ }^{62}$ K.K. Klein, Literaturgeschichte des Deutschtums..., s. 368.

${ }^{63}$ Ibidem [Przywódca niemieckich kręgów staje się w obliczu ogromu otaczających go zadań poetą, poeta zaś, poszukując głębszego sensu swych dzieł, staje się najczęściej przywódcą niemieckich środowisk. Dlatego dostrzegamy wzajemne, silne oddziaływanie między poezją i walką na rzecz narodu niemieckiego. Tłumaczenie M.K.]. 
Zachowanie niemieckiej tożsamości na ziemiach, które po wojnie przypadły w udziale Polsce, stało się nadrzędnym celem działań wielu polityków okresu Republiki Weimarskiej ${ }^{64}$, później zaś Hitlera. Łódź jawi się tu jako swego rodzaju ewenement - miasto nigdy nie było ziemią, do której rościła sobie prawo Rzesza Niemiecka, jak działo się to w okresie międzywojennym w przypadku Pomorza czy Śląska. Łódzcy Niemcy byli niemiecką enklawą lub wyspą (niem. Inseldeutschtum), co w pewnym sensie miało wpływ na ich postrzeganie przez Niemców z Rzeszy. W 1925 r. Karl Christian von Loesch tak pisał o Niemcach „wyspowych”: „Niemals wird das fernere Inseldeutschtum (im Gegensatz zum Grenzlanddeutschtum - geschlossenes Siedlungsgebiet der mitteleuropäischen Deutschen, Anm. d. Verf.) ein Teil des großdeutschen Staates sein können". ${ }^{65}$ [Nigdy Niemcy wyspowi (w odróżnieniu od Niemców z pogranicza - zwartego terenu zasiedleń Niemców środkowoeuropejskich - przyp. M.K.) nie będą mogli stać się częścią niemieckiej Rzeszy] ${ }^{66}$.

To dość negatywne nastawienie, prezentowane przez czołowych szermierzy niemieckiego nacjonalizmu wobec Niemców wyspowych, odbijało się również na ocenie twórczości literackiej. Była ona traktowana marginalnie lub często pomijana przez kanon ogólnonarodowy, nie wykształciła też żadnej konkretnej tradycji. Wspomniany K.K. Klein w swej obszernej pracy na temat literatury Niemców poza granicami państwa niemieckiego twórczości łódzkich Niemców poświęca zaledwie kilka stron. Tendencja ta utrzyma się również wiele lat po wojnie ${ }^{67}$.

Jednak dążenia narodowoniemieckie pojawiły się już po wybuchu rewolucji 1905 r., gdy część niemieckiego mieszczaństwa z Łodzi powołała do życia szereg niemieckich organizacji i towarzystw ${ }^{68}$. Były wśród nich towarzystwa śpiewacze, sportowe, związki strzeleckie i organizacje przeciwpożarowe, które poza krzewieniem wśród miejscowej ludności ideologii narodowoniemieckiej zajmowały się także szerzeniem protestantyzmu. Na czoło tego ruchu wysuwała się działalność kół narodowoniemieckich z takimi działaczami, jak A. Eichler, L. Wolff, W. Neumann i in. Ideologię niemieckiego ruchu narodowego popularyzowały w Łodzi liczne pisma, np. „Lodzer Rundschau”, „Geistiges Leben”, „Freie Presse”, „Der Deutsche Weg” czy „Monatsblätter für die Deutschen in Russland". Zapleczem instytucjonalnym tej działalności był Deutscher Verein für Lodz und Umgegend, którego członkami byli również

\footnotetext{
${ }^{64}$ Por. G. Niedhart, Die Außenpolitik der Weimarer Republik, München 2006.

${ }^{65}$ Volk unter Völkern (Bücher des Deutschtums I), hrsg. v. K. Ch. von Loesch i in., Breslau

66 Tłumaczenie M.K.

${ }^{67}$ Por. K.K. Klein, Literaturgeschichte des Deutschtums..., s. 368. Na temat historii niemieckojęzycznej literatury poza granicami Rzeszy por. W. Kessler, Doppelte Ausgrenzung...

${ }^{68}$ Por. A. Kargel, Deutschtum im Aufbruch, Leipzig 1942.
} 1925, s. 11. 
tworzący w Łodzi poeci niemieckojęzyczni. Należał do nich Julian Will, którego wiersze, wydane w 1935 r. w tomie Fern vom Land der Ahnen. Gesammelte Gedichte, przepełnione są duchem nacjonalizmu. Twórczość Willa nie zalicza się do kanonu literatury niemieckiej, a jej wartość estetyczną oceniano już za życia autora jako nie najlepszą. Uznano go jednak za niemieckiego patriotę, zasłużonego w działalności na rzecz niemczyzny za granicą. Świadczą o tym słowa teoretyka literatury i działacza volkistowskiego Adolfa Bartelsa, który w przedmowie do wspomnianego tomu wierszy napisał: „Will ist [...] keiner unserer modernen Lyriker, aber ein völkisch wertvoller" ${ }^{\prime 69}$. [Will nie jest [...] jednym z naszych nowoczesnych poetów, ale za to cennym pod względem narodowym $]^{70}$.

Z uwagi na immanentne cechy tej literatury, reprezentowane głównie przez utwory Banka, Willa i innych wspomnianych autorów, można nazwać ją literaturą ojczyźnianą - volkistowską lub Grenzlandliteratur, w której dość wyraźnie ujawnia się konflikt społeczno-polityczny i próba jego przezwyciężenia poprzez nawoływanie do działania w duchu ideologii nacjonalistycznej, a także do łączności z Rzeszą, niemiecką kulturą i tradycją, tym samym zatem do zachowania niemieckości.

Literatura łódzka, która rozwijała się na przestrzeni dwóch wieków, nie miała jednorodnego oblicza. Tuż przed wybuchem II wojny światowej nabiera cech predestynujących ją do miana literatury pogranicza. Jej korzenie tkwią w łódzkiej wielokulturowości i wieloetniczności. Łódź XIX i początku XX w. to miasto o wyrazistej specyfice etnicznej i językowej, znacznie różniącej je od Śląska, Pomorza czy Wielkopolski. O ile wielokulturowość i wieloetniczność tych ostatnich była konsekwencją wydarzeń historycznych (np. zmiany granic), to wielokulturowość Łodzi powstała z inicjatywy władz rządowych, pragnących rozwinąć na tym terenie przemysł. Niemniej Łódź, której wielokulturowość nie powstała w wyniku przesunięcia granic czy powolnej ewolucji, można nazwać regionem pogranicza. Nie jest to pogląd odosobniony, bowiem niemiecki historyk Karl Schlögel określił Łódź jako „Grenzstadt - mitten in Polen"71 [miasto pogranicza - w środku Polski]. Tym, co kwalifikuje ją do kategorii regionów pogranicza, jest właśnie swoiste przenikanie czterech kultur: polskiej, niemieckiej, żydowskiej i - w najmniejszym stopniu, ale jednak - rosyjskiej. 0 odrębności Łodzi stanowią takie fenomeny, jak Lodzermensch i Lodzerdeutsch - oba pojęcia wydobywają jej lokalny koloryt. Literatura związana z miastem pojawia się w Łodzi pod koniec lat 30. XX w.

${ }^{69}$ Begleitwort zu Julian Wills Gedichten, [w:] J. Will, Fern vom Land der Ahnen. Gesammelte Gedichte, Łódź 1935, s. 5-6.

70 Tłumaczenie M.K.

${ }^{71}$ K. Schlögel, Lodz - Suche nach dem ,Gelobten Land', „Die Zeit”, 13.09.1996; druk również [w:] K. Schlögel, Promenade in Jalta und andere Städtebilder, Frankfurt/Main 2003, s. 127. 
Jako przykład można tu przywołać utwór Bruno Raymonda $W$ poszukiwaniu ojczyzny, w którym zauważa się szczególny tok narracji, charakterystyczny dla mentalności pogranicza. Wskazuje na to złożona psychika bohatera, ujawniająca się w sposobie myślenia i odczuwania. Jego tożsamość kształtuje się w obliczu konfrontacji: swój - obcy. W postaci głównego bohatera widać alegoryczny emblemat pogranicza ${ }^{72}$ - jest on nosicielem pewnego rodzaju destrukcji, człowiekiem o niepewnym rodowodzie i niejasnych konturach. Bohater doświadcza pogranicza, zadając sobie pytania o istotę i granice własnej tożsamości, którą próbuje określić w konfrontacji z obcością. Obok bohatera z pogranicza pojawiają się też postaci, które można nazwać przedstawicielami centrum o nienaruszalnych własnych przekonaniach, dyktujących warunki i produkujących niejako powszechnie obowiązujące wzorce.

Łódzką literaturę można określić za pomocą definicji zaproponowanej przez Jürgena Heina i Słownik literatury popularnej również w pewnym sensie jako regionalną z uwagi na fakt, że są to utwory krążące $w$ obiegu regionalnym, powstające w regionie łódzkim i stanowiące pewną całość pod względem tematycznym, strukturalnym i typologicznym. Charakterystyczne dla tekstów łódzkich jest to, że nie wszystkie przywołują lokalną tematykę, posługują się gwarą, swoistą dla Łodzi aurą, lokalnym kolorytem, określonym sposobem myślenia i odczuwania, które to cechy podkreślali badacze polscy, niemieccy i francuscy z końca XIX i początku XX w. ${ }^{73}$ Choć łódzką literaturę można w jakimś stopniu zaliczyć do twórczości regionalnej, piśmiennictwa pogranicza czy dzieł ojczyźnianych, to w wielu przypadkach upodabnia się ona do innych trendów, niekiedy wręcz je naśladując. Tak jest z pewnością w przypadku pisarstwa Carla Heinricha Schultza, nawiązującego do utworów powstających w okresie Neue Sachlichkeit, natomiast liryka międzywojenna odwołuje się raczej do niemieckiej tradycji poezji romantyzmu.

Nie można natomiast powiedzieć o literaturze niemieckojęzycznej do 1939 r., iż była literaturą „małych ojczyzn”. Formuła literatury „małych ojczyzn" wiąże się z rekonstrukcją czasu i archeologią miejsc nacechowanych biograficznie. $W$ takim znaczeniu swego rodzaju literaturą reminiscencji jest z pewnością twórczość niemieckojęzycznych łodzian powstająca po $1945 \mathrm{r}$. W tym miejscu należy jednak podkreślić dwie tendencje: po pierwsze, gros tekstów literackich podporządkowano potrzebom ideologicznym państwa niemieckiego, realizowanym w ramach licznych organizacji ziomkowskich. Literatura tego nurtu cechowała się szczególnym poczuciem utraty ojczyzny i niepogodzeniem się z tym faktem, co stymulowało postawy odwetowe. W tym sensie nurt ten nawiązywał do przedwojennej Grenzlandliteratur. Dru-

72 M. Dąbrowska-Partyka, Literatura pogranicza. Pogranicze literatury, Kraków 2009.

73 E. Kuźma, Literatura regionalna, [w:] Słownik literatury popularnej, red. T. Żabski, Wrocław 1997, s. 221-222. 
gi nurt praktykował apoteozę krajobrazu dzieciństwa jako utraconej ojczyzny bez podtekstów ideologicznych, charakterystycznych dla Grenzlanddichtung. Powstającą w Łodzi literaturę ponad wszystko cechowała odrębność i prowincjonalność, a także brak kontaktu z nurtami literackimi w Niemczech i w Polsce.

\subsection{Etapy rozwoju}

\subsubsection{Rozwój literatury do 1914 r.}

Wyjątkowy charakter wielonarodowego miasta i jego szybki rozwój w XIX i pierwszej połowie XX w. spowodował, że piśmiennictwo i literatura piękna rozwijały się w tu sposób szczególny. Dzieje łódzkiej literatury należy podzielić, podobnie jak łódzkiej prasy, na trzy okresy, z których każdy charakteryzuje się odmiennymi cechami. Okres początkowy obejmuje lata od przybycia pierwszych niemieckich osadników na teren Łodzi do wybuchu I wojny światowej, drugi to okres wojenny 1914-1918, trzeci zaś przypada na lata 1918-1939.

Początków łódzkiej literatury należy poszukiwać w dobie, kiedy na teren Łodzi przybyli pierwsi niemieckojęzyczni fabrykanci, a więc $\mathrm{w}$ pierwszej połowie XIX w. Teksty pochodzące z tego okresu są wyjątkowo nieliczne, a ponadto przeważnie bardzo krótkie. Jest to etap przygotowawczy - literatura dźwiga się z niemocy i szuka dla siebie właściwego miejsca. Charakteryzuje się on mnogością dość nieudanych prób stworzenia literatury. Twórczość literacka tego okresu posiłkuje się obcym dorobkiem, przedrukami tekstów z prasy pruskiej, tłumaczeniami i naśladownictwem. Najstarszym zapisem związanym z językiem niemieckim jest pieśń powstała w 1839 r. z okazji poświęcenia budowy „Domu Tkacza”, siedziby Cechu Majstrów Tkackich w Łodzi. Jej autorem jest luterański pastor Fryderyk Gottlob Metzner (1797-1852) ${ }^{74}$.

74 Por. F.G. Metzner, Gesang zur Weihe des neuerbauten Meisterhauses der löblichen Weberinnung zu Lodz am 3ten September 1839, Lodz 1839. Egzemplarz odnaleziony w Wojewódzkiej Bibliotece Publicznej im. Piłsudskiego w Łodzi. Tekst na stronie: Regionalia Ziemi Łódzkiej http://bc.wimbp.lodz.pl/ [dostęp: 10.09.2012]. W polskim przekładzie okazjonalna pieśń brzmi następująco: „W górę, w stronę Boga / Skierujmy głowy dziękczynnie / Okazał nam zmiłowanie, dał szczęście / Pozwolił nam skończyć / Co bractwo nasze zaczęło / Niech nasza moc taka pozostanie / Pozwól nam na to Panie! / Skierujmy ku niemu drugie spojrzenie / Ku jego królewskiemu tronowi / Ku niemu samemu / Co dla nas nosi koronę / Bo to jego ręka czyni /Że jesteśmy tu szczęśliwi / Niech będzie błogosławiony! / Pomyślcie bracia o zamierzchłych czasach / Pomyślcie o wiecznej tułaczce / To on w trudnych chwilach / Zawsze był przy nas / Oby nas nigdy nie opuścił / Oby zawsze u nas gościł! / Pomyślcie o czasach, kiedy tu ugór był 
Utwór ma charakter okazjonalny z akcentami religijnymi. Większość najstarszych niemieckojęzycznych tekstów jest właśnie takiej natury. Ich twórcami są gównie duchowni luterańscy, którzy posługiwali się językiem niemieckim jako ojczystym bądź też polskim. Wśród autorów z trudem można doszukać się wybitnych indywidualności. Teksty powstające w XIX w. są skierowane do prostego odbiorcy, często bez wyrobionego gustu literackiego.

Wśród pierwszych pisarzy-duchownych na uwagę zasługuje pastor Rudolf Gundlach, który w 1899 r. opublikował wraz innymi duchownymi: ks. Juliuszem Bursche (generalnym superintendentem i pastorem warszawskim), ks. Edmundem H. Schultzem (pastorem nowodworskim) oraz ks. Edmundem Holtzem (pastorem aleksandrowskim) Śpiewnik dla Kościoła EwangelickoAugsburskiego w Królestwie Polskim, zawierający 418 pieśni z nutami ${ }^{75}$. Tom ten stał się ważną częścią historii łódzkiego piśmiennictwa. Pomysł napisania śpiewnika zrodził się z ogromnej potrzeby sprostania ówczesnym wymaganiom, ponieważ dotychczasowe zbiory pieśni zawierały utwory nie zawsze zgodne z duchem i nauką kościoła ewangelicko-augsburskiego. Dlatego autorzy podkreślają we wstępie, iż starali się oddać jak najwierniej oryginalny tekst pieśni tłumaczonych z niemieckiego, czeskiego, francuskiego, szwedzkiego, fińskiego i łaciny. Oprócz pieśni śpiewnik zawierał naukę o nabożeństwie ewangelickim, porządek nabożeństw introity (czyli wiersze wstępne na niedziele i święta roku kościelnego), 418 pieśni z nutami jednogłosowymi (cantus firmus), modlitwy, krótką naukę o Komunii Świętej, modlitwy spowiednio-komunijne i lekcjonarz na niedziele i święta, a także porządek chrztu nagłego i porządek pogrzebu bez udziału księdza. Ze śpiewnika korzystano aż do II wojny światowej ${ }^{76}$. Wśród zgromadzonych tu utworów są pieśni niedzielne, adwentowe, wielkanocne, pieśni według porządku katechizmu Marcina Lutra, chrztu świętego i konfirmacji, pieśni poranne i wieczorne, o sądzie i życiu wiecznym. Gundlach jest autorem dwunastu z nich: Progi święte przestąiłem (19), Otwórzcie się szeroko (40), Jutrzenko nowych czasów (101), Wolę Swą odwiecznq świętą (125), Ojca czcić i matkę swoja (126), Święty, święty, święty Boże (127), O dobry Boże, życia drogi (137), Bóg z łaski ten grzesz-

\footnotetext{
/ Kiedy lasy tylko szumiały / Niemiecka pracowitość szerzy się / Wspaniałe miasta wznoszą się / Ojczyzna jest jeszcze wspanialsza / Lecz tu nowa powstaje nasza / Jedność mieszka pośród nas / Którą czcimy wspólnie / Zbierajmy, nie trwońmy / Wierzmy, w dumie nie szalejmy / Na nowym życia szlaku / Nie prowadźmy do rozłamu / Wieńce ozdabiające ten dom / Znikną jak i my / Bo krótkie są próby dni! / Lecz z odwagą patrzcie w dal / Budujcie silny świat / Kto tego nie uczyni / Wzmianki nie jest wart”. Tłumaczenie zamieszczono w reprincie z $1888 \mathrm{r}$. „Jubiläumsbeilage zur Lodzer Zeitung” 276/1863-1888.20.11/2/12.

75 Śpiewnik dla Kościoła Ewangelicko-Augsburskiego w Królestwie Polskim, Warszawa 1899. Zawiera on pieśni w języku polskim. Pastor Gundlach bardzo dobrze posługiwał się tym językiem w swojej twórczości.

${ }^{76}$ Ibidem.
} 
ny świat (213), Przymierze chrztu dziś (306), Boże miły Ojcze w niebie, Tyś... (328), Boże miły Ojcze w niebie, raczki... (338), Bielejq niwy i powisły kłosy (417) $^{77}$. Pieśni Rudolfa Gundlacha o charakterze odnowy moralnej, etycznej i religijnej stanowią znaczący wkład w literacki krajobraz regionu łódzkiego. Według zamysłu autorów miały być skierowane nie tylko do wykształconego luteranina, ale również do prostego człowieka ${ }^{78}$.

Obok Rudolfa Gundlacha na uwagę zasługuje też twórczość liryczna Augusta Hermanna Müllera, pastora z kościoła św. Jana. Był autorem pierwszych „łódzkich” utworów dramatycznych, które zawarł w tomiku wierszy Waldblumen z $1902 \mathrm{r}^{79}$ Müller jako pastor reprezentował konserwatywne poglądy. Często brał aktywny udział w różnych inicjatywach kościelnych, szczególnie w działalności charytatywnej. Wspomniany tomik jego wierszy dzieli się na siedem części: I. Natur und Himmelreich, II. Geistliche Lieder, III. Festlieder, IV. Vereinslieder, V. Vermischte Gedichte, VI. Erzählende Gedichte, VII. Dramatische Gedichte. W zbiorze znalazły się również trzy ballady: Der Harfner und der Fischmarkt, Mutterlieb' und Kindesdank, Des Vaters Schlaf - des Kindes $\operatorname{Tod}^{80}$. Oprócz wierszy i ballad pojawiają się utwory dramatyczne, do których należą Die Märtyrer der Makkabäerzeit i Jonas. Oba teksty zostały oparte na Biblii. Pierwszy z nich to odwołanie do Eleazara, męczennika ze Starego Testamentu, którego śmierć opisuje Druga Księga Machabejska (6,18-31 BT). Autor przenosi akcję dramatu do Jerozolimy, za czasów prześladowania Żydów pod rządami syryjskiego władcy Antiocha IV Epifanesa. Drugi dramat nawiązuje do jednej z ksiąg Starego Testamentu, do Księgi Jonasza ${ }^{81}$.

Osiem lat po ukazaniu się dramatów Müllera Wilhelm Jess napisał Das Verbrechen auf Jasna Góra oder Pater Damasy ${ }^{82}$. Jest to przykład twórczości bardzo mocno związanej z lokalną prasą, utwór powstał bowiem na kanwie głośnego skandalu kryminalno-obyczajowego, opisywanego w wielu polskich i niemieckich gazetach. Inspiracją były autentyczne wydarzenia w klasztorze na Jasnej Górze w dniu 23 października 1909 r. Doszło wówczas do profanacji obrazu i kradzieży klejnotów kościelnych, której dopuścił się miejscowy paulin Damazy Macoch. Do historii przeszedł nie tylko jako osoba,

77 Por. ibidem.

78 Ibidem.

79 A.H. Müller, Waldblumen, Lodz 1902. Tom zawiera teksty w języku niemieckim. Jak wynika z dotychczasowych badań, teksty nigdy nie opublikowano po wojnie ani nie wspominano w żadnym opracowaniu. Pojedynczy egzemplarz tomu znajduje się w Martin-Opitz-Bibliothek w Herne, sygn. Bk21, nr 5420.

${ }^{80}$ Por. ibidem.

81 Ibidem.

82 W. Jess, Das Verbrechen auf Jasna Góra oder Pater Damasy, Lodz 1910. Książka ukazała się nakładem własnym autora. Udało się odnaleźć jedyny jej egzemplarz znajdujący się w Bibliotece UŁ, sygn. 386324. Najprawdopodobniej jej druk nigdy nie był wznawiany. 
która zbezcześciła miejsce uważane za świętość narodu polskiego, ale przede wszystkim jako człowiek reprezentujący wątpliwą postawę moralną. Ksiądz Damazy wiódł hulaszcze życie poza murami klasztoru, a za kradzione pieniądze utrzymywał kochankę Helenę Krzyżanowską. Udzielił jej ślubu z własnym stryjecznym bratem, którego później zabił. Po dokonaniu zbrodni zbiegł do Krakowa, gdzie został schwytany i skazany na dwanaście lat więzienia. Uwięziono również wspólników Macocha, w tym kochankę Helenę Krzyżanowską ${ }^{83}$. Proces Macocha rozpoczął się w 1912 r. i miał kontekst polityczny. Sytuację wykorzystały rosyjskie gazety do ataku na polskie duchowieństwo jako środowisko zepsute moralnie. Celem ataku było osłabienie roli kościoła katolickiego w krzewieniu polskości ${ }^{84}$.

Historia Macocha stała się ogólnonarodową sensacją, o której rozpisywały się ówczesne gazety ${ }^{85}$, podnosząc kwestię moralności katolickiego duchowieństwa i poddając $w$ wątpliwość słuszność celibatu. W swoim utworze Wilhelm Jess nawiązuje do sensacyjno-kryminalnej historii z pierwszych stron gazet, nie trzyma się jednak faktów, skupiając się jedynie na wątku miłosnym między Macochem i Heleną, co przesądza o zakwalifikowaniu utworu do rzędu kiepskich melodramatów. Autor pomija kontekst historyczny i polityczny przedstawianych wydarzeń, mocno podkreślany w tamtym czasie, nie wprowadza również do fabuły wspólników zakonnika, z wyjątkiem sługi klasztornego Zeloga. To on, a nie sam Macoch kradnie kosztowności z klasztoru i dokonuje zbrodni na stryjecznym bracie zakonnika - Wacławie, gdy ten odkrywa, że Macoch był inicjatorem kradzieży. Macoch to człowiek niezdolny do głębszej refleksji nad życiem, który swoją obłudę usprawiedliwia ogólnym zepsuciem społeczeństwa. Krytykuje także duchowieństwo katolickie, kwestionując tradycję spowiedzi. Nawet gdy siedzi w więzieniu (ta scena zamyka utwór), nie rozumie, dlaczego ma ponieść karę za swoje czyny. Główna bo-

${ }^{83}$ Historia Damazego Macocha stała się sensacją dla polskiego społeczeństwa. Gazety śledziły wydarzenia związane z wykryciem sprawców. Historią Macocha zajął się także Tadeusz Boy-Żeleński, tworząc dla kabaretu „Zielony Balonik” tekst Opowieść dziadkowa o cudach jasnogórskich. Szerzej na temat historii Macocha m.in. E. Jabłońska-Deptuła, Trwanie i budowa. Honorat Koźmiński kapucyn 1829-1916, Warszawa 1986, s. 281-282. W szerszym kontekście sprawę przedstawia J. Zbudniewek, Jasna Góra na przełomie XIX i XX w., „Kościół w Polsce. Dzieje i Kultura" 3/2003, s. 111-127. Literaturę na ten temat zestawia Bibliografia Zakonu Paulinów za lata 1500-1990, t. 1, cz. 1-2, oprac. H. Czerwień, J. Zbudniewek, Warszawa 2008, poz. 7618-7778.

${ }^{84}$ Reakcją na historię Macocha była m.in. wydana w 1912 r. publikacja ks. Ignacego Kłopotowskiego, redaktora „Polaka-Katolika”, pt. Zbrodnia Macochowa a wiara nasza.

85 Stanisław Łąpiński poświęcił wiele uwagi historii Macocha na łamach łódzkiego „Rozwoju”. W numerze 47 z 27 lutego 1912 r. gazeta wydała specjalny, ośmiostronicowy dodatek, poświęcony analizie przypadku Macocha. Przedstawiono przebieg śledztwa, rezygnując ze zbędnych szczegółów i opublikowano listę świadków. 
haterka skandalu, Helena, to femme fatale, dla której Macoch organizuje kradzież kosztowności. Utwór pozbawiony jest głębszego sensu, ponieważ nie ukazuje problemu w kontekście historycznym i politycznym. Także jego archaiczna forma i pretensjonalna łatwość rymowania świadczą o wątpliwym kunszcie literackim twórcy.

Oprócz tekstów o charakterze religijnym i utworów dramatycznych w początkowym okresie powstaje piśmiennictwo, które ma charakter naukowy z elementami publicystyki i literatury. Jako przykład może posłużyć monografia Łodzi autorstwa Oskara Flatta pt. Opis miasta Łodzi pod względem historycznym, statystycznym i przemysłowym ${ }^{86}$. Książkę publikowano najpierw w odcinkach w roku 1850 w "Gazecie Rolniczej, Przemysłowej i Handlowej”, dodatku do „Gazety Codziennej”. Opis Flatta, wzbogacony ośmioma rycinami oraz planem miasta, dzielił się na trzy główne części: historyczną, statystyczną i przemysłową. Publikacja ma charakter reportażu - autor opisuje Łódź z perspektywy osoby odwiedzającej miasto. Przedstawia rzeczywiste zdarzenie i towarzyszące im okoliczności, opowiada o sytuacjach, których był świadkiem bądź też o których słyszał lub czytał. Z jednej strony metodę tę cechuje obiektywizm, rzetelność i wierność wobec przedmiotu narracji. Świadczą o tym wszelkie dołączone materiały, a więc mapy czy dane statystyczne, które autor zebrał w miejscowych archiwach. Z drugiej strony jego relacja jest nadzwyczaj subiektywna - zawiera ocenę i opinie autora (niekiedy jedynie sugestie), o czym świadczy nagromadzenie środków leksykalnych o wyraźnych cechach wartościujących, które mają podkreślić wyjątkowość miejsca: porządny, stare, ruchliwe, mały, brudny, nędzna. Bohaterem reportażu jest Łódź i jej błyskawiczny rozwój. Już we wstępie widać, że autor nie jest obojętny wobec języka, którego używa do opisu miasta:

Przed laty trzydziestu, w obrębie ziemi Łęczyckiej, wśród dziewiczych do koła lasów, drzemała snem zapomnienia nędzna mieścina. Niczem się znakomitszem wśród okolicznych nie odznaczała siedzib: mały, brudny rynek i z niego rozpryśniętych kilka ulic, biednie i rzadko zabudowanych, były przytułkiem kilkuset mieszkańców, z rolnictwa byt utrzymujących; handel żaden, bo miasteczko żyło w samem sobie. Wtedy nie każdemu i znaną może nawet była ta osada, jedynie tylko dawnością swego istnienia szczycić się mogąca. [...] W tem ubiegłem trzydziestoleciu Łódź przeżyła wszystkie epoki: było naprzód zapomnienie, ubóstwo, padła potem iskra życia, bujnie wschodzący krzew przemysłu coraz więcej rozrastać się zaczął, wzmagała się pomyślność i po kilku wątpliwych krokach stanęła u szczytu; niebawem nadeszła chwila przesilenia, słabnąć zaczęła działalność fabryk, ale nim się do upadku nachyliły, znowu dźwignięte, ruszyły torem postępu i postawiły Łódź na dzisiejszej stopie zamożności i ustalonego bytu ${ }^{87}$.

${ }^{86}$ O. Flatt, Opis miasta Łodzi pod względem historycznym, statystycznym i przemysłowym, Warszawa 1853.

${ }^{87}$ Ibidem, s. 9. 
W przytoczonym fragmencie autor posługuje się metaforą, przypisując miastu ludzkie cechy, co powoduje, że jego obraz Łodzi nie jest zwykłym opisem historycznym, lecz odznacza się dużą plastycznością. Warto zwrócić uwagę, jak za pomocą słów miasto generuje odmienne wartości i oceny zarówno dodatnie, jak i ujemne. Usytuowane jest więc między tymi dwiema skrajnymi kategoriami, przy czym dawna Łódź kojarzy się głównie z nędzq̨, współczesna natomiast jest synonimem postępu, rozwoju techniki, zamożności oraz - co zaskakuje w dalszym opisie Flatta - czystości:

Tu wszystko tchnie czystością - pisze Flatt - porządkiem, wszędzie widać zabiegłą czynność, wszędzie wpływ klasy pracującej; samo ubóstwo przyjęło tu szlachetniejszą i przyzwoitszą postać, bo dobroczynność postarała się, aby ubogi, jeżeli już nim być musi, współczucie tylko, nie zaś odrazę obudzał. ${ }^{88}$

Język Flatta cechuje plastyczność, jeśli weźmie się pod uwagę fakt, że Opis jest przede wszystkim książką mającą zwrócić uwagę na historię miasta i rozwój przemysłu, ilustrowaną danymi statystycznymi. Autor posługuje się dużą liczbą epitetów: piękny, spacerowy ogród angielski; zieleniejq̨ce wq̨wozy; całotygodniowa, mozolna, utrudzająca praca; regularne, ruchliwe panora$m a$ etc. Przeprowadzając analizę miejsca, dokonuje swoistej reinterpretacji. Istotnym zabiegiem jest tu łączenie dwu perspektyw: przeszłości i obecnego wyglądu miasta. Ogląd dokonuje się nie tylko za sprawą oka jako narządu wzroku, ale i „oka pamięci”, choć opisujący nie jest rdzennym łodzianinem, a jedynie turystą i obserwatorem. Aktywizacja pamięci jest jeszcze jednym sposobem budowania tożsamości miejsca. Opisując fragmenty miasta, autor często przywołuje historię i opowieści, związane z konkretnym miejscem lub jego dawnym wyglądem. Z pewnością są to historie zasłyszane od tutejszej ludności lub odnalezione w materiałach archiwalnych, stanowiących dla autora ważne źródło informacji do badań nad Łodzią. Dzięki użyciu wspomnianego „oka pamięci” autor podejmuje próbę identyfikacji z miejscem, chcąc podkreślić jego walory.

Gdy Flatt opisuje Łódź, „kreuje” miasto, zaczynając od centrum, którym był Stary Rynek, po czym stopniowo roztacza przed czytelnikiem wizję jego sukcesywnego, regularnego rozrastania się. Tę metodę dobrze ilustruje następujący fragment:

Wjechawszy od strony Zgierza potoczystym traktem, przypomnisz sobie stare miasto, ale szybko je minąwszy, tam, gdzie niegdyś nieprzebyte były topiele, wjeżdżasz w szereg nowych, porządnych zabudowań, a wszędzie ruch, a wszędzie życie. Jedziesz wiorstę, drugą i piątą mijasz, a ciągle jesteś w mieście, ciągle jesteś w Łodzi ${ }^{89}$.
${ }^{88}$ Ibidem, s. 114.
${ }^{89}$ Ibidem, s. 10. 
Flatt nadaje miastu szeroką perspektywę, pozwalając czytelnikowi zyskać wrażenie nie tylko jego wielkości, ale i panującego w nim ruchu. Posługuje się czasownikami jedziesz, mijasz, wjeżdżasz oraz epitetami poszerzającymi perspektywę: potoczysty trakt czy nieprzebyte topiele. Również zastosowane w jednym z fragmentów wyliczenie: Jedzisz wiorstę, drugq i piq̨tq, ma na celu pokazanie, jak wielkim miastem jest Łódź. Malowany przez Flatta pejzaż jest w znacznym stopniu zróżnicowany i ma nie tylko charakter miejski, zdominowany przez fabryczne kominy. Jego dodatkowym walorem jest wiejski krajobraz obrzeży: „Mieszkańcy tamecznych okolic doświadczają połączonych przyjemności miejskiego i wiejskiego życia: tuż za domami roztaczają się ogrody, a dalej złotym kłosem bogate łany"90. Flatt opisuje nie tylko samą Łódź, ale zagląda również w okolice miasta i udaje się przykładowo w stronę Łagiewnik i znajdujących się tam kościoła oraz klasztoru.

Przestrzeń miasta jest przykładem jego dynamiczności, którą ilustrują pokonywane po drodze wiorsty. Miasto nieustannie zmienia twarz, którą odsłania przed obserwatorem. Rozwój urbanistyczny wcale nie spowodował chaosu, a wprost przeciwnie - Łódź jawi się jako miasto o regularnym przebiegu ulic układających się w oś stanowiącą łatwy punkt odniesienia:

Długie, regularne, ruchliwe panorama przestawiają oku szeregi większą częścią nizkich (!), murowanych, jednostajnych domków, rozpoczynających się w rynku Nowego miasta - środkowym punkcie ruchu - i biegnących długiem pasmem aż do fabrycznej dzielnicy, gdzie wyniosłe gmachy stanowią wielkie, ostateczne ogniwo tego łańcucha. Z drugiej strony bieży ku północy ulica Piotrkowska, wiążąca Nowe ze Starem miastem. Tu stanąwszy, widzimy się znowu wobec naszych żydowskich miast prowincjonalnych: bo Stare miastem jest tu zarazem dzielnicą żydowską, i jak już wyżej powiedzieliśmy, ogniskiem handlu. W prostym ciągle kierunku wybiega dalej ulica Zgierska, traktem bitym ku Zgierzowi, na Ozorków i Łęczycę. Na przecznicach, bliższych środkowego punktu miasta, większy jeszcze niekiedy ruch dostrzedz (!) można, ale za to wcielone do miasta obszerne dzielnice, zalegające po obu stronach fabrycznej osady, przedstawiają jeszcze sielski widok ${ }^{91}$.

Ukazana w opisie perspektywa panoramiczna wyklucza szczegółowy ogląd i uniemożliwia wyróżnienie z tła poszczególnych obiektów; najmniejszą jednostką odniesienia jest tu dom, który wraz z innymi budynkami tworzy ulice, a te z kolei całe dzielnice miasta.

Autor często odczytuje miasto za pomocą porównania i poprzez analogię do innych znanych mu miast europejskich. Głównym punktem odniesienia jest jego miasto rodzinne, Warszawa, oraz inne prywatne osady fabryczne w Królestwie Polskim. Zauważa jednak pewnego rodzaju niepowtarzalność Łodzi, gdy pisze: „Sam typ jego [miasta - przyp. M.K.] jakże on odmienny od innych miast naszych!"92.
90 Ibidem, s. 114.
${ }^{91}$ Ibidem.
92 Ibidem, s. 116. 
Obszerne fragmenty Opisu przedstawione są w czasie teraźniejszym, nadającym relacji odpowiednie tempo i wywołującym w czytelniku wrażenie równoczesności obserwacji opisywanego miejsca. W wielu fragmentach oglądowi miejskiej przestrzeni sprzyja przede wszystkim perspektywa spaceru. Flatt jawi się tu raczej jako typowy spacerowicz - obcy - flâneur - turysta niezwiązany z miejscem ${ }^{93}$. Wprawdzie dokonuje jego oglądu w ruchu, czyni to jednak dość pospiesznie, a więc także stosunkowo powierzchownie. Choć jest obserwatorem, dąży do jak największego obiektywizmu i stara się nie pominąć istotnych szczegółów, wspomaganych mapami miasta i dołączonymi do opisu danymi statystycznymi. Opis Łodzi jest jednym z niewielu tekstów dokumentujących wczesną twórczość literacką miasta. Jest to również jeden z niewielu przykładów ukazujących Łódź w sposób entuzjastyczny, ponieważ kolejni pisarze i poeci nie są już dla miasta tak łaskawi jak właśnie Oskar Flatt.

Poza wspomnianą wyżej twórczością powstają w Łodzi obrazki, szkice publicystyczne, krótkie opowiadania i bajki, pojawiają się także felietony i dowcipy. Problemy i motywy najczęściej podejmowane w tych utworach są błahe - nie są to wielkie zagadnienia historyczne, nie ma w nich echa walk powstańczych z 1830/1831 i 1863/1864 czy rewolucyjnych z 1905/1907 r., omijają również tematykę walk klasowych i konfliktów społeczno-narodowościowych. Powstaje prosta literatura posługującą się niewyszukanym językiem, przeznaczona dla odbiorcy, który nie ma dużych wymagań intelektualnych. Taką literaturę tworzą głównie osoby przypadkowo związane z literaturą, a więc np. pastorzy, dziennikarze, nauczyciele, uczniowie szkół gimnazjalnych, lekarze, adwokaci czy krajoznawcy. Na ogół twórczość pisarską traktowano jako zajęcie uboczne i dodatkowe źródło dochodu, choć było mało popłatne. Literaci nie są związani z salonami literackimi ani nie reprezentują określonej szkoły, brak wśród nich także znaczących indywidualności literackich. Można zaryzykować stwierdzenie, że niemieckojęzyczna literatura Łodzi ma charakter rudymentarny i nie osiąga poziomu, na który w tym czasie zdołała wspiąć się literatura polskojęzyczna z Łodzi, choć i tu

${ }^{93}$ Flâneur - niespieszny przechodzień, włóczęga, spacerowicz, kluczowa postać XIX-wiecznych paryskich pasaży, traktująca przestrzeń miejską jak wnętrze swojej kamienicy. Postać flâneura obecna była przede wszystkim na początku XX w. w eseistyce Waltera Benjamina (1892-1940), filozofa, pisarza, teoretyka literatury i sztuki, krytyka, tłumacza, autora prac o istotnych zjawiskach kulturowych i cywilizacyjnych XIX i XX w. Por. K. Loska, Flâneur jako metafora współczesnej kultury, [w:] Intermedialność w kulturze końca XX w., red. A. Gwóźdź, S. Krzemień-Ojak, Białystok 1998, s. 41; R. Zielnicki, Od pasaży do parków rozrywki. Szkic o przeobrażeniach flâneuryzmu, „Kultura Współczesna” 3(21)/1999, s. 99; A. Zeidler-Janiszewska, Dryfujący flâneur, czyli o sytuacjonistycznej transformacji doświadczenia miejskiej przestrzeni, [w:] Przestrzeń, filozofia i architektura. Osiem rozmów o poznawaniu, produkowaniu i konsumowaniu przestrzeni, red. E. Rewers, Poznań 1999, s. 125; Z. Bauman, Dwa szkice o moralności ponowoczesnej, Warszawa 1994. 
należy uznać, że to także nie była na ogół literatura najwyższych lotów, oczywiście poza dziełami Tuwima czy Reymonta. Polską literaturę tworzą w Łodzi Wincenty Kosiakiewicz, Zygmunt Bartkiewicz, Ivan Timkovskij-Kostin ${ }^{94}$, Stanisław Łąpiński, Kazimierz Laskowski ${ }^{95}$ i Władysław Rowiński. Są to autorzy prezentujący niewysoki poziom literacki, często wykonujący zawód dziennikarza i wydawcy lokalnych gazet, jak miało to miejsce w przypadku Łąpińskiego, związanego z łódzkim „Rozwojem” czy Rowińskiego, redaktora m.in. „Dziennika Łódzkiego”. Łodzi poświęcają swoje teksty również działacze polityczni, jak choćby Andrzej Strug czy Józef Piłsudski. Wśród polskojęzycznych tekstów pojawiają się do 1914 r. powieści, jak chociażby wcześniej wspominana Bawełna Kosiakiewicza ${ }^{96}$, Wir Mariana Gawalewicza ${ }^{97}$, Wśród kąkolu Walerii Marrené-Morzkowskiej ${ }^{98}$ czy w końcu Ziemia obiecana Reymonta.

W przeciwieństwie do autorów polskich przedstawiciele niemieckojęzycznej literatury z Łodzi nie zdobyli się w pierwszym okresie na twórczość powieściową. W gazetach zamieszczano jedynie krótkie opowiadania, szkice i obrazki. Niewiele osób, parających się piórem, miało szansę opublikowania swej twórczości w formie książkowej, jak miało to miejsce w przypadku Berty Teplitzkiej, autorki zbioru Lodzer Typen, ogłoszonej drukiem w 1913 r. ${ }^{99}$ Ci sami autorzy są jednak także twórcami felietonów jako tej formy literackiej, która pod koniec pierwszej fazy rozwoju łódzkiej literatury przeżywała okres szczególnie intensywnej prosperity.

\subsubsection{Okres I wojny światowej}

I wojna światowa zakończyła definitywnie XIX w. w Europie, sankcjonując rozpad dawnego systemu społeczno-politycznego. Była ściśle związana z tempem przemian cywilizacyjnych, rodzeniem się nowej świadomości społecznej, jak również kryzysem etyki, które znalazły swe odbicie w myśleniu estetycznym ${ }^{100}$. Wpisała się ponadto $\mathrm{w}$ przestrzeń globalnej modernizacji praktycznie we wszystkich sferach życia oraz na płaszczyźnie mentalnej ${ }^{101}$.

${ }_{94}$ Zob. aneks: Łódzkie sylwetki.

95 Ibidem.

${ }^{96}$ W. Kosiakiewicz, Bawełna, Petersburg 1895.

97 M. Gawalewicz, Wir. Powieść z niedawnych czasów, Warszawa 1908.

98 W. Marrené-Morzkowska, Wśród kq̨kolu, 1890 [w:] Łódź, która przeminęła w publicystyce i prozie (antologia), wybór i red. P. Boczkowski, Łódź 2008, s. 171-266.

99 B. Teplitzka, Lodzer Typen, Lodz 1913.

100 Por. M. J. Olszewska, Człowiek w świecie Wielkiej Wojny, Warszawa 2004.

101 Szerzej na temat niezwykłości i wyjątkowości zjawiska, jakim była wojna totalna, por. D. Kielak, Problematyka przełomu w publicystyce i krytyce literackiej, [w:] D. Kielak, Wielka Wojna i świadomość przełomu. Literatura polska lat 1914-1918, Warszawa 2001. 
Jako wojna totalna ogarnęła całe społeczeństwa, zaangażowała bowiem nie tylko armie narodowe, ale również ludność cywilną.

Do łódzkiej literatury I wojna światowa wprowadziła wiele nowych elementów, które spowodowały, że okres ten należy rozpatrywać jako odrębną fazę rozwoju. W pewnym sensie wymusiła na łódzkich pisarzach rewizję dotychczasowych poglądów na świat i człowieka. Nabrała również wymiarów dramatu poznawczego, który zaowocował w niewielu przypadkach próbą stworzenia nowych modeli rzeczywistości, bowiem na ogół łódzcy pisarze podejmowali dyskurs wojenny, pozostając $w$ przekonaniu o aktualności schematów i strategii tradycyjnych, np. romantycznych. Stąd można o niej pisać jako o literaturze drugorzędnej, popularnej lub masowej, propagującej uproszczoną wizję świata, najczęściej wpisaną w schematy melodramatyczne, gdzie wydarzenia wojenne stanowią tło dla burzliwych, miłosnych przygód bohaterów (np. Vermächtnis S. Judeich-Werswa ${ }^{102}$, In den schwarzen Bergen Helmutha Sendera ${ }^{103}$ czy Der Zettel Paula Blitza ${ }^{104}$ ). Autorzy nie podjęli aktualnych tendencji modernistycznych istotnych dla literatury niemieckojęzycznej. W Łodzi nie rozwinęła się własna twórczość ekspresjonistyczna, nie było powieści antywojennej typu Remarque’a ani w czasie wojny, ani po jej zakończeniu. Mimo jednak braku innowacyjnego kształtu tej literatury i związanej z tym rewizji poglądów estetycznych, łódzka literatura na swój sposób zmierzyła się z problemem wojny.

I wojna światowa w znaczący sposób zachwiała rynkiem wydawniczym, tzn. stworzyła trudności w produkcji, dystrybucji i sprzedaży prasy i literatury. Represji uległy miejscowe tytuły. Zamknięto polski „Rozwój” oraz niemiecką „Lodzer Zeitung”. Z drugiej strony otworzył się olbrzymi obszar nowej, atrakcyjnej tematyki oraz pojawiły się nowe możliwości wydawnicze, płynące ze strony instytucji propagandowych. Zamiast zlikwidowanych gazet ukazywały się kolejne, za pomocą których władze niemieckie mogły łatwo oddziaływać na opinię publiczną, były to proniemiecka "Godzina Polska” oraz dwa pisma niemieckojęzyczne: „Deutsche Lodzer Zeitung” i „Deutsche Post”. Za ich pomocą władze okupacyjne uruchomiły ogromną machinę propagandową, ocenzurowano relacje z pola walki poprzez unikanie opisów własnych strat, a wyolbrzymianie okrucieństw popełnionych przez wroga. Tak więc to, co docierało do przeciętnego odbiorcy, było czę-

102 Opowiadanie ukazało się w „Illusrtrierte Sonntagsbeilage zur Neuen Lodzer Zeitung”, 26.08.1917, s. 1-2.

${ }_{103}$ H. Sender, In den schwaryen Bergen, „Illusrtrierte Sonntagsbeilage zur Neuen Lodzer Zeitung", 20.02.1916, s. 1-3.

104 P. Blitz, Der Zettel, „Illusrtrierte Sonntagsbeilage zur Neuen Lodzer Zeitung”, 9.04.1916, s. 62-63. 
sto zafałszowaną rzeczywistością, świadomie konstruowaną relacją z działań wojennych ${ }^{105}$.

Rozwinęły się również, co odróżnia tę literaturę od literatury okresu poprzedniego, nowe formy literackie. Wzrosło znaczenie literatury faktu: reportaży, kronik, relacji z pola bitew czy innych zapisów dokumentu osobistego, jak dzienników, wspomnień, listów, pamiętników. Zdominowały one łódzką literaturę z lat 1914-1918. Ich dokumentarna wartość dawała odbiorcy poczucie prawdy, mimo wcześniej wspomnianych praktyk zafałszowywania wojennych historii przez propagandę ${ }^{106}$.

Prawo do narracji wojennych próbowali sobie zastrzec ci, którzy bezpośrednio w niej brali udział. Dziennikarze wojenni, żołnierze, ich matki, to oni właśnie stawali się nie tylko aktywnie uobecniającymi się autorami tekstu, ale również ich bohaterami manifestującymi swój punkt widzenia.

Oprócz literatury faktu, w tym literatury autobiograficznej, na uwagę zasługuje bogato reprezentowana twórczość liryczna, którą chętnie drukowały miejscowe niemieckie gazety. Biorąc pod uwagę ideologiczny wydźwięk tych tekstów, a więc stosunek do prowadzonych działań wojennych i opowiedzenie się „za” lub „przeciw” wojnie, zauważalne są dwie zupełnie przeciwstawne tendencje. $\mathrm{Z}$ jednej strony powstają w Łodzi teksty o charakterze antywojennym i pacyfistycznym. Ich autorzy to pisarze skupieni wokół gazety „Neue Lodzer Zeitung”, jak Wilhelm Jess, Robert Bräutigam, Theodore Abel czy Heinrich Zimmermann i Carl Heinrich Schultz, propagujący nurt poezji antywojennej. $Z$ drugiej strony na łamach takich pism, jak „Deutsche Lodzer Zeitung” oraz „Deutsche Post”, drukowane były utwory Friedricha Flierla ${ }^{107}$ czy Franza Lüdtkego ${ }^{108}$, które należy jednoznacznie utożsamiać z apologią wojny i zabijania. Twórczość wojenną uzupełniały ponadto kazania pastora Paula Althausa, w latach wojny kapelana wojskowego w Łodzi, który pozostawił po sobie ogromną spuściznę.

Okres I wojny światowej to czas, w którym pisarze zarówno polscy, jak i niemieccy nie podejmują się pisania obszerniejszych utworów powieściowych czy dramatycznych. Te rozkwitną dopiero po odzyskaniu przez Polskę niepodległości.

105 Por. artykuły opublikowane na łamach „Deutsche Post” z okresu wojny, np. list pt. „Sonst sind wir alle verloren“, „Deutsche Post”, 5.07.1915, s. 3, jak również stała rubryka z doniesieniami z pola walki pt. Kurze politische Wochenschau.

${ }_{106}$ Mimo iż to właśnie media i nowe środki przekazu, jak film, fotografia, sprawozdania prasowe, często sterowane ideologicznie, ukształtowały dyskurs o I wojnie światowej, to jednak nie doszło do „całkowitej utraty w wiarygodność narracji wojennych” - jak pisała Olszewska - początek wieku XX to epoka powieści, które będąc dziełem literackim, są odbierane jako „słowna reprezentacja niezależnie istniejącej, zewnętrznej rzeczywistości pokazanej w sposób obiektywny i wierny, a przez to prawdziwy". Por. M.J. Olszewska, Człowiek w świecie Wielkiej Wojny, Warszawa 2004, s. 22.

107 Zob. aneks: Łódzkie sylwetki.

108 Ibidem. 


\subsubsection{Okres Drugiej Rzeczypospolitej}

Rozwój łódzkiej literatury po okresie stagnacji wywołanej doświadczeniami wojennymi nabiera rozpędu w latach powojennych. Literatura rozwija się wówczas w kilku kierunkach. Na plan pierwszy wysuwa się twórczość zaangażowana politycznie. Wielość obozów i partii na polskiej scenie politycznej powoduje, że również niemieckojęzyczni łodzianie jako grupa narodowościowa nie reprezentują jednolitych poglądów. Oprócz niemieckich socjaldemokratów, liberałów i komunistów działają w Łodzi zwolennicy ideologii narodowoniemieckiej, a później narodowosocjalistycznej, promujący w łódzkiej literaturze wcześniej wspomniany nurt Heimatdichtung. Jego rozwój w Łodzi odpowiadał na pewnego rodzaju zapotrzebowanie polityczne. Sytuacja społeczności niemieckiej w Polsce i Łodzi w tym okresie była dość specyficzna. Po I wojnie Polacy odzyskali państwowość i poczuli się wreszcie u siebie, natomiast Niemcy i Żydzi przestali być rosyjskimi poddanymi. W tym czasie - jak pisali Ingo Eser oraz Jerzy Kochanowski - rozpoczął się proces zacierania konturów narodowościowych, uniemożliwiający samookreślenie wielu osobom pochodzenia niemieckiego, zaś po 1933 r. wyraźnie nasiliły się postawy nacjonalistyczne, a co za tym idzie, tendencje do jednoznacznej identyfikacji $\mathrm{z}$ narodowością niemiecką ${ }^{109}$. Na taki stan rzeczy wpłynęło wiele czynników zarówno politycznych, kulturowych, jak i obyczajowych. Na terenie Łodzi państwo polskie nie musiało przestrzegać 9. artykułu traktatu o ochronie mniejszości narodowych. Obowiązywał on jedynie na obszarach, które przed 1 sierpnia 1914 należały do państwa niemieckiego, dlatego władze polskie nie były zobowiązane do utrzymywania niemieckiego szkolnictwa. Wskutek tego liczba niemieckich szkół na terenie Łodzi znacznie zmalała, a ludność niemiecka uczęszczała do placówek z wykładowym językiem polskim ${ }^{110}$. W konsekwencji język i kultura polska zaczęły nabierać konkretnego znaczenia dla osób pochodzenia niemieckiego. Ludność niemiecka musiała znać język polski, by móc porozumieć się choćby w instytucjach państwowych. Dodatkowo każdy mężczyzna posiadający polskie obywatelstwo, a takimi byli przecież Niemcy mieszkający w II Rzeczypospolitej, musiał odbyć służbę w polskim wojsku. Wszystkie te czynniki spowodowały polonizację sto-

109 Por. Polska Centralna. Województwo Śląskie, t. 2, oprac. I. Eser, J. Kochanowski, [w:] Niemcy w Polsce 1945-1950. Wybór dokumentów, red. W. Borodziej, H. Lemberg, Warszawa 2000, s. 7-19; na temat asymilacji Niemców oraz problemów samookreślenia także: K.P. Woźniak, Wystawieni na ciężkq próbę. Antagonizmy i zbliżenia, „Kronika Miasta Łodzi” 3/2005, s. 11-19.

110 Kwestia zamykania niemieckich szkół przez władze polskie spowodowała silny konflikt między ludnością polską i niemiecką. Por. O. Heike, Das deutsche Schulwesen in Mittelpolen, Dortmund 1963. 
sunkowo dużej liczby łódzkich Niemców ${ }^{111}$. Wielu z nich nie akceptowało tej tendencji w obawie przed całkowitym rozpadem „niemieckiej wyspy”. Dlatego w okresie międzywojennym powstawały stowarzyszenia i związki o charakterze nacjonalistycznym, stawiające sobie za cel zjednoczenie wszystkich Niemców w Polsce, a także zachowanie niemieckiej kultury i języka ${ }^{112}$. Obok instytucji ważnym narzędziem w utrzymaniu „niemieckości” na terenie Łodzi i regionu stała się literatura w postaci wyżej wspomnianej Heimatdichtung. Służyła ona głównie konsolidacji narodu niemieckiego, pielęgnowaniu kultury i języka niemieckiego, a tym samych łączności z Rzeszą. Nurt ten obecny jest w wielu utworach takich pisarzy, jak Julian Will, Sigismund Banek czy Edith Malzahn. Niska świadomość niemieckiej tożsamości, która miała wpływ na powstanie w Łodzi Heimatdichtung, spowodowała również inne zjawiska, które były obecne w łódzkiej literaturze. Ważną kwestią, którą zaczęli interesować się pisarze pod koniec omawianego okresu, był problem tożsamości narodowej i etnicznej oraz fenomen ojczyzny. Tendencję tę widać w twórczości Bruno Raymonda, szczególnie w jego ostatniej powieści $W$ poszukiwaniu ojczyzny. Podobnych świadectw jest niestety niewiele, a wpływ na taki stan rzeczy miał wybuch II wojny światowej, który bezpowrotnie zakończył rozwój tej literatury. Również niska samoświadomość niemieckiego społeczeństwa skłoniła niektórych łódzkich pisarzy do zainteresowania się „regionem” łódzkim, jego niemiecką kulturą i niemieckim językiem (Schultz). Nie jest to jednak regionalizm literacki w pełnym tego słowa znaczeniu, w którym świat przedstawiony zaludniałyby liczne postaci, silnie zindywidualizowane etnicznie, środowiskowo i mentalnie, przynależące do danej społeczności, które wyraźnie eksponowałyby język o łatwo rozpoznawalnych cechach, świadczących o swoistej odrębności regionalnej. Łódzcy pisarze jedynie dotykają tych zagadnień, a regionalizm jako taki pojawia się głównie w twórczości felietonistycznej, w której autorzy ciekawie opisują łódzką kulturę, mentalność, miejscowe zwyczaje i obyczaje, natomiast nieliczne utwory liryczne, krótkie opowiadania, dowcipy i dramaty dają również częściowo wgląd w język stylizowany na łódzką niemczyznę. Jest to jednak zjawisko incydentalne i można je traktować raczej jako swego rodzaju egzotykę niż celową strategię narracyjną łódzkich autorów. Twórczość pisarzy niemieckojęzycznych, poruszających w swych tekstach zagadnienia kultury, mentalności i obyczajowości

111 Por. A. Breyer, Deutsche Gaue in Mittelpolen, Katowice 1935; Niemcy w Polsce..., t. 2, s. 7-19.

112 Tendencje asymilacyjne zwalczał utworzony w 1924 r. nacjonalistyczny Deutscher Volksverband in Polen, działający na terenie województw łódzkiego, warszawskiego, lwowskiego i wołyńskiego, a także powołana do życia w 1931 r. Jungdeutsche Partei. Dodatkowo niemieckich nacjonalistów wspierała lokalna prasa, np. „Freie Presse” czy „Der Deutsche Weg” i skupieni wokół niej działacze polityczni, tacy jak Adolf Kargel lub Artur Utta. Por. M. Cygański, Mniejszość niemiecka w Polsce w latach 1918-1939, Łódź 1962. 
Łodzi w okresie międzywojennym, należy postrzegać jako pewnego rodzaju sentymentalizm, poczucie przemijania i utraty niemieckiego charakteru miasta, typowego dla Łodzi XIX-wiecznej.

Oprócz utworów literackich zaangażowanych politycznie, a także tekstów przedstawiających kulturę niemiecką ukazuje się na łamach prasy codziennej i tygodniowej liryka, dla której impulsów dostarczały stosunkowo błahe tematy i wydarzenia dnia codziennego, a więc zmieniające się pory roku, święta religijne, państwowe czy jubileusze. Obecna była ona w twórczości Philippa Kreutza, Alexisa Drewinga, Roberta Bräutigama oraz Wally Thiema.

W okresie międzywojennym pojawia się również twórczość powieściowa, której tematem staje się codzienność, nie tylko łódzka. Takich wątków dostarczają utwory wcześniej wspomnianego Bruno Raymonda, który w powieściach i dramatach podejmuje oprócz kwestii tożsamości także zagadnienia gospodarcze nie tyle $\mathrm{w}$ wymiarze politycznym, ile przede wszystkim etyczno-filozoficznym. 


\section{4. ŁÓDŹ W LATACH WIELKIEJ WOJNY}

\subsection{Liryka antywojenna}

Łódź i region odegrały w czasie I wojnie światowej szczególną rolę. W chwili jej wybuchu miasto było z jednym z największych ośrodków przemysłowych Cesarstwa Rosyjskiego, położonym na peryferiach imperium. Od listopada do grudnia 1914 r. Łódź i okolice były areną jednej z największych bitew I wojny światowej, zwaną Operacją Łódzkąa․ W przeciągu dwóch miesięcy

1 Bitwa pod Łodzią była jedną z większych bitew I wojny światowej na froncie wschodnim. Rozegrała się na przełomie listopada i grudnia 1914 r. pomiędzy armiami niemiecką i rosyjską. Po obu stronach walczyło blisko 700 tys. żołnierzy, a w akcji użyto dziesiątki tysięcy armat. Niemcy bezskutecznie próbowali okrążyć armię rosyjską, ale Rosjanie odparli atak i sami otoczyli nieprzyjaciela. Dywizje niemieckie przedarły się do własnych sił głównych przez Brzeziny. Po starciu Rosjanie musieli opuścić Łódź i wycofać się na linię rzeki Rawki koło Skierniewic. W boju wzięły udział dywizje syberyjskie z Chabarowska, Krasnojarska, Omska i Irkucka, wśród nich wielu Polaków. W skład jednej z nich wchodził 24 syberyjski pułk strzelców, uzupełniony o mieszkańców Mazowsza i Warszawy, wcielonych do armii carskiej. W niemieckiej armii walczył Korpus Posen, w którego składzie było 23 tys. Polaków. Na polu walki ginęli Rosjanie, Niemcy, Austriacy, Polacy, Litwini, Czesi, Ukraińcy, Łotysze i Tatarzy. Zasadniczą bitwę, zakończoną zajęciem Łodzi przez Niemców, stoczono w okolicach Gadki Starej i Rzgowa. Wojskami niemieckimi dowodził gen. Reinhard von Scheffer, stąd nazwa oddziałów niemieckich „grupa Scheffera” (w składzie: 49 i 50 rezerwowa dywizja piechoty oraz 3 dywizja gen. Karla Litzmanna). Po zwycięstwie Niemców okrzyknięto Litzmanna „Lwem spod Brzezin”. W Gadce do dziś zachował się cmentarz wojenny z kamiennymi nagrobkami i płytami, upamiętniającymi bitwę. Na cmentarnym wzgórzu stoi także pomnik z niemieckim napisem: „Tu spoczywa 2000 dzielnych wojowników". Historycy uznają tę bitwę za największą operację manewrową I wojny światowej na Wschodzie. Pod Łodzią Rosjanie po raz pierwszy użyli samochodów pancernych, zaś Niemcy próbowali zastosować broń chemiczną. Straty po obu stronach szacuje się na ok. 100 tys. żołnierzy pochowanych na ponad 200 leśnych cmentarzach na terenie podłódzkich gmin: Rzgowa, Koluszek, Brójca, Gałkówka, Brzezin i in. Zob.: M. Hertz, Łódź w czasie wielkiej wojny, Łódź 1933; W. Bortnowski, Ziemia łódzka w ogniu: 1 VIII - 6 XII 1914 rok, Łódź 1969; A. Adach, Bitwa o Łódź. Przewodnik po polach bitew operacji łódzkiej 1914 roku, Łódź 2004; Wielka Wojna o ziemię obiecanq. Operacja Łódzka 1914, red. P. Werner, Łódź 2006; Walki w okolicach Łodzi 1914 r. Relacje uczestników i świadków, Łódź 2007; M. Lezius, Pod dowództwem Litzmanna. Krwawe walki Operacji Łódzkiej 1914 r., Łódź 2008; Walki 
w walkach w okolicach miasta wzięło udział pond 600 tys. żołnierzy, spośród których mnóstwo poległo. W wyniku działań wojennych łódzka społeczność poniosła nie tylko dotkliwe straty osobowe, ale również materialne i psychiczne. Wojna i jej skutki w znaczący sposób zmieniły życie codzienne zwykłego obywatela.

Wstrzymanie w pierwszych miesiącach wojny produkcji w wielu miejscowych zakładach przemysłowych spowodowało powszechne bezrobocie. 1 września 1914 r. bez środków do życia zostało ponad 60 tys. łodzian². Skutki bezrobocia były zauważalne niemal natychmiast - w mieście zaczęło brakować żywności, a głód i choroby zakaźne zbierały obfite żniwo. Często dochodziło także do zjawisk spekulacyjnych i rabowania okolicznych rolników. Odcięcie dostaw węgla spowodowało natomiast masowe wycinanie lasów w okolicach Dworca Kaliskiego, na Widzewie, w Rudzie Pabianickiej, na Julianowie i Marysinie ${ }^{3}$.

Walka ze skutkami wydarzeń wojennych stała się nadrzędnym celem Głównego Komitetu Obywatelskiego, utworzonego w sierpniu 1914 r. po ewakuacji władz rosyjskich i zatwierdzonego przez ówczesnego gubernatora piotrkowskiego Michała Jaczewskiego. Główna siedziba Komitetu mieściła się przy ul. Piotrkowskiej 96. W skład GKO w różnych okresach jego działalności wchodzili m.in.: Antoni Stamirowski, Józef Adamowicz, Henryk Zaar, Waldemar Bersin, Alfred Ramisch, Stanisław Silberstein, Oskar Kindler, Kazimierz Stebielski, ks. Henryk Przeździecki, ks. Wincenty Tymieniecki, Karol W. Scheibler, dr Henryk Trenkner. Mimo wielu starań podjętych przez tę organizację sytuacja ludności znacznie się pogorszyła, zwłaszcza po wkroczeniu wojsk niemieckich w grudniu 1914 r. Rozpoczęły się wówczas masowe rekwizycje żywności i lekarstw na rzecz wojska. Ogromne straty poniósł również łódzki przemysł, gdyż z chwilą przybycia do miasta niemieccy okupanci dokonali demontażu wszystkich cenniejszych maszyn, aby uniemożliwić ich wykorzystanie po wojnie do odbudowy przedwojennej koniunktury ${ }^{4}$

Wojenna rzeczywistość to nie tylko brak żywności, bezrobocie i rabunki, ale również wszechobecny strach przed śmiercią. Ludność cywilna od początku wojny była narażona na bezpośrednie działania wojenne, ponieważ miasto nie ustrzegło się ostrzałów artyleryjskich, choć większość bitew ro-

pod Łodziq 1914/1915 - relacje prasy i propagandy. Napad pod Kutnem. Walki o Piotrków. Bitwa pod Łodziq̨, Łódź 2008; K.R. Kowalczyński, Łódź 1914. Kronika oblężonego miasta, Łódź 2010; Operacja Łódzka. Zapomniany fakt I wojny światowej, red. J. Daszyńska, Łódź 2012.

2 Por. W. Bortnowski, Ziemia łódzka...

${ }^{3}$ Por. J. Walicki, Samoorganizacja społeczeństwa Łodzi w obliczu wybuchu wojny i działań wojennych w 1914 roku, [w:] Łódź i region łódzki w czasie I wojny światowej. Między wielkq historiq a codziennością, red. K. Radziszewska, P. Zawilski, Łódź 2011, s. 69-86.

${ }^{4}$ Por. W. Pawlak, Na łódzkim bruku 1901-1918, Łódź 1984. 
zegrała się w jego okolicach. 18 listopada 1914 r. nad Łodzią pojawiły się niemieckie samoloty bombardujące domy, place i ulice. Największy dramat przeżyli łodzianie w nocy 21 listopada, kiedy miasto ostrzelano z ciężkich armat. Podczas walk Łódź zamieniła się w jeden wielki szpital, gdyż tu zwożono rannych i zabitych z okolicznych pól bitewnych. Wszelkie obiekty użyteczności publicznej, fabryki i domy prywatne przekształcono w lazarety. 5 grudnia wojska rosyjskie zaczęły ewakuację, a następnego dnia do miasta wkroczyli Niemcy. Szacuje się, że w trakcie Operacji Łódzkiej rannych zostało ok. 35000 osób ${ }^{5}$.

Okres I wojny światowej stał się dla literackiej świadomości Łodzi i regionu czasem niezwykle istotnym. Powstająca wówczas literatura, tworzona wprawdzie na marginesie wiodących, ogólnokrajowych zjawisk i prądów literackich, zaczęła czerpać z nich pewne wzorce, które znalazły odbicie w twórczości niektórych lokalnych autorów. Dużą popularnością wśród tekstów literackich cieszyła się poezja.

Tematyka I wojny światowej zdominowała większość utworów lirycznych, powstałych w tych latach, wykazując dwie przeciwstawne tendencje. $\mathrm{Z}$ jednej strony pojawiają się w Łodzi teksty o charakterze pacyfistycznym. Ich autorzy to pisarze skupieni wokół gazety „Neue Lodzer Zeitung”, tacy jak Wilhelm Jess, Robert Bräutigam, Theodore Abel czy Heinrich Zimmermann, których poezję można określić jako nurt antywojenny. Z drugiej strony na łamach gazet „Deutsche Lodzer Zeitung” czy „Deutsche Post” drukowano utwory Friedricha Flierla czy Margarete Grüner oraz licznych, mało znanych żołnierzy walczących na froncie, bezkrytycznie afirmujących wojnę entuzjastów narodowego „zrywu patriotycznego”, którzy stali się tym samym częścią niemieckiego aparatu propagandowego. Poezję pisarzy łódzkich - zarówno potępiających, jak również gloryfikujących wojnę - cechował naiwny i sentymentalny patriotyzm. Warto przyjrzeć się najpierw wierszom tych pierwszych.

Analiza utworów negujących wojnę pozwala na wyodrębnienie kilku istotnych cech, które można określić jako antyideologemy przeciwstawiane oficjalnym treściom propagandowym, wokół których skupia się krytyka wojny. Wojna okazała się dla wielu łódzkich pisarzy doświadczeniem nieporównywalnym z żadnym innym. Zaskoczyła bezwzględnością, okrucieństwem, walkami bratobójczymi, ogromnymi stratami materialnymi i osobowymi. W wymiarze totalnym stała się siłą destrukcyjną. Dotknęła przede wszystkim ludność cywilną, przynosząc degradację wszelkich norm etycznych i człowieczeństwa. Przeżycia wojenne stały się zatem ważnym doświadczeniem psychicznym i egzystencjalnym. W tym sensie wojna wykroczyła poza

${ }^{5}$ Ibidem. 
ramy historyczne i nabrała znamion wytworu świadomości indywidualnej, będąc swego rodzaju podróżą w głąb zbiorowej podświadomości. Maria Jolanta Olszewska pisze:

Wojna w odczuciu tych, którzy w niej brali udział, przyjmowała nie tyle formę teatru, w którym każdemu przyszło odegrać jakąś rolę, ale stawała się „przestrzenią osaczenia”, „wewnętrznym więzieniem”, „pułapką absurdu”, „wtłoczeniem świata we własne ja” czy „ucieczką do wnętrza”. Ten, kto na stałe doznał wojennego urazu czy szoku, mógł odbyć wędrówkę „w głąb siebie”: po labiryncie własnej duszy, ale tam spotkał tylko „demony”: obsesje, lęki, przeczucia - mrok i pustkę. Został w nie wrzucony, tak jak został wrzucony w „wojnę”, której celów nie znał, a sensu nie rozumiał i która stała się tym samym figurą absurdalnego poczucia życia ${ }^{6}$.

Właśnie to wymuszone na człowieku doświadczenie wojny „od wewnątrz" staje się ważnym punktem krytyki wojennej. Przykładem literackich reprezentacji wojny doświadczanej „od wewnątrz” mogą być słowa Theodore'a Abela, który w balladzie Die vom Sterben sprachen [Ci, którzy mówili o śmierci] tak opisuje to doświadczenie:

Ich hasse den Kampf

Den Allzerstörenden

Es ist ein Sturm

Der zermalmend wütet,

Es ist der Wurm,

Der im Herzen brütet ${ }^{7}$.

Ten sam autor również w innym wierszu Sehnsucht nach Frieden [Tęsknota za pokojem] daje wyraz wewnętrznemu doświadczeniu wojny, pisząc: „Im Herzen ist graue, finstere Nacht" [W sercu szara, ciemna noc ${ }^{8}$. Wewnętrzne cierpienia znajdują też odbicie w zewnętrznej postawie, którą opisuje nieznany łódzki poeta w wierszu Lass das Klagen [Odrzuć żal]:

Du gehst gebückt in Kummer und Sorgen,

Den Mund mit Jammer und mit Klagen voll ${ }^{9}$.

${ }^{6}$ M.J. Olszewska, Człowiek w świecie Wielkiej Wojny. Literatura polska z lat 1914-1919 wobec I wojny światowej. Wybrane zagadnienia, Warszawa 2004, s. 35.

7 Th. Abel, Die vom Sterben sprachen, „Illustrierte Sonntagsbeilage zur Neuen Lodzer Zeitung", 10.06.1917, s. 1 [Nienawidzę wojny, /niszczącej wszystko na drodze. / Jest jak nawałnica / pod nią świat się wali / i jest jak robak, / co się w sercu czai. Tłumaczenie M.K.]. Wiersz nigdy nie ukazał się w żadnym tomie zbiorowym.

8 Th. Abel, Sehnsucht nach Frieden, „Illustrierte Sonntagsbeilage zur Neuen Lodzer Zeitung”, 16.01.1916, s. 14. Wiersz nigdy nie ukazał się w żadnym tomie zbiorowym.

9 K.G., Lass das Klagen, „Illustrierte Sonntagsbeilage zur Neuen Lodzer Zeitung”, 6.05.1917, s. 3 [Idziesz złamany pod brzemieniem męki, / lament z siebie wydajesz i żałosne jęki. Tłumaczenie M.K.]. Wiersz nigdy nie ukazał się w żadnym tomie zbiorowym. 
Doświadczenie wojny „od wewnątrz” jest cechą większości utworów ekspresjonistycznych. Podobnie opisywali swe doświadczenia wojenne uznani dziś za największych liryków tego okresu pisarze niemieckojęzyczni: Georg Trakli, Albert Ehrenstein. Ekspresjoniści uważali wojnę za negatywny przejaw procesu cywilizacyjnego, a jej przyczyny upatrywali nie w konstelacji politycznej, lecz w braku wartości moralnych, etycznych i procesie dehumanizacji. W tym kontekście zrozumiałe stają się postulaty, nawołujące do odnowy moralnej jednostki i zjednoczenia wszystkich narodów ${ }^{10}$. Z tego względu pisarze koncentrowali się na ukazywaniu działań na polu bitwy jako siły niszczącej, często jako wojny maszyn, stanowiących negację kultury i człowieczeństwa. Wśród niemieckich ekspresjonistów, którzy próbowali oddać klimat walki za pomocą opisu technik wojennych, znaleźli się m.in.: Wilhelm Klemm (np. w wierszu Stellung ${ }^{11}$ ), Ernst Toller (w dramacie Die Wandlung ${ }^{12}$ ), Oskar Kanehl (w tomie Die Schande ${ }^{13}$ ) oraz Albert Ehrenstein w wierszu Gottes Tod ${ }^{14}$. Wszyscy ci pisarze ukazywali bezwzględną dominację maszyny nad człowiekiem. Podobną wizję działań na froncie jako wojnę maszyn, a nie ludzi, można odnaleźć u niektórych łódzkich poetów, jak np. u Theodore’a Abela, który w wierszu Aus der Zeit ${ }^{15}$ tak opisuje moment „zawieszenia broni” maszyn wojennych:

Das Werk ist still.

Einst fieberrasend,

Die Räder dröhnten,

Durch Tag und Nacht

Maschinen stöhnten ${ }^{16}$.

Choć Abel przedstawia stan bezruchu, odwołuje się do wcześniejszych działań frontowych, w których uczestniczyły maszyny wojenne. Posługuje się celowo zabiegiem antropomorfizacji, chcąc ukazać ich niszczycielską siłę oraz wzmóc poczucie grozy i niebezpieczeństwa - stan bezruchu jest bowiem tylko stanem przejściowym. W kolejnym fragmencie autor pisze:

Doch kommt der Tag,

Fort wird der Staub geblasen,

10 Por. J. Golec, Postawy antywojenne w poezji i publicystyce niemieckiego ekspresjonizmu, [w:] Pierwsza wojna światowa w literaturze polskiej i obcej. Wybrane zagadnienia, red. E. Łoch, K. Stępnik, Lublin 1999.

11 W. Klemm, Gloria! Kriegsgedichte aus dem Feld, München 1915, s. 53.

12 Por. E. Toller, Die Wandlung. Das Ringen eines Menschen, Potsdam 1920.

13 O. Kanehl, Die Schande: Gedichte eines dienstpflichtigen Soldaten aus der Mordsaison 1914-1918, Berlin-Wilmersdorf 1922.

14 Por. A. Ehrenstein, Gottes Tod, „Die Aktion” 8/1918, s. 134.

15 Th. Abel, Aus der Zeit, „Illustrierte Sonntagsbeilage zur Neuen Lodzer Zeitung”, 7.01.1916, s. 8. Wiersz nigdy nie ukazał się w żadnym tomie zbiorowym.

${ }^{16}$ Ibidem [Ucichło działo. / Wprzódy gorączką trawione / koła się kręciły, / a dniem i nocą / maszyny dudniły. Tłumaczenie M.K.]. 
Und unermüdlich Tag und Nacht

Solln die Maschinen rasen ${ }^{17}$.

Wiersz Theodore'a Abela jest jednym z nielicznych świadectw wprowadzenia do łódzkiej literatury motywu charakterystycznego dla ekspresjonistycznych wizji wojny, jakim jest wojna maszyn. Łódzcy poeci częściej werbalizowali cierpienie wywierające destrukcyjny wpływ na naturalną więź człowieka ze światem. W tym kontekście pojawia się kolejny punkt krytyki. Człowiek doświadczony wojną popada w senne koszmary i gorączkowe majaczenia, a także żywi myśli samobójcze, poddając w wątpliwość celowość ludzkiej egzystencji. Wszechstronne doznanie cierpienia prowokuje pytanie o jego sens i genezę. Literatura ekspresjonizmu zna wiele takich obrazów, w których człowiek wręcz pragnie doświadczyć śmierci, choć często nie jest to możliwe ${ }^{18}$. „Ich sehne mich unterzugehen” [Tęsknię za śmiercią] - pisze Joseph Gregor w wierszu Herbstliches Lebenslied ${ }^{19}$, zaś Albert Ehrenstein w wierszu Verzweiflung ${ }^{20}$ wyznaje: „Ich stürbe so gern” [Chciałbym umrzeć]. Również łódzki poeta Theodore Abel porusza zagadnienie przemijania i śmierci, a towarzyszą mu refleksje nad sensem życia, jak przykładowo w wierszu Die vom Sterben sprachen [Którzy opowiadali o śmierci]:

Sterben möchte ich im glühenden Rosen,

Im Liebestanz;

Auf dem Haupte blühende Rosen,

Im Kranz.

$[\ldots]$

Ich möchte, es würde von tausend Winden

Mein Leib entführt.

Und gleich dem Augenblicke verschwinden

Unberührt...

Vergehen inmitten sorgloser Freuden

Im Augenblick

Ist von allen Glückseligkeiten,

Das höchste Glück... ${ }^{21}$

17 Ibidem [Lecz dzień nadejdzie, / kiedy kurz opadnie, / I dniem i nocą, bezustannie / pracować będą znów maszyny. Tłumaczenie M.K.].

18 Por. A. Zawodny „[...] erbau ich täglich euch den allerjüngsten Tag.“ Spuren der Apokalypse in expressionistischer Lyrik, Kolonia 1999, http://www.google.pl/\#psj=1\&q=A.+Zawodny+\%E2\%80\%9E $\% 5 B . . . \% 5 \mathrm{D}+$ erbau+ich+t $\% \mathrm{C} 3 \% \mathrm{~A} 4 \mathrm{glich}+\mathrm{euch}+\mathrm{den}+$ allerj\%C3\%BCngsten+Tag. $\%$ E2\%80\%9C+Spuren+der+Apokalypse+in+expressionistischer+Lyrik\%2C+Kolonia+1999 [dostęp: 8.08.2013].

19 J. Gregor, Herbstliches Lebenslied, [w:], Botschaft der Freude. Zwölf Skizzen aus dem Markusevangelium, hrsg. v. N. Rheinhardt, Dreieich 2008, s. 111.

${ }^{20}$ A. Ehrenstein, Verzweiflung, [w:] Lyrik des Expressionismus, hrsg. v. S. Vietta, Tübingen 1999, s. 109.

${ }^{21}$ Th. Abel, Die vom Sterben sprachen, „Illustrierte Sonntagsbeilage zur Neuen Lodzer 
Wybuch wojny wymusił na człowieku zmianę wyobrażeń o świecie i zmienił formę uczestnictwa w życiu zbiorowym. Oznacza to, że rozpadły się dawne tradycyjne formy kulturowe, pojęcia i idee. Człowiek doświadczony wojną popada w zwątpienie, czuje się niepewny, zagubiony i pogrążony w chaosie. Z tymi traumatycznie nacechowanymi odczuciami łączy się motyw cierpienia matek. Wojna zdecydowanie zaprzecza istocie macierzyństwa, rodzicielstwa w ogóle i zrywa rodzinne więzy. Matka jako uosobienie bezpieczeństwa, instynktu życia i domowego ciepła traci rację bytu. W tym kontekście pojawia się w łódzkiej literaturze antywojennej motyw zerwanych więzi rodzinnych, a wraz z nim kolejny punkt krytyki wojennej. Podejmuje go w swej twórczości Theodore Abel. W wierszu Mutter, wo bist du? [Matko, gdzie jesteś? ${ }^{22}$ autor wskazuje na zerwane więzi i poczucie samotności:

Mutter, wo bist du?

Ich liege hier...

Totwund...23

W literaturze łódzkiej zerwane więzi rodzinne często łączą się z motywem cierpiących matek, patrzących na śmierć swych dzieci. Kamill Hoffmann tak pisał w wierszu Schneewind [Zamieć]: „Wojna! Wojna! Zły czas! / Dla wszystkich matek największa rozpacz"24. Motyw cierpiących matek, w wielu utworach łódzkich silnie idealizowany, najczęściej ukazany bywa w relacji matka - syn. Z tego względu można porównać tę poezję z twórczością legionową, powstającą w tym czasie w Polsce ${ }^{25}$. Jako przykład może posłużyć tu utwór Józefa Andrzeja Teslara Modlitwa legionisty, w którym autor pisze „Wypłaczą oczy matki nasze”26, lub Pogrzeb szpitalny, w którym dopowiada:

Zeitung", 10.06.1917, s. 1 [Chcę umrzeć w płonących różach, / w tańcu życia;/ na głowie kwitnące róże, / w wieńcu [...] / Chciałbym, aby moje ciało / porwało tysiąc wiatrów / i przeminąć jak chwila - nietknięty. // Przeminąć wśród beztroskich radości / w jednej chwili - jest ze wszystkich szczęść / największe z nich... Tłumaczenie M.K.].

22 Th. Abel, Mutter, wo bist du?, „Illustrierte Sonntagsbeilage zur Neuen Lodzer Zeitung”, 20.08.1916, s. 138. Wiersz nigdy nie ukazał się w żadnym tomie zbiorowym.

${ }^{23}$ Ibidem [Matko, gdzie jesteś? / Leżę tu... / ze śmiertelną raną... Tłumaczenie M.K.].

${ }^{24}$ K. Hoffmann, Schneewind, „Neue Lodzer Zeitung”, 19.01./1.02.1915, s. 3. Wiersz nigdy nie ukazał się w żadnym tomie zbiorowym.

${ }^{25}$ Porównanie z poezją legionową można zaryzykować z dużym zastrzeżeniem, gdyż poezja ta wyrosła z innych tradycji niż literatura łódzka. Tomiki poetyckie takich przedstawicieli tego nurtu, jak Edward Słoński, Józef Mączka czy Józef Andrzej Teslar, były tekstami popularnego obiegu, które wyróżniała skłonność do powielania romantycznych wzorców; autorzy sięgali również do folkloru ludowego oraz polskiej tradycji powstaniowej, a nawet do gatunków charakterystycznych dla kabaretu. Zadaniem tej poezji było zagrzewanie do walki w obronie kraju. Poezja posługiwała się technikami perswazji, które miały uzasadnić jej konieczność. Por. Pierwsza wojna światowa...

${ }^{26}$ J.A. Teslar, Modlitwa legionisty, [w:] Rytmy wojenne 1914-1916, Kraków 1916. 
A gdyby wiedziały,

matki, wszystkie by poszły, których syny zmiata

kosa wojny... Niech tęsknią!... A łzy ich wylane

niechaj ze krwi zmywają pobojowisk pola...

A tymczasem cichutko, bez wojennej chwały

wiozą trumny na cmentarz...27

Utrwalony $\mathrm{w}$ literaturze tego okresu stereotyp matka - syn polega przede wszystkim na przedstawieniu matki pozostającej w domu i płaczącej z powodu utraty syna, który na froncie wciąż ją wspomina i wzywa przed śmiercią. Przykładem może być wiersz nieznanego łódzkiego poety pt. Wein' nicht Mutter! [Nie płacz matko!]

I

Die Mutter weint, muß ihr Sohn

Hinaus ins weite Land.

Wohl hundertmale herzt sie ihn

Und drückt ihm stumm die Hand.

Ihr ists als sähe sie ihr Kind

Zum letzten male hier,

Doch er, ein schmucker Kriegersmann,

Gar tröstend spricht zu ihr:

'Wein nicht, Mutter! Mutter, wein nicht!

Denn wenn der Krieg erst einmal aus

Kehr ich gesund und fröhlich wieder

Zu dir, lieb Mütterlein, nach Haus.'

II

Doch bald liegt auf dem Sterbebett,

Daheim der liebe Sohn $[\ldots]^{28}$.

W przytoczonym wierszu warto zwrócić uwagę na fakt, że pisarze łódzcy zazwyczaj koncentrują się na perspektywie pojedynczej osoby, dostrzegając przede wszystkim człowieka - zwykłego żołnierza, doświadczonego wojną, narażonego na psychiczne i fizyczne zniszczenie, odartego $\mathrm{z}$ aury bohaterstwa. Człowiek, doświadczający chaosu wojennego, nie jest w stanie ogarnąć całego teatru wojny, lecz jedynie mały jego wycinek, w którym się aktualnie znalazł, dlatego najistotniejsze staje się dla niego przeżycie fizyczne i odzy-

${ }^{27}$ J.A. Teslar, Pogrzeb szpitalny, [w:] ibidem.

${ }^{28}$ [b.a.], Wein' nicht Mutter!, „Neue Lodzer Zeitung”, 20.11./3.12.1914, s. 3 [Matka płacze, jej syn musi / hen daleko w nieznany kraj. / Setki razy tuli go, / i ściska dłoń, / jak gdyby widziała go / ostatni raz, / lecz jej syn, szykowny żołnierz: / pociesza ją: / „Nie płacz, matko! Matko nie płacz! / Gdy skończy się wojna, / wrócę zdrów, do Ciebie i do domu. / II / Lecz wkrótce leży na łożu śmierci, / W domu kochany syn. Tłumaczenie M.K.]. Wiersz nigdy nie ukazał się w żadnym tomie zbiorowym. 
skanie równowagi psychicznej. Stąd - nawiązując jeszcze raz do powyższego wiersza - rozpaczliwe wołanie rannego żołnierza, który utracił poczucie równowagi: „Mutter, wo bist Du?” [Matko, gdzie jesteś?].

Opisom ludzkich cierpień i wewnętrznych przeżyć towarzyszą obrazy wojny, kreowane w perspektywie eschatologicznej. Łodzianie posługują się schematami apokaliptycznymi, wyrażającymi sprzeciw wobec totalnego zniszczenia. Świadczą o tym już same tytuły utworów zamieszczanych w lokalnych gazetach, takie jak np. Das letzte Gericht [Sąd Ostateczny] ${ }^{29}$, Dämmerstunden [Szarówka] ${ }^{30}$, Herbst [Jesień] ${ }^{31}$ czy Mein Waldfriedhof [Mój leśny cmentarz $]^{32}$. Ukazany $w$ nich świat jest pełen zła, pozbawiony miłosierdzia i dobra. Dla spotęgowania efektu poeci odwołują się do metaforyki biblijnej i przywołują powtarzające się motywy płynącej krwi, ciemności i mroku, podkreślające nastrój grozy i zagłady. Wyraźnie widać to w wierszu Der Weg zur Höh [Droga do nieba] Teodore'a Abela:

Doch seltsam... dort fern ein Feuer blinkt

In Blut und Donner entfacht

Und Mensch mit dem Menschen im Kampfe ringt

Und der Tod fährt durch die Nacht...33

W przytoczonym fragmencie można znaleźć, podobnie jak w utworach niemieckich ekspresjonistów ${ }^{34}$, odwołanie do symboliki kolorów, w której zazwyczaj dominują ciemne, przygnębiające barwy, nadające wojennym pejzażom swoisty wymiar. Realne krajobrazy, w których zakłóceniu uległa dotychczasowa harmonia, zostały przedstawione w wierszach w sposób eksponujący aurę smutku i apokaliptycznej katastrofy. Naturalne elementy krajobrazu uległy zmianie - w lasach i dolinach pełno jest mogił nieznanych

${ }^{29}$ [b.a.], Das letzte Gericht, aus dem Polnischen des Kasimir Tetmajer, „Illustrierte Sonntagsbeilage zur Neuen Lodzer Zeitung”, 28.05.1916, s. 3-4.

${ }^{30}$ W. Triebe, Dämmerstunden, „Illustrierte Sonntagsbeilage zur Neuen Lodzer Zeitung”, 11. 08.1918, s. 1. Utwór nigdy nie ukazał się w żadnym tomie zbiorowym.

31 W. Triebe, Herbst, „Illustrierte Sonntagsbeilage zur Neuen Lodzer Zeitung”, 8.09.1918, s. 144. Utwór nigdy nie ukazał się w żadnym tomie zbiorowym.

32 A. Kargel, Mein Waldfriedhof, „Illustrierte Sonntagsbeilage zur Neuen Lodzer Zeitung”, 1.11.1914, s. 1. Utwór nigdy nie ukazał się w żadnym tomie zbiorowym.

33 Th. Abel, Der Weg zur Höh, „Illustrierte Sonntagsbeilage zur Neuen Lodzer Zeitung”, 24.12.1916, s. 110 [Dziwne... tam w dali migocze płomień / rozniecony krwią i gromem / ludzie się w walce szamoczą / a śmierć przychodzi nocą... Tłumaczenie M.K.]. Wiersz nigdy nie ukazał się w żadnym tomie zbiorowym.

${ }^{34}$ Por. L. Rubiner, Die feindliche Erde, [w:] idem, Der Dichter greift in die Politik, Leipzig 1976, s. 21-23: „Der Himmel rollte herum dunkel funkelnd im schwarzen hohlen Oval” [Niebo roztaczało się, ciemno migocząc w czarnym pustym owalu. Tłumaczenie M.K.] oraz E.A. Rheinhardt, Melancholie, [w:] Hirnwelten funkeln, hrsg. v. E. Fischer, W. Haefs, Salzburg 1988, s. 267 : „Die Taggilbe dunkelt leichenfleckig” [Wojenna febra szarzeje trupioblado. Tłumaczenie M.K.]. 
żołnierzy, a cmentarzyska tworzą stały element pejzażu. Krajobraz ten w połączeniu z szalejącym wiatrem, śniegiem i ciemnymi barwami: szarością, czernią oraz kontrastującą z nimi czerwienią, tworzą niepokojący obraz, pełen dysonansów. W wierszach łódzkich pisarzy ciemne barwy uzupełniane są odczuciami zimna i chłodu, co ma potęgować negatywne wrażenie. Stąd często podejmowany motyw nocy, wzbogacony dodatkowo opisami scen zimowych i jesiennych. Ponure pejzaże eksponują aurę klęski, śmierci i apokalipsy. Jako przykład warto przytoczyć wiersz Wilhelma Wihana Oktobernacht [Noc październikowa]:

Ein feiner Regen rieselt facht.

Das klingt wie leises Weinen.

Und tiefes Dukel hüllt die Nacht,

Nicht Mond noch Sterne scheinen.

Die Bäume regen kahl und leer

Wie ausgestreckte Hände.

Nun gibt es keine Rosen mehr,

Und alles ist zu Ende ${ }^{35}$.

Często powracający w łódzkiej literaturze motyw grobu (np. w wierszu Ein Flüstern über Gräbern [Szept nad grobami] Ilse Reicke ${ }^{36}$ ), cmentarzy (np. u Wilhelma Jessa w Am Soldatenfriedhof zu Rzgow [Na cmentarzu wojennym w Rzgowie] ${ }^{37}$ czy tego samego poety Zur Weihe des Soldatenfriedhofs bei Effingshausen [Z okazji poświęcenia cmentarza wojennego w Starowej Górze] ${ }^{38}$ ) wraz z obrazem umierających dzieci to świadomy zabieg, świadczący o tym, że autorzy nie godzą się na śmierć i wyraźnie protestują przeciwko totalnej zagładzie. W wierszu Herbststimmung ${ }^{39}$ autorka Irma Teichmann operuje obrazem dziecka-sieroty, który ma dodatkowo szokować okrucieństwem:

Dicht an des Grabes Rand

Knieet das Kind;

${ }^{35}$ W. Wihan, Oktobernacht, „Illustrierte Sonntagsbeilage zur Neuen Lodzer Zeitung”, 29.10.1916, s. 4 [Lekki deszcz mży powoli, / brzmi jak ciche łkanie. / Głęboki mrok osłania noc, / nie księżyc, lecz jeszcze gwiazdy lśnią. // Drzewa wznoszą się gołe bez liści / jak rozpostarte dłonie. / Nie ma już róż / i wszystko się skończyło. Tłumaczenie M.K.]. Wiersz nigdy nie ukazał się w żadnym tomie zbiorowym.

36 I. Reicke, Ein Flüstern über Gräbern, „Illustrierte Sonntagsbeilage zur Neuen Lodzer Zeitung”, 29.10.1916, s. 1. Utwór nigdy nie ukazał się w żadnym tomie zbiorowym.

37 W. Jess, Am Soldatenfriedhof zu Rzgow, „Neue Lodzer Zeitung”, 16.09. 1917, s. 2. Utwór nigdy nie ukazał się w żadnym tomie zbiorowym.

38 W. Jess, Zur Weihe des Soldatenfriedhoffs bei Effingshausen, „Neue Lodzer Zeitung”, 12.11. 1916, s. 5. Utwór nigdy nie ukazał się w żadnym tomie zbiorowym.

${ }^{39}$ I. Teichmann, Herbststimmung, „Illustrierte Sonntagsbeilage zur Neuen Lodzer Zeitung”, 24.09.1916, s. 4. Utwór nigdy nie ukazał się w żadnym tomie zbiorowym. 
Goldiges Lockenhaar

Flattert im Wind.

Zärtlicher Sonnenstrahl

Glutet herab,

Küsset ein Weisenkind,

Küsset ein Grab.

Und das verwelkte Laub,

Leuchtet in Glanz,

Tanzt mit dem Winde

Den Totentanz ${ }^{40}$.

Obrazy te są bez wątpienia świadectwem prawdy o wojnie totalnej, jak również zaprzeczeniem treści rozpowszechnianych przez ówczesną propagandę, idealizującą śmierć na polu walki. Tu poetka pokazuje własną prawdę - mówi nie o bohaterskiej śmierci żołnierzy gotowych stawić czoło wielkiemu wyzwaniu, gotowych do poniesienia ofiary - lecz o cierpiącym dziecku, które stało się ofiarą tej wojny.

Od niemieckiego ekspresjonizmu różni te wiersze często sentymentalny ton. Cierpienia jednostki zdają się tu być łagodzone przeżyciem natury lub nadzieją na zbawienie po śmierci lub wręcz odrodzeniem człowieczeństwa dzięki boskiej pomocy. Łódzkie wiersze nie charakteryzują się wyraźnie ekspresjonistyczną stylistyką - niewiele w nich urywanych zdań, wykrzykników, ekspresywnych neologizmów, fraz wyrażających ekstazę czy głęboki lęk.

Dramatyzm wojenny przekłada się również na znaczące zmiany w zakresie semantycznym takich pojęć, jak Bóg, sumienie czy dobro. Dlatego łódzka literatura podejmuje próbę ukazania w sposób szczególny relacji człowiek - Bóg. Świat nie staje się tu totalnym inferno, w którym kategorycznemu odrzuceniu podlega optymistyczna wiara w Boga. Bóg jawi się w wierszach łódzkich poetów jako adresat wszelkich próśb człowieka bezsilnego, pokonanego przez wojnę, skazanego na życie, będące areną grzechu. Jako przykład mogą tu posłużyć dwa utwory: Wilhelma Jessa Gebet [Modlitwa] oraz Roberta Bräutigama Das Vaterunser. Kriegsgebet [Ojcze nasz. Modlitwa wojenna], w której autor artykułuje prośbę: „Lass Du das Kampfgewimmel, / Lass die rauhen Waffen ruhn" [Zostaw za sobą wojenny zamęt. Niech zamilknie szalejący oręż $]^{41}$, eksponując w ten sposób demonizm i nieludzkość zjawiska wojny

${ }^{40}$ Ibidem [Tuż nad grobem, / klęczy dziecko; / złote loki / rozwiewa wiatr. // Czuły promień słońca / żarzy się, / całuje sierotę / całuje grób // a pożółkłe liście / lśniąc w blasku / tańczą z wiatrem / taniec śmierci. Tłumaczenie M.K.]. Utwór nigdy nie ukazał się w żadnym tomie zbiorowym.

41 R. Bräutigam, Das Vaterunser. Kriegsgebet, „Illustrierte Sonntagsbeilage zur Neuen Lodzer Zeitung", 9.09.1917, s. 1. Tłumaczenie M.K. Utwór nigdy nie ukazał się w żadnym tomie zbiorowym. 
jako totalnej katastrofy. Modlitwa do Boga kierowana jest w konkretnym celu, a suplikanci są przekonani, że koniec wojny położy kres wszelkim cierpieniom. Anonimowy poeta pisze w wierszu Februar 1916 [Luty 1916]:

Keimen, wachsen und vergehen...
Und aus düstrer Winterszeit
Wird das Leben neu entstehen
Keimstark, lichtgrün, lenzbereit! ${ }^{42}$

W innym wierszu również anonimowy autor pisze: „0, lass das Jammern und das bittre Klagen! / Senk' tief den Blick ins Frühlingsblau hinein! / Und du wirst fühlen: bald vergeht das Zagen" [Porzuć lamenty i gorzkie żale! / Skieruj spojrzenie w błękit wiosny / poczuj jak szybko miną / niepewność, rozterki i troski $]^{43}$. Ta naiwna wiara, że koniec wojny przyniesie wybawienie od totalnej zagłady jest tym, co odróżnia twórczość łódzkich autorów od pisarzy ekspresjonistycznych. Dla nich koniec świata nie oznacza wcale wybawienia od cierpień: świadczą o tym chociażby słowa Hugo Sonnenscheina: „Uns wird niemand zertreten, niemand erlösen nach schwerem Tod” [Nikt nas nie zdepcze, nikt nie zbawi po okrutnej śmierci ${ }^{44}$.

Wśród utworów, propagujących postawy antywojenne, znajduje się blisko 60 tytułów poświęconych ginącej przyrodzie. W obliczu wstrzymania ruchu kolejowego Łódź stanęła przed problemem zaopatrzenia w opał. Łodzianie zaczęli więc nielegalnie pozyskiwać drewno z okolicznych lasów. Nielegalny wyrąb spowodował jednak dewastację znacznych obszarów leśnych. Całkowicie zniknął z łódzkiego krajobrazu las widzewski, położony między linią kolejową i ul. Rokicińską ${ }^{45}$. Środowisko łódzkich dziennikarzy i pisarzy, do którego należeli m.in. Carl Heinrich Schultz (pseud Ernst Heiter) i Heinrich Zimmermann, ostro sprzeciwili się niszczeniu przyrody, drukując w gazecie szereg artykułów na ten temat ${ }^{46}$. Epizod ten dał również impuls do ogłosze-

${ }^{42}$ [b.a.], Februar 1916, „Illustrierte Sonntagsbeilage zur Neuen Lodzer Zeitung”, 20.02.1916, s. 35 [Narodziny, dojrzałość, śmierć... / Z ciemności ponurych dni zimowych / znów się odrodzi życie nowe / mocna, jasna zieleń, do wiosny gotowa. Tłumaczenie M.K.]. Utwór nigdy nie ukazał się w żadnym tomie zbiorowym.

${ }^{43}$ K.G., Lass das Klagen, „Illustrierte Sonntagsbeilage zur Neuen Lodzer Zeitung”, 6.05.1917, s. 3. Tłumaczenie: M.K. Utwór nigdy nie ukazał się w żadnym tomie zbiorowym.

${ }^{44}$ Por. H. Sonnenschein, Ein Dichter stirbt im Kriege, [w:] Hirnwelten funkeln..., s. 302304. Jedynym wyjątkiem od tej pesymistycznej wiary, że po śmierci nie czeka człowieka nic dobrego, mogą być słowa J. Gregora, Herbstliches Lebenslied..., s. 111: „Ich sehne mich, unterzugehen, / Aber aus meinem Tode werde wieder Leben" [Tęsknię za śmiercią, ale niech ona zrodzi nowe życie. Tłumaczenie M.K.].

45 Por. W. Pawlak, Na łódzkim bruku..., s. 183-184.

${ }^{46}$ Por. m.in.: Die Aufteilung des Lodzer Stadtwaldes, „Neue Lodzer Zeitung”, 23.09./6.10.1914, s. 4; Das Fällen der Bäume, „Neue Lodzer Zeitung”, 19.09./2.10.1914, s. 3; Waldraub, „Neue Lodzer Zeitung”, 11.24./11.1914, s. 2. 
nia w październiku 1914 r. konkursu poetyckiego pod hasłem „Der sterbende Stadtwald"47. Konkurs miał być z jednej strony wyrazem sprzeciwu wobec negatywnych skutków wojny, z drugiej strony, co było istotniejsze, inicjatorzy pragnęli poznać łódzką poezję i przekonać się o jej kondycji. Świadczą o tym chociażby słowa Zimmermanna, który w jednym z felietonów pisał:

Aber nicht die Schuldfrage ist von Interesse, die Dichtung ist's, worauf es hier ankommt, ist die Stimmung, die Erinnerung wie sie in der Seele der Zartfühlenden fortlebt, der sterbende Stadtwald in der Poesie der Lodzer.

Und wie diese Poesie ist, interessiert uns ${ }^{48}$.

W taki właśnie sposób, poprzez organizowanie konkursów literackich, gazety starały się wspierać twórczość literacką wśród lokalnych pisarzy.

\subsection{Literatura $\mathrm{w}$ kręgu propagandy}

Obok nurtu poezji antywojennej wyłonił się inny nurt liryki patriotycznej, afirmującej wojnę. Wiersze te, drukowane na łamach dwóch łódzkich gazet: „Deutsche Post” i „Deutsche Lodzer Zeitung”, nawiązują w pewnym sensie do twórczości części pisarzy okresu ekspresjonizmu, tworzących w Niemczech pod wpływem oficjalnych inicjatyw propagandowych mających na celu promowanie tzw. idei roku 1914 (Ideen von 1914) ${ }^{49}$.

I wojna światowa wywołała wśród mieszczańskiej części społeczeństwa niemieckiego ogromny entuzjazm ${ }^{50}$. Zaowocował on w literaturze i publicystyce licznymi utworami apologizującymi wojnę, sięgającymi w wielu przypadkach do agresywnej retoryki ${ }^{51}$. Literaturę tę wielu znawców określa jako

${ }^{47}$ Por. informacje na temat konkursu oraz wiersze nadesłane do redakcji „Neue Lodzer Zeitung", 20.09./3.10.1914; 25.10./7.11.1914; 20.09./3.10.1914; 30.09./13.10.1914; 1./14.1 0.1914; 5./18.10.1914; 9.22.10.1914; 12./25.10.1914; 14./27.10.1914; 25.10/7.11.1914. Na konkurs zgłosiło się ok. 60 osób z Łodzi i regionu. Wyniki ogłoszono 7 listopada 1914 r. Wśród zwycięzców znaleźli się łódzcy pisarze, często publikujący na łamach lokalnych gazet, tacy jak Wilhelm Jess, Berta Rosenzweig oraz Theodore Abel.

${ }^{48}$ H. Zimmermann, Der sterbende Stadtwald in der Poesie der Lodzer, „Neue Lodzer Zeitung", 25.10./7.11.1914, s. 1 [Nie jest kwestią zagadnienie odpowiedzialności; poezja, o którą tu chodzi, jest wyrazem nastrojów, wspomnień, które żyją w duszy osób wrażliwych, na temat umierającego lasu w poezji łodzian. Interesuje nas, jaka jest ta poezja. Tłumaczenie M.K.].

${ }^{49}$ Por. J. Golec, Postawy antywojenne...

${ }^{50}$ Por. Cz. Karolak, W. Kunicki, H. Orłowski, Dzieje kultury niemieckiej, Warszawa 2006, s. 409.

51 Chodzi tu m.in. o manifest, podpisany przez 4 tys. wykładowców szkół wyższych Cesarstwa Niemieckiego, w którym zaprotestowali przeciw brytyjskiemu oddzielaniu niemieckiego ducha nauki od ducha pruskiego militaryzmu. Ibidem. 
„literaturę płytkiego, naiwnego i sentymentalnego hurrapatriotyzmu”52. Jej celem było ukazanie wojny przede wszystkim jako powinności walczących wobec państwa i historii, samych zaś żołnierzy jako bohaterów i herosów Germanii. Charakterystyczny dla tych utworów był motyw męczeństwa zbiorowego oraz bezkrytyczna afirmacja wojny jako egzaminu osobowości i wewnętrznego, wzniosłego przeżycia wobec śmierci. Idee roku 1914 generalnie pojmowano jako sąd nad światem, w którym niemiecki duch ma odegrać rolę wybawiciela od francuskiego, angielskiego czy też amerykańskiego materializmu. Głosiły one również, że wojna przyniesie ze sobą oczyszczenie niemieckości z tego, co nieniemieckie. Max Wundt pisał:

W zaślepieniu, które już w najbliższym czasie okaże się niepojęte, zabiega się u nas skrzętnie o wyparcie tego, co wypróbowane, niemieckie i umocnienie wpływów tego, co obce - co rozbudza całkiem nieuzasadnione nadzieje. A niestety, jest to nie tylko zaślepienie, lecz także bardzo jasny i świadomy własnych interesów zamysł, który tu czuwa nad biegiem spraw na pożytek naszych wrogów! Przebudźmy się, nim będzie za późno! Także wewnątrz kraju powinno obowiązywać hasło: co niemieckie, niechaj niemieckie pozostanie ${ }^{53}$.

To szczególne oczyszczenie niemieckości miało usankcjonować prawo do podejmowania wszelkich działań wojennych. Jednak nie tylko niemieckie społeczeństwo było zmotywowane żądzą przygód i chęcią poddania się życiowej próbie, ale również odczuwało znudzenie banalnością dnia codziennego i utratą sensu w warunkach wysoce skomplikowanej cywilizacji ${ }^{54}$. Ernst Jünger tak pisał o wojennej motywacji:

\begin{abstract}
Zbyt jesteśmy rozgałęzieni; soki nie docierają już do zakończeń. Tylko gdy bezpośredni impuls roziskrzy się w nas niczym błyskawica, stajemy się znów prości i wypełniamy się: dotyczy to zarówno jednostki, jak i sumy jednostek, narodu. W tańcu na cienkim ostrzu między bytem i niebytem objawia się człowiek prawdziwy, to co było w nim rozkruszone, stapia się znów w kilka pierwotnych popędów o wielkiej mocy. Cała różnorodność form zyskuje jednolity sens, prosty sens walki ${ }^{55}$.
\end{abstract}

Literatura powstająca w przekonaniu o konieczności podjęcia walki miała za zadanie łagodzić napięcia społeczne, wywołane działaniami wojennymi oraz jednoczyć społeczeństwo wokół słusznej sprawy, a także wspomagać aparat państwowy w podporządkowaniu jednostki celom państwowym i dyscyplinie. Tylko w pierwszych latach wojny ukazało się w Cesarstwie Niemieckim na łamach różnych pism i antologii ponad $3 \mathrm{mln}$ wierszy patrio-

52 Ibidem.

53 M. Wundt, Deutsche Staatsauffassung, „Deutschlands Erneuerung” 2/1918, s. 199; przedruk w „Aufrufe und Reden”, s. 152 i n.

${ }^{54}$ Por. J. Golec, Postawy antywojenne...

55 E. Jünger, Der Kampf als inneres Erlebnis, Berlin 1922, s. 116. 
tycznych, w samej zaś prasie w miesiącu sierpniu 1914 r. ok. 50 tys. ${ }^{56}$, co stanowi swoisty rekord produkcji. Oprócz wierszy drukowano kazania wojenne, śpiewniki, broszury, ulotki i pieśni żołnierskie.

W tym samym czasie na gruncie łódzkim powstaje literatura bardzo podobna w swej wymowie, choć nie tak liczna, jak w przypadku wierszy patriotycznych na terenie Cesarstwa Niemieckiego. Dla przykładu na łamach tygodnika "Deutsche Post” (1915-1918), wydanego łącznie w 176 numerach, wydrukowano w sumie 76 wierszy, z czego najwięcej w drugim i trzecim roku wojny ${ }^{57}$. W porównaniu ze statystykami odnoszącymi się do Cesarstwa Niemieckiego, gdzie liczba tekstów przekraczała tysiące, liczba łódzkich utworów nie była wysoka. Ich autorami byli głównie lokalni pisarze, tacy jak Friedrich Flierl, Franz Lüdtke czy Margarete Grüner.

Wśród łódzkich autorów, popularyzujących idee roku 1914 na łamach tygodnika „Deutsche Post”, na uwagę zasługuje Friedrich Flierl. W swoich wierszach przedstawia udział w wojnie jako obowiązek wobec państwa i historii. Przekonanie to popycha do bezkrytycznej afirmacji wojny jako egzaminu osobowości i wewnętrznego, wzniosłego przeżycia. W wierszu Wir möchten auch, der Friede lebt... [My także chcemy pokoju...] autor odwołuje się do wspomnianego niemieckiego „oczyszczenia”, któremu nadaje sens mistyczny, określając go jako „zbawienie” (niem. Heil) następującymi słowami:

Wir beten um das große Heil

das uns, die restlos sind gebannt

an unsrer Mütter Vaterland

vor neuer Leidenschaft bewahrt ${ }^{58}$.

Natomiast w wierszu Brüder [Bracia] ten sam autor pokazuje niemieckiego żołnierza jako niezwyciężonego herosa otoczonego aurą wzniosłości:

Das junge Blut, das Heldenblut

Hört nicht das Lied vom Sterben.

Singt! „Ist der Feind auch dichtgeschart,

wir sind die Meister seiner Wut!

Des alten Deutschschwurs Erben

Bringt niemand in der Welt zu Fall! ${ }^{59}$

56 Por. Cz. Karolak, W. Kunicki, H. Orłowski, Dzieje kultury...; K. Vondung, Deutsche Apokalypse 1914, [w:] Das wilhelminische Bildungsbürgertum. Zur Sozialgeschichte seiner Ideen, hrsg. v. K. Vondung, Göttingen 1976, s. 154.

57 W 1916 r. ukazały się 22 wiersze, natomiast w 1917 r. - 28.

${ }^{58}$ F. Flierl, Wir möchten auch, der Friede lebt..., „Deutsche Post”, 13.08.1916, s. 2 [Modły wznosimy o wielkie zbawienie, / niech od nas, bez reszty przywiązanych / do ziem ojczystych naszych matek, / nowe cierpienie zechce oddalić... Tłumaczenie M.K.]. Utwór nigdy nie ukazał się w żadnym tomie zbiorowym.

59 F. Flierl, Brüder, „Deutsche Post”, 19.07.1915 [O młoda krwi, krwi bohaterska / nie słuchaj pieśni, pieśni o śmierci. / Śpiewajcie! „Choć wróg w szyku zwartym, / opór stawimy 
Wiersz emanuje militarno-politycznym optymizmem, który ma zachęcić do ponoszenia ofiar na polu walki. W innym utworze Auf dem Weg [W drodze] Flierl opisuje żołnierza oraz jego tężyznę fizyczną:

Die Beine sind uns hart wie Stein,

und unsere Arme sind wie Erz,

Glut, Kälte, schafft uns nimmer Pein.

Warm in der Brust schlägt unser Herz ${ }^{60}$.

Idee roku 1914 obecne są również w twórczości łódzkiej pisarki Margarete Grüner, która w wierszu Kriegsnacht [Wojenna noc] pisze wprost: „Wir Kämpfen alle den heiligen Krieg"61 [Walczymy wszyscy w tej świętej wojnie]. Autorka afirmuje wojnę jako „świętą”, odwołując się tym samym do słów Wernera Sombarta, według którego wojna to rzecz „najświętsza na ziemi”62. Podobnie określa wojnę anonimowy autor wiersza Sieg bei Lodz [Zwycięstwo pod Łodzią]: „Der grosse heilige deutsche Krieg” [Wielka święta wojna niemiecka] ${ }^{63}$. Celem oficjalnej niemieckiej propagandy było podtrzymanie morale wojennego społeczeństwa, ale również zjednoczenie go wokół „słusznej” sprawy, a jednym z jej zabiegów było przywoływanie postaw bohaterów i ich heroicznych czynów. Wielu pisarzy odwołuje się w swoich utworach do wspomnień sukcesów na polu walki i do wierszy opiewających bohaterów tej wojny. Przykładem jest wiersz Franza Lüdtke, poświęcony generałowi Litzmannowi ${ }^{64} \mathrm{w}$ trzecią rocznicę bitwy łódzkiej: „Einer aus Eisen und Leben, Held, deutscher Mann - Litzmann" [Człowiek z żelaza i życia, bohater, Niemiec - Litzmann].

Niemieckich żołnierzy walczących na polach bitewnych i opisujących wojnę cechuje niezwykła lojalność wobec ojczyzny. Werner Wickel tak pisał w wierszu Am Soldatenfriedhof zu Rzgow [Na cmentarzu wojennym w Rzgo-

jego natarciu! / Dziedziców starej niemieckiej przysięgi / nikt na tym świecie nie pognębi. Tłumaczenie M.K.]. Utwór nigdy nie ukazał się w żadnym tomie zbiorowym.

${ }^{60}$ F. Flierl, Auf dem Weg, „Deutsche Post”, 9.08.1915, s. 3 [Nogi twarde niczym głaz / i ręce mamy jak z żelaza, / nie straszny nam chłód ni żar, / gorące serce bije w nas. Tłumaczenie M.K.]. Utwór nigdy nie ukazał się w żadnym tomie zbiorowym.

${ }^{61}$ M. Grüner, Kriegsnacht, „Deutsche Post”, 2.07.1916, s. 3. Utwór nigdy nie ukazał się $\mathrm{w}$ żadnym tomie zbiorowym.

${ }^{62}$ Por. Cz. Karolak, W. Kunicki, H. Orłowski, Dzieje kultury...

${ }^{63}$ [b.a.], Sieg bei Lodz, „Sonderausgabe der Deutschen Lodzer Zeitung”, 8.02.1916, s. 2.

${ }^{64}$ Karl Litzmann (ur. 22 stycznia 1850 r. w Neu Globsow, powiat Ruppin, Brandenburgia, zm. 28 maja 1936 r. w Neu Globsow) w czasie I wojny światowej był generałem dowodzącym wojskami niemieckimi w Bitwie pod Łodzią. W okolicach Brzezin odniósł zwycięstwo nad oddziałami rosyjskimi, za co nadano mu tytuł "Der Löwe von Brzeziny” (Lew spod Brzezin). Por. Th. Jakobs, Der Löwe von Brzeziny, Hamburg 1934; P. Dzieciński, Wykorzystanie postaci generała Karla Litzmanna przez hitlerowska propagandę na terenie Łodzi, [w:] Wielka Wojna..., s. 76; P. Marciniak, Operacja łódzka 1914, „Dzieje Najnowsze” 2/2007, s. 162. 
wie] o swoim przywiązaniu do niemieckiej ojczyzny: „Fern der Heimat - treu dem heimischen Herde" [Z dala od ojczyzny - wierni rodzinnemu ognisku ${ }^{65}$.

Poza wierszami treści propagandowe wzbogacały także liczne kazania ${ }^{66}$. W tym kontekście na uwagę zasługują zwłaszcza te autorstwa ewangelickiego pastora Paula Althausa. Należał do tej warstwy niemieckiego społeczeństwa, która z entuzjazmem odnosiła się do wybuchu I wojny światowej i traktował ją jako „świętą wojnę” oraz „mszę świętą”67. Pastor przybył do Łodzi w czasie I wojny światowej. Miasto stanowiło istotny etap $w$ jego rozważaniach teologicznych. To właśnie $\mathrm{w}$ tym wielonarodowym mieście powstały jego koncepcje dotyczące niemieckiej narodowości [Volkstum] oraz niemieckości [Deutschtum], które stały się później podstawą poglądów na temat teologii stworzenia i obiektem rozważań o ideologii volkistowskiej ${ }^{68}$.

Kiedy pastor Althaus przybył do Łodzi, miasto miało za sobą bogatą historię wielokulturową i wielonarodową. Z uwagi na postępujące procesy asymilacyjne oraz zanikanie niemieckiego charakteru społeczność niemiecka, wyrosła na tym gruncie, stała się dla pastora przedmiotem szczególnego zainteresowania i troski. Wśród niemieckich mieszkańców Łodzi u progu I wojny światowej w znacznym stopniu zatarły się wyraźne kontury narodowościowe. Dotyczyło to w szczególności niższych warstw ludności niemieckiej, które z uwagi na częste kontakty z innymi narodowościami szybciej ulegały asymilacji, a także mieszkańców małych miasteczek i wsi, którym trudniej było utrzymać więź z dawną ojczyzną. Na prowincji szkoła niemiecka nie zawsze była dostępna, a życie w otoczeniu polskiej kultury i tradycji znacznie przyspieszało proces polonizacji. Inaczej natomiast miała się rzecz w przypadku przemysłowców, stanowiących grupę niezwykle homogeniczną, przez długi czas odporną na procesy polonizacji, co odróżniało ją od niemieckiej burżuazji z Warszawy, ulegającej dość szybko spolonizowaniu. Dodatkowo zacieraniu konturów narodowościowych ludności niemieckiej sprzyjała polityka oświatowa władz w odrodzonym państwie polskim, które musiało ponownie scalić trzy obszary byłych zaborów nierówne pod wieloma względami. W marcu 1919 r. wprowadzono uchwałę Rady Ministrów, a w 1932 r. ustawę o szkołach prywatnych, w myśl których nauczanie w miejscowościach, zamieszkałych przez większość polską, miało odbywać się w języku polskim. W wyniku tej polityki zmniejszyła się liczba szkół z wykładowym językiem

${ }^{65}$ W. Wickel, Am Soldaten Friedhof zu Rzgow, „Deutsche Lodzer Zeitung”, 16.09.1917, s. 2.

${ }^{66}$ Obszerne fragmenty kazań pastora Althausa opublikowano w tekście: I wojna światowa w świetle badań literaturoznawczych. Kazania pastora Paula Althausa z lat 1915-1917, [w:] Między wielkq historiq..., s. 111-127.

${ }^{67}$ Por. Paul Althaus: Kriegsdienst und Gottesdienst, 21.02.1915, Brzeziny, [w:] P. Althaus, Kommt, laßt uns anbeten!: 8 Kriegspredigten in Russisch-Polen, Berlin 1915, s. 47.

${ }^{68}$ Por. T. Hetzer, „Deutsche Stunden“. Volksgemeinschaft und Antisemitismus in der politischen Theologie bei Paul Althaus, München 2009. 
niemieckim. Inne ważne czynniki, przyspieszające procesy asymilacyjne po 1918 r., to: wprowadzenie powszechnego obowiązku służby wojskowej, rosnąca atrakcyjność polskiej kultury oraz języka polskiego, którym posługiwano się w urzędach oraz zawieranie mieszanych małżeństw ${ }^{69}$.

Procesy polonizacyjne wśród społeczności niemieckiej w Łodzi nie były zjawiskiem popieranym przez znaczną część tego środowiska. Postawy nacjonalistyczne zaczęły się kształtować jeszcze przed wybuchem I wojny światowej i w całej Kongresówce można było zaobserwować wzmożoną działalność organizacji narodowoniemieckich. Niezwykłą aktywnością wykazywały się w Łodzi trzy wielkie związki niemieckie II Rzeszy, do których należały Gustav Adolf Verein, Allgemeiner Deutscher Schulverein zur Erhaltung des Deutschtums im Auslande oraz Deutscher Flottenverein ${ }^{70}$. Świadczyło to o ogromnej roli tego miasta w organizowaniu życia społecznego tamtejszej ludności niemieckiej. Wymienione organizacje szerzyły protestantyzm i uprawiały propagandę narodowoniemiecką, wspierając tworzenie lokalnych organizacji. 5 marca 1916 r. powstał Deutscher Verein für Lodz und Umgegend, który w lutym następnego roku rozszerzył zakres oddziaływania na całą strefę okupacyjną i zmienił nazwę na Deutscher Verein, Hauptsitz in Lodz. Jednym z celów tej organizacji była bezwzględna walka z polonizacją miasta. Podobne cele realizowała również inna organizacja, a mianowicie utworzony w 1924 r. Deutscher Volksverband in Polen (dalej: DVV). Organizacja ta starała się zwalczać nie tylko przejawy asymilacyjne wśród niemieckiej społeczności, ale również dążyła do odbudowy niemieckiego szkolnictwa. Znaczną radykalizację życia politycznego ludności niemieckiej przyniósł rok 1933, kiedy hitlerowska polityka narodowościowa zaczęła pojmować wspólnotę narodową Niemców niezależnie od miejsca zamieszkania, co wpłynęło na zainteresowanie Niemcami w Polsce, w tym w Łodzi. W konsekwencji lokalne organizacje, takie jak wspomniana wcześniej DVV, starały się podejmować wszelkie możliwe działania integracyjne, służące podniesieniu świadomości narodowej Niemców niemających kontaktów ze starą ojczyzną. Szczególny nacisk kładziono na naukę języka niemieckiego, ale otwierano także biblioteki, propagowano czytelnictwo literatury i prasy oraz podtrzymywano tradycję historyczną i wojskową przedhitlerowskich Niemiec. 0 ile kilkadziesiąt lat wcześniej, na początku rozwoju Łodzi przemysłowej, konflikty powstawały przede wszystkim z powodu różnic klasowych i majątkowych, podziały religijne były ważniejsze niż językowe, o tyle po $1918 \mathrm{r}$. wyraźne stały się podziały narodowościowe. Wszelkie zabiegi na polu społecznym, politycznym i kulturowym, podejmowane przez narodowo nastawionych Niemców, spowodowały pod koniec lat 30. głęboką polaryzację społeczeństwa polskiego i niemieckiego ${ }^{71}$.

${ }^{69}$ Por. Niemcy w Polsce 1945-1950. Wybór dokumentów, red. W. Borodziej, H. Lemberg, t. 2, Warszawa 2000.

${ }^{70}$ Por. M. Cygański, Mniejszość niemiecka w Polsce w latach 1918-1939, Łódź 1962.

71 Por. Niemcy $w$ Polsce... 
Paul Althaus wspierał swoją działalnością niemiecki ruch narodowy w Łodzi. Dla łódzkiej społeczności wygłosił ponad sto kazań, publikowanych najpierw w lokalnej gazecie codziennej „Deutsche Lodzer Zeitung” oraz tygodniku „Deutsche Post”, a następnie wydanych w kilku tomach, z których pierwszy pt. Der Tod ist verschlungen in den Sieg ${ }^{72}$ ukazał się w 1915 r., drugi pt. Lodzer Kriegsbüchlein ${ }^{73}$ w 1916 r., natomiast trzeci Um Glauben und Vaterland $^{74} \mathrm{w} 1917 \mathrm{r}$. Althaus wygłaszał swoje kazania w każdą niedzielę, początkowo w kościele św. Jana w Łodzi, później zaś w parafii ewangelicko-augsburskiej w Zgierzu. Krąg słuchaczy liczył od 2000 do 3000 osób. Jego działalność pasterska nie ograniczała się jedynie do odprawiania nabożeństw, gdyż po założeniu gimnazjum dziewczęcego nauczał tam religii. Utworzenie właśnie tej szkoły było według Althausa ważnym wydarzeniem dla społeczności niemieckiej Łodzi. Pastor był przekonany, że niemieccy luteranie w Polsce przetrwają tylko wtedy, gdy zachowają swój niemiecki charakter oraz pobożność, a szkoła stwarzała ku temu trwałe fundamenty ${ }^{75}$.

Kazania pastora Althausa były przesiąknięte niemieckim duchem i ideologią narodowoniemiecką. Ich autor rozwinął w nich stosunkowo radykalnie rozumiane pojęcie volkizmu, które kształtowało się w szczególnych warunkach. Wiele uwagi poświęcił sytuacji mniejszości niemieckiej w Łodzi przed i w czasie I wojny światowej, w szczególności zaś problemom tożsamości. W swoich tekstach łączył teologię z polityką, wojną i społeczno-kulturalną sytuacją Niemców w Łodzi. Dlatego jego teksty nie były wyłącznie tekstami teologicznymi w pełnym znaczeniu tego słowa, lecz przede wszystkim tekstami politycznymi, w których wyrażał kontrowersyjne opinie, sięgając przy tym do argumentów teologicznych. Często podkreślał, że wojna toczy się nie tylko na froncie - również poza nim trwa walka o zachowanie niemieckiej krwi ${ }^{76}$.

Jego kazaniom przyświecały zasadniczo dwa cele. Po pierwsze były poświęcone społeczności niemieckiej, która jako wyrosła na gruncie wielokulturowości miała stać się świadoma swojego pochodzenia i tożsamości, a którą rozumiał w sposób bardzo konserwatywny w duchu ideologii volkistowskiej ${ }^{77}$, po drugie miały zwrócić uwagę państwa niemieckiego na sytuację mniejszości niemieckiej w Polsce $^{78}$.

72 P. Althaus, Der Tod ist verschlungen in den Sieg!, Lodz 1915.

${ }^{73}$ P. Althaus, Lodzer Kriegsbüchlein. Deutsch-evangelische Betrachtungen, Göttingen 1916.

${ }^{74}$ P. Althaus, Um Glauben und Vaterland. Neues Lodzer Kriegsbüchlein, Göttingen 1917.

75 Por. G. Jasper, Paul Althaus 1888-1966. Professor, Prediger und Patriot in seiner Zeit, Göttingen 2013.

${ }^{76}$ Por. P. Althaus, Lodzer Kriegsbüchlein...

77 Ibidem.

78 Por. T. Hetzer, „Deutsche Stunden“. Volksgemeinschaft und Antisemitismus in der politi- 
Jedną z najważniejszych myśli towarzyszących pastorowi w jego kazaniach było przekonanie, że dla Niemców z Łodzi prawdziwą ojczyzną jest państwo niemieckie, o którym nie powinni zapominać. Althaus nie próbował zrozumieć szczególnej historii Niemców łódzkich, których rodzice i dziadkowie urodzili się już poza Niemcami. Nie posługiwał się w swoich kazaniach kategorią Heimat, lecz Vaterland. Ignorował wręcz możliwość nowej transkulturowej świadomości. W przedmowie do tomu z 1917 r. Paul Althaus tak pisał o obowiązku walki za niemiecką ojczyznę:

Um Glauben und Vaterland ringen die Besten der Deutschen in Polen in diesen schweren Jahren. Um den Christenglauben, dass er in der Wirrnis harter Tage nicht sterbe. Um ein Vaterland: aus der stumpfen Vaterlandlosigkeit sind sie aufgestanden, mit der brennenden Sehnsucht nach einem Vaterlande im Herzen, nach dem heiligen Lande, für das man Liebe und Leben opfern kann, das aus der furchtbaren Enge des Geldgeistes zu erlösen vermag. Sie ringen bei sich um das alte deutsche Vaterland, daß es von denen, die es nie sahen, mit stolzer Treue neu gegrüßt werde ${ }^{79}$.

Tematyka, jaką pastor poruszał w łódzkich kazaniach, była różnorodna i dotyczyła ludzkich słabości, miłości bliźniego, przemijania, cierpienia oraz aktualnie trwającej wojny. W licznych fragmentach kaznodzieja zajmował stanowisko wobec wydarzeń na froncie, w wielu odwoływał się również do sytuacji łódzkich Niemców, nie tylko zresztą tej duchowej, ale także i przede wszystkim społeczno-politycznej. Był przekonany, że łódzcy Niemcy po odzyskaniu przez Polskę niepodległości zapragną pozostać Niemcami, zachowując swoją kulturę, język, a tym samym łączność z macierzą. Nie brał pod uwagę specyficznego rozwoju miasta, także konieczność konsolidowania państwa polskiego po 1918 r. była dla niego nieistotna. Pielęgnowanie niemczyzny poza granicami Niemiec okazało się ogromnym wyzwaniem dla państwa niemieckiego, a I wojna światowa stała się dla pastora Althausa szczególnym pretekstem do zachowania czystości języka niemieckiego:

Jede Entscheidungsstunde deutscher Geschichte macht die Freude an unserer Muttersprache aufs neue lebendig. Jede große deutsche Zeit drückt aber auch der Sprache ihre Spuren auf. Seit Kriegsbeginn führt die deutsche Heimat einen zähen Kampf gegen die Fremdwörter ${ }^{80}$.

schen Theologie bei Paul Althaus, München 2009.

79 P. Althaus, Um Glauben..., s. VII [Za wiarę i ojczyznę walczą w tych trudnych czasach najlepsi spośród Niemców w Polsce. Za wiarę chrześcijańską, by nie umarła w zamęcie ciężkich dni. Za ojczyznę: przebudzili się ze zobojętnienia wobec braku ojczyzny, z trawiącą serce tęsknotą za ojczyzną, za świętym krajem, dla którego można poświęcić miłość i życie, który zdoła wybawić od straszliwej ciasnoty ducha mamony. Walczą u siebie o starą niemiecką ojczyznę, by ci, którzy jej nigdy nie widzieli, z dumą mogli oddać jej na nowo pokłon. Tłumaczenie M.K.].

${ }^{80}$ Ibidem, s. 109 [Każda rozstrzygająca chwila niemieckiej historii na nowo podsyca radość z naszej ojczystej mowy. Każda ważna dla Niemiec chwila odciska swe piętno także na 
Według niego wojna sprawiła, że wiele słów nabrało nowego znaczenia, którymi autor nawoływał do wojny i agresji:

Eine Sprache lebt erst dann wirklich, wenn ihre Edelworte nicht nur Reliquien, Schatten und Begriffe für das lebende Geschlecht sind, sondern heißen Lebens voll. Es ist herrliche Gesundung der Sprache, wenn alte Worte, in denen der Väter heiliges deutsches Erleben geborgen war, wieder zu sprechen und zu klingen beginnen. Volk, Vaterland, Liebe, Treue, Dienst, Opfer, Not, Gott - vor dem Kriege waren diese Wörter uns oft genug leblose Schatten, entseelte Hüllen. Aber es ist ihnen ergangen wie den Schatten der Unterwelt in der griechischen Sage: wenn sie Blut tranken ${ }^{81}$.

Przytoczony fragment odzwierciedla entuzjastyczny stosunek Althausa do wojny. W wielu kazaniach przekonywał o słuszności prowadzenia wojny przez Niemcy i gotowości do ponoszenia ofiar w imię trwania niemieckiego narodu. Był przeświadczony, że właśnie czas wojny buduje wspólnotę rodzinną i narodową, jest bowiem okresem próby dla takich wartości, jak miłość do ojczyzny i rodziny czy prawo narodu do ojczystej ziemi. Utożsamiał wojnę prowadzoną przez naród niemiecki ze świętością. W kazaniu Deutscher Frühling! [Niemiecka wiosna!] pisał: „Jedes deutsche Feld, jeder Anger ist im Kriegsjahre doppelt heilig. Unser Volk streitet für seine Erde, aber seine Erde kämpft selber mit in dem Riesenkampfe" [Każda piędź niemieckiej ziemi jest w czasie wojny podwójnie święta. Nasz naród walczy o swoją ziemię, a także jego własna ziemia toczy wraz z nim bój w tej wielkiej walce $]^{82}$. Słowa te wyraźnie definiują charakterystyczny dla późniejszej nazistowskiej ideologii pogląd, że niemiecki naród ma prawo do przestrzeni życiowej. Prawo narodu niemieckiego do powiększania terytorium, które również tłumaczy politykę ekspansji, wyraża się także w sformułowaniu „Recht auf ein größeres Deutschland" [prawo do większych Niemiec], którym Althaus często się posługuje. Nawoływanie do walki widać wyraźnie również w innym fragmencie kazań:

Mitten in Kampfeszeiten mag es uns wohl die Sehnsucht nach einem Jahrhundert des Friedens ohne Kriege der Nationen und ohne völkische Kämpfe ergreifen. Aber wir wollen nicht schwächlich jammern ${ }^{83}$.

języku ojczystym. Od początku wojny niemiecka ojczyzna toczy zacięty bój z obcymi słowami. Tłumaczenie M.K.].

81 Ibidem, s. 111 [Język naprawdę ożywa dopiero wtedy, gdy jego szlachetne słowa dla żyjących pokoleń to nie tylko relikwie, cienie i pojęcia, lecz żywa materia. Język wspaniałe ożywa, gdy stare słowa, w których utkwiła święta niemiecka historia przodków, znów zaczynają przemawiać i rozbrzmiewać. Naród, ojczyzna, miłość, wierność, służba, ofiara, bieda, bóg - przed wojną te słowa były dla nas często pozbawionymi życia cieniami, bezdusznymi szczątkami. Ale stało się z nimi tak jak z duszami zmarłych w greckiej mitologii: gdy skosztowały krwi, odzyskały świadomość i życie. Tłumaczenie M.K.].

${ }^{82}$ Ibidem, s. 40. Tłumaczenie M.K.

83 P. Althaus, Via dolorosa, [w:] idem, Um Glauben ..., s. 96 [Wśród wojennej zawieruchy 
Althaus często wyraża myśl, że wojna jest bardzo potrzebna całemu światu, gdyż sprawi, że powstanie nowy ład, korzystniejszy dla narodu niemieckiego:

Welcher Deutsche stände nicht unter dem Zauber dieses verheißungsvollen Klanges: neu! Viele mag es geben, auch gerade hier in Lodz, denen das Wort ,neue Zeit' bitter klingt. Darin gerade erblicken sie den Jammer des Krieges für sich selbst, dass er alte, bequeme, geliebte Verhältnisse zerschlug. Wir anderen aber, deren Blick mehr in die Weite und Tiefe der Dinge geht, begreifen von Monat zu Monat deutlicher, wie unerträglich und voll quälender Spannung die Verhältnisse in der Welt und auch in unserem Deutschland vor dem Kriege waren. Dafür segnen wir den Weltkrieg, dass er eine neue Welt zu schaffen anhebt ${ }^{84}$.

Dla pastora Althausa wojna jest niezwykle istotnym elementem historii Niemiec, które na przestrzeni dziejów stoczyły wiele zwycięskich bitew i w efekcie utrwaliły niemiecką potęgę. W kazaniu Via dolorosa autor mówi o szczególnym losie państwa niemieckiego, które na swej drodze przeżyło wiele wojen, sankcjonując tym samym słuszność prowadzenia działań militarnych:

Über unzählige Schlachtfelder, durch blutiges Ringen ohne Ende, durch tausendfaches Weh hat der Weg zu Deutschlands Größe seit Alters geführt. Keinen Schritt vorwärts hat unser Volk in seiner langen Geschichte tun können ohne harte Kämpfe und tiefe Wunden. Um seiner Freiheit willen hat es 1813 geblutet, für seine Einheit 1866 und 1870, und heute muss es seine Zukunft und seinen gottgeschenkten Weltberuf unter schweren Schmerzen und furchtbarer Erschütterung verteidigen ${ }^{85}$.

Przyglądając się stanowisku Althausa wobec wojny, można stwierdzić, że w jej wybuchu pastor dostrzega ratunek dla polskich Niemców, gdyż jak uważał, dopiero wojna skłoni tę społeczność do refleksji nad własną tożsamością. „[...] In jedem Falle ist vielleicht der Ausbruch des Krieges für das

może nas ogarnąć tęsknota za czasami pokoju, bez wojen między narodami i innych walk narodowościowych. Ale nie chcemy jedynie bezsilnie lamentować. Tłumaczenie M.K.].

84 P. Althaus, Deutsche Pfingsten, [w:] idem, Um Glauben..., s. 73 [Kto z Niemców nie poddałby się urokowi tego wielce obiecującego dźwięku: nowy! Pewnie niemało jest, również tu w Łodzi takich, dla których słowa „nowe czasy” brzmią gorzko. Właśnie w nich upatrują dla siebie samych niedorzeczności wojny, która zniszczy stare, wygodne, ukochane stosunki. My inni natomiast, których wzrok sięga dalej w głąb rzeczy, z miesiąca na miesiąc widzimy coraz wyraźniej, jak bardzo nieznośne i straszliwie napięte były stosunki na świecie i również u nas, w Niemczech, przed wojną. Dlatego błogosławimy wojnę światową, bo przyniesie nowy ład. Tłumaczenie M.K.].

85 P. Althaus, Via dolorosa ..., s. 95 [Od zawsze droga Niemiec ku wielkości wiodła przez niezliczone pola bitewne, niekończące się krwawe walki, bezmierne cierpienie. W swej długiej historii nasz naród nie mógł uczynić ni jednego kroku naprzód bez ciężkich bitew i głębokich ran. Przelewał krew za wolność w 1813, za jedność w 1866 i 1870 r. Także dziś musi bronić swej przyszłości i swej danej mu przez Boga pozycji, doznając srogich cierpień i okrutnych wstrząsów. Tłumaczenie M.K.]. 
polnische Deutschtum die Rettung gewesen. Denn die Polonisierung hätte, wenigstens in den Städten, bald die ganze deutsche Gesellschaft angefressen"86 - pisał Althaus w 1916 r. Nie brał natomiast pod uwagę, w jakich warunkach żyli Niemcy w Polsce, przyczyn, dla których ich przodkowie znaleźli się z dala od pierwotnej ojczyzny. Ignorował również analogiczną sytuację innych grup narodowościowych w Niemczech - nie nawoływał do tworzenia polskich, francuskich, czeskich, duńskich stowarzyszeń w Niemczech. Zakładał wyższość niemieckiej kultury.

Wojna obnażała według pastora Althausa „prawdę”: „Jesu Kreuz ist Weltgericht. Darum gehören Krieg und Karfreitag zusammen. Denn auch der Krieg reißt Völkern und Menschen die Masken ab und zeigt uns die Wahrheit" [Krzyż Jezusa to Sąd Ostateczny. Dlatego wojna i Wielki Piątek mają ze sobą wiele wspólnego. Również wojna zdziera z narodów maski i ukazuje prawdę $]^{87}$. Posługiwał się argumentacją religijną i tworzył typowe fałszywe sylogizmy, by nie tylko usprawiedliwić wojnę, lecz także uczynić ją świętym obowiązkiem każdego Niemca.

Gdy Althaus wygłaszał kazania, stawał się przewodnikiem wprowadzającym swych słuchaczy w przestrzeń religijno-patriotycznego misterium, dla którego wszechobecny był germanocentryzm. Świadczą o tym często występujące frazy, dla których znamienne jest podkreślanie pozytywnie konotowanego przymiotnika deutsch: die Sonne deutschen Sieges [słońce niemieckiego zwycięstwa], die deutsche Märzsonne [niemieckie słońce marcowe], der deutsche Frühling [niemiecka wiosna], deutsche Felder [niemieckie pola]. Specyficzny dla epoki kod myślenia i działania wniknął w strukturę kazań i podpowiedział zasadę reżyserowania przestrzeni komunikacyjnej. „Ja” pastora Althausa to podmiot, przeświadczony o szczególnym posłannictwie Niemców z Rzeszy (tzw. Reichsdeutsche) wobec społeczności niemieckojęzycznej z Łodzi, zaś sam autor pełni rolę pośrednika między Niemcami łódzkimi i rdzennymi. Już na płaszczyźnie językowej można poczynić obserwację, że w Łodzi Niemiec Niemcowi nierówny. Widać to dokładnie przy zestawieniu dwóch zaimków osobowych: my (Niemcy z Rzeszy) oraz wy (Niemcy łódzcy), a także częste używanie zaimków dzierżawczych: nasze - wasze.

Ihr nennt uns, die Reichsdeutschen, so oft glücklicher als euch selbst. Und habt ihr nicht recht? Unsere Jugend darf für die deutsche Sache das Schwert ziehen, die eure sehnt sich innerlich danach oder wird, reifer geworden, vom Zwist der Gefühle umhergetrieben oder ist, inmitten aller häuslichen und lokalen Interessen, in der Geschäftsluft eurer Stadt noch garnicht zum Verständnis dessen erwacht, dass eine große Stunde für die deutsche

${ }^{86}$ P. Althaus, Lodzer Kriegsbüchlein..., s. 17 [W każdym razie wybuch wojny był dla polskich Niemców ratunkiem, gdyż w innym wypadku polonizacja, przynajmniej w miastach, w krótkim czasie zlikwidowałaby całą niemiecką społeczność. Tłumaczenie M.K.].

87 P. Althaus, Cruzifixus, [w:] idem, Um Glauben ..., s. 51. Tłumaczenie M.K. 
Jugend allüberall jetzt da ist. Unsere Zukunft, in Gottes und unseres herrlichen Heeres Gewalt geboren, ist nach Menschenerwägen klar, sieghaft und groß. Die eure scheint noch so unsicher; das will manche arbeitsfrohe Hand lähmen und zieht immer wieder wie ein Schatten über die gemeinsamen Tage deutscher Freude, die wir miteinander in Lodz erleben, ihr und wir ${ }^{88}$.

W kazaniu wygłoszonym 21 października 1915 r. pastor Althaus wspomina jedną z większych operacji militarnych I wojny światowej na froncie wschodnim - bitwę pod Łodzią. Rozegrała się na przełomie listopada i grudnia 1914 r.:

Und auch ihr Lodzer Deutschen, kommt her und sammelt euch mit uns zu der großen deutschen Totensonntagsgemeinde! Auch euch hat doch das Sterben deutscher Söhne das Herz tief bewegt, und gerade heute gehen eure Gedanken um ein Jahr zurück zu den schweren Novembertagen 1914. Heute, am 21. November, ist es ein Jahr her, dass am Nordostausgange von Brzeziny die schweren Kämpfe im Rücken unserer Truppen begannen, die dann mit dem glorreichen Durchbruche endeten. Morgen, am 22. November, kehrt der Tag wieder, an dem im vergangenen Jahre rings um Lodz, zumal bei Rzgow, die Kämpfe am heißesten und blutigsten entbrannten; viele der Massengräber tragen das Datum des 22. November. Liebe Deutsche von Lodz, euer Blut, deutsches Blut war es, das da floß. Lodz ist rings umtränkt, umflossen mit deutschem Blute! Und ist es nicht auch für euch geflossen? ${ }^{89}$

\section{Althaus za pomocą zestawienia my - Niemcy z Rzeszy i wy - Niemcy łódz-} cy kreśli obraz dwu nienależących do siebie światów i pokazuje ich dychotomię, którą chce przezwyciężyć. Stwarza tym samym pewnego rodzaju dystans między kaznodzieją i słuchaczami, podporządkowany celom dydaktycznym,

88 P. Althaus, Ihr und wir, [w:] idem, Lodzer Kriegsbüchlein..., s. 19 [0 nas, Niemcach z Rzeszy, często mówicie, że jesteśmy o wiele bardziej szczęśliwi niż wy sami. Lecz czyż nie macie racji? Naszej młodzieży wolno dobyć miecza w obronie niemieckiej sprawy, wasza zaś tęskni za tym w skrytości ducha lub w dojrzalszych latach przeżywa mieszane uczucia, albo też wśród wszystkich tych spraw domowych i lokalnych, w przesiąkniętym interesami powietrzu waszego miasta jeszcze się nie ocknęła, by zrozumieć, że teraz dla niemieckiej młodzieży wszędzie wybiła wielka godzina. Nasza przyszłość, zrodzona z woli Boga i naszej wspaniałej armii, jest jasna, zwycięska i wielka. Wasza natomiast wydaje się wciąż niepewna. To sprawia, że niejedna ręka chętna do pracy omdlewa i człowiek wciąż błądzi niczym cień wśród wspólnych dni niemieckiej radości, jaką przeżywamy razem w Łodzi, wy i my. Tłumaczenie M.K.].

${ }^{89}$ P. Althaus, Der Tod ist..., s. 5 [Przybądźcie również wy, Niemcy łódzcy i przyłączcie się do wielkiej niemieckiej wspólnoty z okazji Święta Zmarłych! Także wasze serca głęboko poruszyła śmierć niemieckich synów i właśnie dziś powracacie w myślach do wydarzeń sprzed roku, z listopada 1914. Dziś, 21 listopada, mija rok od rozpoczęcia przez nasze wojska na północny wschód od Brzezin ciężkich walk, zakończonych zwycięskim odwrotem. Jutro, 22 listopada, znów przypada rocznica najbardziej zaciętych i krwawych starć, do jakich doszło w minionym roku w okolicy Łodzi, zwłaszcza pod Rzgowem. Na wielu masowych grobach widnieje data 22 listopada. Drodzy łódzcy Niemcy, tam popłynęła wasza krew, niemiecka krew. Łódź zalana, pogrążona jest ze wszystkich stron w niemieckiej krwi! I czy nie przelano jej także za was? Tłumaczenie M.K.]. 
tj. nauczaniu wypływającemu z postawy oratora - nauczyciela i przewodnika duchowego, jaką pełnił pastor w okresie wojny. Dychotomiczny obraz świata ukazuje również inny podział, a mianowicie na dobro i zło. Kazanie, które ma być drogowskazem wiary, jest także oparte na ocenie i wyraźnym przeciwstawieniu postępowania dobrego i złego, co stanowi podstawową cechę tekstów argumentacyjnych. Kaznodzieja wielokrotnie zwraca uwagę na konflikt między dobrą i złą drogą, spośród których należy dokonać wyboru. Kazanie odsłania przed wierzącym dwie drogi, ale do niego samego należy wybór tej właściwej, choć argumenty, jakimi posługuje się kaznodzieja, są zabiegami sugerującymi wierzącemu jedyny słuszny wybór. Niemiec, który akceptuje swoją przynależność do polskiego społeczeństwa lub odrzuca walkę jako sposób na określenie swej tożsamości, decyduje się na „zło”.

W wielu fragmentach kazań ich autor odwoływał się w argumentacji do nauki Marcina Lutra, chcąc m.in. przekonać łódzkich Niemców do zachowania w Polsce niemczyzny, mówił: „Aber Martin Luther zwingt euch immer wieder zum Deutschen zurück P. Althaus, Deutschtum und lutherische Kirche in Polen" [Ale Marcin Luther wciąż na nowo nakazuje wam powrócić do niemieckości $]^{90}$. W swoich wypowiedziach Althaus dodatkowo nadużywał autorytetu Pisma św., poddając go odpowiedniej interpretacji. Najczęściej wyjaśniał sens biblijnych źródeł w wymiarze alegorycznym i moralnym. Doszukiwał się analogii między rzeczywistością ukazaną w Biblii a sytuacją państwa i narodu niemieckiego. Analizą biblijnych zdarzeń i opisów wzbogacał argumentację swoich wystąpień, dodając patosu wydarzeniom politycznym. Często powtarzane słowa to: bohaterstwo, odwaga i wierność, które używał w kontekście nawoływania do wojny, ksenofobii czy tworzenia koncepcji wroga.

Ważnym zabiegiem retorycznym, stosowanym przez Althausa i zwiększającym wagę wypowiadanych opinii, było odwoływanie się do wypowiedzi osób znanych i powszechnie poważanych. Dlatego często przywoływał cytaty z literatury pięknej, kryptocytaty i aluzje. W swoich kazaniach powoływał się na takich pisarzy, jak Goethe, Schiller czy ojczyźniany pisarz austriacki Peter Rosegger, a także przytaczał słowa cesarza Niemiec Wilhelma II, który był zdecydowanym zwolennikiem polityki wojennej. Odwołania te nawiązują do wspólnego uniwersum kulturowego, w którym religia i patriotyzm zawsze splatały się w jedno. Wiele cytatów inkorporowanych w strukturę kazania powodowało częściową zmianę biblijnego tonu - z jednej strony stylizując kazanie na poezję wieszcza, z drugiej zaś na mowę przywódcy politycznego.

Kazania pastora Althausa są napisane w stylu perswazyjnym, dążącym do ukierunkowania odbioru wypowiedzi i zachęcającego odbiorcę do przyjęcia hierarchii, wyznaczonej przez osobę formułującą komunikat. Jego teksty

90 P. Althaus, Lodzer Kriegsbüchlein..., s. 22. Tłumaczenie M.K. 
zawierają wiele określeń wartościujących, schematyzujących, zachęcających i nakazujących. Posługiwał się przy tym wyrazami o konotacjach zdecydowanie wartościujących: dodatnich i ujemnych. Oprócz określeń wartościujących w kazaniach Althausa występuje też wiele słów o charakterze zachęcającym i nakazującym. Wyrazy te, użyte $\mathrm{w}$ trybie rozkazującym (np. należy, trzeba, musi się, wolno), uzupełnione są formą negującą (nie wolno, nie należy). Wszystkie zawierają element oceny: nadawca daje do zrozumienia, że opisywana sytuacja jest pozytywna lub negatywna i że będzie źle, jeżeli odbiorca nie zastosuje się do zalecenia lub będzie stosował odmienny system wartości. Wyrazy te stanowią słownictwo normatywne, umożliwiające mówiącemu wyrażenie własnych przekonań. Jest to słownictwo bliskie wyrażeniom imperatywnym, zachęcającym do przyjęcia określonych postaw i akceptacji określonych wartości. Przykładowo autor formułuje następujące zdania wykrzyknikowe: „Geht doch, ihr Trauernden und Bedrückten, um die Gräber der Gefallenen leuchtet der Sieg!” [Idźcie, żałobnicy i pogrążeni w smutku, nad grobami poległych świeci zwycięstwo!], „Nicht der Tod triumphiert sondern der Sieg!" [To nie śmierć triumfuje, lecz zwycięstwo!].

Kaznodzieja przepowiada z pozycji autorytetu. Jego stwierdzenia z założenia powinny być zatem przez wierzących odbierane jako nauczanie Chrystusa, artykułowane ustami człowieka. Pozycja kaznodziei, jako osoby wygłaszającej wyższą, niepodważalną prawdę, ujawnia się w sposób zauważalny w procesie analizy językowej. Kaznodzieje często przedstawiają swoje racje apodyktycznie, jako niepodlegające dyskusji. Podkreślają absolutną wartość swych twierdzeń za pomocą wielkich kwantyfikatorów, typu: wszystko, zawsze, nigdy, każdy, tylko itp. Elementy dodatkowe to słowa uogólniające i superlatywy, uprzedzanie zarzutów przez potwierdzenie (np. prawdziwy, autentyczny, niepodważalny), wybieg polegający na odejściu od szczegółów do ogólników (prawda, cierpienie, ból, zwycięstwo, sprawiedliwość, miłośc). $\mathrm{W}$ wielu zdaniach występują również powtórzenia, których zadaniem jest zwrócenie uwagi na konieczność zachowania niemczyzny wśród Niemców w Łodzi. Althaus pisze m.in.: „Darum müssen die Evangelischen Polens mit allem Ernste schon um der Zukunft ihrer Kirche willen deutsch bleiben, deutsch reden, deutsch beten, deutsch singen" [Dlatego ewangelicy w Polsce muszą z całą powagą już tylko ze względu na przyszłość swojego kościoła zadbać o niemiecki charakter, mówić po niemiecku, modlić się po niemiecku i po niemiecku śpiewać] ${ }^{91}$. Charakterystyczne jest wiązanie wspólnoty narodowej, religijnej i wspólnoty losu - Schicksalsgemeinschaft. Nie jest to jednak uzasadnione obiektywnymi faktami. Podkreślanie ewangelickości Niemców pomagało w oddzieleniu ich od katolickich Polaków.

\footnotetext{
91 Tłumaczenie M.K.
} 
Istotną rolę w perswazji językowej kazań pastora Althausa odgrywają pytania. W wielu homiliach mają one charakter ekspresywny. Nadawca takiej wypowiedzi daje w swych słowach wyraz postawie uczuciowego wzburzenia i usiłuje być jak najbardziej przekonujący. Pytania retoryczne mają spotęgować w słuchaczu proces myślenia i zastanawiania się nad przedmiotem dyskusji, a w dalszej kolejności dotarcie do prawdy. Oto kilka przykładów takich pytań retorycznych z kazań Althausa: „Czyż to wszystko nie jest zwycięstwem, wspaniałym zwycięstwem?”, „Pogrążone w żałobie wdowy i matki zapytałyby z bólem w sercu: nie masz nam nic więcej do powiedzenia?”, „Kto na świecie ma do powiedzenia ostatnie słowo, śmierć czy życie?"

Efektywność głoszonych w kazaniu treści zależy również od formy adresatywnej. Zastosowanie różnego rodzaju form adresatywnych ma na celu kreowanie określonego rodzaju związku między odbiorcą i nadawcą. W analizowanych homiliach najczęściej występuje jedna forma adresatywna (kochana wspólnoto, drodzy koledzy, drodzy Niemcy z Łodzi), której celem jest tworzenie poczucia więzi wspólnotowej, zaś formy takie jak kochani czy dro$d z y$ wskazują na chęć nawiązania bliskiego kontaktu emocjonalnego.

Perswazyjność jest ważną cechą kazań pastora Althausa. Cel, jaki pragnął uzyskać, wygłaszając swoje homilie, to głównie przekonać Niemców łódzkich o słuszności prowadzonej wojny, która stworzy na świecie nowy ład. Innym ważnym celem było wzbudzenie przekonania, że łódzcy Niemcy powinni zachować w Polsce niemczyznę i pamiętać, że ich ojczyzną są Niemcy.

\subsection{Raport z wojennych miast}

W okresie I wojny światowej wzrosło znaczenie literatury faktu i różnych zapisów dokumentalnych, ukazujących przeżycia wojenne z perspektywy zwykłych ludzi, przypadkowo wciągniętych w wir wielkiej historii i doświadczających bezmiernego okrucieństwa. Ich dramatyczne losy i utrata tożsamości dały asumpt do prezentacji różnych alternatywnych, konkurujących ze sobą narracji, dlatego też nie mamy tu do czynienia z jednym obrazem wojny, lecz z wizjami wielu twórców. Łódzka literatura tego okresu na łamach lokalnych gazet prezentowała szereg wojennych dyskursów, a szczególnie upodobała sobie przy tej okazji takie gatunki, jak dziennik czy pamiętnik. Pozwalały one bowiem spojrzeć na działania wojenne z perspektywy łodzian, stając się istotną alternatywą dla doniesień oficjalnych władz.

Jednym z pierwszych aktów wojennego okrucieństwa, które utrwaliła miejscowa literatura, było zniszczenie Kalisza. Motyw ten wykorzystali nie tylko niemieccy pisarze z Łodzi - warto wspomnieć, że stał się on również ważną częścią fabuły utworów polskich pisarzy, takich jak Maria Dąbrowska, 
Cezary Jellenta, Czesław Jankowski czy Zofia Nałkowska. Dąbrowska wykorzystała obraz zniszczenia Kalisza w dwóch powieściach: Noce i dnie oraz Przygody człowieka myślqcego. Zaprezentowana tu wizja eksponowała szczególne okrucieństwo i absurdalność wojny, której towarzyszyły bezradność, bezsilność i nastrój apokalipsy. Do tego motywu odniósł się także łódzki pisarz i dziennikarz Carl Heinrich Schultz w dzienniku Die Schrecken von Kalisch [Akty okrucieństwa z Kalisza], opartym na wspomnieniach osoby, która przeżyła atak na miasto i opowiedziała swoją historię autorowi tekstu ${ }^{92}$. Schultz opisuje nastroje panujące wśród mieszkańców, którzy 2 sierpnia 1914 r., kiedy do miasta miały wkroczyć niemieckie wojska, wylegli na uli$\mathrm{ce}^{93}$. Podkreśla w szczególności atmosferę, jaka zapanowała wśród ludności w obliczu nadciągających wydarzeń:

Als Kalisch am Sonntag, den 2. August, sich selbst überlassen war, herrschte natürlich unter den Einwohnern eine große Spannung und eine Bangigkeit vor dem Ungewissen: was wird kommen? Man konnte ja gar nichts voraussehen, ja man wußte auch noch nicht einmal, ob die Deutschen kommen. Auf der Straße große Menschenmegen: die Einen sprechen von ihren Besorgnissen, die Anderen heucheln Sorglosigkeit und suchen die Umstehenden durch Späße zu erheitern ${ }^{94}$.

Bezpośrednie działania wojenne poprzedziło przybycie pruskiego ułana - niczym biblijny Jeździec Apokalipsy wtargnął do miasta, które tym bardziej zastygło w oczekiwaniu mających nadejść wydarzeń. Oczekiwaniom towarzyszyła złowroga cisza:

Ruhe. Nur ein Raunen und Tuscheln geht durch die Menschenmenge, die neugierig die Ankömmlinge betrachtet. So vergeht eine Stunde. Wieder das Dröhnen von Marschschritten und Pferdegetrappe ${ }^{95}$.

W końcu do miasta docierają oddziały II batalionu pruskiego 155. pułku piechoty pod dowództwem majora Hermanna Preuskera, witane przez

${ }^{92}$ C.H. Schultz, Die Schrecken von Kalisch, „Neue Lodzer Zeitung”, 24.08./6.09.1914, s. 1. Tekst nigdy nie ukazał się w żadnym tomie zbiorowym.

93 Więcej na temat Kalisza w czasie I wojny światowej zob.: M. Lisiecka, K. Pawlak, Kalisz - rok 1914. Materiały źródłowe, Kalisz 1980; M.A. Woźniak, Kalisz - 1914: pogrom miasta, Kalisz 1995, idem, Zniszczenie Kalisza w 1914 roku w świetle zeznań świadków przed komisjami rządowymi Rosji i Polski, „Rocznik Kaliski” 2003.

${ }^{94}$ C.H. Schultz, Die Schrecken..., s. 1 [Kiedy w niedzielę, 2 sierpnia, pozostawiono Kalisz samemu sobie, naturalnie zapanowało wśród mieszkańców miasta wielkie napięcie i obawa przed nieznanym: co się stanie? Nie sposób było cokolwiek przewidzieć i nawet nie było wiadomo, czy Niemcy przyjdą. Na ulicach tłumy ludzi: jedni mówią o swoich obawach, inni udają beztroskę i żartami próbują rozweselić stojących wokół. Tłumaczenie M.P.].

95 Ibidem [Cisza. Szepty tylko biegną wśród ciżby, z zaciekawieniem obserwującej przybyszy. Tak mija godzina. Potem znów dudnienie maszerujących wojsk i tętent koni. Tłumaczenie M.P.]. 
prezydenta Bronisława Bukowińskiego. Jeszcze tego samego dnia polała się krew. Ostrzelano dwa pruskie patrole, a Preusker oskarżył kaliszan o podstępny napad. Nałożył na miasto kontrybucję w wysokości 50 tys. rb i wziął zakładników, w tym prezydenta Bukowińskiego. Od nocy z 3 na 4 sierpnia aż do 7 sierpnia na rozkaz Preuskera trwał ostrzał miasta. Wybuchały liczne pożary, a ludzie w popłochu opuszczali domy. Schultz tak opisywał ich dramatyczną ucieczkę:

Ein unbeschreibliches Entsetzen erhob sich. Am Mittwoch floh alles, was fliehen konnte. Männer mit angstentstellten Gesichtern, Frauen die vor Grauen sich kaum auf den Füßen zu halten vermochten, Kinder, die im Gedränge ihre Eltern verloren hatten und weinend und schreiend diese suchten - alles suchte zu entkommen aus diesem Orte der Verwüstung und des Schreckens. Die Einen waren mit Hausrat beladen und nahmen oft das Unbrauchbare und Unnützliche mit, andere liefen ohne Kopfbedeckung, wieder Andere ohne Schuhe ${ }^{96}$.

Dramat mieszkańców Kalisza ma wymiar uniwersalny i staje się dramatem każdego miasta doświadczonego przez wojnę. Autor opisuje wojenne pejzaże pełne trupów. Dodatkowo ukazuje zagładę codziennego i uporządkowanego świata zwykłych ludzi. W kolejnym fragmencie pisze:

Da fährt ein Handwagen, von einem Manne geschoben. Er fährt eine entsetzliche Last: zwei Leichen; die Gesichter der Toten sind entstellt, aber in den weit offenen Augen ist das Entsetzen erstarrt, die Fäuste sind krampfhaft geballt, die Zähne im Todeskampf aufeinandergepreßt. Da die Josephkirche: keine Fenster, keine Rahmen, die offenen Löcher schauen wie drohende Augen. Und so flieht man von dem Orte, der noch vor wenigen Tagen eine blühende, lebhafte Stadt gewesen, wo man froh war und traurig, wo man lebte, wie andere Menschen mit dem alltäglichen Leid und der alltäglichen Freude, die ja so nichts sind im Vergleich zu dem Ernst, den diese Stätte der Verwüstung atmet ${ }^{97}$.

Wobec bezwzględności wojny ludność cywilna była całkowicie bezbronna i wydana na pastwę wrogiego wojska. Wróg był tym, który niósł ze sobą

${ }^{96}$ Ibidem [Zapanowało nieopisane przerażenie. W środę uciekał każdy, kto mógł. Mężczyźni z przerażeniem w oczach, kobiety, które w obliczu okrucieństw ledwo trzymały się na nogach, płaczące i krzyczące dzieci, szukające w tłumie zgubionych rodziców - wszyscy chcieli uciec z tego miejsca spustoszenia i grozy. Jedni, obładowani domowymi sprzętami, zabierali często rzeczy zupełnie niepotrzebne, inni biegali z gołą głową, jeszcze inni na bosaka. Tłumaczenie M.P.

${ }^{97}$ C. H. Schultz, Die Schrecken von Kalisch II, „Neue Lodzer Zeitung”, 26.08./8.09.1914, s. 1 [Mężczyzna pcha ręczny wózek. Popycha straszne brzemię: dwa trupy o zdeformowanych twarzach; w szeroko otwartych oczach zastygło przerażenie, ręce kurczowo zwinięte w pięści, a zęby zaciśnięte w śmiertelnej walce. Kościół św. Józefa: ani jednego okna, ani futryny, ziejące wyrwy spoglądają groźnymi oczami. I tak ucieka się z miejsca, które zaledwie kilka dni temu było kwitnącym, tętniącym życiem miastem, gdzie przeżywało się radości i smutki, gdzie żyło się jak inni codziennymi problemami i zwykłymi radościami, które są niczym w porównaniu z powagą, jaką teraz oddycha to miejsce spustoszenia. Tłumaczenie M.P.]. 
śmierć, dlatego jego obraz autor kreuje za pomocą hiperbolizacji i przejaskrawienia, jak we fragmencie pokazującym pruskie wojsko:

Da kommen sie auch schon wieder, die Leute mit den Pickelhauben, die sich in drei Tagen mehr verhaßt gemacht haben als einst die Scharen Attilas in Rom, als die düsteren Inquisitoren des spanischen Mittelalters ${ }^{98}$.

W efekcie działań wojennych w Kaliszu w gruzach legło kilkaset budynków mieszkalnych, wiele zakładów przemysłowych, a także ratusz, kościół, teatr, poczta i telegraf. W końcu roku w mieście pozostało ok. 5 spośród 70 tys. przedwojennych mieszkańców ${ }^{99}$.

Podobne opisy polskich miast stworzyli też inni łódzcy pisarze, jednak każdorazowo były to indywidualnie opowiedziane historie. Miejsca wojennych bitew opisywano jako miejsca totalnej zagłady i zniszczenia. Nakreślone pejzaże, podobne w doborze elementów i kolorystyce, wpisują się w przestrzeń wojennego teatru śmierci. Heinrich Zimmermann przekształca w swoich opowiadaniach rzeczywisty obraz miasta i okolic Łodzi tak, by wyrażały smutek i podkreślały apokaliptyczny nastrój - klęskę, śmierć i zagładę. W opowiadaniu Konstantynow nach der Schlacht [Konstantynów po bitwie] ${ }^{100}$ nawiązuje do jednej z bitew stoczonych w ramach operacji łódzkiej. W wyniku ostrzału artyleryjskiego i bombardowania zniszczeniu uległo w mieście wiele domostw, kościół katolicki, ewangelicko-augsburski i liczne fabryki ${ }^{101}$. Autor stworzył tu panoramiczny obraz miasta wyniszczonego przez bitwę. „Wszędzie ruiny i gruzowiska” - pisał Zimmermann - „a ludzie stoją nad nimi z rozpaczą w oczach" ${ }^{102}$. Towarzyszą mu ponure krajobrazy czasu klęski wegetatywnej, wyrażonej w wizji okaleczonych gałęzi drzew (niem. verkrüppelte Zweige) i spróchniałych konarów (niem. morsche Äste). Autor wpisuje się tym samym w charakterystyczną dla tego nurtu literatury sferę pojęć aksjologicznych: okaleczonego życia, bez nadziei na zmartwychwstanie, które łączą się z elementami poddanymi mortualizacji: rozbitymi murami (niem. zertrümmerte Mauerwände) i pogorzeliskami, uzupełnionymi o motywy natury: matowego, ołowianego i ciężkiego nieba. Obraz niepokojący w swej dyshar-

${ }^{98}$ Ibidem [I oto nadchodzą, ludzie w pikielhaubach, w ciągu trzech dni znienawidzeni bardziej niż niegdyś oddziały wojsk Attyli w Rzymie, bardziej niż ponura hiszpańska inkwizycja w czasach średniowiecza. Tłumaczenie M.P.].

${ }_{99}$ Por. J.A. Splitt, Burzenie Kalisza w 1914 roku, http://www.kalisz.info/burzenie-kalisza. html [dostęp: 10.12.2013].

${ }^{100}$ H. Zimmermann, Konstantynow nach der Schlacht, „Neue Lodzer Zeitung”, 27.11./10.12.1914, s. 3. Tekst nigdy nie ukazał się w żadnym tomie zbiorowym.

${ }^{101}$ W czasie bitwy o Łódź w 1914 r. polem walki stały się podłódzkie miejscowości, takie jak Zgierz, Aleksandrów, Tuszyn i Konstantynów. Por. W. Bortnowski, Ziemia łódzka...

${ }^{102}$ H. Zimmermann, Konstantynow..., s. 1. 
monii, oparty na ekspresjonistycznej metaforyce grozy, dopełniają onomatopeje naśladujące przeraźliwe dźwięki: jęki, huk i szloch:

Mattblau dehnt sich der Himmel über die rauchenden Trümmer. Weit, unendlich weit ist der Himmel; es ist als ob er staunend fragen wollte: „Ist das die Stadt des Nikolaj Krzywiec von Okolowicz, des Gründers von Konstantynow?“ Eine bange Melancholie gleitet an zertrümmerten Mauerwänden und Greisin Einsamkeit, so tief wie die Nacht, kauert auf den Ruinen und tausend Sorgen drücken ihre Brust. Von irgendwoher dringt eine schluchtzende Stimme. Haben nicht die verkrüppelten Zweige zu stöhnen angefangen, mit grollerfüllten Blicken und zerzausten Haaren? ${ }^{103}$

Ten przerażający krajobraz staje się wielkim oskarżeniem wojny jako bezwzględnego zła, które przekształciło otoczenie człowieka w pejzaż śmierci. Dalej Zimmermann tak pisze o Konstantynowie:

Manches Häuschen steht in sich geduckt, als ob es Angst hätte emporzublicken, weil es einst in trüber Stunde den Tod durch die Lüfte sausen hörte. Manches Häuschen ist wie eine schwere Frage an das Schicksal, wie ein letzter Säufzer, wie ein röchelndes Stöhnen. Und manches steht einsam und still da, schaut auf die Trümmer nieder und weiß nicht, was in den Tage des brausenden Sturmes geschehen ist, wo die Luft erzitterte und die Erde erdröhnte, als ob es der Anfang vom Ende wäre. Und jedes Häuschen erzählt die Geschichte seines Todes, trägt die Reime der Vernichtung in sich. An jedem Hause ging der feuersprühende Tod vorüber, berührte mit seinen knochigen Händen die Wände und alles stürzte und sank ${ }^{104}$.

Obraz, przedstawiony przez Zimmermanna i wpisany w poetykę śmierci, przekształca się $\mathrm{w}$ jedno wielkie cmentarzysko: na ulicach leżą trupy zabitych koni, w powietrzu unosi się zapach zgnilizny i rozkładających się ciał, a człowiek w tej przestrzeni odczuwa bezradność wobec otaczającego go zła. Autor pisze: „Die Schweikertsche Fabrik erbebte, die Maschinen erzitterten, die Fensterscheiben klirrten und die Menschen gruben sich Löcher aus, als

${ }^{103}$ Ibidem, s. 1 [Nad dymiącymi ruinami rozpościera się matowy błękit nieba. Daleko, nieskończenie daleko jest niebo; wydaje się jakby chciało zapytać zdziwione: „Czy to miasto Mikołaja Krzywca-Okołowicza, założyciela Konstantynowa?” Zalękniona melancholia wlecze się wzdłuż zniszczonych murów, a staruszka samotność, ciemna jak najgłębsza noc, przycupnęła na zgliszczach i tysiąc zgryzot ściska jej pierś. W dali słychać szloch. Czy to nie jęczą okaleczone gałęzie, spróchniałe konary, stojące gdzieś na drodze? Czy coś nie toczy się z głębi, ze wzrokiem przepełnionym krzykiem i zmierzwionymi włosami? Tłumaczenie M.P.].

104 Ibidem [Niejeden domek przycupnął skulony, jakby bał się podnieść wzrok, bo słyszał kiedyś w złej godzinie, jak śmierć mknie w przestworzach. Niejeden domek jest jak trudne pytanie do losu, jak ostatnie westchnienie, jak charczący jęk. I niejeden stoi samotnie i cicho, patrzy na zgliszcza i nie wie, co się wydarzyło w dniach wojennej pożogi, gdy drżało powietrze i dudniła ziemia, jakby nadchodził początek końca. A każdy domek opowiada dzieje własnej śmierci, pielęgnuje w sobie rymy zniszczenia. Do każdego domu zajrzała ziejąca ogniem śmierć, dotknęła kościstymi dłońmi ścian i wszystko runęło i rozpadło się. Tłumaczenie M.P.]. 
ob sie sich bei Lebzeiten eigene Gräber errichteten"105. Kreśli obraz wojny w perspektywie eschatologicznej, posługując się dodatkowo schematami apokaliptycznymi. Pokazuje to na przykładzie zburzenia kościoła katolickiego:

Kyrie eleison, Herr erbarme dich! Die Inschrift der Kirche wird lebendig und betet. Es sausen die Kugeln und tragen den Tod. Kyrie eleison! Eine Granate schlug ein, ein Haus ist in Brand geraten. Kyrie eleison! Häuser stürzen, Stimmen schluchzen. Kyrie eleison! Das Gebet verstummt, die Kirche brennt selbst nieder. Alles singt und stürzt... Ist das das Ende der Welt? ${ }^{106}$

Podobny obraz zniszczenia przedstawia autor w opowiadaniu Auf den Schlachtfeldern in der Umgegend von Lodz [Na polach bitewnych pod Łodzią ${ }^{107}$. Posługuje się $\mathrm{w}$ nim jednym $\mathrm{z}$ elementów, nieustannie przewijających się w literaturze wojennej, a mianowicie motywem zniszczonych, opuszczonych pól uprawnych, które zamieniły się w pola bitewne. Ziemia staje się ugorem i pustynią, a z wizją tą współgrają obrazy okaleczonej przyrody, wykorzystane przez Zimmermanna już wcześniej w opisie Konstantynowa. Krajobraz wypełniają chore, cierpiące i usychające drzewa, o których Zimmermann pisze:

Öde und vernichtet liegen die Felder da, wie blühende Reiche, die gestürmt wurden. Am Wegrande stehen wie in stille Wehmut gehüllt einzelne zerschossene Bäume, entlaubt und fröstelnd und irgendwo, weit, weit erhebt zagend ein trauernder Wald seine kahlen Gipfel $^{108}$.

Ludzki instynkt niszczenia jest tak silny, że dosięga nawet tego, co wieczne i nieśmiertelne, a więc ziemi, odwiecznego symbolu płodności i życia. Teraz stała się ona makabrycznym teatrem śmierci, unicestwiającym ludzkość, zamieniła się w pole bitwy i olbrzymie cmentarzysko, miejsce nacechowane szczególnie negatywnie: „Blutgetränkt ist die müde Erde, und der Himmel über ihr ist bleiern und schwer"109. Zimmermann, utożsamiający zagładę

105 Ibidem [Fabryka Schweikerta zatrzęsła się, maszyny zadrżały, zadzwoniły szyby w oknach, a ludzie kopali doły, jakby za życia przygotowywali sobie groby. Tłumaczenie M.K.].

106 Ibidem [Kyrie elejson, Panie, zmiłuj się nad nami! Inskrypcja na kościele ożyła i modli się. Świszczą kule i niosą śmierć. Kyrie elejson! Wybuchł granat, budynek stanął w płomieniach. Kyrie elejson! Rozpadają się domy, szlochają głosy. Kyrie elejson! Modlitwa cichnie, kościół dopala się. Wszyscy śpiewają i upadają na ziemię... Czy to koniec świata? Tłumaczenie M.P.].

107 H. Zimmermann, Auf den Schlachtfeldern in der Umgegend von Lodz, „Neue Lodzer Zeitung", 29.11./12.12.1914, s. 1. Tekst nigdy nie ukazał się w żadnym tomie zbiorowym.

108 Ibidem [Opustoszałe i zniszczone pola, niczym ograbieni kwitnący krezusi. Na skraju drogi stoją pogrążone w cichym smutku podziurawione pociskami pojedyncze drzewa, pozbawione liści, drżąc z zimna, a gdzieś, hen daleko, pogrążony w żałobie las niepewnie unosi bezlistne wierzchołki drzew. Tłumaczenie M.P.].

${ }^{109}$ Ibidem [Zmęczona ziemia przesiąkła krwią, a nad nią ołowiane i ciężkie niebo. Tłumaczenie M.P.]. 
ziemi z unicestwieniem życia, tak pisze o poległych żołnierzach: „Hunderte Leichen liegen umher, verstümmelt und zerstückelt, mit gebrochenen Augen und wächsernen Gesichtern und die Lippen sind so blaß, als ob sie nie Blut gehabt hätten"110.

Przestrzeń bitewna jest miejscem, w którym zachodzi egzystencjalna metamorfoza, w której dokonują się straszliwe okaleczenia, ma miejsce zmaganie ze śmiercią i okrutna agonia. Pobojowisko jawi się jako przestrzeń zdesakralizowana i zdegradowana. Gdy cichnie odgłos strzałów, na pole bitewne wkraczają „hieny cmentarne”, dokonując grabieży na pomordowanych żołnierzach:

Plötzlich tauchen einige schwarze Gestalten auf. Wie auf leisen Sohlen schleichen sie heran, gebückt und geduckt und machen sich an den Leichen zu schaffen. Schlachtfelderhyänen. Mit schwarzen Gedanken und dreisten Händen. Sie wühlen in den Taschen herum, suchen in den Stiefeln, zerschneiden die Kleider, vernichten die Hemden. Sie scheuen vor dem Heiligsten nicht zurück, vor der Würde des Todes ${ }^{111}$.

Autor pokazuje jednoznacznie, że wojna dotyka także umarłych. W innym opowiadaniu również sięga do motywu zmarłych, tym razem jednak doszukując się w ich ofierze sensu wojny. W opowiadaniu Die Nacht der Toten [Noc umarłych] ${ }^{112}$ świszczące kule, wybuchające granaty i wystrzeliwane $\mathrm{z}$ armat szrapnele budzą zmarłe dusze:

Sausende Kugeln stürmten über den stillen Friedhof hin. Splitter von Granaten und Schrapnells schlugen in die kostbaren Denkmäler ein und stürzten sie um. Eine bange Unruhe brach unter den Toten aus und sie sprengten die Gräber und fragten erstaunt: „Was ist geschehen, wer wagt unsere Ruhe zu stören?" „Das Ende der Welt ist gekommen", sagte eine gläubige Seele ${ }^{113}$.

Podobnie jak w przypadku poezji, również proza kształtuje charakterystyczny dla siebie motyw śmierci, różny od tego, postrzeganego przez ekspresjonistów. Dla łódzkich pisarzy śmierć jest wybawieniem od trosk i cierpień, i w tym autor doszukuje się sensu umierania, pisze bowiem:

110 Ibidem [Dokoła setki trupów, okaleczonych i poćwiartowanych, o zgasłych oczach, woskowych twarzach i wargach tak bladych, jakby nigdy nie płynęła w nich krew. Tłumaczenie M.P.].

111 Ibidem [Nagle wyłania się kilka czarnych postaci. Skradają się po cichu, przygarbione i schylone i dobierają się do trupów. Hieny pól bitewnych. Pełne złych zamiarów, o zuchwałych rękach. Przetrząsają kieszenie, przeszukują buty, tną na kawałki ubrania, rozrywają koszule. Nic sobie nie robią z największej świętości, z powagi śmierci. Tłumaczenie M.P.].

112 H. Zimmermann, Die Nacht der Toten, „Neue Lodzer Zeitung”, 30.11./13.12.1914, s. 1. Tekst nigdy nie ukazał się w żadnym tomie zbiorowym.

${ }^{113}$ Ibidem [Świszczące kule spadły na cichy cmentarz. Odłamki granatów i szrapnele uderzyły i obaliły drogocenne nagrobki. Straszny niepokój ogarnął zmarłych, którzy powstali z grobów i pytali ze zdziwieniem: „Co się dzieje, kto ośmiela się burzyć nasz spokój?” „Nadszedł koniec świata”, rzekła jedna z dusz. Tłumaczenie M.P.]. 
„Wir haben den europäischen Krieg“. „Den europäischen Krieg?“ fragte verwundert die gläubige Seele. „Der Kampf aller gegen alle?“ „Die größten aller Kämpfe, die die Weltgeschichte je erlebt hat", erwiderte die Seele, die von allen neugierig umringt wurde. „Und wie leben die Menschen in dieser Zeit? fragte die Seele des Winkeladvokaten. „Fragt lieber nicht danach“ sagte seufzend die neue Seele, „überall gibt es Not und Hunger. Niemand weiß was der Morgen bringt. Alles schwankt und stürzt. Dichte Wolken bedecken den Welthorizont und drohen zu entladen. Fragt nicht danach Freunde, ich freue mich, daß ich bei euch bin, daß ich endlich Ruhe und Frieden habe". Ein Schrapnell explodierte in der Luft. Zitternd und frierend zogen sich die Seelen in ihre stillen Gräbern zurück und ein Gefühl göttlichen Friedens empfing sie in dem Bewußtsein, daß sie nicht mehr unter den Lebenden weilen ${ }^{114}$.

W obliczu wojennej codzienności najistotniejszym problemem staje się zaspokojenie głodu. Posługiwanie się tym motywem w łódzkiej literaturze może przypominać tradycje naturalizmu, dobrze rozpoznającego walkę o byt. Łódzkie teksty starają się podejmować tematykę głodu i jego fizjologii, eksponując siłę oddziaływania instynktu. Głód nie ma charakteru jednostkowego, dotknięte są nim całe grupy społeczne. Sprawia, że wszelkie działania człowieka są bez reszty podporządkowane zdobywaniu pożywienia. Wola przetrwania powoduje, że całą energię człowieka pochłania poszukiwanie pokarmu. Problem ten dotyka również ludzi z wyższych sfer, którzy nigdy wcześniej nie zaznali głodu. Wojna zmieniła także ich codzienność i głównym wyznacznikiem egzystencji uczyniła walkę o byt. W opowiadaniu In einer billigen Küche [W kuchni dla ubogich] Heinrich Zimmermann opisuje, jak głodne ciało domaga się bezwzględnie zaspokojenia swoich potrzeb, choć człowiek walczy z poczuciem wstydu:

Sinnend steht er an der Tür, zwei Mächte kämpfen in ihm, die Scham und der Hunger, aber der Hunger ist stärker als die Scham, er ist wie ein reißender Wolf, wie eine brausende Flut, die alles mit sich reißt und mit sich zieht ${ }^{115}$.

114 Ibidem [„Mamy wojnę europejską”. „Wojnę europejską?” - zapytała zdziwiona dusza. „Wojnę wszystkich przeciw wszystkim?” „Batalie najcięższe ze wszystkich, jakich doświadczyła ludzkość”, odparła dusza, wokół której zgromadziły się wszystkie inne, zaciekawione. „A jak się powodzi teraz ludziom?”, zapytała dusza adwokaciny. „Lepiej nie pytaj”, westchnęła dusza nowo przybyła. „Wszędzie bieda i głód. Nikt nie wie, co przyniesie jutro. Świat się chwieje i upada. Gęste chmury okryły horyzont i w każdej chwili może nadciągnąć burza. Nie pytajcie o to, przyjaciele, cieszę się, że jestem wśród was, że wreszcie zaznaję ciszy i spokoju". Szrapnel wybuchł w powietrzu. Drżąc z zimna dusze skryły się znów w swoich cichych grobach i przepełniło je uczucie boskiego spokoju, dając im świadomość, że nie ma ich już wśród żywych. Tłumaczenie M.P.].

115 H. Zimmermann, In einer billigen Küche, „Neue Lodzer Zeitung”, 16/29.10.1914, s. 2 [Zamyślony stoi przy drzwiach, a w jego wnętrzu ścierają się dwie siły, wstyd i głód, ale głód jest silniejszy niż wstyd, jest jak drapieżny wilk, jak rwący nurt, który porywa wszystko i pogrąża w otmęcie. Tłumaczenie M.P.]. Tekst nigdy nie ukazał się w żadnym tomie zbiorowym. 
Interesującym obrazem, ilustrującym wojenny pejzaż miasta, jest obraz Łodzi w dzienniku Heinricha Zimmermanna, zatytułowanym Aus unvergesslichen Tagen. Tagebuchaufzeichnungen [Z niezapomnianych dni. Dzienniki], który ukazał się w dwunastu odcinkach na łamach „Neue Lodzer Zeitung” na przełomie listopada i grudnia 1915 r. ${ }^{116}$ Podobnie jak w przypadku opisu Kalisza i Konstantynowa, obraz miasta przemienia się tu w przestrzeń alienacji i śmierci. Zimmermann opisuje atmosferę niepewności i przerażenia mieszkańców oczekujących nadejścia niemieckich wojsk:

Immer lansamer und immer schwerer tropfen die Minuten, die Sekunden - Es ist als ob sie keine Eile hätten, als ob sie keine Lust verspüren, in das brandende Meer der Ewigkeit zu sinken. Und jede Stunde birgt ungeheuer Möglichkeiten, sie kann über Leben und Tod Tausender von Menschen entscheiden. Jede Stunde kann wie ein Dolchstoß sein, der Leben vernichtet, kann aber auch wie eine Arznei sein, die blutige Wunden heilt. Und eine Frage, so schwer wie das Schicksal, martert das Hirn: Was wird uns die nächste Stunde bringen, die unbekannte, geheimnisvolle Stunde? Eine nervöse Unruhe legt sich wie ein schwarzer Mantel über uns, als ob sie uns erdrücken wolle. Die Ungewißheit verhält sich zur Wirklichkeit, wie das Sterben zum Tode. Der Tod ist nicht so schrecklich wie das Sterben. Der Prozeß des Sterbens, der Kampf zwischen Leben und Tod, die bange Furcht, das leise Hinüberdämmern ins Jenseits, das jähe Zerreiße der letzten Lebensfäden, das ist das bange Leid, das unsere Seele mit unendlichem Weh erfüllt. Die Ungewißheit ist wie das Liegen im Sterben ${ }^{117}$.

Na ulicach panuje spokój, natomiast prawdziwe życie pulsuje w kawiarniach, bowiem tam zbierają się łodzianie: politycy, dziennikarze, handlarze, rozmawiający o oczekiwanych wydarzeniach. Do ostatniej chwili łudzono się nadzieją, że Niemcy nie zaatakują Łodzi, gdyż w mieście ulokowano zbyt wiele niemieckiego kapitału ${ }^{118}$. 16 grudnia 1914 r. padają jednak pierwsze strzały. Zimmermann kreuje w dzienniku przestrzeń Łodzi, która w ludzkiej

116 H. Zimmermann, Aus unvergeßlichen Tagen. Tagebuchaufzeichnungen, „Neue Lodzer Zeitung", 14.11.1915, 16.11.1915, 18.11.1915, 19.11.1915, 21.11.1915, 23.11.1915, 25.11.1915, 28.11.1915, 1.12.1915, 2.12.1915, 5.12.1915, 6.12.1915. Tekst nigdy nie ukazał się w żadnym tomie zbiorowym.

117 Ibidem, s. 5 [Coraz wolniej i ciężej mijają minuty, sekundy - to tak, jakby się wcale nie spieszyły, jakby nie miały ochoty zatonąć w kipiącym morzu wieczności. A każda godzina skrywa nieskończenie wiele możliwości i może rozstrzygnąć o śmierci i życiu tysięcy ludzi. Każda godzina może być jak cios zadany sztyletem, który przerywa życie, ale może też być jak lekarstwo, które leczy krwawiące rany. Lecz jedno tylko pytanie, ciężkie jak los, męczy umysł: co przyniesie nam najbliższa godzina, nieznana i tajemnicza godzina? Rozedrgany niepokój otula nas jak czarny płaszcz, jakby chciał nas udusić. Niepewność tak ma się do rzeczywistości jak śmierć do życia. Śmierć nie jest tak straszna jak umieranie. Proces umierania, walka między życiem i śmiercią, przerażający strach, ciche przechodzenie na tamtą stronę, nagłe zerwanie ostatnich nici życia, wszystko to jest strasznym cierpieniem, napełniającym naszą duszę niekończącym się bólem. Niepewność jest jak agonia. Tłumaczenie M.K.].

118 Ibidem, s. 2. 
świadomości kojarzy się ze zniewoleniem. Gdy ludność rzuca się do ucieczki, okazuje się, że drogi prowadzące do miasta są zamknięte. Ludzie czują się tak, jakby zamknięto ich w klatce. Zimmermann pisze: „Man kommt sich wie in einem großen Käfig vor" [Człowiek czuje się tak, jakby tkwił w wielkiej klatce $]^{119}$. Tak więc przestrzeń wojny to przestrzeń zamknięta, w której człowiek traci poczucie bezpieczeństwa. Zasadniczym wyznacznikiem ludzkiego losu w czasie wojny jest samotność i poczucie wyobcowania. Wojna to niezaprzeczalnie epoka bezdomności. Topos wojennego domu, a w szczególności jego zagłada, rozumiana jako zniszczenie materialne i unicestwienie trwałych wartości, to jeden z ważniejszych motywów podejmowanych przez literaturę tego okresu. W czasie wojny dom traci chroniące człowieka granice, bo wojna w sposób bezwzględny opuszcza pole bitwy i wkracza w przestrzeń intymną. Zimmermann bardzo sugestywnie opisał zniszczenie domów w Łodzi. Wojenny wstrząs, wywołany utratą domu, przedstawił w kategoriach krzywd osobistych i nadał mu charakter uniwersalnego dramatu, wobec którego człowiek nie potrafi się odnaleźć:

Plötzlich ein furchtbares Dröhnen, ein langgezogenes Heulen, ein stürmisches Klagen, ein dumpfes Krachen - rritrritrrit... Einige Häuser in der Umgegend und an der Peripherie der Stadt geraten in Brand. Züngelnde Flammen lodern empor. Der Tod geht mit grinselndem Lächeln durch die Häuserreihen. Die Menschen jagen und rennen, laufen und lärmen und wandern massenweise in die Stadt. Am meisten haben die Häuser in der Aleksandrowska-, Zimmer-, Reiter-, Kelbach-, Graniczna-, Polna-, Feliksa-, Dolna-, Brajer-, Zgierska- und Łagiewnickastraße gelitten. Aus Baluty, Zudardz und Radogoszcz treffen zahlreiche Familien ein. In Julianow brennen viele Häuser nieder, das Palais des Baron Heinzel ist stark beschädigt worden. Aus Aleksandrow und Konstantynow treffen betrübende Nachrichten ein. In Kochanowka brach unter den Wahnsinnigen in der Heilanstalt eine Panik aus. Die Geisteskranken warfen sich heulend und schreiend auf die Dienerschaft und das Dienstpersonal, viele Kranke suchten sogar Selbstmord zu begehen. [...] Immer mehr nimmt auf den Straßen die Zahl der Heimatlosen aus der Umgegen $\mathrm{zu}^{120}$.

119 Ibidem, s. 1.

120 Ibidem [Nagle potworny huk, przeciągłe wycie, potężny gwizd, głuchy łoskot - trrrraaachchch... Kilka domów w najbliższej okolicy i na peryferiach miasta stoi w płomieniach. Jęzory ognia strzelają w górę. Z szyderczym uśmieszkiem śmierć przechodzi wzdłuż kolejnych domów. Ludzie pędzą i gnają, biegną i krzyczą i masowo wędrują w kierunku miasta. Najbardziej ucierpiały domy przy Aleksandrowskiej, Zimmer-, Reiter-, Kelbachstraße, przy Granicznej, Polnej, Feliksa, Dolnej, Brajerstraße, przy Zgierskiej i Łagiewnickiej. Wiele rodzin przybywa z Bałut, Żubardzia i Radogoszcza. Na Julianowie doszczętnie spaliło się mnóstwo domów, wielkiego uszczerbku doznał pałac barona Heinzla. Z Aleksandrowa i Konstantynowa docierają smutne wieści. W szpitalu w Kochanówce wśród umysłowo chorych wybuchła panika. Obłąkani, wyjąc i krzycząc, rzucili się na lekarzy i pielęgniarzy, wielu chorych próbowało nawet odebrać sobie życie. [...] Na ulicach wciąż przybywa bezdomnych z okolicznych miejscowości. Tłumaczenie M.P.]. 
0 tym, jak bardzo wojna wkracza w intymną przestrzeń człowieka, można się przekonać analizując opis Zimmermanna, który sugestywnie przedstawił śmierć kobiety tuż po narodzinach dziecka. Obraz ten dobitnie pokazuje destrukcję i upadek sacrum. Ludzka natura, cel wszelkich działań, w czasie wojennego kataklizmu ulega całkowitemu unicestwieniu ${ }^{121}$.

Także opisane przez Zimmermanna bombardowanie Łodzi w grudniu 1914 r. spowodowało, że jej mieszkańcy stali się świadkami zmieniającej się przestrzeni miasta:

Lodz gleicht einem großen Lazarett. In den Theatern und in den Privatschulen, in den Gymnasien und un den Vereinslokalen sind Lazaretts errichtet. Lodz ist nicht mehr Evakuationspunkt, Lodz ist ein riesiger Verbandplatz ${ }^{122}$.

Opisane powyżej przeżycia świadczą o wrażliwości łódzkich pisarzy na wojenne wydarzenia. Wielu z nich nie przeszło obojętnie obok zniszczeń, jakie miały miejsce w tym czasie w Łodzi.

\section{4. Łódź oczami niemieckiego okupanta}

I wojna światowa doskonale wpisuje się w pojęcie współczesności jako wieku dokumentu ${ }^{123}$. Powstające w obliczu działań wojennych, na froncie lub na tyłach, dokumenty osobiste i literatura faktu, a więc reportaże, wiadomości, relacje prasowe, sprawozdania czy dzienniki, definiowały rzeczywistość jako swego rodzaju mozaikę fragmentarycznych zdarzeń od strony „historii zdarzeniowej” oraz „historii życia codziennego” ${ }^{24}$. Łódź w czasie I wojny światowej doczekała się również spojrzenia z zewnątrz. Działania wojenne, prowadzone przez wojska niemieckie, opisali przybywający do miasta niemieccy żołnierze, jak również towarzyszący im korespondenci wojenni w formie wspomnień, dzienników i pamiętników. Wiele z nich powstało na przestrzeni 1915, 1916 i 1917 r.; często drukowano je najpierw w niemieckich gazetach, a następnie wydawano $\mathrm{w}$ formie książkowej. Przykładem takiej publikacji jest zbiór zapisków wojennych Wilhelma Feldmanna Mit der Heeresgruppe

${ }^{121}$ Ibidem.

122 Ibidem [Łódź przypomina jeden wielki lazaret. W teatrach i prywatnych szkołach, w gimnazjach i lokalach różnych stowarzyszeń urządzono wojskowe szpitale. Łódź nie jest już punktem ewakuacyjnym, Łódź jest jednym ogromnym miejscem opatrywania chorych. Tłumaczenie M.P.].

${ }^{123}$ Na ten temat powstało wiele publikacji, wśród których na szczególną uwagę zasługuje książka Z. Ziętek, Wiek dokumentu. Inspiracje dokumentarne w polskiej prozie współczesnej, Warszawa 1999.

124 Por. M.J. Olszewska, Człowiek w świecie... 
des Prinzen Leopold von Bayern nach Weißrussland hinein. Najpierw ukazał się w „Berliner Tageblatt” w lipcu, sierpniu i wrześniu 1915 r., a następnie wydany został w 1916 r. w wydawnictwie Oskar Beck w Monachium ${ }^{125}$. Wspomnienia niemieckich żołnierzy, uczestniczących bezpośrednio w działaniach wojennych, pozwalają spojrzeć na tamte burzliwe czasy oraz na miasto i jego mieszkańców z całkiem innej, niezwykle interesującej perspektywy. Większość wspomnień przedstawia sceny z codziennego życia żołnierzy, a nawet oddaje towarzyszące podróży nastroje. Wielu autorów szczegółowo opisuje działania wojenne, koncentrując się głównie na manewrach wojskowych. Przykładem takiej publikacji jest dziennik generała brygady Artura von Loebella pt. Der Weltkrieg 1914/1915. Gesammelte Berichte, który ukazał się w czterech tomach: Bis zu den Kämpfen um Lodz, Von der Einnahme von Lodz bis zur Befreiung von Lemberg, Von der Wiedereinnahme von Lemberg bis zum Jahresschluß 1915 oraz Von Beginn 1916 bis zum Ausbruch des rumänischen Krieges Ende August 1916. Zamiarem autora było przede wszystkim przybliżenie zwykłemu czytelnikowi wojennego rzemiosła ${ }^{126}$. Ze strategicznego punktu widzenia Loebell przypisuje planowanym bitwom pod Łodzią największe znaczenie:

„Ein Blick auf die Karte genügt, um die Gefährlichkeit dieser Operation für die Russen darzutun." [...] wichtige Ereignisse bereiteten sich auf dem östlichen Kriegsschauplatz vor. Den gemeldeten Kämpfen östlich und südlich Lodz war vom strategischen Standtpunkte aus die größte Bedeutung beizulegen ${ }^{127}$.

Relacje większości autorów to spójne przekazy, ponieważ posługują się oni stałymi motywami w opisie miasta i jego mieszkańców. Wkraczający do Łodzi żołnierze i korespondenci wojenni postrzegali ją jako miasto brudne, nieposiadające kanalizacji, w którym nie dba się o higienę. Korespondent wojenny Wilhelm Conrad Gomoll pisał we wspomnieniach Im Kampf gegen Russland und Serbien:

Schmutzmassen ließen die russische Mißwirtschaft erkennen, die in Lodz gewaltet hatte. Auf den Marktplätzen lag der Kot in hohen Haufen; denn dort, mitten in der Stadt, hatten Stallungen gestanden, und niemand hatte daran gedacht, den Schmutz zu entfernen ${ }^{128}$.

125 W. Feldmann, Mit der Heeresgruppe des Prinzen Leopold von Bayern nach Weißrussland hinein, Monachium 1916.

${ }_{126}$ Por. Vorwort, [w:] A. von Loebell, Der Weltkrieg 1914/1915. Gesammelte Berichte, Bd. 1: Bis zu den Kämpfen um Lodz, Leipzig 1915, s. 1.

127 A. v. Loebbel, Der Weltkrieg 1914/1915..., s. 82 [„Wystarczy jeden rzut oka na mapę, aby zrozumieć jak niebezpieczna to operacja dla Rosjan”. [...] najważniejsze wydarzenia szykowały się na Wschodzie. Strategicznie najważniejsze bitwy zaplanowano na wschód oraz południowy wschód od Łodzi. Tłumaczenie M.K.].

128 W.C. Gomoll, Im Kampf gegen Russland und Serbien, Leipzig 1916, s. 64 [Po bezmiarze brudu można było poznać niegospodarność Rosjan, którzy rządzili w Łodzi. Na rynkach leżały 
Podobne spostrzeżenia na temat Rosjan zanotował Alfred Katsczinski w swoim dzienniku Unser Kampf für die Heimat 1914. Po przybyciu do Łodzi 10 grudnia 1914 r. pisał: „Die Russen haben hier entsetzlich gehaust und das in ihrem eigenen Lande. Die Kirche sieht aus wie ein Schweinestall. Und was dazu die Leute erzählen, ist grauenerregend"129. Bezpośrednia krytyka pod adresem rosyjskich władz, które opuściły Łódź po wielu latach zaborów, była jednym z chwytów strategicznych, jakimi posługiwała się propaganda niemiecka. Wroga ośmieszano za pomocą wszelkich możliwych mechanizmów, najczęściej uwypuklając niegospodarność Rosjan, niechlujstwo i bałagan, który po sobie zostawili. Dopełnieniem tej strategii było ukazanie własnych poczynań w okupowanej Polsce jako niezbędnych dla „naprawienia” i „ulepszenia" położenia zastanego po poprzednim zaborcy, choć sami Niemcy nie postrzegali siebie jako kolejnego okupanta. W tym samym dzienniku Katsczinski pisze dalej o wkraczających do Łodzi niemieckich wojskach, które stopniowo nadają miastu charakter. Łódź zaczyna tętnić zupełnie innym życiem. Wprawdzie na ulicach wciąż jeszcze panuje chaos, spowodowany zniszczeniami po ostrzałach artyleryjskich, lecz mimo to miasto sprawia wrażenie przyjaznego miejsca. Napływające do Łodzi oddziały niemieckich żołnierzy rozwieszają czarno-czerwono-żółte flagi przed budynkiem magistratu, Grand Hotelem i w pasażu Meyera, a niemieckie samochody pomykają po łódzkich ulicach. Centralnym punktem miasta stał się Grand Hotel, w którym stacjonował niemiecki sztab wojskowy. Niemieccy oficerowie mieszkali również w hotelu Savoy. Wszystko to sprawia, że Łódź zaczyna nabierać niemieckiego charakteru. Wraz z wojskiem do miasta wkracza niemiecki Ordnung. Jedną z pierwszych akcji zarządzonych przez Niemców jest oczyszczenie miasta znajdującego się w fatalnym stanie sanitarnym. Wszystkich mieszkańców dysponujących miotłą i szufelką, Polaków i Żydów, zapędzono pod nadzorem niemieckich żołnierzy do sprzątania miasta. W końcu Łódź lśni porządkiem, a wszędzie słychać język niemiecki ${ }^{130}$.

Katsczinski posługuje się w dzienniku czarno-białą wizją świata, w której dominującą rolę pełnią niemieccy żołnierze. Łatwo przywodzi to na myśl skojarzenia z tzw. krzewicielami kultury (Kulturträger), którzy kolonizując inne narody, narzucają im własną cywilizację. Ta schematyczna relacja sprawia, że przedstawiane wydarzenia są bardzo wyidealizowane. W sposób uproszczony przedstawiono postawę łódzkiej społeczności wobec wkraczających wojsk niemieckich. Autor najpierw pisze o początkowej dezorientacji

kupy gnoju, bo w środku miasta urządzono stajnie i nikt nie pomyślał, żeby ten cały brud posprzątać. Tłumaczenie M.P.].

129 A. Katsczinski, Unser Kampf für die Heimat 1914, Tilsit 1917, s. 44-45 [Rosjanie mieszkali tu w opłakanych warunkach i to we własnym kraju. Kościół wygląda jak chlew. A co poza tym ludzie jeszcze mówią na ten temat - okropność. Tłumaczenie M.K.].

${ }^{130}$ Por. W.C. Gomoll, Im Kampf..., s. 65. 
łodzian: „Zuerst, als die deutschen Farben erschienen, wußte die Lodzer Bürgerschaft nicht recht, ob sie zufrieden sein durfte; denn so fragte man sich allgemein, wie lange wird Lodz nun unter dem Zeichen Schwarz-Weiß-Rot stehen?"131, następnie stwierdza, że po trzech tygodniach od przejęcia miasta ludność nabiera zaufania do nowej władzy i traktuje ją jako „lepszą” od poprzedniego zaborcy (Rosjan) ${ }^{132}$. To oczywiście daleko idąca pozytywna interpretacja, nieuwzględniająca wielu faktów historycznych, jak choćby dokonanej przez niemieckiego okupanta bezlitosnej grabieży zakładów przemysłowych, która spotkała się z silnym sprzeciwem przeważającej części mieszkańców Łodzi ${ }^{133}$.

Podobnie tendencyjnie pokazał stosunek łódzkiego społeczeństwa do wkraczających wojsk niemieckich Wilhelm Renner we wspomnieniach Feldmarschall von Mackensen; ein Lebens- und Charakterbild ${ }^{134}$ [Feldmarszałek Mackensen. Życie i osobowość]. Książka jest w zamyśle biografią feldmarszałka Augusta von Mackensena, dowódcy wojsk niemieckich i austro-węgierskich podczas ofensywy pod Gorlicami i Tarnowem w maju 1915 r., zdobywcy Belgradu w 1915 r. i Bukaresztu w 1916 r. Mackensen uczestniczył też w bitwach pod Gąbinem, Łowiczem i Łodzią. Renner wspomina, że łódzcy Niemcy, ewangelicy, szczególnie przyjaźnie reagowali na fakt obecności niemieckich wojsk:

Da begannen in Lodz die evangelischen Militärgottesdienste. Vier Deutsche schliechen sich in den ersten Gottesdienst, scheu: sie fürchteten die Spitzel, sehnten sich aber danach, auch einmal einen echt deutschen Gottesdienst mitzumachen, und überwanden Furcht und Schrecken gegenüber ihrem Hunger nach Stärkung ihres deutsch-evangelischen Glaubens. Mackensen hat das große Verdienst, die Bedeutung der Teilnahme der deutschen Bürger an dem Gottesdienst sofort erkannt zu haben. Schnell wuchs die Zahl der Teilnehmer. Aus den Militärgottesdiensten entstand eine deutsch-evangelische Bewegung, und Mackensen sprach wiederholt dem Geistlichen seine Freude darüber aus, daß die Schar von Sonntag zu Sonntag zunahm ${ }^{135}$.

131 Ibidem [Gdy w mieście pojawiły się niemieckie barwy, łodzianie nie wiedzieli, czy mają być zadowoleni; pytali tylko, jak długo Łódź będzie niemiecka? Tłumaczenie M.K.].

132 Ibidem.

133 Por. W. Pawlak, Na łódzkim bruku...

134 Por. W. Renner, Feldmarschall von Mackensen; ein Lebens- und Charakterbild, Berlin 1915.

135 Ibidem, s. 117 [W Łodzi rozpoczęły się msze polowe. Czterech Niemców nieśmiało zakradło się na pierwszą: obawiali się donosicieli, jednak widać było, że pragnęli uczestniczyć w prawdziwej niemieckiej mszy i w końcu pokonali strach. To była zasługa Mackensena, który natychmiast dostrzegł potrzebę uczestnictwa łódzkich Niemców w nabożeństwie. Liczba uczestników bardzo szybko wzrosła. Z mszy polowych narodził się ruch niemiecko-ewangelicki, a Mackensen cieszył się, że wiernych przybywało z niedzieli na niedzielę. Tłumaczenie M.K.]. 
Autor ograniczył swoje spostrzeżenia do niemieckich ewangelików, pomijając całkowicie reakcję polskiej i żydowskiej części społeczeństwa łódzkiego, a także niemieckich katolików. Również w tym przypadku mamy do czynienia z postawą Kulturträgera w osobie feldmarszałka Mackensena, który przynosi łódzkim Niemcom niemiecką kulturę. Także w innych osobistych zapiskach z tego okresu można zauważyć pomijanie wielonarodowej struktury łódzkiej społeczności. 10 grudnia 1914 r. Alfred Katsczinski pisał w swoim dzienniku: „Nur deutsche Einwohner treffen wir an, nicht einen Polen. Ist denn vor Lodz alles deutsch, oder sind die eigentlichen Polen vor uns ausgerückt?"136.

Literatura niemieckojęzyczna okresu I wojny światowej rejestruje zachodzące zmiany społeczno-polityczno-militarne, dlatego o jej poetyckim kształcie zadecydował kontekst historyczny. Oddaje niepokój wywołany wojennymi wydarzeniami. W łódzkich utworach, szczególnie w poezji, uwidaczniają się cechy niemieckiego ekspresjonizmu, ale też jest wiele elementów różniących obie literatury. Badacz łódzkiej twórczości okresu I wojny odnajdzie w niej zarówno podobieństwa, jak i różnice z powstającą w tym czasie literaturą polskojęzyczną. Ten swoisty konglomerat cech sprawia, że łódzka literatura doby wojny zyskuje charakterystyczny wymiar. Nie jest w stanie w całości czerpać wzorów z niemieckiego ekspresjonizmu czy literatury młodopolskiej, gdyż pisarze łódzcy to w dużej mierze amatorzy, sporadycznie zajmujący się pisarstwem. Dlatego ich możliwości literackiej wypowiedzi były dość ograniczone.

Łódzka literatura okresu I wojny światowej, podobnie jak literatura ogólnokrajowa, pozwala wypowiedzieć się nie tylko pisarzom, lecz również zwykłym ludziom wciągniętym w wir tragicznej historii. Stąd mamy tu do czynienia z relacjami żołnierzy, ich matek lub naocznych świadków tragicznych wydarzeń.

Literatura łódzka posługuje się również nowymi środkami przekazu, jakimi były dzienniki, kroniki, pamiętniki i sprawozdania z pól bitewnych. Wszystkie one wywarły silny wpływ na jej kształt ideowy i estetyczny. Znamienny jest w tym kontekście zwłaszcza dorobek dwóch pisarzy: Heinricha Zimmermanna i Carla Heinricha Schultza, którzy relacjom z pól bitewnych poświęcili znaczącą część swojego dorobku z tego okresu. Ich opisy walk, toczonych w okolicach Łodzi i w samym mieście, należy traktować nie jako rzeczywiste źródła historyczne, lecz przede wszystkim jako świadectwo zróżnicowanych form ludzkiego doświadczenia.

Podobnie jak literatura niemieckiego ekspresjonizmu, także literatura łódzka, szczególnie na początku wojny, nie była jednorodna. Z jednej strony

136 A. Katsczinski, Unser Kampf..., s. 44 [Spotykaliśmy tylko Niemców, ani jednego Polaka. Czyżby w Łodzi wszystko było niemieckie, albo może wszyscy Polacy przed nami uciekli? Tłumaczenie M.K.]. 
wyłonił się w niej nurt antywojenny, skupiony wokół liberalnej gazety „Neue Lodzer Zeitung"; natomiast drugi nurt, zgodny z realizowanymi w Cesarstwie Niemieckim ideami roku 1914, skupił się wokół „Deutsche Lodzer Zeitung” i „Deutsche Post”. Oba kierunki miały swoich zwolenników i przeciwników, wyrosły bowiem niejako naturalnie z wcześniejszych poglądów i upodobań politycznych łódzkich Niemców, zrzeszonych w najróżniejszych stowarzyszeniach i partiach politycznych.

Doświadczenie wojenne jest dla wielu autorów tekstów o charakterze antywojennym doświadczeniem traumatycznym. Dlatego pisarze wyraźnie protestują przeciw wojnie totalnej. Wizje spustoszonych krajobrazów, masowych grobów i cmentarzy przeciwstawiają się treściom propagandowym, idealizującym śmierć na polu chwały. Łódzcy autorzy przedstawiają wojnę jako cierpienie, od którego jedyną ucieczką jest śmierć. 


\section{INNE PRZESTRZENIE ŁÓDZKIEJ POEZJI}

\subsection{Zaangażowanie polityczne łódzkiej poezji}

\subsubsection{Nurt ojczyźniany}

W okresie międzywojennym powstawała w Łodzi literatura, nawiązująca do popularnego w Niemczech pod koniec XIX w. „nurtu ojczyźnianego” (Heimatkunst). Działacze polityczni, a często także pisarze, tacy jak Adolf Eichler, Friedrich Flierl, Ludwig Wolff, Sigismund Banek, Edith Malzahn, Julian Will, Adolf Kargel czy Artur Utta i Albert Breyer, postrzegali Łódź jako miasto, które powstało dzięki żywiołowi niemieckiemu; dlatego uważali za konieczne wzmacnianie ducha niemieckości wśród lokalnych Niemców. $\mathrm{Z}$ tego względu tworzona przez nich literatura naznaczona była - podobnie jak miało to miejsce w przypadku literatury innych regionów, w szczególności tzw. Niemieckiego Wschodu (a więc Prus Wschodnich, Śląska i Pomorza) - tzw. kompleksem „Wschodu”, wywołanym poczuciem „politycznej niepewności", spowodowanym zmianą granic, powstaniem nowych państw po I wojnie światowej i plebiscytami ${ }^{1}$. Dla odzyskania poczucia pewności politycznej literatura ta zaczęła propagować na szeroką skalę motywy nierozerwalnych związków ze stronami rodzinnymi (Heimat) i niemiecką ojczyzną (Vaterland).

Przez wiele lat twórczość określana mianem Heimatliteratur czy też Blut-und-Boden-Dichtung napotykała na silną krytykę, ponieważ ze względu na walory estetyczne kwalifikowano ją jako tzw. literaturę trywialną, posiłkującą się idealizacją i prostymi schematami, utwierdzającymi czytelnika we wszelkich możliwych uprzedzeniach. Pod względem ideologicznym natomiast

${ }^{1}$ Por. Cz. Karolak, W. Kunicki, H. Orłowski, Dzieje kultury niemieckiej, Warszawa 2006, s. 439-440; J. Zaprucki, Kultura reminiscencji - reminiscencje kultury. Motyw małej ojczyzny w twórczości Siegfrieda Lenza, Horsta Bienka i Johannesa Bobrowskiego, Jelenia Góra 2006, s. 12. 
dzieła te głosiły hasła rasistowskie i szowinistyczne, wskutek czego nurt ojczyźniany przez długi czas dyskredytowano. Mimo wielu negatywnych cech literatura tego gatunku była jednak obecna w świadomości niemieckiego społeczeństwa (również w Łodzi) i to ona - obok innych tekstów kultury - kształtowała jego mentalność.

Literackie motywy ideologii ojczyźnianej pojawiają się w twórczości wielu łódzkich poetów. Na uwagę zasługuje tu zwłaszcza twórczość Juliana Willa, dalece przesiąknięta afirmacją „ojczyzny”. Ojczyźniane zaangażowanie poety najlepiej egzemplifikuje cykl wierszy zamieszczonych w tomie Fern vom Land der Ahnen [Z dala od kraju przodków], opublikowanym w $1935 \mathrm{r}^{2}$, w rozdziale Heimat [Mała ojczyzna], w którym autor daje wyraz miłości do natury ojczystego regionu (Dobrzyń nad Wisłą), podkreślając jednocześnie swój związek z niemiecką ojczyzną. W wierszu Mein Dobrzyner Land [Moja Dobrzyńska Ziemia] poeta nie tylko mówi o miłości do ojczystej przyrody, lecz eksponuje też, podobnie jak wielu innych niemieckich przedstawicieli nurtu ojczyźnianego, zwłaszcza zaś literatury „krwi i ziemi” (Blut-und-Boden-Literatur), nierozerwalny związek z ziemią i wspólnotą krwi:

Sag, kennst du das Ländchen so schlicht und so schön,

Das Ländchen der Seen, der Täler und Höhn,

Wo Kiefer und Birke die Sandhügel deckt,

Wo betend die Pappel zum Himmel sich streckt?

Wo wogende Felder und blumige Aun

Des Wanderers Augen und Freuden erschaun?

Wo Gutshof und Dorf aneinander sich reihn,

Dazwischen die Städtchen und Flecken so klein?

Und biederen Sinnes der Landmann sich müht

und Furche und Furche bedächtig wohl zieht

Auf heimlicher Scholle mit kundiger Hand?

Es ist meine Heimat, das Dobrzyner Land! ${ }^{3}$

Wiele miejsca poświęca autor nie tylko „małej ojczyźnie”, ale także tej, z której wywodzą się jego przodkowie, a więc Niemcom. W utworze $O, d u$ Deutschland! [0, niemiecka ojczyzno!] wyraża przywiązanie i podziw do kraju ojców:

2 J. Will, Fern vom Land der Ahnen. Gesammelte Gedichte, Lodz 1935, s. 43. Po wojnie nigdy nie wznowiono druku tomu.

${ }^{3}$ J. Will, Mein Dobrzyner Land, [w:] idem, Fern vom Land..., s. 11 [Powiedz mi, znasz kraj niewielki, powszedni i zwykły, krainę jezior, dolin i pagórków, gdzie sosny i brzozy na piaszczystych wzgórzach, gdzie topola w modlitwie wystrzela ku górze? Gdzie łany rozkołysane i kwieciste łąki cieszą i oko i serce wędrowca? Gdzie dwór i wieś tuż obok siebie leżą, między nimi miasta i poletka skromne? Gdzie poczciwy wieśniak w trudzie nie ustaje, skibę za skibą odkładając w ziemi ojczystej swoją wprawną ręką? To moja ojczyzna, Dobrzyński Kraj! Tłumaczenie Małgorzata Półrola, dalej: M.P.]. 
Alt-Heidelberg, schönste von allen,

Die ich unter Städten gesehn,

0 , laß dir mein Singen gefallen,

Dich Hochburg der Musen, erhöhn" .

Will akcentuje w swych utworach również szczególną rolę pisarza, który staje się duchowym przywódcą niemieckiego narodu $\left(\right.$ Volk ${ }^{5}$. Bardzo wyraźnie widać to w wierszach, takich jak Dich liebe ich, mein Volk [Ciebie kocham, mój narodzie] ${ }^{6}$, Wach auf, mein Volk [Obudź się, mój narodzie] ${ }^{7}$ czy Für Dich, mein Volk [Dla Ciebie, mój narodzie]. W tym ostatnim autor tak pisze o swoim zaangażowaniu na rzecz niemieckiego narodu:

Für Dich, mein Volk, will wirken ich und leben,

Dir schlägt mein Herz, Dir soll es fürder schlagen,

Bis man mich wird zur letzten Ruhe tragen,

Dir, Dir mein Volk, will ich mein Bestes geben.

Dir, o mein Volk, Dir galt und gilt mein Streben,

Dir meine Luft, Dir meine Angst und Klagen

Du bist mein Trost, wenn mich die Zweifel plagen,

Wenn Kleinmutsgeister höhnend mich umschweben ${ }^{8}$.

Zaangażowanie Willa, ale również innych łódzkich pisarzy, jak choćby Sigismunda Banka czy Artura Utty, na rzecz niemieckiego narodu podporządkowane było ogólnej koncepcji konsolidacji wszystkich Niemców. Istotną

${ }^{4}$ J. Will. O, du Deutschland!, [w:] ibidem, s. 104 [0 stary Heidelbergu, najpiękniejsze ze wszystkich miast, jakie widziałem. Pozwól mi pieśń śpiewać na twą chwałę, nad inne wywyższyć cię jako muz ostoję. Tłumaczenie M.P.].

${ }^{5}$ Pojęcie „naród” w języku niemieckim oznacza Volk albo Nation, przy czym oba wyrazy mają inne konotacje. Volk oznacza wspólnotę etniczną rozumianą poza kontekstem historycznym oraz politycznym. Na początku XX w. używane było jako biologiczna wspólnota krwi i rasy (Blut und Boden), łączyła się z kultem Heimat stron ojczystych. Drugie pojęcie Nation to naród rozumiany w sensie politycznym, ukonstytuowany historycznie. Kwestia używania tych dwóch terminów w odniesieniu do Niemiec jest zagadnieniem problematycznym, chociażby z uwagi na późne rozwinięcie się świadomości narodowej Niemców. Dlatego używanie pojęcia narodu jako Volk i Nation było szeroko omawiane w dyskursie niemieckim. Najistotniejsze prace na ten temat wyszły spod pióra takich autorów, jak: Bernhard Giesen, Benedict Anderson, Eric Hobsbawm czy Ernest André Gellner. W niniejszej pracy tłumaczone na język polski słowo „naród” należy rozumieć jako Volk.

${ }^{6}$ J. Will, Dich, liebe ich mein Volk, [w:] ibidem, s. 45.

7 J. Will, Wach auf, mein Volk, [w:] ibidem, s. 53.

${ }^{8}$ J. Will, Für Dich, mein Volk, [w:] ibidem, s. 45 [Dla Ciebie, mój narodzie, chcę żyć i pracować, dla Ciebie bije me serce, dla Ciebie winno bić aż do ostatniego mego tchnienia, tobie, tobie, mój narodzie, chcę dać, co najlepsze. // Dla ciebie starałem się i starać się będę, / dla ciebie me tchnienie, mój strach i rozpacz. / Tyś mym pocieszeniem w chwilach zwątpienia, / gdy wokół mnie szyderstwo podłych ludzi. Tłumaczenie M.P.]. 
rolę pełnił w niej nie naród w sensie Nation, lecz właśnie w sensie Volk. Tak więc literatura ojczyźniana wyraźnie podążała w kierunku utrwalania „substancji narodowej”, czyli „ujmowania narodu jako wielkości zmistyfikowanej, możliwej do ujęcia jedynie w kategoriach pozaspołecznych"9. Niemcy żyjący poza granicami kraju, na obcej ziemi, mieli czuć silny związek z macierzą. W łódzkiej poezji ojczyźnianej związek ten eksponowany był m.in. w takich wierszach Willa, jak Gelübde [Ślubowanie] ${ }^{10}$, Wir sind Deutsche [Jesteśmy Niemcami] ${ }^{11}$ czy Lied für Auslanddeutsche [Pieśń dla Niemców poza granicami], który stał się hymnem Niemców mieszkających poza niemiecką ojczyzną. Autor pisze:

[...] Deutscher Sehnsucht Schwere
Zieht den deutschen Sinn
Über Land und Meere
Zu den Bergen hin,
wo die Wartburg thronet,
wo die Lorlei singt
deutsche Treue wohnet
deutsche Sprache klingt.
Leiden und entbehren
Schafft uns herbe Pein...
Doch wer will uns wehren,
deutsch und treu zu sein?
Wie's die Welt mag treiben,
wie sie uns auch droht:
Wir sind deutsch und bleiben
Deutsche bis in den Tod!12

Konsolidacji narodu służył również postulat zachowania niemczyzny i niemieckiej kultury wśród Niemców żyjących w Polsce - kolejny motyw podejmowany przez łódzką poezję nurtu ojczyźnianego. W wierszu Mahnung [Przestroga] poeta wzywa do zachowania niemieckiej tradycji:

9 Por. J. Zaprucki, Kultura reminiscencji..., s. 12.

${ }^{10}$ J. Will, Gelübde, [w:] idem, Fern vom Land..., s. 46.

11 J. Will, Wir sind Deutsche, [w:] ibidem, s. 44.

12 Ibidem [...Brzemię niemieckiej tęsknoty zaprząta naszą myśl. / Daleko, poprzez lądy i morza / do tych gór, / gdzie wznosi się Wartburg, / gdzie śpiewa Loreley, / gdzie gości niemiecka wierność, / gdzie rozbrzmiewa niemiecka mowa. // Cierpienie i tęsknota / przynoszą wielki ból, / lecz kto powstrzyma nas, / byśmy pozostali wiernymi Niemcami? / Niech galopuje świat, / niech nawet straszy nas: /Jesteśmy Niemcami i nimi będziemy, Niemcami aż po grób! Tłumaczenie M.P.]. Por. również tłumaczenie: B. Ratecka, Niemiecki Pegaz w Łodzi. Szkic o twórczości literackiej Niemców łódzkich, [w:] Niemcy w dziejach Łodzi do 1945 r. Zagadnienia wybrane, red. K.A. Kuczyński, B. Ratecka, Łódź 2002, s. 250-251. 
Welch edel Gut dürft ihr doch euer nennen!

Bleibt dessen bis zum Grabe eingedenkt:

Und ob euch voneinander Wellen trennen

Die Sprache eint euch! Sie sei das Geschenk

Für eure Kinder, eures Wesens Erben.

Die Väter Sprache darf nicht mit euch sterben.

Denkt daran! $!^{13}$

Literatura ojczyźniana miała więc za zadanie pokazać silne związki Niemców żyjących poza granicami z ich starą ojczyzną. W tym kontekście J. Will odwołuje się bezpośrednio do pojęcia Großdeutsches Reich, korelującego z ekspansją terytorialną Niemiec i poszerzeniem przestrzeni życiowej (Lebensraum) dla narodu niemieckiego. Mówią o tym przykładowo słowa: „Ein einig Volk im großen Deutschen Bunde” [Zjednoczony naród w wielkim Niemieckim Związku], którymi autor posłużył się w wierszu Willkommen hier zu festlich-froher Stunde [Witajcie w uroczystej chwili] ${ }^{14}$. Ponadto silne związki z macierzą i nawoływanie do zjednoczenia wszystkich Niemców dobrze współgrały z treściami ideologicznymi, podejmowanymi w łódzkich utworach. W wierszach Willa na pierwszy plan wysuwają się właśnie treści ideologiczne, a wraz z nimi centralne hasła charakterystyczne dla retoryki narodowosocjalistycznej, a więc Ehre [godność], Treue [wierność], Trommel [werble], Fahne [chorągiew], Blut [krew], Volk [naród], Flamme [płomień] czy Gott [Bóg], wyraźnie eksponujące niemieckiego ducha. Za ich pomocą autor podkreślał, że naród niemiecki ma do spełnienia szczególne posłannictwo w dziejach świata. Przekonanie to wyraził np. w wierszu Wir sind Deutsche! [Jesteśmy Niemcami!]:

Wir sind Deutsche, hör es, Welt,

Wollen Deutsche bleiben,

Wenn auch nimmer dir gefällt

Unser Tun und Treiben.

Möchtest, die vom Reich wir fern,

Uns die Seelen rauben,

Doch wir folgen unserem Stern

Unserm deutschen Glauben.

Deutsche Treue und Einigkeit

Sollen stets uns zieren

Daß wir nicht im Bruderstreit Unser Erb verlieren.

Deutscher Geist sei unsere Wehr,

${ }^{13}$ J. Will, Mahnung, [w:] idem, Fern vom Land..., s. 51 [Jakie szlachetne dobro możecie nazwać swoim! / Nie zapomnijcie do końca waszych dni: / nawet jeśli dzielą was dalekie kraje - / łączy was język! To dar / dla waszych dzieci, wasze naturalne dziedzictwo. / Język ojców nie może umrzeć wraz z wami! / Pomyślcie o tym! Tłumaczenie M.K.].

${ }^{14}$ J. Will, Willkommen hier zu festlich-froher Stunde, [w:] ibidem, s. 82. 
Wenn die Feinde wettern,

Wenn uns droht des Hasses Heer

Grimmig zu zerschmettern ${ }^{15}$.

Wyjątkowemu posłannictwu narodu niemieckiego towarzyszył również szczególny rodzaj cierpienia: „Deutsche! Uns formt die Not! / wuchtet, hämmert und bricht, / stürzt, was morsch, in den Tod / hebt, was gesund ans Licht" [Niemcy! Nas kształtuje cierpienie! Podnosi, rozbija i łamie / popycha ku śmierci to, co zmurszałe / wynosi ku światłu, co zdrowe] - pisał autor w wierszu Not [Cierpienie] ${ }^{16}$, zaś w innym miejscu podkreślał: „Wer deutsch ist, muß leiden" [Kto jest Niemcem, ten musi cierpieć ${ }^{17}$. Cierpieniu narodu niemieckiemu towarzyszy również katastrofizm, akcentowany dodatkowo takimi słowami-kluczami, jak: letzte Kraft [ostatnia siła], letzter Schlag [ostatnie uderzenie], letzte Nacht [ostatnia noc], das letzte Mal [ostatni raz], dunkle Schalen [głuche dźwięki] oraz Dunkelheit [ciemność].

Podobnie jak inne utwory tego nurtu, łódzka literatura ojczyźniana przekonuje swoich czytelników o istnieniu realnego zagrożenia dla narodu niemieckiego. Dlatego w wierszach uwidacznia się dychotomia wartości politycznych i etycznych. Świat konstruowany jest na zasadzie my - oni, gdzie „my” to niemiecki naród, zaś „oni” to zdrajcy narodu (Volksverräter) czy też nieprzyjaciele (Feinde). Taka konstrukcja jest obecna w wielu wierszach Willa, np. w cytowanym wcześniej Wir sind Deutsche! czy Feindeseinfall [Atak nieprzyjaciela] ${ }^{18}$, w których nieprzyjaciel czy też zdrajca nie jest jednak bliżej określony. Natomiast w wierszu Dich liebe ich, mein Volk! [Ciebie kocham, mój narodzie!] autor zwraca uwagę na zagrożenie dla społeczności niemieckiej w Polsce, pisząc:

Denn sieh! Ich galube, du, mein Volk, wirst leben,

Wirst auch im Weichselland nicht untergehen

Trotz der Gefahren, die uns heute umschweben ${ }^{19}$.

15 J. Will, Wir sind Deutsche!, [w:] ibidem, s. 44 [Jesteśmy Niemcami, usłysz to, świecie / i Niemcami chcemy pozostać, / nawet jeśli nie podobają ci się / nasze czyny i dzieła. / Nam, żyjącym z dala od ojczyzny, / pragniesz skraść duszę, / lecz my podążać będziemy za naszą gwiazdą, / naszą niemiecką wiarą. // Niemiecka wierność i jedność / winny nam wciąż towarzyszyć, / byśmy w bratobójczej walce / nie zaprzepaścili spuścizny. / Niech będzie nam tarczą niemiecki duch, / gdy zbliża się nieprzyjaciel, / gdy nadejdzie czas, by rozgromić / nienawiść naszych wrogów. Tłumaczenie M.P.].

${ }^{16}$ J. Will, Not, [w:] ibidem, s. 58.

${ }^{17} \mathrm{~J}$. Will, Wer deutsch ist, muß leiden!, [w:] ibidem, s. 84.

${ }_{18}$ J. Will, Feindeseinfall, [w:] ibidem, s. 15.

19 J. Will, Dich liebe ich mein Volk!, [w:] ibidem, s. 45 [Bo oto wiedz! Ja wierzę, mój narodzie, że żyć będziesz, / i że nie zginiesz w Nadwiślańskim Kraju / mimo niebezpieczeństw, które dziś na cię czyhają. Tłumaczenie M.P.]. 
W jeszcze innym wierszu pojawia się wyraźniej krytyka państwa polskiego. W utworze Ein heißes Weinen [Żałosny płacz] Will wskazuje na państwo polskie jako teren, na którym Niemcy mają ograniczone możliwości uczenia się w szkole języka niemieckiego ${ }^{20}$ :

Ein heißes Weinen geht durchs Weichselland...

Ich hör das Schluchzen, seh' den tiefen Schmerz.

Die himmelwärts empor gestreckte Hand,

Die Tränenaugen... Stürmisch pocht mein Herz.

Ein heißes Weinen geht durchs Weichselland...

Mein deutsches Volk um seine Schule klagt,

Entrissen ihm durch Staates harte Hand, $[\ldots]^{21}$.

Podobne idee jak w przypadku twórczości ojczyźnianej Willa realizuje w swoich wierszach inny łódzki poeta, Sigismund Banek. Również on w szczególny sposób eksponuje związek niemczyzny na obczyźnie z macierzą. W jednym z wierszy z tomu Werk und Wehr [Czyn i obrona] z 1939 r. Banek pisze:

Bleib treu der Fahne, der du dich verschworen,

Und trag dein Licht durch alle Finsternis

Solang du selbst dich nicht in Nacht verloren,

Ist Gott dir nah und jeder Sieg gewiß ${ }^{22}$.

Banek podkreśla jeszcze bardziej sugestywnie niż Will idealistyczne podejście do dziejowego posłannictwa narodu niemieckiego. W wierszu Du bist zu hohem Dienst entboten [Jesteś powołany do wielkiego dzieła] pisze:

Du bist zu hohem Dienst entboten,

Und wo du stehst in Werk und Wacht,

Stehst du im Banne heiliger Toten,

Die deinen Leib ans Licht gebracht.

${ }^{20}$ Istotnie, na mocy uchwały Rady Ministrów z marca 1919 r. oraz ustawy o szkołach prywatnych z 1932 r. tylko w szkołach, w których zebrało się powyżej 40 uczniów niemieckojęzycznych, można było wprowadzić obowiązkowe zajęcia w języku niemieckim. Por. K. Woźniak, Wystawieni na ciężkq próbę. Antagonizmy i zbliżenia, „Kronika Miasta Łodzi” 3/2005, s. 11-19.

${ }^{21}$ J. Will, Ein heißes Weinen, [w:] idem, Fern vom Land..., s. 59 [Żałosny płacz słychać w Nadwiślańskim Kraju... / Słyszę płacz, widzę twe wielkie cierpienie, / dłoń wyciągniętą ku niebu, / łzy płynące z oczu... Mocno bije me serce. // Żałosny płacz słychać w Nadwiślańskim Kraju... / Mój niemiecki naród upomina się o swą szkołę, / którą odebrała mu silna dłoń państwa... Tłumaczenie M.P.].

22 S. Banek, Bleib treu der Fahne!, [w:] idem, Werk und Wehr, Poznań 1939, s. 33 [Bądź wierny sztandarowi, na któryś przysięgał / i nieś twe światło poprzez wszelki mrok. / Jak długo sam nie zbłądzisz pośród nocy czerni, / Bóg blisko ciebie i zwycięstwo pewne. Tłumaczenie M.P.]. 
Du stehst, zu hohem Dienst entboten,

Du immerdar in Haft und Pflicht

Mit jedem Tun vor deinen Toten

Und ihrem ehernen Gericht ${ }^{23}$.

Swoisty idealizm w traktowaniu dziejowego posłannictwa narodu niemieckiego, jak również idea „rzeszy” oraz mit biologicznie zdeterminowanej narodowej tożsamości etnicznej składają się w literaturze ojczyźnianej na „los” kierujący biegiem wypadków ${ }^{24}$. Przeznaczenie podlega w twórczości łódzkich pisarzy racjonalizacji etycznej (obowiązek) i religijnej („wola Boża"). W swojej twórczości Banek często eksponuje wiarę w moc sprawczą sił nadprzyrodzonych stojących ponad człowiekiem, którym ten musi się poddać. W jednym z wierszy autor pisze: „Und dich segnet jede Ferne, / Und du ruhst in Gottes Hand"25.

W podobnym tonie utrzymane są wiersze łódzkiego działacza politycznego Artura Utty, który podobnie jak Banek, w utworze Ohne Glocken [Nie biją dzwony] podkreśla rolę Boga jako tego, który wybrał naród niemiecki do zwycięstwa:

Harte Fäuste schmieden Schwerter

Fahnen hoch zum Sturm empor!

Nicht mehr Dulder/ Wegbereiter!

Wir sind Kämpfer, sind die Streiter,

die einst Gott zum Sieg erkor ${ }^{26}$.

Łódzcy autorzy, nawiązujący w swej twórczości do nurtu ojczyźnianego, opisywali w wierszach szczególny rodzaj walki narodu niemieckiego. Wyjątkowo ekspresyjnie konieczność podjęcia takiej walki wyraża Edith Malzahn w wierszu Wir [My]:

Wir reichen uns nicht zum Bunde die Hand,

wir brauchen die Hände zum Rühren.

${ }^{23}$ S. Banek, Du bist zu hohem Dienst entboten, [w:] ibidem, s. 15 [Tyś powołany do wielkiego dzieła. / Tam, gdzie się trudzisz i gdzie straże pełnisz, / pieczę nad tobą ma święta moc zmarłych, / którzy twe ciało wynoszą ku światłu. [...] Tyś powołany do wielkiego dzieła, / na zawsze w misję obowiązku dany / i każdym czynem swym osądowi / czcigodnych przodków swych poddany. Tłumaczenie M.P.]. Po wojnie nigdy nie wznawiano druku tomu.

${ }^{24}$ Por. Cz. Karolak, W. Kunicki, H. Orłowski, Dzieje kultury..., s. 439-440.

${ }^{25}$ Por. S. Banek, Der grosse Kreis, [w:] Werk und Wehr..., s. 28 [I błogosławi cię wszelka dal / i spoczywasz w rękach Boga. Tłumaczenie M.P.].

${ }^{26}$ A. Utta, Ohne Glocken, [w:] Du stehst in großer Schar: Junge deutsche Dichtung aus Warthe- und Weichselland, hrsg. v. H. Kindermann, Breslau 1939, s. 53 [Twarde pięści wykuwają miecze, / sztandary w górę do ataku! / Już nie męczennicy - lecz pionierzy! / Jesteśmy wojownikami, jesteśmy bojownikami, / których niegdyś Bóg wybrał, by zwyciężali. Tłumaczenie M.P.]. Po wojnie nigdy nie wznawiano druku tomu. 
Ein Blick sagt alles. Was einer ahnt

Der andere muss es spüren.

\section{$[\ldots]$}

Wir spüren den Morgenrot neuer Zeit, wir wissen um unsere Plichten:

Wir können sterben in Kampf und Streit, doch wird man uns nimmer vernichten ${ }^{27}$.

Podobnie jak inni przedstawiciele łódzkiej literatury ojczyźnianej, także ta autorka poświęca wiele swoich utworów (np. Deutschland ${ }^{28}$ ) niemieckiej ojczyźnie, starając się podkreślić łączność łódzkich Niemców z macierzą. Opiewa w nich wspólnotę krwi i ziemi, odwołując się do niemieckiej kultury i tradycji:

Wir Kinder fremder Steppen und Berge und Wälder,

Ob wir auch in der Fremde

Nach unserer Mütter Königtum darben -

Du bist unser!/ Für ewige Zeiten,

Tragen wir deine Sonne

Und deinen Wind, deine Schwere und Tiefe

Und die Sehnsucht nach dir,

Deutschland

In unserem Blut; Und wo wir auch weilen,

Wir Deutschen da draußen, Wir dienen um dich ${ }^{29}$.

W tematyce niemieckiej literatury ojczyźnianej z Łodzi zauważalne są organiczne koncepcje narodowe. Do najczęściej poruszanych motywów należy, oprócz specjalnego posłannictwa Niemiec, także szczególny rodzaj cierpienia, częste powoływanie się na krew przodków i wezwanie do walki. Podobnie jak wielu innych pisarzy niemieckich tego nurtu (dla przykładu: Bruno Behm, Edwin Erich Dwinger czy Karl Broeger), łódzcy autorzy dostrzegali w walce idealistyczno-narodową i etyczno-egzystencjalną próbę oczyszczenia.

${ }^{27}$ E. Malzahn, Wir, [w:] ibidem, s. 57 [Podajemy sobie dłoń nie dla przyjaźni, / potrzebujemy rąk, by poruszyć. / Jedno spojrzenie mówi wszystko. Co jeden pomyśli - / drugi musi odczuć. [...] Czujemy wiatr, powiew nowych czasów, / znamy nasze obowiązki: / Możemy umrzeć w walce i kłótni, / ale nikt nas nigdy nie pokona! Tłumaczenie M.P.]. Po wojnie nigdy nie wznawiano druku tomu.

${ }^{28}$ E. Malzahn, Deutschland, [w:] ibidem, s. 58.

${ }^{29}$ Ibidem, s. 58 [My, dzieci obcych stepów, gór i lasów, / nawet jeśli na obczyźnie tęsknimy / za królestwem naszych matek - / tyś nasza / na zawsze! / W naszej krwi nosimy twe słońce, / twój wiatr, ciężar i głębię / i tęsknotę za tobą, / niemiecka ojczyzno, / i tam, gdzie jesteśmy, / my, Niemcy za granicą, / służymy tobie... Tłumaczenie M.P.]. Po wojnie nigdy nie wznawiano druku tomu. 
Od początku lat 20. XX w. łódzcy autorzy często posługują się słowamikluczami, zaczerpniętymi z retoryki narodowosocjalistycznej (Volk, Not, Fahne, Blut, Trommel, Glut, Schar, Herz, Blutsverräter, Flamme, Träne, Feuer, hoch, heilig, kämpfen, wachen, erwachen, siegen, schwer, hell, ewig, deutsch, dunkel), które można pogrupować w trzech zakresach terminologicznych: religijno-kultowym, biologiczno-organologicznym i militarystycznym. Należy jednak zwrócić uwagę, że niektóre z tych określeń funkcjonują również jako pojęcia metafizyczne. Słowa, takie jak Flamme [płomień] czy Glut [żar], ewokują postawę aktywistyczną i zachęcają do walki (choć nie tylko, gdyż wywodzą się z określonej tradycji kulturowej, dla której ogień ma właściwości oczyszczające). Sploty semantyczne powodują, że poezja ta nabiera cech wzniosłości, wzmocnionej jeszcze nakazami moralno-politycznymi, wyraźnie dochodzącymi do głosu w takich hasłach, jak: „Steh auf, mein Volk!” [Powstań mój narodzie!] „Deutsch bis in das Mark!” [Niemiecki aż do szpiku] czy „Glück auf zum Fest!” [Szczęść Boże z okazji świąt!]. Zastosowany w tych utworach patetyczny styl potęgują też liczne hiperbole, służące wzmocnieniu wrażenia i intensyfikacji ekspresji.

Charakterystyczne dla tego typu twórczości są również szczególne połączenia rzeczowników z przymiotnikami, pozwalające autorom na tworzenie nowych pól stylistycznych z nowymi znaczeniami, jak np. heiliger Mut [święta odwaga], heiße Sehnsucht [gorąca tęsknota], treuer Dienst [wierna służba], heiliger Gott [święty Bóg], deutsche Treue [niemiecka wierność], deutsche Sprache [niemiecki język], deutsche Sehnsucht [niemiecka tęsknota], deutscher Glaube [niemiecka wiara], heilige Glut [święty żar], heilige Flamme [święty płomień], deutsche Art [niemiecki charakter].

Choć powyższe cechy wydają się zgodne z tendencjami widocznymi również w wierszach innych autorów nurtu ojczyźnianego z Niemiec, to jednak twórczość łódzkich pisarzy nie wzbudzała zbyt wielkiego uznania ówczesnych niemieckich pisarzy i historyków. Wskazywali oni przede wszystkim na fakt, że niemieckojęzyczni łodzianie są w swych literackich osiągnięciach bardzo niedojrzali. Jednym z nich był Albert Breyer, który w 1931 r. w artykule pt. Neuerscheinungen im Deutschen Schrifttum Mittelpolens (1925-1930) ${ }^{30}$, wydrukowanym w czasopiśmie „Deutsche Blätter in Polen”31, wyraził opinię na temat twórczości literackiej niemieckojęzycznych łodzian, stwierdzając m.in.:

Das Deutschtum Mittelpolens ist über die Stufe der Entwicklung, die junge Sprachinseln durchmachen müssen, noch nicht herausgekommen. Es fehlen ihm Kräfte des gei-

30 A. Breyer, Neuerscheinungen im Deutschen Schrifttum Mittelpolens (1925-1930), „Deutsche Blätter in Polen" 8 /1931, s. 227-230.

31 „Deutsche Blätter in Polen” - miesięcznik wydawany w Poznaniu od 1924 r. (w latach 1924-1925 kierowany przez Hermanna Rauschninga, w 1926 r. przez tegoż samego oraz Viktora Kaudera i Martina Kagego, natomiast w okresie 1927-1931 przez Paula Zöcklera). Na łamach tego czasopisma drukowano artykuły dotyczące historii niemieckiego osadnictwa, kultury i literatury Niemców w Polsce. 
stig schaffenden Willens und des völkischen Bewusstseins; ganz auf das Praktische, Nützliche, Gegenwärtige ist es eingestellt. Primitive Menschheitstriebe beherrschen sein Denken und Wollen ${ }^{32}$.

Przyczyną krytyki i daleko idącego dystansu do literatury powstającej w Łodzi może być sytuacja, w jakiej znalazła się tutejsza mniejszość niemiecka po I wojnie światowej (ale także w latach wojennych). Łódzcy Niemcy byli zawsze tzw. niemczyzną wyspową (Inseldeutschtum), otoczoną większością polską („słowiańskim morzem”). Łódź i rejon raczej nie leżały w orbicie zainteresowań terytorialnych państwa niemieckiego, jak miało to miejsce w przypadku zachodnich i północnych rejonów II Rzeczypospolitej. To właśnie tym obszarom państwo niemieckie poświęcało najwięcej uwagi i tam starano się za wszelką cenę utrzymać Niemców, szczególnie po I wojnie światowej. W ocenach Niemców z Rzeszy niemieckojęzyczni łodzianie byli w dużej mierze zasymilowani z polskością i zainteresowani przede wszystkim budowaniem własnej egzystencji. Warto również wspomnieć o otoczeniu wielokulturowym, w którym wzrastali i do którego przywykli, dlatego szerzenie wśród nich postaw nacjonalistycznych często natrafiało na opór ${ }^{33}$. Stąd powstająca tu literatura ojczyźniana nie posiadała zbyt silnych akcentów rasistowskich, szczególnie cennych dla celów politycznych po 1933 r. Z pewnością była szowinistyczna, wyolbrzymiała i bezrefleksyjnie przedstawiała przywiązanie oraz podziw dla Niemiec i własnej grupy etnicznej. Uzurpowała sobie również prawo do deprecjonowania Polski, podsycając poczucie istniejącego tu zagrożenia dla mniejszości niemieckiej. Nadrzędnym jej celem było podtrzymywanie poczucia wspólnoty niemieckiej, łączności z macierzą, a także zachowanie w Polsce języka i niemieckiej kultury.

\subsection{2. „Prosimy o dowody!” Wiersze zaangażowane Carla Heinricha Schultza}

W końcu lat 30. XX w. społeczeństwa polskie i niemieckie podlegały coraz głębszej polaryzacji ${ }^{34}$, a sytuacja stała się szczególnie napięta w chwili, gdy niemiecki rząd coraz śmielej zaczął wysuwać roszczenia pod adresem Polski.

32 A. Breyer, Neuerscheinungen..., s. 227 [Środowisko Niemców z centralnej Polski jeszcze nie wyszło poza ten etap rozwoju, przez jaki przechodzą najmłodsze enklawy językowe. Brak im siły sprawczej intelektu i świadomości narodowej; nastawieni są wyłącznie na cele praktyczne, użytkowe, przydatne i aktualne. Ich sposobem myślenia i działania rządzą prymitywne instynkty. Tłumaczenie Wolfgang Kessler].

${ }_{33}$ Por. np. działalność niemieckich socjaldemokratów oraz liberalnie nastawionych środowisk niemieckich.

${ }^{34}$ Por. K.P. Woźniak, Wystawieni na ciężkq próbę..., s. 11-19. 
W 1938 r. minister spraw zagranicznych Rzeszy, Joachim von Ribbentrop, zaproponował Józefowi Lipskiemu włączenie Gdańska do Niemiec, zbudowanie eksterytorialnej autostrady i linii kolejowej, wiodącej przez polskie Pomorze, a ponadto przedłużenie polsko-niemieckiego układu o nieagresji na 25 lat z gwarancją wzajemnej granicy, współpracę przy emigracji Żydów z Polski oraz kooperację w kwestiach kolonialnych. Niecały rok później Niemcy już zdecydowanym głosem domagali się przyłączenia Pomorza Gdańskiego i zaproponowali przystąpienie Polski do paktu antykominternowskiego. W tej sytuacji zarysował się ostry konflikt w stosunkach polsko-niemieckich, a bardzo już napiętą atmosferę dodatkowo podgrzewała niemiecka propaganda, głosząc, że mniejszość niemiecka w Polsce jest prześladowana ${ }^{35}$. Również lokalne stosunki między Polakami i Niemcami znacznie się pogorszyły; coraz częściej dochodziło do utarczek ustnych między ludnością polską i niemiecką, a także do wzajemnych ataków ${ }^{36}$. W maju 1939 r. przed niemieckim konsulatem i redakcjami niemieckich gazet w Łodzi demonstrowano przeciw miejscowym Niemcom (działaczom nacjonalistycznym ${ }^{37}$ ), zaś w sierpniu 1939 r. polscy robotnicy pikietowali przed bramami łódzkich fabryk, aby nie dopuścić do pracy niemieckich kolegów ${ }^{38}$.

Atmosferę napięcia utrwaliła również łódzka literatura. W 1938 r. tygodnik „Der Deutsche Wegweiser” opublikował cykl wierszy politycznych, krytykujących narodowy socjalizm i odcinających się ideologicznie od nurtu literatury ojczyźnianej. Ponieważ sytuacja społeczno-polityczna w Polsce pozwalała na artykułowanie takich postaw, twórczość tego rodzaju mogła rozwijać się na łamach gazety bez jakichkolwiek przeszkód.

Wiersze, o których będzie tu mowa, można zaliczyć do tekstów zaangażowanych. Chodzi o takie zjawiska literackie, jak poezja polityczna, ulotna, zaangażowana, okolicznościowa, moralistyczna czy też - jak wyraził się Janusz Dunin - wiersze publicystyczne, powstałe w momentach określonych czasowo i historycznie ${ }^{39}$. Twórczość zaangażowaną Schultza (pseud. Ernst Heiter) z uwagi na jej charakter można również porównać do wierszy nurtu tzw. Nowej Rzeczowości (Neue Sachlichkeit), reprezentowanego przez takich niemieckich pisarzy, jak Erich Kästner, Kurt Tucholski czy Bertolt Brecht. Podobnie jak utwory tzw. poezji użytkowej (Gebrauchslyrik), wiersze Schultza po-

35 Por. J. Krasuski, Historia Niemiec, Wrocław 2002, s. 449-450.

${ }^{36}$ Por. Niemcy w Polsce 1945-1950. Wybór dokumentów, red. W. Borodziej, H. Lemberg, t. 2, Warszawa 2000, s. 19.

37 Ibidem.

38 Por. K.P. Woźniak, Wystawieni na ciężkq próbę..., s. 11-19.

${ }^{39}$ J. Dunin, Wiersze w prasie. Zapomniany gatunek publicystyki. Artykuł niepublikowany, udostępniony autorce przez dr Joannę Mikosz, adiunkta w Katedrze Dziennikarstwa i Komunikacji Społecznej UŁ. 
dejmowały aktualną problematykę, a prostotą formy ich autor pragnął trafić do szerokiego grona odbiorców. W taki sam sposób postąpił Bertold Brecht, który w tomie z 1934 r. pt. Lieder, Gedichte, Chöre ${ }^{40}$ zwrócił się ku twórczości antyfaszystowskiej, przestrzegając przed narodowym socjalizmem i polityką zagraniczną Adolfa Hitlera.

Jednak żadne z wyżej wymienionych określeń nie definiuje wyczerpująco tekstów, o których będzie mowa, wiele z nich wymyka się bowiem temu czy innemu pojęciu. Elementem łączącym je wszystkie jest uchwycenie rzeczywistości jako świadectwa czasu oraz posługiwanie się specyficznym językiem. Wiersze te można również określić mianem literatury „walczącej”, podejmującej $\mathrm{w}$ danym momencie kwestie istotne dla zbiorowości i żywo reagującej na wszystkie ważniejsze fenomeny z życia wspólnoty niemieckiej w Łodzi. Utwory powstałe pod wpływem impulsu historycznego miały charakter utylitarny i bardzo często pozbawione były walorów artystycznych, pełniąc rolę podobną do publicystyki.

Czołowym przedstawicielem literatury, którą można określić mianem twórczości zaangażowanej, opowiadającej się przeciw nasilającym się tendencjom narodowosocjalistycznym i radykalizacji życia politycznego w Łodzi, był pisarz i dziennikarz Carl Heinrich Schultz (1882-1940), przez wiele lat związany ze środowiskiem łódzkich Niemców, nastawionych lojalnie do Polski i Polaków ${ }^{41}$. W 1938 r. na łamach tygodnika „Der Deutsche Wegweiser" opublikował wiele utworów, które należy odczytywać jako polemikę z hitlerowską polityką narodowościową i działalnością lokalnych działaczy narodowosocjalistycznych. Jednym z nich jest utwór Lied der Polendeutschen [Pieśń polskiego Niemca], polemizujący z przytoczonym wcześniej wierszem Juliana Willa pt. Lied für Auslanddeutsche [Pieśń Niemców z zagranicy]. Schultz pisze:

Przodkowie nasi ongiś tu ściągali $\mathrm{z}$ rozlicznych stron, z niemieckich krain, tam z trudem koniec z końcem wiązali, tu zacząć wszystko od nowa zamierzali. Przybyli zatem do polskiej krainy

40 B. Brecht, Lieder, Gedichte, Chöre, Paris 1934.

${ }^{41}$ Więcej informacji na temat życia i działalności Carla Heinricha Schultza znajduje się w aneksie: Łódzkie sylwetki oraz w książce, która ukazała się pod redakcją M. Kucner, Literackie i nieliterackie obrazy miasta. Łódź przełomu wieków oczami niemieckojęzycznego autora - Carla Heinricha Schultza / Nicht nur literarische Bilder einer Stadt. Lodz in den Augen eines deutschsprachigen Autors - Carl Heinrich Schultz, Łódź 2011. Wszystkie zamieszczone fragmenty utworów Carla Heinricha Schultza pochodzą z tej dwujęzycznej polsko-niemieckiej publikacji. W kolejnych przypisach odsyła się najpierw do tłumaczenia polskiego, a następnie do oryginału niemieckiego. Utwory C.H. Schultza zostały odnalezione w niemieckojęzycznym czasopiśmie „Der Deutsche Wegweiser". 


\begin{abstract}
życie budując od podwalin,
tutaj znaleźli drugą ojczyznę,

której swe serca bez reszty oddali.

To los tak chciał, to los nas wiąże

z naszym ojczystym krajem, z Polską.

Choć czasy, choć ludzie się zmieniali, myśmy na zawsze Niemcami zostali.

Niemiecką duszę, niemiecką krew mamy,

obojgu wierni będziemy bez granic.

Lecz tu, gdzieśmy blask świata ujrzeli

i życia naszego karty spisywać poczęli,

choć różnie się toczyć będą losy Polski,

my jej na zawsze dochowamy wierności!

To los tak chciał, to los nas wiąże

z naszym ojczystym krajem, z Polską ${ }^{42}$.
\end{abstract}

Zarówno wiersz Willa, jak i tekst Schultza to ważne deklaracje ideowe Niemców, żyjących poza granicami państwa niemieckiego. W obu utworach autorzy identyfikują się z losami rodaków na obczyźnie, ale odmiennie traktują pojęcie „ojczyzna” (Heimat). Wiersz Willa należy rozpatrywać w kontekście ideologii nacjonalistycznej, głoszonej w Łodzi już od początku XX w. Dla niego ojczyzną są i na zawsze pozostaną Niemcy, a więc kraj przodków. Stąd wyraźne odwołanie do ojcowizny, ukorzenienia plemiennego i niemieckich symboli narodowych, takich jak Wartburg czy Loreley. U Schultza, pisarza, który nie był związany ze środowiskiem łódzkich narodowych socjalistów, widać wyraźnie, że Niemcy potrafili zbudować sobie w Polsce nową ojczyznę, a kraj przodków nie przedstawia dla nich większej wartości. Związek z macierzą nie jest również tak silny jak w wierszu Willa, bo pragną dochować wierności nowej ojczyźnie. Eksponowanie w utworach literackich silnego przywiązania do macierzy i nakaz dochowania wierności niemieckiej ojczyźnie nie przeszkadzał niemieckim nacjonalistom deklarować w życiu politycznym lojalności wobec państwa polskiego.

Wiersz Schultza należy postrzegać w kontekście działalności organizacji Vereinigung der Deutschen in Polen, którego autor był członkiem. Program stowarzyszenia zakładał m.in. równouprawnienie obywateli pochodzenia niemieckiego $\mathrm{z}$ obywatelami polskimi, powołanie do życia ogólnoniemieckiej organizacji, obsadzenie bezrobotnych Niemców w województwach wschodnich (gdzie mieli pełnić rolę bastionu przeciw bolszewizacji), tolerancję wyznaniową, dopuszczenie obywateli pochodzenia niemieckiego do piastowania funkcji państwowych i oczyszczenie redakcji niemieckich

${ }^{42}$ C.H. Schultz, Pieśń polskiego Niemca, [w:] Literackie i nieliterackie obrazy miasta..., s. 44 (Lied der Polendeutschen, [w:] ibidem, s. 159-160). 
gazet z obywateli z Rzeszy, jednym słowem - walkę z działalnością kulturalną i literacką, wywierającą zgubny wpływ na życie społeczności niemieckiej w Polsce. W programie znalazły się też postulaty socjalne: poprawa stanu zdrowia, kształcenie obywateli i prawo do emerytury. Choć Niemcy lojalnie nastawieni do Polski domagali się swoich praw, opowiadali się również za przyjazną współpracą Polaków i Niemców ${ }^{43}$. Nic dziwnego, że Schultz deklaruje w swym wierszu chęć pielęgnowania niemieckiej kultury i tradycji, ale w obrębie polskiej państwowości i przy zachowaniu postawy lojalnej wobec polskiego państwa i narodu ${ }^{44}$.

Wiersze obu autorów wyraźnie pokazują, że społeczność niemiecka w Łodzi była politycznie zróżnicowana. Należeli do niej głosiciele idei nacjonalistycznych i haseł pangermańskich, ale również Niemcy, którzy poddali się procesowi asymilacji i na trwale związali ze swą łódzką ojczyzną ${ }^{45}$. Jako członek Vereinigung der Deutschen in Polen oraz osoba zasymilowana z polskością, Schultz pod pseudonimem Ernsta Heitera w wielu wierszach wyrażał poglądy tej właśnie części niemieckiej społeczności Łodzi, pokojowo nastawionej do Polaków, dystansując się tym samym od wszelkiej działalności narodowych socjalistów. W wierszu Beweise her! [Prosimy o dowody!] pisał:

Jakże wiele się zmieniło z tego, co niegdyś oczywiste było:

tu w Polsce Niemcy mieszkali, którzy się nigdy na Berlin nie oglądali.

W polityce dalekie im było poczucie niemieckości,

bo chodziło o sprawy, wymagające zwykłej uczciwości.

Przywykliśmy tu do wszystkiego, pracując w pocie czoła, nie szerząc nienawiści, nie mając się za pępek świata zgoła.

Gdy skończyła się wielka wojna, a wraz z nią okupacja,

sądziliśmy, że już nigdy z Rzeszy nie dotrze tu agitacja ${ }^{46}$.

Utwory Schultza pisane są z perspektywy człowieka zasymilowanego z polskością, dodatkowo zaangażowanego politycznie i występującego przeciw radykalizacji życia politycznego. Tendencja ta jest widoczna w licznych wierszach, nawiązujących do aktualnej sytuacji społeczno-politycznej, w których autor wiele miejsca poświęca kwestiom międzynarodowym. W wierszu Nirgends Friede [Nigdzie nie ma pokoju] Schultz odwołuje się m.in. do sytuacji w Palestynie, jaka miała miejsce w lipcu 1938 r., gdy doszło do licznych

${ }^{43}$ Por. [b.a.], Klassenkampf und Futterkrippenkrieg, „Der Deutsche Wegweiser”, 5.03.1938, s. $2-3$.

44 [b.a.], Staat, Kirche und Polendeutschtum, „Der Deutsche Wegweiser”, 10.07.1938, s. 1.

45 Por. Polacy - Niemcy - Żydzi $w$ Łodzi $w$ XIX-XX, [w:] Sąsiedzi dalecy i bliscy, red. P. Samuś, Łódź 1997, s. 127.

${ }^{46}$ C.H. Schultz, Prosimy o dowody!, [w:] Literackie i nieliterackie obrazy miasta..., s. 56-57 (Beweise her!, [w:] ibidem, s. 172-173). 
aktów terrorystycznych, jak również do wojny chińsko-japońskiej, która wybuchła w 1937 r. Pisze m.in.:

W Palestynie wielki zamęt, kraj w ogniu stoi cały, walczą bez pardonu, jakby byli bandytami.

Ludzkim życiem szafują jak tanimi przedmiotami, zapominając, że wszyscy są przecież Semitami!

Bo i Arabowie, jak powszechnie wiadomo, są od zarania dziejów Semitami de domo, z Żydami mają zatem wspólne pochodzenie; mimo to ogarniają ich nienawiści płomienie.

Jeśli obie strony bez reszty się unicestwią z hasłami patriotyzmu na ustach, jak z pieśnią zaiste, trudno będzie wytłumaczyć potomnym, jakie źródło zrodziło ten ich antagonizm.

Jeśli wzrok skierujemy na Daleki Wschód, tam także ujrzymy chmur gradowych w bród: panowie bolszewicy, trudno ów fakt przeoczyć, zapragnęli z Japońcami wojenkę sobie stoczyć ${ }^{47}$.

Odniesienia do międzynarodowych wydarzeń są również w wierszu Keine Ruhe! [Ni chwili spokoju], w którym autor nawiązuje do sytuacji politycznej w Jugosławii w 1939 r., przyłączenia do III Rzeszy północnej Słowenii oraz okupacji Albanii przez Włochy:

Ni krzty spokoju w Jugosławii, Włochy ślą wojska do Albanii, a Trzecia Rzesza w ślad za nimi to samo robi już w Słowenii.

Von Ribbentrop i hrabia Ciano znów spotykają się potajemnie wierząc, że uda im się od „Osi” korzyści pozyskać dla siebie.

A już niebawem do związku „Osi” Japonia ma się przyłączyć

(jak tu zrozumieć politykę, jak przejrzeć cel w intryg gąszczu)! $!^{48}$

Także w wierszu Zeitgemäße Betrachtungen [Rozważania współczesne] autor wspomina o aktualnie toczonej wojnie domowej w Hiszpanii, wojnie japońsko-chińskiej, powstaniu Generała Saturnino Cedillo w Meksyku przeciwko rządowi i prezydentowi Cardenasowi:

W Hiszpanii ni chwili spokoju,

Franco grzmoci tam czerwonych,

47 C.H. Schultz, Nigdzie nie ma pokoju, [w:] Literackie i nieliterackie obrazy miasta..., s. 44 (Nirgends Friede, [w:] ibidem, s. 152-153).

${ }^{48}$ C.H. Schultz, Ni chwili spokoju, s. 61 (Keine Ruhe!, [w:] ibidem, s. 178). 
zdzierają na wylot buty,

lecz nie przechytrzą brązowych.

Gorzej na Dalekim Wschodzie.

Na skośnookich zasadzka,

Japończyków i Chińczyków.

Tam nikt się z nimi nie cacka.

[...] Nawet w dalekim Meksyku

groch z kapustą, zamęt wokół.

Ludzie, zaprzestańcie walki,

musicie zakłócać pokój? ${ }^{49}$

Przytoczone fragmenty wierszy są przykładem rejestracji ówczesnych wydarzeń politycznych, których autor staje się kronikarzem. Jednak nie jest to beznamiętna relacja, gdyż Schultz nie jest powściągliwy w eksponowaniu emocji, co zbliża jego twórczość do publicystyki. Szczególnie silny ładunek emocjonalny pojawia się w wierszach, w których łódzki poeta pisze o polityce zagranicznej Trzeciej Rzeszy. W wierszu Kommintern triumphiert [Komintern triumfuje] padają ostre słowa:

$[\ldots]$

W te pędy zatem udają się wręcz galopem

do krasnej Moskwy różne Ribbentropy,

na miejscu, ani sekundy nie zwlekając,

pod „Paktem” własnoręczne podpisy składają.

A wszystko to tylko jest rodzaj fortelu, bo przecież to jedynie „kawałek papieru”!

Tak, tak, Trzeciej Rzeszy pomysłów nie brak, jak po raz kolejny „uszczęśliwić” świat.

I nikogo to chyba nie napawa smutkiem; pan Stalin w kułak śmieje się ukradkiem: pokonał wroga i poszło mu jak z płatka oto rozsadził „Antykomintern” od środka.

A Trzecia Rzesza już z prądem dryfuje i do dość dziwnej polityki się odwołuje, której kurs zdaje się potwierdzać fakt, że bez namysłu podpisała ów pakt.

Lepiej byłoby jednak, gdyby kurs zmieniła i na rozsądne negocjacje się zdobyła. Na pewno więcej by dzięki temu zyskała, gdyby była mniej butna, mniej zarozumiała ${ }^{50}$.

${ }^{49}$ C.H. Schultz, Rozważania współczesne, [w:] Literackie i nieliterackie obrazy miasta..., s. 32-33 (Zeitgemäße Betrachtungen, [w:] ibidem, s. 146-147).

${ }^{50}$ C.H. Schultz, Komintern triumfuje, [w:] Literackie i nieliterackie obrazy miasta..., s. 64-65 (Kommintern triumphiert, [w:] ibidem, s. 181-182). 
Autor poświęca również wiele miejsca Polsce i sytuacji politycznej Gdańska. W wierszu Lebensraum poddaje w wątpliwość ideologię narodowego socjalizmu i pokazuje, że za pozornymi deklaracjami lojalności kryje się cyniczna gra interesów. Wskazuje ponadto na brak spójności między działaniem przeciwników politycznych i deklaracjami, jakie składają przed Niemcami w Polsce:

„Lebensraum” - tak Trzeciej Rzeszy brzmi najnowsze hasło,

„Lebensraum” to przestrzeń do życia, gdy narodowi za ciasno!

„Rzesza” to wielki kraj. Czy tak jest w istocie, nikt nie pyta,

lecz sama wielkość kraju nie usprawiedliwia wilczego apetytu.

„Prawo narodów do samostanowienia” - to zawsze trzeba szanować, ale „Czechy” i „Morawy” zaraz na „Protektoriaty” przemianować?

Co niemieckie, ma być prawdziwe, fałsz nie wart funta kłaków, rujnuje tylko reputację w oczach biografów i etnografów.

Wiadomo, że jeśli kto raz skłamał, trudno mu znów dać wiarę. Prawdą nie wolno dowolnie kręcić, bo to nie werk ani zegarek.

Jeśli „Czechy” i „Morawy” to dla Rzeszy nowy „Lebensraum”, wypada uznać, że i Polska ma prawo upomnieć się o Gdańsk ${ }^{51}$.

W przytoczonym tekście Schultz stara się wyrazić pogląd uniwersalny, że wszyscy obywatele mają prawo do życia. Odwołuje się przy tym do słów Friedricha Schillera, który w balladzie Der Alpenjäger [Alpejski myśliwy] stwierdził: „Raum für alle hat die Erde!” [Na ziemi jest miejsce dla wszystkich!]. Łódzki autor uderza tym stwierdzeniem w powszechnie akceptowane patriotyczne rekwizytorium, jakim jest właśnie ta podniosła wypowiedź. Również w tym wierszu jasno deklaruje poglądy polityczne, opowiadając się za polską racją stanu i polskimi interesami, poddając tym samym w wątpliwość polityczne dążenia Trzeciej Rzeszy, gdy pisze o poszerzeniu niemieckiej przestrzeni życiowej. Pragnie tu zdemaskować prawdziwe oblicze niemieckiej polityki. W wierszu Keine Ruhe [Nic spokoju] stwierdza:

Świat patrzy na Gdańsk, choć niektórzy faktom i tak zaprzeczają, my jednak dobrze wiemy, co hitlerowskie zwyczaje oznaczają.

Forster wygłosił płomienną mowę, ale się z prawdą daleko mijał i nie stwierdził w niej niczego, co by wątpliwości rozjaśniło.

Wygląda na to, że „Schupo" w Gdańsku niezbyt pewnie się czuje, o tam „Gestapo" aresztuje, a „Schupo" najwyżej w kajdany zakuje ${ }^{52}$.

51 C.H. Schultz, Lebensraum, [w:] Literackie i nieliterackie obrazy miasta..., s. 59 (Lebensraum, [w:] ibidem, s. 175-176).

${ }^{52}$ C.H. Schultz, Ni chwili..., s. 61 (Keine Ruhe!..., s. 178). 
Autor próbuje również bezpośrednio zdemaskować prawdziwe mechanizmy niemieckiej propagandy. Wyraźnie widać to w wierszu Kommintern triumphiert [Komintern triumfuje], w którym odwołuje się do paktu Ribbentrop-Mołotow podpisanego przez III Rzeszę ze Związkiem Radzieckim 23 sierpnia 1939 r. Schultz widział w nim przede wszystkim kolejny trik państw-sygnatariuszy tego dokumentu:
W światowej polityki zaklętych kręgach
trik pozwala po całkiem inne cele sięgać
niż te, o których wieszczy „propaganda”,
bowiem w praktyce... odmiennie się działa.
Ustanawia się zatem przeróżne klauzule,
bo bardzo pragnie się „wyzwolić” świat,
więc żeby wojna nam nie zagroziła,
najlepiej podpisać „O nieagresji pakt”53.

O zakłamaniu polityki narodowosocjalistycznej pisze również w jednym ze swych ostatnich wierszy Beweise her! [Prosimy o dowody!]. Nie pozostawia żadnych złudzeń, że działalność narodowych socjalistów (Konrada Henleina, Ludwiga Wolffa, Adolfa Eichlera - członków Der Deutsche Volksverband) jest bardzo niebezpieczna. Również i tu odwołuje się do wcześniej wspomnianej idei Lebensraumu:

Henleiny i Wolffy to „Führerzy” „germańskości na świecie”, kto nie wierzy, ten „zdrajca” - grzmi nazistowskie podziemie. Bo „podziemiem” jest „Volksverband” - propaganda krzyczy który zagranicy bezwolnie pozwala się wieść na smyczy.

Na nic zapewnienia, że tylko „Oni postępują «lojalnie»”, nigdy tego nie dowiedli, co świadczy o nich fatalnie.

„Niemcy mogą mieć Gdańsk? („Volksverband” milczy wymownie).

„Zgadzacie się na warunki Becka?” „Tak” byłoby „ryzykowne”.

Naziści stosują tricki, nie mówią, co naprawdę ważne -

to „naziści-bolszewiści”, spory tłumaczą „Lebensraumem”.

Niemieccy obywatele, czas, byście się dowiedzieli,

kim są ów pan Wolff, pan Kargel i ich przyjaciele...

Pomyślcie o tym przez chwilę! $!^{54}$

W przytoczonych fragmentach wierszy widać wyraźnie ich agitacyjny i perswazyjny charakter. Jako członek Vereinigung der Deutschen in Polen Schultz starał się zdemaskować fałsz i zakłamanie polityki narodowych socjalistów. W tym celu posługiwał się wieloma środkami, które miały służyć

${ }^{53}$ C.H. Schultz, Komintern triumfuje..., s. 61 (Kommintern triumphiert..., s. 181-182).

${ }^{54}$ C.H. Schultz, Prosimy o dowody!..., s. 57 (Beweise her!..., s. 173). 
przekonaniu czytelnika o słuszności prezentowanych poglądów. Wiele elementów zostało zaczerpniętych $\mathrm{z}$ instrumentarium perswazji. Istotnym elementem budowy wierszy Schultza jest bezpośredni zwrot do odbiorcy, wyznacznik kompozycji wielu utworów. „Kinder, seid doch keine Frösche!” [Ludziska, nie bądźcie tchórzem podszyci] - pisał łódzki poeta w wierszu Verkanntes Heldentum [Niedocenione bohaterstwo] ${ }^{55}$; „Liebe Leser” [Drodzy czytelnicy!] w utworze Zeitgemäße Betrachtungen [Rozważania współczesne] ${ }^{56}$; „Deutsche Bürger" [Niemieccy obywatele] w wierszu Beweise her $!^{157}$ [Prosimy o dowody!]; ,Liebe Kinder” [Drogie dzieci] w utworze Schönen Dan$k^{!^{58}}$ [Piękne dzięki!]. Tych bezpośrednich zwrotów do czytelnika jest zresztą znacznie więcej. Personalizacja adresata wypowiedzi ma zmniejszyć dystans między autorem i czytelnikiem, ale ma również za zadanie włączyć czytelnika w określone działanie. Elementy te każdorazowo nadają wypowiedzi perswazyjny charakter. Podobnie dzieje się w przypadku stosowania wykrzykników, które autor wykorzystał np. w wierszu An die Angsthasen! ${ }^{59}$ [Do strachajłów!]. Budują one wyraźne napięcie dialogowe i nakłaniają do przyjęcia określonej postawy. „Hört nicht” [nie słuchajcie], „bleibt” [zostańcie], „Hütet euch“ [strzeżcie się] - to tylko niektóre przykłady stosowania tego rodzaju perswazyjnych elementów. W innym utworze pt. Zu den Wahlen! [Ruszajmy do urn!] autor wyraźnie identyfikuje się z odbiorcą, pisząc: „Skoro dziś pakujemy się w nowe zmartwienie, niechaj do czynu popycha nas pobożne życzenie"60. Identyfikacja z czytelnikiem budzi wiarygodność osoby przekonującej i ułatwia samo przekonanie, ponieważ nie buduje sztucznego podziału między autorem i odbiorcą.

Istotne znaczenie perswazyjne mają również pytania retoryczne, nadające wypowiedzi charakter ekspresywny. Za pomocą pytań Schultz wyraża, po pierwsze, postawę uczuciowego wzburzenia i stara się być przekonujący, po drugie, wyznacza pole poszukiwań i pobudza do myślenia. „Czego się boicie?” - pyta w wierszu An die Angsthasen! ${ }^{61}$. W utworze Lebensraum daje wyraz swojemu wzburzeniu, pisząc: „Co się podoba Mussoliniemu, muszą Polacy respektować?”62. W tym samym wierszu formułuje kolejne pytanie: „Prawo

55 C.H. Schultz, Niedocenione bohaterstwo, [w:] Literackie i nieliterackie obrazy miasta..., s. 36-37 (Verkanntes Heldentum!, [w:] ibidem, s. 150-151).

${ }^{56}$ C.H. Schultz, Rozważania współczesne..., s. 32 (Zeitgemäße Betrachtungen ..., s. 147).

57 C.H. Schultz, Prosimy o dowody!..., s. 57 (Beweise her!..., s. 173.).

${ }_{58}$ C.H. Schultz, Piękne dzięki!, [w:] Literackie i nieliterackie obrazy miasta..., s. 60 (Schönen Dank!, [w:] ibidem, s. 150-151).

${ }_{59}$ C.H. Schultz, Do strachajłów, [w:] Literackie i nieliterackie obrazy miasta..., s. 62-63 (An die Angsthasen!, [w:] ibidem, s. 179-180).

${ }^{60}$ C.H. Schultz, Ruszajmy do urn!, [w:] Literackie i nieliterackie obrazy miasta..., s. 42-43 (Zu den Wahlen!, [w:] ibidem, s. 157-158).

${ }^{61}$ C.H. Schultz, Do strachajłów..., s. 62-63 (An die Angsthasen!..., s. 179-180).

${ }^{62}$ C.H. Schultz, Lebensraum ..., s. 59 (Lebensraum..., s. 175). 
narodów do samostanowienia - to zawsze trzeba szanować, ale Czechy i Morawy zaraz na Protektoraty przemianować?"63.

Kompozycję wielu wierszy wyznacza wspomniana agitacyjność, przejawiająca się w specyficznie ukształtowanej intonacji, doborze słownictwa, licznych paralelizmach i składni. Język wierszy Schultza jest nasycony emocjonalnie i najczęściej odwołuje się do tego, co oburza lub budzi niechęć. Treści agitacyjne są napastliwe i demaskatorskie, a przez to szybciej i łatwiej osiągają skutek perswazyjny. Dzięki skrótowości, stosowaniu wykrzykników i apeli, agitacja w przeciwieństwie do propagandy, próbuje wpływać na sferę emocji, by w końcu zmusić do działania. Przykładem takiego oddziaływania jest wiersz Zu den Wahlen! [Ruszajmy do urn!], w którym autor odnosi się do wyborów parlamentarnych, przeprowadzonych w Polsce 6 listopada 1938 r. Już w tytule agituje do pójścia na wybory i głosowania na Obóz Zjednoczenia Narodowego (popularnie nazywanego też Ozon) ${ }^{64}$. Język wiersza pełni funkcję apelatywną - autor nakłania odbiorcę, mówiąc: „Tylko OZN, wybierajcie ludzi z tej grupy!"65. W wypowiedziach mających na celu uzyskanie akceptacji, a w konsekwencji podjęcie konkretnych działań, bardzo ważna jest argumentacja, dlatego autor posługuje się związkami przyczynowo-skutkowymi. W tym samym wierszu [Ruszajmy do urn] pisze: „Jeśli się z ludźmi z OZON-u sprzymierzymy, nadziei na lepsze jutro nie zaprzepaścimy"66.

W wielu miejscach Schultz posługuje się elementami, które mają ośmieszyć i wyszydzić przeciwnika, a także pokazać, że nie ma on racji -stąd niekiedy posiłkowanie się dosadnymi określeniami czy wręcz wulgarnymi epitetami. Ich obecność wzmacnia ekspresję i pełni funkcję wartościującą, jak np. w wyrażeniach: „Nazi-Bolschewisten” [naziści-bolszewiści], „Hitlers Untertanen” [poplecznicy Hitlera], ,Narren” [baranie głowy], ,Krethi und Plethi” [hałastra], „Esel” [osioł], „,wilde Sarabande” [dzika sarabanda]. W innym miejscu Schultz pisze: „weiß der Kuckuck” [Licho wie] albo „Paar kriegen auf die Wange” [Jakaś pięść nieznana natłucze im gębę], ,,jeder macht sich in die Hose" [0 rety, toż oni znów mają pełne gacie]. Wszystkie te elementy świadczą również o emocjonalnym zaangażowaniu autora. Język większości wierszy czerpie z zasobów potocznych, a nawet gwarowych. Schultz, kreujący się na trybuna ludowego, wykorzystuje ekspresyjność potocznego stylu do walki z przeciwnikami

63 Ibidem.

64 Obóz Zjednoczenia Narodowego został utworzony z polecenia marszałka Edwarda Rydza-Śmigłego w 1936 r. Organizacja cieszyła się popularnością wśród środowisk sanacyjnych, a jej celem było wzmożenie obronności kraju i wdrożenie postanowień konstytucji kwietniowej. Ostatecznie organizację oskarżano o tendencje faszystowskie i antysemickie. Por. J. Majchrowski, Silni - zwarci - gotowi: Myśl polityczna Obozu Zjednoczenia Narodowego, Warszawa 1985.

65 C.H. Schultz, Ruszajmy do urn..., s. 62-63 (Zu den Wahlen!..., s. 157-158).

66 Ibidem. 
politycznymi. Jest to celowy zabieg językowy, mający stworzyć pozory wspólnego odczuwania rzeczywistości. Styl kolokwialny dostarcza przede wszystkim słownictwa nacechowanego emocjonalnie, które dla sprawnego mówcy jest niezwykle cennym, a wręcz niezbędnym elementem języka perswazji. Autor stosuje styl potoczny i epitety najczęściej w opisach przeciwnika politycznego, co służy wzmocnieniu dychotomii: autor - jego przeciwnicy polityczni, a w konsekwencji prowadzi do leksykalnej deprecjacji adwersarzy. W ten sposób wyraźnie wskazuje na dychotomię środowiska łódzkich Niemców, dzieląc świat na „swoich” i „obcych”.

W wielu tekstach (np. w wierszu-apelu An die Angsthasen!) autor dążył do uniwersalizacji. Zamieszczenie w tytule bezpośredniego zwrotu do adresata pozwala na grę z klasycznym gatunkiem ody, umożliwiającej sformułowanie apelu do pewnej grupy ludzi.

Metaforyka wierszy Schultza jest stosunkowo ograniczona. Teksty te operują obrazami wprawdzie sugestywnymi, ale łatwymi do odczytania i dość oczywistymi. Autor sięga ponadto do znanych związków frazeologicznych (takich jak np. „es wird nichts so heiß gegessen, wie es gekocht wird" [nie taki diabeł straszny, jak go malują]). Poszczególne elementy konstrukcyjne wiersza prowadzą do uproszczenia przekazu i przesuwają utwór w stronę poetyki wiecowej. Wiersz kojarzy się ze skierowaną do masowego odbiorcy odezwą. Wykrzyknienia, takie jak: „Lieber hört auf mich!” [Lepiej mnie posłuchajcie!]; „nicht auf Krethi und auf Plethi!” [Nie tej całej hałastry]; „Ja, die Nerven müssen stark sein” [Tak, nerwy muszą być na wodzy]; „'s heisst halt: Durchhalten!” [Po prostu wytrzymać]; „,heute kann ich nicht mehr weiter!” [Dziś już więcej nie mogę!]; „Das sind wirklich nun mal ,Ferien“ - nicht!” [To nie są wakacje!], prowadzą do emocjonalizacji wypowiedzi i jej silnej retoryzacji.

W wierszach Schulza zauważa się także dialogowość (np. w wierszu polemicznym Der Deutsche Weg ${ }^{67}$ [Niemiecka Droga]). Autor nawiązuje tu do artykułu, który ukazał się w tygodniku „Der Deutsche Weg”, w którym przeciwnicy polityczni zarzucili swoim adwersarzom zorganizowanie kolonii letnich dla niemieckich dzieci z Łodzi i okolic. Dyskusję, jaka się wówczas wywiązała, prowadzono przez kilka tygodni w licznych publikacjach, a polemizujące strony próbowały wzajemnie przekonywać się o słuszności własnych sądów. Konfrontowano się również za pomocą wiersza. U Schulza dialogowość widoczna jest w następujących fragmentach:

„Barycz, wielkie mi co!” prycha wściekle.

Tam są tylko kocie łby - wylicza zaciekle,

67 „Der Deutsche Weg” [Niemiecka Droga] - tygodnik wychodzący w Łodzi w latach 1935-1939. Wydawcą gazety był Ludwig Wolff, redaktorem Kurt Rapke, współpracownikami m.in. Artur Utta i Peter Nasarski. 
a poza tym droga, która wiedzie do niej,

nazbyt ciernista jest dla małych stworzeń.

„Patrzcie!” ciska gromy, perorując dosadnie:

„Inni nie wysyłają swych pociech, gdzie popadnie.

A u nas - proszę - od razu, na jeden mały znak

aż dwa tysiące dzieci posłano w cały świat!"68

Przytaczanie cudzych wypowiedzi i wbudowywanie ich w strukturę wiersza ma na celu uwiarygodnienie przekazu.

Opisane środki retoryczne prowadzą do wzmocnienia ekspresji tekstu i mocniejszego wydobycia na pierwszy plan jego funkcji perswazyjnej. Pozwalają także na (przede wszystkim negatywne) wartościowanie przedstawianych postaw, nadając wierszowi tym samym wymiar etyczny.

Krytykując politykę zagraniczną Hitlera i jego ideologię, Schultz sięga do bogatego zasobu słownictwa narodowosocjalistycznego. Często odwołuje się do symboli narodowych socjalistów (takich jak okrzyki: Sieg heil, Heil Hitler) czy do elementów ubioru (np. buty-oficerki), czy wreszcie do swastyki, ale są to atrybuty kłamstwa, agresji i w końcu zagłady. Autor przeciwstawia im etyczną wspólnotę łączącą go z Niemcami, lojalnie nastawionymi do Polski i Polaków.

Wiersze Schultza należy bezdyskusyjnie łączyć z pacyfizmem, w latach 20. bardzo popularnym wśród liberalnej i lewicowej inteligencji europejskiej. Na gruncie niemieckim w Łodzi środowisko to skupione było wokół Vereinigung der Deutschen in Polen i właśnie to stowarzyszenie stało się orędownikiem haseł głoszących zdecydowany sprzeciw wobec wszelkich tendencji militarystycznych. Z dzisiejszej perspektywy niewinnie wyglądający pacyfizm budził jednak wówczas niemałe kontrowersje zarówno w polskim, jak i niemieckim środowisku Łodzi. Z powodu otwartości, z jaką krytykował ducha ówczesnej epoki, tj. rysujące się wśród łódzkich Niemców tendencje nacjonalistyczne i narodowosocjalistyczne, Schultz zyskał sobie ze strony wyznawców narodowego socjalizmu przydomek "renegata” ${ }^{69}$. Politycznej postawy autora nie rozumiały także inne kręgi niemieckich mieszkańców Łodzi, pragnących trzymać się z dala od polityki. W ich przekonaniu Schultz był nazbyt „polityczny", natomiast w Polakach, zajętych po I wojnie światowej budowaniem własnej państwowości, budził nieufność ${ }^{70}$. Choć jego wiersze mają wyraźnie

${ }^{68}$ C.H. Schultz, Niemiecka droga, [w:] Literackie i nieliterackie obrazy miasta..., s. 39 (Der Deutsche Weg, [w:] ibidem, s. 154-155).

${ }^{69}$ Por. M. Cygański, Mniejszość niemiecka w Polsce centralnej w latach 1919-1939, Łódź 1962.

${ }^{70}$ W. Kessler, Carl Heinrich Schultz a kontekst łódzki / Carl, Heinrich Schultz im Lodzer Kontext, [w:] Literackie i nieliterackie obrazy miasta..., s. 8, 122. 
antywojenny wydźwięk, automatycznie wpisują się w kontekst wielkich wojen politycznych i ideologicznych międzywojnia. $Z$ tego powodu ostra reakcja części narodowych socjalistów nie powinna dziwić, gdyż Schultz dostarczył swoim wrogom dobrego casus belli. W styczniu $1940 \mathrm{r}$. aresztowano go wraz z grupą polskich intelektualistów i osadzono w więzieniu w łódzkim Radogoszczu, gdzie po kilku miesiącach zmarł.

Jego wiersze rejestrowały wydarzenia i incydenty z życia społeczno-politycznego społeczności niemieckiej w Łodzi, mówiły o osobach, opisywały zjawiska i tworzyły społeczno-polityczny obraz Polski. Autor postawił sobie za cel obnażanie fałszu aktywistów niemieckich i działaczy narodowosocjalistycznych. Stąd ważną cechą jego twórczości była otwartość w przekazywaniu faktów. Nie chodziło mu jednak wyłącznie o ukazanie prawdziwego oblicza polityki zagranicznej Hitlera, ale przede wszystkim o zapis walki, prowadzonej przez zasymilowaną część społeczności niemieckiej o najistotniejsze wartości.

W wielu wierszach Schultza przewija się poczucie zagrożenia. W połowie 1939 r. nie było już żadnych wątpliwości, że szykują się duże zmiany. Historia dokonywała zwrotu, a wiersze wyraźnie rejestrowały nastrój niepokoju. Pragnienie demaskacji zakłamania obozu hitlerowskiego powtarzało się w wielu wierszach na tyle intensywnie, że czytelnik mógł uznać je za prawdziwe i przyjął jako obowiązujący pogląd.

Wiersze zaangażowane Schultza były twórczością z ambicjami jak najszerszego oddziaływania. Dlatego nie można oczekiwać od tych tekstów wyjątkowych walorów estetycznych. Pod presją różnych wydarzeń politycznych autor zrezygnował z poszukiwania oryginalnych form artystycznego wyrazu, koncentrując się przede wszystkim na jednoznacznej prezentacji własnych racji. Posługiwał się przy tym argumentacją retoryczną, pełną treści dydaktyczno-programowych. W sposób zasadniczy podejmował zagadnienie walki z narodowym socjalizmem, a podstawowym tworzywem swej twórczości uczynił język potoczny. Do jego wierszy wkroczyła również parodystycznie retoryka publicystyczna z hasłami głoszonymi przez narodowych socjalistów. Autor pragnął stać się jednym z wielu głosów w donośnym chórze, a jego wiersze należy interpretować jako formę kronikarskiego zapisu $\mathrm{z}$ jednej strony, z drugiej zaś jako akt niezgody na aktualne wydarzenia.

\subsection{W poszukiwaniu miłości i szczęścia}

Łódzcy poeci, tworzący poza wspomnianym nurtem zaangażowanym politycznie, to grupa bardzo liczna, choć ich życiorysy i twórczość nie są obecne w świadomości współczesnego społeczeństwa. Również w latach 20. i 30. XX w. nie byli autorami na tyle znanymi, by cieszyć się dużą popularnością 
wśród czytelników. Była to grupa stosunkowo hermetyczna i anonimowa, często zajmująca się pisaniem wierszy hobbystycznie. Łódzcy poeci mieli niewielkie szanse na opublikowanie swoich utworów w wydaniach książkowych, dlatego najpopularniejszą formą rozpowszechniania tej twórczości były lokalne gazety, nie zawsze o profilu literackim. Często wiersze trafiały do gazet codziennych lub dodatków niedzielnych. Wśród łódzkich poetów na uwagę zasługuje kilkoro twórców. Należą do nich: Wally Thiem, Edith Seiler, Wally Reimann, pastor Philipp Kreutz, Alexis Drewing, Erwin Jenske czy Joseph Möller. Ich twórczość obejmuje wiele utworów poświęconych zagadnieniu miłości i szczęścia, a więc motywom najbardziej eksploatowanym w poezji w ogóle.

Łódzcy poeci chętnie wykorzystywali je w swojej twórczości, posługując się przy tym starymi, sprawdzonymi formami literackimi, takimi jak romanca, ballada, oda, a nawet średniowieczną formą dworskiej liryki miłosnej (tzw. Minnesangiem ${ }^{71}$ ). Przykładem tego ostatniego może być twórczość Josepha Möllera, który stylizował swoje wiersze właśnie na średniowieczne liryki miłosne ${ }^{72}$. W utworze Einst brach ... pisze:

Einst brach für seine Lebenstraute die Blume, die heut nicht mehr blüht der Sänger, auf der gold'nen Laute, im sehnsuchtsvollen Minnelied.

Er durfte seine Liebe grüßen und tragen ihrer Farben Band; sein höchster Lohn - wenn ihm zu Füßen die Rose fiel von ihrer Hand ${ }^{73}$.

${ }^{71}$ Utwory gatunku Minnesang rozwinęły się w średniowieczu. Ich tematyka koncentrowała się wokół zagadnień niespełnionej miłości względem szlachetnie urodzonej damy. Najwybitniejszym przedstawicielem średniowiecznego Minnesangu był Walther von der Vogelweide. Por. J. Jabłkowska, Minnesang, [w:] Słownik rodzajów i gatunków literackich, red. G. Gazda, S. Tynecka-Makowska, Kraków 2006, s. 413-414; H. Haferland, Hohe Minne. Zur Beschreibung der Minnekanzone, Berlin 2000; Minnesang. Niemiecka średniowieczna pieśn miłosna, tłum. i oprac. A. Lam, przedm. A. Nowicka-Jeżowa, Warszawa 1997; G. Schweikle, Minnesang, Stuttgart-Weimar 1995; E. Willms, Liebesleid und Sangeslust. Untersuchungen zur deutschen Liebeslyrik des späten 12. und frühen 13. Jahrhunderts, Düsseldorf 1990.

${ }^{72}$ Niestety, nie udało mi się dotrzeć do innych utworów z tego cyklu. Jedyny wiersz opatrzony notatką, że pochodzi z całego tomu, znajduje się w „Illustrierte Sonntagsbeilage. Neue Lodzer Zeitung", 7./20.03.1910, s. 1.

${ }^{73}$ J. Möller, Einst brach..., „Illustrierte Sonntagsbeilage. Neue Lodzer Zeitung”, 7./20.03.1910, s. 1 [Niegdyś dla swej wybranki / na złotej lutni grając / tęskną pieśń o miłości / śpiewak złamał kwiat, dziś zwiędły. // Sławił swe uczucie i nosił jego znak. / Nagrodę największą odbierał, / gdy ukochana do jego stóp / rzucała róży kwiat. Tłumaczenie M.P.]. Po wojnie tekst nigdy nie znalazł się w żadnym tomie zbiorowym. 
Wśród liryki miłosnej na uwagę zasługuje również twórczość Wally’ego Thiema, który podobnie jak inni łódzcy poeci, regularnie publikował swoje wiersze na łamach lokalnych gazet. Pisał nastrojowe utwory liryczne, przepełnione uczuciowością, które cechowała lapidarność, klarowność i prostota. Należą do nich m. in. Du [Ty], Liebe [Miłość], Was bist du, Glück?[Czym jesteś, szczęście?], Heimweh [Tęsknota za domem], Zuweilen... [Niekiedy...] czy Abend [Wieczór]. Na szczególną uwagę zasługują te, poświęcone szczęściu i miłości. W wierszu Liebe [Miłość] autor wpada w łatwą pułapkę patosu i podchodzi do tematu w sposób szablonowy, odwołując się do utartych schematów, takich jak wielka, zbawienna miłość czy miłość ofiarna:
$\mathrm{Du}$, die du von Anbeginn der Welt gewesen
und immer doch die Ewigtreue bliebst,
Die in des Menschen tiefgeheimes Wesen
Mit zarter Hand gepflanzt der Sehnsucht Trieb,
Du, die in Freuden, Seligkeit und Tränen
In hohem Glück, in tiefem Leid uns naht,
Du opferfreudige, heilandsgroße Liebe
Komm, kränz auch meiner stillen Tage $\mathrm{Pfad}^{74}$.

Autor przedstawia miłość jako doświadczenie ambiwalentne, przynoszące najwyższe szczęście i największe cierpienie. Natomiast w wierszu Was bist du, Glück? [Czym jesteś, szczęście?] istotę szczęścia rozumie jako samo poszukiwanie, stąd cały wiersz zasadza się na ciągu pytań:

Bist du eine Blume rosator,

Bist du ein Strahl im Abendrot,

Bist du ein winziges Körnlein Sand,

Eines Gottes gütige Hand? ${ }^{75}$

W innym wierszu pt. An... [Do...] łódzki poeta Erwin Jenske sięga do motywu nieszczęśliwej miłości wywołującej przemożną tęsknotę. Takie potraktowanie uczucia zbliża utwór do tradycji romantycznej, dla której znamienna jest miłość niespełniona, nieszczęśliwa i tragiczna, powodująca cierpienie i prowadząca do nieuchronnego rozstania lub katastrofy:

${ }^{74}$ W. Thiem, Liebe, „Die Welt im Bilde. Sonntagsbeilage zur Neuen Lodzer Zeitung”, 12.05.1929, s. 6 [Ty, która jesteś od początku świata / i wiecznym żalem pozostajesz, / która głęboko w duszy człowieka / delikatną dłonią tęsknotę zasiewasz - // Ty, co przychodzisz, niosąc radość, rozkosz i łzy, / raz wielkie szczęście, raz bezkresne cierpienie / przybądź ofiarna, zbawienna miłości / bądź ukoronowaniem mego spokojnego życia. Tłumaczenie M.P.]. Po wojnie tekst nigdy nie znalazł się w żadnym tomie zbiorowym.

75 W. Thiem, Was bist Du, Glück?, „Die Welt im Bilde. Sonntagsbeilage zur „Neuen Lodzer Zeitung", 5.05.1929, s. 6 [Czy jesteś czerwonym kwiatem, / czy promieniem wieczornej zorzy, / czy malutkim ziarenkiem piasku, / Boga dobrotliwą ręką? Tłumaczenie M.P.]. Po wojnie tekst nigdy nie znalazł się w żadnym tomie zbiorowym]. 
Soll ich dich nie mehr Wiederseh'n

Vergebens all mein Suchen bleiben,

Soll jener ferne Augenblick

erhofften und ersehnten Glücks

nie wieder mich zu dir erhöh'n? ${ }^{76}$

Utwór Erwina Jenskego pozbawiony jest rymów i strof, jednak swego rodzaju podział wprowadzają pytania. Każde z nich, rozpoczynające się od czasownika sollen, jak np. „,Soll deiner Stimme milder Klang mich zärtlich nimmermehr umweben" [Czy twego głosu łagodny dźwięk nigdy mnie nie dosięgnie], poddaje nową myśl, która wpływa na rytm tekstu. Każde z pytań zawiera też antytezę. Stosowanie pytań buduje atmosferę niepewności, melancholii i smutku, w szczególności gdy zostaje powtórzone: „Soll ich dich nie mehr wiederseh'n?" [Mam cię już nigdy nie ujrzeć?] Tym pytaniem autor antycypuje niespełnienie uczucia i nieszczęśliwe zakończenie. Wiersz posiłkuje się formą monologu wewnętrznego, na który wskazują kolejne fragmenty utworu:

[...] sehnend klingt die stumme Frage,

Wie schluchzend/ Und wie inniges Fleh'n;

Und tief in meiner Seele trage

Ich deiner Augen

Treuen Glanz ${ }^{77}$.

Wiele utworów poświęcił motywom miłości i szczęścia pastor Philipp Kreutz. W utworze Das Mädchen und die Linde [Dziewczyna i lipa] nawiązuje formalnie do średniowiecznych utworów z rodzaju romanca:

Mädchen: Ach, liebliche Linde, wo bleibt nur Dein Duft,

Gedenkst du noch der köstlichen Blüte?

Du willst gar nicht hören, wenn jemand dich ruft

Und stehst mit verzagtem Gemüte!

Linde: Ja, ich erinnere mich dessen genau;

Ach, wenn es doch immer so bliebe:

Du gingst mit dem Liebsten auf blumiger $\mathrm{Au}$,

Er sprach dir damals von Liebe ${ }^{78}$.

Miłość jest tu uczuciem niespełnionym. Do młodzieńczej miłości nawiązuje także w niektórych swych wierszach Carl Heinrich Schultz.

${ }^{76}$ E. Jenske, An..., „Die Welt im Bilde. Sonntagsbeilage zur Neuen Lodzer Zeitung”, 1.12.1929, s. 6 [Mam cię już nigdy nie ujrzeć? / Na nic wszystkie me poszukiwania. / Czy tak daleka chwila szczęścia, / wyczekiwanego z utęsknieniem, / nigdy się ku mnie nie zbliży?. Tłumaczenie M.P.]. Po wojnie tekst nigdy nie znalazł się w żadnym tomie zbiorowym.

77 Ibidem [Tęsknie rozbrzmiewa nieme pytanie, / jak szloch i rozpaczliwe błaganie; / głęboko w duszy noszę / blask twoich oczu. Tłumaczenie M.P.].

${ }^{78} \mathrm{Ph}$. Kreutz, Das Mädchen und die Linde. Romanze, „Illustriertes Sonntagsblatt. Beilage zur Neuen Lodzer Zeitung”, 7.10.1923, s. 2 [Dziewczyna: Ach, piękna lipo, gdzież twa woń? 


\subsection{Impresje z podróży}

Łódzka poezja czerpie także ze znanego innym epokom wątku podróży. Najliczniejsze wiersze, poświęcone temu motywowi, składają się na twórczość Philippa Kreutza, który był nie tylko pastorem, ale i podróżnikiem. W latach międzywojennych odwiedził niemal całą Europę - był w Niemczech, Danii, na Białorusi, zwiedził Gdańsk, Sopot, Berlin, Kronborg, Helsingør, Kopenhagę, Półwysep Helski, jezioro Narocz, a wyprawy te pozostawiły trwały ślad w jego bogatej twórczości. Szczególnie fascynowało go morze. W lipcu 1931 r., w czasie wakacji nad Bałtykiem, napisał wiersz Meeresschloß [Zamek na morzu]:

\footnotetext{
Ein Silberweg führt durch das Meer,

Durch grüne Wogenschläge

Und meine Sehnsucht ging einher

Auf diesem Silberwege,

Es stieg das Meer, die Woge floß

Und trug, so weit sie konnte

Die Sehnsucht fern bis an ein Schloß

Am blauen Horizonte ${ }^{79}$.
}

Opisy krajobrazów, wyłaniające się z utworów Kreutza, zawierają wiele elementów baśniowych. W dalszym fragmencie wiersza autor maluje obraz wynurzającego się z morskiej głębiny złotego zamku, w którym mieszka tajemnicza narzeczona króla. Elementy bajkowe, a wraz z nimi charakterystyczne opisy przyrody, zbliżają twórczość Kreutza do tradycji romantycznej. Autora fascynuje niezależna, nieujarzmiona i potężna przyroda, zachwyca go żywiołowość, dynamizm i tajemniczość krajobrazów. Wiersz Zoppot [Sopot] rozpoczyna następująco:

Tief aus dem Meere braust Gewitter schwül

Auf eine Wolke und verschlingt den Tag,

Der Dampfer stampft ein wenig schwer und zag

Durch dunkler Wogen brandendes Gewühl ${ }^{80}$.

\footnotetext{
/ Pamiętasz jeszcze twe wspaniałe kwiecie? / Nie chcesz słuchać, kiedy ktoś cię woła - / stoisz niepewna i zalękniona! // Lipa: Jak dobrze to pamiętam. / Ach, gdyby tak mogło być zawsze: / kroczysz z ukochanym po zielonej łące, / a on ci szepcze słowa miłości. Tłumaczenie M.P.]. Po wojnie tekst nigdy nie znalazł się w żadnym tomie zbiorowym.

${ }^{79} \mathrm{Ph}$. Kreutz, Das Meeresschloß, „Die Welt im Bilde. Sonntagsbeilage zur Neuen Lodzer Zeitung", 6.09.1931, s. 6 [Srebrzysty szlak wiódł przez morze, / poprzez zieleń wzburzonych fal; / moja tęsknota kroczyła ze mną, / prowadził ją ten sam srebrzysty trakt. / Wezbrało morze i fale uniosły / tęsknotę daleko, jak najdalej / hen, aż do pałacu / na błękitnym widnokręgu. Tłumaczenie M.P.]. Po wojnie tekst nigdy nie znalazł się w żadnym tomie zbiorowym.

${ }^{80} \mathrm{Ph}$. Kreutz, Zoppot, „Die Welt im Bilde. Sonntagsbeilage zur Neuen Lodzer Zeitung”, 19.8.1928, s. 6 [Z głębiny morza przebija duchota burzy, / wstępuje na chmury i pożera dzień.
} 
Opisom wzburzonego morza towarzyszy często uczucie tęsknoty, co doskonale oddaje wiersz Am Danziger Haff [W gdańskim porcie]:

Die Planke bebt, an die ich leicht mich lehne,

Mein Herz beschleicht so eine süße Qual:

O. Meer, o Meer, wie ich mich nach dir sehne ${ }^{81}$.

W innym wierszu pt. Loreley autor odwołuje się do starej niemieckiej historii, która była inspiracją dla wielu poetów i kompozytorów. Loreley to tajemnicza, stroma i wysoka skała u nabrzeża Renu, w pobliżu Koblencji. Wzmiankowana już w dokumentach z okresu średniowiecza, stanowiła dla żeglujących po Renie wielkie zagrożenie. W jej pobliżu często rozbijały się statki, co dało początek wielu historiom. Według jednej z nich pod skałą ukryty jest słynny skarb Nibelungów, inna natomiast głosi, że ze szczytu skały rzuciła się w odmęty Renu zdradzona przez oblubieńca młoda dziewczyna o imieniu Loreley. Zamieniona później w syrenę, zwodziła swym pięknym śpiewem przepływających tamtędy żeglarzy, posyłając ich na pewną śmierć.

$\mathrm{O}$ Loreley pisali m.in. Clemens Brentano w utworze $\mathrm{Zu}$ Bacharach am Rheine $^{82}$, Heinrich Heine w utworze Die Lore-Ley ${ }^{83}$ (muzykę do jego słynnej ballady skomponował Friedrich Silcher (1789-1860)). Motyw Loreley wykorzystał również Erich Kästner i wielu innych, a sama legenda posłużyła Maxowi Bruchowi w 1863 r. jako kanwa wielkiej opery romantycznej Die Loreley do libretta Emmanuela Geibela. Postać Loreley stworzona przez Philippa Kreutza ma - podobnie jak Loreley Heinego - złote włosy, które czesze złotym grzebieniem, śpiewając przy tym uwodzicielsko i jest - tak jak u Clemensa Brentano - postacią tragiczną. Kreutz opowiada historię pięknej dziewczyny rzucającej na mężczyzn tak zniewalający urok, że nie zważając na nic, narażają dla niej swoje życie. Tu autor dokonuje jednak zabiegu stylizacji. Jego Loreley to femme fatale, bezwzględnie wykorzystująca swój czar. Lecz motyw ten nie jest oryginalny, bowiem Joseph von Eichendorff wykorzystał go w utworze Waldgespräche [Rozmowa leśna]. Kreutz tak pisze o Loreley:

\footnotetext{
/ Parowiec przebija się niepewnie, z trudem / przez czarnych fal bezdenną kipiel. Tłumaczenie M.P.]. Po wojnie tekst nigdy nie znalazł się w żadnym tomie zbiorowym.

${ }^{81}$ Ph. Kreutz, Am Danziger Haff, „Die Welt im Bilde. Sonntagsbeilage zur Neuen Lodzer Zeitung", 19.8.1928, s. 6 [Drży burta, o którą się wspieram, / a w mym sercu słodkie katusze: / 0 morze, o morze, jakże tęsknię za tobą! Tłumaczenie M.P.]. Po wojnie tekst nigdy nie znalazł się w żadnym tomie zbiorowym.

${ }^{82}$ Polska wersja $W$ Bacharach nad Renem ukazała się w przekładzie Andrzeja Lama, „Pobocza”, 4(14)/2003, http://kwartalnik-pobocza.pl/pob14/cvb.html [dostęp: 2.09.2013].

83 Mistrzowskiego przekładu Lorelei dokonał Aleksander Kraushar. Por. L. Kolago, Lorelei i inne wiersze. Mistrz melodii, słowa, rytmu i krótkich form lirycznych, [w:] Arcydzieła literatury niemieckojęzycznej, red. E. Białek, G. Kowal, Wrocław 2011, s. 491-508.
} 
Welch eine Ähnlichkeit mit einem stolzen Weibe

Das in ihr Zaubernetz manch einen Freund gezogen

Und ihn nach kurzem Glück dann wieder hat betrogen -

Und neue Opfer sucht zum neuen Zeitvertreibe

Du stolze Loreley, du schöne, sagenreiche,

Wieviel Geschlechter schon verrauschten mit dem Rheine,

Du bist so wie du warst, dieselbe und die gleiche,

Das Haupt voll Sonnenglanz und doch das Herz vom Steine ${ }^{84}$.

Postać Loreley wywołuje ambiwalentne uczucia: z jednej strony jej uroda przyciąga uwagę i fascynuje, z drugiej zaś jej zgubna natura wzbudza nienawiść. Kreutz tak o tym pisze:

O Haß - o Lieb, schlaget über mich zusammen,

Daß ich die Lorelay lieb', wer will mich verdammen?! ${ }^{85}$

Warto wspomnieć, że w swoich impresjach z podróży autor posługuje się tradycyjną formą sonetu, sprzyjającą snuciu refleksji nad otaczającą poetę przyrodą. Wiele wierszy Kreutza dowodzi, że krajobrazy niemieckiej ojczyzny wzbudzają w nim wiele emocji, a niemieckie miasta i zabytki wywołują ogromną tęsknotę za ojczystym krajem. Wyraźnie widzimy to w wierszu An den Rhein! [Do Renu!], w którym autor pisze:

Daß ich dich heute erst, du Strom der Sehnsucht sehe!...

Soll ich dich wieder lassen? Wehe mir, ach wehe,

Ich weiß, ich werde diesen Abschied nie verschmerzen! ${ }^{86}$

Przytoczone fragmenty wierszy pokazują, że pastor Philipp Kreutz był poetą-nawiązującym do wzorców romantycznych. Jego teksty zdradzają również silny związek z kulturą i tradycją niemiecką, z nich bowiem czerpał tematy i twórcze inspiracje, odwołując się do swych genealogicznych korzeni.

${ }^{84} \mathrm{Ph}$. Kreutz, Lorelei, „Die Welt im Bilde. Sonntagsbeilage zur Neuen Lodzer Zeitung”, 12.09.1937, s. 6 [Jakże podobna do dumnej niewiasty, / wabiącej w sidła niejednego śmiałka, / by po krótkim szczęściu znowu go porzucić / i nowej ofiary szukać na swej drodze. // Dumna Loreley, piękna i mityczna, / ile już pokoleń zginęło tam, w Renie, / tylko ty wciąż taka, jaką byłaś zawsze - / głowa w promieniach słońca i serce z kamienia. Tłumaczenie M.P.]. Po wojnie tekst nigdy nie znalazł się w żadnym tomie zbiorowym.

${ }^{85}$ Ibidem, s. 6 [0 nienawiści, o miłości, spadnijcie na me barki! / Któż mnie potępi za to, że kocham Loreley?!. Tłumaczenie M.P.].

${ }^{86} \mathrm{Ph}$. Kreutz, An den Rhein!, „Die Welt im Bilde. Sonntagsbeilage zur Neuen Lodzer Zeitung", 5.09.1937, s. 6 [Dziś zaledwie cię ujrzałem, rzeko mej tęsknoty!... I znów mam cię opuścić! Biada mi, ach, biada. / Dziś już wiem, że nie przeboleję tego rozstania! Tłumaczenie M.P.]. Po wojnie tekst nigdy nie znalazł się w żadnym tomie zbiorowym. 


\subsection{Okazją są jubileusze}

Istotną cechą literatury łódzkiej jest jej ścisłe powiązanie z różnymi wydarzeniami politycznymi, społeczno-kulturalnymi i religijnymi. 0 ich silnej obecności w kulturze Łodzi może świadczyć fakt, że nie było w zasadzie sytuacji, która nie dawałaby pretekstu do ułożenia jakiegoś wiersza bądź wygłoszenia mowy. Okazją dla poetów stawały się najczęściej jubileusze różnych placówek społeczno-politycznych, religijnych i kulturalnych. Oprócz tego, że miały coś lub kogoś uczcić, stanowiły swoisty literacki prezent.

Wiersze okolicznościowe, o których będzie tu mowa, cechuje schematyzm i osadzenie w bardzo czytelnej konwencji, dobrze znanej odbiorcy. Charakterystyczne są dla niej dwie kategorie: panegiryzm i parenetyzm. Z jednej strony utwory łódzkich autorów wychwalają zalety przeważnie jakiejś osoby, przy czym zalety te nie zawsze są rzeczywiste. Bogata tradycja utworów panegirycznych wypracowała cały szereg motywów i schematów, z których każdy autor mógł w zasadzie swobodnie czerpać. Wychwalano nie tylko to, czego dana osoba lub jej przodkowie dokonali, lecz nawet to, czego mogli dokonać. Z drugiej strony utwory okolicznościowe pouczały, wychowywały i przekazywały dobre rady, dlatego wiersze te tak często niosły ze sobą treści moralizatorskie, skierowane do związanej z daną okolicznością osoby bądź instytucji. Warto również podkreślić, że elementy panegiryczne i parenetyczne przeważnie splatały się ze sobą w obrębie tego samego tekstu.

Popularność literatury okolicznościowej w Łodzi była ogromna. Należące do tego nurtu utwory wychodziły zarówno spod pióra anonimowych poetów, jak i autorów regularnie drukujących je na łamach prasy, których można uznać za osoby doświadczone w tej materii, jak choćby Philipp Kreutz, Wally Thiem czy Theodor Abel.

Tradycja łódzkiego nurtu okolicznościowego sięga roku 1839, kiedy z okazji poświęcenia domu Majstrów Tkackich powstał wiersz pastora Fryderyka Gottloba Metznera (1797-1852) pt. Gesang zur Weihe des neuerbauten Meisterhauses der löblichen Weberinnung zu Lodz am 3ten September $1839^{87}$. Utwór stanowił artystyczną oprawę uroczystości, dodając splendoru nie tylko samej placówce, ale przede wszystkim życiu społeczno-kulturalnemu miasta.

Twórczość okazjonalna kwitła przez cały okres rozwoju Łodzi przemysłowej, ale jej szczytowy rozwój nastąpił w okresie międzywojennym. $\mathrm{Na}$ te lata przypadły bowiem jubileusze wielu towarzystw i instytucji życia społeczno-kulturalnego miasta. Były to m.in. 50. rocznica powstania gminy ewangelicko-augsburskiej przy kościele św. Jana, 75. rocznica powstania

87 Por. rozdział 3.2.1: Rozwój literatury do 1914 r. 
Towarzystwa Śpiewaczego przy Kościele św. Trójcy, 50. rocznica powstania Towarzystwa Śpiewaczego „Harmonia” w Konstantynowie, rocznica powstania parafii św. Mateusza, 50. rocznica powstania łódzkiej straży ogniowej, 25. rocznica powstania towarzystwa śpiewaczego Kazimierza Danysza, 50. rocznica powstania gminy baptystów, 20. rocznica powstania gimnazjum niemieckiego i in. Z tych okazji publikowano w Łodzi szereg ksiąg jubileuszowych, opisujących działalność instytucji i ich wpływ na rozwój życia społeczno-kulturalnego miasta. Wśród nich znalazły się m.in. takie księgi okolicznościowe, jak: 50 Jahre göttlicher Barmherzigkeit: Festschrift anläßlich des 50-jährigen Jubiläums der evang.-luth. St. Johannisgemeinde zu Lodz ${ }^{88}$, Festschrift zur Feier des 75.[fünfundsiebzig]-jährigen Jubiläums des Kirchengesang-Vereins der St. Trinitatis-Gemeinde zu Lodz: 1859-1934 ${ }^{89}$, Festschrift zum 50-jährigen Jubiläum des Kirchengesangvereins der evang.-lutherischen St. Johannis-Gemeinde zu Lodz: 1884-193490, Festschrift zur 50. [fünfzigjährigen]Wiederkehr des Gründungstages des evangelisch-lutherischen Kirchengesangvereins "Harmonia“ in Konstantynow: 1879-192991, Allein Gott in der Höh sei Ehr': Festschrift anläßlich der Einweihung der evang[elisch]-luth[erischen] St. Matthäikirche ${ }^{92}$, Festschrift zur Feier des 50-jährigen Jubiläums der Lodzer Freiwilligen Feuerwehr: 14 V 1876-1926 $6^{93}$, Festschrift zur Feier des 100-jährigen Jubiläums der Webermeister-Innung zu Lodz 1812-192494, Festschrift zur 75-jährigen Jubelfeier des Lodzer Männer-Gesang-Vereins 1846-1921: Feier

${ }^{88}$ J. Dietrich, 50 Jahre göttlicher Barmherzigkeit: Festschrift anläßlich des 50-jährigen Jubiläums der evang.-luth. St. Johannisgemeinde zu Lodz, Lodz 1934. Tekst dostępny w Wojewódzkiej Bibliotece Publicznej im. Marszałka Józefa Piłsudskiego w Łodzi, sygn. 22592 KZ.

${ }^{89}$ Festschrift zur Feier des 75. [fünfundsiebzig]-jährigen Jubiläums des Kirchengesang-Vereins der St. Trinitatis-Gemeinde zu Lodz: 1859-1934, Lodz 1934. Tekst dostępny w Wojewódzkiej Bibliotece Publicznej im. Marszałka Józefa Piłsudskiego w Łodzi, sygn. 1//78 PR.

${ }^{90}$ Festschrift zum 50-jährigen Jubiläum des Kirchengesangvereins der evang.-lutherischen St. Johannis-Gemeinde zu Lodz: 1884-1934, Lodz 1934. Tekst dostępny w Wojewódzkiej Bibliotece Publicznej im. Marszałka Józefa Piłsudskiego w Łodzi, sygn. 126//2 PR.

${ }^{91}$ Festschrift zur 50. [fünfzigjährigen] Wiederkehr des Gründungstages des evangelisch-lutherischen Kirchengesangvereins „Harmonia“ in Konstantynow: 1879-1929, Lodz 1929. Tekst dostępny w Wojewódzkiej Bibliotece Publicznej im. Marszałka Józefa Piłsudskiego w Łodzi, sygn. $30181 \mathrm{KZ}$.

${ }_{92}$ J. Dietrich, Allein Gott in der Höh' sei Ehr': Festschrift anläßlich der Einweihung der evang[elisch]-luth[erischen] St. Matthäikirche, Lodz 1928. Tekst dostępny w Wojewódzkiej Bibliotece Publicznej im. Marszałka Józefa Piłsudskiego w Łodzi, sygn. 46//2 PR.

${ }_{93}$ Festschrift zur Feier des 50-jährigen Jubiläums der Lodzer Freiwilligen Feuerwehr: 14. V. 1876-1926, Lodz 1926. Tekst dostępny w Wojewódzkiej Bibliotece Publicznej im. Marszałka Józefa Piłsudskiego w Łodzi, sygn. 19269 KZ.

${ }_{94}$ R. Klikar, Festschrift zur Feier des 100-jährigen Jubiläums der Webermeister-Innung zu Lodz 1812-1924, Lodz 1924. Tekst dostępny w Wojewódzkiej Bibliotece Publicznej im. Marszałka Józefa Piłsudskiego w Łodzi, sygn. 45669 KZ. 
am 16. und 17. Juni 1923 in den Räumen des Vereinshauses Petrikauer Strasse Nr. $143^{95}$, Festschrift zur 50-jährigen Jubiläumsfeier der Fahnenweihe des Evangelisch-Augsburgischen Kirchen-Gesangvereins zu Pabianice ${ }^{96}$, Gesangverein „Danysz“: Festschrift anläßlich des 25-jährigen Bestehens des Vereins 1903-192897, Gedenkschrift anläßlich des 20-jährigen Jubiläums der Anstalten des Hauses der Barmherzigkeit in Lodz: 21 X 1908-21 X 192889, Gedenkschrift anläßlich des 50-jährigen Jubiläums der Baptistengemeinde Lodz, Nawrot $27^{99}$, Gedenkschrift aus Anlaß des 20-jährigen Bestehens des Deutschen Gymnasiums zu Lodz ${ }^{100}$, Festschrift zur Feier des 100-jährigen Jubiläums der WebermeisterInnung zu Lodz ${ }^{101}$.

Szczególnym rodzajem niemieckiego piśmiennictwa, na który warto zwrócić uwagę, były księgi jubileuszowe. Z jednej strony opisywały historię danej instytucji i zasługi jej działaczy, wpisujące się w wielokulturowy charakter miasta, z drugiej zaś pokazywały mentalność mieszkańców oraz to, co było dla nich w danym momencie najbardziej istotne. Księgi bogato zdobiono, zaopatrywano w wiele fotografii i wyszukanych elementów. Oprócz tekstów o charakterze historycznym zawierały również tabele, statystyki i spisy członków. Wraz z księgami jubileuszowymi często pojawiały się wiersze okolicznościowe, nie tylko pełniące rolę dodatku literackiego, ale również będące pewną formą podziękowania za wieloletnią działalność instytucji. I tak przykładowo z okazji 50-lecia powstania Towarzystwa Śpiewaczego, działającego przy kościele św. Jana w Łodzi, opublikowano wiersz okolicznościowy Juliana Willa, w którym autor pisze:

${ }^{95}$ Festschrift zur 75-jährigen Jubelfeier des Lodzer Männer-Gesang-Vereins 1846-1921: Feier am 16. und 17. Juni 1923 in den Räumen des Vereinshauses Petrikauer Strasse Nr. 143. Tekst dostępny w Wojewódzkiej Bibliotece Publicznej im. Marszałka Józefa Piłsudskiego w Łodzi, sygn. 90//78 PR.

${ }_{96}$ A.W. Sonnenberg, Festschrift zur 50-jährigen Jubiläumsfeier der Fahnenweihe des Evangelisch-Augsburgischen Kirchen-Gesangvereins zu Pabianice, Pabianice 1917. Tekst dostępny w Wojewódzkiej Bibliotece Publicznej im. Marszałka Józefa Piłsudskiego w Łodzi, sygn. 30168 KZ.

${ }^{7}$ C.H. Schultz, Gesangverein „Danysz“: Festschrift anläßlich des 25-jährigen Bestehens des Vereins 1903-1928, Lodz 1928. Tekst dostępny w Wojewódzkiej Bibliotece Publicznej im. Marszałka Józefa Piłsudskiego w Łodzi, sygn. 7594 KZ.

${ }_{98}$ Gedenkschrift anläßlich des 20-jährigen Jubiläums der Anstalten des Hauses der Barmherzigkeit in Lodz: 21. X. 1908 - 21 X 1928 / Haus der Barmherzigkeit, Lodz 1928. Tekst dostępny w bibliotece Martina Opitza w Herne, sygn. ADMY 05483.

${ }_{99}$ Gedenkschrift anläßlich des 50-jährigen Jubiläums der Baptistengemeinde Lodz, Nawrot 27, Lodz 1928. Tekst dostępny w bibliotece Martina Opitza w Herne, sygn. ADMY 05479a.

100 Gedenkschrift aus Anlaß des 20-jährigen Bestehens des Deutschen Gymnasiums zu Lodz, Lodz 1928. Tekst dostępny w bibliotece Martina Opitza w Herne, sygn. ADMB 01348b.

101 Festschrift zur Feier des 100-jährigen Jubiläums der Webermeister-Innung zu Lodz, Lodz 1924. Tekst dostępny w formie elektronicznej w bibliotece Martina Opitza w Herne, sygn. CDROM 2278, ADMB 036454. 


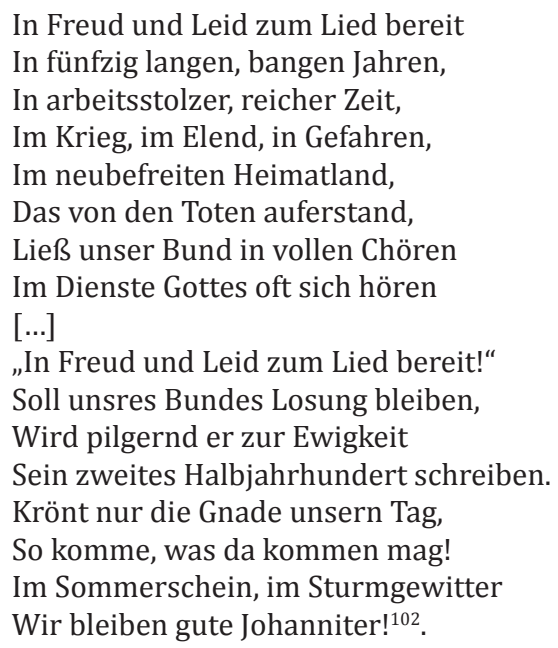

Również jego autorstwa jest tekst Gelübde [Ślubowanie], napisany z okazji 25. rocznicy powstania Ewangelicko-Augsburskiego Towarzystwa Młodzieżowego w Aleksandrowie. Will pisze w nim:

Fünfundzwanzig Jahre auf der Wacht

Für des Glaubens, für des Volkstums Güter,

Heiligen Vätererbes treuer Hüter

In der Zeit voll Hass und Zweifelsnacht:

So hat unser Jugendbund gestanden ${ }^{103}$.

Wiersze okolicznościowe ukazywały się nie tylko na łamach ksiąg jubileuszowych. Również lokalne gazety zamieszczały teksty upamiętniające rocznice, ważne dla miasta i jego mieszkańców. 9 listopada 1924 r., w 100. rocznicę powstania Zgromadzenia Majstrów Tkackich, „Lodzer Illustriertes Sonntagsblatt" opublikował wiersz Philippa Kreutza, w którym autor odwoływał się do mitu założycielskiego miasta i roli niemieckich tkaczy:

102 J. Will, In Freud und Leid zum Lied bereit!, [w:] Festschrift zum 50-jährigen Jubiläum des Kirchengesangvereins..., s. 6-7 [W radości i cierpieniu gotowi do pieśni, / przez pół wieku długich i niełatwych lat, / w czasie pracowitym, ale i owocnym, / w wojnę, w niedoli i zagrożeniu, / w wyzwolonym ojczystym kraju, / który powstał z martwych, / rozbrzmiewał chór naszych głosów / w służbie Bogu. [...]„W radości i cierpieniu gotowi do pieśni!” - / Niechże te słowa będą naszym hasłem, / byśmy pielgrzymując mogli zapisać / kolejnych pięćdziesiąt lat naszej historii. / Niech łaska będzie nam dana, / niech będzie, co ma być! / W słońca blasku czy w nawałnicy / będziemy trwać, prawdziwi joannici. Tłumaczenie M.P.].

103 J. Will, Gelübde. Zum 25-jährigen Jubiläum des evang.-lutherischen Jugendvereins zu Aleksandrow bei Lodz, [w:] Festschrift zum 25-jährigen Bestehen des ev.-luth. Jugendvereins 1909-1934 zu Aleksandrow bei Lodz, Lodz 1934, s. 3 [Ćwierć wieku na straży / wiary i dobra narodu, / świętego dziedzictwa ojców, / w czasie pełnym nienawiści i zwątpienia / trwał nasz związek młodzieży... Tłumaczenie M.P.]. 
Im Polenland, auf dieser Erde

Da ließen sich die Väter nieder,

Hier bauten sie ihr Haus und Herd,

Hier sangen sie der Heimat Lieder.

Und wirkten und woben

Die feinen und groben,

Die lieblichsten Garne zu den Geweben,

Sie ließen die Hände

Sich regen behende

Und liebten den Webstuhl mehr als ihr Leben.

Und aus dem Fleiß,

Aus Müh' und Kampf,

Aus Spindeln, Stühlen, Maschinen und Dampf

Stieg der Arbeit gold'ner Preis,

Wuchs der Großstadt Riesenleib,

Wo vieltausend Hände weben,

Wo vieltausend Menschenleben

Finden Brot und Zeitvertreib.

Euch gilt der Lohn!

Und wenn nun heut' zum Himmelsthron

Die wärmsten Dankgebete schweben,

So klingt zugleich

Der Wunsch für Euch:

Die Innung soll noch manch Jahrhundert leben!104

Lokalna literatura okolicznościowa opiewała nie tylko instytucje życia społeczno-kulturalnego i kultu religijnego, lecz także luminarzy łódzkiej społeczności. W 1917 r. niemieckojęzyczna „Neue Lodzer Zeitung” świętowała 25. rocznicę (1892-1917) pracy dziennikarskiej Aleksandra Milkera, który był nie tylko dziennikarzem tej gazety, ale wraz z Alexisem Drewingiem również jej założycielem. Z tej okazji zamieszczono wiele artykułów na temat działalności Milkera i dokonań gazety. Życiu i twórczości dziennikarza jeden ze swych wierszy poświęcił łódzki poeta Theodor Abel, zwracając w nim uwagą na szczególny talent jubilata, a mianowicie jego ugodowość i nieustanne dążenie do porozumienia w latach konfliktów, co w wielonarodowym mieście było wyjątkową umiejętnością. Abel tak pisał o Milkerze:

${ }_{104} \mathrm{Ph}$. Kreutz, Ein Jahrhundert Webermeisterinnung in Lodz, „Lodzer Illustriertes Sonntagsblatt. Beilage zur Neuen Lodzer Zeitung", 9.11.1924, s. 2. Tekst opublikowano również w Anhang zur Festschrift zur Feier des 100-jährigen Jubiläums der Webmeisterinnung zu Lodz 1824-1924, Lodz 1924, s. 2 [...W polskim kraju, na tej ziemi / osiedlili się ojcowie; / tu zbudowali swój dom, / tu śpiewali swej ojczyźnie pieśni. / Pracowali i tkali, / cienkie i grube nici splatając / w najpiękniejsze tkaniny, / ich ręce poruszały się zwinnie, / a krosno kochali nad życie. // Ich pracowitość, / ich trud i walka, / wrzeciona, krosna, maszyny i dym / przyniosły nagrodę za ich trud - / rosło ogromne cielsko wielkiego miasta, / w którym tysiące rąk tkało, / w którym tysiące ludzi znalazło / chleb i rozrywkę. / Wam trzeba za to składać dzięki! / I jeśli dziś do nieba bram / wznoszą się słowa dziękczynienia, / wraz z nimi was składamy / życzenia: / Niech Cech nasz przetrwa jeszcze wiele lat!. Tłumaczenie M.P.]. 


\begin{abstract}
Du nahmst die Feder
und in reichen Mühen

hast Du in Schaffenskraft gebaut.

Und freudig sahst Du jenes Werk erblühen,

Das dir das Schicksal anvertraut.

Dein Schaffen war ein froh' Gedeihen:

Stets tratst für Einigkeit Du ein,

Im heißen Kampf der hadernden Parteien

Verstandst Du,s Bindeglied zu sein ${ }^{105}$.
\end{abstract}

Osobą, której jubileusz obchodzono równie uroczyście jak rocznicę działalności Milkera, był pastor Wilhelm Petrus Angerstein, dla którego parafianie przygotowali liczne wiersze okolicznościowe z okazji jubileuszu posługi kapłańskiej. Angerstein (1848-1928) był niezwykle zasłużony dla łódzkiej parafii św. Jana ${ }^{106}$. Jego rodzina przybyła z niemieckiego Achim do Warszawy, a następnie do Łodzi. Angerstein studiował teologię najpierw w Erlangen w Bawarii, a potem w Lipsku. Po ukończeniu studiów pracował w parafii w Krakowie, jako ordynariusz we Wrocławiu, w Czarnym Lesie i Wiskitkach. W 1885 r. został proboszczem nowo założonej parafii św. Jana w Łodzi, w której pracował czterdzieści dwa lata, zaś w 1912 r. powołano go na stanowisko superintendenta diecezji piotrkowskiej. W latach swej kapłańskiej posługi brał aktywny udział w życiu kościoła. Założył wiele organizacji (m.in. Stowarzyszenie Młodzieńców, Misję Miejska, Stowarzyszenie Pań), wspierał budowę kolejnego kościoła dla ewangelików (czyli kościoła św. Mateusza), zajmował się również działalnością publicystyczną, ogłaszając swe teksty w „Zwiastunie Ewangelickim” i „Evangelisch-Lutherisches Kirchenblatt”, a w polskojęzycznej wersji wydał „Głosy Kościelne w Sprawie Kościoła Ewangelicko-Augsburskiego". Bronił tradycyjnego podejścia do luteranizmu, zwalczał wszelkie nurty „liberalne” pojawiające się w kościele i był przeciwnikiem wprowadzonej w Prusach unii z 1817 r., w wyniku której powstał Ewangelicki Kościół Unii Staropruskiej. Mimo niemieckiego pochodzenia uważał się za Polaka ${ }^{107}$. W 1899 r. jego parafianie tak pisali o działalności Angersteina:

105 Th. Abel, Dem unermüdlich Schaffenden. Herrn Aleksander Milker zu seinem 25-jährigen Journalistenjubiläum , „Illustrierte Sonntagsbeilage zur Neuen Lodzer Zeitung”, 29.04.1917, s. 2 [...Chwyciłeś za pióro - i z trudem / budowałeś twórczą siłą. / Z radością patrzyłeś, jak powstają dzieła, / które powierzył ci los. // Twoja twórczość kwitła. / Wciąż byłeś za jednością, / w zaciętej bójce zwalczających się stron / byłeś ogniwem łączącym. Tłumaczenie M.P.].

106 Więcej na temat pastora zob. T. Stegner, Ks. Wilhelm Piotr Angerstein. Duszpasterz Polaków i Niemców, [w:] Ewangelicy ziem polskich XIX wieku. Sylwetki wybitnych postaci, Gdańsk 2008, s. 147-167; B. Kopczyńska-Jaworska, K. Woźniak, Łódzcy luteranie. Społeczność i jej organizacja, Łódź 2002, s. 128-129.

107 Por. Das 25-jährige Amtsjubiläum des Pastors der St. Johannis-Gemeinde zu Lodz, Wilhelm Petrus Angerstein: am 29. November 1899, Lodz 1900. 
Zeigt uns, wie fest der Kirchen Säulen stehen,

Gestützt von Männern, wie der Jubilar.

Er hat mit reinem, starkem Gottvertrauen

Den langen schweren Weg zurückgelegt.

Auf seinem Dornenfeld sind heute zu erschauen

Die reichen Früchte, die sein Wirken trägt:

Wir wünschen nun, das Gott in seiner Gnade

Mit reichem Segen dieses Leben schütze,

Dass er veredelnd auf die dunklen Triebe

Der Menschheit wirke und dem Glauben nütze ${ }^{108}$.

25. rocznicę posługi kapłańskiej świętował również pastor Juliusz Dietrich. 9 grudnia 1923 r. „,llustriertes Sonntagsblatt. Beilage zur Neuen Lodzer Zeitung" zamieściła szereg artykułów na temat jego działalności, a także wiersze okazjonalne. Pastor Dietrich był organizatorem życia religijnego i społecznego przy parafii i dawał liczne dowody lojalności wobec państwa polskiego. Z tego właśnie powodu 11 grudnia 1939 r. został aresztowany w Łodzi przez Gestapo. Pastor Philipp Kreutz tak pisał o Juliuszu Dietrichu:

So stehst Du heut nach fünfundzwanzig Jahren auf gold'nen Höh'n der reichen Lebensbahn! $\mathrm{Zu}$ Deinen Füßen treu sich Freunde scharen, Nur Dankbarkeit und Achtung blickt Dich an. Für Dich fleht heiß die liebende Gemeinde: „Gott schütze Dich, Du treuer Jubilar Und schenke uns, wir bitten Dich, das Eine: Herrn Pastor ja noch fünfzig Jahr!“"109

Wierszami okolicznościowymi czczono również rocznice śmierci łódzkich fabrykantów. 19 października 1905 r. „Neue Lodzer Zeitung” zamieściła utwór okolicznościowy z okazji śmierci Juliusza Kunitzera (1843-1905), łódzkiego przemysłowca i działacza społecznego. Kunitzer przybył do Łodzi

108 B. Hartmann, Festgedicht zum 25-jährige Amtsjubiläum des Herrn Pastor W. P. Angerstein, [w:] Das 25-jährige Amtsjubiläum des Pastors der St. Johannis-Gemeinde..., s. 33-34 [Pokażcie nam, jak silnie są filary świątyni, / wspierane przez ludzi takich, jak jubilat. / Z czystą i silną wiarą w Boga / pokonał długą, ciężką drogę. / Na jego cierniowej drodze widać dziś / bogaty plon jego pracy. / Życzmy mu więc, aby Bóg w swej łasce / błogosławił mu i strzegł jego życia, / by uszlachetnił ciemne strony / ludzkości i służył wierze, / by po następnych dwudziestu pięciu latach / złoty laur spoczął na jego głowie, / a jego pobożna działalność / znalazła wdzięczność i miłość wiernych... Tłumaczenie M.P.].

${ }_{09} \mathrm{Ph}$. Kreutz, Juliusz Dietrich, „Illustriertes Sonntagsblatt. Beilage zur Neuen Lodzer Zeitung", 9.12.1923, s. 2 [Dziś, po dwudziestu pięciu latach, jesteś / na złotych wyżynach bogatego życia! / U twoich stóp wielu przyjaciół / patrzy na ciebie z wdzięcznością i szacunkiem. / Za ciebie błaga kochająca cię gorąco społeczność: / Niech Bóg cię chroni, wierny Jubilacie / i da nam, prosimy cię, jedno: / Pastorowi Dietrichowi pięćdziesiąt kolejnych lat!. Tłumaczenie M.P.]. 
ok. 1855 r. Najpierw zatrudnił się w fabryce wyrobów wełnianych Edwarda Hentschela, a następnie w 1874 r. przejął ją na własność wraz ze szwagrem Ludwikiem Meyerem. Jego kariera zaczęła nabierać rozpędu w latach 80. XIX w., kiedy razem z Juliuszem Heinzlem, jednym z najpotężniejszych przemysłowców łódzkich, założył spółkę Akcyjną Wyrobów Bawełnianych. Na początku XX w. w jego zakładach znalazło zatrudnienie ok. 3000 robotników, dla których wybudował 150 drewnianych domów. Kunitzer był nie tylko odnoszącym sukcesy przemysłowcem, ale też aktywnym działaczem społecznym. Dla Łodzi zrobił wiele: przez szereg lat zajmował stanowisko prezesa Łódzkiego Chrześcijańskiego Towarzystwa Dobroczynności, zainicjował powstanie Towarzystwa Łódzkich Kolei Elektrycznych i Łódzkich Wąskotorowych Elektrycznych Kolei Dojazdowych, ale zasłynął także niechlubnie, jako bezwzględny kapitalista. W okresie rewolucji 1905 r. zadeklarował się jako zaciekły przeciwnik strajków robotniczych. Zginął w 1905 r., zastrzelony przez dwóch działaczy PPS. Łódzki historyk Kazimierz Badziak tak pisał o jego śmierci:

30 września 1905 r. około godziny 18 Juliusz Kunitzer wracał w towarzystwie kilku osób tramwajem z Widzewa do Łodzi. Przed ulicą Nawrot z wnętrza wagonu wyszło dwóch osobników, z których jeden stanąwszy na stopniu wyjął pistolet i oddał do niego kilka strzałów. Ciężko rannego Kunitzera przewieziono do pogotowia ratunkowego, gdzie zmarł po 20 minutach. Policji udało się zatrzymać sprawcę zabójstwa, którym okazał się 23-letni pracownik firmy Desurmont i Ska - Adolf Szulc. Drugiemu terroryście udało się zbiec $^{110}$.

Śmierć Kunitzera wywarła ogromne wrażenie na łódzkiej społeczności, zarówno na robotnikach jak i fabrykantach. Uroczysty pogrzeb na Starym Cmentarzu przy ul. Ogrodowej odbył się 3 października 1905 r. W „Neue Lodzer Zeitung" tak pisano o zmarłym:

\author{
Einsam hinter öder Kirchhofsmauer \\ Hochgeschaufelt ragt ein frisches Grab. \\ Gelbe Blätter weh'n in stummer Trauer \\ Auf den Hügel wehmutsbang herab... \\ Dich, der noch vor wenig, wenig Tagen \\ Schaffensfreudig unter uns geweilt, \\ Mußten weinend wir zu Grabe tragen, \\ Hat der Tod Dich, ach, viel zu früh ereilt; \\ Viel zu früh für unsere Armen, Kranken, \\ Viel zu früh für Dein getreu Gemahl, \\ Früh für Die, die Alles Dir verdanken, \\ Viel zu frühe für uns allzumal ${ }^{111}$.
}

110 K. Badziak, J. Kunitzer - symbol Łodzi wielonarodowościowej i wielkoprzemysłowej, [w:] Polacy - Niemcy - Żydzi w Łodzi. Sąsiedzi dalecy i bliscy, red. P. Samuś, Łódź 1997, s. 192-228.

111 J. Williams, Dem Gedächtnis des verstorbenen Manufakturrats Julius Kunitzer, „Neue Lodzer Zeitung. Handels- und Industrieblatt", 6./19.10.1905, s. 2 [Samotnie za opuszczonym 
Również jednemu z największych łódzkich fabrykantów, królowi łódzkiej bawełny, Karolowi Wilhelmowi Scheiblerowi (1820-1881) wystawiono pomnik w postaci wiersza okolicznościowego. W 25. rocznicę śmierci jeden z robotników jego fabryki napisał utwór, który przekazał żonie, Annie Scheibler. Oto jego fragment:

\author{
Herr Scheibler hat in unserm Herzen \\ Ein bleibend Denkmal sich gestellt! \\ Er nahm in Kummer, Leid und Schmerzen, \\ Wie es bekannt in aller Welt! \\ Der Armen sich stets hilfreich an, \\ Als Menschenfreund und edler Mann. \\ [...] \\ Er hat ein bleibendes Gedächtnis \\ Gestiftet sich bei Jedermann; \\ Wie das eröffnete Vermächtnis Uns, \\ den Bedachten, kund getan: \\ Für Kirch', Schul', Armen hat zuletzt \\ Er hohe Summen ausgesetzt. \\ Selbst Arbeiter sind nicht vergessen! \\ Auch wir erhielten ein Geschenk! \\ Wir freuen uns!! - und sind indessen \\ Auch dieser Wohltat eingedenkt!!! \\ Der Herr gedenk auch einst daran, \\ Was hier im Glauben ward getan!!!112
}

Wierszem okolicznościowym świętowano również rocznice śmierci zwykłych łodzian. I tak w 1912 r., w pierwszą rocznicę śmierci matki, Adolf Kargel napisał wiersz, opublikowany na łamach „Neue Lodzer Zeitung”, w którym się skarży:

Ein Jahr ging hin, daß zu dem Grabe

Man trug ein treues Mutterherz,

murem cmentarza / spoczywa świeża mogiła. / Żółte liście opadają w cichej żałobie / na usypany wzgórek... / Ciebie, który zaledwie kilka dni temu / tak energiczny, byłeś wśród nas, / musieliśmy w płaczu złożyć do grobu. / Za wcześnie zabrała cię śmierć, / o wiele za wcześnie dla naszych ubogich, chorych, / o wiele za wcześnie dla twej wiernej małżonki, / za wcześnie dla tych, którzy zawdzięczają ci tak dużo, / o wiele za wcześnie dla nas wszystkich. Tłumaczenie M.P.].

112 K.O., Herr Scheibler, „Osterbeilage. Neue Lodzer Zeitung”, 2.15.04.1906, s. 122 [Pan Scheibler pozostawił w naszych sercach / po sobie trwały pomnik! / W potrzebie, cierpieniu i bólu, / jak powszechnie wiadomo, / zawsze opiekował się biednymi / jako przyjaciel ludzi i szlachetny człowiek. [...] Na trwałe zapisał się / w pamięci każdego z nas. / I w swej ostatniej woli nie zapomniał o nas: / na kościół, szkołę, biednych / przeznaczył znaczne sumy. / I nie zapomniał o robotnikach! / Obdarował także nas! / Wielka to radość! - Zachowamy pamięć / o tym dobrodziejstwie!!! / Bóg również mu nie zapomni tego, / czego dokonał tu, na ziemi!!! Tłumaczenie M.P.]. Po wojnie tekst nigdy nie znalazł się w żadnym tomie zbiorowym. 


\footnotetext{
Daß man begrub all meine Habe

Und mir zurückließ nur den Schmerz.

Ein langes Jahr... Und doch wie gestern

Hör ich ganz leis' den dumpfen Klang,

Die Glocken sind's - gleich lieben Schwestern

Weih'n sie der Toten ihren Sarg! ${ }^{113}$
}

Nurt okolicznościowy, kultywowany z okazji jubileuszy działalności zarówno instytucji społeczno-kulturalnych, religijnych, jak i zasłużonych dla miasta osobowości, cieszył się w Łodzi ogromną popularnością. Cała twórczość okazjonalna była mało wymagającym tworzywem literackim, dlatego mogli ją uprawiać nawet ludzie pozbawieni gruntownego wykształcenia i szczególnej wrażliwości artystycznej. Środowisko łódzkich autorów, którzy nie mieli okazji uczestniczyć w życiu literackim miasta (bo takowe po prostu nie istniało), często posługiwali się więc prostym językiem. Stąd już od początku XIX w. powstawały w Łodzi teksty o charakterze użytkowym. Choć często bywały artystycznie nieporadne, na stałe wpisały się w literacki krajobraz miasta.

\subsection{Kalendarz liturgiczny}

Łódzka twórczość okolicznościowa podążała również za paradygmatem roku kalendarzowego, w której dominował kalendarz liturgiczny (święta Bożego Narodzenia, Wielkanoc, Zielone Świątki, Święto Zmarłych), tożsamy z następstwem pór roku. Tak jak całą literaturę okazjonalną, wiersze te również cechowała stereotypowość, powtarzalność i ugruntowany, oczywisty dla czytelnika obraz świata. W tym sensie literatura ta rejestrowała mentalność ludzi i ich przekonania charakterystyczne dla okresu, w którym powstawała. O wiośnie pisano z radością, bo przyroda budziła się do życia; Zielone Świątki odpowiadały letniemu przesileniu, dlatego towarzyszyła im wesołość i beztroska; Święto Zmarłych skłaniało do refleksji nad przemijaniem, starością i śmiercią; Boże Narodzenie, przypadające na miesiące zimowe, było z jednej strony czasem wyczekiwania na wiosnę, z drugiej zaś - w sensie religijnym - okresem narodzin Chrystusa, niosącym nadzieję na przyszłość.

113 A. Kargel, Der Mutter Todestag, „Illustrierte Sonntagsbeilage zur Neuen Lodzer Zeitung” 15/1912, s. 119 [Rok minął, kiedym w grobie / złożył ukochaną matkę; / z nią pogrzebano wszystko, com posiadał / i pozostał mi tylko ból. // Długi rok... A jakbym wczoraj / słyszał cichy, głuchy dźwięk. / To dzwony, które niczym siostry / kochające błogosławią trumnę zmarłej. Tłumaczenie M.P.]. Po wojnie tekst nigdy nie znalazł się w żadnym tomie zbiorowym. 
Najbardziej uroczystym świętem było w Łodzi Boże Narodzenie. Okres ten obchodzono bardzo uroczyście w gronie rodzinnym. Świętowały zarówno rodziny ewangelickie, jak i katolickie, polskie i niemieckie ${ }^{114}$.

Okres świąt Bożego Narodzenia był również wyzwaniem dla lokalnych gazet i miejscowych literatów. Na ten czas prasa zmieniała swą nudną szatę graficzną, ozdabiając wydania ciekawym materiałem literackim, licznymi okolicznościowymi rycinami, zdjęciami i kolorowym drukiem ${ }^{115}$. Wśród wielu opowiadań bożonarodzeniowych zawsze znalazło się też miejsce dla liryki okolicznościowej. Przykładem takiej twórczości okazjonalnej są wiersze pastora Philippa Kreutza, który znaczną część swych utworów publikował na łamach dodatku do „Neue Lodzer Zeitung”. Centralne miejsce w jego twórczości zajmują wiersze o tematyce Bożego Narodzenia, o którym tak pisał:

Ach, die Sterne funkeln wieder
Und die Weihnacht senkt sich nieder,
Wieder wird die Welt so schön
Froh erklingen dann die Glocken
Und ein seliges Frohlocken
Tönt im Tal und auf den Höhen...

Bezpośredni okres, poprzedzający święta Bożego Narodzenia, to oczywiście Adwent, o którym Kreutz tak napisał:

Mach Dich bereit zum herzlichen Empfang!

Der Herr steht vor der Tür,

Er kommt zum Trost, zum Heil und zum Gerichte,

Und alle Nacht entflieht vor seinem Lichte! $!^{117}$

Szczególnie uroczyście obchodzono w środowisku łódzkich ewangelików Wielkanoc ${ }^{118}$. Jak wynika z literatury wspomnieniowej, był to okres niezwykle radosny. Często w rodzinach, w których jedno z małżonków było

114 Por. Gdzie sq Niemcyz tamtych lat - wspomnienia łódzkich Niemców, red. K. Radziszewska, Łódź 1999, s. 28-33, 56-63.

115 Por. dla przykładu „Pfingstgruß der Neuen Lodzer Zeitung”, 22.05./4.06.1911.

$116 \mathrm{Ph}$. Kreutz, Weihnachten, „Lodzer Illustriertes Sonntagsblatt. Beilage zur Neuen Lodzer Zeitung”, 27.12.1925, s. 5 [Ach, znów migoczą gwiazdy, / nadchodzi Boże Narodzenie, / świat znowu będzie piękny, / wesoło zabrzmią dzwony / i wielka radość / zagości w górach i dolinach... Tłumaczenie M.P.]. Po wojnie tekst nigdy nie znalazł się w żadnym tomie zbiorowym.

117 Ph. Kreutz, Advent, „Lodzer Illustriertes Sonntagsblatt. Beilage zur Neuen Lodzer Zeitung”, 29.11.1925, s. 3 [Bądź gotów na przyjęcie! / Pan stoi u bram, / przybędzie jeszcze dziś do ciebie, / aby pocieszać, uzdrawiać i sądzić. / Przed jego blaskiem ustąpi nawet noc! Tłumaczenie M.P.]. Po wojnie tekst nigdy nie znalazł się w żadnym tomie zbiorowym.

118 Por. B. Kopczyńska-Jaworska, Zwyczaje i obyczaje ludności Łodzi, [w:] Łódź. Dzieje miasta, t. 1: Do roku 1918, red. B. Baranowski, J. Fijałek, Łódź-Warszawa 1980, s. 493-507. 
ewangelikiem, a drugie katolikiem, dochodziło do przemieszania zwyczajów katolickich i ewangelickich ${ }^{119}$. I tak ewangelicy na Wielkanoc wystawiali w koszyczkach potrawy do święcenia, wśród których znajdowały się - zgodnie z katolickim zwyczajem - kiełbasa, chleb, gotowane jajka i wiele innych produktów ${ }^{120}$. Święta wielkanocne kojarzyły się ze zmartwychwstaniem i przebudzeniem przyrody. I właśnie w tym kontekście Philipp Kreutz pisał o Wielkanocy jako o czasie, w którym wszystko budzi się do życia:

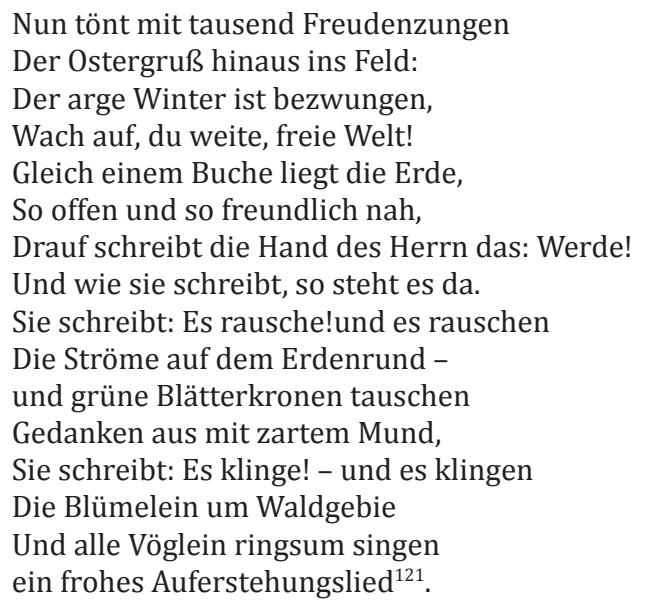

Świętom wielkanocnym towarzyszyło nadejście wiosny. Na ten temat wiele pisali łódzcy autorzy, wśród nich m.in. Wally Reimann w wierszu Vorfrühling [Przedwiośnie], Wally Thiem w utworze Frühlingsbitte [Wiosenna prośba], Edith Seiler w wierszach Frühlingsahnung [Wiosenne przeczucie] i Stille [Cisza], Tträumende Frühlingsandacht... [Modlitwa wiosenna...], Philipp Kreutz w wierszach Sonne, herrsche! [Słońce, świeć!] i Mein Frühling [Moja wiosna], Klara Gnauk w licznych wierszach zebranych w tomie Auf einsamen Wegen [W samotnej drodze] czy też Erwin Jenske w utworze Frühlingssonne [Słońce wiosenne]. Nadchodzącą wiosnę tak opisywał Wally Reimann w wierszu Vorfrühling [Przedwiośnie]:

119 J. Grohmann, Polacy, Niemcy, Żydzi, [w:] Gdzie sq Niemcy..., s. 28-33, 141-151.

120 R. Kornacker, Po stracie naszej ojczyzny zbudowaliśmy nowa, [w:] ibidem, s. 51-55, 166-170.

121 Ph. Kreutz, Ostern, „Die Welt im Bilde. Sonntagsbeilage zur Neuen Lodzer Zeitung”, 31.03.1929, s. 1 [Tysiącem radosnych głosów / rozbrzmiewają świąteczne życzenia: / oto zła zima pokonana. / Zbudź się, ogromny, wolny świecie! / Ziemia jak księga / otwarta i pogodna. / Nagle ręka Pana pisze w niej: Stań się! / I jak napisano, tak się też stało. / Ręka pisze: Szumcie! - i oto / szumią na ziemi potoki, / a liście w zieleniejących koronach / drzew rozmawiają ze sobą. / Ręka pisze: Rozbrzmiewajcie! / i oto kwiaty w lesie, a z nimi / wszystkie ptaki dookoła, nucą / radosną pieśń zmartwychwstania. Tłumaczenie M.P.]. Po wojnie tekst nigdy nie znalazł się w żadnym tomie zbiorowym. 
Geduld,

Nur noch ein Weilchen,

Bald, bald

Zieht Lenz und sein Gefolge

Durch Feld und Wald.

Es sind des Winters Spuren

Ja schon fast ganz verweht,

Schon träumen Feld und Fluren,

Daß es gen Frühling geht ${ }^{122}$.

Trzecim wielkim świętem łodzian były Zielone Świątki. Był to okres niezwykle radosny, gdyż do miasta ściągały wówczas wesołe miasteczko i cyrk, natomiast Towarzystwo Strzeleckie organizowało w tym czasie na Wodnym Rynku zabawę o nazwie „fajka”. Poza tym wybierano króla kurkowego i strzelano do tarczy. O Zielonych Świątkach Kreutz pisał:

\author{
Ein Glockenklang \\ Tönt feierlich durch erlöste Welt, \\ Vom Festgesang \\ Erzittern hoch des Äthers lichte Sphären, \\ Es steigt das Lied zum blauen Himmelszelt \\ und jubelt laut dem heiligen Gott zu Ehren. \\ 0 Pfingstzeit, o frohe Zeit, \\ Gib uns die rechte Freudigkeit ${ }^{123}$.
}

Począwszy od dnia Trzech Króli świętowano w Łodzi karnawał. Łodzianie uczestniczyli w licznych maskaradach i pochodach przebierańców, którym towarzyszyła miejscowa orkiestra. W tym czasie odbywały się również bale, organizowane przez łódzkich fabrykantów, które często miały charakter charytatywny. I tak przykładowo w lutym 1887 r. zorganizowano w sali teatru „Thalia” bal maskowy na rzecz szpitala św. Aleksandra ${ }^{124}$. Łódzki poeta Wally Thiem tak pisał o tym okresie:

Einmal nur glänzen, im festlichen Saal

Sich tummeln, bei tausender Lichter Strahl

${ }^{122}$ W. Reimann, Vorfrühling, „Lodzer Illustriertes Sonntagsblatt. Beilage zur Neuen Lodzer Zeitung”, 12.03.1924, s. 4 [Cierpliwości, / jeszcze tylko chwila, / i zaraz, zaraz / nadciągnie wiosna ze swym orszakiem / przez pola i lasy. / Już prawie znikły / ślady zimy. / Śnią już pola, marzą niwy, / że w końcu nadejdzie wiosna. Tłumaczenie M. P.]. Po wojnie tekst nigdy nie znalazł się w żadnym tomie zbiorowym.

${ }^{123}$ Ph. Kreutz, Pfingsten, „Lodzer Illustriertes Sonntagsblatt. Beilage zur Neuen Lodzer Zeitung”, 8.06.1924, s. 5 [Uroczyste bicie dzwonów / płynie nad zbawionym światem, / pieśń dźwięczy w górze, / wypełnia jasne sfery eteru, / pieśń wznosi się ku niebu / i niesie cześć Panu Niebieskiemu. / Zielone Świątki, czasie wesołości, / przynieś nam mnóstwo radości!. Tłumaczenie M.P.]. Po wojnie tekst nigdy nie znalazł się w żadnym tomie zbiorowym.

${ }^{124}$ Por. M. Piestrzeniewicz, Rozrywka łodzian na przełomie XIX i XX w., Łódź 2010. 
In köstlich schimmerndem Seidengewand

Ringgeschmückt jeden Finger der Hand

Und sitzen an weiter Tafelrunde,

Glänzenden Aug's mit lächelndem Munde

Trinken den feurigen, perlenden Wein.

...Einmal umjubelt, gefeiert nur sein

Fühlen die Blicke, die um mich werben

Und glücklich sein... ganz glücklich... und sterben ${ }^{125}$.

Dzień Wszystkich Świętych był okazją do rozmyślań na temat istoty przemijania. Rozważania te stały się głównym motywem utworu Kreutza pt. Totensonntag [Zaduszki], w którym pisze:

Sonntag ist heute, doch Sonntag der Toten,

Deren Gedanken die Liebe beweint,

Denen die Erde für immer verboten,

Denen das düstere Grabeslicht scheint;

Ist es die Mutter, die keiner vergessen,

Ist es die Gattin, die Liebste, das Kind?

Heute beweinst du, was du einst besessen,

Heute noch weinst du die Augen dir blind,

Schaurig und traurig

Klagen die Lüfte,

Ist es der Toten ergreifender Chor? ${ }^{126}$

Charakterystyczny dla wszystkich przedstawionych tu wierszy był fakt, że wychodziły naprzeciw popularnemu poczuciu poetyckości: były rymowane, miarowe. Tytuły jasno określały temat, natomiast nazwisko poety schodziło na plan dalszy. Pod wieloma utworami okazjonalnymi często nie ma nawet podpisu autora. Wiele z tych wierszy ewokowały motywy natury. Jednakże sposób przedstawiana przyrody nie wpisuje się w żaden ówcze-

125 W. Thiem, Faschingswünsche, „Illustrierte Sonntagsbeilage zur Neuen Lodzer Zeitung”, 13.01.1924, s. 3 [Choć raz zabłysnąć, w pięknej sali / pląsać, w blasku tysiąca świateł, / w cudnej jedwabnej sukni, / a na każdym palcu lśni pierścień; / siedzieć wśród mnóstwa biesiadników, / z błyszczącymi oczyma, z uśmiechem na ustach / i pić ogniste, musujące wino. / ...Choć raz być adorowaną i uwielbianą, / czuć wzrok, który zabiega o względy / i być szczęśliwą... naprawdę szczęśliwą... i umrzeć. Tłumaczenie M.P.]. Po wojnie tekst nigdy nie znalazł się w żadnym tomie zbiorowym.

${ }^{126}$ Ph. Kreutz, Totensonntag, „Welt im Bild. Sonntagsbeilage zur Neuen Lodzer Zeitung”, 23.11.1930, s. 6 [Dziś jest niedziela, lecz niedziela zmarłych, / których pamięć opłakujemy z miłością, / których na zawsze zabrano z tej ziemi, / którym przyświeca mroczne światło grobu. / Czy to matka, której nikt nie zapomniał, / czy żona, czy ukochana albo dziecię? / Dziś opłakujesz tych, którzy kiedyś byli z tobą, / dziś jeszcze wypłakujesz za nimi oczy. / Strasznie / i smutno / skarży się wiatr. / Czy to zmarłych przejmująca pieśń? Tłumaczenie M.P.]. Po wojnie tekst nigdy nie znalazł się w żadnym tomie zbiorowym. 
śnie panujący nurt literacki. Wprawdzie może przypominać ze względu na podejmowane motywy rozwijającą się w latach 20. i 30. XX w. w Niemczech literaturę przyrody (niem. Naturlyrik), to jednak należy podkreślić, iż wiersze te są bardzo różne. Lirykę przyrody charakteryzowała subwersywność. Autorzy fascynujący się przyrodą, tacy jak O. Loerke, E. Langgässer, G. Eich, P. Huchl czy W. Lehmann, często posługiwali się elementami baśniowymi, mitycznymi, kreowali aurę wzniosłości i powagi. Loerke nawiązywał w swoich wierszach do tradycji symbolizmu i impresjonizmu (zawarte w tomach: Der längste Tag 1926, Atem der Erde 1930, Silberdistelwald 1934), Langgässer natomiast odwoływała się do symboliki nieba (Die Tierkreisgedichte 1935). Poeci ci posługiwali się wyszukanymi metaforami i obrazami, a ich świat przedstawiony nie był idealny, jak jest to widoczne w poezji Eicha (Gedichte 1930). Wiersze łódzkich poetów są pozbawione tej bogatej metaforyki i przedstawiają w sposób naiwny świat wyidealizowany. Piszący nadawali tym tekstom wielokrotnie uroczysty ton, odpowiadając tym samym na emocjonalne oczekiwania czytelników.

Warto podkreślić, iż przestrzenie łódzkiej poezji wypełnia różnoraka twórczość. Choć pojawiło się kilka tomów ze zbiorami wierszy łódzkich autorów, to niewielu z nich mogło sobie pozwolić na publikację książkową. Przez cały okres twórczości niemieckojęzycznych łodzian ważną rolę w jej popularyzowaniu odegrały lokalne gazety. Dlatego nie miała ona większych szans na recepcję zagraniczną ani też krajową. Oprócz wcześniej wspomnianego Bartelsa, który krytycznie wyraził się o twórczości Willa, trudno jest odnaleźć innych krytyków, znawców tematu, którzy podjęliby się rzetelnej oceny.

W łódzkiej poezji ważne miejsce zajmuje nurt ojczyźniany, rozpowszechniający ograniczone klisze, idealizujące realia społeczne i utwierdzający różnorakie uprzedzenia.

Pod koniec lat 30. XX w. pojawiają się w Łodzi także wiersze antyfaszystowskie, sytuując się na przeciwległym biegunie nurtu ojczyźnianego. Wszystkie te utwory, choć nie posługują się subtelnym językiem ani wyszukanymi środkami artystycznymi, na trwałe wpisały się w krajobraz literacki przemysłowego miasta i stanowią ważny element kultury łódzkich Niemców, dając wyraz ich mentalności i współkształtując ich tożsamość.

Istotną jej część stanowi literatura okazjonalna, pisana w różnych okolicznościach: na jubileusze znanych postaci, zasłużonych dla miasta, jak również instytucji życia społeczno-kulturalnego i religijnego. Wśród łódzkiej twórczości nie brak również wierszy okolicznościowych podążających za paradygmatem roku kalendarzowego i liturgicznego, odwołujących się do stałych, utrwalonych wartości, łatwo czytelnych dla łódzkiej społeczności. 



\section{LODZERMENSCH I JEGO WIZERUNKI LITERACKIE}

\subsection{Mit Lodzermenscha}

Fenomenem Łodzi, odróżniającym ją od wielu miast europejskich, było wykształcenie na przełomie XIX i XX w. odrębnej tożsamości, która w stosunkowo krótkim czasie stała się dla ówczesnej łódzkiej społeczności żywym mitem. Polskojęzyczna publicystyka i literatura wykreowała swoisty wizerunek Lodzermenscha (czyli „łódzkiego człowieka”), który na trwałe wpisał się w historię miasta. Pierwszą publicystyczną próbę opisu fenomenu podjął Antoni Wiśniewski na łamach „Przeglądu Tygodniowego” (1889). Tak oto scharakteryzował znaczną część łodzian:

Jeżeli w Warszawie i innych miastach naszego kraju prawie zawsze można jasno określić, czy dane indywiduum jest Polakiem czy Niemcem, w Łodzi bardzo często bywa to rzeczą trudną. Oto np. p. A. zapytany o narodowość, powiada, że jest Polakiem, prenumeruje nawet pismo polskie, mówi dobrze po polsku, w cukierni obok niemieckich czytuje i polskie pisma, a mimo to $\mathrm{w}$ domu u siebie mówi po niemiecku, w tym samym języku przemawia na wszystkich zebraniach publicznych, w nim prowadzi swe księgi handlowe i korespondencję, do kościoła chodzi na kazania niemieckie, w domu ma jedno z miejscowych pism niemieckich i przynajmniej jedno zagraniczne, pismo polskie zaś trzyma jedynie miejscowe, warszawskiego zaś nie zobaczycie u niego. Rozgniewawszy się na pismo polskie, zacznie na nie wymyślać i stawiać mu za wzór oba dzienniki niemieckie, gdy zaś z tymi zadrze, dziwi się istnieniu tutaj tych gazet. Rozmowę z każdym zaczyna w języku niemieckim, chyba że wie, iż tamten tego nie lubi. Takich osobników znajdziecie w Łodzi tysiącami i podczas gdy jedni uważają ich za Polaków, drudzy zaliczają ich do Niemców, co się zaś mnie tyczy, należę do tych drugich, przy czym dla bliższego określenia charakteru tego rodzaju osobników nazywam ich łodzianami ${ }^{1}$.

Sugestywnie opisywali łodzian Artur Glisczyński i Antoni Mieszkowski w książce Łódź, miasto i ludzie ${ }^{2}$ (1894), a także Adolf Starkman w broszurze

\footnotetext{
${ }^{1}$ A. Wiśniewski, Łódź i łodzianie, cz. I, „Przegląd Tygodniowy” 6/1889, s. 75.

2 X.Y.Z. (właśc. Artur Glisczyński, Antoni Mieszkowski), Łódź miasto i ludzie, Łódź 1894.
} 
Łódź i łodzianie 3 (1895). Wszyscy ci autorzy zwracali uwagę na wyjątkowość mieszkańców tego miasta, określanych mianem Lodzermenschów. W 1898 r. inny dziennikarz, Antoni Sygietyński, pisał:

Zaiste, typ to szczególny, jakkolwiek w Łodzi i pod Łodzią dość zwykły podobno, z mowy cynik potworny, z postępowania squatter amerykański, z wyznania protestant, z obyczajów Niemiec, z kultury Polak. Dziwna mieszanina - to prawda, lecz kto wie, czy Łódź z czasem nie będzie zbiorowiskiem tego typu właśnie ${ }^{4}$.

Fenomen Lodzermenscha wzbudził również zainteresowanie Stefana Gorskiego, który poświęcił mu obszerne fragmenty w wydanym na początku XX w. zbiorze felietonów pt. Łódź spółczesna. Obrazki i szkice publicystyczne. Autor tak pisał o łodzianach:

Łódź, mimo iż nie stanowi ani kraju, ani państwa, ma swoją własną narodowość - są to z niemiecka zwani „lodzermensche”. Pierwotną ich ojczyzną były Niemcy; dłuższe od kilku pokoleń ich przebywanie w kraju naszym przeobraziło w końcu ich patryjotyzm germański, lecz nie pociągnęło do narodowości polskiej. Są to ludzie przeważnie bez zasad politycznych - ojczyznę znaleźli na gruncie łódzkim, tu zdobyli byt i stanowiska, przywiązali się do miasta i dzisiaj są bardzo patriotycznymi „lodzermenschami”.

Znamienna jest w tym kontekście wypowiedź publicysty Aleksandra Mogilnickiego, który w 1902 r. tak opisywał Lodzermenscha:

Co to jest Lodzermensch? Wyraz obcy, znaczy w dosłownym przekładzie „łódzki człowiek" - zyskał u nas prawo obywatelstwa na oznaczenie typowego karierowicza łódzkiego, który - gdyby w ogóle wiedział, co to jest poezja - mógłby powiedzieć o sobie słowami poety: „Wiarą mą pieniądz, dogmatem - kariera”. Wyraz ten tak się utarł w języku miejscowym, że niektórzy piszą go nawet przez małe „l” i „sz” - lodzermensz. Zasadniczą cechą Lodzermenscha jest brak wszelkich zasad etycznych. Cel uświęca środki, a celem jest zyskanie największej ilości pieniędzy. Praca od rana do późnej nocy, wyzyskiwanie ludzi i chwili, bezwzględna obojętność na to, co nie jest zyskiem - oto wszystko ${ }^{6}$.

Przytoczone tu fragmenty pokazują, w jakim kierunku podążali polscy publicyści, opisując istotę tożsamości mieszkańców Łodzi. Lodzermensch był ich zdaniem beznarodowościowcem - ni to Polakiem, ni Niemcem - człowiekiem bez korzeni i bez konkretnego wyznania7. Jego ojczyzną była Łódź, miasto dające wszechstronne możliwości zarobkowania. Ten negatywny wi-

\footnotetext{
${ }^{3}$ A. Starkman, Łódź i łodzianie (Szkic społeczno-obyczajowy), Łódź 1895.

${ }^{4}$ A. Sygietyński, Znasz-li ten kraj, „Kurier Warszawski” 348/1898, s. 2.

5 S. Gorski [Michał Nałęcz], Łódź spółczesna. Obrazki i szkice publicystyczne, Łódź 1904.

${ }^{6}$ A. Mogilnicki, Z ognisk polskiego przemysłu, cz. III, „Przegląd Tygodniowy” 15/1902,
} s. 197.

7 Por. Ilustrowany przewodnik po Łodzi i okolicach, Łódź 1912, s. 114. 
zerunek, oparty na pojęciu brutalnego egoizmu, cynizmu i obojętności wobec innych, świadczy jednoznacznie o specyfice miasta, ale także o tym, jakim jawiło się ono obserwatorom z zewnątrz. Jednak nie tylko polska publicystyka krytycznie postrzegała Lodzermenscha. W podobnym duchu wypowiadali się o nim również polscy poeci i pisarze. Polska literatura na wiele lat utrwaliła o nim negatywną opinię, a jednym z bardziej krytycznych recenzentów fenomenu był polski poeta Julian Tuwim, który w niezwykle dosadnych słowach opisywał jego najbardziej typowe cechy:

Gdy fabryki łódzkie dostają jakieś większe zamówienie, gdy zjawia się koniunktura - zaczyna tam świecić słońce, zakwitają bzy, słowiki turkocą w Helenowie, błoto się mieni spektralnymi kolorami, a ospali lodzermensche stają się übermenschami, odzyskują gibkość ruchów, żywość spojrzeń, bystrość myśli. Pietryna wre. Grynbergi, Grynfeldy, Grynsteiny i Goldbergi uwijają się po mieście jak opętani, wyskakują z dorożek, wskakują do kawiarni, telefonują, zapisują, telegrafują, jadą, wracają, znowu jadą, notują, obliczają: „Fynef und cwancyk... zyben und drasyk... hundert achcyk...”, „gemacht, zrobione, to ja do niego zadzwonię, panie Grynholz, leć pan do Grand Cafe, ja pójdę tymczasem do banku, hallo, panie Goldberg, no co? Hallo, panie Grynszpan załatwione?" Sto tysięcy skaczących nieprzytomnych Grynmacherów wprawia Łódź w drgawki geszeftu. Ten febryczny stan łódzkiej ulicy ma fachową nazwę: „Ruszyło się" ${ }^{\text {. }}$.

Pierwsze literackie przyczynki do portretu Lodzermenscha można odnaleźć w powieści Wincentego Kosiakiewicza pt. Bawełna (1895) ${ }^{9}$, jednakże najpełniejszy jego obraz literacki prezentuje Władysław Stanisław Reymont w powieści Ziemia obiecana ${ }^{10}$. Oba utwory przedstawiają Lodzermenscha jako postać negatywną, zdegradowaną moralnie. Ich bohaterowie stają się prawdziwymi Lodzermenschami, porzucając stare wartości, tradycję i kulturę. Karol Borowiecki z powieści Reymonta tak mówi o wyzbyciu się ograniczeń narzuconych przez tradycję:

Cóż mi pomoże część tradycji do zbytu perkalików! Cóż mi pomogą moi kasztelańscy przodkowie, gdy stawiam fabrykę i muszę szukać kredytu! Dają mi go Żydzi, a nie wojewodowie. A cały ten balast rupieci, ta tradycja, jest jak cierń w nodze, przeszkadza do szybkiego chodzenia. Człowiek dnia dzisiejszego, który nie chce zostać cudzym parobkiem, musi być wolny od więzów przeszłości, szlachectwa i tym podobnych przesądów, to krępuje wolę i obezsila w walce z przeciwnikiem bez skrupułów - bo bez tradycji; z przeciwnikiem dlatego strasznym, że jest sam sobie przeszłością, teraźniejszością i przyszłością, środkiem i celem ${ }^{11}$.

\footnotetext{
8 J. Tuwim, Wspomnienia o Łodzi, „Wiadomości Literackie” 33/1934, s. 19.

9 W. Kosiakiewicz, Bawełna, [w:] Łódź, która przeminęła, w publicystyce i prozie, red. P. Boczkowski, Łódź 2008, s. 267-386.

${ }^{10}$ W.S. Reymont, Ziemia obiecana, Warszawa 1899.

11 W.S. Reymont, Ziemia obiecana, Łódź 1991, s. 251.
} 
Mit Lodzermescha wykorzystali również noweliści, np. Stanisław Łąpiński w utworze $\mathrm{Tkacz}^{12}$ oraz Władysław Rowiński w noweli Julka ${ }^{13}$. Środowisko łódzkich fabrykantów przedstawiono tu schematycznie, odnosząc go do negatywnego obrazu, charakterystycznego dla ówczesnej epoki. Również stereotypowo sportretowali Lodzermenscha Kazimierz Laskowski w powieści Lokaut ${ }^{14}$ i Zygmunt Bartkiewicz w cyklu reportaży pt. Złe miasto ${ }^{15}$.

W okresie międzywojennym mit Lodzermenscha utrwalił się na tyle, że pojęcie to odnotowano w słowniku Michała Arcta, który wyjaśniał, iż Lodzermensch to „typ łódzkiego geszefciarza”"16.

Wizerunek Lodzermenscha, wykreowany na przełomie XIX i XX w., miał w zasadzie dwojakie znaczenie. Pierwsze, zarysowane powyżej, odwoływało się do negatywnego obrazu człowieka, którego trudno jednoznacznie zaliczyć do konkretnej grupy narodowościowej. Lodzermensche byli więc postaciami przedstawianymi w polskiej literaturze i publicystyce w sposób negatywny, niekiedy wręcz pogardliwy, stanowiąc niejako synonim braku zasad etycznych, a także karierowiczostwa i bezwzględnego dążenia do zdobywania pieniędzy. Ten negatywny obraz wydaje się uzasadniony sytuacją społeczno-polityczną tamtego okresu, gdyż został wykreowany przez łódzką i warszawską inteligencję w czasie, gdy Polacy pragnęli uzyskać niepodległość, a w polskim społeczeństwie zaczęły się kształtować postawy nacjonalistyczne. Na Lodzermenscha spoglądano więc przez pryzmat polskości. Warto również nadmienić, iż jest to okres budzenia się świadomości społeczno-politycznej wśród robotników (w 1892 r. wybucha łódzki bunt), a Lodzermenschów kojarzono przecież wówczas z fabrykantem-kapitalistą, dążącym bezwzględnie do zdobycia pieniędzy i wyzysku robotnika. Stąd te jednoznacznie negatywne konotacje, które tak silnie wpisały się w historię miasta.

$\mathrm{Z}$ drugiej strony należy spojrzeć na Lodzermenscha z perspektywy jego faktycznych dokonań w sferze społeczno-kulturowej. Bywał wprawdzie bezwzględnym kapitalistą, ale jednocześnie nie sposób zapomnieć, że dawał zatrudnienie robotnikom i wykazywał się dbałością o sferę socjalną, wykształcenie na najniższym poziomie, a także o ofertę kulturalną. Historia Łodzi zna przecież wiele przykładów, świadczących o zaangażowaniu łódzkich fabrykantów w różnorodne inicjatywy społeczne i kulturalne. Budowali szpitale, szkoły, ochronki dla dzieci i domy dla swoich pracowników, angażowali się

12 S. Łąpiński, Tkacz. Obrazek z życia łódzkich robotników, 1898.

${ }^{13}$ W. Rowiński, Julka, Łódź 1899.

${ }^{14}$ K. Laskowski, Lokaut, Łódź 1907.

15 Z. Bartkiewicz, Złe miasto. Obrazy z 1907 roku, Warszawa 1911.

${ }^{16}$ M. Arcta, Słownik wyrazów obcych. 33000 wyrazów, wyrażeń i przysłów cudzoziemskich, Warszawa 1946, przedruk fotograficzny z roku 1936, s. 180. 
w działalność charytatywną, wspierali wiele instytucji i stowarzyszeń, zakładali chóry i towarzystwa kulturalne, sami także bywali w teatrze. Byli zatem nie tylko właścicielami fabryk wyzyskującymi robotników, ale dbali również o miasto w szerokim znaczeniu tego słowa ${ }^{17}$. Wielu robotników potrafiło docenić zaangażowanie właściciela fabryki, co potwierdzają m.in. wywiady przeprowadzone przez Marię A. Łukowską z najstarszym pokoleniem robotników łódzkich fabryk, w tym m.in. zakładów Izraela Kalmanowicza Poznańskiego i Widzewskiej Manufaktury ${ }^{18}$. Wielu postrzegało ich jako ludzi opiekujących się swoimi robotnikami i interesujących się ich losem ${ }^{19}$. Po roku 1990 mit Lodzermenscha ulega radykalnej zmianie - wprawdzie nadal wskazuje się na fakt, że jest to człowiek bez zasad moralnych i wyzuty z wszelkich skrupułów ${ }^{20}$, ale coraz częściej ma też miejsce odwołanie do takich jego cech, jak zaradność, pracowitość i zmysł do interesów. W tym duchu postrzega Lodzermenscha łódzki Niemiec, Karl-Heinz Goeppert:

Na przestrzeni dziesięcioleci łodzianie pracowali, cierpieli i pomagali sobie wzajemnie, niezależnie od tego, jakiej byli narodowości i jakiego wyznania. W ten sposób narodził się „lodzermensch”, któremu zazdroszczono, ponieważ był pracowity i umiał sobie radzić w życiu. W wielonarodowościowej Łodzi wszyscy wyrastaliśmy myśląc demokratycznie. Tego rodzaju społeczność mogła przetrwać tylko, jeśli nie myślano o ludziach w kategoriach narodowościowych, nieważne czy było się Polakiem, Niemcem, Żydem czy Rosjaninem. Wszyscy musieli polegać na sobie wzajemnie. Łódź była azylem dla wszystkich, którzy tutaj mieszkali ${ }^{21}$.

Dlatego z biegiem czasu wykształca się odmienna ocena Lodzermenscha. Biorąc pod uwagę przytoczone argumenty, fenomen ten można analizować w kontekście paradygmatu człowieka racjonalnego, tzw. homo oeconomicus, który interesował wielu filozofów, wśród nich Adama Smitha (1723-1790) i Johna Stuarta Milla (1806-1873). W swoich pracach z zakresu ekonomii politycznej Mill22 tak zdefiniował pojęcie homo oeconomicus:

It is concerned with him solely as a being who desires to possess wealth, and who is capable of judging of the comparative efficacy of means for obtaining that end. It predicts only

17 Por. S. Pytlas, Łódzka burżuazja przemysłowa w latach 1864-1914, Łódź 1994.

18 Por. M.A. Łukowska, Fabrykant łódzki we wspomnieniach robotników, Łódź 2007.

19 Ibidem, s. 100.

${ }^{20}$ Por. S. Pytlas, Łódzka burżuazja...

${ }^{21}$ K.H. Goeppert, Sic transit gloria mundi - tak przemija chwała świata, [w:] Gdzie sa Niemcy z tamtych lat - wspomnienia łódzkich Niemców, red. K. Radziszewska, Łódź 1999, s. 44-45.

22 Por. J.S. Mill, Essays on Some Unsettled Questions of Political Economy, London 1844, wydanie polskie: Zasady ekonomii politycznej, tłum. E. Taylor, Warszawa 1966. Na ten temat istnieje wiele opracowań, m.in. J. Stelmach, B. Brożek, W. Załuski, Dziesięć wykładów o ekonomicznej analizie prawa, Warszawa 2007; S. Zabieglik, Homo oeconomicus, [w:] Etyczne podstawy ekonomii - teoria i praktyka, red. J. Kubka, Gdańsk 2003, s. 27-34. 
such of the phenomena of the social state as take place in consequence of the pursuit of wealth. It makes entire abstraction of every other human passion or motive ${ }^{23}$.

Człowiek, według Milla, jest istotą dążącą z natury do posiadania dóbr materialnych. Aby je zdobyć, wybiera najbardziej adekwatne środki do celu, kierując się przede wszystkim egoizmem, ponieważ interesuje go głównie pomnażanie własnego dobra ${ }^{24}$. Myśląc o własnych profitach, homo oeconomicus dokonuje racjonalnych wyborów, ale - jak podkreślał drugi z filozofów, Adam Smith - dążąc do zaspokojenia własnych interesów, człowiek racjonalny przyczynia się jednocześnie do dobra ogółu²5. Przyglądając się bliżej cechom charakteru Lodzermenscha, można odkryć pewne analogie z opisanym wyżej modelem. Znamienne okazuje się, że jest on jednostką wolną i egoistyczną: gwarancję wolności stanowi gromadzony przez wiele lat majątek, zaś egoizm wykształcił koncentrując się na własnych korzyściach, w jakimś stopniu przyczyniając się też bezsprzecznie do dobra ogólnego. W XIX i XX w. miasto potrzebowało tego typu ludzi: na swój sposób bezwzględnych geszefciarzy, odnoszących (niestety, za wszelką cenę) sukces finansowy, przekładający się następnie w jakiejś mierze na sukces gospodarczy miasta, a w dalszej kolejności całego kraju. Choć Lodzermensch jako taki nie był znawcą sztuki i literatury, był jednak jednostką produktywną, zdolną do tworzenia nowych instytucji oświatowych, kulturalnych, społecznych i religijnych, gwarantujących lokalnej społeczności prawidłowe funkcjonowanie aglomeracji.

\subsection{Typy łódzkie według Berty Teplitzkiej i Heinricha Zimmermanna}

Jak wynika z wcześniejszych rozważań, polscy publicyści i literaci wykreowali negatywny wizerunek Lodzermenscha. Warto jednak postawić pytanie, jak ów mit traktowała niemieckojęzyczna literatura Łodzi. Czy podobnie jak polska literatura odwoływała się do tych samych schematów, czy również oceniała go negatywnie? Aby odpowiedzieć na te pytania, trzeba przyjrzeć się

${ }^{23}$ J.S. Mill, On the Definition of Political Economy, and on the Method of Investigation Proper to It, „London and Westminster Review”, October 1836; idem, Essays on Some Unsettled Questions of Political Economy, London 1874, http://www.gutenberg.org/files/12004/ 12004-h/12004-h.htm [dostęp: 9.09.2012].

${ }^{24}$ Por. J. Stelmach, B. Brożek, W. Załuski, Dziesięć wykładów...

25 Por. A. Smith, An Inquiry into the Nature and Causes of the Wealth of Nations, London 1774, polskie wydanie: Badania nad naturą i przyczynami bogactwa narodów, Warszawa 1954; zob. także A. Cieślak, Behawioralna ekonomia finansowa, „Materiały i Studia NBP” 165/2003. 
najpierw postaci Lodzermenscha wykreowanej w łódzkich portretach nakreślonych przez Bertę Teplitzką ${ }^{26}$.

0 autorce zbioru łódzkich felietonów satyrycznych wiadomo niewiele ponad to, że była dziennikarką niemieckojęzycznego pisma „Neue Lodzer Zeitung”. Regularna częstotliwość ukazywania się jej felietonów wydaje się świadczyć o tym, że było to zajęcie stałe. Językiem niemieckim Teplitzka posługiwała się bardzo sprawnie, choć potwierdzona dokumentami informacja o jej przesiedleniu w 1939 r. do Litzmannstadt Getto pozwala przypuszczać, że autorka miała żydowskie korzenie. Nie wiadomo wszakże, czy sama uważała się za Żydówkę, za Niemkę czy też może za Polkę wyznania mojżeszowego. Zmarła prawdopodobnie 2 stycznia $1942 \mathrm{r}^{27} \mathrm{Na}$ łamach „Neue Lodzer Zeitung" regularnie publikowała krótkie felietony, w których podejmowała różnorodne tematy, kreśląc $\mathrm{w}$ nich niezwykle umiejętnie zbiorowy portret łódzkiej społeczności. Swoje szkice zatytułowała Lodzer Typen [Łódzkie typy], nadając mieszkańcom Łodzi tym samym status zbiorowości wyjątkowej, obdarzając ją niepowtarzalnymi cechami i wyróżniając ją spośród innych. Warto zatem przyjrzeć się bliżej, co według autorki charakteryzowało ten szczególny, łódzki typ człowieka.

W Łódzkich typach Teplitzkiej wielokrotnie pojawiają się postacie obdarzone cechami typowego Lodzermenscha, wywołującymi negatywne konotacje. Są wśród nich obsesyjni karierowicze, dla których najważniejszą, wręcz jedyną wartością jest pieniądz, od którego zależy dosłownie wszystko. Dlatego życiową dewizą każdego Lodzermenscha jest nieustanne zabieganie o imponujące konto:

Pieniądz nade wszystko! - pisała Teplitzka. Według zawartości portfela ocenia się również swych bliźnich: konta tych godnych uwagi i zasługujących na szacunek muszą się zaczynać od kwot siedmiocyfrowych ${ }^{28}$.

Gdy w felietonie pt. Młody człowiek ${ }^{29}$ Teplitzka pisze o braku umiłowania sztuki, a także niedostatku solidnego wykształcenia, tym samym pozbawia

${ }^{26}$ B. Teplitzka, Lodzer Typen, Lodz 1913. W 2008 r. ukazała się przygotowana przez Koło Germanistów przy Katedrze Literatury i Kultury Niemiec, Austrii i Szwajcarii UŁ we współpracy z Łaskim Domem Kultury i Klubem Europejskim w Stuttgarcie polska wersja książki pt. Berta Teplitzka. Portrety łódzkie, opracowana przez Małgorzatę Półrolę. Publikacja ta jest pierwszym polskojęzycznym wydaniem zbioru felietonów niemieckojęzycznej autorki z $1913 \mathrm{r}$. Przekład wzbogacono o kilka komentarzy na temat Lodzermenscha, m.in. autorstwa M. Półroli i P. Caracciolo. Publikacja ta ma szczególne znaczenie w kontekście badań naukowych, prowadzonych w ostatnich latach w Łodzi nie tylko w zakresie historii, ale także kultury i literatury.

${ }^{27}$ http://www.centrumdialogu.com/archiwum-lg/212-portret-lodzermensza [dostęp: 9.09.2013].

${ }^{28}$ Kupiec, [w:] Berta Teplitzka. Portrety łódzkie, oprac. M. Półrola, Łódź 2007, s. 79.

${ }^{29}$ Młody człowiek, [w:] ibidem, s. 25. 
czytelnika wszelkich iluzji. Próbuje stylizować swe postaci jednoznacznie negatywnie, podobnie jak czyniła to większość polskich publicystów i literatów. Typowy Lodzermensch, według niej, jest człowiekiem próżnym, który wiele rzeczy robi ostentacyjnie na pokaz. Tak właśnie postępuje typowy snob, opisany w szkicu pod tym samym tytułem:

Jego dewizą jest zwracać na siebie uwagę. Nie poprzestaje wyłącznie na tym, by być modnym i eleganckim, pragnie bowiem również, by inni dostatecznie doceniali i podziwiali go w całej jego okazałości. [...] Jest przy tym święcie przekonany, że wiedzie żywot prawdziwego arystokraty, w ogóle nie zdając sobie sprawy, że reprezentuje właśnie tę drugą stronę medalu - sposób bycia snoba ${ }^{30}$.

Ponadto Teplitzka odmawia łodzianom kreatywności i nowatorstwa podkreślając, że ograniczają się oni jedynie do naśladownictwa i powielania obcych wzorów. Na tę cechę zwraca szczególną uwagę w opisie łódzkiego kupca:

Łódzki kupiec jest zwierzęciem stadnym, podążającym wszędzie za „samcem przywódcą” i to zarówno w interesach jak i sprawach prywatnych. Tak więc nie brakuje dziedzin gospodarki, będących obecnie „w modzie”, nawet jeśli już od dawna istnieje nadprodukcja pewnych towarów - otóż wśród łódzkich kupców jest wielu sumiennych pracowników, ale znikoma ilość twórczych talentów ${ }^{31}$.

Także oszczędność nie jest domeną Lodzermenscha - zarówno kobiety, jak i mężczyźni są bowiem ludźmi niezwykle rozrzutnymi ${ }^{32}$, pozwalającymi sobie na częste podróże po Europie i zakupy w modnych sklepach ${ }^{33}$. Mimo tak wielu negatywnych cech Lodzermensch jest u Teplitzkiej postacią odmienną niż w publikacjach polskich autorów. Tu łodzianin wzbudza sympatię, nawet jeśli jest karierowiczem, snobem czy sprytnym kupcem, dla którego najwyższą wartość ma pieniądz. Berta Teplitzka wyposaża Lodzermenscha w konglomerat cech pozytywnych, podejmując tym samym polemikę z jego wizerunkiem utrwalonym w piśmiennictwie polskim. U niej łodzianin odznacza się nieprzeciętnym zmysłem do interesów, co pokazuje przykładowo w portrecie pt. Pośrednik mieszkaniowy ${ }^{34}$. Autorka odsłania w nim tajniki sztuki biznesu, uprawianego z wielką finezją przez Lodzermenschów: „Najpierw [pośrednik] zabiera się za właściciela domu, by go odpowiednio urobić. [...] Gdy już jedna ze stron jest odpowiednio przygotowana, udaje się do strony

\footnotetext{
30 Snob, [w:] ibidem, s. 87.

${ }^{31}$ Kupiec..., s. 79.

32 Madame na wojażach, [w:] Berta Teplitzka..., s. 123-129.

${ }^{33}$ Ibidem.

${ }^{34}$ Pośrednik mieszkaniowy, [w:] Berta Teplitzka..., s. 62-63.
} 
przeciwnej [...]."35 To właśnie Lodzermenschom nadała autorka status pionierów tego miasta pisząc, że założył je łódzki człowiek:

Łódzki kupiec stworzył Łódź, to on uczynił Łódź wielką - w sensie komercyjnym; ale jeśli Łódź także pod względem higieny, kultury, stanu sanitarnego i w wielu innych aspektach nie jest niczym innym niż właśnie tym, czym jest - wynika to z faktu, że Łodzianin nie jest i nie może być nikim innym jak tylko tym jedynym - kupcem ${ }^{36}$.

Ponadto Lodzermensche szybko adaptują się do nowego środowiska ${ }^{37}$, odznaczają się poczuciem humoru, są dowcipni, uwielbiają pławić się w luksusie, chadzają także do teatru i kina. Z powyższego wynika, że Teplitzka wyposaża łódzkiego człowieka w wiele zalet, stanowiących przeciwwagę dla rezerwuaru negatywnych przymiotów Lodzermenscha, akcentowanych w polskiej publicystyce. Dlatego felietony niemieckojęzycznej autorki należy postrzegać jako swoiste narzędzie kanalizowania społecznych frustracji, których w społeczności Łodzi w XIX i na początku XX w. nie brakowało ${ }^{38}$. Teplitzka wyraźnie dystansuje się od negatywnych skojarzeń, jakie wywoływało pojęcie Lodzermenscha na przełomie XIX i XX w., posługując się w łódzkich portretach formą literacką z pogranicza „felietonu, eseju oraz satyry”39. W swoich tekstach autorka dowcipnie, a zarazem wnikliwie opisała różne typy ludzkie, kształtujące specyficzną łódzką mentalność.

Łódzkie typy Berty Teplitzkiej wpisały się trwale w ówczesną atmosferę miasta, stając się żywym, ludzkim portretem tej unikalnej aglomeracji. Autorka szkiców okazała się niezwykle uważną obserwatorką łódzkiej rzeczywistości, której udało się w sposób lekko ironiczny i żartobliwy uchwycić klimat Łodzi przełomu wieków. Wyodrębnienie pewnych cech charakterystycznych dla łódzkiej społeczności można uznać za próbę wytworzenia więzi społecznych, skupiających jednostki danej zbiorowości jako podstawowy wyznacznik wszelkich form życia społecznego. Obrazki i szkice Teplitzkiej są zatem wyrazem trwałości spoiwa łączącego łodzian, ich wzorów zachowań, wspólnych wartości i tradycji.

Na uwagę zasługują również inne kreacje Lodzermenscha, np. stworzone przez Heinricha Zimmermanna w felietonach i krótkich opowiadaniach. Warto wspomnieć tu zwłaszcza dwa teksty, znamienne dla wizerunku Lodzermenscha, łodzianin jest bowiem dla ich autora konglomeratem cech
35 Ibidem, s. 63.
36 Kupiec..., s. 79.
37 Por. Młody człowiek..., s. 25.
${ }^{38}$ M. Półrola pisała o „oswajaniu” odrębności mentalnych, kulturowych i językowych. Por. Berta Teplitzka..., s. 285.

39 Por. M. Półrola, Lodzermensch - unikalny towar z polskiego Manchesteru?, [w:] ibidem, s. 283-287. 
wzajemnie się wykluczających. W opowiadaniu pt. Die Erschaffung des Lodzers. Eine Legende, in der Sommerfrische zu lesen [Stworzenie łodzianina. Legenda do czytania na wakacjach ${ }^{40}$ Zimmermann twierdzi, że Lodzermensch to wspólne dzieło diabła i anioła. W swoim tekście odwołuje się on do biblijnego mitu stworzenia świata. Gdy Bóg stworzył świat, szatan okazał niezadowolenie, gdyż boskie dzieło było idealne. Dlatego sam zapragnął stworzyć człowieka prawdziwego, ze wszystkimi ułomnościami, wadami i ciemnymi stronami jego natury. $\mathrm{W}$ tym celu zawarł $\mathrm{z}$ aniołem zakład, że stworzy go w krótkim czasie, a mianowicie w godzinę, z resztek, które pozostały. W tym celu wraz z innym, napotkanym po drodze małym aniołem powołuje do życia spółkę z o.o., w ramach której ma się dokonać idealne (zdaniem diabła) dzieło stworzenia. Współpraca nie układa się wprawdzie najlepiej, jednak ostatecznie anioł i diabeł osiągają kompromis:

Der Teufel gab dem Menschen den Blick eines Adlers, damit er vieles sehen kann, das Gehör eines Hasen, damit er vieles hören kann. Er legte ihm den Witz in den Mund, damit er über alles spötteln kann, gab ihm die Gleichgültigkeit mit, damit er nie aus der Fassung gerät. Er gab ihm die Nase eines Hundes, damit er gut riechen kann und träufelte ihm in den Magen einen farblosen Tropfen, damit er immer indifferent bleibt. Als der Termin der Schöpfung verstrichen war, eilte der Engel herbei und fragte den Teufel: „Wie ist es mit Deinem Menschen? Ich möchte gerne Deine Schöpfung sehen.“ Der kleine Engel wurde schamrot, der Teufel aber fasste sich und sagte: „Du musst Dich noch ein wenig gedulden, der Mensch ist gleich vollbracht.“ Der Engel aber erwiderte: „Du bist unpünktlich, wer weiß, ob auch nicht Deine Schöpfung immer unpünktlich sein wird. Ich warte noch einige Minuten, und wenn bis dahin der Mensch nicht fertig wird, dann hast Du die Wette verloren." Der Teufel willigte ein. Im sausenden Tempo ging die Vollendung des Menschen vor sich. „Wollen wir ihm auch etwas von der Kunst mitgeben?" fragte der kleine Engel. „Nicht nötig“, erwiderte der Teufel, „wir haben keine Zeit mehr, man kann auch ohne Kunst leben“. "Wollen wir ihm etwas von der Wissenschaft mitgeben?" fragte wieder der kleine Engel. „Wir haben keine Zeit“, erwiderte der Teufel, „man kann auch ohne Wissenschaft auskommen“. So wurde der Lodzer geschaffen. Im Herzen Gleichgültigkeit, auf der Zunge Spöttlein und als Fluch der „Väter“ schleppt er die Unpünktlichkeit auf dem Rücken ${ }^{41}$.

${ }^{40}$ H. Zimmermann, Die Erschaffung des Lodzers. Eine Legende, in der Sommerfrische zu lesen, Beilage zu Nr. 302 „Neue Lodzer Zeitung”, 25.06./8.07.1914, s. 2.

41 Ibidem, s. 2 [Szatan dał człowiekowi wzrok orła, aby mógł wiele zobaczyć i słuch zająca, by mógł wiele usłyszeć. W jego usta włożył dowcip, by mógł ze wszystkiego szydzić i dał mu dar obojętności, by nigdy nie tracił zimnej krwi. Podarował mu nos psa, by miał dobry węch, a do jego żołądka wsączył bezbarwną kroplę, by zawsze był obojętny. Gdy upłynął termin tworzenia, przybiegł anioł i zapytał diabła: „No więc jakże z tym twoim człowiekiem? Chciałbym obejrzeć twoje dzieło”. Aniołek zarumienił się ze wstydu, ale szatan nie stracił rezonu i odparł: „Musisz jeszcze trochę poczekać, człowiek zaraz będzie gotowy”. Anioł odpowiedział jednak: „Jesteś niepunktualny i kto wie, czy twoje stworzenie też nie będzie zawsze niepunktualne. Poczekam jeszcze kilka minut, ale jeśli człowiek nadal nie będzie gotów, przegrałeś zakład". Szatan przystał na ten warunek i w największym pośpiechu kończył dzieło tworzenia człowieka. „Damy mu też coś ze sztuki?”, zapytał aniołek. „Niekoniecznie”, odparł diabeł, „nie mamy już czasu, a bez sztuki też da się żyć.” „Damy mu coś z nauki?”, zapytał znów aniołek. „Nie 
Ta zabawna historia pokazuje z jednej strony wyjątkowość Lodzermenscha, gdyż jego postać nie mieści się w żadnej gotowej formule, będąc zlepkiem skrajnych cech, które w połączeniu dały człowieka szczególnego, przypisanego do tego jednego miejsca: do miasta Łodzi. Z drugiej strony zwraca uwagę dystans, jaki zachowuje autor wobec tej postaci. Podobnie jak Teplitzka traktuje Lodzermenscha w kategorii humorystycznej, przydatnej do kanalizowania napięć społecznych.

Lodzermensch, według Zimmermanna, to także pragmatyczny realista, dla którego najważniejsze jest działanie. Autor podkreśla jego nierozerwalną więź z łódzką ulicą będącą synonimem miasta. Miasto, a zwłaszcza ulica, to miejsce, bez którego Lodzermensch nie może się obejść i które stanowi podstawę jego egzystencji. W felietonie Der Lodzer und die Strasse [Łodzianin i ulica] Zimmermann pisze:

Der Lodzer und die Strasse sind die intimsten Freunde; sie gehren zusammen und sind untrennbar wie ein Liebespaar im ersten Jahre ihres Glücks. [...] Was ist der Makler, der Händler, der Lodzer Mensch ohne die Strasse? Ein Schiff ohne Steuer, ein Haus ohne Dach ${ }^{42}$.

\subsection{Lodzermensch w dowcipach Reinholda Piela}

Łódzki kupiec ma w swoim życiu tylko dwa cele: zarabiać pieniądze i opowiadać dowcipy. Jedno dla ciała, drugie zaś dla ducha. Pierwsza myśl, która przychodzi mu do głowy w przypadku nowej wiadomości, z jaką się styka, to: „Ile na tym zarobię?” Zaś druga, być może nieświadoma, to: „Czy da się z tego zrobić jakiś dobry dowcip?” Z natury rzeczy wynika, że wszystkie lokalne dowcipy łódzkich kupców mają charakter biznesowy, ponieważ rodzą się z bankructw, protestów, prolongat, przędzy wełnianej i bawełnianej, sztucznej wełny itp. ${ }^{43}$

Tak pisała przywołana wcześniej Berta Teplitzka, autorka zbioru felietonów Lodzer Typen, o stosunku łodzian do dowcipów. Również baczny obserwator Łodzi, Stefan Gorski, podkreślał ich popularność w tym mieście:

Żartami w ścisłem znaczeniu łodzianie w ogóle delektują się i bez „witzów” nie może obejść się żadna lżejsza pogawędka towarzyska. Niemieckie „Witzblatty” znajdują wielu

mamy czasu”, odpowiedział diabeł, „bez nauki też można się obejść.” I tak stworzono łodzianina. W sercu obojętność, na języku drwina, a jako przekleństwo przodków dźwiga na swych ramionach brzemię niepunktualności. Tłumaczenie M.K.].

${ }^{42}$ Der Lodzer und die Strasse, „Neue Lodzer Zeitung”, 26.09./9.10.1914, s. 3 [Łodzianin i ulica to najbardziej intymni przyjaciele; należą do siebie i są nierozłączni jak para zakochanych w pierwszym roku wspólnego szczęścia. [...] Czym jest makler, handlarz, Lodzermensch bez ulicy? To statek bez steru i dom bez dachu. Tłumaczenie M.K.].

${ }^{43}$ Kupiec..., s. 79. 
stałych odbiorców, a pisma humorystyczne w cukierniach po kilku dniach pozostawiają po sobie tylko strzępy. „Witz” znalazł królestwo w Łodzi. Dobrym „witzem” można zawsze wprowadzić w dobry humor łodzianina ${ }^{44}$.

Dowcipy, inaczej kawały lub z niemieckiego „wice”, cieszyły się w Łodzi ogromną popularnością i stały się na przełomie wieków nieodłącznym elementem miejskiej codzienności. Drukowano je w większości lokalnych gazet zarówno polskich, jak i niemieckich. Dla zazwyczaj krótkich, kilkuzdaniowych dowcipów rezerwowano stałe rubryki, zamieszczając je najczęściej na ostatniej stronie obok szarad i krzyżówek ${ }^{45}$.

Przed dokonaniem analizy łódzkich dowcipów i wyłaniającego się z nich obrazu Lodzermenscha, warto przytoczyć zwięzłą charakterystykę dowcipu jako formy tekstowej. Według Słownika pojęć i tekstów kultury, dowcip to „jeden z tekstów kultury popularnej, krótki tekst narracyjny z zaskakującą puentą, który ma na celu rozbawienie odbiorcy. Ich rolą jest łamanie na ogół tabu obyczajowego, środowiskowego, politycznego. Przekazywane są ustnie - opowiadane podczas spotkań towarzyskich, występów estradowych (gatunek twórczości estradowej); bywają też publikowane w formie książkowej [...]. Istnieją grupy tematyczne żartów, np. [...] o narodach"46.

Dowcip jest więc ze swej natury zwięzłym tekstem o charakterze komicznym, zakończonym pointą ${ }^{47}$ i służącym rozbawieniu odbiorcy; cechy te przesądzają o jego kategoryzacji i pozwalają odróżnić go od innych form językowych. Definicja, przytoczona na potrzeby niniejszej pracy, wydaje się wystarczająca, natomiast o wiele bardziej istotne są kwestie związane z informacjami, jakich dostarcza czytelnikowi dowcip jako forma językowa, gdyż zawiera on $\mathrm{w}$ sobie znamienny sposób fragmentarycznego postrzegania świata. Odwołując się do rozważań Jerzego Bartmińskiego, należy podkreślić, że językowy obraz świata to zawarta w języku interpretacja rzeczywistości, którą można ująć w postaci zespołu sądów o świecie ${ }^{48}$. Jak twierdzi Anna Wierzbicka, „każdy kawał zawiera odrobinę zbiorowej mądrości, doświadczenia i sposobów myślenia" ${ }^{49}$. W tym kontekście dowcip jest symptomem określonego stosunku do wycinka rzeczywistości. Jest również przykładem tekstu, wykorzystującego cały arsenał istniejących stereotypów, które

${ }^{44}$ S. Gorski, Łódź spółczesna ..., s. 42.

45 Dla przykładu w dodatku „Lodzer Illustriertes Sonntagblatt. Beilage zur Neuen Lodzer Zeitung" drukowano rubrykę Humor vom Tage.

46 Słownik pojęć i tekstów kultury, red. E. Szczęsna, Warszawa 2002, s. 309-310.

47 Por. D. Buttler, Polski dowcip językowy, Warszawa 1968.

48 J. Bartmiński, Punkt widzenia, perspektywa, językowy obraz świata, [w:] Językowy obraz świata, red. J. Bartmiński, Lublin 1990, s. 110.

${ }^{49}$ A. Wierzbicka, Akty i gatunki mowy w rożnych językach i kulturach, [w:] eadem, Język - umysł - kultura, red. J. Bartmiński, Warszawa 1999. 
- z uwagi na swój schematyczny charakter - utrwala w społecznej świadomości. Tak jak w przypadku innych tekstów o charakterze stereotypowym, dowcip przejaskrawia jedne cechy, osłabiając inne. Istotny jest również fakt, w jakiej sytuacji społecznej rodzi się i funkcjonuje, istnieją bowiem tematy, które niezależnie od uwarunkowań społecznych pozostają niemal zawsze aktualne. Często jednak mamy do czynienia z żartami językowymi, mocno osadzonymi w konkretnej sytuacji społecznej. Wśród dowcipów powstałych w Łodzi na przełomie XIX i XX w. największą grupę stanowią te, przedstawiające wielokulturowy charakter miasta. $\mathrm{W}$ tym przypadku kolejną, łatwo zauważalną zależnością jest fakt, że liczba powstających i będących w obiegu dowcipów na temat Łodzi i jej wielokulturowego charakteru okazuje się wprost proporcjonalna do poziomu frustracji społeczeństwa. Komizm, którym posługuje się dowcip, pozwala bowiem zdystansować się od licznych konfliktów i napięć wynikających z przemieszania kultur. Śmiech, jako wyraz dystansu wobec odrębnych kultur, religii, mentalności i języków, uchodził za jedną ze strategii przetrwania w wielonarodowościowym tyglu. Niewątpliwie łódzkie dowcipy pełniły funkcję katarktyczną - służyły odreagowaniu nadmiernego pobudzenia, a także wyzwalały reakcje rozładowujące lęk i wrogośćs0. Pomagały również oswoić i zneutralizować wiele sytuacji tragicznych ${ }^{51}$, pełniąc funkcję swego rodzaju „wentyla bezpieczeństwa” ${ }^{52}$.

W przypadku Łodzi warto ponadto wspomnieć o jeszcze innej funkcji tej formy wypowiedzi językowej, na którą w swych rozważaniach o istocie dowcipu zwróciła uwagę Aleksandra Tokarz. „Dowcip” - pisała badaczka - „można uznać za przejaw twórczości w jej wydaniu zalążkowym, recepcję dowcipów za ćwiczenia właściwości, odpowiedzialnych za myślenie twór-

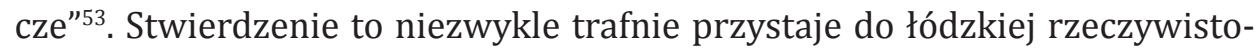
ści. W chwili gdy w Łodzi masowo powstawały dowcipy, a więc do wybuchu I wojny światowej, twórczość literacka znajdowała się we wstępnej fazie rozwoju. Jak wynika z dotychczasowych ustaleń, nie pojawiły się w tym czasie żadne poważniejsze dzieła niemieckojęzyczne, w przeciwieństwie do literatury polskiej tych lat, gdy powstały utwory dla Łodzi najważniejsze, takie jak np. Ziemia obiecana Władysława Stanisława Reymonta, Bawełna Wincentego

50 Por. A. Tokarz, Poczucie humoru a aktywność twórcza człowieka, „Psychologia Wychowawcza" 4/1991, s. 305.

${ }^{51} \mathrm{~W}$ opracowaniu Łukasiewicza znajduje się fragment poświęcony społecznej psychologii dowcipu politycznego. Wymienione przez autora funkcje społeczne tego typu żartów to: (1) wyrażanie przekonań, (2) „wentyl bezpieczeństwa”, (3) bierny opór, (4) kontrola społeczna (karząco-korygująca), (5) tworzenie wspólnoty. Por. P. Łukasiewicz, Porzq̨dek społeczny w potocznych wyobrażeniach i przekazach (spojrzenie na społeczeństwo polskie), Warszawa 1991, s. $123-130$.

52 Por. M. Półrola, Lodzermensch..., s. 285.

53 A. Tokarz, Poczucie humoru..., s. 309. 
Kosiakiewicza czy Lokaut Kazimierza Laskowskiego. Wszystkie one w mniejszym (lub jak w przypadku Ziemi obiecanej) w większym stopniu portretowały mentalność Lodzermenscha i kreśliły obraz wielokulturowego miasta, gdy tymczasem twórczość niemieckojęzyczna koncentrowała się na formach literackich niewymagających większego zaangażowania intelektualnego. Należały do nich głównie wiersze okazjonalne, proste opowiadania, nowele, szkice, obrazki rodzajowe, felietony i dramaty, podejmujące wątek skandalu obyczajowego. Dowcipy łódzkich autorów, podobnie jak inne teksty, stanowią ważny element tworzący literacką rzeczywistość tego miasta, eksplikują bowiem tematycznie zagadnienia łódzkiej mentalności, o której niewiele wiadomo z innych utworów powstających w tym czasie w Łodzi. To właśnie w dowcipach najdobitniej przejaskrawiano obraz Lodzermenscha, jego wady i zalety, ale też z dowcipów można odczytać nastawienie łódzkiej społeczności do tego typu człowieka.

W 1913 r. Reinhold Piel ${ }^{54}$ opublikował jako Wilfried Spectator niewielki tom z dowcipami, krążącymi w XIX w. w okolicach Łodzi i Pabianic, który zatytułował Ne Mütze voll Witze aus Lodz und Pabianice ${ }^{55}$ [Czapka pełna wiców z Łodzi i Pabianic].

Piela interesowała mentalność Lodzermenscha, fenomenu wywołującego w Łodzi wiele emocji, stąd tak uzasadniał potrzebę wydania tego zbioru: „Wenn es euch gelingt, ihr losen Blätter die Menschen zu einen; wenn es euch gelingt, auf Charaktereigentümlichkeiten hinzuweisen, die einer Einigung im Wege stehen [...] dann ist eure Aufgabe erfüllt! ${ }^{56}$. Autor tomu uznał zatem mentalność Lodzermenscha za zjawisko, które może okazać się przeszkodą na drodze do wzajemnego porozumienia między mieszkańcami miasta. Już we wstępnie wskazał na fakt, że jego obserwacje są negatywnie nacechowanymi kliszami, które zapewne wywołają sprzeciw wielu czytelników: „[...] die Juden werden mich als Antisemiten schelten, die Polen als Hakatisten verurteilen und die Deutschen als Tadler und unliebsamen Kritikaster..." ${ }^{57}$.

Autor zgromadził w swoim tomie 68 różnej objętości dowcipów, opatrzonych każdorazowo trafnym tytułem. Niektóre spośród zebranych anegdot oddają także miejscowy język, stylizowany na tzw. Lodzerdeutsch, czyli wykształcony tu wariant niemczyzny, jakim na przełomie wieków posługiwa-

${ }^{54}$ Zob. aneks: Łódzkie sylwetki.

55 R. Piel, Ne Mütze voll Witze aus Lodz und Pabianice, Lodz 1913, http://www.difmoe. eu/?content=Monographien [dostęp: 9.09.2013].

56 Ibidem, s. 7 [Jeśli wam, kartom tej książki, uda się zjednoczyć ludzi, jeśli uda się wam wskazać na te właściwości charakterów, które są przeszkodą na drodze do pojednania, [...] to spełniłyście swe zadanie! Tłumaczenie M. Półrola, Cały ten interes, [w:] Tygiel Kultury. Wrastanie, Łódź 2008, s. 61-71].

${ }^{57}$ R. Piel, Ne Mütze voll Witze..., s. 7 [Żydzi nazwą mnie antysemitą, Polacy hakatystą, a Niemcy powiedzą, że jestem [zbyt] surowym krytykiem. Tłumaczenie M.P.]. 
ło się wielu łodzian ${ }^{58}$. Bohaterami tekstów są Polacy, Niemcy i Żydzi z całym, właściwym im rezerwuarem typowych cech. Czytelnik nie wie dokładnie, czy dany dowcip lub anegdota traktuje o przedstawicielach konkretnej narodowości. Wskazówką są jedynie cechy języka - w przypadku Żydów autor posługuje się typowym „żydłaczeniem” oraz charakterystycznymi imionami i nazwiskami, natomiast w przypadku Niemców łódzką odmianą niemczyzny (tzw. Lodzerdeutsch). Stąd można wnioskować, że bohaterem swojego zbioru jego autor pragnął uczynić po prostu Lodzermenscha ze wszystkimi jego wadami i zaletami.

Lodzermenschów przedstawiono tu jako ludzi dbających ponad wszystko o swój własny interes. Oto jeden z dowcipów:

Mojsze Geschwindmacher wydaje za mąż córkę, więc zamierza splajtować. Szlojme Feingeruch szybko wyczuł pismo nosem i kombinuje, jakby tu uratować pożyczone kiedyś Geschwindmacherowi kilkaset rubli. Udaje się więc na ślub jego córki, a kiedy uroczystość dobiega końca, w obecności wszystkich gości staje przed Geschwindmacherem, mówiąc bardzo głośno i wyraźnie: „Mojsze, dla młodych niech będzie mazeł tow, ja będę tobie życzył, żebyś ty oglądał swoje wnuki i prawnuki, ale pod warunkiem, że ty mnie najpierw oddasz moje pieniądze!"59

W dowcipie zatytułowanym Anspruchsvolle Chefs [Wymagający szefowie] autor zwraca uwagę na brak wykształcenia oraz przemożny pęd Lodzermenscha do kariery:

Mojsze Schwarzer: „Może pan mógłbyś dać mi posadę dyrektora w pańskiej tkalni?”

Szef: „A pan dobrze znasz się na tej branży, żebyś pan mógł być dyrektorem mojej tkalni?”

Schwarzer: „Co się znaczy się zna? Kiedy ja już będę ten dyrektor, to przecież wystarczy, że się znam na tkactwie, po co ja miałbym się jeszcze znać na branży?"60

Chyba najbardziej sugestywny obraz Lodzermenscha zaprezentował Reinhold Piel w anegdocie pt. In hoc signo vinces, w której jeden z praktykantów pewnej firmy poucza starszego kolegę-urzędnika:

${ }^{58}$ Zob.: O. Kossmann, Wie sprechen wir?, „Freie Presse”, 19.02.1928, s. 8; idem, Lodzer Deutsch, „Freie Presse”, 27.06.1928, s. 9; idem, Die Sprache des Lodzer Deutschen, [w:] Das Lodzer Deutsche Gymnasium. Im Spannungsfeld zwischen Schicksal und Erbe 1906-1981, hrsg. v. P.E. Nasarski, Berlin-Bonn 1981, s. 34-40; R. Sadziński, Osadnictwo niemieckie w regionie łódzkim w świetle faktów językowych, [w:] Niemcy w dziejach Łodzi, red. K.A. Kuczyński, B. Ratecka, Łódź 2001, s. 258-279; J. Riecke, Deutsch in Lodz und Lodzer Deutsch. Grundzüge einer Geschichte der deutschen Sprache in Lodz im 19. und 20. Jahrhundert, [w:] Deutsch in multilingualen Stadtzentren Mittel- und Osteuropas, hrsg. v. M. Nekula, V. Bauer, A. Greule, Wien 2008, s. 163-182; E. Effenberger, Das Lodzerdeutsch. Die Umgangssprache der Deutschen im Lodzer Raum. Historie und Wörtersammlung, Mönchengladbachn 2009/2010; R. Sadziński, W. Sadziński, Die Sprache der Lodzer Deutschen, [w:] Studien und Forschung zur Deutschland- und Österreichkunde in Polen, Warszawa 2011, s. 329-339.

${ }_{59}$ R. Piel, Ne Mütze voll Witze..., s. 15. Tłum. za: M. Półrola, Cały ten..., s. 61-71.

${ }^{60}$ Anspruchsvolle Chefs, [w:] R. Piel, Ne Mütze voll Witze..., s. 28. Tłum. za: M. Półrola, Cały ten..., s. 61-71. 
Panie Hochberg - [...] ja myślę, że z wekslami jest jak z ludźmi: najpierw trzeba zapytać, kim taki człowiek jest, a potem, jak mu się powodzi. Najpierw więc trzeba pytać, ile ma lat i skąd pochodzi, a w przypadku weksli jest to data i miejsce ich wystawienia. - Potem pytamy, jak się nazywają ojciec i matka; w przypadku weksli wystarczy znać imię ojca, a to jest wystawca. - Wśród ludzi są tacy, którzy zawsze muszą pilnować innych: to są plotkarki. W przypadku weksli robi to ten, któremu należą się pieniądze, tego więc też trzeba znać. - Następnie człowiek idzie do szkoły, a jako że jest wtedy przeważnie jeszcze bardzo młody i miękki jak wosk, to każdy, u którego się uczy, może wycisnąć na nim swój stempel; w przypadku weksli robią to żyranci. - No, a potem człowiek kończy szkołę i wyrusza w świat i taki weksel pojawia się w naszym interesie. - Człowiek zawsze bardzo dokładnie wie, kiedy już się wszystkiego nauczył, a w przypadku weksli też należy to wiedzieć. - Ale jest jeszcze jedna rzecz: u ludzi nie wiadomo, ile ktoś jest wart [...], ale w przypadku weksli ich wartość musi być zapisana czarno na białym. W przypadku weksli trzeba też wiedzieć, jak długo będą w obiegu i gdzie trzeba je wykupić, ale człowiek nie wie, jak długo będzie chodził po tym świecie i gdzie zakończy swoje życie. No, ale musi też być jakaś różnica, bo inaczej wszyscy ludzie byliby wekslami, a wszystkie weksle ludźmi. Niekiedy u ludzi zdarza się, że umierają śmiercią obywatelską - „Kiedy ich ześlą na Syberię", mówi Benedek, ale ja myślę, że taki weksel też może umrzeć śmiercią obywatelską, gdy tylko opuści naszą firmę; a że o ludziach umierających śmiercią obywatelską trzeba wiedzieć, od jak dawna nie żyją, to i w przypadku weksli też trzeba o tym pamiętać"61.

Świat, w którym żyją Lodzermensche, jest olbrzymim tyglem, gdzie nieustannie ścierają się ze sobą antagonistyczne siły. Najwyraźniej manifestuje się to zjawisko w fenomenie wielokulturowości, odsłaniającej głębszy sens i ujawniającej destrukcyjną moc chaosu, gdyż w konfrontacji kultur często dochodzi do spalania energii życiowej. Wielokulturowość, przedstawiona w dowcipach Piela, jest przejawem chaosu świata, odkrywającego swą naturę w wielu sytuacjach komunikacyjnych, którym towarzyszy mnogość dźwięków różnych języków, wymieszanych do tego stopnia, że człowiek nie może się w nich odnaleźć. Nie przypadkiem pojawiają się w łódzkich dowcipach takie określenia, jak wieża Babel, pozwalające zrozumieć i opisać procesy zachodzące w tym czasie w Łodzi. Jako przykład niech posłuży dowcip Einer, der beim Turmbau zu Babel mitgeholfen [0 jednym takim, co pomagał budować wieżę Babel]:

Wściekły szef: „Sam bies by się w tym nie połapał: czytam ten list po żydowsku, a brzmi to tak jakoś po rusku; przymierzam się czytać po rusku, to wydaje mi się, że jest po niemiecku, no i wreszcie, kiedy chcę go czytać po niemiecku, to mam wrażenie, że napisał go jakiś Litwak!”62

${ }^{61}$ In hoc signo vinces, [w:] R. Piel, Ne Mütze voll Witze..., s. 22-26. Tłum. za: M. Półrola, Cały ten..., s. 61-71.

${ }^{62}$ Einer, der beim Turmbau zu Babel mitgeholfen, [w:] R. Piel, Eine Mütze voll Witze..., s. 30. Tłum. za: M. Półrola, Cały ten..., s. 61-71. 
Eksponowane w dowcipach antagonizmy kulturowe zdają się współtworzyć wizję świata jako chaosu, poddanego rygorom nieustannej konfrontacji i walki. Spotkanie kultur dokonujące się w przestrzeni tych tekstów zdradza cechy takiego starcia żywiołów, w jakim manifestuje się rasowa obcość, a bardzo często także frustracja. Oto inny przykład, w którym autor wskazuje na problem komunikacji międzyludzkiej - dowcip pt. Lodz auf dem Kopfe [W Łodzi wszystko postawione jest na głowie]:

Iech versteih nischt, wues tut sich mit die Kommissioneere vin Lodz: as iech will koifn Hausen (d.i. Hosen), führen se mir aran zu a Mäkler, wues verkoift Haaser (d.i. Häuser); as ich will koifn a Hos (d.i. Haus), führn se mir aran zu a Schnaader mit Hausen, und as iech broch zi gein zu B. Grohmann, dem Jüd, führn se mir aran zu L. Grohmann, dem Christ. Iech versteih nischt wues tut sich mit die Kommissioneere vin Lodz! ${ }^{13}$

Problemem miasta $w$ fazie intensywnego uprzemysłowienia była również pauperyzacja w pierwszych latach XX w. Sytuacja fabrykantów, którzy początkowo błyskawicznie gromadzili majątki, znacznie pogorszyła się tuż przed wybuchem I wojny światowej. W Łodzi można było rzeczywiście bardzo szybko zrobić karierę, ale równie szybko przegrać swą szansę. Na ten problem także zwrócił uwagę Reinhold Piel w dowcipie pt. Die Wiederbringung aller Dinge [Wszystko wraca do punktu wyjścia]:

Kiedy Jankiel Pomeranc był w Łodzi w 1909 roku, niejeden szewc czy krawiec, rzeźnik albo piekarz, słowem każdy pies Burek, zamieniał się w domorosłego fabrykanta. Ponownie zjawił się w Łodzi w 1911 roku, kiedy na rynku wyrobów manufakturowych zapanował kompletny spadek kursów i wyprzedawano za bezcen jedną fabrykę po drugiej. Zdumiony stwierdza: „Toż to prawdziwy cud od Boga! Dwa lata temu każdy szmaciarz zamieniał się w fabrykanta, a dziś z każdego fabrykanta robi się szmaciarz!”64.

Reinhold Piel oddał w swoim zbiorze koloryt trzech kultur spotykających się w łonie łódzkiej społeczności: polskiej, niemieckiej i żydowskiej, których wspólnym idiomem był Lodzermensch. Przedstawił wymieszanie kultur, a także żywioł wielokulturowości i kulturowej różnorodności jako wartości samej w sobie. Wizerunek Lodzermenscha opiera się tu na stereotypowych wyobrażeniach tej postaci. Piel wskazuje na takie jego cechy, jak chęć zrobienia szybkiej kariery, dążenie do odniesienia sukcesu finansowego za wszelką

${ }^{63}$ Lodz auf dem Kopfe, [w:] R. Piel, Ne Mütze voll Witze..., s. 9 [Nie rozumiem, co się dzieje z ludźmi w Łodzi: kiedy chcę kupić spodnie (w Lodzerdeutsch Hausen, a po niemiecku Hosen), prowadzą mnie do maklera, który sprzedaje domy (po niemiecku Häuser); kiedy chcę kupić dom (w Lodzerdeutsch Hos, a po niemiecku Haus), prowadzą mnie do krawca, a kiedy potrzebuję pójść do B. Grohmanna, Żyda, prowadzą mnie do L. Grohmanna, katolika. Nie rozumiem, co się dzieje z ludźmi w Łodzi. Tłumaczenie M.P.].

${ }^{64}$ Die Wiederbringung aller Dinge, [w:] R. Piel, Ne Mütze voll Witze..., s. 31. Tłum. za: M. Półrola, Cały ten ..., s. 61-71. 
cenę i zmysł do interesów. Podobnie jak w przypadku typów łódzkich, sportretowanych przez Bertę Teplitzką, Lodzermensch Reinholda Piela nie budzi u czytelnika skrajnie negatywnych emocji. Autor wskazuje bowiem wyraźnie na okoliczność, że wszelkie emocje są przejawem frustracji łódzkiej społeczności, którą za wszelką cenę należy neutralizować za pomocą śmiechu, poczucia humoru i dowcipu sytuacyjnego.

\subsection{Lodzermensch - zmiana paradygmatu?}

Wśród kreacji Lodzermenscha, stworzonych przez środowisko łódzkich pisarzy, na uwagę zasługują te pozostawione przez Bruno Raymonda ${ }^{65}$, jednego z niewielu autorów niemieckiego pochodzenia, tworzących w języku polskim i niemieckim. Wśród nich są m.in. takie powieści, jak: $W$ poszukiwaniu ojczyzny (1938) ${ }^{66}$, Miłość, student a wojna (1933) ${ }^{67}$, oraz dramaty, jak Isabella. Motive aus der Komödie der Ehe (1928) ${ }^{68}$ czy Ucieczka przez błękit nieba $(1935)^{69}$. Akcja wszystkich utworów rozgrywa się w Łodzi w okresie międzywojennym, w środowisku fabrykanckim. Obraz Lodzermenschów, nakreślony tu przez autora, zasługuje na dokładniejsze omówienie, ponieważ dotyka ówczesnej sytuacji gospodarczej i stosunków narodowościowych w tym mieście.

Zanim przybliżone zostaną czytelnikowi portrety Lodzermenschów w utworach Raymonda, kilka słów o sytuacji gospodarczej i stosunkach narodowościowych w Łodzi w latach międzywojnia ${ }^{70}$.

Po zakończeniu I wojny światowej państwo polskie stanęło przed niezwykle trudnym zadaniem odbudowy życia politycznego i społecznego, przede wszystkim zaś zrujnowanej gospodarki. Niemiecki okupant w latach wojny wyjątkowo bezwzględnie obchodził się z polskim przemysłem, zmierzając do celowego zniszczenia potencjału produkcyjnego. Co więcej-odbudowa państwa przebiegała w niestabilnej sytuacji politycznej i ekonomicznej na świecie. Dlatego proces ten przekładał się na brak stabilizacji polskiej gospodarki ${ }^{71}$. Lata poprzedzające wybuch II wojny światowej charakteryzo-

${ }^{65}$ Zob. aneks: Łódzkie sylwetki.

${ }^{66}$ B. Raymond, W poszukiwaniu ojczyzny, Łódź 1938.

${ }^{67}$ B. Raymond, Miłość, student a wojna, Łódź 1933.

${ }_{68}$ B. Raymond, Isabella. Motive aus der Komödie der Ehe, Lodz 1928.

${ }^{69}$ B. Raymond, Ucieczka przez błękit nieba. Dzieje miłości w trzech aktach z epilogiem bez słów, Łódź 1935.

${ }^{70}$ Por. K.P. Woźniak, Wystawieni na ciężkq próbę. Antagonizmy i zbliżenia, „Kronika Miasta Łodzi" 3/2005, s. 11-19.

71 Por. A. Jewtuchowicz, A. Suliborski, Struktura gospodarcza Łodzi w latach 1918-1989, s. 297. 
wały się częstymi zmianami koniunktury, niepozostającymi bez wpływu na rozwój produkcji przemysłowej w Łodzi. Łódzki przemysł w okresie I wojny światowej został w znaczny sposób osłabiony, jednak mimo trudnej sytuacji finansowej i zniszczonej infrastruktury łódzcy przedsiębiorcy niezwłocznie przystąpili do odrabiania strat. Łódź szybko stała się wiodącym ośrodkiem decyzyjnym dla innych przedsiębiorstw na terenach polskich. Tu miały siedziby dwa największe kartele przemysłowe i przedstawicielstwa firm światowych zajmujących się wyrobem wszystkiego, co było niezbędne dla produkcji włókienniczej ${ }^{72}$. Pierwsze zakłady włókiennicze ruszyły w 1919 r., musiały jednak walczyć z przeciwnościami i inną specyfiką rynku niż przed wybuchem wojny. Wobec braku rynków zbytu na Wschodzie (w Rosji) łódzcy przedsiębiorcy musieli zadowolić się rynkiem wewnętrznym, a także o wiele bardziej wymagającymi rynkami krajów bałkańskich i nadbałtyckich (Estonia, Łotwa, Litwa). Pociągnęło to za sobą wiele działań mających na celu modernizację i reorganizację pracy. Sytuacja łódzkiego przemysłu miała ogromny wpływ na kondycję i warunki życiowe mieszkańców miasta, z których większość była zatrudniona w przemyśle ${ }^{73}$. Na początku lat 20. łódzka gospodarka zanotowała nieznaczny wzrost; powstały nowe miejsca pracy oraz nowe fabryki, rozwinął się przemysł maszynowy, chemiczny, drzewny, metalurgiczny, poligraficzny, spożywczy i papierniczy. Niestety, okres koniunktury nie trwał długo. Już w 1924 r. zmniejszył się popyt na wyroby przemysłowe, a dodatkowo do znacznej destabilizacji przyczyniło się zjawisko hiperinflacji. Łódzka gospodarka ustabilizowała się ponownie w 1926 r., kiedy zmienił się układ sił na rynkach międzynarodowych. Stabilizacja i wzrost produkcji przemysłowej trwał do 1929 r., a więc kolejnego (tym razem wielkiego) światowego kryzysu, którego symbolem stał się krach na giełdzie w Nowym Jorku. Łódzki przemysł włókienniczy i tym razem negatywnie zareagował na zapaść na rynkach międzynarodowych. Brak zamówień na towary, zwolnienia robotników i niewypłacalność miejscowych kupców spowodowały ograniczenia w działalności zakładów lub ich całkowite zamykanie. Zamykano nie tylko fabryki włókiennicze; kryzys dotknął również inne branże: metalową, gumową i budowlaną ${ }^{74}$.

Niekorzystna sytuacja gospodarcza spowodowała zmianę polityki państwa, które w coraz większym stopniu decydowało się na interwencję w sferę gospodarczą. Skutkiem było wykupywanie przez państwo zadłużonych spółek, tworzenie nowych przedsiębiorstw i zajmowanie miejsc wycofujących się firm zagranicznych. W okresie międzywojennym państwo miało ogromny wpływ na sytuację wielu zakładów przemysłowych. W tym celu wspierało

\footnotetext{
72 Ibidem, s. 298.

73 Ibidem, s. 300.

${ }^{74}$ Ibidem, s. 304.
} 
również tworzenie karteli i stowarzyszeń regulujących ceny, warunki płatności i limitujących sprzedaż towarów w kraju. Znaczny ich wzrost nastąpił w latach 30. XX w. Dla Łodzi tworzenie monopoli było nowym, jednak w niepewnej sytuacji gospodarczej niezbędnym zabiegiem ratującym wiele przedsiębiorstw przed bankructwem. W drugiej połowie lat 20. XX w. utworzono dwa kartele obejmujące najważniejsze dla miasta działy produkcji: wełny i bawełny. W 1926 r. powstało w Łodzi pierwsze tego typu porozumienie kartelowe, zrzeszające 12 przędzalń pod nazwą Konwencja Przędzalń Wełny Czesankowej w Państwie Polskim. Trzy lata później powołano do życia kolejne Zrzeszenie Producentów Przędzy Bawełnianej w Polsce, zrzeszające 40 przedsiębiorstw. Kartele miały dbać o interesy firm zrzeszonych, regulować produkcję i wpływać na wysokość cen. W rzeczywistości jednak pogłębiły kryzys, proponując zbyt wysokie ceny, których odbiorcy nie byli w stanie zapłacić, zatem nierentowne zakłady i tak zamykano ${ }^{75}$.

Łódzka gospodarka walczyła z oznakami kryzysu nie tylko tworząc kartele. Na przełomie lat 20. i 30. XX w. rozpoczęto proces decentralizacji i specjalizacji produkcji, co wydawało się zabiegiem bardziej efektywnym w czasach kryzysu. Mniejsze fabryki, specjalizujące się w określonym typie produkcji o elastycznym systemie organizacji pracy, potrafiły szybko reagować na zmianę koniunktury. W rezultacie w tym okresie rosła w Łodzi liczba małych i średnich przedsiębiorstw. Ta dychotomia w życiu gospodarczym miasta (z jednej strony wielkie kartele, $\mathrm{z}$ drugiej małe zakłady szybko reagujące na zmiany koniunkturalne) powodowała ostrą walkę konkurencyjną. Wielcy fabrykanci występowali przeciw małym przedsiębiorcom, żądając likwidacji ich fabryk. W konsekwencji tej wojny znikło z Łodzi wiele przedsiębiorstw - zarówno dużych, zrzeszonych w kartelach, jak i małych fabryk. Po okresie kryzysu nastąpiła faza wzrostu produkcji, ożywienie odnotowano również w rzemiośle i handlu. Jednak łódzki przemysł nie odbudował kapitału utraconego w latach I wojny. Przedsiębiorstwa włókiennicze wprawdzie się rozwijały, ale w okresie międzywojennym na znaczeniu zyskiwały coraz bardziej inne branże przemysłu, takie jak odzieżowa, elektromaszynowa i drzewna ${ }^{76}$.

W tej trudnej sytuacji gospodarczej zmienił się również paradygmat Lodzermenscha. Łódzcy fabrykanci musieli walczyć przez niemal cały okres międzywojenny ze zmieniającą się koniunkturą. Doprowadziło to do zmiany postawy wobec świata, którą starał się uchwycić w swoich tekstach Bruno Raymond. Autor ten zasługuje na szczególną uwagę, gdyż jako jeden z niewielu posiada w swym dorobku utwory dramatyczne i powieściowe. Pisał ponadto zarówno w języku polskim, jak i niemieckim. Był autorem żywo interesującym się współczesnymi mu czasami, a tematem swych utworów

\footnotetext{
${ }^{75}$ Ibidem, s. 305-306.

${ }^{76}$ Ibidem, s. 309.
} 
uczynił środowisko łódzkich fabrykantów z początku XX w. Oczywiście, jego powieści nie są literaturą o Łodzi na miarę Ziemi obiecanej Reymonta, a ich autor nie traktuje realiów miasta wielopłaszczyznowo. Łódź (bądź też - jak wyraża się Raymond - jakieś miasto przemysłowe w centrum Polski) jest w wielu miejscach zaledwie tłem do rozważań na różnorakie tematy, począwszy od kapitalizmu poprzez stosunki między przemysłowcami i robotnikami, wymianę pokoleniową i obyczajowość, a na wychowaniu, kwestiach filozoficznych i trywialnym temacie miłości kończąc. Pisarz krytycznie postrzegał również zagadnienie moralności ówczesnego społeczeństwa. Znamiennym elementem jego utworów są postaci kobiece, nadające treści utworów specyficzny charakter. Są one z jednej strony przedstawione jako matki, córki, siostry, narzeczone, żony i kochanki, z drugiej zaś - w przestrzeni publicznej - przede wszystkim jako kobiety w świecie zdominowanym przez mężczyzn.

Warto przyjrzeć się bliżej zagadnieniom poświęconym Lodzermenschowi w utworach Raymonda. W napisanej po polsku powieści pt. Miłość, student a wojna (1933) autor podejmuje najróżniejsze kwestie, wśród których na plan pierwszy wysuwa się problem antysemityzmu i stosunków narodowościowych. Akcja utworu rozpoczyna się w 1914 r., kiedy szaleje wojna, a główny bohater zostaje wysłany do obozu jenieckiego w głąb Niemiec. Dalsze wydarzenia rozgrywają się w wielu krajach europejskich, do których podróżują główne postacie - Janek i Tadek. Udają się oni do różnych krajów, poznając obce kultury niczym prawdziwi globtroterzy. Akcja powieści kończy się w polskim Manchesterze, czyli w Łodzi, przy czym miasto przedstawiono tu jako miejsce, które już od dawna nie jest dla przybyszów mityczną „ziemią obiecaną":

To Łódź - wskazał Janek przez okno limuzyny. To jest to miasto, które tak niedawno jeszcze było ziemią obiecaną, przyjmującą z otwartemi ramionami wszystkich śmiałków. Dzisiaj jest ona zaledwie cieniem tego, czem była za czasów swego tytanicznego rozwoju, nie bacząc na to, że las kominów wraz z lasem protestów wyrosły o kilkanaście metrów wyżej ${ }^{77}$.

Tadek, jedna z głównych postaci powieści, to łódzki fabrykant, którego wspólnikiem jest Żyd. Prowadzą w Łodzi interes, chylący się jednak ku upadkowi, gdyż Tadek nie jest w stanie spłacić wysokiego kredytu. Autor, opisując wspólne interesy między Tadkiem i jego wspólnikiem, zwraca uwagę na stosunki narodowościowe panujące w Łodzi w okresie międzywojennym. W tym miejscu warto przytoczyć łódzkich historyków badających to zagadnienie. Paweł Samuś tak opisuje stosunki między poszczególnymi nacjami:

We wszystkich bodaj grupach etnicznych dawały znać o sobie niekiedy także nastroje szowinistyczne, w niektórych kręgach społeczeństwa polskiego czasem również ksenofobia,

77 B. Raymond, Miłość, student..., s. 495. 
będąca w jakimś sensie niejako naturalnym objawem odreagowania emocjonalnego przeżyć niedawnej epoki zaborów i okupacji, zaś w łomie społeczności niemieckiej i żydowskiej były widoczne oznaki przewrażliwienia na punkcie rzekomego zagrożenia polonizacyjnego ${ }^{78}$.

Nastroje szowinistyczne, o których wspomina Samuś, w latach 30. uległy dalszej radykalizacji ${ }^{79}$. Ówczesne władze samorządowe, w których przeważali przedstawiciele obozu narodowego, w znacznym stopniu przyczyniły się do zaostrzenia konfliktów, opowiadając się za ograniczeniem praw obywatelskich dla ludności żydowskiej, zwolnieniem Żydów ze służby miejskiej i redukcją subwencji dla żydowskich instytucji ${ }^{80}$. Wkrótce deklaracje polityczne wyszły poza mury łódzkiego magistratu, przenosząc się na ulice. Radykalni działacze obozu narodowego rozpoczęli kampanię antysemicką podczas wyborów parlamentarnych, bojkotując demonstracje pierwszomajowe i handel żydowski, a także niejednokrotnie wszczynając konflikty wprost na ulicach miasta. Antyżydowskie nastroje panujące wśród elit rządzących nie pozosta-

${ }^{78}$ Por. P. Samuś, Łódź - mała ojczyzna Polaków, Niemców, Żydów, [w:] Polacy - Niemcy - Żydzi w Łodzi. Sq̨siedzi dalecy i bliscy, red. P. Samuś, Łódź 1997, s. 118-161.

${ }^{79}$ Wiek XIX to okres, gdy odradzały się nacjonalizmy i państwa narodowe. Pojawił się wówczas etniczny wymiar antysemityzmu, a wraz z nim oskarżenia ludności żydowskiej o dążenie do przejęcia władzy nad światem. Te negatywne tendencje zaowocowały licznymi pogromami ludności żydowskiej, jak np. pogromem warszawskim (1881) i pogromami galicyjskimi (1897). W zaborze rosyjskim najgłośniejsze pogromy miały miejsce w czasie rewolucji 1905 r. Inspirowane były przez endecję, której bojówki wykazywały się szczególną aktywnością w Warszawie i Łodzi. Po zakończeniu I wojny światowej antyżydowskie nastroje nie osłabły. Nadal dochodziło do pogromów, m.in. we Lwowie (1918) czy w Pińsku. Również sytuacja polityczna w II Rzeczypospolitej, tuż po odzyskaniu suwerenności, sprzyjała antyżydowskiemu nastawieniu. Polska jako państwo dopiero kształtowała się w starciu z sąsiednimi krajami. Żydów oskarżano o kolaborowanie z Niemcami i bolszewikami. Antyżydowskim poglądom sprzyjała też endecja, zwłaszcza Roman Dmowski. Sytuacja poprawiła się na jakiś czas, gdy podjęto starania w celu wprowadzenia równych praw dla ludności, autonomii kulturalnej, oświatowej i religijnej. Prawa te znalazły się w konstytucji marcowej z 1921 r. W 1931 r. zniesiono wszystkie akty prawne dyskryminujące Żydów, co było najważniejszym osiągnięciem w regulowaniu sytuacji społeczności żydowskiej w Polsce. Zapewne wpłynęła na to postawa marszałka Józefa Piłsudskiego. W 1919 r., po raz pierwszy w historii Polski, ludność żydowska miała swoich przedstawicieli w Sejmie (m.in. rabina Abrahama Ozjasza Thona (1870-1936), rabina Abrahama Cwi Perlmuttera (1843-1930) i adwokata Maksymiliana Apolinarego Hartglasa (1883-1953)). Często poparcie Piłsudskiego dla Żydów tłumaczy się tym, że Marszałek widział w tej grupie prawdopodobnie przeciwwagę dla endecji. Jako dowód może posłużyć jego dekret z 1919 r., w którym normował status prawny gmin żydowskich, dając im prawo do prowadzenia działalności gospodarczej i oświatowej, jak również umożliwiając pobieranie podatków gminnych. W latach 30. nastąpiła kolejna fala wzrostu antysemityzmu. Po śmierci Piłsudskiego postsanacyjny Obóz Zjednoczenia Narodowego sukcesywnie ograniczał prawa Żydów. Pojawiły się różne formy dyskryminacji, nasilały się akty agresji. Por. Najnowsze dzieje Żydów w Polsce w zarysie (do 1950 roku), red. J. Tomaszewski, Warszawa 1993.

${ }^{80}$ Por. P. Samuś, Łódź - mała ojczyzna ..., s. 158-159. 
ły bez wpływu na postawy społeczne, jednak akty antysemityzmu nie były charakterystyczne wyłącznie dla Łodzi. Również w innych miejscach w kraju zauważało się działania antyżydowskie, a ogromne znaczenie dla postaw społecznych miała także propaganda antysemicka hitlerowskich Niemiec. Należy mimo to zauważyć, że Łódź międzywojenna nie była tylko i wyłącznie areną konfliktów polsko-żydowskich. W latach 30. radykalizacji uległy też stosunki polsko-niemieckie, zwłaszcza wobec rosnących nastrojów prohitlerowskich i napięć w relacjach między Polską i Niemcami pod koniec $1938 \mathrm{r}$.

Bruno Raymond zajmuje się w swej powieści problematyką polsko-niemiecko-żydowską, niezwykle w tym czasie skomplikowaną. Pojmuje kwestię żydowską nie tylko jako antysemityzm, ale też przedstawia zagadnienie w szerszym kontekście, jako negatywny stosunek jednych narodów wobec drugich. Problem ten rozpatruje z jednej strony z perspektywy religijnej, pokazując judaizm i porównując go z chrześcijaństwem, z drugiej zaś podejmuje dyskusję na temat zasad etycznych i moralnych, a także ich roli w życiu człowieka. Choć porusza w swej powieści wątki antysemickiego nastawienia niektórych społeczności, w tym również polskiej, snuje również bardziej ogólną refleksję natury filozoficznej. Znamienny jest tu często prezentowany pogląd, iż kwestia żydowska, redukowana jedynie do aspektu antysemityzmu, służy zazwyczaj bardziej „do rozniecania nienawiści niż do poszukiwania właściwych źródeł zagadnienia" ${ }^{\prime 1}$. Podobnych wypowiedzi jest w książce znacznie więcej. W innym miejscu bohater powieści stwierdza: „Zagadnienie żydowskie jest dość obszerne, a często zjadliwie omawiane i opisywane"82. Antysemityzm pojawia się $\mathrm{w}$ powieści $\mathrm{w}$ różnych postaciach. Po pierwsze ujawnia się w prezentowanych przez niektórych bohaterów poglądach, w sposobie postrzegania i określonym słownictwie. Raymond opisuje również wprost zachowania antysemickie. Gdy podczas podróży Janek pragnie przedstawić innemu Polakowi Żyda-studenta, ma miejsce następujące zdarzenie:

W tej chwili, dziwnym zbiegiem okoliczności, przechodził rodak. Spostrzegłszy mnie, przystanął i zamienił ze mną słów kilka. Przedstawiłem go starozakonnemu koledze, lecz przybysz udał, że nie rozumie, o co chodzi i pożegnał się ze mną. Był to niemiły dla mnie gest, wobec czego zamilkłem. Student-żyd zamierzał również pożegnać się ze mną ${ }^{83}$.

Autor ze smutkiem konstatuje, że podobne gesty nie należą niestety do rzadkości i w przyszłości nie sposób będzie ich uniknąć. Wyraża również swój krytycyzm wobec postaw antysemickich i zastanawia się, jak walczyć $\mathrm{z}$ aktami agresji wobec ludności żydowskiej. Zwraca też uwagę na międzynarodowy wymiar problemu, zauważając ksenofobię nie tylko u wśród Polaków, ale również u Szwajcarów:

81 B. Raymond, Miłość, student..., s. 318.

82 Ibidem, s. 317.

83 Ibidem, s. 144. 
Wśród Polaków znalazłem, jak wszędzie zresztą, dużo młodzieży żydowskiej, najwięcej jednak napłynęło jej z Rosji. Był to element niemile widziany w sferach gościnnych Szwajcarów, ponieważ często można było napotkać w tamecznych gazetach ogłoszenia: „Zimmer zu vermieten. Keine Russen!"84

Zdeklarowany antysemityzm niektórych postaci powieści zanika jednak w toku akcji. Nieprzejednani antysemici, tacy jak Tadek, prowadzą w Łodzi interesy z Żydami, liczne są też przypadki zawierania małżeństw polsko-żydowskich, niemiecko-polskich i niemiecko-żydowskich, a także wspólne interesy między Polakami, Żydami i Niemcami. Łódź to miasto, w którym istnieją wprawdzie konflikty narodowościowe, jednak priorytetem jest współpraca na polu gospodarczym, bowiem żaden z łódzkich fabrykantów nie pogardzi żadną perspektywą dobrze zapowiadającego się interesu. Tadek za wszelką cenę pragnie ożywić swe interesy w Łodzi, nieco podupadłe na skutek światowego kryzysu. Odwołuje się przy tym do mitu „ziemi obiecanej”:

O! Już ja ułożę się teraz z tymi oszustami! - rozprawiał Tadek ze sobą, przechadzając się wielkimi krokami po pokoju. - A może wystarczy też na spłacenie Towarzystwa Kredytowego? Zresztą wszystko jedno! Na to się jest, aby walczyć! Nasza fabryka wraz z naszym grodem stanie się znowu ziemią obiecaną! Tak, stanie się! Czerpie powietrze zagraniczne, musi więc istnieć przez zagranicę. Mimo to musimy ją częściowo przebudować i sami stać się także elastyczniejsi, założyć w zdrowych murach nowe warsztaty dla własnych potrzeb, konkurując ze światem, z całym światem... Precz z cłem! Ha, założę fabrykę tanich samochodów! ${ }^{85}$

Obraz Łodzi w powieści Raymonda to wizja miasta, które dla Lodzermenschów nie jest już mityczną „ziemią obiecaną”, lecz miejscem konfliktów narodowościowych. Łódzcy fabrykanci muszą zmagać się z brakiem koniunktury i upadającymi interesami, a Lodzermensch nie odnosi już sukcesów gospodarczych, lecz jest uwikłany w konflikty polityczno-społeczne.

Nieco inny obraz Lodzermenscha wyłania się z utworów dramatycznych Raymonda. Pierwszy z nich, napisany w języku niemieckim, Isabella. Motive aus der Komödie der Ehe, powstał w 1928 r. Akcja dramatu rozgrywa się w jednym z miast przemysłowych w Polsce na początku XX w. Oprócz postaci kobiecych, głównej bohaterki Isabelli, jej matki pani Wilmer i siostry Isabelli, Hermine, ważną rolę odgrywają w utworze mężczyźni, m.in. przemysłowiec Wilmer, jego syn Bernhard, architekt Lernes i prawnik Notableski. Osią dramatu jest trywialny motyw miłości tytułowej bohaterki Isabelli, kobiety zamężnej, zakochującej się w architekcie o imieniu Lernes. Ich wzajemne uczucie staje się impulsem do dyskusji na temat moralności i lojalności ówczesnego społeczeństwa. W postaci Isabelli udało się autorowi sportretować

\footnotetext{
${ }^{84}$ Ibidem, s. 156.

85 Ibidem, s. 524.
} 
osobę rozdartą między potrzebami wewnętrznymi i tym, co je warunkuje z zewnątrz, czyli konwencjami. Wymowa utworu jest jednoznaczna - autor nie daje kobiecie przyzwolenia na zachowanie odbiegające od wyznaczonych norm społecznych. Dlatego na końcu bohaterka ponosi karę i umiera. Choć fabuła dramatu wydaje się trywialna, autor podejmuje w nim kwestie dla kultury Łodzi szczególnie interesujące, mianowicie w postaci przemysłowca Wilmera portretuje również typowego Lodzermenscha. Wilmer to przykład fabrykanta i kapitalisty, dla którego najwyższą wartością jest pieniądz i wyzysk robotnika. W jednej z rozmów tak mówi o przejmowaniu przez robotników akcji przedsiębiorstw, w których pracują:

Notabelski: Herr Willmer, soll Ihre Bemerkung von der Teilnahme der Arbeiter am Unternehmen nicht etwa so gedeutet werden, dass Aktien oder dergleichen Wertobjekte sukzessiv aus den Händen der Arbeitgeber in jene der Arbeiter überzugehen haben? Wilmer: um sie sukzessive weiter in unberufene Hände fliessen zu lassen! Cäcilie: Warum in unberufene Hände? Wilmer: Weil, erstens, die Hände der Arbeitermassen von impulslosen Köpfen geleitet werden und, zweitens, den Aktienerwerbern auf Kosten der unerfahrenen Sparer ein noch umfangreicheres Parasitenspiel in die Hand gegeben wird. Cäcilie: Halten sie den Arbeiter wirklich für impulslos? Wilmer: Er hat ihn wohl, jedoch mit der Peitsche und dem Brotbeutel vor den Augen. Notabelski: Muten sie dem Arbeiter nicht zu viel zynisches Phlegma zu, Herr Wilmer? ${ }^{86}$

Wilmer uważa robotników za bezwartościową masę, wobec której można uciekać się do przemocy. Sądzi również, że robotnicy nie posiadają wystarczających zdolności, by móc współdecydować o losach fabryki. W utworze pobrzmiewa również głos rewolucji, która miałaby przynieść robotnikom wolność. Również w tym przypadku Wilmer stoi na stanowisku, że wolność mas może doprowadzić do upadku narodu. W opozycji do Wilmera pozostaje jego syn Bernhard, reprezentujący nowe pokolenie Lodzermenschów, upatrujące możliwości rozwoju kraju w tworzeniu związku producenckich. Sprzeciwia się także używaniu wobec robotników „bata”, o którym mówił jego ojciec. Młode pokolenie Lodzermenschów jest już inną generacją, inaczej pojmującą kwestię własności i posiadającą wizję przyszłości kraju.

${ }^{86}$ B. Raymond, Isabella. Motive..., s. 22-23 [Notabelski: Panie Wilmer, czyżby Pańska uwaga o udziale robotników w przedsiębiorstwie miała oznaczać, że akcje i inne tego rodzaju wartościowe papiery winny sukcesywnie przechodzić z rąk pracodawców $\mathrm{w}$ ręce robotników? Wilmer: Żeby później znów sukcesywnie trafiały w niepowołane ręce! Cecylia: Jak to w niepowołane ręce? Wilmer: Bo po pierwsze, rękami mas pracujących kierują pozbawione impulsów głowy, a po drugie kosztem niedoświadczonych ciułaczy nabywcom akcji wpadają w łapy zakrojone na jeszcze większą skalę pasożytnicze zagrywki. Cecylia: Czy naprawdę uważa Pan robotników za ludzi pozbawionych impulsów? Wilmer: Ależ on ich lubi, ale oczyma wyobraźni widzi bat i sakiewkę z chlebem. Notabelski: Panie Wilmer, a czy nie przypisuje Pan robotnikom nazbyt wiele cynicznego flegmatyzmu? Tłumaczenie M.K.]. 
Ucieczka przez błękit nieba ${ }^{87}$, kolejny dramat Raymonda, można potraktować jako swego rodzaju kontynuację poprzedniego utworu. Jego bohaterem autor czyni fabrykanta Bernharda Wilmera i jego żonę, Elżbietę. Akcja dramatu rozgrywa się wczesną wiosną w mieście fabrycznym, w pałacu bogatego przemysłowca; stwierdzenie Wilmera: „Zanosi się na Kochanówek?”, pozwala przypuszczać, że tym miastem jest właśnie Łódź. Podobnie jak we wcześniejszym dramacie autor wykorzystuje motyw miłości jako najważniejszy element fabuły. Jednak tym razem bohater nie przypomina już typowego Lodzermenscha wyzyskującego robotników. Młody Wilmer głosi nową ideę, gdy mówi: „Należy znaleźć sposoby zrównoważenia i zjednoczenia produkcji oraz zachętę do solidnej pracy!"88 Uważa, że człowieka trzeba zachęcać do rzetelnej pracy, a także przekonać, że jedynie współpraca robotników i „konsumentów” daje gwarancję dobrobytu. Ta myśl stanowi zalążek sprawiedliwości społecznej w ramach jednego systemu ekonomicznego. Autor proponuje przyjazną współpracę, która przyniesie produkcji wymierne korzyści. Ponadto jest także rzecznikiem współpracy reprezentantów wszystkich gałęzi przemysłu, nawiązując tym samym do tworzonych w Łodzi karteli przemysłowych. Nie wyklucza również współpracy wielkich i małych producentów, która w rzeczywistości w Łodzi się nie powiodła, gdyż drobne zakłady przemysłowe stanowiły nie lada konkurencję dla dużych fabryk. Stąd wielcy łódzcy przedsiębiorcy próbowali je zwalczać za wszelką cenę. Bernhard ceni nade wszystko pracę, gardzi natomiast dyplomacją i pustymi słowami. Opowiada się za sprawiedliwością społeczną, a przede wszystkim jest wyznawcą postaw altruistycznych w systemie gospodarczym:

Z tego też względu kompromis udziału ludzi nieprodukcyjnych, lecz zawodowych - mówił Bernhard - zechcemy rozszerzyć w tym właśnie kierunku, aby pogłębić zainteresowanie ludzi o czystych rękach, którym ideowość sprawy jest bliższa sercu, niż zbytek egzystencji ${ }^{89}$.

Raymond proponuje swego rodzaju idealistyczny i utopijny program, który w praktyce jest niemożliwy do zrealizowania:

Bernhard: Nam przede wszystkim potrzebny jest ten „basen”, ten system, który zawiera wszelkie dane ludzi genjalnych.

Doktor B: Z którymi zazwyczaj program idzie do grobu ${ }^{90}$.

Bernard pragnie oprzeć system produkcyjny na twórczej sile ludzi genialnych, dostrzegając $w$ niej panaceum na postępujący kryzys w produkcji przemysłowej, jaki miał miejsce w Łodzi po I wojnie światowej.

\footnotetext{
87 B. Raymond, Ucieczka przez błękit...

88 Ibidem, s. 45.

89 Ibidem, s. 47.

90 Ibidem, s. 46.
} 
Całkowita zmiana postrzegania Lodzermenscha następuje jednak dopiero w ostatniej polskiej powieści Raymonda pt. W poszukiwaniu ojczyzny. Jak sugeruje jej tytuł, Lodzermensch porzuca swoje miasto i w poszukiwaniu własnej tożsamości udaje się w podróż dookoła świata. W tym celu odwiedza miasta swych niemieckich przodków. Lernes, główny bohater, dorastał w Królestwie Polskim w wielonarodowym i wielokulturowym społeczeństwie, a przez kilka lat przebywał w Łodzi. Kontakty z napotkaną w czasie podróży ludnością, która nie ma problemu z określeniem tożsamości narodowej i kulturowej, uświadamiają mu, jak trudna jest droga do odnalezienia własnej tożsamości. Relacje z innymi ludźmi są impulsem do weryfikacji własnej etnocentrycznej postawy, wyznaczając w ten sposób pole dialogu. Lernes nie jest człowiekiem zamkniętym, wręcz przeciwnie - jest bardzo otwarty na kontakty z obcymi, a ponadto świadomy własnej odmienności: „Czuję - ciągnął Lernes znacznie ciszej - że we mnie są dwie dusze..." ${ }^{\prime 1}$. Otoczenie reaguje jednak dość sceptycznie na brak tożsamości, która dla mieszkańców niewielkiej niemieckiej wsi (autor nie pisze dokładnie, gdzie znajduje się to miejsce w Niemczech) oznacza głównie identyfikację narodową:

- 0 co to właściwie Panu chodzi? - zapytał żandarm, znowu nieco podejrzliwie.

- O swoją ojczyznę! - odpowiedział gość dość wyniośle.

$[\ldots]$

- Czy Pan jest Niemcem z pochodzenia? - zgadnął żandarm po kilku sekundach.

- Nie wiem!

- A gdzie się Pan urodził?

- W Polsce.

$[\ldots]$

- Czy pan jest Polakiem? - zagadnął żandarm żywo.

- Byłbym, gdybym miał polskie nazwisko, a przynajmniej polski paszport.

- Obowiązuje chyba miejsce urodzenia? - odezwał się żandarm raczej głuchym niż twardym głosem. A gdy nie dostał odpowiedzi nieco napastliwie: Powinien pan wiedzieć, że przydzielone im [Polakom - M.K.] obszary przewyższają procentowość polskiego ludu. $[\ldots]$

- Czy Pan się czuje Polakiem?

- Prawdę mówiąc - odpowiedział nagle gość głosem miękkim i nieharmonizującym z głosem żandarma ani jego poprzednim - miałem od maleństwa pewien sentyment dla narodu polskiego. Może dlatego - dodał znacznie powolniej, podczas gdy żandarm zamilkł zupełnie - że obcowałem z nimi zawsze, chociaż nie wdając się nigdy w ich bolączki polityczne.

$[\ldots]$

- Jest Pan dla mnie niezrozumiały - odpowiedział żandarm poważnie ${ }^{92}$.

Gdy bohater nie odnajduje tożsamości, opuszcza miejsce dotychczasowego pobytu i udaje się statkiem w podróż do Indii. Wydarzenia z życia głów-

91 B. Raymond, W poszukiwaniu..., s. 112.

92 Ibidem, s. 20-22. 
nej postaci przedstawione zostały fragmentarycznie, co pozwala czytelnikowi poznać jedynie wybrane wycinki biografii. W drodze do Indii bohater zatrzymuje się w Egipcie, kontemplując kulturę Wschodu. Narracja powieści ma charakter subiektywny - narrator często zwraca się bezpośrednio do czytelnika, choć nie zdradza swej tożsamości. Jego relacja jest pełna niejasności i niedomówień, a wydarzenia przedstawia w sposób wyrywkowy, pozostawiając czytelnikowi trud ich powiązania. Zarówno główny bohater, jak i jego życie mają pozostać dla czytelnika tajemnicze. Taki zabieg skłania do głębszej refleksji nad zagadnieniem tożsamości człowieka. Język utworu jest obrazowy i sugestywny, co sprzyja budowaniu atmosfery wzniosłości i tajemniczości.

Przedstawione w rozdziale różne wizerunki Lodzermenscha pokazują stosunek niemieckojęzycznych pisarzy do tej postaci. Traktowali oni fenomen Lodzermenscha z przymrużeniem oka, o czym świadczą choćby Łódzkie typy Berty Teplitzkiej, portrety stworzone przez Heinricha Zimmermanna czy też dowcipy zebrane przez Reinholda Piela. Dzięki humorystycznej perspektywie wszyscy ci autorzy wykazują dystans wobec fenomenu Lodzermenscha, co można potraktować jako swego rodzaju metodę kanalizacji frustracji społecznych. Nie wolno zapominać, że Łódź była w XIX i XX w. miejscem wielu konfliktów społecznych, a napięciom wybitnie sprzyjała zróżnicowana struktura społeczna tego miejsca. Polacy żyli obok Niemców, Żydów, Rosjan, Czechów i innych nacji; katolicy obok ewangelików, prawosławnych i ludności wyznania mojżeszowego; robotnicy i miejska biedota obok bogatych fabrykantów. Nie brakowało zatem w mieście punktów zapalnych, bardzo różniących łodzian. Lodzermensch jest miejscowym „wytworem” kumulującym wszystkie cechy, które pozwalały mu przetrwać w mieście w latach najbardziej drapieżnego kapitalizmu. Musiał żyć w wielkiej aglomeracji, w sztucznym środowisku, wśród produktów przemysłowych, pozbawiony tradycyjnych punktów odniesienia, zanurzony w szybkim prądzie postępu.

Warunki, w jakich Łódź stawała się miastem wielkoprzemysłowym, z dzisiejszego punktu widzenia mogą wydawać się nieludzkie. Drapieżny kapitalizm dotykał nie tylko nędznie opłacanych robotników, pozbawionych zabezpieczenia socjalnego i pracujących w bardzo złych warunkach powodujących wysoką śmiertelność, ale również bogatych fabrykantów, częstokroć zmuszonych do walki z niekorzystną koniunkturą gospodarczą. Dlatego według niemieckojęzycznych autorów Lodzermensch posiada cechy, które pomagają mu przetrwać i osiągnąć sukces. Jest człowiekiem, dla którego największymi wartościami są pieniądz i chęć odniesienia sukcesu. Ale łódzcy pisarze przedstawiają go również jako człowieka szukającego wyjścia z trudnych sytuacji, osobnika pomysłowego, zdolnego do wypracowania innowacyjnych koncepcji wyjścia z kryzysu. Lodzermensch jest zatem nie tylko bezwzględ- 
nym kapitalistą, ale także człowiekiem kreatywnym, pragnącym mimo złej passy przyczynić się do rozwoju kraju, w którym przyszło mu żyć. Na uwagę zasługuje również jedna z ostatnich kreacji Lodzermenscha, przedstawiona przez Bruno Raymonda w powieści W poszukiwaniu ojczyzny. Lodzermensch opuszcza kraj zamieszkania, by udać się na poszukiwanie swojej tożsamości. Czy postać ta mogłaby przesądzić o zmianie paradygmatu? Czy w rzeczywistości bezwzględny Lodzermensch staje się człowiekiem poszukującym własnych korzeni? Z pewnością późniejsze dzieje wielu łodzian świadczą o tym, że autor przewidział ich los; po 1945 r. na zawsze opuścili swą małą ojczyznę. Okres wojny i lata powojenne zmieniły oblicze miasta i jego mieszkańców, zatem musiało to oznaczać również zmianę paradygmatu Lodzermenscha. W końcu opuścił on przecież miasto, w którym nie widział już możliwości rozwoju własnej inicjatywy ani miejsca dla zachowania swej odrębności. 



\section{7. ŁÓDŹ - PROBLEMATYKA SPOŁECZNA}

\section{1. Łódź - miasto kontrastów}

Ein buntes Durcheinander, ein Konglomerat der verschiedenartigen Elemente, die kontrastieren wie Feuer und Wasser, eine Stadt, in der sich die Gegensätze sichtbar aneinanderreihen wie Licht und Schatten - das ist Lodz ${ }^{1}$.

Łódzki pisarz i dziennikarz Heinrich Zimmermann w jednym ze swych felietonów, zatytułowanym Lodzerin [Łodzianka], w kilku zwięzłych słowach niezwykle trafnie uchwycił istotę wielonarodowego miasta będącego swoistym tyglem kultur. Łódź to miasto kontrastów, w którym tuż obok siebie żyli Polacy, Niemcy, Żydzi, Rosjanie i przedstawiciele innych nacji, a ich wzajemne stosunki nacechowane były zarówno przejawami rywalizacji i antagonizmami, jak również przyjazną koegzystencją i przenikaniem odmiennych wzorców kulturowych. Przybysze, napływający do Łodzi nie tylko z zagranicy, ale także z małych miast i wsi, budowali to miasto wspólnym wysiłkiem. To właśnie etos pracy, który stał się ważną częścią łódzkiej tożsamości, sprawił, że Łódź z małej, nic nieznaczącej miejscowości przerodziła się w przemysłową metropolię, w której dokonywały się żywiołowe procesy urbanizacyjne i cywilizacyjne. Nie należy jednak zapominać, że rozwój przemysłu nie szedł bynajmniej w parze z rozwojem społecznym. Łódź również w XIX i w pierwszej połowie XX w. nie była w stanie uporać się z wieloma poważnymi problemami społecznymi. Życie mieszkańców w warunkach szybkiego rozwoju miasta zasługuje na szczególną wagę, gdyż powstająca tu literatura podejmowała często problemy społeczne. Sytuacja ludności Łodzi, zwłaszcza w latach kryzysów, była niezwykle trudna, ponieważ w XIX i w pierwszej połowie

${ }^{1}$ H. Zimmermann, Lodzerin, „Lodzer Frauenzeitung. Beilage zur Neuen Lodzer Zeitung”, 2./15.04.1914, s. 1 [Kolorowa mieszanina, konglomerat różnorodnych elementów, kontrastujących ze sobą jak ogień i woda; miasto, w którym przeciwności sąsiadują ze sobą jak światło i cień - to właśnie jest Łódź. Tłumaczenie M.K.]. Tekst nigdy nie był publikowany w formie książkowej. 
XX w. koniunktura załamywała się stosunkowo często. Wielu tkaczy traciło wówczas zatrudnienie, ceny artykułów gwałtownie rosły, pogarszał się stan sanitarny miasta, a ludzie głodowali. Kryzysom często towarzyszyła ponadto klęska nieurodzaju i epidemie chorób zakaźnych, jak przykładowo w latach 1844-1848, kiedy wiele osób zapadło na cholerę i czerwonkę 2 . W wyniku kolejnego kryzysu w 1861 r. pracę straciło 1,4 tys. osób, zaś w 1863 r. liczba bezrobotnych sięgnęła 3,5 tys. W latach 1871-1873 liczba robotników zmniejszyła się o 44\%. Kryzys dotykał zarówno przemysłu wełnianego, jak i bawełnianego, mniejsze i większe fabryki. Drastycznie spadały także płace: w latach 1883-1886 o 38\% w przemyśle wełnianym i o 24\% w branży bawełnianej. Skutki kryzysu natychmiast uwidaczniały się w mieście - głodni, obdarci, wychudzeni pracownicy zamykanych fabryk wychodzili na ulice, by żebrać choćby o kromkę chleba ${ }^{3}$. W mieście mnożyły się przypadki kradzieży i żebractwa. Władze miejskie nie szczędziły wysiłków, by wspierać ubożejące społeczeństwo, często z pomocą miejscowej burżuazji. Wypłacano zasiłki pieniężne, wydawano nieodpłatnie żywność, węgiel, drewno opałowe i leki. W 1876 r. utworzono Komitet Wsparcia Biednych, który usiłował zwalczać skutki kryzysu, rozdając żywność i wypłacając zasiłki. W tym celu zorganizowano dla bezrobotnych i ich rodzin tzw. tanie kuchnie, wydające posiłki przez sześć dni w tygodniu. Mimo wszystkich starań akcje charytatywne okazywały się niewystarczające. Z kryzysem nie poradził sobie także utworzony w 1912 r. Komitet Obywatelski Niesienia Pomocy Biednym5 . Pomimo działalności filantropijnej tysiące osób żyło w skrajnej nędzy, a wielu zrozpaczonych ludzi targało się na własne życie. Do pogłębienia kryzysu przyczyniały się również ówczesne warunki bytowe ludności, gdyż większość łódzkiego społeczeństwa mieszkała w zatłoczonych, jednoizbowych pomieszczeniach, których stan sanitarny pozostawiał bardzo wiele do życzenia.

Jednak tuż obok biedoty mieszkali bogaci fabrykanci opływający we wszelkie możliwe luksusy. Każdy liczący się w mieście przemysłowiec musiał posiadać pałac lub choćby okazałą willę, bowiem kubatura rezydencji i jej wyposażenie świadczyło o statusie społecznym właściciela. Niektóre z siedzib łódzkich fabrykantów wyróżniały się piękną architekturą nawiązującą do europejskich rezydencji królewskich ${ }^{6}$. Rozmachem stylów imponował

${ }^{2}$ Por. J. Fijałek, Położenie ludności, [w:] Łódź. Dzieje miasta, red. R. Rosin, t. 1: Do roku 1918, red. B. Baranowski, J. Fijałek, Łódź-Warszawa 1980, s. 313.

3 Ibidem, s. 314.

${ }^{4}$ W 1884 r. tanimi kuchniami kierowało Chrześcijańskie Towarzystwo Dobroczynności. Ogółem w tym czasie funkcjonowały w Łodzi trzy kuchnie, które wydawały 350-450 posiłków dziennie. Ibidem, s. 337.

5 Ibidem, s. 344-346.

${ }^{6}$ Por. W. Pawlak, Na łódzkim bruku 1901-1918, Łódź 1984. 
ukończony na początku XX w. pałac Izraela Poznańskiego, ale też okazałe posiadłości Scheiblerów, Kunitzerów i Herbstów ${ }^{7}$. Bogactwo i ubóstwo stykały się w Łodzi niemal na każdym kroku, dlatego istotę tego miasta stanowiła jego wielowymiarowość, podkreślana również w literaturze polskiej.

Łódzka literatura żywo reagowała zarówno na kontrasty społeczne, jak i problemy socjalne mieszkańców. W 1924 r. redakcja gazety „Neue Lodzer Zeitung” opublikowała w „Illustriertes Sonntagsblatt der Neuen Lodzer Zeitung" opowiadanie Olenki Teschner pt. Aus dem Skizzenbuch des Karnevals [Notatnik karnawałowy] ${ }^{8}$, w którym autorka poruszała problem biedy i bogactwa w mieście. Jest to historia żebraczki umierającej na schodach budynku, w którym odbywa się bal charytatywny dla głodującej ludności miasta. Nikt z uczestników balu nie interesuje się losem ubogiej kobiety, dla której śmierć jest wybawieniem od ziemskiej udręki. Autorka opowiadania pragnie zwrócić uwagę na powierzchowny charakter filantropii, poddając krytyce instytucje dobroczynne działające dla uspokojenia sumienia, ale niedostrzegające prawdziwej biedy wokół siebie.

Problem głodu podejmuje także Carl Heinrich Schultz w szkicu Hunger [Głód] ${ }^{9}$. Przedstawia w nim przypadek młodego, dobrze wykształconego człowieka, przedstawiciela wyższych sfer, oskarżonego o popełnienie zbrodni. Z przebiegu procesu czytelnik dowiaduje się, że motywem, który popchnął bohatera na drogę przestępstwa, był głód. Początkowo pracował jako szanowany obywatel w Powszechnym Banku Dyskontowym. Jego oddanie pracy i talent szybko znalazły uznanie w oczach przełożonych i zostały nagrodzone awansem. Wkrótce młody człowiek został prokurentem z dobrym uposażeniem. Prywatnie obracał się w najlepszym towarzystwie, do którego zresztą i tak należał dzięki swemu pochodzeniu i wychowaniu. Zadowolony ze swej życiowej sytuacji zamierzał właśnie założyć rodzinę, lecz gdy zaczął ubiegać się o względy odpowiedniej dziewczyny, z miejsca pracy dotarła do niego nieoczekiwanie wiadomość o samobójczej śmierci generalnego dyrektora banku. Powodem samobójstwa było bankructwo instytucji, do którego doprowadziły nierozważne, prywatne spekulacje samobójcy. Wkrótce bank zamknięto i zwolniono stu czterdziestu pracowników, w tym głównego bohatera. Przez kilka miesięcy żył z oszczędności, które zdołał zgromadzić jako sumienny

7 Por. M. Koter, M. Kulesza, W. Puś, S. Pytlas, Wpływ wielonarodowego dziedzictwa kulturowego na współczesne oblicze miasta, Wydawnictwo UŁ, Łódź 2005.

${ }^{8}$ O. Teschner, Aus dem Skizzenbuch des Karnevals, „Illustriertes Sonntagsblatt der „Neuen Lodzer Zeitung" 9/1924.03.2, s. 4. Tekst nigdy nie był publikowany w formie książkowej.

${ }^{9}$ C.H. Schultz, Głód. Szkic, [w:] Literackie i nieliterackie obrazy miasta. Łódź przełomu wieków oczami niemieckojęzycznego autora - Carla Heinricha Schultza / Nicht nur literarische Bilder einer Stadt. Lodz in den Augen eines deutschsprachigen Autors - Carl Heinrich Schultz, red. M. Kucner, Łódź 2011, s. 102-104 (Hunger. Skizze, [w:] ibidem, s. 220-222). 
urzędnik. W tym samym czasie bez powodzenia poszukiwał innej pracy. Ponieważ oszczędności topniały w szybkim tempie, młody człowiek postanowił wyjechać do innego, dużego miasta z nadzieją znalezienia jakiegoś zajęcia. Stołował się w najtańszych jadłodajniach, by jak najmniej uszczuplić i tak już skromne finanse. Wkrótce jednak pieniędzy zabrakło i młodzieniec zaczął głodować. Autor opowiadania tak opisuje dojmujące uczucie głodu:

Dalej było jednak coraz gorzej. Organizm zaczął wyraźnie słabnąć, miałem bóle głowy, nie potrafiłem jasno myśleć. Piłem wodę, wodę i tylko wodę. Czyniłem to jednak zupełnie bezwiednie - byle tylko czymkolwiek napełnić żołądek. Później zacząłem odczuwać kłucie i palenie w trzewiach - był to straszny, żrący ból i nie potrafiłem już myśleć o niczym innym, jak tylko o jedzeniu, o jedzeniu... Wówczas w mojej głowie, pełnej splątanych myśli, zrodziło się postanowienie: musisz zdobyć coś do jedzenia, nawet gdybyś miał kogoś zabić! [...] 0, w więzieniu jest o wiele lepiej niż na wolności, ale - głodować... Nawet gdybym ponownie miał się znaleźć w takim położeniu - nie potrafiłbym zaręczyć, że nie sięgnąłbym znów po to samo rozwiązanie... Głód to największa ze wszystkich możliwych pasji; jestem tego pewny tak samo, jak jestem pewien, że ten świat istnieje ${ }^{10}$.

Autor wyraźnie podkreśla, że nędza dotyka nie tylko ludzi najbiedniejszych, ale również dobrze wykształconych, sytuowanych i pracujących. Fakt ten oznacza, że ówczesny system był wyjątkowo bezwzględny dla każdego, nie omijał bowiem nawet ludzi, których sytuacja materialna była na pozór zadowalająca. Opisany przypadek przywodzi na myśl wiele łódzkich historii, gdy fabrykanci błyskawicznie stawali się bogatymi przedsiębiorcami, by za chwilę popaść w finansową ruinę ${ }^{11}$. Dobrze ilustruje tę sytuację literatura polska, w szczególności zaś Ziemia obiecana Reymonta, który na przykładzie trójki przyjaciół - Polaka, Niemca i Żyda - pokazał, jak szybko można w tym mieście stać się wielkim fabrykantem, ale jeszcze szybciej zaprzepaścić cały majątek $^{12}$.

Nieco inny wymiar biedy czy też zubożenia ludności Łodzi opisuje Max Adolphi w opowiadaniu Schicksal [Los] ${ }^{13}$. Poza tym pisarza zajmuje również kwestia kontrastu między wielkim miastem Łodzią i prowincją, w której żyje kilka rodzin arystokratycznych. Tworzą one zamknięte środowisko, pielęgnując własne tradycje i żyjąc w zgodzie z własnymi obyczajami. Główna bohaterka, arystokratka i mieszkanka małego, prowincjonalnego miasta, zakochuje się w podróżującym po świecie młodzieńcu. Ponieważ popełnia

${ }^{10}$ C.H. Schultz, Głód..., s. 104 (Hunger..., s. 222).

11 Por. S. Pytlas, Łódzka burżuazja przemysłowa w latach 1864-1914, Wydawnictwo UŁ, Łódź 1994.

12 Por. W.S. Reymont, Ziemia obiecana, Warszawa 1899.

13 M. Adolphi, Das Schicksal, „Illustriertes Sonnntagsblatt. Beilage zur Neuen Lodzer Zeitung", 2.12.1923, s. 2-4. Tekst nigdy nie był publikowany w formie książkowej. 
mezalians, musi opuścić rodzinny dom, w którym bezwzględnie przestrzega się wartości i tradycji. Udaje się więc do Łodzi, ale tu szybko traci swą pozycję społeczną: bogata arystokratyczna dama staje się biedną pracownicą jednej z łódzkich fabryk.

Miasto przedstawiono jako miejsce, w którym nie liczą się ani wartości, ani tradycja, lecz wyłącznie ciężka praca nadająca sens życiu każdego człowieka. 0 etosie pracy traktują również dwa wiersze łódzkich poetów, Juliana Willa i Sigismunda Banka. W wierszu Abschied von Lodz [Pożegnanie z Łodzią] Julian Will tak pisał o rodzinnym mieście:

Leb wohl, du Stadt der tausend Schlotte,

Die aufwärts ragen wie ein Wald,

Du Stadt, gehorchend dem Gebote

Der Arbeit! Ihrer Allgewalt

Dich beugen willig deine Söne,

ob niedrig oder hoch die Löhne;

Die Arbeit hat dich groß gemacht ${ }^{14}$.

Natomiast u Sigismunda Banka miasto nabiera cech ludzkich: autor wyodrębnia charakterystyczne przymioty tego wizerunku, odpowiadające portretowi jego matki:

Ich liebe die Stadt,

weil sie fürwahr

so ist wie meine Mutter war:

Ein schlichtes Kleid, bestaubte Schuh'

viel Plag und Arbeit, wenig Ruh'

vom Alltag spröde ihre Hand,

die Augen manchmal weit ins Land,

des Schicksals Strenge im Gesicht,

das Herz tief innen - wärmend Licht,

selbst voller Sorgen - Trost in Not,

für jedes Kind ein Stückchen Brot,

viel Hoffnung auf den guten Stern

und feiertags ein Wort des Herrn ${ }^{15}$.

${ }^{14}$ J. Will, Abschied von Lodz, „HKG Mitteilungsblatt der Heimatkreisgemeinschaft der Deutschen aus dem Lodzer Industriegebiet" (dalej: HKG) 9/August 1987, s. 2 [Żegnaj, miasto tysiąca kominów, / pnących się w górę jak las, / miasto, które podąża za etosem / pracy! Przed jej wszechwładną siłą / twoi synowie chętnie chylą kark, / czy niskie czy wysokie twoje zarobki; / to praca uczyniła cię wielkim. Tłumaczenie M.K.].

15 S. Banek, Lodz, HKG 5/August 1983, s. 7 [Kocham miasto, które / jest jak moja matka: / prosta suknia, zakurzone buty, / wiele udręki i pracy, mało spokoju, / spracowane ręce, / wzrok zapatrzony w dal, / twarzy naznaczył twardy los, / głęboko w sercu - ciepłe światło, / pełna troski - z otuchą w biedzie, / dla każdego dziecka ma kawałek chleba, wiele nadziei na dobrą gwiazdę, / a w święta słowo Pana. Tłumaczenie M.K.]. 
Miasto jest dla Banka synonimem swojskości, porównuje je bowiem z własną matką, pełną ciepła, miłości i troski. Oznacza to, że miejska przestrzeń postrzegana jest jako oswojona, zadomowiona i wyjątkowa.

Również w krótkim opowiadaniu Was Herr Zimperlich aus Sochaczewka in Lodz erlebte [Co pan Zimperlich z Sochaczewki przeżył w Łodzi] ${ }^{16}$ Berta Teplitzka zwraca uwagę na wyjątkowość tego miasta. Portret Łodzi naszkicowany został metodą kontrastu, gdyż autorka charakteryzuje przestrzeń wielkiej aglomeracji w opozycji do prowincjonalnego miasta o nazwie Sochaczewka. Bohater opowiadania, pan Zimperlich [niem. przesadnie wrażliwy], postrzega Łódź przez pryzmat niewielkiej mieściny, w której mieszka z rodziną od wielu lat. Gdy przyjeżdża do Łodzi, odbiera pięciusettysięczne miasto jako kompletnie obcy mu świat. Zauważa odmienność łódzkich obyczajów i powierzchowność kontaktów międzyludzkich:

Komme ich in eine Restaurant und sehe ich die wie die Diplomaten eleganten Kellner in ihren Fracks, die meinen schönen schwarzen Rock, den ich in Sochaczewka seit 15 Jahren bei feierlichen Gelegenheiten trage, so von oben herab ansehen, dann ist es mir unangenehm, einen Gulasch und eine Glas Helles zu bestellen wie hier, und ich nehme etwas Ausländisches, wie z.B. Chateaubriand, das zwar viel teurer kostet als Gulasch, sich aber als ein Bissen Fleisch in einem Meer von Sauce entpuppt. Un dazu bestelle ich eine halbe Flasche Mosel, der mir jedesmal Magenbeschwerden macht. Un wenn ich „Diplomaten" dann mit hungrigem Magen die Zeche bezahle und ihm ein Zwanzigkopekenstück als Trinkgeld beilege, ich imponiere ihm weniger damit, als unserem Andrzej [... ${ }^{17}$.

Zimperlich, uchodzący w Sochaczewce za powszechnie szanowanego rentiera, w Łodzi dostrzega anonimowość każdego człowieka i stwierdza: „Hier [in Sochaczewka - przyp. M.K.] sind wie doch etwas, hier stellen wir doch etwas vor - wer kennt uns dort [in Lodz - przyp. M.K.] unter den 500000 Menschen?!"18. Łódź przeraża Zimperlicha również chaosem przestrzennym, hałasem i ludzkim ściskiem. Bohater zauważa, że łodzianie kierują się innymi wartościami niż ludzie na prowincji, odmawiając drugiemu człowiekowi

${ }^{16}$ B. Teplitzka, Was Herr Zimperlich aus Sochaczewka in Lodz erlebte, „Neue Lodzer Zeitung", 27.01./9.02.1913, s. 3. Tekst nigdy nie był publikowany w formie książkowej.

17 Ibidem [Kiedy wchodzę do restauracji i widzę elegancko niczym dyplomaci ubranych kelnerów we frakach, patrzących z pogardą na mój piękny czarny garnitur, który w Sochaczewce noszę od piętnastu lat na specjalne okazje, czuję się nieswojo, chcąc zamówić kufel piwa i gulasz; dlatego biorę coś zagranicznego, np. szatobriand, który kosztuje wprawdzie więcej niż gulasz, a okazuje się kawałkiem mięsa pływającym w morzu sosu. Do tego zamawiam butelkę wina mozelskiego, po którym zawsze miewam bóle żołądka. A gdy wciąż z pustym żołądkiem płacę „dyplomacie” rachunek i zostawiam mu dwadzieścia kopiejek napiwku, imponuję mu znacznie mniej niż naszemu Andrzejowi, Tłumaczenie M.K.].

${ }^{18}$ Ibidem [Tutaj [w Sochaczewce - przyp. M.K.] przynajmniej kimś jesteśmy, jakoś się prezentujemy - a kto nas zna tam [w Łodzi - przyp. M.K.], wśród 500000 ludzi?! Tłumaczenie M.K.]. 
atencji i szacunku. Uwagę przybysza zwraca też odejście od tradycyjnych metod wychowywania dzieci, bezgraniczne hołdowanie pracy i podejrzliwość wobec bliźnich. Dla Zimperlicha zadziwiające są również frywolne tytuły sztuk teatralnych, świadczące o odmiennej obyczajowości:

Da wir doch schon einmal in der Großstadt waren, wollten wir auch gern ins Theater gehen. Aber es wurden immer solche Stücke gegeben, bei deren Titel meine Kunigunde schon bis über die Ohren errötete. Denken Sie mal: Luxusweibchen, Autoliebchen, das Liebesalter, Hochheit tanzt Walzer - sind dann denn das Stücke, die eine anständige Frau sehen kann? ${ }^{19}$

Bohater opowiadania stwierdza, iż powszechnym zjawiskiem jest w Łodzi upadek zasad moralnych, dlatego jako człowiek pielęgnujący stare tradycje nie potrafi utożsamić się z tym miejscem: „Begreifen Sie jetzt, daß ich mich mit der Lodzer Moral nicht einverstanden erklären konnte ${ }^{20}$ - mówił, opowiadając o niemoralnej sztuce, na którą jednak zdecydował się pójść razem z żoną - „Diese Unmoral treffen Sie dort auf allen Gebieten”21. Kończąc wywody na temat miasta, określił je mianem jaskini grzechu demoralizującej społeczeństwo: „Also, was meinen Sie, meine Herren, in solch einen Sündenpfuhl soll ich mich freiwillig begeben? Nein, nein, und nochmals nein! Es lebe Sochaczewka und seine Sittenreinheit!"22

Obrazem tym Berta Teplitzka wpisuje się w stereotypowe postrzeganie miasta jako miejsca, w którym nie obowiązują zasady moralne, zaniedbuje się tradycyjne wartości, w którym panuje wielkomiejska anonimowość oraz szalone tempo życia. Jednakże nie dokonuje bezwzględnej krytyki Łodzi. Krytyce poddaje przede wszystkim małomiasteczkowość głównego bohatera, który nie jest w stanie odnaleźć się w wielkiej aglomeracji.

Portret miasta, wyłaniający się z innych opowiadań i felietonów, to Łódź pełna kontrastów i konfliktów. Zwraca na to uwagę Heinrich Zimmermann w utworze Streiflichter [Smugi światła], w którym opisuje sytuację w Łodzi po 1919 r::

19 Ibidem [Ponieważ pierwszy raz byliśmy w wielkim mieście, chcieliśmy pójść do teatru. Ale grali tam takie sztuki, których tytuły wywoływały rumieniec wstydu na twarzy mojej Kunegundy. Proszę tylko posłuchać: Luksusowa kobietka, Samochodowa kochanka, Wiek miłości, Jego Wysokość tańczy walca - czy to są sztuki, które może oglądać porządna kobieta? Tłumaczenie M.K.].

${ }^{20}$ Ibidem [Czy teraz Panowie rozumieją, dlaczego nie zgadzam się z łódzką moralnością? Tłumaczenie M.K.].

${ }^{21}$ Ibidem [Tę niemoralność spotyka się tam na każdym kroku. Tłumaczenie M.K.].

22 Ibidem [A więc co o tym sądzicie, moi Panowie, czy mam dobrowolnie przenieść się do tej jaskini grzechu? Nie, nie i jeszcze raz nie! Niech żyje Sochaczewka i jej czystość obyczajów! Tłumaczenie M.K.]. 
Die Straße ist ein Meer von Menschen. Ein Wirrwarr von Stimmen durchzittert die Luft. Losungen werden verkündet, Reden gehalten, Rufe ausgestoßen. Und doch ist etwas Häßliches, Tragisches um diese Demonstration. Sie hat zwei Stimmen und zwei Hände: Die eine schreit: Wir wollen Gerechtigkeit und Wahrheit! Und die andere: Nieder mit den Deutschen! Nieder mit den Juden! ${ }^{23}$

W tekstach literackich i felietonach łódzcy autorzy pokazali niedostatecznie w Łodzi rozwiniętą kulturę, zwracając uwagę m.in. na słabe zainteresowanie łodzian sztuką. W felietonie Streiflichter Zimmermann podejmuje wątek łódzkiego teatru, który przez długi czas przeżywał lata zarówno dobrej koniunktury, jak i stagnacji. Autor krytykuje sposób myślenia właścicieli łódzkich teatrów kierujących się, podobnie jak miejscowi fabrykanci, jedynie chęcią zysku: „Entweder bekomme ich meine gewünschte Miete, oder ich verwnadle das Theater in ein... Bankhaus" ${ }^{24}$ - oświadcza jeden z dzierżawców teatru. Zimmermann konstatuje:

Brauchen wir denn wirklich Theatergebäude in Lodz? Wozu? Macht aus Scala-Theater ein Bankhaus, aus dem Großen Theater eine Badeanstalt, aus dem Polnischen einen Tanzsaal und aus dem Thalia - eine Markthalle. Kunst ist Dunst, Theater - Narretei. Es lebe die Mark! Es lebe das Geld, das viele Geld ${ }^{25}$.

Pokazując miasto jako swego rodzaju „pustynię kulturową”, autor odnosi się do stereotypowego postrzegania Łodzi jako miejsca pozbawionego instytucji kultury i twórczości artystycznej, a więc miejsca, w którym ludzie nie nawykli obcować ze sztuką. Taki obraz Łodzi ukształtowała również literatura polska, pisana zazwyczaj z perspektywy Warszawy, gdzie kultura wpisana była w tradycję i historię miasta ${ }^{26}$. Także Zimmermann w felietonie Musikleben in Lodz [Życie muzyczne w Łodzi] przytacza kąśliwą uwagę warszawiaków na temat łódzkiego życia muzycznego:

Die Stadt der Milionäre konnte sich nicht den Luxus leisten, ein eigenes Sinfonieorchester zu haben. Die Musik fand leider keine Unterstützung bei den Großindustriellen, die

${ }^{23}$ H. Zimmermann, Streiflichter, „Neue Lodzer Zeitung”, 21.09.1919, s. 3 [Ulica to morze ludzi. Gwar rozedrganych ludzkich głosów wypełnia powietrze. Słychać obwieszczane hasła, wygłaszane mowy, krzyki. I jest w tej demonstracji coś obrzydliwego i tragicznego. Ma dwa głosy i dwie ręce. Jeden krzyczy: Chcemy sprawiedliwości i prawdy, a drugi: Precz z Niemcami! Precz z Żydami! Tłumaczenie M.K.]. Tekst nigdy nie był publikowany w formie książkowej.

${ }^{24}$ H. Zimmermann, Streiflichter, „Neue Lodzer Zeitung”, 14.08.1919, s. 3 [Albo otrzymam mój czynsz, albo zamienię teatr na... bank. Tłumaczenie M.K.].

${ }^{25}$ Ibidem [Czy naprawdę potrzebujemy w Łodzi teatru? Po co? Zróbcie ze Scali bank, z Teatru Wielkiego basen, z Polskiego salę taneczną, a z Thalii halę targową. Sztuka to złudzenie, a teatr jest błazeństwem. Niech żyje marka, niech żyją pieniądze, dużo, dużo pieniędzy. Tłumaczenie M.K.]. Tekst nigdy nie był publikowany w formie książkowej.

${ }^{26}$ Por. W.S. Reymont, Ziemia obiecana...; W. Marrené-Morzkowska, Wśród kąkolu, „Biesiada Literacka" 1890. 
lieber ein Fabrikgebäude nach dem anderen bauten, als Opfergaben auf den Altar der Kunst zu legen ${ }^{27}$.

Patrząc na rozwój kultury w Łodzi z perspektywy historii tego miasta, trzeba podkreślić, że pod tym względem było $\mathrm{w}$ porównaniu z Warszawą bardzo zapóźnione. Nie należy jednak zapominać, że napływający do Łodzi przybysze z zewnątrz mieli za zadnie wspierać tu przede wszystkim przemysł. Powolny rozwój życia kulturalnego rozpoczął się dopiero, gdy znacznie poprawiły się warunki materialne wielu fabrykantów. Wówczas to powstały niemieckie gazety, podjął działalność teatr i różnego rodzaju stowarzyszenia kulturalne. Z tego powodu stereotypowe, literackie postrzeganie Łodzi jako pustyni kulturalnej jest dla miasta krzywdzące i nieobiektywne, a mimo to bezkrytycznie powielane także przez pisarzy niemieckojęzycznych.

\section{2. Łódź sentymentalna w twórczości Carla Heinricha Schultza}

W 1938 r., wraz z pojawieniem się na łódzkim rynku prasowym nowego tygodnika o antyhitlerowskim charakterze pod nazwą „Der Deutsche Wegweiser”, zaczęto drukować felietony, w znacznej części poświęcone zagadnieniom kultury i obyczajowości Łodzi. Autorem wszystkich tekstów był znany niemieckojęzyczny pisarz, tłumacz i publicysta, Carl Heinrich Schultz.

Pojawienie się na łamach „Der Deutsche Wegweiser” cyklu felietonów na temat Łodzi uzasadniono sytuacją społeczno-polityczną, w jakiej znalazła się ludność pochodzenia niemieckiego w tym mieście. Odrodzenie polskiej państwowości przyspieszyło widoczny już pod koniec XIX w. proces polonizacji miasta i przyrostu polskiej inteligencji. Choć w latach międzywojennych aktywnie działały liczne organizacje, uświadamiające łódzkim Niemcom ich silny związek z krajem przodków, procesów asymilacyjnych nie sposób było powstrzymać. Ludność niemiecka była ze wszystkich stron otoczona polskim językiem i polską kulturą, zyskującą coraz bardziej na atrakcyjności. Po odzyskaniu przez Polskę niepodległości, wielu niemieckich mieszkańców Łodzi zaczęło przyjmować polskie nazwiska. 0 fakcie tym z dużą dozą ironii pisał C.H. Schultz w felietonie Wie schreiben Sie sich? [Jak Pan się pisze?] ${ }^{28}$ :

27 H. Zimmermann, Das Musikleben in Lodz, Beilage zu Nr. 215 „Neue Lodzer Zeitung”, 13.08.1919, s. 1 [Miasto milionerów nie mogło pozwolić sobie na luksus posiadania własnej orkiestry symfonicznej. Muzyka nie znalazła mecenasów w wielkich przemysłowcach, którzy woleli budować fabryki niż składać ofiarę na ołtarzu sztuki. Tłumaczenie M.K.].

${ }^{28}$ C.H. Schultz, Jak Pan się pisze?, [w:] Literackie i nieliterackie obrazy miasta..., s. 72-74 (Wie schreiben Sie sich, [w:] ibidem, s. 189-190). 
Mam pewnego dobrego znajomego, który onegdaj (czyli przed wojną, a także w latach wojennych) nazywał się August Rosner. Nazwisko to wywodzi się od słowa „Rose” [tj. niem. róża] i już samo jego brzmienie sprawia, że wokół rozchodzi się miły zapach. Później Polska stała się niepodległym państwem i mój przyjaciel Rosner „spolonizował” swe rodowe nazwisko: od tej pory podpisywał się „Rozner”. Podobno tylko dlatego, jak twierdził, żeby Polacy prawidłowo je wymawiali. Próbowałem go przekonać, że nie istnieje żaden powód do innego sposobu jego zapisywania. Nawet jeśli w najgorszym razie jakiś niewykształcony Polak, czytając nazwisko, wymówi je jako „Roßner”, to i tak aspekt fonetyczny wcale na tym nie ucierpi. Wyraziłem natomiast zdanie, że Niemiec, widząc nową pisownię nazwiska, przeczyta je jako „Rotzner”. Moje zastrzeżenia na nic się nie zdały. Ponieważ jednak jestem człowiekiem nieco złośliwym, nazywałem go odtąd panem „Rotznerem” [czyli mniej więcej „Zasmarkanym”], co oczywiście zaowocowało wyraźnym rozluźnieniem naszych wzajemnych kontaktów. On pozostał jednak przy swoim, a ja rozkoszowałem się świadomością, że doprowadzam go do białej gorączki ${ }^{29}$.

Autor felietonu opowiada się jednoznacznie za zachowaniem nie tylko niemieckiej pisowni, ale również pamięci o przodkach; dlatego ironicznie pisze o osobach dążących za wszelką cenę do asymilacji z Polakami. Równie krytycznie odnosi się Schultz do mentalności łodzian, zwracając uwagę na ich głupotę i brak rozwagi w różnych sytuacjach. W felietonie Zauberei. Ein Kulturbild [Czary mary. Z życia kulturalnego] wyśmiewa zabobony, w które wierzyli wówczas mieszkańcy Łodzi:

Niedawno otrzymałem pismo w języku polskim, którego treść brzmi jak następuje: „Życzenia szczęścia i zdrowia. Nie zrywać tego łańcucha - napisz 9 kopii, a dalej ślij je do 9 najwięcej inteligentnych osób z twoich przyjaciół. Pierwszym ogniwem tego łańcucha stworzył we Flandrii jeden porucznik amerykańskiej artylerii i łańcuch ten musi trzy raz obchodzić ziemię. Ślij kopie dalej, najlepiej w 24 godzin od czas otrzymania tego listu. W wypadku zrywania łańcucha dotknie cię nieszczęście. Przez dalsze 9 dni (licz po kolei) napotka cię szczęście, co cię ocali. Gdy nie weźmiesz łańcucha poważnie i nie wyślesz kopii jak należy, dopadnie cię złe fatum. Ta przepowiednia zawsze się wypełnia". Poniżej figurowały nazwiska osób, stanowiących ogniwa „łańcucha szczęścia” - nazwiska najwyraźniej mocno zniekształcone, z których wiele brzmiało przeważnie z włoska (wśród nich arystokratyczne, m. in. „książę René de Bourbon”). Dalej widniały nazwiska największych łódzkich fabrykantów i członków ich rodzin, a na końcu także kilkorga moich znajomych, którzy najprawdopodobniej zainicjowali tę absurdalną zabawę (mam na myśli przesłanie listu na mój adres). Właściwie powinienem im podziękować, że zaliczają mnie do grona „najwięcej inteligentnych ze swych przyjaciół“. Niestety, nie mogę zrewanżować się im tym samym komplementem, gdyż w głębi ducha wcale nie uważam ich za osoby szczególnie inteligentne, skoro przyłączyli się do tego „łańcucha”30.

U progu XX w. Łódź była wielką metropolią przemysłową, liczącą ponad 300 tys. mieszkańców. Jednak za imponującym rozwojem przemysłu nie szedł rozwój miejskiej infrastruktury. W mieście odczuwano powszechny

${ }^{29}$ C.H. Schultz, Jak Pan..., s. 72 (Wie schreiben..., s. 189).

${ }^{30}$ C.H. Schultz, Czary mary. Z życia kulturalnego, [w:] Literackie i nieliterackie obrazy miasta..., s. 75-76 (Zauberei. Ein Kulturbild, [w:] ibidem, s. 191-192). 
brak mieszkań, szkół, szpitali i zielonych parków, zaś szczególnie dotkliwie brak kanalizacji i wodociągów. Ulicami płynęły cuchnące rynsztoki, a ludzie czerpali wodę z płytkich przydomowych studni, skażonych ściekami z mieszkań, fabryk i otwartych ulicznych kanałów. Najgorsze warunki sanitarne panowały w dzielnicach robotniczych, najbardziej w tym czasie przeludnionych i zaniedbanych, kontrastujących - przynajmniej zewnętrznie - z wielkomieszczańskim śródmieściem i domami najbogatszych fabrykantów ${ }^{31}$, a także stale rosnącą liczbą aut, świadczących o wysokim statusie majątkowym i społecznym ich właścicieli. Pod koniec 1935 r. po ulicach Łodzi poruszało się 1009 prywatnych samochodów osobowych, 225 taksówek, 310 samochodów półciężarowych i ciężarowych, 131 autobusów, 508 motocykli, 6726 rowerów i 950 dorożek konnych ${ }^{32}$. Zważywszy, że ponad jedna trzecia łódzkich dróg pozostawała nieutwardzona, można sobie wyobrazić, jak przekładało się to na ruch uliczny. Z tego względu Schultz pisał z przekąsem m.in. o fatalnym stanie łódzkich ulic, o braku kanalizacji i zasad poruszania się po ulicach:

Iluż to automobilistów zupełnie zapomina o konieczności sygnalizowania swych zamiarów albo też w ostatniej chwili uruchamia klakson na maksymalną głośność, tak że pieszy dosłownie kamienieje z przerażenia i kompletnie nie wie, w którą stronę się obrócić. Gdyby jednak w Łodzi wprowadzono zakaz używania klaksonu, zdarzałoby się tu pewnie jeszcze więcej wypadków. Nie należy zatem mylić Łodzi z metropolią z prawdziwego zdarzenia. Szczególnie fatalnie wygląda sprawa automobili podczas deszczu. Nie zważając na koszmarną jakość ulicznego bruku, pokrywającego w 90 procentach ulice naszego uroczego miasta (bo z powodu kanalizacji i innych robót drogowych większości ulic i tak nie sposób porządnie wybrukować), szoferzy beztrosko i z wyraźnie złośliwą uciechą pędzą przed siebie niczym na wyścigach, zupełnie nie troszcząc się o pieszych, poruszających się po chodnikach. Podczas wymijania automobiliści częstokroć jeżdżą nawet niewłaściwą stroną ulicy. Dlatego Bogu ducha winny przechodzień natychmiast zostaje przyozdobiony ulicznym błotem od stóp do głów ${ }^{33}$.

W swoich felietonach niemiecki autor pokazywał przede wszystkim niepowtarzalny klimat miasta, w którym dominującą rolę odgrywały osoby o niemieckim pochodzeniu i które jako takie powoli przestawało istnieć już w okresie międzywojennym. Pisał o tym np. w felietonie Pfingsten in Alt-Lodz [Zielone Świątki w dawnej Łodzi]:

Oczywiście, są jeszcze na świecie „starzy łodzianie”, chętnie wspominający dawne, dobre czasy. Ale trudno się dziwić - w końcu czasy, które minęły, zawsze wydają się piękne.

${ }^{31}$ Por. Łódź. Dzieje miasta...

32 Por. Łódź - monografia miasta, red. S. Liszewski, Łódź 2009, s. 346.

33 C.H. Schultz, Łódzki ruch uliczny, [w:] Literackie i nieliterackie obrazy miasta..., s. 82-83 (Lodzer Strassenverkehr, [w:] ibidem, s. 198-199). Podobny obraz miasta bez kanalizacji, brudnego, pełnego chaosu na ulicach, oddaje Joseph Roth w powieści Hotel Savoy, Berlin 1924. 
Jednak... Łódź przed czterdziestu, pięćdziesięciu laty - to było całkiem inne miasto. Powróćmy więc pamięcią do owych czasów sprzed czterdziestu czy pięćdziesięciu lat ${ }^{34}$.

Zielone Świątki były jednym z najbardziej lubianych świąt, obchodzonym przez łodzian pod koniec maja. Świąteczne dni stwarzały możliwość uczestniczenia w wielu imprezach, organizowanych w miejscowych parkach, restauracjach i ogródkach. W XIX w. Zielone Świątki trwały aż cztery dni, a do dni świątecznych wliczano również zwyczajowo najbliższą niedzielę. W „pierwsze święto" (czyli w niedzielę Zielonych Świąt) łodzianie odwiedzali miejscowy „Schützenplatz”, położony przy Wodnym Rynku obok parku Kwela, w którym ustawiano na tę okoliczność teatrzyki lalkowe, budki strzelnicze, huśtawki, karuzele i stragany ze słodyczami. Imprezom towarzyszył wielobarwny tłum, muzyka, gwar i ogólna wesołość. Wiele radości, szczególnie najmłodszym łodzianom, dostarczały cyrki przybywające z tej okazji do miasta. Każdy łodzianin, uważający się za przedstawiciela lepszej warstwy społecznej, odwiedzał „Schützenhaus” i „Schützengarten”. Kolejne dni świąteczne obchodzono równie uroczyście. Trzeciego dnia w ogródku „Meisterhausgarten” zbierali się strzelcy, członkowie dawnego łódzkiego Towarzystwa Strzeleckiego, i stąd też wyruszał barwny pochód, któremu towarzyszyła miejscowa kapela, wygrywająca na blaszanych instrumentach i na werblu Marsz króla kurkowego. Pochód ciągnął ulicami Piotrkowską i Główną aż do „Schützenhausu”, gdzie spożywano niezwykle obfity obiad, a potem rozpoczynały się zawody „króla kurkowego", trwające aż do wieczora „czwartego dnia”. Wówczas ogłaszano zwycięzców: nowego króla kurkowego, marszałka i rycerza. Łódzkie gazety aktywnie włączały się w te świąteczne obchody, podając do publicznej wiadomości np. liczbę punktów zdobytych przez kandydatów na króla strzelców. Na koniec w „Schützenhausie” odbywał się wielki bal rozpoczynany tradycyjnie polonezem, później zaś tańczono kontry, lancery (kadryle), walce i krojcpolki. Jedną z ulubionych konkurencji towarzyszących zabawie była wspinaczka na wysoki drewniany maszt, na którego szczycie umieszczano nagrodę. Dla utrudnienia i ku ogólnej wesołości widzów słupy smarowano do wysokości kilku metrów szarym mydłem. Zabawom i radości nie było końca. Autor tak podsumowuje niemieckie tradycje, które po I wojnie przeminęły bez śladu:

Tradycja tych zawodów liczyła sobie w Łodzi kilkadziesiąt lat. Ale nawet ona bezpowrotnie zaginęła i nie zastąpią jej żadne lunaparki. Co współcześni łódzcy dwudziesto- czy trzydziestolatkowie o niej wiedzą? Wolą łamać sobie nosy albo nogi, uprawiając boks czy też futbol. Dzisiaj więcej się zresztą myśli nogami niż głową, a hasło brzmi: Pobić rekord! Czy to także kiedyś przeminie? Zielone Świątki za pięćdziesiąt lat - w Łodzi - kto doczeka tych czasów? ${ }^{35}$

${ }^{34}$ C.H. Schultz, Zielone Świq̨tki w dawnej Łodzi, [w:] Literackie i nieliterackie obrazy miasta..., s. 77-78 (Pfingsten in Alt-Lodz, [w:] ibidem, s. 193-194).

35 C.H. Schultz, Zielone Świątki..., s. 77-78 (Pfingsten..., s. 193-194). 
Z nutką nostalgii Schultz zwraca również uwagę na fakt, że „dziś element niemiecki nie kształtuje już charakterystycznego oblicza [tego] miasta"36. Szczególnie wyraźnie widać to w felietonie Lodzer Gassenhauer [Szlagiery łódzkiej ulicy $]^{37}$, poświęconym starym łódzkim piosenkom i przyśpiewkom. Współczesny czytelnik znajdzie tu wiele ciekawych informacji na temat obyczajowości dawnej Łodzi. Autor podkreśla m.in. bogatą tradycję śpiewaczą lokalnej społeczności niemieckiej. Piosenki, o których pisze, można określić mianem piosenek biesiadnych, chodnikowych lub brukowych, wykazujących na różnych poziomach podobieństwa do tradycyjnej pieśni ludowej: poczynając od prymitywizmu treściowo-tematycznego, poprzez operowanie konkretnym czasem i przestrzenią, a także ubóstwo opisu, aż po typizację bohaterów i odwoływanie się do niewyszukanej symboliki oraz ubogiego zasobu leksykalnego. Formalne podobieństwo uprawnia jednak tylko pozornie do postrzegania tej muzyki jako kontynuacji twórczości ludowej, ponieważ chodnikowy repertuar, powstały w Łodzi na przełomie wieków, prezentuje całkowicie odmienną wizję rzeczywistości, związaną ze specyficznym typem obyczajowości i wpisaną w nią hierarchią wartości.

Schultz opowiada m.in. o ówczesnej modzie na przyśpiewki biesiadne (tzw. Rumpellieder), wykonywane przeważnie przez bywalców knajp przy kuflu mocniejszego trunku i przywołuje jedną z nich:

A nasz miły X. niech nam żyje sto lat,

w wielkim dostojeństwie, ku ozdobie dat!

Niechaj go też cieszy wprost książęcy zbytek

jako i nas wszystkich w Rzeczypospolitej!

Więc stukajmy, więc stukajmy...

Hopsa sa sa!

Radujmy się, weselmy, bracia!

Hopsa sa sa!

Może to i głupie, ale my to mamy w.... ${ }^{38}$

Pieśni biesiadne rejestrowały również nowe zjawiska społeczne, oswajając tym samym w pewnym stopniu nowinki i pomagając przywyknąć do nowej rzeczywistości. Takim nowym zjawiskiem było w Łodzi powstanie pod koniec XIX w. Towarzystwa Cyklistów, posiadającego u zbiegu ulic Przejazd i Dzikiej (Dzika to późniejsza Mikołajewska, dzisiejsza Sienkiewicza) własny „cyklodrom”. Osoby nienależące do stowarzyszenia, które chciały opanować sztukę jazdy na bicyklu, ćwiczyły natomiast na Zielonym Rynku. Ciekawscy łodzianie, podpatrujący zmagania śmiałków z niezwykłym pojazdem, ułożyli

${ }^{36}$ C.H. Schultz, Szlagiery łódzkiej ulicy, [w:] Literackie i nieliterackie obrazy miasta..., s. 68 (Lodzer Gassenhauer, [w:] ibidem, s. 185).

${ }^{37}$ C.H. Schultz, Szlagiery łódzkiej..., s. 68-71 (Lodzer Gassenhauer..., s. 185-188).

${ }^{38}$ C.H. Schultz, Szlagiery łódzkiej..., s. 68 (Lodzer Gassenhauer..., s. 185). 
na tę okoliczność wesołą przyśpiewkę do melodii popularnego wówczas marszu Flotte-Studio (Auf der grünen Wiese, czyli Na zielonej łące):

Na Zielonym Rynku

facet jeździ w koło.

A jakiś kurdupel

Prask, kamieniem w koło.

„Mały, puknij że się w czoło!”

"Chłopie, czego kręcisz w koło?

Jakbyś tak w kółko nie frygał,

kamykiem bym nie smyrgał!"39

Łódzkie przyśpiewki odnotowały również fakt oddania na użytek komunikacji miejskiej pod koniec lat 90. XIX w. kolejki elektrycznej, kursującej ze Zgierza do Pabianic. Jej fundatorami byli łódzcy przemysłowcy, założyciele Towarzystwa Kolei Dojazdowych. Piosenka brzmiała mniej więcej tak:

\footnotetext{
Mamy w naszej w Łodzi całkiem nowy wic:

tylko za pięć kopiejek pana Finkela kicz,

za osiem kopiejek jazda pierwszą klasą,

dryń dryń, pomykamy klocowatą trasą ${ }^{40}$.
}

Tematem przyśpiewek łodzianie czynili również łódzkie osobistości, do których zaliczał się m.in. pewien redaktor żydowskiego pochodzenia o nazwisku Kohn. Do Łodzi przybył z Galicji, podając się za wybitnego wiedeńskiego dziennikarza i zatajając swój semicki rodowód. Człowiek ten posiadał jednak bardzo wątpliwe kwalifikacje zawodowe i był powszechnie nielubiany z powodu swej jawnie okazywanej agresji. Także jego żona, śpiewaczka o nie mniej wątpliwych umiejętnościach, wzbudzała w łódzkiej społeczności wiele negatywnych emocji już choćby dlatego, że jej mąż próbował za wszelką cenę wylansować ją jako wielką artystkę ${ }^{41}$. Para wzbudzała tak silną niechęć łodzian, że śpiewano o niej następującą piosenkę chodnikową:

Przy świetle ogni bengalskich spaceru zażyje nawet mały Kohn, bo żonka Rojza na majówkę musi do parku, do Helenówka.

Czy widział Pan może małego Kohna?

Czy tu przechodził, czy mijał Pana?

Ach, bo on w tym okropnym tłumie

\footnotetext{
${ }^{39}$ C.H. Schultz, Szlagiery łódzkiej..., s. 69 (Lodzer Gassenhauer..., s. 186).

${ }^{40}$ Ibidem.

${ }^{41}$ C.H. Schultz, Szlagiery łódzkiej..., s. 70 (Lodzer Gassenhauer..., s. 187).
} 
się nic a nic rozeznać nie umie.

Więc ja wciąż szukam, ze strachu drżąc:

No patrz Pan, przepadł mój mały mąż! $!^{42}$

Powszechną modą wśród łodzian z wyższych sfer były wyjazdy do tzw. wód, czyli krajowych i zagranicznych kurortów uzdrowiskowych. Dla poratowania zdrowia łódzcy przemysłowcy chętnie udawali się do modnych miejscowości, by zażywać kąpieli słonecznych, stosować kuracje mineralne i odbywać spacery po malowniczych okolicach. Najbogatsi wybierali uzdrowiska w Szwajcarii, Austrii, Francji i we Włoszech. Żona Karola Scheiblera, Anna, regularnie wyjeżdżała do belgijskiej Ostendy nad Morzem Północnym, natomiast Juliusz Kunitzer preferował włoskie kurorty ${ }^{43}$. Mniej zamożni łodzianie tłumnie oblegali polskie uzdrowiska, a więc Szczawnicę, Krynicę, Iwonicz, Nałęczów, Inowłódz, Ciechocinek czy też Zduńską Wolę. Również na okoliczność wyjazdu do wód łodzianie ułożyli piosenkę śpiewaną na melodię walca Landstreicher [Włóczęga] Ziehrera. Wychwalano w niej błogi stan bycia słomianym wdowcem po wyjeździe żony:

Każdego lata jedzie moja stara

do cud-letniska Zduńska Wola.

I mówi do mnie, wprost tonąc we łzach:

Ja dziś wyjeżdżam, ty zostajesz sam! ${ }^{44}$

Klimat XIX-wiecznej Łodzi utrwaliły stare łódzkie szlagiery, ale pielęgnowano go również w starych knajpach i restauracjach, w których przygrywały łódzkie orkiestry. Między rokiem 1880 i 1910 Łódź powoli zaczynała nabierać wielkomiejskiego charakteru i - jak zauważyli niektórzy felietoniści - „coraz bardziej zatracała swą dawną "przytulność « ${ }^{45}$. Ogromną popularnością wśród niemieckojęzycznych łodzian cieszył się lokal „Paradyz” przy ul. Piotrkowskiej 175. We frontowym budynku mieściła się przytulna restauracja z letnim ogródkiem, chętnie odwiedzanym przez „starych łodzian”. W lokalu grywały orkiestry wojskowe i nie tylko (goście mogli podziwiać także kunszt muzyków z Orkiestry 37 Jekateryńskiego Pułku Piechoty pod batutą Dietricha, Orkiestry 3 Batalionu Strzeleckiego pod dyrekcją kapelmistrza Hensela, Orkiestry Węgierskiej dyrygowaną przez Pytyo Sandora czy też Węgierskiej Orkiestry Młodzieży pod dyrekcją Filipa Donna-Wella ${ }^{46}$ ).

Ogromne wzięcie miała również pełna uroku restauracja na rogu Piotrkowskiej i Przejazd o nazwie „Meisterhaus”, do której należał też atrakcyjny

42 Ibidem.

43 Por. M. Piestrzeniewicz, Rozrywka łodzian na przełomie XIX i XX w., Łódź 2010, s. 73-74.

${ }^{44}$ C.H. Schultz, Szlagiery łódzkiej..., s. 71 (Lodzer Gassenhauer..., s. 188).

${ }^{45}$ C.H. Schultz, Dawne łódzkie knajpy, [w:] Literackie i nieliterackie obrazy miasta..., s. 86-87 (Alte Lodzer Kneipen, [w:] ibidem, s. 202-204).

${ }^{46}$ Por. M. Piestrzeniewicz, Rozrywka łodzian ..., s. 65. 
ogródek. Można było w niej dobrze i tanio zjeść oraz wypić. W latach 90. i jeszcze na początku XX w. grywała tam, podobnie jak w „Paradyzu”, wojskowa orkiestra, najpierw pod batutą kapelmistrza Dietricha, później Adamczyka, w 1907 r. zastąpiona przez zespół smyczkowy Karla Morgenrota. „Stary »Meisterhaus « - jak pisał Schultz - widywał całe pokolenia łódzkich Niemców" ${ }^{47}$. Łódzkie restauracje i bary odwiedzali najpierw dawni sukiennicy, później fabrykanci, a następnie ich synowie i wnukowie, którzy już kazali sobie podawać prawdziwe francuskie koniaki i szampany. Autor wraca również we wspomnieniach do willi z przyległym ogrodem i stawem na zachodnim krańcu ul. Milscha (Kopernika), nazywanej „Waldschlösschen” [Leśny zameczek]. Latem pływano po stawie łódkami, zimą zaś jeżdżono na łyżwach. $\mathrm{Na}$ obrzeżach terenu należącego do willi znajdował się las, chętnie odwiedzany przez łodzian w czasie majówek.

Jak każde miasto także Łódź posiadała miejsca odwiedzane zależnie od statusu społecznego. Biedniejsza ludność spotykała się w podwórku posesji na rogu Żwirki i Żeromskiego (naprzeciw fabryki Rossenblatta), gdzie stała słynna „Eierbude“ [Budka z jajkami], należąca do niejakiego Markgrafa, w której łodzianie udający się na majówkę mogli kupić gotowane na twardo jajka, a mężczyźni kieliszek alkoholu. Lepsze towarzystwo gromadziło się w restauracji domu koncertowego „Konzerthaus”, który podczas przerw często odwiedzali też widzowie niemieckiego teatru. Gościom serwowano tam dobrą strawę, wyśmienite napitki, muzykę i śpiew, a czas umilał im kwartet fortepianowy, prezentujący się na zmianę z jakimś etatowym komikiem. Przez wiele lat restauracja była własnością Emila Benndorfa, później należała do niejakiego Tamme i braci Vogel.

Schultz wspomina również o restauracji przy „Hotelu Klukasa” na rogu Cegielnianej i Widzewskiej (Kilińskiego), prowadzonej przez małżonków Schnelke. Lokal, urządzony swojsko i przytulnie, odwiedzali licznie niemieccy fabrykanci, aktorzy niemieckiego i polskiego teatru, kupcy, malarze, inżynierowie i dziennikarze, posiadający tu tzw. sztammtysze. W lokalu przygrywał znakomity kwartet muzyczny, prowadzony przez skrzypka Röwera. Schultz tak pisał o atmosferze tego miejsca:

Gdy mniej więcej w okolicach godziny drugiej w nocy tłum gości zaczynał się przerzedzać, „ciotka Anna” zajmowała miejsce przy sztammtiszu i zaczynała opowiadać najnowsze kawały. Były to ostatnie restauracyjne „suflety z dawnej Łodzi”48.

W Łodzi istniały również lokale z eleganckim wystrojem, odwiedzane przez nadzwyczaj doborowe towarzystwo. Należały one do największych hoteli, takich jak Grand Hotel. W restauracji zawsze grał znakomity zespół

${ }^{47}$ C.H. Schultz, Dawne łódzkie..., s. 86 (Alte Lodzer..., s. 202).

${ }^{48}$ C.H. Schultz, Dawne łódzkie..., s. 87 (Alte Lodzer..., s. 203). 
muzyczny Gottlieba Teschnera, a latem w ogrodzie hotelowym dawała koncerty orkiestra symfoniczna (od 1907 r. pod batutą nadwornego kapelmistrza księstwa Altenburg, Richarda Höninga). Również restauracja w hotelu „Manteuffel” zarezerwowana była dla lepszego towarzystwa, do którego należeli niemieccy i polscy dziennikarze, natomiast w restauracji wybudowanego przez Klukowa Hotelu Polskim do końca XIX w. spotykali się wyłącznie Niemcy. Artystyczny światek Łodzi upodobał sobie restaurację przy Teatrze Polskim, w którym następnie urządzono Teatr Miejski ${ }^{49}$, a później po pożarze, jaki wybuchł w 1909 r., kino Casino ${ }^{50}$.

Jako jeden z niewielu autorów Schultz jeszcze przed II wojną światową pisał o łódzkiej niemczyźnie, dając w kilku swoich tekstach próbki tego języka $^{51}$. Lodzerdeutsch, bo o nim tu mowa, można uznać za potoczny język łódzkich Niemców z przełomu XIX i XX w., rozpowszechniony głównie w postaci mówionej ${ }^{52}$. Dotychczas nie zdołała się rozwinąć tradycja pisana, jednak w zbiorach archiwalnych zostały odnalezione krótkie teksty, takie jak felietony, opowiadania, wiersze, fragmenty dramatów i dowcipy, powstałe w Łodzi

${ }^{49}$ Ibidem.

50 Ibidem.

51 Przez wiele lat zagadnienie języka Lodzerdeutsch nie było przedmiotem obszerniejszych opracowań naukowych. Do tej pory ukazało się na ten temat niewiele artykułów, które w dużej mierze miały charakter przyczynkowy. Z powojennych opracowań należy wymienić kilka tekstów Oskara Kossmanna: Lodzer Deutsch, „Freie Presse”, 27.06.1928; Wie sprechen wir?, „Freie Presse”, 19.02.1928; Lodzer Deutsch - ein Stück der Heimat, [w:] Ein Lodzer Heimatbuch, Hannover 1967, s. 200-214; Die Sprache des Lodzer Deutschen, [w:] Das Lodzer Deutsche Gymnasium. Im Spannungsfeld zwischen Schicksal und Erbe 1906-1981, hrsg. v P.E. Nasarski, Berlin-Bonn 1981, s. 34-40. Na temat tego języka piszą również polscy badacze - Roman Sadziński oraz Witold Sadziński. Zob. R. Sadziński, Osadnictwo niemieckie w regionie łódzkim w świetle faktów językowych, [w:] Niemcy w dziejach Łodzi, red. K.A. Kuczyński, B. Ratecka, Łódź 2001, s. 263 oraz R. Sadziński, W. Sadziński, Die Sprache der Lodzer Deutschen, [w:] Studien und Forschung zur Deutschland- und Österreichkunde in Polen, Warszawa 2011, s. 329-339. Oba artykuły dotyczą wpływu różnych dialektów na powstanie Lodzerdeutsch i zawierają glosariusz z typowymi dla tego języka wyrażeniami, ze szczególnym uwzględnieniem zapożyczeń z języka polskiego. Na uwagę zasługuje także artykuł Jörga Riecke: Deutsch in Lodz und ,Lodzer Deutsch: Grundzüge einer Geschichte der deutschen Sprache in Lodz im 19. und 20. Jahrhundert, [w:] Deutsch in multilingualen Stadtzentren Mitel- und Osteuropas, hrsg. v. M. Nekla, V. Bauer, A. Greule, Wien 2008, s. 163-182. Na temat Lodzerdeutscha wypowiadał się również Edmund Effenberger w broszurze Das Lodzerdeutsch. Die Umgangssprache der Deutschen im Lodzer Raum, która jest próbą usystematyzowania cech fonetycznych, gramatycznych i semantyczno-leksykalnych tego języka. Należy jednak zauważyć, że autor nie jest z wykształcenia językoznawcą, pisze zatem z perspektywy bacznego obserwatora, mieszkańca Łodzi i jej wielkiego miłośnika. W ostatnim czasie podjęto kolejne próby opracowania tego języka. Dużą wartość badawczą ma artykuł A. Czechowskiej-Błachiewicz, Lodzer Deutsch / Lodzerdeutsch - język potoczny Niemców łódzkich, [w:] Kultura jako czynnik rozwoju miasta na przykładzie Łodzi, red. V. Krawczyk-Wasilewska, M. Kucner, E. Zimnica-Kuzioła, Łódź 2012, s. 57-78.

52 Por. A. Czechowska-Błachiewicz, Lodzer Deutsch / Lodzerdeutsch..., s. 57-78. 
przed 1939 r. $^{53} \mathrm{~W}$ tekście pt. Lodzer Deutsch [Łódzka niemczyzna: Lodzer Deutsch $]^{54}$ Schultz próbuje w sposób atrakcyjny dla czytelnika opisać najważniejsze cechy tego wariantu niemczyzny. Zwraca przy tym uwagę na wykształcenie swoistego idiomu gwarowego, ściśle związanego z wielokulturową historią miasta. Przybywający do Łodzi niemieckojęzyczni tkacze z Wielkopolski, Śląska, Saksonii, Czech, Brandenburgii i Moraw znaleźli się w środowisku bardzo zróżnicowanym językowo, żyjąc wśród ludności polskiej i żydowskiej, a po powstaniu styczniowym również rosyjskiej. Dlatego wpływy różnych języków i dialektów od początku przenikały do mowy potocznej. W rezultacie powstał Lodzerdeutsch o dominujących cechach gramatyki języka niemieckiego i wyraźnym wpływie dialektów niemieckich ${ }^{55}$. Schultz tak pisał o wielokulturowym środowisku Łodzi i kształtowaniu się tego języka:

Wszyscy nowi osadnicy byli Niemcami, pochodzącymi głównie z Saksonii, Śląska, Brandenburgii i niemieckich Czech. Dlatego jeszcze czterdzieści - pięćdziesiąt lat temu także Łódź (oraz leżące w jej pobliżu przemysłowe miasta i miasteczka) zdominowana była w dziedzinie kultury i języka przez element niemiecki. Jeszcze trzydzieści lat temu (Łódź liczyła wtedy już około 400000 mieszkańców) niektóre dzielnice nosiły takie nazwy jak „Neu-Schlesien” (w łódzkiej niemczyźnie „Nei-Schlesing”), „Böhmische Linie”, „Kamerun” itp. Wśród robotników przeważali Polacy, natomiast większość fabrykantów, dyrektorów, majstrów fabrycznych i innych osób na kierowniczych posadach stanowili Niemcy. Do nich pół wieku wcześniej dołączyli jeszcze fabrykanci żydowscy, którzy z konieczności - nie dysponując fachowcami z własnym rodowodem - kierownicze stanowiska także obsadzali głównie Niemcami. Niemców było więc na tyle dużo, że nawet niektórzy Polacy czasami ulegali „zniemczeniu”, przede wszystkim żeniąc się z kobietami, pochodzącymi z niemieckich rodzin. Obecnie natomiast można zaobserwować częściową asymilację ludności niemieckiej w kierunku polskim.

${ }^{53}$ Moje badania na temat literatury i prasy wielokulturowej Łodzi pozwoliły odnaleźć na przestrzeni ostatnich kilku lat teksty, których fragmenty są najprawdopodobniej pisane w Lodzerdeutsch. Należą do nich m.in.: C.H. Schulz, Lodzer Deutsch, „Der Deutsche Wegweiser”, 13.07.1938, s. 7; idem, Pfingstgespräche, „Der Deutsche Wegweiser”, 28.05.1939, s. 7; tego samego autora fragment wiersza Zeitgemäße Betrachtungen, „Der Deutsche Wegweiser”, 3.07.1938, s. 8; fragmenty dramatu B. Raymonda, Isabella. Motive aus der Komödie der Ehe, Lodz 1928 oraz Wilfrieda Spectatora (ps. Reinhold Piel), Ne Mütze voll Witze aus Lodz und Pabianice, Lodz 1913. Powyższe teksty posłużą do analizy języka, która zostanie przeprowadzona w ramach projektu realizowanego we współpracy z prof. Jörgiem Riecke z Uniwersytetu w Heidelbergu. Jego celem jest opublikowanie antologii niemieckojęzycznych tekstów literackich na temat Łodzi, powstałych zarówno przed, jak i po 1939 r. Po wojnie Niemcy wysiedleni z Łodzi zadbali o to, aby pamięć o ich tradycji, zwyczajach, obyczajach i języku, którym się posługiwali, przetrwała wiele dziesięcioleci. W licznych publikacjach ziomkowskich ukazywały się, począwszy od lat 60. XX w., teksty w Lodzerdeutsch. Są to krótkie opowiadania, anegdoty i wiersze, i to one właśnie obok innych tekstów literackich znajdą się w planowanej antologii.

${ }^{54}$ C.H. Schultz, Łódzka niemczyzna: Lodzer Deutsch, [w:] Literackie i nieliterackie obrazy miasta..., s. 79-81 (Lodzer Deutsch, [w:] ibidem, s. 195-197).

55 Por. E. Effenberger, Das Lodzerdeutsch. Die Umgangssprache der Deutschen im Lodzer Raum, Mönchengladbach 2009/2010, s. 15-16. 
Ojczyste warianty dialektalne niemieckich osadników - a więc saksoński, śląski, brandenburski i niemiecko-czeski - stopiły się z czasem w jeden wspólny dialekt, który wchłonął również niektóre słowa polskie. W ten sposób narodził się tzw. „Lodzer Deutsch”. Oczywiście, wykształcony mieszkaniec Łodzi posługuje się czystą niemczyzną literacką, jednak nie poczytuje sobie za ujmę posiłkować się od czasu do czasu miejscowym „dialektem"56.

Autor omówił też pokrótce cechy fonetyczne języka, zwracając uwagę na podobieństwo $\mathrm{w}$ wymowie z różnymi dialektami niemieckimi. Oto przykład:

Łodzianin przeważnie wymawia głoskę „," jako „trącą” (w sposób typowy dla niemieckiego południa i wschodu), rzadziej zaś jako "gardłową", charakterystyczną dla niemczyzny z północy. Łodzianin nie pała szczególną miłością do rozróżniania form „mir” i „mich” [„mi” i „mnie”], ograniczając się, podobnie jak berlińczycy, do formy „mir” nawet wtedy, gdy jest ona akurat poprawna. Słowo to wymawia zresztą zazwyczaj jak "mia”, tak samo jak nad końcówkę „-er” przedkłada „-a”; dlatego woli mówić „Breslaua”, „wieda”, „Kalenda”, „Lehra”, zamiast „Breslauer” [Wrocławianin], „wieder” [znów], „Kalender” [kalendarz], „Lehrer” [nauczyciel] itd. Słowo „Wurst” [kiełbasa] brzmi w jego ustach jak „Woscht”. „Mir” (albo „mia”) używa się tu niekiedy także, mając na myśli „wir” [my]. Czasami łodzianin posługuje się również wyrażeniami czystej wody berlińskimi, jak przykładowo „von wegen” [a gdzież tam] albo „destowegen” [z tego powodu] $]^{57}$.

Ponieważ język ten wykształcił się w wielokulturowym otoczeniu, występuje w nim znaczna liczba zapożyczeń leksykalnych z języka polskiego, rosyjskiego oraz jidysz. Schultz tak pisze o zapożyczeniach:

Łódzki Niemiec chętnie za to przeklina po polsku i zamiast „Donnerwetter” klnie „psiakrew”, a jakiemuś leniowi wymyśla od „łobuzów”. Poza tym do łódzkiej niemczyzny wkradło się wiele innych polskich słów; są w niej na przykład „Punschken” [pączki] i „Katschken” [kaczki], zaś tzw. „Klammern” nazywają się tu „Gruschken”. Popularnym przekleństwem jest tu ponadto słowo „Jope”, które jednak ma zabarwienie raczej przyjazne, a jego sens można by przetłumaczyć jako „barani łeb”58.

Autor podejmuje również próbę oceny popularności tego języka wśród ówczesnych łodzian. Zauważa, że dla wielu Niemców, szczególnie dobrze wykształconych, łódzki dialekt jest „odrażający”. Wielu z nich określa ów język jako „roh" [surowy], „plump” [ciężki] i „ungeschliffen” [nieokrzesany]. Jednak mimo ambiwalentnych odczuć w stosunku do łódzkiej niemczyzny autor z uznaniem odnotowuje fakt, że łódzcy potomkowie niemieckich osadników fabrycznych na przestrzeni wielu lat zdołali zachować w kraju z obcym językiem swą odrębność, własną kulturę i mowę. Oprócz cech istotnych dla języka autor opisuje również mentalność łódzkich Niemców:

56 C.H. Schultz, Łódzka niemczyzna ..., s. 79 (Lodzer Deutsch..., s. 195).

${ }_{57}$ C.H. Schultz, Łódzka niemczyzna ..., s. 79-80 (Lodzer Deutsch..., s. 195).

58 C.H. Schultz, Łódzka niemczyzna ..., s. 79 (Lodzer Deutsch..., s. 195). 
[...] łódzki Niemiec [...] trzyma się swoich korzeni i pilnie czyta wszystkie trzy niemieckie dzienniki, nie mówiąc już o całym mnóstwie ukazujących się w Łodzi niemieckich tygodników, dwutygodników i miesięczników - no i oczywiście bardzo wiele gazet prosto z Niemiec, czyli „reichsdeutsche Blätter”. Jeśli chodzi o niemieckie poczucie humoru, to tu w Łodzi jakoś niewiele go widać, chociaż łodzianin bardzo lubi wice i dowcipy, zwłaszcza gdy już „zaliczył” kilka „okowitek” (aqua vitae). Sentencje w rodzaju: „Menschenskinder, habt Verstand, fresst Kartoffeln ohne Sand” („Człowieku, miejże we łbie olej i żryj kartofel, choć w gębę kole”) niekoniecznie świadczą o wyjątkowej filozoficznej głębi: „No nee, he?" [„Co, nie?”]

Łódź nie jest tu postrzegana jedynie jako miasto bez kultury, pełne kontrastów i biedy. Według Schultza zasługuje ono nawet na porównanie z Warszawą i Berlinem. W felietonie Ein Spaziergang durch Helenenhof [Spacerkiem po Helenowie $]^{60}$ autor konstatuje:

Tak jak Berlin posiada swą menażerię i ogród zoologiczny, zaś Warszawa swój Ogród Saski i Trakt Królewski, tak Łódź ma swój Park Helenów. Choć park ten pozostaje własnością prywatną, pod względem wielkości i urody śmiało może rywalizować z publicznymi ogrodami innych wielkich miast. Jeśli latem zachodzi potrzeba zorganizowania w Łodzi jakiegoś wielkiego festynu pod gołym niebem, wszystkie instytucje publiczne i prywatne, pragnące z góry zapewnić sobie powodzenie, rezerwują na ten cel Helenów ${ }^{61}$.

Schultz proponuje dość ambitne zestawienie Łodzi z Berlinem czy Warszawą, miastami o zupełnie odmiennym charakterze. Mimo wielostronnej działalności zaborcy, zmierzającej do przekształcenia Warszawy w prowincjonalny ośrodek gubernialny, w czasie gdy Schultz porównywał z nią Łódź, nie przestała ona pełnić funkcji stolicy dla narodu i ważnego ośrodka kulturalnego kraju. Natomiast Berlin, stolica Cesarstwa Niemieckiego, rozwijał się w bardzo szybkim tempie, stając się europejską metropolią kulturalną i przemysłową. Zapierający dech w piersiach przemysłowy rozwój Łodzi wydawał się więc dla Schultza wystarczająca legitymacją, by porównać to miasto z obiema wspomnianymi stolicami, co należy odczytywać jednoznacznie jako wielką nobilitację miejsca i jego mieszkańców.

Jeden ze swoich felietonów Schultz poświęca opisowi parku helenowskiego. W istocie łódzkie parki były wizytówką miasta. Należał do nich m.in. prywatny park Helenów, zwany też letnim salonem Łodzi ${ }^{62}$. Helenów założyli synowie Karola Anstadta w 1881 r. Od początku był przeznaczony dla zamożniejszych łodzian i miał charakter zamknięty. Chętni do jego zwiedzania musieli zapłacić za wstęp i wszelkiego rodzaju atrakcje oferowane spa-

\footnotetext{
${ }^{59}$ C.H. Schultz, Łódzka niemczyzna ..., s. 80-81 (Lodzer Deutsch ..., s. 195-196).

${ }^{60}$ C.H. Schultz, Spacerkiem po Helenowie, [w:] Literackie i nieliterackie obrazy miasta..., s. 66-67 (Ein Spaziergang durch Helenenhof, [w:] ibidem, s. 183-184).

61 C.H. Schultz, Spacerkiem ..., s. 66 (Ein Spaziergang..., s. 183).

${ }^{62}$ Por. S. Gorski, Łódź spółczesna. Obrazki i szkice publicystyczne, Łódź 1904.
} 
cerowiczom. Stylem park helenowski nawiązywał do ogrodów angielskich i francuskich. Nie brakowało tu romantycznych grot, kaskad, pawilonów i długich alejek ocienionych szpalerem rosnących po obu stronach wspaniałych, starych drzew. Wśród nich ukryty był wielki staw z łabędziami, po którym pływały łódki z wioślarzami. Ponadto ogród posiadał muszlę koncertową, w której podczas letnich miesięcy przygrywała lokalna orkiestra pod batutą kapelmistrza Eduarda Webera, oraz wieżę widokową. Odbywały się tu liczne imprezy okolicznościowe, przyciągające tłumy zamożnych łodzian. Park stanowił też centrum sportowe miasta - organizowano w nim wyścigi cyklistów, zawody gimnastyczne i mecze piłki nożnej, a zimą urządzano lodowisko, na którym ćwiczyli łyżwiarze. Atrakcją Helenowa był również ogród zoologiczny z wybiegami dla niedźwiedzi, z klatkami i zagrodami dla dzikich i oswojonych zwierząt, z ptakami, strusiami, małpami, jeżozwierzami, kondorami i lisami.

Park zachwycał nie tylko egzotycznymi zwierzętami, ale również bogatą i oryginalną roślinnością przyciągającą wzrok gości. Pod koniec XIX w. powstał tu ponadto pawilon restauracyjny, w którym sprzedawano piwo produkowane w browarach Anstadta. Opis parku kończy autor stwierdzeniem, że „Łódź może być dumna i rzeczywiście jest dumna ze swego Helenowa”. Jakże odmienny jest ten opis od słów Stefana Gorskiego, który tak postrzegał Helenów:

Jak na park spacerowy za dużo wygód i filisterstwa, ale za drogo płacone wejście łodzianin ma w zamian wszystko, na co stać „salon letni” w stolicy królów bawełnianych. W Helenowie ma się wszystko „na miejscu” - jest to typowy park burżuazji ${ }^{63}$.

Schultz umiejętnie przedstawił również procesy cywilizacyjne zachodzące w Łodzi w latach międzywojnia. Istotne zmiany w jakości infrastruktury miejskiej dotyczyły zwłaszcza rozbudowy sieci elektrycznej, gazowej i miejskiej kanalizacji. Do budowy tej ostatniej przystąpiono w maju 1925 r., zaś w 1934 r. rozpoczęto budowę komunalnej sieci wodociągowej. W okresie międzywojennym poprawiła się także jakość nawierzchni dróg i ulic. W 1935 r. ich ogólna długość wynosiła 357,8 km. Mimo wielu starań aż jedna trzecia łódzkich ulic pozostawała jednak nadal nieutwardzona; jedynie główne arterie miasta pokrywała kostka granitową, jeszcze mniej asfalt, kostka bazaltowa i drewniana. Większość łódzkich ulic brukowano kamieniem polnym $^{64}$. W wierszu Die Verschönerung von Lodz [Upiększanie Łodzi] Schultz dostrzegł pozytywne strony procesu modernizacji miasta:

O Boże, a cóż to znów za lato!

Tak wzdychać musi wielu z nas,
${ }^{63}$ Ibidem, s. 17.
${ }^{64}$ Por. Łódź. Dzieje miasta... 


\author{
w skrytości ducha marząc za to, \\ żeby skończyło się jak raz. \\ Trwa wielka renowacja fasad, \\ stawiają płoty z siatek i sztachet, \\ tam odświeżają okiennice, \\ domom nadają nowy fason. \\ Znów rozkopany bruk uliczny \\ pod całkiem nową kanalizację. \\ Ach, głowa boli wprost od hałasu, \\ ale przynajmniej już się zacznie. \\ Choćby niejeden pokpiwał z boku: \\ No patrzcież państwo, idzie jak z płatka! - \\ gdy farbą w kropki go przyozdobią, \\ zaraz na żarty przejdzie mu chrapka. \\ Gdzie byś nie spojrzał - rusztowania, \\ a już po deszczu - wprost koniec świata! \\ W błoto zapadasz się po kolana, \\ cały rozgardiasz śląc do kata. \\ Lecz przecież inne dni też nadejdą. \\ Wtedy otworzysz zdumione oczy: \\ Łódź nam się wreszcie modernizuje. \\ Skończy się całe to upiększanie, \\ znów zapanuje święty spokój! ${ }^{65}$
}

Łódź wykreowana przez C.H. Schultza jest niewątpliwie miejscem posiadającym własną osobowość. Autor opisywał miasto końca XIX w. z nostalgią, posługując się przy tym swobodnym, wręcz gawędziarskim stylem. Typowe cechy jego utworów to temperament narracyjny, smak, poczucie humoru, swoboda i spostrzegawczość. Autor posługuje się językiem potocznym, by być zrozumiałym dla jak największego grona czytelników. Uwidacznia się to szczególnie w składni i frazeologii z elementami łódzkiej niemczyzny. Felietony Schultza mają ocalić od zapomnienia starą Łódź, która przeminęła i jej dawny charakter, który miasto bezpowrotnie utraciło.

Obraz miasta, jaki wyłania się z omówionych tekstów niemieckojęzycznych autorów, nie jest jednorodny. Z jednej strony Łódź jawi się jako miasto, w którym panuje kult pieniądza, liczy się kariera i etos pracy, z drugiej natomiast to miasto nędzy i powszechnej biedy, którego ulice zdominował chaos i brak zasad, zaś mieszkańców uczynił świadkami upadku wartości moralnych. Teksty, portretujące miasto i mentalność jego mieszkańców, pro-

${ }^{65}$ C.H. Schultz, Upiększanie Łodzi, [w:] Literackie i nieliterackie obrazy miasta..., s. 41 (Die Verschönerung von Lodz, [w:] ibidem, s. 156). 
wadzą narrację w sposób nieskomplikowany i jednowątkowy. Ich autorzy nie są doświadczonymi pisarzami, dlatego ich utwory należy zaliczyć do gatunku literatury popularnej, kreującej obraz rzeczywistości w sposób dość schematyczny.

Nie wolno jednak zapominać, że właśnie owe teksty posiadają wartość dokumentu, poświadczającego atmosferę tamtych czasów i dostarczają współczesnemu czytelnikowi cennych informacji o minionej epoce, zaś dla współczesnego badacza Łodzi stanowią istotne źródło wiedzy o klimacie miasta z przełomu wieków, utrwalonym w zapiskach Schultza. 



\section{ZAKOŃCZENIE}

Na początku XIX w. Łódź była miastem bez przeszłości, w którym nie istniało życie kulturalne i literackie. Przybywający do miasta osadnicy zaczynali budować wszystko od nowa. Posługiwali się przy tym wzorcami kulturowymi, które przywieźli ze swoich małych ojczyzn. Na przestrzeni kilkudziesięciu lat rozwinęła się literatura charakterystyczna tylko dla tego miejsca. Jej rozwój był niezależny od ówcześnie panujących nurtów literackich zarówno polskich, jak i niemieckich. W początkowym okresie dźwigała się z niebytu - w latach 30. XIX w. zaczęły powstawać teksty o charakterze okazjonalnym, w tym pieśni religijne. Na pierwszy plan wysunęła się twórczość luterańskich pastorów, którzy stali się luminarzami niemieckiej literatury. Niezwykle aktywnymi działaczami byli pastor Fryderyk Gottlob Metzner, pastor August Hermann Müller czy Rudolf Gustaw Gundlach. Kiedy w mieście pojawiły się pierwsze niemieckie gazety, na ich łamy wkroczyła twórczość lokalnych autorów. Oprócz pastorów twórczością literacką zaczęli zajmować się dziennikarze, uczniowie szkół średnich, nauczyciele i działacze polityczni. Należeli do nich m.in. Wilhelm Jess, Berta Teplitzka, Reinhold Piel, Heinrich Zimmermann, Alexis Drewing. Tworzyli oni proste teksty, a wśród nich wiersze, opowiadania, felietony oraz pierwsze dramaty, które odzwierciedlały nie najlepszą kondycję literacką łódzkiego społeczeństwa.

Tematyka pierwszych tekstów była dość banalna. Burzliwemu rozwojowi miasta, przemysłu, techniki, a także stosunkom społecznym i konfliktom poświęcano niezbyt dużo miejsca w porównaniu z ówcześnie powstającymi utworami polskich autorów. Należy przecież pamiętać, iż w pierwszym okresie rozwoju niemieckojęzycznej literatury, czyli do 1914 r., polscy pisarze zdobyli się na kilka powieści o tym mieście, z których najważniejsza to Ziemia obiecana Władysława Stanisława Reymonta, ale przytoczyć trzeba również wcześniej przywoływaną Bawełnę Wincentego Kosiakiewicza czy Wśród kqkolu Walerii Marrené-Morzkowskiej. Niemieckojęzyczna literatura wykazuje w porównaniu z polską dość duże opóźnienie. Dopiero w okresie późniejszym powstają pierwsze obrazy miasta, choć są one mało wyraźne i na pewno brak jest wśród nich wizerunków miasta na miarę reymontowskiej powieści (Schultz, Raymond). Natomiast podobnie jak polscy literaci i publicyści, 
niemieckojęzyczni pisarze podjemują w prostych felietonach i dowcipach zagadnienie fenomenu Lodzermenscha. Stoi on jednak w wyraźnej kontrze do polskich opisów. Polski Lodzermensch, o czym świadczą pierwsze teksty (Gorski, Reymont, Laskowski, Kosiakiewicz), jest postacią negatywną, zdegradowaną moralnie, bez ojczyzny, cyniczną. Niemieckojęzyczni pisarze natomiast, w tym Teplitzka, wyposażają Lodzermenscha w konglomerat cech pozytywnych. Łodzianie odznaczają się nieprzeciętnym zmysłem do interesów, które uprawiają z wielką finezją. Są poza tym inicjatorami nowych idei, siłą napędową łódzkiej przedsiębiorczości (Raymond). Autorzy ci mają również wiele dystansu do tej postaci, opisując ją w niezwykle żartobliwy sposób (Piel).

Łódzka literatura starała się reagować na wielkie wydarzenia polityczne. I wojna światowa wciągnęły w swą orbitę lokalnych literatów usiłujących włączyć problemy i spory światopoglądowe, ideologiczne i polityczne w wielogłos opisujący i zmieniający świat. Niemieckojęzyczna literatura Łodzi stała się w tym okresie ważną częścią narracji zaangażowanych w dyskurs polityczny. Wyzwoliła ona ekstremalne postawy: z jednej strony niechęć i wrogość wobec działań wojennych (Jess, Bräutigam, Abel czy Zimmermann), z drugiej zaś poparcie (Flierl, Grüner). Tematyka wojenna była podejmowana już nie tylko w wierszach, ale przede wszystkim na łamach pamiętników, dzienników czy innych relacji z pól walki.

W okresie międzywojennym istotne miejsce w łódzkiej literaturze zajmował nurt Heimatdichtung (Will, Banek, Eichler, Malzahn, Utta). Różnił się on wprawdzie od tego aktualnie rozwijającego się w Rzeszy, ale cieszył się dużą popularnością wśród sporej części społeczeństwa łódzkiego. W tym czasie wiele miejsca pisarze poświęcają aktualnym zagadnieniom politycznym (Schultz). Nie brakuje również zwykłych tematów - łódzkiej codzienności. Na plan pierwszy wysuwa się reprezentowana przez wielu autorów poezja okolicznościowa (Kreutz, Kargel, Thiem, Abel). W końcu tego okresu pojawia się twórczość powieściowa oraz kolejne utwory dramatyczne, w których pobrzmiewa temat tożsamości jednostki w wielokulturowym mieście, a przykładem są tu powieści i dramaty Bruno Raymonda, autora tworzącego w języku polskim i niemieckim. Zapewne jego twórczość można potraktować jako zwrot ku tematyce ambitniejszej, ciekawszej z perspektywy wielokulturowości, jednakże wybuch II wojny światowej położył kres jej dalszemu rozwojowi.

Literatura, która powstawała w Łodzi na przestrzeni tych kilkudziesięciu lat, nie da się zamknąć w jednej gotowej formule. Na pewno była różnorodna, bowiem tworzyli ją głównie pisarze-amatorzy, niezwiązani na ogół z żadną szkołą warsztatową czy konkretnym nurtem literackim (wyjątek mogą stanowić tu pisarze z kręgu Heimatdichtung). Tworzyli tak, jak im w duszy gra- 
ło. W wielu przypadkach stawiali pierwsze kroki na polu literackim (Abel, Schultz), a ich świadectwa drukowała lokalna prasa. Nie tworzyli zatem prawdziwego środowiska literackiego, które posiadałoby różnorakie instytucje wspierające rozwój literatury w społeczeństwie i ich indywidualną twórczość. Rolę tych placówek, na ile było to możliwe, przejęła prasa, jak również szkoła, powołująca do życia najróżniejsze kółka zainteresowań, w ramach których młodzież poznawała literaturę oraz różnorakie organizacje kulturalne, organizujące odczyty literackie czy zakładające biblioteki. Były to oczywiście niewystarczające inicjatywy, aby wśród twórców wykształcić jednostki wybitne, które przebiłyby się do świadomości czytelnika ogólnopolskiego. Na pewno wybijającą się postacią na gruncie lokalnym był Carl Heinrich Schultz, pisarz wszechstronny, którego twórczość obejmowała wiersze okolicznościowe, felietony, opowiadania, reportaże, artykuły publicystyczne oraz działalność przekładową. Oprócz niego na uwagę zasługuje również poeta-pastor Philipp Kreutz, który przez długi czas był związany z Łodzią.

Literatura, którą tworzyli niemieckojęzyczni pisarze, ignorowała współczesne prądy literackie. Autorzy nie czerpali ani z nurtów modernistycznych, ani z epoki weimarskiej. Nie opisywali fabryk łódzkich, wielkiego miasta czy maszyn, nie fascynowali się nimi. Brakowało w ich twórczości estetyki brzydoty, która stosowana była w niemieckim naturalizmie. Stylizowane opisy przyrody wykorzystywały bezrefleksyjnie toposy romantyczne, które cofnęły tę twórczość do XVIII-XIX w. Ma ona zatem charakter epigonalny, który zapewne z jednej strony wziął się z wielkiego zamiłowania do klasyki weimarskiej i jej przedstawicieli, tak chętnie omawianych na lekcjach niemieckiego $\mathrm{w}$ ramach kółek literackich czy też upamiętnianych przy okazji różnych jubileuszy. Z drugiej strony odwoływanie się do klasyki weimarskiej oraz niemieckiego romantyzmu miało na celu podtrzymywanie tożsamości kulturowej, która w XX w. zanikała wśród łódzkiej społeczności niemieckiej. Mimo iż literatura ta pozostawała obojętna wobec ówczesnych zjawisk literackich, to nie należy jej całkowicie przekreślać. Jak słusznie zauważył Eugen Nippe, w odniesieniu do twórczości Sigismunda Banka współcześni awangardowi poeci byli dla niego luksusem L'art pour l’art, na który nie mógł sobie po prostu pozwolić ${ }^{1}$. Słowa te mogą być odniesieniem dla całego łódzkiego środowiska pisarzy-amatorów. Byli zbyt słabi, za mało wykształceni i bez większego doświadczenia literackiego, aby zrozumieć zjawiska zachodzące na polu literackim. Pozostali do końca, czyli do wybuchu II wojny światowej, grupą zamkniętą, rzadko nawiązującą kontakty z pisarzami polskimi czy niemieckimi. Dlatego brak jest recepcji tej literatury. Niemniej jednak teksty

${ }^{1}$ Por. E. Nippe, Sigismund Banek. Ein ganzes Leben für den Dienst am Volk, [w:] Der Deutsche Schul- und Bildungsverein zu Lodz. Erinnerungsschrift zum 50. Jahrestag seiner Gründung, hrsg. v. H. Markgraf, F. Weigelt, Weinheim 1957, s. 47-50. 
niemieckojęzycznych łodzian stanowią niezwykle istotną część historii miasta, jego kultury i literatury. Należy je traktować jako swoiste źródło wiedzy o Łodzi oraz jej mieszkańcach. Bowiem to właśnie ci prości poeci i pisarze kształtowali świadomość literacką ówczesnego łodzianina i współokreślali jego tożsamość, dlatego warto dokładniej się im przyjrzeć.

Na zakończenie należy podkreślić, iż niniejsza książka jest pierwszą tego rodzaju próbą usystematyzowania badań nad literaturą niemieckojęzycznych łodzian. Jej celem było zapełnienie ważnej z perspektywy szeroko pojmowanych dziejów Łodzi luki badawczej. Praca wprowadziła do stanu wiedzy nowe nazwiska i utwory, które nie były do tej pory obecne w społecznej świadomości, uporządkowała chronologicznie rozwój tej literatury, ukazała najczęściej podejmowane tematy oraz stosunek wobec ówczesnych prądów literackich. Jednocześnie należy nadmienić, że publikacja ta nie rości sobie praw do całościowego opracowania tematu, jest zaledwie wstępem do badań, które warto podjąć w przyszłości. 


\section{ANEKS}

\section{Łódzkie sylwetki}

W niniejszym aneksie zostały zebrane życiorysy łódzkich pisarzy, dziennikarzy, wydawców i działaczy politycznych związanych z łódzkim środowiskiem literackim. Wiele z nich było niedostępnych czytelnikowi z uwagi na rozproszenie $\mathrm{w}$ różnych archiwach lub występowanie $\mathrm{w}$ różnorodnych kontekstach. Przykładem może być Theodore Abel, znany do dziś na całym świecie jako socjolog, który do tej pory nie funkcjonował w przestrzeni literackiej Łodzi, choć jego utwory chętnie drukowano w lokalnych gazetach niemieckich. To samo dotyczy działaczy politycznych, np. Adolfa Eichlera i Alberta Breyera - również oni znani są głównie z działalności politycznej i społecznej na rzecz mniejszości niemieckiej, natomiast zupełnie nieznana pozostaje ich twórczość literacka. Podobnie jest w przypadku Alexisa Drewinga, redaktora „Neue Lodzer Zeitung”. Z uwagi na sposób przedstawianych informacji aneks mógłby stanowić przyczynek do tworzenia bazy pisarzy Łodzi i regionu łódzkiego.

\footnotetext{
Abel Theodor(e) (1896-1988), pisarz, socjolog. Urodził się w Łodzi w rodzinie niemieckich fabrykantów. Przodkowie ojca Teodora byli anabaptystami (huterianami), którzy przywędrowali do Polski z Westfalii w XVIII w., uchodząc przed prześladowaniami. Matka Jadwiga z domu Lorenz pochodziła z rodziny o włoskich korzeniach. Oboje rodzice byli ewangelikami. Theodore Abel uczęszczał do szkół w Łodzi z wykładowym językiem niemieckim, brał również potajemnie lekcje polskiej historii i literatury. W czasach szkolnych świetnie opanował język angielski, co odegrało niebagatelną rolę w jego późniejszej karierze zawodowej. W 1914 r. uzyskał maturę. Jako młody, zdolny poeta skierował swe pierwsze próby literackie do lokalnej niemieckiej gazety „Neue Lodzer Zeitung”. Wydawca i właściciel gazety, Aleksander Milker, zaintrygowany talentem pisarskim młodego człowieka, zaproponował mu stanowisko w redakcji. Abel pracował w gazecie do 1918 r. Nie zamierzał jednak zajmować się wyłącznie pracą dziennikarską, pragnął bowiem podjąć studia matematyczne u sławnego Dawida Hilberta w Getyndze. Wybuch wojny pokrzyżował jego plany, dlatego w 1918 r. rozpoczął studia na Uniwersytecie Warszawskim, na Wydziale Prawa. Wojna polsko-bolszewicka ponownie przekreśliła jego marzenia. Zgłosił się
} 
wówczas jako ochotnik do I pułku artylerii konnej i walczył na froncie lwowskim. Ranny w bitwie pod Przemyślem dostał się do niewoli, z której uciekł. Ponownie wrócił do armii, by wziąć udział w ofensywie kijowskiej. Był oficerem łącznikowym YMCA w oddziałach obsługujących jednostki frontowe. W $1920 \mathrm{r}$. wydał publikację poświęconą historii tej organizacji. Po zakończeniu wojny powrócił na studia prawnicze, uczestnicząc w wykładach prawnika, socjologa i filozofa Leona Petrażyckiego, a także Tadeusza Kotarbińskiego. W 1920 r. przeniósł się wraz z rodzicami do Poznania, a rok później rozpoczął studia socjologiczne oraz filozoficzne na tamtejszym uniwersytecie. Był studentem m.in. Floriana Znanieckiego, Michała Sobeskiego oraz Adama Żółtowskiego. W połowie $1923 \mathrm{r}$. Abel wyjechał na stypendium do Columbia University w Nowym Jorku, gdzie w 1925 r. uzyskał dyplom magistra. Po studiach zaproponowano mu etat assistant professor na Wydziale Socjologii. W latach 1925-1929 pracował jako wykładowca, a później zastępca profesora na Unversity of Illinois. Doktorat otrzymał w 1929 r. w Columbia University. W latach 1933-1934 przebywał w Niemczech, gdzie ogłosił konkurs na najlepszą historię życia zwolennika Hitlera. W ramach konkursu zgromadził ponad 600 pamiętników aktywistów NSDAP, na podstawie których przygotował monografię Why Hitler Came Into Power. Praca, która ukazała się w 1938 r., była wznawiana w 1965 r. oraz 1986 r. i należy do klasycznej literatury na temat nazizmu. Jest również powszechnie uznaną pozycją w socjologii światowej. Do $1967 \mathrm{r}$. Abel pracował naukowo jako profesor zwyczajny. Był dyrektorem Instytutu Socjologii w Hunter College, the University of New York oraz Dziekanem Wydziału Socjologicznego. Jako emerytowany profesor wykładał w katolickich uczelniach Notre Dame University w Indiana, University of Waterloo w Kanadzie oraz University of New Mexico w Albuquerque. Prace naukowe publikował w języku angielskim, natomiast twórczość literacką w języku niemieckim. Był autorem dziennika, który prowadził od 1930 r. Dziennik obejmuje 23 pisane po angielsku tomy, zawierające komentarze na temat dramatycznych wydarzeń historycznych, codziennych zdarzeń, podróży do Polski, sprawozdania z dyskusji intelektualnych i działań politycznych. Wybór źródeł: R. Bierstedt, Teodor Abel (1896-1988), [w:] International Encyklopedia of the Social Sciences. Biographical Supplement, ed. D.L. Sills, vol. 18, New York 1979, s. 1-4; H. Schoeck, Abel, Theodore, [w:] Internationales Soziologenlexikon, hrsg. v. W. Bernsdorf, H. Knospe, Bd. 2, Stuttgart 1984, s. 2; Z. Dulczewski, Teodor Abel (1896-1988), „Kultura i Społeczeństwo” 3-4/1989, s. 89-102; E. Hałas, Oni podzielali wizję, czym powinna być socjologia. Teodor Abel (1896-1988), „Przegląd Polonijny” 15(4)/1989, s. 99-104; E. Hałas, Socjologia i socjologowie w perspektywie autobiograficznej. Theodor Abel: Dziennik myśli i wydarzeń, „Kultura i Społeczeństwo” 4/1994, s. 165-185; Teodor Abel o Florianie Znanieckim. Wybór z dziennika. Wybrała, przełożyła, opatrzyła wstępem i przypisami Elżbieta Hałas, Lublin 1996; E. Hałas, Abel Theodore Fred, [w:] Leksykon kultury polskiej poza krajem od roku 1939, t. 1, Lublin 2000, s. 1-3; W. Wincławski, Abel Theodore, [w:] Słownik biograficzny socjologii polskiej, Warszawa 2001, s. 1-3.

Adler Jankiel (1895-1949), żydowsko-polski malarz, grafik i poeta. Wybór źródeł: J. Ładnowska, Jankiel Adler (1895-1949) - malarz polsko-żydowski, malarz żydowsko-polski, „Tygiel Kultury” 7-9/2000; M. Stolarska-Fronia, Adler Jankiel, [w:] Żydzi polscy. Historie niezwykłe, Warszawa 2010, s. 5-7. 
Althaus Paul (1888-1966), pastor, teolog ewangelicki. Studia odbywał w Tybindze i Getyndze. Od 1919 r. był profesorem w Rostocku, od 1925 r. w Erlangen. Głównymi obszarami jego działalności była dogmatyka, teologia św. Pawła i teologia Marcina Lutra. Zasłynął z kontrowersyjnych poglądów na temat narodowego socjalizmu, za którym się opowiadał oraz z postawy antysemickiej. Z przyczyn zdrowotnych nie mógł bezpośrednio uczestniczyć w działaniach wojennych. Ponieważ jednak nie był jeszcze księdzem i nie mógł zaciągnąć się do armii jako kapelan wojskowy, zgłosił się na ochotnika do pomocy medycznej w lazarecie. W listopadzie 1914 r. wyruszył wraz z armią na front wschodni do Królestwa Polskiego. Początkowo pełnił służbę jako sanitariusz, potem zaś został ordynowany i przejął obowiązki kapelana wojskowego. W połowie sierpnia 1915 r. przybył do Łodzi, gdzie pozostał już do końca wojny. Wybór źródeł: W. Lohff, Paul Althaus, [w:] Tendenzen der Theologie im 20. Jahrhundert. Eine Geschichte in Porträts, hrsg. v. H.-J. Schultz, Stuttgart-Berlin-Freiburg 1966, s. 296-302; P. Knitter, Die Uroffenbarungslehre von Paul Althaus - Anknüpfungspunkt für den Nationalsozialismus? Eine Studie zum Verhältnis von Theologie und Ideologie, „Evangelische Theologie” 2/1973, s. 138-164; K. Meier, Der evangelische Kirchenkampf, Bd. 1: Der Kampf um die „Reichskirche“, Halle 1976; H. Graß, Paul Althaus, [w:] Theologische Realenzyklopädie, hrsg. v. G. Krause, G. Müller, Bd. 2, Berlin-New York 1978, s. 329-337; G. Denzler, Volker Fabricius: Die Kirchen im Dritten Reich. Christen und Nazis Hand in Hand?, Bd. 1: Darstellung, Frankfurt/Main 1984; R.P. Ericksen, Theologen unter Hitler. Das Bündnis zwischen evangelischer Dogmatik und Nationalsozialismus, München-Wien 1986; W. Mann, Ordnungen der Allmacht. Paul Althaus der Jüngere über die Ordnungen, Hannover 1987; K. Scholder, Die Kirchen und das Dritte Reich, Bd. 1: Vorgeschichte und Zeit der Illusion 1918-1934, München 2000; G. Besier, Die Kirchen und das Dritte Reich, Bd. 3: Spaltungen und Abwehrkämpfe 1934-1937, Berlin-München 2001; F. Lohmann, Ein Gott - zwei Regimente. Überlegungen zur "Zwei-Reiche-Lehre" Martin Luthers im Anschluss an die Debatte zwischen Paul Althaus und Johannes Heckel, „Luther” 3/2003, s. 112-138.

Banek Sigismund (1896-1945), niemiecki nauczyciel, pisarz. Urodził się na Kujawach w miejscowości Synogac, a lata młodości spędził w Sompolnie, gdzie ukończył szkołę podstawową. Z wykształcenia był nauczycielem, absolwentem niemieckiego Seminarium Nauczycielskiego w Łodzi. Od 1930 r. zaangażował się w działalność Lodzer Deutsches Schul- und Bildungsverein (LDSBV). W ramach związku organizował pracę kół młodzieżowych, wieczory autorskie i spotkania muzyczne. Oprócz pracy nauczyciela Banek zajmował się również bibliotekarstwem, działalnością społeczną i polityczną. Od 1939 r. pracował jako kierownik biblioteki miejskiej w Łodzi. Jego twórczość literacką publikowały miejscowe gazety niemieckojęzyczne i kalendarze. W 1944 r. wstąpił do Wehrmachtu. Zginął najprawdopodobniej w okolicach Poznania na polu walki. W 1939 r. ukazał się tom zbiorowy utworów Banka Werk und Wehr (Poznań 1939), zaś w 1940 r. opublikowano w Berlinie cykl jego wierszy Aufbruch und Heimkehr (Berlin 1940). Teksty Banka przedrukowano również w tomie Rufer des Ostens, zredagowanym przez Huberta Müllera (Posen 1941). Wybór źródeł: A. Kargel, Letztes Zusammensein mit Sigismund Banek, „Weg und Ziel” 3/1954, s. 6; E. Nippe, Sigismund Banek. Ein ganzes Leben für den Dienst am Volk, [w:] Der Deutsche 
Schul- und Bildungsverein zu Lodz. Erinnerungsschrift zum 50. Jahrestag seiner Gründung, hrsg. v. H. Markgraf, F. Weigelt, Weinheim 1957, s. 47-50; R. Kornacker, Unsere mittelpolnischen Heimatgebiete im Lichte ihrer Persönlichkeiten, „Jahrbuch Weichsel-Warthe" 52/2006, s. 122-132.

Barczyński Henryk (Henoch) (1896-1941), malarz, grafik pochodzenia żydowskiego, członek grupy Jung Idysz. Wybór źródeł: J. Pollakówna, Malarstwo polskie, t. 5: Między wojnami 1918-1939, Warszawa 1982; J. Sandel, Barczyński (Barciński) Henryk (Henoch), [w:] Słownik artystów polskich i obcych w Polsce działających. Malarze, rzeźbiarze, graficy, t. 1: A-C, Wrocław-Warszawa-Kraków-Gdańsk 1971, s. 213-214; K.T. Witczak, Słownik biograficzny Żydów tomaszowskich, Łódź-Tomaszów Mazowiecki 2010, s. 32-35.

Bartkiewicz Zygmunt (1867-1944), pisarz, felietonista, reporter. Absolwent Wyższej Szkoły Handlowej Kronenberga. Debiutował w 1898 r. felietonami w „Gońcu Łódzkim” i „Rozwoju”. Pierwszą nowelę opublikował w 1899 r. w „Gońcu Łódzkim” i warszawskiej „Gazecie Porannej”. W latach 1903-1905 współpracował z petersburskim „Krajem” i „Kurierem Warszawskim”. Autor takich utworów, jak: Z mroków życia (1908), Złe miasto. Obrazy z 1907 r. (1911), Papuga (1913), Psie dusze (1910), Historia jednego podwórza (1922), Stare gniazda - nowe ptaki (1909). W 1928 r. otrzymał za wybór nowel Polityka w lesie (1925) nagrodę im. E. Orzeszkowej. W 1935 r. został odznaczony złotym Wawrzynem PAL. Wybór źródeł: Z. Dębicki, Zygmunt Bartkiewicz, [w:] Portrety, Warszawa 1927; „Trzy listy prababki” i inne opowiadania, posłowie J. Bartnicka, Warszawa 1959; E. Kozikowski, Zygmunt Bartkiewicz, [w:] Łódź i pióro, Łódź 1972; J. Nowakowski, Proza Z. Bartkiewicza, J. Germana, A. Konara, Rzeszów 1976.

Behrens Eduard von (1877-1940), syn niemieckiego pastora z Modlina. Był konsulem rosyjskim na Dalekim Wschodzie, referentem do spraw Kościoła Ewangelickiego w Ministerstwie Wyznań i Oświecenie rządu J. Moraczewskiego, dyrektorem agendy Zgromadzenia Kupców Polskich w Warszawie, a także tajnym informatorem Biura Wywiadowczo-Prasowego i dyrektorem wydawnictwa „Lodzer Freie Presse". Wraz z pastorem Juliuszem Dietrichem stanął na czele łódzkiego Zarządu Deutschtumbund i zorganizował nacjonalistyczne wydawnictwo „Libertas" z siedzibą w Łodzi przy ul. Piotrkowskiej 86. Po 1923 r. przebywał w Niemczech. Wybór źródeł: D.B. Lakeberg, Die deutsche Minderheitenpresse in Polen 1918-1939 und ihr Polen- und Judenbild, Frankfurt/Main i in. 2010.

Berlewi Henryk (1894-1976), malarz, grafik, krytyk sztuki żydowskiego pochodzenia. Absolwent warszawskiej Szkoły Sztuk Pięknych. Wybór źródeł: Z. Baranowicz, Polska awangarda artystyczna 1918-1939, Warszawa 1979.

Blumenthal Oscar (1852-1917), niemiecki pisarz i krytyk literacki, wydał m.in. dzieła Christiana Dietricha Grabbego. Współpracował z wieloma czasopismami literackimi, m.in. „Berliner Tageblatt”. Znany ze swoich krytycznych opinii jako „krwiożerczy Oskar". W latach 1888-1897 dyrektor Teatru im. Lessinga w Berlinie. W do- 
datku do „Neue Lodzer Zeitung” opublikowano m.in. utwór wierszowany pt. Oster Bilanz, „Illustrierte Sonntagsbeilage Neue Lodzer Zeitung”, 16/3.04.1911. Wybór źródeł: K. Richter, Blumenthal, Oskar. [w:]: Neue Deutsche Biographie (NDB), Bd. 2, Berlin 1955, s. 333.

Blüthgen Klara (1856-1934), niemiecka pisarka, autorka nowel, wierszy, opowiadań, m.in. Aus der Art geschlagen, 1893; Gute Kameraden, Das weiße Kleid, Frau Hedwig, Im Sonnenschein, Illusion perdue, Die Ichform, 1897; In Seeleneinsamkeit (wiersze), 1898; Tintentropfen (aforyzmy), 1898; Hand in Hand, 1899; Frauenehre, Zwischen Gräbern, Nur eine Episode (opowiadania), 1901; Liebesleute, 1901; Das böse Buch (szkice), 1902; Dilettanten des Lasters (powieść), 1902; Wenn die Schatten wachen (powieść), 1903; Zwischen zwei Ehen (powieść), 1905; Meine fixe Idee und andere Geschichten, 1916; Brillanten und andere heitere Geschichten, 1919. „Illustrierte Sonntagsbeilage” zamieściła 18.02.1917 r. jej opowiadanie pt. Therese. Wybór źródeł: F. Brümmer, Lexikon der deutschen Dichter und Prosaisten vom Beginn des 19. Jahrhunderts bis zur Gegenwart, Bd. 1, Leipzig 1913, s. 268-269; E. Friedrichs, Die deutschsprachigen Schriftstellerinnen des 18. und 19. Jahrhunderts. Ein Lexikon, Stuttgart 1981, s. 29.

Bock Alfred (1859-1932), pochodzący z Gießen fabrykant i pisarz żydowskiego pochodzenia, honorowy doktor uniwersytetu im. Justusa Liebiga w Gießen, w 1924 r. otrzymał nagrodę im. Georga Büchnera. Jego opowiadanie pt. Der Orgelbauer von Trient zamieszczono w „Illustrierte Sonntagsbeilage. Neue Lodzer Zeitung. Handels- und Industrieblatt”, 24.08./6.09.1903. Wybór źródeł: F. Droop, Alfred Bock. Ein Lebens- und Schaffensbild, Marburg 1919; M. Keuerleber, Alfred-Bock-Bibliographie, Fernwald 1990; M. Keuerleber, Alfred-Bock-Lesebuch, Fernwald 1991; M. Keuerleber, Untersuchungen zum Werk Alfred Bocks, Frankfurt/Main i in. 1996; Ein Straßenname in Gießen und „Ein Sucher nach dem Herzen der Dinge“. Der Schriftsteller Alfred Bock, [w:] Literarisches Leben in Oberhessen, Gießen 1993; Alfred Bock (1859-1932). Ein Gießener Schriftsteller. Ausstellungskatalog, Gießen 1979.

Braun Mieczysław (1902-1941 lub 1942), polski poeta i adwokat żydowskiego pochodzenia. W 1919 r. publikował wiersze w „Głosie Polskim“, później w czasopismach „Skamander”, „Wiadomości Literackie”, „Nowa Sztuka”, „Zwrotnica”, „Almanach Nowej Sztuki” oraz łódzkich gazetach „Republika” i „Express Ilustrowany”. W 1927 r. publikował w „Naszym Przeglądzie”, w latach 1935-1939 w „Naszej Opinii”, zaś w okresie 1937-1938 w „Sterze”. Współpracował z „Nową Kulturą”. Był współpracownikiem „Kultury Robotniczej”, legalnego organu Komunistycznej Partii Robotniczej Polski. Wybór źródeł: J. Jagielski, Przewodnik po cmentarzu żydowskim w Warszawie przy ul. Okopowej 49/51, z. 1: Kwatery przy Alei Głównej, Warszawa 1996, s. 82-83; Żydzi dawnej Łodzi. Słownik biograficzny Żydów łódzkich oraz z Łodziq̨ zwiq̨zanych, t. 1, Łódź 2001.

Brauner Ida (1891-1949), siostra Wincentego Braunera, malarka żydowskiego pochodzenia. Wybór źródeł: J. Malinowski: Grupa „Jung Idysz” i żydowskie środowisko „Nowej Sztuki” w Polsce: 1918-1923, Warszawa 1987. 
Brauner Wincenty (1887-1944), malarz, grafik, metaloplastyk, scenograf żydowskiego pochodzenia. Wybór źródeł: J. Malinowski: Grupa „Jung Idysz" i żydowskie środowisko „Nowej Sztuki” w Polsce: 1918-1923, Warszawa 1987.

Bräutigam Robert (?), dyrygent orkiestry symfonicznej, fagocista, śpiewak oraz poeta. Był członkiem zarządu Stowarzyszenia Wzajemnej Pomocy Muzyków Orkiestrowych, którego statut obejmował szeroko zakrojoną działalność, służącą m.in. niesieniu pomocy materialnej jego członkom, utworzeniu orkiestry symfonicznej oraz kierowaniu muzyczną szkołą zawodową. Bräutigam grał ponadto w Orkiestrze Symfonicznej Łódzkiego Towarzystwa Muzycznego, był także dyrygentem orkiestry dętej „Stella”. Działał aktywnie jako członek Łódzkiego Towarzystwa Muzycznego. Pracował ponadto jako nauczyciel w Szkole Muzycznej działającej przy Towarzystwie Muzycznym im. Chopina (tzw. Szkole Chopina). Należał też do I Łódzkiego Kółka Operowego, które w 1915 r. wystawiło w teatrze „Thalia” operę Trubadur Verdiego, następnie Carmen Bizeta i Barona Cygańskiego w Teatrze Polskim. W ostatnim przedstawieniu R. Bräutigam śpiewał partię hrabiego Homonaya, a jego występ spotkał się z bardzo dobrym przyjęciem krytyki. Był autorem wierszy ukazujących się na łamach dodatków beletrystycznych do „Neue Lodzer Zeitung”. Wybór źródeł: „Neue Lodzer Zeitung” 583/1904, 542/1905; „Rozwój” 245/1904; Przedstawienie operetkowe „Baron Cygański” op. Jana Straussa, „Gazeta Łódzka”, 14.11.1915, s. 3; A. Wirth, Die Musik in Lodz, „Jubiläumsschrift der Lodzer Zeitung” 1913; A. Pellowski, Kultura muzyczna Łodzi do roku 1918, Łódź 1994.

Breyer Albert (1889-1939), nauczyciel i badacz osadnictwa niemieckiego w Polsce Kongresowej. Urodził się w Żyrardowie jako syn Ferdynanda Breyera i Berty z domu Schoen. Ukończył szkołę w Żyrardowie, a następnie szkołę handlową w Łodzi. W 1906 r. rozpoczął pracę jako nauczyciel i kantor we wsiach w okolicach Łodzi. W latach 1906-1908 był nauczycielem w szkole prywatnej w Koluszkach, potem w szkole prywatnej w Łodzi. W 1912 r. ukończył seminarium nauczycielskie, a dwa lata później został powołany do armii rosyjskiej. W 1916 r. ożenił się z Adelą Raths w St. Petersburgu. W czasie rewolucji 1917 r. przebywał wraz z rodziną w Charkowie. Po wojnie wrócił do Polski i znalazł zatrudnienie w szkole w Brzezinach niedaleko Łodzi. W czasie wojny polsko-bolszewickiej zgłosił się jako ochotnik do polskiej armii. W latach 1919-1925 był nauczycielem w szkole średniej w Zgierzu. Uczył geografii, chemii, rysunku, fizyki i biologii. W tym samym czasie uczestniczy w tworzeniu Deutscher Volksverband i czasopisma „Volksfreund”. Z uwagi na nacjonalistyczny charakter tej organizacji stracił posadę nauczyciela. Przeprowadził się do Sompolna i rozpoczął pracę w tamtejszej szkole Emila Kaschubesa, uważanej za duchowe centrum niemczyzny. Był autorem licznych artykułów na temat ludności niemieckiej w Polsce: Das Schrifttum über das Deutschtum im ehem. Kongreßpolen (bis 1930), „Deutsche Wissenschaftliche Zeitschrift für Polen” (dalej: DWZP) 19/1930; Die Entstehung der deutschen Industrie in Polen, vor allem in Kongreßpolen, [w:] K. Lück, Deutsche Aufbaukräfte in der Entwicklung Polens. Plauen i.V. 1934; Deutsche Gaue in Mittelpolen, Posen 1935; Ostdeutschland als Mutterland der deutschen Siedlungen in Mittelpolen, „Deutsche Monatshefte in Polen” (dalej: DMP) 1-2/1935; Die Entwicklung des deutschen Schulwesens im Gostyniner Lande (1780-1936), DMP 
2-3/1937; Die Auswanderung deutscher Bauern des Gostyniner Landes nach Wolhynien (1855-1885), DMP 8-9/1937; Die deutschen Dörfer der Umgebung von Lodz, „Freie Presse, Lodz”, August 1938; Karte der deutschen Siedlungen in Mittelpolen. 1:500000, [w:] V. Kauder, Das Deutschtum in Polen. Ein Bildband. Leipzig 1938 (dgl.), „Jomsburg” 2(l)/1938; Die deutschen ländlichen Siedlungen des mittelpolnischen Warthebruchs, DWZP 34/1938; Deutsche Bauernkultur in Mittelpolen vor 150 Jahren, DMP 11-12/1939; Zur Geschichte des deutschen Schulwesens in Mittelpolen, DMP 40/1939; Deutsche Tuchmachereinwanderung in den ostmitteleuropäischen Raum von 1550 bis 1830 Leipzig-Posen 1941; Zur Geschichte von Sompolno und Umgegend, Posen 1938. Wybór źródeł: Spuścizna Alberta Breyera, Archiwum Państwowe w Poznaniu - Zespół 53.968/0; W. Kühn, Albert Breyer, DMP 16/1939; W. Kuhn, Albert Breyer, „Deutsche Monatshefte”, November/Dezember 1939; E.O. Kossmann, Albert Breyer, ,Jomsburg" 3-4/1939; A. Eichler, Albert Breyer. Zum Gedächtnis an den deutschen Kämpfer im Osten, „Deutsche Post aus dem Osten, Arbeitsgemeinschaft von Vereinen deutscher Kolonisten aus der Ukraine und Polen", Januar 1940; A. Lattermann, Albert Breyer, Deutsche Wissenschaftliche Zeitschrift für das Wartheland (dalej: DWZW) 1/1940; A. Eichler, Deutschtum im Schatten des Ostens. Ein Lebensbericht, Dresden 1942; A. Kargel, Albert Breyer, [w:] A. Kargel, E. Kneifel, Deutschtum im Aufbruch, Leipzig 1942; R. Breyer, Albert Breyer 1889-1939, Lehrer und Volkstumsforscher; [w:] Von unserer Art. Vom Leben und Wirken deutscher Menschen im Raum von Weichsel und Warthe, hrsg. v. F. Weigelt, Wuppertal 1963; W. Kühn, Eine Jugend für d. Sprachinselforschung, "Jahrbuch der Schlesischen Friedrich-Wilhelm-Universität zu Breslau” 23/1982; R. Breyer, Breyer, Albert Schulmann und Siedlungsforscher, „Ostdeutsche Gedenktage", 1989, s. 9-11; J. Zimmermann, Die Kulturpreise der Stiftung F.V. S. 19351945, Hamburg 2000.

Broderson Mojżesz (1890-1956), poeta tworzący w języku jidysz, malarz i rysownik żydowskiego pochodzenia, czołowa postać żydowskiej awangardy w Łodzi. Twórca popularnego w Łodzi i w Polsce Łódzkiego Żydowskiego Rewiowo-Kameralnego Teatru „Ararat” (1927). Wybór źródeł: P. Piekarski, Zaśpiewaj mi w jidysz, Kraków 2000; G. Rozier, Mojżesz Broderson. Od Jung Idysz do Araratu, Łódź 2008; D. Pawłowski, Przypomnienie [rec. książki G. Rozier pt. Mojżesz Broderson. Od Jung Idysz do Araratu], ,Polska. Dziennik Łódzki. Kocham Łódź”, 30.01.2009, s. 23.

Cleinow Georg (1873-1936), publicysta, działacz polityczny, wydawca. Pochodził z Lublina, był czołowym publicystą i głównym rzeczoznawcą II Rzeszy w sprawach polskich i rosyjskich. Redagował gazetę o tendencjach antypolskich „Der Grenzbote", był członkiem zarządu Deutscher Ostmarkenverein, szefem zarządu prasowego Oberost, zaś w latach 1915-1918 szefem wydziału prasy i cenzury niemieckiej administracji cywilnej. Generał gubernatorstwa w Warszawie. Do Łodzi przybył 14 maja 1915 r. Aktywnie działał na rzecz szerzenia nacjonalizmu niemieckiego. Zlikwidował wydawaną przez rodzinę Petersilgego gazetę „Lodzer Zeitung”, a w jej miejsce utworzył okupacyjną „Deutsche Lodzer Zeitung”. Wybór źródeł: K. Ammon, Cleinow Georg, [w:] Neue Deutsche Biographie (NDB), Bd. 3, Berlin 1957, s. 279; Z. Janeczek, „Wiadomości Polskie”. Pismo zakazane na Śląsku i w Zagłębiu Dąbrowskim, „Rocznik Muzealny Siemianowicki" 2/2003, s. 13-32. 
Czajewski Wiktor (1857-1922), literat, dziennikarz, wydawca gazet i właściciel drukarni prasowej. Wybór źródeł: Słownik pracowników książki polskiej, WarszawaŁódź 1972; L.S. Szychowski, Zarys dziejów drukarstwa łódzkiego 1859-1918, Łódź 1993; J. Strzałkowski, Drukarnie i księgarnie w Łodzi do 1944 r., Łódź 1999, s. 62-64; M. Laskowski, Dzieje drukarstwa łódzkiego, Łódź 1989, s. 32.

Drewing Alexis (Aleksis) (1869-1924), dziennikarz, współwłaściciel i współwydawca ugodowej „Neue Lodzer Zeitung”. Absolwent Uniwersytetu w Dorpacie. 25 lutego 1892 r. przyjechał do Łodzi, gdzie podjął pracę w redakcji „Lodzer Zeitung". Wraz z Aleksandrem Milkerem brał czynny udział w życiu społecznym i kulturalnym Łodzi. Był współzałożycielem i prezesem Vereinigung deutschsingender Gesangvereine in Polen, członkiem Kirchen-Gesangverein der St. Trinitatisgemeinde, członkiem honorowym Kirchengesangverein des St. Johannisgemeinde, członkiem Lodzer Männergesangverein, członkiem zarządu Deutscher Gymnasialverein, Deutscher Schul- und Bildungsverein, prezesem honorowym Lodzer Touring-Club, współzałożycielem i członkiem honorowym Verein Deutschsprechender Meister und Arbeiter, Lodzer Sport- und Turnverein, członkiem zarządu Deutsche Bürgerliche Partei, członkiem Christlicher Wohltätigkeitsverein oraz Christliche Gewerkschaft. Wybór źródeł: W. Kaszubina, Bibliografia prasy łódzkiej, 1863-1944, Warszawa 1967.

Eichler Adolf (1877-1945), działacz polityczny, publicysta, pisarz. Był synem majstra w fabryce Scheiblera. Kształcił się w zawodzie kupieckim. Był akwizytorem niemieckiej firmy Badische Anilin und Soda Fabrik w Ludwigshafen, prowadził także własną firmę handlową w Łodzi przy ul. Ewangelickiej 5. Był czołowym ideologiem narodowoniemieckim. Redagował liczne niemieckie gazety, m.in. „Deutsche Post aus dem Osten” i „Lodzer Rundschau”. Wybór źródeł: M. Ostrowski, Adolf Eichler. Ein Beitrag zum Bild des faschistischen Łódź, [w:] A. Kozłowski, M. Znyk, Między Śląskiem a Wiedniem. Księga jubileuszowa z okazji 60. urodzin prof. dr. hab. Krzysztofa Kuczyńskiego, Płock 2008, s. 381-389.

Elster Otto Wilhelm Philipp (1852-1922), niemiecki dziennikarz, pisarz, polityk, historyk, autor powieści i nowel, jak np.: Maria Stuarts Kampf um Schottlands Krone (powieść historyczna), 1913, Giganten und Zwerge, Der Klosterschüler von Corvey, Die Husaren des Herrn von Riedesel, Die Lippoldshöhle, Durch eigene Kraft, sztuki teatralnej Unter dem Totenkopf, 1895. Jego tekst Das Kreuz der Mutter (wspomnienia bitwy pod Sedanem) opublikowała „Illustrierte Sonntagsbeilage” 12./25.08.1910. Wybór źródeł: O. Elster, Chronik der Familie Elster, Berlin 1936.

Federn Karl (1868-1943), austriacki pisarz, tłumacz i prawnik. Napisał m.in.: Dante und seine Zeit, Leipzig-Wien-Berlin 1899; Der Chevalier von Gramont. Hamiltons Memoiren und die Geschichte, 2 Bde., München 1911; Hundert Novellen, Bd. 1, München 1912; Bd. 2, München1913; Mazarin, München 1922; Rosa Maria. Roman, Berlin 1925; Ein Justizverbrechen in Italien. Der Prozess Murri-Bonmartini, Berlin 1925; Richelieu, Wien 1927; Hauptmann Latour. Nach den Aufzeichnungen eines Offiziers. Sponholtz, Hannover 1929; Das Diamantkreuz, „Illustrierte Sonntagsbeila- 
ge", 31.07./13.08.1911. Wybór źródeł: E. Egli-Griesser, Karl Federn. Insbesondere als Novellist, Krauseneck 1953; Exil in Dänemark. Deutschsprachige Wissenschaftler, Künstler und Schriftsteller im dänischen Exil nach 1933, hrsg. v. W. Dähnhardtund, B.S. Nielsen, Heide 1993, s. 503-506.

Fiszer Ludwik (ok. 1843-1900), łódzki księgarz i wydawca, jego syn, również Ludwik Fiszer (1890-1962) był wydawcą i księgarzem w Warszawie. Wybór źródeł: J. Krakowiak, Od Fiszera do „Pegaza”, Łódź 2005.

Flatt Oskar (1822-1872), krajoznawca, autor licznych opracowań z zakresu geografii, historii, statystyki i etnografii. Był dziennikarzem i współredaktorem „Gazety Codziennej”, w której publikował reportaże. Opisywał folklor, zwyczaje i obyczaje Mazowsza, Podlasia, Podhala, Tatr, Kujaw, Pomorza i innych regionów Polski. W 1855 r. opublikował w „Gazecie Codziennej” relację Jarmark $w$ Łowiczu. W latach 50. XIX w. zafascynował go „fenomen przemysłowy” Łodzi. Wybór źródeł: Oskar Flatt - pierwszy monografista Łodzi, [w:] M.Z. Wojalski, Działo się w Łodzi..., Łódź 1966; A. Kutrzebianka, Oskar Flatt, [w:] Polski słownik biograficzny (dalej: PSB), t. 7, Kraków 1948-1958, s. 31.

Flierl Friedrich (1888-?), dziennikarz, pisarz, publicysta. Urodził się 27 czerwca 1888 r. w Fürth. Pierwsze teksty literackie napisał w wieku osiemnastu lat. W latach 1911-1913 pracował jako dziennikarz i literat w „Lodzer Rundschau”, od 1915 r. współpracował z „Deutsche Post”. Po wojnie zatrudniony w dziale prasowym VDA w Berlinie, zajmował się również propagandą prasową w niemieckim Schutzbundzie. Redagował pismo „Volk und Heimat” oraz „Deutscher Brief”, był również pracownikiem niemieckich wydawnictw w Jugosławii i Banacie. Wybór źródeł: Archiv der Deutschen aus Mittelpolen und Wolhynien, sygn. A1cIX nr 6449.

Glisczyński Artur, pseud. Glizda, Argus i in. (1869-1910), poeta, dziennikarz, humorysta i satyryk. Ukończył szkołę handlową L. Kronenberga w Warszawie. Ok. 1890 r. przybył do Łodzi, gdzie zajął się publikowaniem artykułów w miejscowych pismach. Brał udział w życiu kulturalnym miasta, współpracował m.in. ze stowarzyszeniem muzycznym „Lutnia”. Redagował kalendarz informacyjno-adresowy „Łodzianin” (1894, 1895), wydał trzy roczniki humorystycznego pisma „Łodzianka” (1894-1896), pisywał stale w „Gońcu Łódzkim” oraz w tygodnikach „Ognisko Rodzinne” i „Świat”. W 1901 r. powrócił do Warszawy, gdzie współpracował z „Wiekiem” i współredagował „Kurier Świąteczny”, zaś w 1903 r. objął redakcję działu miejskiego w „Kurierze Warszawskim”; w latach 1903-1906 ogłaszał „rymowane pogwarki” (wierszowane felietony) w „Bluszczu” i utwory humorystyczno-satyryczne w „Kolcach”, których był pod koniec życia redaktorem i wydawcą. W 1886 r. ogłosił tomik Pierwsze loty, zawierający obok własnych wierszy przekłady A. Puszkina. Glisczyński był piewcą życia fabrycznej Łodzi. W zbiorkach wierszy (Z mroku i dymu, 1901) i realistycznych Obrazkach (1907) pozostawił wymowny dokument życia wielkomiejskiej biedoty i proletariatu, przedstawił wyczerpującą i niebezpieczną pracę w fabrykach, sportretował wielkoprzemysłowe miasto (wierszowany obrazek Mańka nawiązuje 
do buntu robotniczego w Łodzi w 1892 r., w innych utworach pobrzmiewają echa wydarzeń lat 1905-1907). W 1912 r. ukazał się pośmiertnie zbiorek Humor i satyra. Wybór źródeł: Z. Hajkowski, Artur Glisczyński, pierwszy poeta łódzki, „Prace Polonistyczne" 3/1939; H. Walterowa, Artur Glisczyński, [w:] PSB, t. 8, Wrocław 1959-1960, s. 72; H. Karwacka, Artur Glisczyński, pieśniarz fabrycznej Łodzi, Łódź 1975.

Gorczyński Bolesław (1880-1944), dramatopisarz, dyrektor teatrów. Wybór źródeł: S. Marczak-Oborski, Bolesław Gorczyński, [w:] PSB, t. 8, Wrocław 1959-1960, s. 296-297; Bolesław Gorczyński, [w:] Słownik biograficzny Teatru Polskiego 17651965, Warszawa 1973.

Grüner Margarete (?), niemiecka pisarka z Łodzi, autorka związana z nurtem narodowoniemieckim. Jej wiersze publikowała m.in. nacjonalistyczna "Deutsche Post”. Wybór źródeł: „Jahrbuch des Deutschen Vereins für Lodz und Umgegend” 1917.

Gundlach Rudolf (1850-1922), pastor, autor pieśni religijnych. Wybitna postać kościoła ewangelicko-augsburskiego. Jego rodzina Gundlacha pochodziła z małej miejscowości o nazwie Paproć Duża. Ojciec był nauczycielem szkoły elementarnej dla kolonistów niemieckich i weteranem powstania listopadowego. Rudolf Gundlach miał dziewięcioro rodzeństwa. Uczęszczał najpierw do gimnazjum w Łomży, następnie od 1867 r. do gimnazjum w Warszawie, a po jego ukończeniu wyjechał na studia teologiczne do Dorpatu. 18 kwietnia 1875 r. został ordynowany w kościele św. Trójcy w Warszawie. Po roku wikariatu w Warszawie został pastorem w Kamieniu koło Chełma na Lubelszczyźnie, a potem w Wiskitkach koło Żyrardowa. Do Łodzi przybył w 1898 r. i został wybrany pierwszym pastorem tutejszej parafii św. Trójcy. Urząd ten pełnił przez dwadzieścia cztery lata. Stał na czele Łódzkiego Chrześcijańskiego Towarzystwa Dobroczynności. W okresie I wojny światowej pełnił obowiązki zastępcy generalnego superintendenta w Polsce i był założycielem Głównego Komitetu Obywatelskiego, powołanego w celu opanowania chaosu, powstałego po wybuchu wojny i opuszczeniu miasta przez dotychczasowego prezydenta Władysława Pieńkowskiego. Razem z dr. Jonscherem zbierał fundusze na budowę szpitala Anny Marii. Zmarł 11 października 1922 r. Wybór źródeł: A. Milker, Konsistorialrat Pastor Rudolf Gundlach, „Illustriertes Sonntagsblatt. Beilage zur Neuen Lodzer Zeitung”, 23,15.10.1922, s. 1-2, 4; A. Rynkowska, Gundlach Rudolf Gustaw 1850-1922, [w:] PSB, t. 9, Wrocław 1960-1961, s. 157-158; M. Budziarek, Skromna wielkość, Rudolf Gustaw Gundlach (1850-1922), [w:] Łodzianie, Łódź 2000.

Gutentag Zofia (1899-1993), malarka żydowskiego pochodzenia. Wybór źródeł: J. Malinowski, Grupa "Jung Idysz" i żydowskie środowisko "Nowej Sztuki" w Polsce: 1918-1923, Warszawa 1987.

Habermann Eduard (1880-?), łódzki pisarz niemieckiego pochodzenia, inżynier, pedagog. Studiował na wydziale chemicznym w Rydze. Był profesorem fizyki, chemii, matematyki, nauk przyrodniczych i ekonomicznych. Lektor języka niemieckiego w Politechnice i Instytucie Handlowym w Kijowie. Od 1914 r. mieszkał w Łodzi, a następnie w 1919 r. przeniósł się do Jarocina, gdzie pracował jako nauczyciel 
w progimnazjum i wyższej szkole żeńskiej. Jego twórczość literacką drukowały łódzkie gazety. Wybór źródeł: Sprawozdanie Państwowego Gimnazjum Humanistycznego im. św. Barbary w Chodzieży za czas od 1922-1929 r., Chodzież 1929, s. 13.

Heike Otto (1901-1990), publicysta, pisarz, badacz historii Niemców w Polsce. Autor takich książek na temat historii Łodzi, jak: Die Provinz Südpreußen. Preußische Aufbau- und Verwaltungsarbeit im Warthe- und Weichselgebiet 1793-1806, Marburg 1953; Das Deutschtum in Polen 1918-1939, Bonn 1955; Das deutsche Schulwesen in Mittelpolen, Dortmund 1963; Das deutsche Lehrerseminar in Mittelpolen, Troisdorf 1963; Die Aufbauleistung rheinischer Textilpioniere in Mittelpolen, Neuss 1964; Die deutsche Arbeiterbewegung in Polen 1835-1945, Dortmund 1969; Aufbau und Entwicklung der Lodzer Textilindustrie, Mönchengladbach 1971; 150 Jahre Schwabensiedlungen in Polen 1795-1945, Leverkusen 1979; Die deutsche Minderheit in Polen bis 1939, Leverkusen 1985; Leben im deutsch-polnischen Spannungsfeld. Erinnerungen eines deutschen Journalisten aus Lodz, Essen 1989. Wybór źródeł: Otto Heike „niemiecki dziennikarz z Łodzi” jako historyk, red. B. Kwoka, Herne 2004; M. Kucner, Otto Heike jako dziennikarz i historyk, „Studia Niemcoznawcze” 33/2006, s. 109-116.

Hertz Mieczysław (1870-1939), łódzki fabrykant, historyk, działacz społeczny związany z Łodzią. Pochodził z rodziny zasymilowanych Żydów polskich, mieszkających w Łodzi. Był członkiem korporacji akademickiej „Arkonia” i Towarzystwa Przyjaciół Łodzi. Pełnił funkcję prezesa tutejszej Izby Przemysłowo-Handlowej. Słynął nie tylko z inicjatyw gospodarczych, był również znanym społecznikiem i działaczem kulturalnym. Publikował książki z zakresu historii Łodzi w okresie I wojny światowej. W 1939 r. aresztowany przez Niemców i osadzony w więzieniu na Radogoszczu. Poza żydowskim pochodzeniem powodem aresztowania były jego przedwojenne publikacje opisujące okres I wojny światowej, bardzo krytyczne wobec Niemców. Autor apelował w nich o odszkodowania dla rodzin, których jedyni żywiciele zmarli z wycieńczenia wskutek ciężkich robót w Niemczech. Hitlerowcy torturowali sześćdziesięcioletniego Hertza: „musiał czołgać się na brzuchu naokoło sali, wygrzebywać palcami dołki w twardej nawierzchni po to, aby pokaleczyć sobie palce i ręce”. Bezlitośnie skatowanego zamordowano go w lasach lućmierskich w czasie Intelligenzaktion Litzmannstadt. Wybór źródeł: S. Rapalski, Byłem w piekle. Wspomnienia z Radogoszcza, Łódź 1960; M. Prokopowicz, W. Sienkiewicz, Żydzi polscy. Historie niezwykłe, Warszawa 2010.

Hiller Karol (1891-1939), artysta i malarz, urodzony w Łodzi w rodzinie o niemieckich korzeniach. Jego ojciec był mistrzem tkackim. W latach 40. XIX w. dziadek Johann Hiller przybył do Łodzi z Dolnego Śląska. Hillerowie byli katolikami. Karol uczęszczał do Łódzkiej Szkoły Rzemieślniczo-Przemysłowej (Łodzinskoje Manufakturno-Promyszlennoje Ucziliszcze), potem studiował w Wyższej Szkole Technicznej w Darmstadt w Niemczech (studiów nie skończył). W 1912 r. rozpoczął studia na Wydziale Inżynieryjno-Budowlanym Instytutu Politechnicznego w Warszawie (również nie ukończył). W 1917 r. rozpoczął naukę w Akademii Sztuk Pięknych w Kijowie, w pracowni wybitnego ukraińskiego malarza-bizantynisty Michajło Bojczuka. 
W latach 20. przebywał w Łodzi, tworząc i udzielając się społecznie. Pracował również jako nauczyciel rysunku i robót ręcznych w nowo powstałym Społecznym Polskim Gimnazjum Męskim. W 1926 r. stworzył siedmioosobowy zespół łódzkich malarzy, którzy w 1926 r. zorganizowali wielką wystawę jako „Grupa Łódzka”. W 1931 r. był jednym z założycieli Zrzeszenia Artystów Plastyków (dalej: ZAP) w Łodzi. Przygotowywał i wygłaszał odczyty w łódzkim Instytucie Propagandy Sztuki i w Miejskim Muzeum. Jedna $\mathrm{z}$ takich prelekcji odbyła się podczas otwarcia wystawy malarstwa Jankiela Adlera w 1935 r. Hiller angażował się także w działalność Ligi Obrony Praw Człowieka i Obywatela, udzielając pomocy więźniom politycznym Berezy Kartuskiej, zwłaszcza po procesie brzeskim. W tej działalności wspierała go żona Jadwiga, która w latach 30. XX w. zorganizowała w Łodzi wiele ważnych akcji charytatywnych. W 1938 r. Hiller był jednym z organizatorów Klubu Demokratycznego w Łodzi. Po serii napadów na Żydów, dokonanych w Łodzi przez młodych aktywistów radykalnych organizacji skrajnej prawicy, zaczął otwarcie występować przeciw hitleryzmowi i rodzimym tendencjom faszystowskim. Wybór źródeł: Karol Hiller (1891-1939). Katalog wystawy, 1967; Słownik artystów polskich, t. 3, Warszawa 1979; Karol Hiller (1891-1939). Katalog wystawy, 2002 (w tym Z. Karnicka, K. Hiller, Kalendarium życia i twórczości); M. Jastrun, Eseje, Warszawa 1984.

Hoefig Aleksander (1886-1939), dziennikarz, redaktor „Der Deutsche Wegweiser", aresztowany 9 października 1939 r. za przynależność do Vereinigung der Deutschen in Polen, od 27 października 1939 r. w Rawiczu, zmarł w 1939 r. w Dachau. Autor licznych artykułów na temat historii Łodzi, w tym m.in. Das deutsche Kirchen- und Volkslied in Mittelpolen, „Neue Lodzer Zeitung”, 27.03.1937; Nationalitätenpolitik im Wandel der Zeiten. Die Rolle des Deutschtums im kongresspolnischen Nationalitätenproblem, „Neue Lodzer Zeitung”, 18.07.1937; Aus der Geschichte der Stadt Lodz, „Neue Lodzer Zeitung”, 28.07.1935; Nationalitätenprinzip im Wandel der Zeiten, „Neue Lodzer Zeitung”, 18.07.1937; Das Hundertjährige Jubiläum der Lodzer Tuchmachergeselleninnung, "Illustriertes Sonntagsblatt. Beilage zur Neuen Lodzer Zeitung”, 28.06.1925; Kirchenpolitik, „Der Deutsche Wegweiser”, 15.05.1938. Wybór źródeł: Eksterminacja inteligencji Łodzi i okręgu łódzkiego, 1939-1940, red. A. Galiński, M. Budziarek, Łódź 1992.

Jess Wilhelm (?), nauczyciel szkoły fabrycznej Spółki Akcyjnej F.W. Schweikert, poeta, redaktor "Neue Lodzer Zeitung”, tłumacz klasyki rosyjskiej. Jednym z ważniejszych przekładów był Demon Michaiła Lermontowa. Jess był autorem jednego z pierwszych dramatów niemieckich w Łodzi Pater Damasy oder das Verbrechen auf Jasna Góra. Wybór źródeł: „Illustrierte Sonntagsbeilage zur Neuen Lodzer Zeitung”, 2./15.11.1914.

Kargel Adolf (1891-1985), działacz polityczny, pisarz, publicysta. Był działaczem politycznym i redaktorem niemiecko-języcznych gazet łódzkich: od 1918 r. „Lodzer Freie Presse”, od 1940 r. „Litzmannstaedter Zeitung”. W 1913 r. rozpoczął współpracę z „Lodzer Zeitung”, która po dwóch latach przestała się ukazywać. Od $1915 \mathrm{r}$. współpracował z „Deutsche Lodzer Zeitung”. Historyk i dziennikarz Hans Preuschoff 
(1905-1989) tak pisał o Kargelu: „Spokojny, szlachetny człowiek. Po reorganizacji gazety został powiedzmy zdetronizowany i powołany na redaktora lokalnego, co zniósł z charakterystyczną dla niego godnością. Większość czasu w trakcie podróży miał do dyspozycji dwóch redaktorów. Ograniczenie działu politycznego miało być, jak już wcześniej zauważyłem, zrekompensowane poprzez intensywniejsze działania na polu lokalnym. Adolf Kargel i jego żona byli jedynymi osobami, z którymi utrzymywaliśmy w Litzmannstadt przyjacielskie stosunki. Należał do Deutsches Verein für Lodz und Umgegend, Volksverband oraz Deutscher Schul- und Bildungsverein. Po wojnie wyjechał do Niemiec i był jednym z redaktorów „Weg und Ziel”, z którym współpracował do 1970 r. Obok Otto Heikego, Adolfa Eichlera i Juliana Willa przyczynił się do utworzenia Archiwum Niemców z Polski Środkowej i Wołynia. Współpracował również z rocznikiem Niemców łódzkich „Jahrbuch Weichsel-Warthe” i był założycielem Ziomkostwa Wisła-Warta. Interesował się historią Łodzi, zbierał książki, monety i medale. Pasjonowała go archeologia. Był autorem m.in. takich publikacji, jak: Letztes Zusammensein mit Sigismund Banek, „Weg und Ziel” 3/1954, s. 6; Die preußische Verwaltung in Süd- und Neuostpreußen, „Weg und Ziel” 8/1960, s. 2-3; Petrikauer Straße 361 - Ein Lodzer Haus mit Geschichte, „Weg und Ziel” 9/1960, s. 3-4; Das Warschauer Deutschtum im 19. Jahrhundert, „Weg und Ziel” 8-9/1961, s. 4-5; Die Deutsche Schule in Tomaschow, „Weg und Ziel” 12/1965, s. 8-9; 20 Jahre Mitteilungen unseres Hilfkomitees, „Weg und Ziel” 11/1966, s. 2-3; Die lutherische Kirche in Gostynin, „Weg und Ziel” 12/1966, s. 2; 150 Jahre Universität Warschau, „Weg und Ziel” 4/1967, s. 2; Das Gefecht von Dobra bei Zgierz, „Weg und Ziel” 4/1967, s. 7-8; Der Gesangverein „Polyhymnia” in Alexandrow, „Weg und Ziel” 4/1969, s. 8-9; Die deutschen Gerber von Radom, „Weg und Ziel” 5/1969, s. 6-7; Graf von Berg Förderer des Lodzer Deutschtums, „Weg und Ziel” 6/1969, s. 3-4; Zgierzer Gesangverein „Concordia“, „Weg und Ziel” 7-8/1969, s. 4; (Eduard) Kaiser unter den Lodzer Zeitungsreportern, „Weg und Ziel” 7-8/1969, s. 10-11; Kirchengesangverein „Harmonia“ Konstantynow, „Weg und Ziel” 9/1969, s. 8-9; Polen im Denkmal der Deutschen Schaumünze, „Weg und Ziel" 12/1969, s. 3-4; Ehrenrettung einer Straße und einer Stadt im Osten - Die Petrikauer Straße in Lodz, „Weg und Ziel” 1/1971, s. 7-12; Deutsche Reigenspiele. Festbräuche und Kinderreime aus Kongresspolen, „Deutsche Wissenschaftliche Zeitschrift für Polen” 1/1923, s. 55. Wybór źródeł: H. Preuschoff, Journalist im Dritten Reich, Münster 1987; ADiMuW, sygn. Sammelmappe Adolf Kargel A1C IX 2310, A1CIX 6327, A1CIX 1176, A1CIX 2488.

Kosiakiewicz Wincenty (1863-1918), literat, dziennikarz, tłumacz, działacz polityczny. Publikował m.in. w „Gazecie Polskiej”, „Bibliotece Warszawskiej”, „Kurierze Codziennym”. Wybór źródeł: M. Puchalska, Kosiakiewicz Wincenty, [w:] PSB, t. 14, Wrocław 1968-1969; M. Puchalska, Wincenty Kosiakiewicz 1863-1918, [w:] Obraz literatury polskiej XIX $i$ XX w., seria czwarta: Literatura polska w okresie realizmu i naturalizmu, t. 4, Warszawa 1971.

Kościelecki Łucjan (1850-1907), inicjator i twórca stałej sceny polskiej w Łodzi. Wybór źródeł: A. Kuligowska-Korzeniewska, Łódź teatralna: polska, niemiecka i żydowska, „Tygiel Kultury” 3/1996. 
Kraśniański Aleksander (1900-1929), poeta, dziennikarz. Debiutował w dodatku literackim „Nowego Kuriera Łódzkiego” (1915), cztery wiersze zamieścił w jednodniówce harcerzy „Czuwaj!” (Łódź 1917, tam na s. 20-21 zamieścił parafrazę Pierwszej brygady pt. Raduje się serce), publikował na łamach "Gazety Łódzkiej” (1917), „Dziennika Łódzkiego” (1919), , Republiki” (1925) i „Głosu Polskiego” (1929). Pośmiertnie nakładem Syndykatu Dziennikarzy Łódzkich wydano wybór jego poezji Wiolonczele i księżyc. Wybór źródeł: M. Braun, Słowo wspomnienia o Aleksandrze Kraśniańskim, „Głos Polski” (dodatek społeczno-literacki), 12.01.1929; L. Stolarzewicz, Literatura Łodzi w ciągu jej istnienia. Szkic literacki i antologia, Łódź 1935; M. Braun, Aleksander Kraśniański 1900-1929, „Prace Polonistyczne” 1937; T. Gicgier, Opowieści o dawnych poetach Łodzi, Łódź 1995, s. 79-86; A. Kempa, M. Szukalak, Żydzi dawnej Łodzi. Słownik biograficzny Żydów łódzkich oraz z Łodziq związanych, t. 2, Łódź 2002, s. 60; A. Kempa, Literaci, dziennikarze, publicyści, [w:] Żydzi łódzcy. Jews of Łódź, red. A. Machejko, Łódź, 2004, s. 43.

Kremnitz Mite, Bardeleben Marie Charlotte von, pseud. George Allan, Dito und Idem (1852-1916), niemiecka pisarka, której utwory chętnie publikowała łódzka prasa. W 1875 r. przeniosła się wraz z mężem Wilhelmem Kremnitzem do Bukaresztu. Tam zaprzyjaźniła się z królową Elizabeth, piszącą pod pseudonimem Carmen Sylva, od $1881 \mathrm{r}$. była oficjalnie jej damą dworu. Autorka m.in. Fluch der Liebe. Novellen, 1881; Neue rumänische Skizzen, 1881; Rumänische Märchen, 1882; Aus der rumänischen Gesellschaft, zwei Romane, 1882; Ein Fürstenkind. Roman, 1883; Rumäniens Anteil am Kriege 1877-78, 1887; Ausgewanderte. Roman, 1890; Elina. Zwischen Kirche und Pastorat. 2 Novellen, 1894; Sein Brief. Novellen, 1896; Herr Baby. Eine Kindergeschichte, 1901; Mann und Weib. Novellen, 1902; Fatum. Erzählungen, 1903; Ist das - das Leben? Roman, 1909. Wspólnie z królową Elizabet, Dito und Idem, Anna Boleyn, historisches Trauerspiel, 1886; Dito und Idem, Astra. Briefroman, 1886; Dito und Idem, Feldpost. Briefroman, 1886; Dito und Idem: Rache und andere Novellen, 1888. Wybór źródeł: R. Grebing, Mite Kremnitz (1852-1916) - eine Vermittlerin der rumänischen Kultur in Deutschland, Frankfurt/Main-Bern 1976. W Łodzi drukowano m.in. szkic pt. Das verlassene Haus, „Illustrierte Sonntagsbeilage Neue Lodzer Zeitung”, 28./15.05.1911, nowelę Das Geheimnis der Weiche B. M., „Illustrierte Sonntagsbeilage zur Neuen Lodzer Zeitung", 4.17.1916.

Kreutz Philipp (1890-1954), pastor, pisarz. Urodził się w Chełmcu niedaleko Nowego Sącza jako syn Philippa Kreutza i Karoliny z domu Meiser. Studiował teologię w Wiedniu i Lipsku. Był wikariuszem we Lwowie i w Czechach. W latach 1918-1922 pełnił posługę kapłańską w Jarosławiu, przez kolejne dwa lata w Pabianicach, a następnie w okresie 1924-1939 w Sompolnie i na Dolnym Śląsku. Więziony podczas wojny wyjechał później do Wrocławia, stamtąd do Holzkirchen w Bawarii, a od 1951 r. przebywał w Ellingen niedaleko Norymbergii. Zmarł 9 czerwca 1954 r. w Weißenburgu, pochowany został w Pleinfeld. Był żonaty z Ireną z domu Neiheiser i miał czworo dzieci: Ingę, Gunhildę, Hansa i Philippa. W 1937 r. ukazał się tom jego poezji zatytułowany Zeit und Ewigkeit, a w 1954 r. kolejny Traum und Tag. W Niemczech współpracował z czasopismem „Der Heimatobote. Mitteilungs- 
blatt für die Glieder der ev.-augsburgischen Kirche", którego wydawcą był pastor Gerhard Richter. Gazeta ukazywała się w Kilonii-Holtenau w latach 1948-1989. Wybór źródeł: Personalverzeichnis der Evangelischen Kirchen in Polen 1935-1938, „Wolhynischer Volkskalender für das Jahr 1936”, http://www.google.pl/url?sa $=$ t\&rct=j\&q=philipp $\% 20$ kreutz\% 20 pastor\&source=web\&cd=3\&cad=rja\&ved=0CEAQFjAC\&url=https\%3A\%2F\%2Fwww.sggee.org\%2Fdeutsch\%2Fresearch ger\%2Fparishes_ger\%2Fparish_histories_ger\%2FPersonal-Verzeichnis1935-38. pdf\&ei=750IUfWRFYfLswbTt4H4Dg\&usg=AFQjCNGo7f-RLcAwZKtYrxSFoYgCTigopg\&bvm=bv.41642243,d.Yms [dostęp: 20.10.2012]; Pastor Philipp Kreutz, „Illustriertes Sonntagsblatt. Beilage zur Neuen Lodzer Zeitung", 15.04.1923, s. 1-2.

Krönig Artur (1896-1953), ukończył siedem klas gimnazjum niemieckiego w Łodzi (lub Szkołę Marii Grabskiej w Łodzi), maturę zdał jako ekstern (1916); zaliczył cztery semestry Wydziału Prawa UW (od 1917 r., skreślony z listy studentów 1 lipca 1924 r.), podoficerski kurs rachunkowy (listopad-grudzień 1918 r.), kurs oficerów gospodarczych (1919-1920), kurs żołnierskiego wyszkolenia liniowego (1920). W latach 1914-1916 nauczyciel domowy w Modlnej (pow. Łęczyca); w okresie 19171918 nauczyciel w niemieckim progimnazjum w Pabianicach; od listopada $1918 \mathrm{r}$. ochotnik WP, kolejno: Legia Akademicka (oficer kasowy), Komisja Gospodarcza Szpitala Wojskowego nr 1 w Łodzi (oficer kasowy od 1920 r.), w 28 Pułku Strzelców Kaniowskich, ppor. w Wojskowym Okręgowym Zakładzie Gospodarczym nr IV w Łodzi, zwolniony do rezerwy w styczniu 1921 r. jako student; ppor. rez. (14.01.1921). W okresie międzywojennym dziennikarz w Łodzi, pracownik „Lodzer Freie Presse”, dziennikarz (krótko red. naczelny) „Lodzer Volkszeitung”, współpracownik „Volksstimme”, „Volkswille”, „Volksfreund” i „Freiheit”. W 1922 r. współzałożyciel Deutsche Arbeitspartei (sekretarz generalny i kier. wydz. polit.), następnie członek Deutsche Sozialistische Arbeitspartei Polens (prezes ZGiRN) i jej reprezentant na II (1925) i III (1928) Kongresie Socjalistycznej Międzynarodówki Robotniczej. W połowie stycznia 1930 r. urzędnik KKO w Łodzi. W 1935 r. dokonał rozłamu w Deutsche Sozialistische Arbeitspartei Polens i związał się z Deutscher Volksverband oraz z Christlicher Commisverein (przewodniczący). Sympatyk NSDAP, członek niemieckiego stowarzyszenia kulturalno-oświatowego „Fortschritt”, komitetu niesienia pomocy uchodźcom z ZSRR, stowarzyszenia pracowników umysłowych. Po wybuchu II wojny światowej internowany przez władze polskie i deportowany na wschód kraju. Uwolniony przez wojska niemieckie w okolicach Stoczka. Od 1945 r. mieszkał w Poczdamie. Wybór źródeł: Słownik biograficzny działaczy polskiego ruchu robotniczego. T. 3: K, red. F. Tych, Warszawa 1992 (biogram autorstwa Lucjana Kieszczyńskiego); P. Majewski, Posłowie i senatorowie Rzeczypospolitej Polskiej 1919-1939: słownik biograficzny. T. 3: K- $€$, Warszawa 2005, s. 228-229 (nota biograficzna ze zdjęciem).

Laskowski Kazimierz (1861-1913), pisarz związany z warszawskimi czasopismami (m.in. „Słowo”, „Kolce”, „Mucha”, „Gazeta Warszawska”, „Tygodnik Ilustrowany”, ,Niwa”, „Bluszcz”, „Kurier Warszawski”). Autor powieści pt. Zrośli z ziemiq (1897) oraz Lokaut (1907). Wybór źródeł: A. Jopek, Kazimierz Laskowski, [w:] PSB, t. 16, Wrocław 1971, s. 528-529. 
Litt Theodor (1880-1962), zajmował się pedagogiką i filozofią. Od 1918 r. był profesorem nadzwyczajnym na Uniwersytecie w Bonn, a od 1920 r. profesorem zwyczajnym na Uniwersytecie w Lipsku, gdzie uczył do 1937 r., a po wojnie jeszcze dwa lata. W 1947 r. wrócił na Uniwersytet w Bonn. Jego najważniejsze prace naukowe to: Individuum und Gemeinschaft, 1919; Kant und Herder als Deuter der geistigen Welt, 1930; Einleitung in die Philosophie, 1933; Mensch und Welt, 1948; Denken und Sein, 1948; Hegel, 1953. Spuścizna Litta znajduje się obecnie na Uniwersytecie w Lipsku. Wybór źródeł: A. Reble, Theodor Litt. Eine einführende Überschau, Bad Heilbrunn 1950; R. Lassahn, Das Selbstverständnis der Pädagogik Theodor Litts, Ratingen 1968; R. Lassahn, Theodor Litt, Münster 1970; L. Funderburk, Erlebnis, Verstehen, Erkenntnis. Theodor Litts System der Philosophie aus erkenntnistheoretischer Sicht, Bonn 1971; U. Bracht, Zum Problem der Menschenbildung bei Theodor Litt. Studien zur wissenschaftstheoretischen Problematik im Gesamtwerk Theodor Litts, Bad Heilbrunn 1973; Theodor Litt. Pädagogische Analysen zu seinem Werk, hrsg. v. F. Nicolin, Bad Heilbrunn 1973; F. Nicolin, Theodor Litt, [w:] Geschichte der Pädagogik des 20. Jahrhunderts, hrsg. v. J. Speck, Stuttgart 1977; W. Klafki, Theodor Litt, [w:] Klassiker der Pädagogik, hrsg. v. H. Scheuerl, München 1979; H.-K. Beckmann, Der Erziehungsauftrag der Schule, [w:] Die pädagogische Gestaltung des Schullebens, hrsg. v. F. Schmaderer, München 1979, s. 29-41; W. Ritzel, Philosophie und Pädagogik im 20. Jahrhundert. Die philosophischen Bemühungen des 20. Jahrhunderts, Darmstadt 1980; W. Klafki, Die Pädagogik Theodor Litts. Eine kritische Vergegenwärtigung, Königstein 1982; G. Steindorf, Lernen und Wissen. Theorie des Wissens und der Wissensvermittlung, Bad Heilbrunn 1985; Th. Friederich, Theodor Litts Warnung vor "allzu direkten Methoden“, [w:] Deutsche Philosophen 1933, hrsg. v. W.F. Haug, Berlin 1989; H. Glöckel, Vom Unterricht, Bad Heilbrunn 1990, s. 99-124; W.M. Schwiedrzik, Lieber will ich Steine klopfen. Der Philosoph und Pädagoge Theodor Litt in Leipzig, Leipzig 1996; W. Schulz, Untersuchungen zur Kulturtheorie Theodor Litts. Neue Zugänge zu seinem Werk, Weinheim 1990; Theodor-Litt-Jahrbuch, Leipzig 1999 i n.; H. Burckhart, Theodor Litt: Das Bildungsideal der deutschen Klassik und die moderne Arbeitswelt, Darmstadt 2003.

Lubowski Käte (1875-1932?), autorka popularnych na początku XX w. powieści i nowel: Die ihr gesegnet seid, 1915; Gabi Schaffner, 1918; Liebesopfer, 1921; Die Krone des Lebens, 1927; Du sollst begehren! Novelle, 1926; Die Ihr gesegnet seid!, 1930; Die Stimme des Blutes. Roman, 1928. Wiele z nich publikowano w łódzkich gazetach. W dodatku do „Neue Lodzer Zeitung” wydrukowano nowelę pt. Palmsonntag, „Ilustrierte Sonntagsbeilage Neue Lodzer Zeitung”, 9.04./27.03.1911, historię detektywistyczną Der Geniestreich, „Ilustrierte Sonntagsbeilage Neue Lodzer Zeitung”, 23.10./5.11.1911, nowelę Im guten Glauben, „Ilustrierte Sonntagsbeilage Neue Lodzer Zeitung”, 4.12./17.12.1911, nowelę Ueberlistet, „Ilustrierte Sonntagsbeilage Neue Lodzer Zeitung”, 12./25.08.1910, Hohe Zinsen, „Ilustrierte Sonntagsbeilage Neue Lodzer Zeitung”, 23.09/6.10.1910, Die Lebensquelle „Ilustrierte Sonntagsbeilage Neue Lodzer Zeitung”, 15./28.01.1912, Die goldene Last, „Illustrierte Sonntagsbeilage. Neue Lodzer Zeitung”, 6./19.01.1913, Der erste Schuss, „Illustrierte Sonntagsbeilage. Neue Lodzer Zeitung", 21.04/4.05.1913. Wybór źródeł: http://www.literaturport.de/index. php?id=26\&user_autorenlexikonfrontend_pi1\%5Bal_aid\%5D=1384\&user_autoren- 
lexikonfrontend_autorenlexikonfrontend_pi1\%5Bal_opt\%5D=1\&cHash=9f09d38cc18ade4a0a2e328102fa5a14 [dostęp: 12.12.2013].

Lüdtke Franz, pseud. Frank Hinrich Brastatt (1882-1945), działacz polityczny, nauczyciel, poeta, pisarz, redaktor pisma „Ostland”, członek nazistowskiej organizacji Bund Deutscher Osten, jak również Honorowy Obywatel Bydgoszczy. Był autorem powieści, nowel i opowiadań. Wiersze swoje publikował na łamach literackich czasopism berlińskich i prasy niemieckiej ukazującej się w Polsce, m.in. Zur Nacht, „Deutsche Lodzer Zeitung", 18.01 .1916 [b.s.]. Wśród zasługujących na uwagę utworów są m.in.: Der Heilandsweg des Benedikt Freudlos, Das Jahr der Heimat, Die Nacht der Erlösung i Die grauen Blätter Valentin Brunns, des Goldmachers. Lüdtke był ponadto autorem podręcznika historii dla Wehrmachtu zatytułowanym 1000-letnia wojna między Niemcami i Polską. Wybór źródeł: F. Lüdtke, [w:] S. Błażejewski, J. Kutta, M. Romaniuk, Bydgoski słownik biograficzny, t. 4, Bydgoszcz 1997, s. 70-71.

Łaganowski Karol Teofil (1856-1917), prawnik, dziennikarz i poeta. Współpracował z warszawskim czasopismem „Nowiny”, „Kurierem Codziennym” i „Kurierem Warszawskim”, od 1887 r. z „Dziennikiem Łódzkim”, w którym zamieszczał felietony, kroniki tygodniowe, krytyki teatralne i literackie. W latach 1898-1903 współpracował z „Gońcem Łódzkim”. We wrześniu 1903 r. rozpoczął współpracę z „Gońcem”, a następnie „Rozwojem”, gdzie publikował artykuły poświęcone problematyce politycznej, społecznej i prawnej. Wybór źródeł: Z. Gostkowski, „Dziennik Łódzki" w latach 1884-1892. Studium nad powstawaniem polskiej opinii publicznej $w$ wielonarodowym mieście fabrycznym, Łódź 1963, s. 55; W. Kaszubina, Łaganowski Karol Teofl, [w:] PSB, t. 16, Wrocław 1971, s. 190-191; A. Kempa, Sylwetki łódzkich dziennikarzy i publicystów, Łódź 1991; Zbiór poetów polskich XX w., oprac. P. Hertz, t. 4, Warszawa 1965, s. 264-265.

Ląpiński Stanisław (1848-1921), dziennikarz, krytyk teatralny, pisarz, poeta. Inicjator Polskiego Towarzystwa Teatralnego, Rzemieśliniczego Towarzystwa Śpiewaczego „Lira”, redaktor „Dziennika dla Wszystkich”. Autor dramatów, jednoaktówek, nowel, krótkich opowiadań, w tym Wykolejony, Nad Pilica, Córka zawiadowcy, Ojciec, Oblężenie Rakowca. Często wystawiany na scenach polskich teatrów. Autor obrazka z życia łódzkich robotników pt. Tkacz (1898). Publikował m.in. na łamach „Kuriera Warszawskiego”, w „Ognisku Rodzinnym” i „Dniu”, od 1898 r. współpracował z „Rozwojem”. Kierownik artystyczny teatru „Lutnia”. Wybór źródeł: S. Rachalewski, Zastygły nurt życia. Łódź, która odeszła, Łódź 1938, s. 79; W. Kaszubina, Łąpiński Stanisław Jan, [w:] PSB, t. 18, Wrocław 1973, s. 320-321; Z. Piąstka, W cieniu alej cmentarnych. Przewodnik po cmentarzach przy ulicach Ogrodowej i Srebrzyńskiej w Łodzi, Łódź 1990, s. 58-59; A. Kempa, Sylwetki łódzkich dziennikarzy i publicystów, Łódź 1991, s. 27.

Matus Dina (1899-1940), malarka, grafik i scenograf polskiego pochodzenia. Autorka scenografii w teatrze „Azazel” i „Ararat”. Wybór źródeł: J. Strzałkowski, Artyści, obrazy i zbieracze w Łodzi do 1918 r., Łódź 1991, s. 11, 62; J. Malinowski, Malarstwo i rzeźba Żydów polskich w XIX i XX w., Warszawa 2000; H. Kubaszewska, Matus Dina, 
[w:] Słownik artystów polskich i obcych w Polsce działających, t. 5, Warszawa 1993, s. 444-445; A. Kempa, M. Szukalak, Żydzi dawnej Łodzi. Słownik biograficzny Żydów łódzkich oraz z Łodzią związanych, t. 3: A-Z, Łódź 2003, s. 78.

Mieszkowski Antoni Wincenty (1865-1900), literat, dziennikarz, w latach 1892-1899 związany z Łodzią. Krótko przed śmiercią redagował tygodnik kulturalno-literacki o nazwie „Ognisko Rodzinne” (1899-1900), którego wydawcą był Ludwik Fiszer. Publikował w „Przeglądzie Literackim i Artystycznym” i „Nowej Reformie”, był wydawcą „Gońca Łódzkiego”. Wybór źródeł: W. Kaszubina, Antoni Wincenty Mieszkowski, [w:] PSB, t. 16, Wrocław 1971; S. Szenic, Cmentarz Powązkowski 1891-1918. Zmarli i ich rodziny, cz. III, Warszawa 1983; Słownik dziennikarzy polskich 1661-1945, red. W. Zuchniewicz, Warszawa 1984; A. Kempa, Sylwetki łódzkich dziennikarzy i publicystów, Łódź 1991.

Milker Aleksander (1867-1924), dziennikarz, współwłaściciel i współwydawca ugodowej „Neue Lodzer Zeitung”. Autor wielu artykułów oraz felietonów. Wybór źródeł: Aleksander Milker, [w:] „Illustrierte Sonntagsbeilage zur Neuen Lodzer Zeitung", 29.04.1917, s. 69-70; Bibliografia prasy łódzkiej 1863-1944, Warszawa 1967.

Metzner Friedrich (1797-1852), pastor, pisarz. Pochodził z Chemnitz, teologię studiował w Lipsku, a po studiach przybył do Królestwa Polskiego. W 1827 r. został pierwszym pastorem tworzonej właśnie parafii ewangelicko-augsburskiej św. Trójcy w Łodzi. Pastor Metzner był bardzo sprawnym organizatorem życia religijnego, społecznego i kulturalnego lokalnej społeczności luterańskiej. Podobnie jak większość osadników niemieckich, którzy na ogół nie znali języka polskiego i polskich tradycji, w 1830 r. opowiedział się przeciw powstaniu listopadowemu, zaś w czasie wojny polsko-rosyjskiej w 1831 r. współpracował z władzami rosyjskimi. Działał aktywnie w Radzie Opiekuńczej szpitala św. Aleksandra, był opiekunem szkoły ewangelickiej, aktywnie uczestniczył w organizowaniu cmentarza przy ul. Ogrodowej. Oprócz tego rodzaju działalności społecznej zajmował się pisaniem tekstów literackich. Wybór źródeł: G. Schedler, Eben-Ezer, Eine Jahrhundertgeschichte der evangelischen St. Trinitatisgemeinde zu Lodz, Łódź 1929; E. Kneifel, Die Pastoren der EvangelischAugsburgischen Kirche in Polen, Eging 1967; K. Stefański, Stary cmentarz ewangelicko-augsburski w Łodzi, Łódź 1992; M. Budziarek, Łodzianie, Łódź, 1999; B. Kopczyńska-Jaworska, K. Woźniak, Łódzcy Luteranie: społeczność i jej organizacja, Łódź 2002; K. Woźniak, Łódzcy luteranie. Społeczność i organizacja, Łódź 2002.

Morzkowska Waleria Marrené, primo voto, de domo Mallet de Grandville-Malletski (1832-1903), pisarka, publicystka, krytyk literacki, autorka licznych powieści, z których pierwsza Nowy gladiator powstała w 1857 r. W swych utworach poruszała tematykę emancypacji kobiet. Była redaktorką czasopisma „Świt”, publikowała również na łamach „Przeglądu Tygodniowego”, „Gazety Warszawskiej”, „Tygodnika Ilustrowanego”, „Kłosów” i „Biblioteki Warszawskiej”. Prowadziła salon literacki. Wybór źródeł: I. Wyczańska, Marrené Waleria (1832-1903), [w:] PSB, t. 20, Wrocław 1975, s. 60-62; J. Maciejewski, R. Loth, T. Witczak, Dawni pisarze polscy od początków piśmiennictwa do Młodej Polski, Waszawa 2000; H. Karwacka, Łódź 
w oczach pozytywistki. „Wśród kq̨kolu” Walerii Marrené-Morzkowskiej - pierwsza powieść o fabrycznym mieście, „Prace Polonistyczne” 1975, ser. XXXI, s. 147-174.

Müller August Hermann (?-1917), niemiecki pastor z Łodzi (parafia św. Jana), pisarz, poeta, autor 3 tomów „Waldblumen” z 1902 r. Wydawca pisma „Wider das vierblättrige Kleeblatt am Sektenstengel”. Wybór źródeł: E. Kneifel, Geschichte der Evangelisch-Augsburgischen Kirche in Polen, Roth bei Nürnberg 1964, s. 236.

Nasarski Peter Emil (1914-2001), ukończył niemieckie gimnazjum w Łodzi, studiował w Wiedniu, redaktor niemieckiego dziennika „Freie Presse” i wydawca „Zelte im Osten”. W redakcji „Der Deutsche Weg” odpowiedzialny za wiadomości sportowe i felietony. W latach 1940-1945 żołnierz-sprawozdawca wojenny z Rosji, Ukrainy, Finlandii i Włoch. Po wojnie współpracownik wielu rozgłośni radiowych w Berlinie Zachodnim. Autor słuchowisk radiowych, książek, redaktor czasopisma „Westöstliche Begegnung”. Korespondent gazet zachodnioniemieckich. Po przeniesieniu się do Kolonii redaktor naczelny „Kulturpolitische Korrespondenz” oraz redaktor czasopisma „Nachbarn in Ostmitteleuropa”. Tłumacz wielu dzieł z języka polskiego. Do 1997 r. wydawca roczników Ziomkostwa Wisła-Warta. Wybór źródeł: M. Czgaski, Peter Emil Nasarski - „reformator” bońskiego rewizjonizmu, Opole 1968, http://kulturportal-west-ost.eu/biographies/nasarski-peter-e-2/ [dostęp: 10.12.2013].

Ortmann Reinhold (1859-1929), autor ponad sześćdziesięciu powieści i dramtów oraz krótkich opowiadań m.in.: Kismet, Bettler, Die Urlaubsreise. Wybór źródeł: F. Fiedler, Aus der Literaturwelt. Charakterzüge und Urteile. Tagebuch, Göttingen 1996, s. 539.

Pawlak Władysław (1902-1958), pisarz, autor m.in. powieści Kamienica wielkiego miasta. Wybór źródeł: R. Leszczyński, Pawlak Władysław, [w:] PSB, t. 25, Wrocław 1980, s. 414-415.

Petersilge Jan (1830-1905), właściciel zakładu litograficznego, wydawnictwa i drukarni. Był synem złotnika Johanna Mikołaja i wnukiem hiszpańskiego kupca Don Peter Silge, który osiedlił się w Niemczech. Wybór źródeł: J. Jaworska, Petersilge Jan (1830-1905), [w:] PSB, t. 25, Wrocław 1980, s. 677-678; J. Tynecki, Łódzki rynek prasowy w dwudziestoleciu międzywojennym, „Prace Polonistyczne” 1983, ser. XXXIX.

Piel Reinhold (?), pisarz, autor m.in. zbioru dowcipów pt. Ne Mütze voll Witze aus Lodz und Pabianice, Lodz 1913. Wybór źródeł: M. Półrola, Cały ten interes, [w:] Wrastanie, „Tygiel Kultury” 7-9/2008, s. 61-71.

Przedborska Felicja Maria (1888-?), nauczycielka, poetka, dziennikarka, działaczka społeczna, łodzianka żydowskiego pochodzenia. Wybór źródeł: L. Stolarzewicz, Literatura Łodzi w ciagu jej istnienia. Szkic literacki i antologia, Łódź 1935; Zbiór poetów polskich XX w., oprac. P. Hertz, księgi 1-7, Warszawa 1959-1975; Z. Skibiński, B. Stelmaszczyk-Świontek, Kwiaty łódzkie. Antologia poezji o Łodzi, Łódź 1982; 
T. Gicgier, Opowieści o dawnych poetach Łodzi, red. W. Grochowalski, Łódź 1995, s. 133; A. Kempa, M. Szukalak, Żydzi dawnej Łodzi. Słownik biograficzny Żydów łódzkich oraz z Łodziq zwiqzzanych, t. 2: A-Z, Łódź 2002, s. 93.

Rabon Israel, właśc. Izrael Rubin (1900-1941), żydowski pisarz tworzący w języku jidysz. Od $1902 \mathrm{r}$. mieszkał w Łodzi, gdzie założył czasopismo literackie „Os”. Autor m.in. takich powieści, jak: Di gas [Ulica] i Balut [Bałuty]. Wybór źródeł: http://portalwiedzy.onet.pl/6526,,,,rabon_izrael,haslo.html [dostęp: 12.12.2013].

Raymond Bruno, właśc. Bruno König (?-1944), niewiele wiadomo o jego życiu. Prawdopodobnie był potomkiem przybyłego do Łodzi w XIX w. Ferdynanda Königa (1849-1917), właściciela cegielni i założonej w 1885 r. przędzalni, która funkcjonowała do 1931 r. Jego willa przy ul. Pabianickiej 49 stoi do dziś i stanowi część parku Sielanka. Grób Bruno Raymonda znajduje się najprawdopodobniej na Starym Cmentarzu w Łodzi przy ul. Ogrodowej.

Richter Juliusz Cezar (1846-1905), księgarz i wydawca, właściciel pierwszej w Łodzi księgarni nakładczej. Swoją działalnością zaspokajał potrzeby kulturalne lokalnej społeczności. Wybór źródeł: R. Kaczmarek, Od Jankiela do Cezara, „Głos Robotniczy" 22/1960; L. Waszkiewicz, Cezary Richter, pionier łódzkiego księgarstwa, „Dziennik Łódzki” 107/1961, s. 3-4; B. Gralak, Cezar Juliusz Richter, księgarz i pierwszy nakładca łódzki, Warszawa 1984; J. Jaworska, Poczq̨tki księgarstwa w Łodzi, Łódź 1999; J. Strzałkowski, Drukarnie i księgarnie w Łodzi do 1944 r., Łódź 1999; J. Krakowiak, Od Fiszera do „Pegaza”, Łódź 2005.

Roda Roda Alexander, właśc. Šandor Friedrich Rosenfeld (1872-1945), austriacki pisarz i publicysta chorwackiego pochodzenia, autor reportaży wojennych, powieści opowiadań. Jego utwory często publikowały niemieckie gazety z Łodzi, jak np.: „Illustrierte Sonntagsbeilage. Neue Lodzer Zeitung”. Wybór źródeł: H. Eulenberg, So war mein Leben, Düsseldorf 1947; I. Stiaßny-Baumgartner, Roda Rodas Tätigkeit im Kriegspressequartier. Zur progandistischen Arbeit österreichischer Schriftsteller im Ersten Weltkrieg, Wien 1982; R. Hackermüller, Einen Handkuss der Gnädigsten - Roda Roda, Bildbiographie, Wien-München 1986; I. Stiaßny-Baumgartner, Roda Alexander (Sándor), [w:] Österreichisches Biographisches Lexikon 1815-1950 (ÖBL), Bd. 9, Wien 1988, s. 193; V. Obad, Roda Roda und die deutschsprachige Literatur aus Slawonien. Mit einer Anthologie unbekannter Texte, Wien-Köln-Weimar1996; O. Pausch, Rebellakatzentier und Artilleriehund - die Affäre Adele Sandrocks mit Alexander Roda 1900/1901. Mit einer Edition sämtlicher Korrespondenzen, Wien-KölnWeimar 2001; M. Kaiser, Roda Roda, Alexander, [w:] Neue Deutsche Biographie (NDB), Bd. 21, Berlin 2003, s. 687-689.

Rosenzweig Berta (1894-?), pisarka. Urodziła się w Błaszkach koło Kalisza. Jako dziecko przeniosła się z rodzicami do Frankfurtu nad Menem, gdzie ukończyła szkołę. Publikowała wiersze w „Frankfurter Frauenzeitung” oraz „Neue Lodzer Zeitung”. Wybór źródeł: Literackie i nieliterackie obrazy miasta. Łódź przełomu wieków oczami niemieckojęzycznego autora - Carla Heinricha Schultza / Nicht nur literarische Bilder 
einer Stadt. Lodz in den Augen eines deutschsprachigen Autors - Carl Heinrich Schultz, red. M. Kucner, Łódź 2011.

Rowiński Władysław (1868-1918), literat, dziennikarz, w latach 1886-1906 związany z Łodzią, redaktor działu kulturalnego „Dziennika Łódzkiego”, korespondent „Kuriera Codziennego”, właściciel „Gońca Łódzkiego”. Wybór źródeł: A. Kempa, Sylwetki łódzkich dziennikarzy i publicystów, Łódź 1991.

Rudnicki Lucjan, pseud. Ludwik, Mały, Krawiec, Kazimierz Lubiński (18821968), pisarz, działacz polityczny. Do Łodzi przybył w 1898 r. Pracował w zakładach Heinzla i Kunitzera na Widzewie. Był działaczem wielu partii, m.in. PPS i SDKPiL. Od grudnia 1918 r. do sierpnia 1938 r. członek Komunistycznej Partii Robotniczej Polski (KPRP)/Komunistycznej Partii Polski (KPP). W latach 20. publikował w prasie komunistycznej artykuły wymierzone w działalność PPS i PSL Wyzwolenie. W $1942 \mathrm{r}$. wstąpił do PPR, współpracował z GL i ZWM. Po II wojnie światowej zajmował się głównie pracą pisarską. W grudniu 1948 r. był delegatem na I Zjazd PZPR, w marcu 1954 r. na III Zjazd PZPR. W latach 1952-1956 sprawował mandat posła na Sejm PRL I kadencji. W 1957 r. był współzałożycielem i członkiem Zarządu Głównego Stowarzyszenia Ateistów i Wolnomyślicieli. Współpracował z Zakładem Historii Partii przy KC PZPR. W 1951 r. otrzymał Nagrodę Państwową II stopnia, był także odznaczony Orderem Budowniczych Polski Ludowej, Krzyżem Komandorskim Orderu Odrodzenia Polski i Orderem Sztandaru Pracy I klasy. Pochowany na Cmentarzu Wojskowym na Powązkach w Warszawie (kw. A 28 rz. Tuje m. 20). Wybór źródeł: K. Woźniakowski, Lucjan Rudnicki, [w:] PSB, t. 32, Wrocław 1989/1991, s. 637-641.

Rżewski Aleksy (1885-1939), był komisarzem rządowym, a następnie prezydentem miasta, pierwszym jego administratorem po odzyskaniu niepodległości przez Polskę. Autor książek, m.in Za wolność i lud, W walce z przemoca. Wspomnienia, Szlakami walki i buntu. Wspomnienia $z$ walk rewolucyjnych z trójzaborcami, $W$ walce z trójzaborcami o Polskę niepodległą. Wybór źródeł: 11 dzielnych ludzi. W 90. rocznicę odzyskania przez Polskę niepodległości, red. J. Warzecha, Warszawa 2008.

Schettler Paul Aleksander (1884-1935), pisarz, wydawca „Dresdner Nachrichten”, autor m.in. opowiadania Die Träne, które zamieściła gazeta „Illustrierte Sonntagsbeilage”, 7.05.1916. Wybór źródeł: http://www.dresden-lexikon.de/Zahlen/Personendetail.php?id=229\&l=de\&user=\&login= [dostęp: 10.04.2014].

Schmidt Karl (?), redaktor „Lodzer Zeitung”. Wybór źródeł: W. Kaszubina, Bibliografia prasy łódzkiej 1863-1944, Warszawa 1967.

Schultz Carl Heinrich (Karol Henryk Schultz lub Szulc), pseud. Ernst Heiter (1882-1940), pisarz, dziennikarz, publicysta. Zginął w 1940 r., rozstrzelany za działalność antyhitlerowską. Urodził się w Łodzi, ukończył tu szkołę powszechną i gimnazjum, a do 1914 r. studiował nauki ekonomiczne na uniwersytecie w Kijowie. Na krótko przed wybuchem I wojny światowej powrócił do rodzinnego miasta, w którym pozostał do 1933 r. Następne lata spędził w Warszawie, w 1938 r. ponownie 
przeniósł się do Łodzi, a tuż przed wybuchem II wojny światowej przeprowadził się do Pabianic. Karierę dziennikarską i literacką rozpoczął w 1904 r. w „Neue Lodzer Zeitung. Handels- und Industrieblatt". Ponieważ szybko zauważono jego talent literacki i dziennikarski, jego teksty publikowało wiele pism lokalnych i zagranicznych, takich jak „Schlesische Volkszeitung”, „Lodzer Volkszeitung”, „Łódzki Głos Obywatelski” czy „Der Deutsche Wegweiser”. Bogata twórczość Schultza obejmuje liczne wiersze (głównie tzw. lirykę okazjonalną) poświęcone aktualnym wydarzeniom politycznym, poza tym krótkie formy narracyjne, takie jak opowiadania, nowele, szkice i baśnie oraz gatunki publicystyczne i dziennikarskie, a więc artykuły przewodnie, recenzje, reportaże i felietony. Poza tym przekładał także na niemiecki autorów francuskich, rosyjskich i polskich, jak np. A. Terrier, F. de Nion czy P.R. Polewoj. Z autorów polskich tłumaczył m.in. wiersze Adama Asnyka, Andrzeja Niemojewskiego i Jerzego Żuławskiego. Wybór źródeł: Eksterminacja inteligencji Łodzi i okręgu łódzkiego 1939-1940, red. A. Galiński, M. Budziarek, Łódź 1992; Literackie i nieliterackie obrazy miasta. Łódź przełomu wieków oczami niemieckojęzycznego autora Carla Heinricha Schultza / Nicht nur literarische Bilder einer Stadt. Lodz in den Augen eines deutschsprachigen Autors Carl Heinrich Schultz, red. M. Kucner, Łódź 2011.

Seeliger Ewald Gerhard, pseud. Ewger Seeliger, Ewger Seeliger Menschheit, Marquardt van Vryndt (1877-1959), niemiecki pisarz urodzony na Śląsku, autor m.in. An der Riviera, Leipzig 1901; Aus der Schule geplaudert, Hamburg 1902; Der Stürmer, Berlin 1904; Chinesen, Hamburg 1905; Nordnordwest, Berlin 1905; Der Schrecken der Völker, Berlin 1908; Englands Feind, Wiesbaden 1910; Meerfahrt, München i in. 1910; Zurück zur Scholle, München i in. 1910; Schlesische Historien, München i in.: 1. Siebzehn schlesische Schwänke, 1911; 2. Schlesien, 1911; 3. Zwischen Polen und Böheim, 1911; Die Weiber von Löwenberg, München i in. 1911; Buntes Blut, München i in. 1913; Niß Ipsen von Bombüll und anderes, Reutlingen 1913; Das sterbende Dorf, München i in. 1914; Der gelbe Seedieb, Berlin i in. 1915; Max Doberwitz, der Tantenmörder, Dresden 1915; Das amerikanische Duell, Berlin i in. 1916; Die weißen Indianer, Berlin 1918; Junker Schlörks tolle Liebesfahrt, München 1919; Die Macht, Leipzig 1919; Der Streit um die Rote Rose, Berlin 1928; Glaube mit Humor, Berlin 1940 (pod pseud. Ewger Seeliger); Liebe mit Humor, Berlin 1940 (pod pseud. Ewger Seeliger), Siege mit Humor, Berlin 1940 (pod pseud. Ewger Seeliger). Jego nowelę pt. Zwischen Polen und Böheim zamieściła „Illustrierte Sonntagsbeilage”, 2. 10./15.11.1911. Wybór źródeł: B. Gräfrath, Ketzer, Dilettanten und Genies, Hamburg 1993; I. Sophia, Was man nicht lachend sagen kann, ist keine Wahrheit. Zum provokativen Werk Ewald Gerhard Seeligers, „Jahrbuch zur Kultur und Literatur der Weimarer Republik” 13-14/2011, s. 121-149.

Seidler Oskar (?-1940), współzałożyciel Deutsche Arbeitspartei Polens (dalej: DAP) oraz Deutsche Sozialistische Arbeitspartei Polens (dalej: DSAP). Aresztowany w 1939 r. i osadzony w więzieniu w Radogoszczu w 1940 r, gdzie zmarł. Wybór źródeł: B.D. Lakeberg, Die deutsche Minderheitenpresse in Polen 1918-1939 und ihr Polen- und Judenbild, Oldenburg 2007. 
Skowronnek Fritz (1858-1939), niemiecki pisarz, dziennikarz, dramaturg, wielbiciel Mazur, pisał pod pseudonimem Fritz Bernhard i Hans Windeck. W latach 1883-1889 był nauczycielem, od 1892 r. przebywał w Berlinie, gdzie pracował jako dziennikarz, od 1897/1898 r. jako redaktor „Breslauer Morgenzeitung”. Autor wielu powieści, m.in.: Die Jagd, 1901; Masurenblut, 1904; Mein Freund Baruch und andere Erzählungen, 1907; Der Angelsport, 1909; Das deutsche Waidwerk, 1909; Halali. Bunte Bilder aus Waidwerk und Fischwaid, 1910; Der Hungerbauer. Ein Dorfroman aus Masuren, 1911; Seelenleben der Tiere, 1911; Jagdgeschichten, 1911; Die Zeitung des Waldes und andere Jagdgeschichten, 1912; Die Verlobung beim Bärenfang und andere humoristische Erzählungen, 1913; Josepha und andere Erzählungen, 1913; Rittergut Hohensalchow. Gutsroman, 1914; Der Erbsohn. Roman, 1915; Die braune Sascha und andere masurische Dorferzählungen, 1915; Aus Masurens Wäldern, 1915; Der Mann von Eisen. Roman aus Ostpreußens Schreckenstagen, 1915; Die Bestrafung Serbiens. Schilderungen aus dem Weltkriege 1914-1916, 1916; U-Deutschlands Fahrt, 1916; Der Hecht im Karpfenteich. Ein lustiger Roman aus Masuren, 1916; Herd und Schwert. Ein Roman aus Ostpreußen, 1916; Die Pension des Glücks. Roman, 1916; Das sinkende Schiff. Roman aus der Ostmark, 1916; Hindenburg, der Befreier des deutschen Ostens, 1916; Auf eigener Scholle. Roman, 1917; Ein seltsames Mädel. Roman, 1917; Der Muckerpfaff. Roman, 1918; Ein ehrlicher Lump. Roman, 1918; Der Polenflüchtling. Ein Roman aus dem Osten, 1918; Der graue Stein. Ein Roman aus Masuren, 1918; Das schleichende Gift. Masuren-Roman, 1919; Pan Kaminsky. Roman, 1919; Die Lore auf dem Dach. Roman, 1919; Heimatfeuer. Roman, 1920; Das Vermächtnis. Ein polnischer Gutsroman, 1920; Der Dämon von Kolno. Ein Grenzroman, 1921; Dies irae. Ein ostpreußischer Zukunftsroman, 1922; Lebensgeschichte eines Ostpreußen. Autobiografie, 1925; Der Dämon. Roman, 1927. W dodatku do "Neue Lodzer Zeitung” opublikowano jego szkic pt. Das Gottesgericht, „Illustrierte Sonntagsbeilage Neue Lodzer Zeitung”, 3./16.06.1911. Wybór źródeł: P. Brock, Überragt vom Turm der Kirche. Lyck, die Hauptstadt Masurens wurde vor 555 Jahren gegründet, „Ostpreußenblatt”, 30.08.1980, s. 11; B. Chołuj, Grenzliteraturen am Beispiel von Masuren und Oberschlesien. Fritz Skowronnek und Wilhelm Wirbitzky und Horst Bienek. / Problematyka granicy u Fritza Skowronka i Wilhelma Wirbitzkego/, [w:] Nachdenken über Grenzen, hrsg. v. R. Görner, S. Kirkbright, München 1999, s. 235-247; F. Skowronnek, Ich war der erste, der die neuen Farben führte, [w:] K.U. Bertrams, Als Student in Königsberg, Hilden 2006, s. 111-113; Von den drei Philipponenklöstern in der Johannisburger Heide ist nur noch eines in Eckertsdorf erhalten, „Ostpreußenblatt”, 14.11.2009, s. 14.

Stolarzewicz Ludwik (1890-1960), literat, bibliograf, autor bibliografii i szkiców literackich dotyczących Łodzi, historyk literatury. Wybór źródeł: http://www. wimbp.lodz.pl/wimbp/pliki/kalend_2010.pdf [dostęp: 12.12.2014].

Strakun S. (?), był wydawcą i księgarzem, który zajmował się sprzedażą książek rosyjskich. Wybór źródeł: J. Róziewicz, Kontakty naukowe polsko-radzieckie w latach 1919-1939. Materiały wstępne, „Kwartalnik Historii Nauki i Techniki” 12(4)/1967, s. 769-799. 
Strauch Józef Alfred (1877-1934), księgarz, właściciel łódzkiej księgarni i wydawca książek. Wybór źródeł: J. Jaworska: Początki księgarstwa w Łodzi, „Roczniki Biblioteczne" 1-2/1969, s. 118-133; J. Strzałkowski: Drukarnie i księgarnie w Łodzi do 1944 roku, Łódź 1999, s. 128; J. Krakowiak: Od Fiszera do „Pegaza”, Łódź 2005, s. 92.

Symcha-Bunim Szajewicz (1907-1944), autor poematu Lech lecho, związany z kręgiem pisarzy i poetów w getcie Litzmannstadt. Wybór źródeł: K. Radziszewska, Flaschenpost aus der Hölle, Texte aus dem Lodzer Getto, Frankfurt/Main i in. 2011.

Szeliga Maria, właśc. Loevy, primo voto Czarnowska, de domo Mirecka (18541927), urodziła się w Jasieńcu Soleckim w Królestwie Polskim, zmarła w Chaville pod Paryżem. Powieściopisarka, poetka, publicystka społeczna, socjalistka, pionierka międzynarodowego ruchu emancypacyjnego kobiet, polska działaczka emigracyjna. Tworzyła pod pseudonimami B. Saryusz, Bolesław Saryusz, Ciotka Marynia, Jerzy Horwat, Matylda Mahon, Vox. Wiersze i szkice powieściowe Marii Szeligii drukowały m.in.: „Opiekun Domowy”, „Kłosy”, „Biblioteka Romansów i Powieści”, „Przegląd Tygodniowy” i „Przyjaciel Dzieci”. W 1873 r. ukazały się w wydaniu książkowym jej dwie powieści - Dla ideału i $W$ przeddzień - oraz zbiór wierszy Pieśni i piosenki. Wybór źródeł: P. Kuczalska-Reinszmitt, Międzynarodowe Kongresy Kobiece w Pary$z ̇ u$, „Przegląd Tygodniowy” 44/1889; C.W. Wojnarowska, Francusko-międzynarodowy kongres kobiecy, „Głos” 29/1889, s. 365-367; J. Orka, Maria Szeliga, „Tygodnik Mód i Powieści" 11/1909, s. 5; C. Walewska, Ruch kobiecy w Polsce, Warszawa 1909; P. Kuczalska-Reinszmitt, Zjazd Ligi wyborczych praw kobiet w Budapeszcie, „Ster” 13-14/1913, s. 77-87; Księga pamiq̨tkowa PPS, Warszawa 1923; J. Krawczyńska, Wspomnienie o redaktorce „Ogniska”, „Bluszcz” 4/1927, s. 13-14; S. Moszczyński, Śp. Maria Szeliga, „Ognisko” 256/1927, s. 2; C. Walewska, Walka o równe prawa. Nasze bojownice, Warszawa 1930.

Szpigel Jeszajahu (1906-1990), urodził się Łodzi, zmarł w Tel Awiwie. Autor wierszy i opowiadań w łódzkiej i warszawskiej prasie żydowskiej. Przeżył getto Litzmannstadt, Auschwitz i obozy pracy na terenie Rzeszy. Od 1950 r. mieszkał w Izraelu. Należał do kręgu czasopisma „Di goldene kejt”. Wybór źródeł: Przeżyliśmy. Proza Jeszajahu Szpigla z getta łódzkiego, red. K. Radziszewska, M. Zaremba, Łódź 2011.

Szwarc Marek (1892-1958), malarz i rzeźbiarz żydowskiego pochodzenia. Wybór źródeł: http://www.marekszwarc.com/about.html [dostęp: 12.12.2013].

Teichmann Irma (?), niemiecka pisarka z Łodzi, pisała do miejscowych gazet w tym „Neue Lodzer Zeitung”. Wybór źródeł: I. Teichmann, Warum?, „Illustrierte Sonntagsbeilage zur Neuen Lodzer Zeitung", 14.01.1917, s. 1-2.

Teslar Józef Andrzej (1889-1961), poeta, filozof, filolog polski. Był legionistą 2 pp II Brygady Legionów Polskich oraz referentem prasowym Komendy Legionów. W latach 1915-1917 należał do 4 pp III Brygady Legionów Polskich. Aresztowany przez Austriaków został osadzony w Witkowicach, następnie w Warszawie. Był ponadto sekretarzem sekcji szkolnictwa średniego w Ministerstwie Wyznań Religijnych 
i Oświecenia Publicznego. W 1919 r. ponownie trafił do 4 pp Legionów. Prowadził zajęcia w Korpusie Kadetów w Krakowie. W 1920 r. otrzymał posadę sekretarza Generalnego Komitetu Obrony Narodowej. W latach 1922-1939 pracował jako wykładowca języka polskiego w Ecole Superieure de Guerre w Paryżu. Wykładał również na innych zagranicznych uczelniach (m.in. w Edynburgu, Londynie i Glasgow). Ogłosił m.in. Rytmy wojenne. 1914-1916 (1916) oraz Mocniejsza niźli śmierć. 1914-1919 (1920). Wybór źródeł: Lista starszeństwa oficerów Legionów Polskich $w$ dniu oddania Legionów Polskich Wojsku Polskiemu (12 kwietnia 1917), Warszawa 1917, s. 27; Rocznik oficerski 1924, Warszawa 1924, s. 1278; Rocznik oficerski 1928, Warszawa 1928, s. 821; Rocznik oficerski 1932, Warszawa 1932, s. 391, 798.

Teplitzka Berta (?), dziennikarka, pisarka żydowskiego pochodzenia, związana z niemieckojęzyczną „Neue Lodzer Zeitung”. Wybór źródeł: Berta Teplitzka. Portrety łódzkie, oprac. M. Półrola, Łódź 2008.

Texel (Teksel) Józef (1839-1904), aktor, śpiewak operetkowy, reżyser teatralny. Występował w różnych miastach Polski: w Brześciu, Busku, Kielcach, Kobryniu, Lublinie, Siedlcach i Warszawie. W 1867 r. dotarł po raz pierwszy do Łodzi. Wybór źródeł: http://portalwiedzy.onet.pl/50869,,,,teksel_jozef,haslo.html [dostęp: 12.12.2013].

Thiele August (?), redaktor „Lodzer Zeitung”. Wybór źródeł: W. Kaszubina, Bibliografia prasy łódzkiej 1863-1944, Warszawa 1967.

Thieme Friedrich (1862-1945), niemiecki pisarz i dziennikarz, autor opowiadań, m.in.: Abenteuer eines Studentenvaters. Lustige Geschichten aus dem Jenaer Studentenleben, Leipzig 1897; Der Offizialverteidiger. Zwei Kriminalnovellen, Berlin 1903; Mysteriöse Geschichten. Kriminalistisches und Anderes, Erfurt 1898; Das Zauberfernrohr und andere Kriegshumoresken, Regensburg 1917; powieści, takich jak: Eine Vergangenheit, Berlin 1901; Der Fall Gembalsky, 1901; Der einzige Zeuge, 1905; Dr. Ohloffs Geheimnis, 1906; Ein Millionendiebstahl des zwanzigsten Jahrhunderts. Kriminalroman, Berlin 1900. Jego nowelę pt. Freiwilige Schuld opublikowała „Illustrierte Sonntagsbeilage”, 2./15.01.1911. Wybór źródeł: M. Geißler, Führer durch die deutsche Literatur des zwanzigsten Jahrhunderts, Weimar 1913; H. Voß i in., Literarische Silhouetten. Die Dichter und Denker und ihre Werke, Leipzig 1907/1910 (4 Bde.); Reclams Kriminalromanführer, hrsg. v. A. Arnold i in., Stuttgart 1978, s. 329-330.

Timkovskij-Kostin Ivan (?), korespondent rosyjski, który przybył do Łodzi w latach rewolucji. W 1907 r. wydał cykl reportaży w przekładzie Stanisława Majewskiego. Wybór źródeł: I. Timkovskij-Kostin, Miasto proletariuszów (Łódź), Łódź 2001.

Torn Teo von, właśc. Telesfor Szafranski (1865-1914), autor humoresek i powieści, np.: Humor im Deutschen Reichstag, 1894; Die Affäre Hellström und andere Geschichten, 1900; Offiziersgeschichten, 1900; Die weiße Weste, 1903; Der Verdacht, 1910; Stille Wasser, 1910; Das blaue Auto. Humoresken, 1912. Był również redaktorem 
berlińskiego tygodnika „Die Woche”. W Łodzi ukazała się m.in. humoreska pt. Der Freiweber, „Illustrierte Sonntagsbeilage. Neue Lodzer Zeitung. Handels- und Industrieblatt”, 28.08/10.09.1905. Wybór źródeł: http://www.tomaszgabis.pl/2011/08/17/ feliks-stefan-burdecki/ [dostęp: 10.12.2013].

Ulinower Miriam (1890-1944), urodziła się w Łodzi. Jej wiersze ukazywały się w „Lodzer Folksblat”. W 1922 r. w Warszawie opublikowano zbiór jej wierszy Der bobes ojcer [Skarby babci]. W czasie wojny przebywała w łódzkim getcie, następnie deportowana do Auschwitz. Wybór źródeł: K. Radziszewska, Flaschenpost aus der Hölle. Texte aus dem Lodzer Getto, Frankfurt/Main i in. 2011, s. 104-112; M. Czuku, Poetki miasta Łodzi http://widzew.nazwa.pl/marek/index2.php?option=com_content\&do_pdf=1\&id=59 [dostęp: 10.04.2014].

Utta August (1887-1940), urodził się w Augustynowie (koło Wielunia) jako syn niemieckich osadników: Karla Utty i jego żony Julianny, zmarł w 1940 r. Działacz mniejszości niemieckiej w Polsce, radny Łodzi, poseł na Sejm I i II kadencji (1922-1930), senator III kadencji. W latach 1902-1905 uczęszczał do niemieckiego seminarium ewangelickiego w Warszawie. Po jego ukończeniu pracował przez siedem lat jako nauczyciel w Woli Młockiej. Był założycielem biblioteki, organizacji młodzieżowej i uczestniczył w odczytach. Do Łodzi przybył w 1913 r. i zaangażował się w działalność Deutscher Schul- und Bildungsverein. W czasie wojny służył w armii rosyjskiej, po wojnie powrócił do Łodzi, pracował jako nauczyciel i dyrektor szkoły. Wybór źródeł: E. Kneifel, Geschichte der Evangelisch-Augsburgischen Kirche in Polen, Niedermarschacht 1964; Kto był kim w Drugiej Rzeczypospolitej, red. J. Majchrowski, Warszawa 1994, s. 556-557 (biogram nr 2109); August Utta 50 Jahre, „Freie Presse”, 5.06.1937, s. 1 .

Wandurski Witold (1891-1934), dramaturg, poeta, publicysta, reżyser, działacz polityczny i kulturalno-oświatowy. W latach 1916-1919 studiował w Rosji prawo, był wykładowcą w Wolnej Wszechnicy Sztuki oraz reżyserem i kierownikiem polskiego amatorskiego teatru w Charkowie. Po powrocie do Polski kierownik teatru w Łodzi. Działacz KPP. Współzałożyciel dziennika „Republika”, redaktor miesięcznika „Dźwignia”. Autor wielu dramatów i plakatów scenicznych. W 1929 r. wyemigrował do Związku Radzieckiego. Niesłusznie oskarżony w okresie „wielkiej czystki”, zmarł w więzieniu. Napisał: Śmierć na gruszy, W hotelu, Imperializm, Nowa scena robotnicza, Wiersze i dramaty. Imię Witolda Wandurskiego przypomniano w 1958 r. po rehabilitacji, do tego czasu przez wiele lat pozostawało w zapomnieniu. Wybór źródeł: http://polonia.kharkov.ua/index.php/pl/polacy-w-charkowie/66-witold-wandurski.html [dostęp: 12.12.2013].

Warrikow Maks, pseud. Herman Heine (?), redaktor „Lodzer Zeitung”, autor wielu felietonów, opowiadań i sylwetek łódzkich fabrykantów. Pisał również artykuły historyczne dotyczące Łodzi, Zgierza i Pabianic, które zamieszczano w jubileuszowych wydaniach gazety, np. w „Jubiläumsschrift der Lodzer Zeitung” 1863-1913 i 1863-1888 oraz w dodatkach beletrystycznych, a także wydaniach codziennych gazety. Wybór źródeł: W. Kaszubina, Bibliografia prasy łódzkiej 1863-1944, Warszawa 1967. 
Winfeld Lenelotte (?), niemiecka pisarka, autorka nowel publikowanych w dodatkach beletrystycznych i kalendarzach. W Łodzi opublikowano jej nowelę pt. Die Mauer, „Illustrierte Sonntagsbeilage Neue Lodzer Zeitung”, 7.05/24.04.1911. Wybór źródeł: L. Winfried, Begegnung, „Der Glücksbote. Illustrierter Haus- und Familien-Kalender" 1930.

Wilkens Karl (?), jeden z redaktorów „Lodzer Zeitung”. Na uwagę zasługuje jego postawa wobec idei utworzenia resursy obywatelskiej, która zjednoczyłaby łodzian. W jubileuszowej księdze „Lodzer Zeitung” (1863-1888) napisał: „Uważny obserwator tej ważnej części życia społecznego nie będzie mógł się oprzeć wrażeniu, że jeszcze dużo tu zostaje do zrobienia, żeby z masy obok siebie żyjących obywateli stworzyć społeczeństwo dążące do wyższego rozwoju. Brakuje nam przede wszystkim miejsca, neutralnego terenu, na którym - zachowując dobry ton i wykwintny styl życia - rozmaite elementy naszej ludności mogłyby się spotkać w sposób nieskrępowany i będąc z sobą w stałym kontakcie, nauczyć się wzajemnego współżycia”. Redaktor „Lodzer Zeitung” wyobrażał sobie, że takim neutralnym miejscem - za wzorem innych miast, w których kwitło życie towarzyskie - mogłaby być „resursa obywatelska”. Zwolennikiem podobnej idei był na gruncie polskim Kościelecki, który propagował ją na łamach „Dziennika Łódzkiego”. Cyt. za: A. Kuligowska-Korzeniewska, Łódź teatralna: polska, niemiecka i żydowska, „Tygiel Kultury” 1-3/2005. Wybór źródeł: W. Kaszubina, Bibliografia prasy łódzkiej 1863-1944, Warszawa 1967.

Will Julian (1890-1941), działacz polityczny, nauczyciel, dziennikarz, poeta, członek Deutscher Verein für Lodz und Umgebung oraz Deutsch-Evangelischer Landesschulverband, a od $1928 \mathrm{r}$. poseł na Sejm. Urodził się w niewielkiej miejscowości Liciszewo koło Lipna na Kujawach. W latach 30. XX w. przybył do Łodzi, gdzie związał się z narodowosocjalistycznym Deutscher Volksverband, którego organem prasowym była „Freie Presse”. W kwestii roli kościoła ewangelickiego w Polsce opowiedział się przeciwko biskupowi Bursche i jego poglądom, wspierającym polską rację stanu. Był zatem Will postacią o dość spójnych poglądach politycznych - zawsze opowiadał się za zachowaniem na ziemiach polskich niemieckiej kultury i języka. W tym duchu poświęcił się pracy nauczycielskiej w szkołach w Sompolnie, Rawiczu i Zgierzu. Po wkroczeniu Niemców do Polski w 1939 r. uznano jego postawę - mimo zaangażowania na rzecz zachowania niemczyzny w Polsce - za zbyt lojalną wobec Polski i Polaków, co popchnęło go w 1941 r. do samobójczej śmierci. W 1935 r. ukazał się tom jego poezji Fern vom Land der Ahnen. Utwory Willa wydawano w wielu tomach zbiorowych, m.in. Volk an der Grenze. Gedichte. Nachwort von Norbert Langer (1937). Wśród pisarzy, których dorobek opublikowano w tym tomie, znaleźli się m.in. Josef Weinheber, Hans Kloepfer, Hans Leishelm, Josef Georg Oberkofler, Paula Grogger, Max Mell, Richard Billinger, Herbert Sigler, Arthur von Wallp, Robert Hohlbaum, Franz Zumler, Ernst Leibl, Alfred Görgl, Hans Deitzinger, Hans Watzlik, Franz Höller, Emil Merker, Josef Schneider i Friedrich Bischoff. Ich wiersze były poświęcone małej ojczyźnie (Heimat). Julian Will zamieścił we wspomnianym tomie pieśn Lied für Auslanddeutsche, która stała się hymnem wszystkich Niemców żyjących poza granicami kraju. Wybór źródeł: A. Kargel, Julian Will, ein unermüdlicher Rufer des deutschen Ostens, 
„Litzmannstädter Zeitung”, 21.12 .1941 [b.s.]; F. Weigelt, Von unserer Art. Vom Leben und Wirken deutscher Menschen im Raum von Weichsel und Warthe, Wuppertal 1963.

Wolff Ludwig (1908-1988), niemiecki polityk, związany z kręgiem działaczy narodowosocjalistycznych. Pochodził z rodziny nauczycielskiej, która już podczas I wojny światowej angażowała się w ruch niemieckonarodowy. W latach 1918-1928 uczęszczał do łódzkiego Gimnazjum Niemieckiego, w 1926 r. założył tam organizację młodzieżową, 23 zastęp o nazwie „Goci”. W tym samym roku utworzył organizację Deutsche Jungenschaft in Polen zrzeszającą grupy gimnazjalistów uprawiających turystykę pieszą. Podczas studiów w Warszawie w latach 1929-1930 awansował do stopnia Landesführera i został pierwszym przewodniczącym Verein deutscher Hochschüler in Warschau. W 1925 r., a następnie w latach 1933-1934 odbywał służbę w polskim wojsku. Od jesieni 1934 r. kierował w łódzkim Niemieckim Zwiqzzu Szkolno-Oświatowym pracą z młodzieżą, $\mathrm{w}$ tym samym roku wprowadził związki młodzieżowe do organizacji Deutscher Volksverband in Polen (Niemiecki Związek Ludowy w Polsce), pierwotnie partii konserwatywno-narodowej. W 1936 r. został zastępcą przewodniczącego partii; a w maju 1938 r. jej przewodniczącym. W czasie wojny był członkiem SS w randze Obersturmbannführera oraz pierwszym komisarycznym kierownikiem NSDAP w powiecie (Kreisleiter). Brał udział w sporządzaniu „niemieckiej volkslisty", która miała obejmować wszystkie osoby niemieckiego pochodzenia. Po wojnie wyjechał do Monachium. Od czerwca 1956 do $1967 \mathrm{r}$. był zastępcą rzecznika Landsmannschaft Weichsel-Warthe i członkiem zarządu krajowego. Wybór źródeł: G. Zorn, Nach Ostland geht unser Ritt, Berlin-Bonn 1980; E. Stockhorst, 5000 Köpfe. Wer war was im Dritten Reich, Kiel 2000; W. Chu, The German Minority in Interwar Poland, Cambridge 2012; Die kompletten NS-Personalakten Ludwig Wolffs (PDF; 6,5 MB), Archiv der CIA, http://www.foia.cia.gov/sites/default/files/document_conversions/1705143/WOLFF,\%20LUDWIG_0022.pdf [dostęp: 12.12.2013].

Zelikowicz Józef (1897-1944), urodził się w Konstantynowie pod Łodzią, pochodził z rodziny chasydzkiej. Studia odbył na Uniwersytecie Humboldta w Berlinie. Brał udział w wojnie polsko-bolszewickiej 1920 r. Był członkiem żydowskiej łódzkiej grupy awangardowej Jung Jidysz. Publikował w „Najer Folksblat” i „Lodżer Tageblat”. Był autorem kilku sztuk dla łódzkich teatrów żydowskich „Ararat” i „Azazel”, a także członkiem zarządu Łódzkiego Towarzystwa Przyjaciół Żydowskiego Instytutu Naukowego YIVO w Wilnie. W czasie wojny przebywał w getcie Litzmannstadt. Był sekretarzem Żydowskiego Związku Kulturalnego (Jidysze Kultur Gezelszaft - Litzmannstadt Getto). Tworzył teksty do gettowych varietes, był też współredaktorem „Biuletynu Kroniki Codziennej”; pisał reportaże i sprawozdania oraz Encyklopedię getta. W czasie akcji deportacyjnej we wrześniu 1942 r. prowadził prywatny dziennik zatytułowany In jene koszmarne teg. W 1944 r. został wywieziony do Auschwitz i tam zamordowany. Wybór źródeł: K. Radziszewska, Flaschenpost aus der Hölle. Texte aus dem Lodzer Getto, Frankfurt/Main i in. 2011.

Zerbe Armin (1899-1929), urodził się w Łodzi, uczęszczał do łódzkiego Gimnazjum Niemieckiego. W latach 1919-1921 studiował ekonomię na uniwersytetach w Poznaniu oraz we Frankfurcie nad Menem. W 1921 r. wrócił do Łodzi, był działa- 
czem socjalistycznym, współzałożycielem DAP, naczelnym redaktorem „Lodzer Volkszeitung”, członkiem Syndykatu Dziennikarzy w Łodzi, od 1928 r. redaktorem „Der Landbote”. Wybór źródeł: A. Zerbe, „Ilustrowana Republika”, 22.11.1929, s. 8 oraz „Der Landbote”, 1.12.1929, s. 1.

Zerbe Emil (1897-1954), pochodził z rodziny łódzkich kamieniczników i rzemieślników. Od 1915 r. pracował w Kolonii w fabryce maszyn, gdzie zainteresował się działalnością Niemieckiej Partii Socjaldemokratycznej. W 1918 r. podjął studia w Wyższej Szkole Technicznej w Darmstadt, następnie zaangażował się jako członek SPD i USPD (w lewym odłamie SPD, która podczas I wojny światowej opowiadała się za programem pacyfistycznym). Po powrocie do Łodzi w 1922 r. założył wspólnie z Arturem Kronigiem Niemiecką Partię Pracy (DAP), która stawiała na ścisłą współpracę z partiami robotniczymi innych łódzkich grup narodowościowych, a więc z Polską Partią Socjalistyczną i Ogólnożydowskim Związkiem Robotników „Bund”. W 1922 r. został posłem na Sejm na dwie kadencje. Jako poseł ściśle współpracował z polskim i żydowskimi socjalistami. Był redaktorem naczelnym „Lodzer Volkszeitung”, a także korespondentem zagranicznym czasopism „Vorwärts” i „Volkswille”. W 1925 r. znalazł się we władzach krajowych Niemieckiej Socjalistycznej Partii Pracy (DSAP), a w 1934 r. został jej przewodniczącym. Sam się nazywał „Niemcem-Polakiem" i zajmował krytyczne stanowisko wobec komunistycznych wpływów w Niemieckiej Socjalistycznej Partii Robotniczej. Od 1930 r. prowadził konsekwentną walkę z wpływami narodowosocjalistycznymi. Redagował ulotki przeciw narodowemu socjalizmowi. W wyborach komunalnych w 1934 r. DSAP kandydowała ze wspólnej niemiecko-żydowskiej listy. Doprowadziło to do ataków na Zerbego i zniesławiania go przez organizacje o nastawieniu narodowym. Zarzucano $\mathrm{mu}$ „zerwanie z niemieckością" i brak „jakiegokolwiek niemieckiego charakteru”. Wraz z innymi przedstawicielami łódzkiej inteligencji został aresztowany w Łodzi 1 września 1939 r., wypuszczono go po interwencji prezydenta miasta, Kwapińskiego. Następnie udał się do Warszawy, gdzie uczestniczył w formowaniu przez PPS batalionów robotniczych. Przeżył wojnę w podziemnych kryjówkach, a po jej zakończeniu powrócił do Łodzi. Aresztowany na jakiś czas, nie został poddany procesowi weryfikacyji ani rehabilitacji. Zmarł w 1954 r. Wybór źródeł: L. Chajn, Materiały do historii klubów demokratycznych i Stronnictwa Demokratycznego, t. 2, Warszawa 1964, s. 315 (krótka notka biograficzna w przypisie); O. Heike, Die deutsche Arbeiterbewegung in Polen 18351945, Nordrhein-Westfalen 1969; Cz. Brzoza, Emil Zerbe, [w:] Kto był kim w Drugiej Rzeczypospolitej, red. J. Majchrowski, Warszawa 1994, s. 486 (biogram nr 1668); P. Blachetta-Madajczyk, Klassenkampf oder Nation? Deutsche Sozialdemokratie in Polen 1918-1939, Düsseldorf 1997; S. Glica, Czerwona Łódź wielu narodów, „Trybuna Robotnicza", 24.07.2008.

Zimmermann Heinrich, Henryk Cymerman (?), felietonista, eseista, literat, założyciel amatorskiego teatru Freie Bühne i efemerydalnego pisma o tym samym tytule, poświęconego życiu kulturalnemu i literackiemu. Jego utwory często publikowano w niemieckojęzycznej „Neue Lodzer Zeitung” i dodatkach kulturalnych. Jak podaje „Neue Lodzer Zeitung”, jego teksty ogłoszono w tomie zbiorowym, który ukazał się w berlińskim wydawnictwie Federverlag. Swoją działalność poświęcił głównie 
łódzkiemu teatrowi, a jego zaangażowanie w sprawę sztuki scenicznej zaowocowało m.in. tym, iż ówczesny teatr niemiecki sięgał w wystawianych tu sztukach po tematykę żydowską. W 1918 r. zaprezentowano w Łodzi sztukę Liona Feuchtwangera Żyd Süß, która nie odniosła większego sukcesu. Zimmermann był również autorem sztuk teatralnych Marga, wystawionej w 25 stycznia 1918 r. i gorąco oklaskiwanej przez publiczność oraz wystawionej w 1920 r. Der Bund der Freunde. Był również autorem recenzji teatralnych, artykułów na temat literatury, a także felietonów i wierszy lirycznych. W wielu swoich recenzjach w ostrych słowach krytykował łódzką scenę teatralną. 0 jego ogromnym oddaniu dla sprawy niemieckiego teatru w Łodzi świadczą również inne przedsięwzięcia. W 1913 r. powołał do życia związek o nazwie Schul- und Bildungsverein, w ramach którego działała sekcja dramatyczna i literacka. Celem tej organizacji było edukowanie łódzkiej publiczności teatralnej i kształtowanie jej gustów estetycznych poprzez proponowanie koncertów i prelekcji. 31 sierpnia 1919 r. zainicjowała swą działalność Freie Bühne, która miała zastąpić teatr „Thalia”. Pierwsze przedstawienie pod kierownictwem Zimmermanna odbyło się w sali teatru „Scala”. Uroczysty program otwarcia obejmował m.in. sceniczny prolog Zimmermanna Also spricht die Freie Bühne. Działalność Freie Bühne skończyła się z chwilą wyjazdu Zimmermanna najpierw do Berlina (1920), gdzie wygłaszał odczyty na temat literatury i filozofii, a następnie do Jeny, Erfurtu i Weimaru. Zainteresowania literackie ustąpiły miejsca tematom politycznym. Zimmermann poświęcił się licznym debatom z takimi działaczami politycznymi, jak Lenin, Trocki czy Owen. Po powrocie do Łodzi w 1923 r. jego działalność na rzecz łódzkiego teatru nie była już tak spektakularna. Zarówno badaczom Łodzi, jak i znawcom teatru niemieckiego nie są znane wojenne losy Zimmermanna. Od początku swej kariery zawodowej Zimmermann był związany z łódzkimi gazetami, głównie niemieckojęzyczną „Neue Lodzer Zeitung”, w której redagował dział kulturalny. Na uwagę zasługują jego recenzje teatralne, wyróżniające się dobrym poziomem merytorycznym, oryginalnym spojrzeniem i dogłębną analizą, co świadczy o starannym wykształceniu ich autora. Zainteresowania Zimmermanna nie skupiały się jedynie na twórczości teatralnej - był wykształconym humanistą, więc interesował się również sprawami społecznymi i filozofią. W czasie I wojny światowej wygłosił szereg odczytów, które cieszyły się dużym zainteresowaniem łódzkiej publiczności. Z poglądami Zimmermanna mogły zapoznać się nie tylko środowiska lokalne, ponieważ był także prelegentem w Akademickim Towarzystwie Literackim w Berlinie oraz Berliner Künstlerhaus. W 1916 r. zaangażował się w tworzenie instytucji o nazwie Stowarzyszenie Artystów i Zwolenników Sztuk Pięknych w Łodzi, której prezesem został architekt Henryk Lewinson, a wśród członków zarządu znaleźli się m.in. przyszły współtwórca formizmu Andrzej Pronaszko (wówczas przejściowo związany z Łodzią). W latach 1921-1922 Zimmermann przebywał w Berlinie z cyklem wykładów na temat literatury niemieckiej. Po powrocie rozpoczął odczyty także w Łodzi, ale dotyczyły one głównie problemów społecznych. Heinrich Zimmermann był również znanym w Łodzi esperantystą. Łódź jako miasto wielu kultur, religii i języków zyskała sobie szczególne miejsce w propagowaniu tego języka. 20 września 1908 r. odbyło się tu zebranie Polskiego Towarzystwa Esperanckiego, któremu przewodniczył prezes PTE, Antoni Grabowski. W zarządzie znaleźli się m.in. Franciszek Ender, prof. Andrzej Lipski, Alfred Dominikiewicz, Stanisław Miszewski 
i dr Arkadiusz Goldenberg. Środowisko łódzkich esperantystów prowadziło szeroko zakrojoną akcję informacyjną o powstaniu nowego, międzynarodowego języka. Na łamach lokalnych gazet propagowano ideę esperanto, organizowano kursy tego języka, tłumaczono na esperanto dzieła literatury polskiej, popularyzując je poza granicami kraju. Powstało także kółko dramatyczne i 30-osobowy chór. W 1913 r. powołano do życia Łódzkie Towarzystwo Esperantystów, grupujące niemieckojęzycznych entuzjastów tego języka, którym przydzielono w gazecie „Neue Lodzer Zeiutng” stałą rubrykę. Zarząd tworzyli Heinrich Zimmermann, S. Szulc i H. Hapner. Wybuch I wojny światowej przerwał działalność esperantystów, ale idea międzynarodowego języka pozostała żywa. W 1917 r. Zimmermann wznowił działalność Łódzkiego Towarzystwa Esperantystów. Wybór źródeł: K. Prykowska-Michalak, Deutsches Theater in Lodz in der Darstellung von Heinrich Zimmermann. Migrationen / Standortwechsel deutsches Theater in Polen, hrsg.v. A. Pełka, K. Prykowska-Michlak, Łódź-Tübingen 2007.

Zoner Leopold (1839-1915), właściciel zakładu litograficzno-drukarskiego oraz wydawnictwa. Do Łodzi przybył ze Lwowa. Od 1881 do 1905 r. wydawał niemiecki dziennik „Lodzer Tageblatt”, zaś w latach 1894-1914 rosyjską „Lodzinskij Listok”. Wybór źródeł: W. Kaszubina, Bibliografia prasy łódzkiej 1863-1944, Warszawa 1967; J. Jaworska, Zakłady graficzne Leopolda Zonera w Łdzi (1874-1914), „Biuletyn Poligraficzny" 3/1977, s. 42-51; J. Tynecki, Łódzki rynek prasowy w dwudziestoleciu międzywojennym, „Prace Polonistyczne” 1983, ser. XXXIX; L. Szychowski, Zarys dziejów drukarstwa łódzkiego, Łódź 1993, s. 29-33; J. Strzałkowski, Drukarnie i księgarnie w Łodzi do 1944 r., Łódź 1999, s. 149-150. 



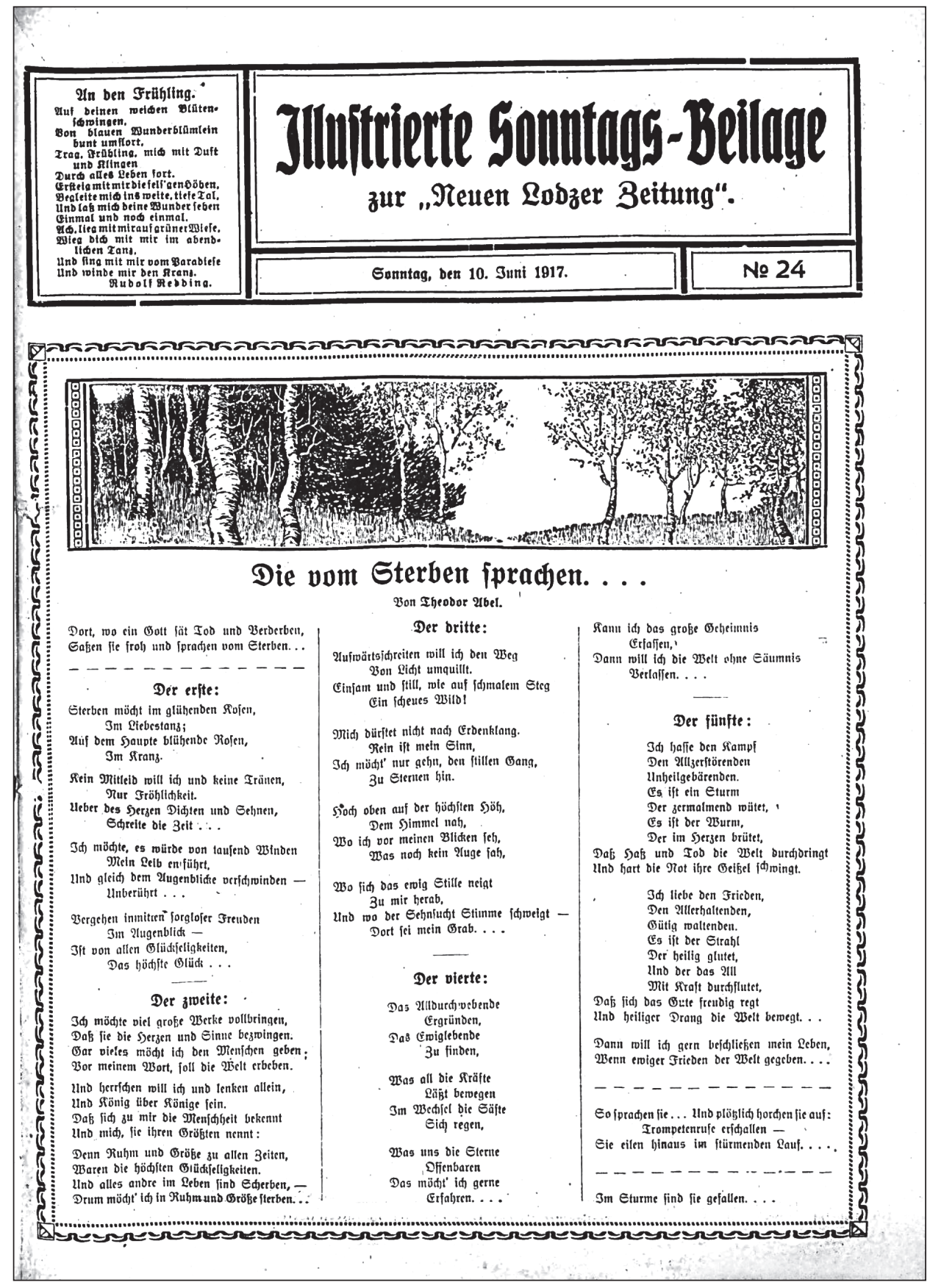

Fot. 1. Utwór Die vom Sterben sprachen Theodore'a Abela

Źródło: „Illustrierte Sonntagsbeilage zur Neuen Lodzer Zeitung”, 10.06.1917 
Jir. 3

\section{Uniere Didhter.}

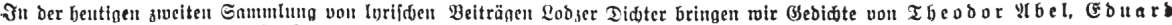

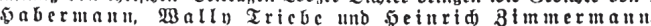

Edvard Habermann

\section{Das Leben ift wie eine perlenidnut.}

Das Reben ift wie eine Berlenidimur:

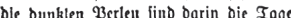
Durd) bie fid zicht lyerzticjen Qeibes Epur.

Die teuditend becllen find bic Jrendenträuen, Die aus bem 3orne bes Bemuils elupprungen, bie uns entlodit ber Liebe f)eifes Sel)nen.

Mit biejen ßerlen, Dunklen unb ben hellen, (d) müd Deiner Tage zeitbegrenzten Flub: EaB Treub und Qeid aus beiner Tieje quellert.

\section{6ott.}

3m Eturmesrauldon [prad) ber S)err zu mir

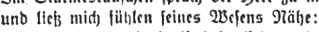
Wic klein, mie nidttig ift bein (Erocmuehe, bu reisheile und vernunfibegabtes Tier.

Du bift erfüllt von erviger 2 egier: wie aus bem Nidjts Das 2Ill entftehe? wie aus bem Flußs das Eein geidebe? unb brauft und kodit das Qebenselrier.

Vergebens willft bu mir bie Elerne rauben! Bergebens ftreb[t ou nad Dem S)immelsglanz! Meiu ift bie Wahrbeit, und mein ift fie ganz! Du komm it zu ibr nut Durh) ein ftarkes (Slauben.

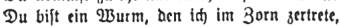
brum gilt bir eins nur: leide, hämpf unb bete!

Hoinrich Zimmermann.

\section{Jdyll.}

Etill fliefjet bas filberne Bädjlein

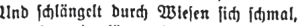
Bon ferne ba läutet cin Glödlein. Reis raunen bie $\mathfrak{B i p f e l}$ im Tal.

Ein Mäbden, das fiţet am Bädlcin, Singt leife, ganz leife ein Lieb. (Fin S)irte, Der liegt ibr ju Jüber, Das Blödklein tönt bange und müb.

Das Riebden verklinget, verhallet. Der S)irte umjdjlinget bie Maib Dann ift's, als ob plöblid) er[d)allet Die Stimme Der Bottheit von weif.

Ein Märden, ein kleines, erroadet, . . . . Sibt ftille aln Bädlein unto ladjt. Cin Iraum rirb lebenbig und gleitet If $m$ flięertoen Bädtein fo fadt.

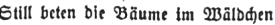
Die Etimme bes Friebens erldallt: 3rei çötter find Süngling unb Mäbden,

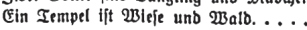
Etill fließet das filberne Bädjlein Unb (d)längelt butd) Wiejen fid (d)mal, Bon ferme ba läutet ein olödilein geis raunen bie $\mathfrak{B i p f e l}$ im Tal.
Theodor Abel.

\section{Rriegsmüde.}

Nodj;fübl'en wir bie Siraft, Die uns bejeclt

3u kömpfen;

פlod) find roir bereit

Im Iobesfturm

3u Iterben -

Dod) wir find milbe

Des STampis.

Den lebten Tropfen

Blutes gerne

wir opfern,

Llino la!fen ben Geinb

2In uniern Reibern

Beridillen -

Tur finb roir mübe

Des Siampis.

Es ruft uns zurïd

Ein beiber Ruf

3ur Sjeimat.

Und fitehen wir gleids

Iuf barter Wadt -

Wir hör'n ihn.

Denn roir find mübe

Des Siampis.

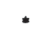

Mein Sonnentraum.

Ein Sonnentraum, wat meine Licbe... Tief unter bem Gdince liegt fie begraben, Wo einit viel Blumen geitanden haben.

Dem Frühling gleid), war meine Liebe . .. Eo buftig unb zart, fo gró unb ethaben Iebt kräcbsen barüber bungrige Raben.

Und nimer erwadt meine Liebe ..... Blaut aud ber Simmel wieder ba broben, Mein Gonnentraum ift für ervig seritoben ....

\section{vilion.}

Id) blide bie Edienen entlang. Mein Serz $_{3}$ ift bang!. . . . . In bämunernde $\mathfrak{B}_{\text {eilen }}$ Eebnend meine Gedanken gleiten.

Unb Berge und Mecre zu S)auf, Türmen (id) auf

3u madtboller Etärhe.

Эd) idjaue bie göttlider Werke,

Id fdaue bas Wunder lo groß Eo namenlos -

Es grübt... und fimintet

unb nimmer mein Iuge es finbet....

Id) blide bie Edilenen entlang.

So traurig unb jo bang.....

Uus bämmernben שelten,

Geb rieber ben erlitag id iकreiten.
Ringen in mit.

Die $\mathscr{B}_{\text {elt }}$ und Gott, ringen um meinc Eeele.. Welt will, dáb bie Gele Siörper werbe, Dás fie fing forge und taumelud falle und quäle. Ind fid vergrabe in Dunkle Erbe.

(Bott ruft mich (aut mit flanumenber Gefänge S)eiliger $2 \mathfrak{B}$ elten!jarmonie, . . . .

(Bott ruft mid) laut, Daf3 id) bie Sietten fprenge, Unb aufroärts zu bern Steruen ziel. .....

3d) harre ftill in Ringen ber Oervalten. Tein 3iel bleibt rein im sireusen ber filtingen: उd will bic $23_{\text {elt }}$ in meinen s)änben holten Jlno bie 2Inendlidgkett Durdjorungen.

Wally Trlebe.

\section{Deine Augen.}

Deine lieben Träumeraugen finb fo meeresticf.

Wedien in mir alle Gebujudt,

a bie verborgen idilief.

Unb fie zeigten ferne wege voller Riebe mir.

Meine leidftbejdrwingte Secle folgt zur Syöbe bir.

3eigten mir ein fernes, weites, lidjteg গMärdjenIand,

Siebjter, faßs mid) bort verweilen $\mathfrak{M}$ it bir S)and in 5anb.

Deine licben Iräumeraugen find io fo lieb unb linb.

Ruhn an beinem S)erzen mödt id WBie ein krankes Sinb.

IIlen meine bittren Edmerzen Bringen fie zur Ruh. . . . .

Meine $\mathfrak{B}$ elt find beine 2 tugen, Wicine $\mathfrak{B e l t}_{\text {bilt }} \mathcal{D}$ u.

\section{Rebel.}

$\mathfrak{E}_{s}$ gleiten Nebel unb gleiten, ઉerbüllen mir Straud) unb Băaum,

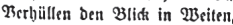
Beklommen atme idh kaum.

Ilno blaffe, itumme Geitalten, Gie ranken und manbern mit, Gebilbe Dunkler Bervalten S)aften mit lautlofem Iritt.

Eie ftürmen ohne Berweilen, Id) rufe lie fehniudtgkrank, Dod immet weiter fie cilen, Mir wirb fo feltiam, fo bang.

3it es mein $\mathfrak{B}$ äniden, mein Fragen Mein glühender Sugendtraum, Den ftumm fie su Grabe tragen, Die blabbleiden Mebelfraun?

Es qleiten Tebel unb gleiten, 3ieh'n über Felb, über Rieb. शach fermen verbullten $w_{\text {eeiten }}$ Tönt in mir tin Sehnjuhtslieb. 


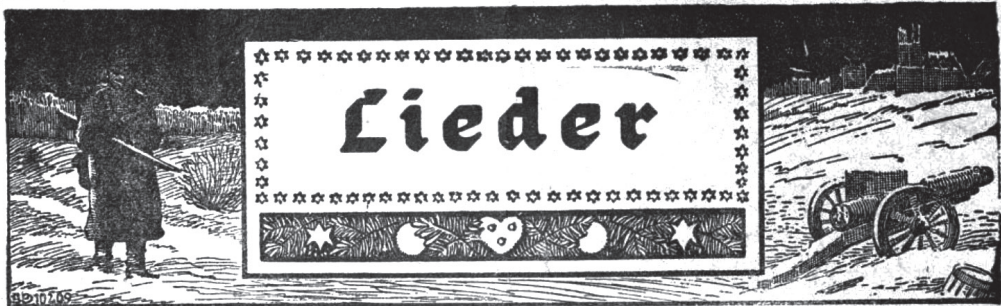

\section{für den Militär-Gottesdienst in Lodz am 1. Oiterfeiertag: 4./4. 1915.}

D Du fröhliche, o Du ielige, (5nabenbringende Diterzeit!

Welt lag in Banden,

Ehrift ift eritanden:

Frene, freule did), o (Shrijtenbeit!

$\mathfrak{D}$ Du fröhliche, o du felige,

snadenbringende Diterzeit!

Tod iit bezmungen,

Eeben errungen:

Frelle, freue dich, o (Ehriftenbeit!

D Du fröhliche, o du felige,

(Snadenbringelloe Diterzeit!

Rrait ift gegeben,

Shm lẩ uns leben:

Freue, freule dich), o (Shriftenheit!

Sefus lebt, mit ibnt aud) idf!

Tod, wo find mun Deine Sdjrecken?

(Er, er lebt und mird aud) mich

Bon Den Toten auferwecken.

(Fr verklärt mich) in fein $\mathcal{E} i d$ ht,

Dies ift meine 3uverficht.

Seius lebt! ihm ijt bas Reich

Uleber alle Welt gegeben;

$\mathfrak{N i t}$ ihm mero aud id zugleid)

(Fvig herrichen, ewig leben.

(5ott erfüllt, was er veriprid)t,

(D)es ift meine 3uverjicht.

Se[us lebt! wer mun verzagt,

Qäjtert ihm und Gottes (shre;

Gnabe hat er zugeiagt.

Daß ber Eünder fict bekehre. (5ott veritöß̧st in (Ehrijto nicht,

Dies ift meine 3uverficht.

Jeius lebt! ich bin gemín,

Tichts joll mich vou Sefus idjetben,

Seine Macht ber Finiternis,

Reine Serrlidfelt, kein Reiben.

Er gibt firaft zu diefer Pflicht,

Dies ift meine 3uverftcht.

Wir treten zım Beten

Bor Golt, Den Sierechten,

(Er waltet und haltet

(Ein itrenges (5erid)t,

Er läß̄t von den $\sigma_{\text {dhledyten }}$

Ticht bie (Guten knechten,

Eein Name fei gelobt,

(Er bergiñt unjer nidht! frei!

Serr, mach uns frei!

Im Streite zur Seite

Ijt (Gott uns geitanden,

(s) mollte, es follte

Das Recht fiegreid) fein:

Da warb, kaum begonmen,

Die Edhlacht johon gewonnen.

Du, Gott, warit ja mit uns!

Der Sieg, er war dein!

Wir loben bich oben,

Du Renker Der Schlachten,

Und flehen, mögit itehen

Uns fernerhin bei,

Tá̉ Deine (Bemeinde

Nid)t Opfer ber Feinde.

Dein Name jet gelobt,

D Serr, mad) uns frei!

Serr, mad) uns frei!

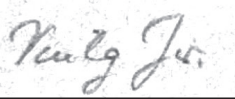

Fot. 3. Pieśń śpiewana podczas mszy wojskowej w Łodzi z okazji świąt wielkanocnych 4.04.1915 r.

Źródło: Archiv der Deutschen aus Mittelpolen und Wolhynien Mönchengladbach: sygn. 3428 II (A1c) Lodz 5.1 


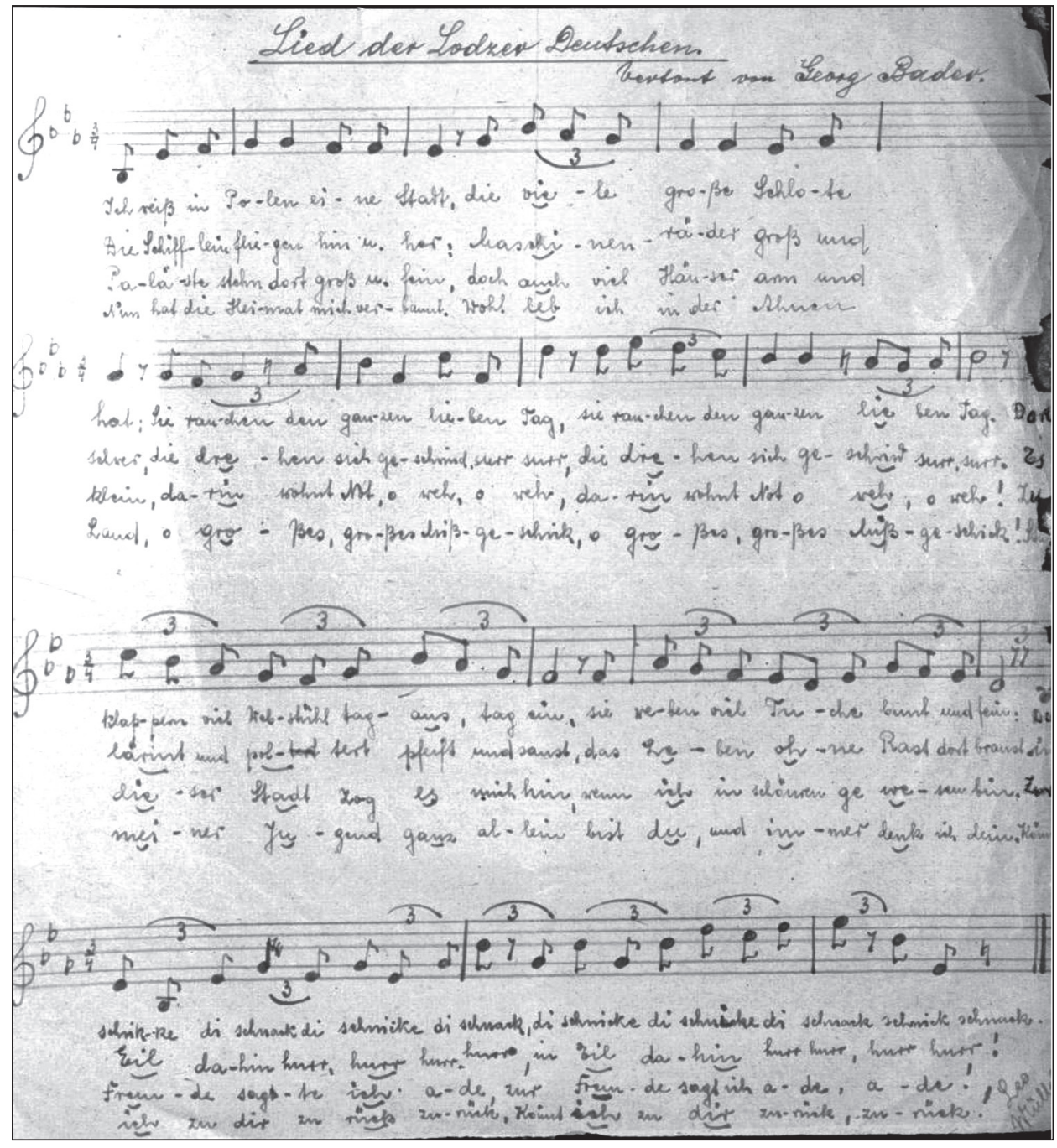

Fot. 4. Pieśń Niemców z Łodzi. Tekst: Leo Müller, muzyka: Georg Bader Źródło: Archiv der Deutschen aus Mittelpolen und Wolhynien Mönchengladbach: sygn. 2952 (A1c XIV) Deutschtum Lodz 3.2 


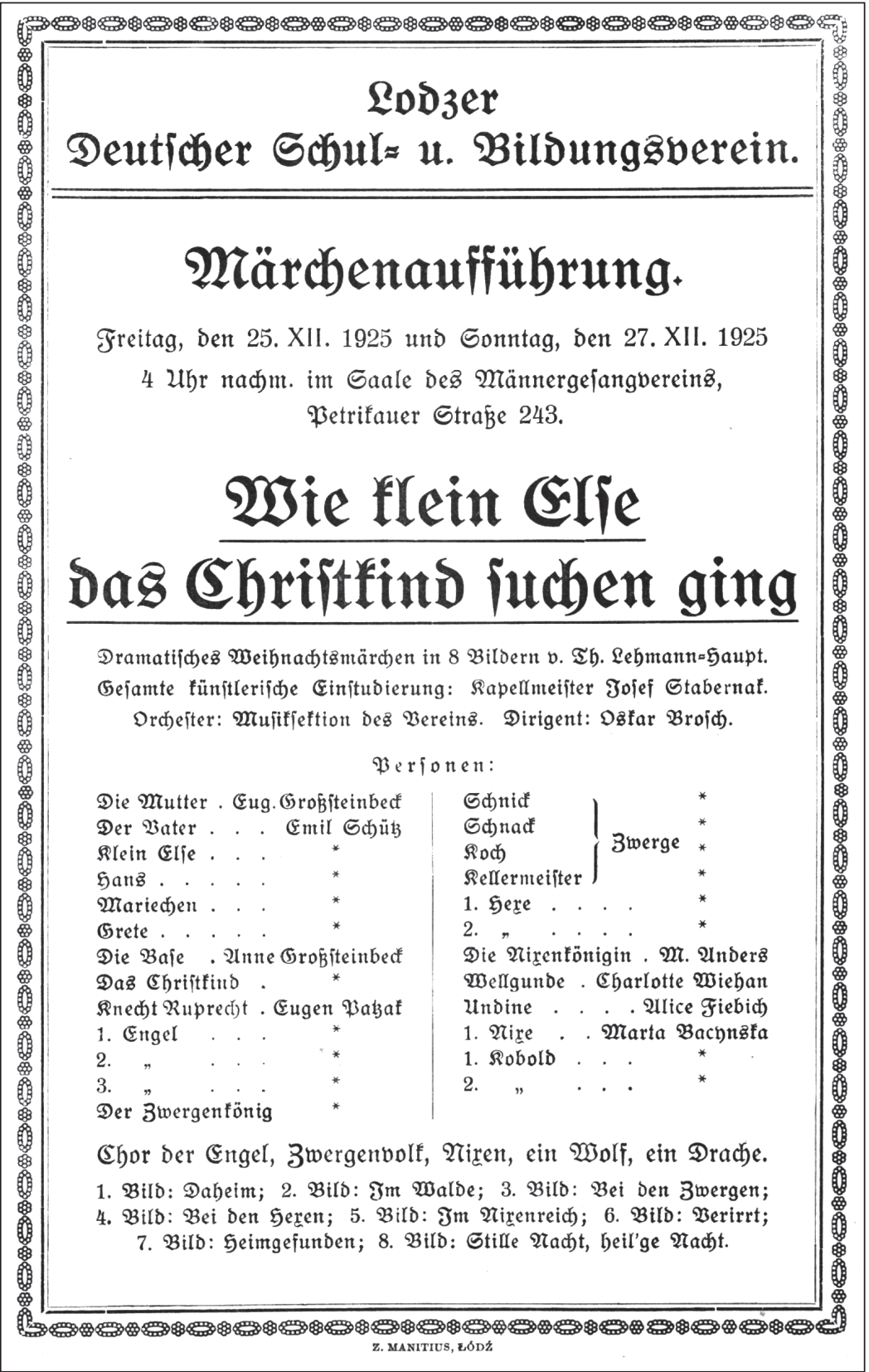

Fot. 5. Ogłoszenie Łódzkiego Niemieckiego Stowarzyszenia Popierania Oświaty na temat przedstawienia bajkowego pt. Jak mała Elza poszła szukać Dzieciątka Jezus z 25 i 27.12.1925 r.

Źródło: Archiv der Deutschen aus Mittelpolen und Wolhynien Mönchengladbach: sygn. $612(\mathrm{~A} 1 \mathrm{cV})$ Lodz 6.6 


\section{Soethe}

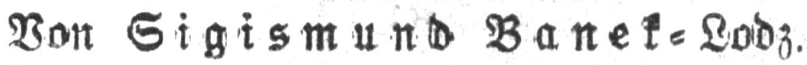

Moit Dirritenden Sintrent

Giveritizulibetigen

itts flutertbe Seben

alles $\mathfrak{B}_{\text {Berbentben }}$

beirlige Sguäntheit

zul jøatuen;

in emiger Qual

unts ewiger $\mathfrak{B}$ antre

emoiger Trentuntig,

emiger Bintoung

Sdjmerzen unb Freuben

medjiertio zul tragen;

Durd) Söhen uth Tiefent

eignent $\mathfrak{B e j e t t s}$

in währentrer Sandiuntg

aujwärts ju jureiten;

mirfettber ar räfte

iegnende siifle

in rajtrojem Sdjaffen

frei zul entfialtert;

athes um Biebe.

jum Lidyte jiefyen,

fiiflent unto reiben

und Metrijen ơ jein

nach Deintem Birdo

Tehre mid, Goethe! 


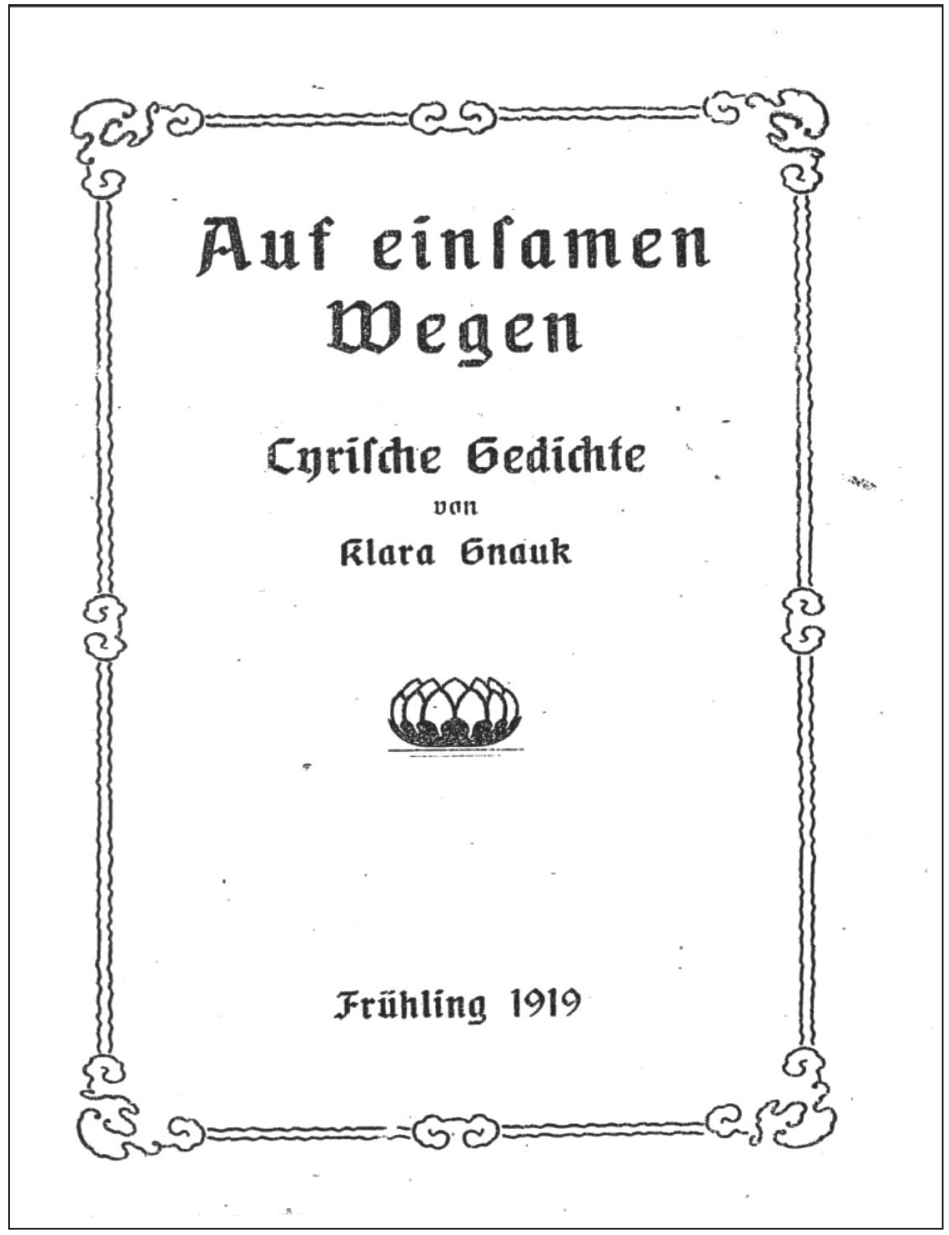

Fot. 7. Strona tytułowa zbioru wierszy Klary Gnauk pt. Auf einsamen Wegen: lyrische Gedichte z 1919 r. Źródło: Biblioteka Martina-Opitza w Herne: sygn. ADMB 11767, 2007.9508 


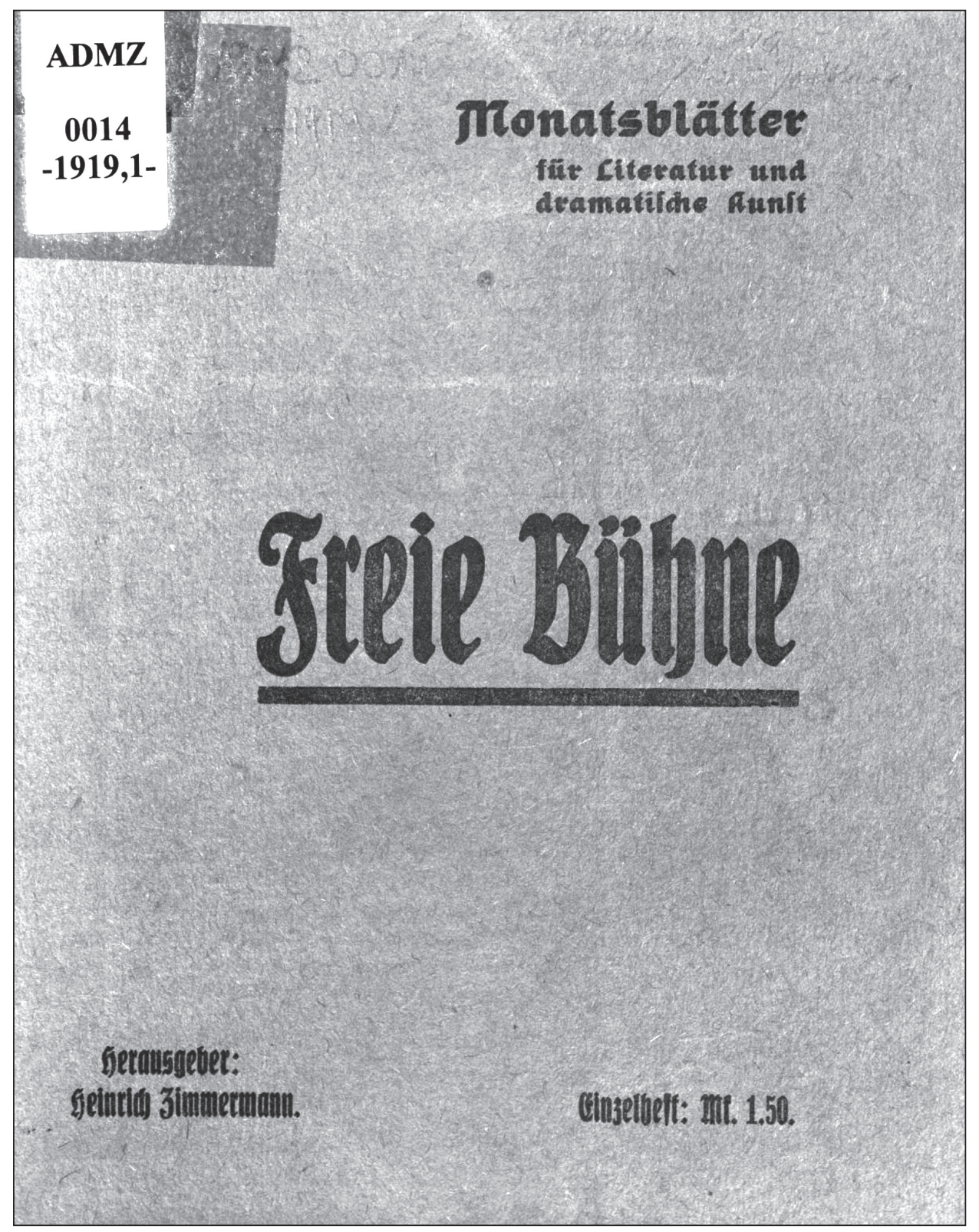

Fot. 8. Okładka pierwszego numeru łódzkiego czasopisma poświęconego literaturze i kulturze z października 1919 r., wyd. Heinrich Zimmermann

Źródło: Archiv der Deutschen aus Mittelpolen und Wolhynien Mönchengladbach: sygn. 3620 (Bk 1 III) Lodz 7.1 


\section{Zeitgemäß̈e Betradtungen}

Pfingften, licblichitez ber Geite, - wo voll Grün find alle alefte, - wo fo lieblid) bie Edjalmeien - flöten ben Gejang bom Maien, - wo bie tapiren Dolesverbäno. ler, - jene Rlughelt-Wiberitänbler, - burd)

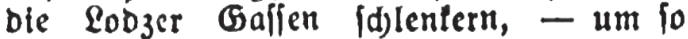
red) gebeim 3 u ftänlern, - wo fle mand. mal einen Beinbrud) - wagen bei 'nem Diebltabl8einbrud), wenn fie allf bie Leiter ftetgen, um зu ftebl'n, was nidjt lhr eigen. Mander lagt: $e \bar{B}$ wär' 'ne Sdande - und eв wär' 'ne Rallelbanbe, - bie zum Stch. len nan gebungen... - Uber's finb bod bumme Jungen! - Sa) glaub': Niemano batte bejoblen, - baßj fle 's Edilb ber. unterbolen, - Sdulb find baran bie Ge: (đ)wäger, ausigeitreut burd) wülte gezer. Dod) mir facint fdoon jebt mitunter: ber "Werbanb" tommt langlam 'runter, barum ift er ungcballen, - möd)te gern ben Eturz aufbalten. - 2ber ' 8 bilft niditz:

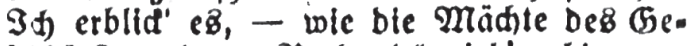
(a)ideB - Den "Vorbant" zieb'n bin zum Eterben... - Bald gibtż bavon nur nod) Gderben. - Troboem idrelen fie fid beifer - noer 'n bojfen "Wegeweifer", - baju fommen in bie Ruere - "rausgefdmiff'ne Reballeure." - \$đ la $\mathfrak{B}$ mid) ba nid)t be"

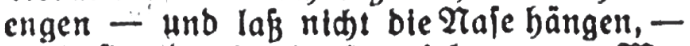
well fie bamit nithts crzielen: - wer nid)! bören will, muß fäblen." - Dod genug mit bem Geidmetter! - widliger: wie wirb bas 2 etter? - wirb man in ber Goune (d)wiben - ober bübja zubaule fisen? - Wirb Die Gonne oben winlen,wird man balt im freien trinlen, - tommt bon oben eine Braufe, - na, ba trinlt man balt zubaule! - Bitte, fid nidht 34 ver. laufen: - trinlen meine id), nid)t faufen! Zur Erbeitepung! fo făreit er, - nämlid ocr bles farelbt:

Ernst Heiter. 


\title{
(Gedidhte heimijher $\mathfrak{B e r f a f f e r . " ) ~}$
}

\author{
Bon Margarete Grïtrer.
}

\section{Julinadt.}

um Mitternadit - in Den Spelzen leije lad)t Dag sorn.

$\mathfrak{U} \mathfrak{n}$ ben (Grenzen treulid wacht Der Jorn.

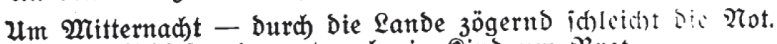
galb im Sd)lafe wimmert nod) ein Rind um Brot.

Serr Der Ernte, Dräนe Du Der Wolfe!

Serr Der Ernte, jei mit Deinem $\mathfrak{B}$ olfe!

Deine Ednitter fdneiben, ah), fo lange?

Deine Wühlen mahlen bumpi und bange:

um Mitternah)t, da jhwillt Daz Rorn Der Ernte ju.

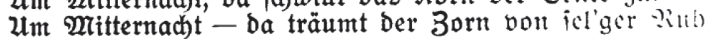

\section{Erde.}

Jn meine Ebne $30 \mathrm{~g}$ Der $\mathfrak{M}$ orgen ein.

Er war mit reichem Perlentau bejhlagen,

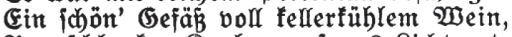

Bon ihlanfen Rnaben auf ans Lid)t getragen.

Jn jeinem Epiegelfreije lag bas Land

Bom füblen Gold der Sonne überiloilen.

Jn reiner $R$ undung war jein heitrer $2 i a n b$

Bejtimmt, Dod zart am Sintmel angeidfloiicu.

und meine Gelber zogen breit baher,

Gewiegt im Rhythmuz grofer itummer Gerden,

Jn rubevollen wellen tand daz 2 Teer

Der Erbe vffen jungem werben.

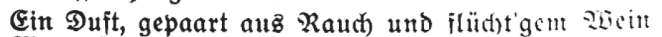

War nä̉) t'gem Sh)ōe zauberitart entboben.

Jm lid)te $30 \mathrm{~g}$ er fihleierhait und jein

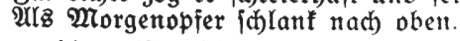

Dort, wo die weiken Wolfenderubim

Dem 5 öd)iten dienen mit erbobnen Edwingen,

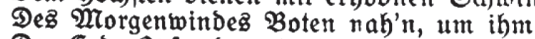

Der Erbe Opfer Demutooll zu bringen.

Dort fniet mein Gleh'n vor (Gottez Thron unt ipridt:

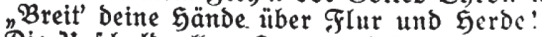

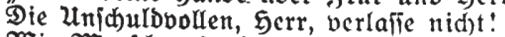

Wir Menjwen jterben gern für unire Ėric:"

*) Die Berfafier ber nadjefenden (Sedid)te find nid)t heimifa in Eimi sir Bugehörigfeit

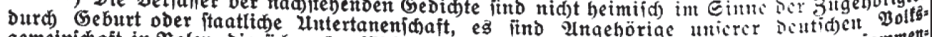

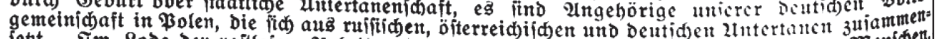

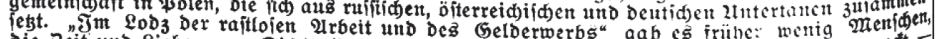
Die Seit und Riebe, 3um Didten" fanben, Der Rrieg hat nellez geitiges "eben erwedt, -

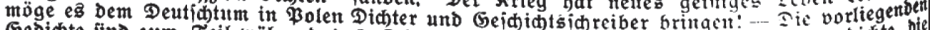

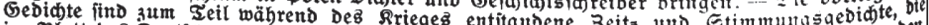

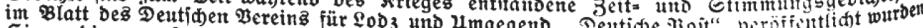
Gie verbienen gejammelt im Jahrbud des จereins weiterzuleben.

Fot. 10. Wiersze Margarete Grüner

Źródło: Jahrbuch des Deutschen Vereins für Lodz und Umgegend 1917,

Herausgegeben von der Hauptleitung des Deutschen Vereins,

Verlag der Deutschen Presse, Lodz 1917.

Archiv der Deutschen aus Mittelpolen und Wolhynien Mönchengladbach, sygn. 6355 (Bk 2II), Lodz 8.2 


\section{BIBLIOGRAFIA}

\section{Literatura podmiotowa}

ABEL Theodore, Aus der Zeit, „Illustrierte Sonntagsbeilage zur Neuen Lodzer Zeitung”, 7.01.1916, s. 8.

ABEL Theodore, Der Weg zur Höh, „Illustrierte Sonntagsbeilage zur Neuen Lodzer Zeitung”, 24.12.1916, s. 110.

ABEL Theodore, Die vom Sterben sprachen, „Illustrierte Sonntagsbeilage zur Neuen Lodzer Zeitung", 10.06.1917, s. 1.

ABEL Theodore, Mutter, wo bist du?, „Illustrierte Sonntagsbeilage zur Neuen Lodzer Zeitung”, 20.08.1916, s. 138.

ABEL Theodore, Sehnsucht nach Frieden, „Illustrierte Sonntagsbeilage zur Neuen Lodzer Zeitung", 16.01.1916, s. 14.

ADOLPHI Max, Das Schicksal, „Illustriertes Sonntagsblatt der Neuen Lodzer Zeitung”, 2.12.1923, s. 2-5.

ALTHAUS Paul, Der Tod ist verschlungen in den Sieg!, Eger, Lodz 1915.

ALTHAUS Paul, Lodzer Kriegsbüchlein. Deutsch-evangelische Betrachtungen, Vandenhoeck \& Ruprecht, Göttingen 1916.

ALTHAUS Paul, Um Glauben und Vaterland. Neues Lodzer Kriegsbüchlein, Vandenhoeck \& Ruprecht, Göttingen 1917.

[b.a.], Februar 1916, „Illustrierte Sonntagsbeilage zur Neuen Lodzer Zeitung”, 20.02.1916, s. 35.

[b.a.], Heimatklänge: deutsche Dichtungen aus dem ehem. Kongreßpolen. Mit Widmung von Albert Breyer an „die dankbaren Heimatgenossen”, Libertas, Lodz 1925.

[b.a.] Sieg bei Lodz, „Sonderausgabe der Deutschen Lodzer Zeitung”, 8.02.1916, s. 2.

[b.a.] Wein' nicht Mutter!, „Neue Lodzer Zeitung”, 20.11./3.12.1914, s. 3.

BANEK Sigismund, Aufbruch und Heimkehr, Grenze u. Ausland, Berlin 1940.

BANEK Sigismund, Werk und Wehr, Deutscher Büchereiverein, Poznań 1939.

Berta Teplitzka. Portrety łódzkie, oprac. Małgorzata PÓŁROLA, Biblioteka, Łódź 2008.

BRÄUTIGAM Robert, Das Vaterunser. Kriegsgebet, „Illustrierte Sonntagsbeilage zur Neuen Lodzer Zeitung", 9.09.1917, s. 1.

DIETRICH Julius, Allein Gott in der Höh' sei Ehr': Festschrift anläßlich der Einweihung der evang[elisch]-luth[erischen] St. Matthäikirche, Manitius, Lodz 1928.

DIETRICH Julius, 50 Jahre göttlicher Barmherzigkeit: Festschrift anläßlich des 50-jährigen Jubiläums der evang.-luth. St. Johannisgemeinde zu Lodz, Manitius, Lodz 1934.

Du stehst in großer Schar: Junge deutsche Dichtung aus Warthe- und Weichselland, hrsg. v. Heinz KINDERMANN, Hirt, Breslau 1939.

FELDMANN Wilhelm, Mit der Heeresgruppe des Prinzen Leopold von Bayern nach Weißrussland hinein, Beck, München 1916. 
Festschrift zum 50-jährigen Jubiläum des Kirchengesangvereins der evang.-lutherischen St. Johannis-Gemeinde zu Lodz: 1884-1934, Kirchengesangverein der Evang.-Luth. St. Johannis Gemeinde, Lodz 1934.

Festschrift zur Feier des 75. [fünfundsiebzig]-jährigen Jubiläums des Kirchengesang-Vereins der St. Trinitatis-Gemeinde zu Lodz: 1859-1934, [b.w.], Lodz 1934.

Festschrift zur Feier des 100-jährigen Jubiläums der Webermeister-Innung zu Lodz, Webermeister-Innung, Lodz 1924.

Festschrift zur 50. [fünfzigjährigen] Wiederkehr des Gründungstages des evangelisch-lutherischen Kirchengesangvereins „Harmonia” in Konstantynow: 1879-1929, Ev.-luth. Kirchengesangverein Harmonia, Lodz 1929.

Festschrift zur 75-jährigen Jubelfeier des Lodzer Männer-Gesang-Vereins 1846-1921: Feier am 16. und 17. Juni 1923 in den Räumen des Vereinshauses Petrikauer Strasse Nr. 143, Männer-Gesang-Verein, Lodz.

FLATT Oskar, Opis miasta Łodzi, Drukarnia „Gazety Codziennej”, Warszawa 1853.

FLIERL Friedrich, Wir möchten auch, der Friede lebt..., „Deutsche Post”, 13.08.1916, s. 2.

FLIERI Friedrich, Brüder, „Deutsche Post”, 19.07.1915

FLIERL Friedrich, Auf dem Weg, „Deutsche Post”, 9.08.1915, s. 3.

Gedenkschrift anläßlich des 20-jährigen Jubiläums der Anstalten des Hauses der Barmherzigkeit in Lodz: 21 X 1908 - 21. X 1928 / Haus der Barmherzigkeit, Manitius, Lodz 1928.

Gedenkschrift anläßlich des 50-jährigen Jubiläums der Baptistengemeinde Lodz, Nawrot 27, Neue Lodzer Zeitung, Lodz 1928.

Gedenkschrift aus Anlaß des 20-jährigen Bestehens des Deutschen Gymnasiums zu Lodz, Manitius, Lodz 1928.

GOMOLL Wilhelm Conrad, Im Kampf gegen Russland und Serbien, Brockhaus, Leipzig 1916.

GRÜNER Margarete, Kriegsnacht, „Deutsche Post”, 2.07.1916, s. 3.

HOFFMANN Kamill, Schneewind, „Neue Lodzer Zeitung” 19.01./1.02.1915, s. 3.

JESS Wilhelm, Am Soldatenfriedhof zu Rzgow, „Neue Lodzer Zeitung”, 16.09.1917, s. 2.

JESS Wilhelm, Das Verbrechen auf Jasna Góra oder Pater Damasy, [b.w.], Lodz 1910.

JESS Wilhelm, Zur Weihe des Soldatenfriedhoffs bei Effingshausen, "Neue Lodzer Zeitung”, 12.11.1916, s. 5.

KARGEL Adolf, Der Mutter Todestag, „Illustrierte Sonntagsbeilage zur Neuen Lodzer Zeitung”, 5/1912, s. 119.

KARGEL Adolf, Mein Waldfriedhof, „Illustrierte Sonntagsbeilage zur Neuen Lodzer Zeitung”, 1.11.1914, s. 1.

KATSCZINSKI Alfred, Unser Kampf für die Heimat 1914, Reylaender, Tilsit 1917.

K.G., Lass das Klagen, „Illustrierte Sonntagsbeilage zur Neuen Lodzer Zeitung”, 6.05.1917, s. 3.

KLIKAR Robert, Festschrift zur Feier des 100-jährigen Jubiläums der Webermeister-Innung zu Lodz 1812-1924, Webermeister-Innung, Lodz 1924.

KREUTZ Philipp, Advent, „Lodzer Illustriertes Sonntagsblatt. Beilage zur Neuen Lodzer Zeitung", 29.11.1925, s. 3.

KREUTZ Philipp, Ostern, „Die Welt im Bilde. Sonntagsbeilage zur Neuen Lodzer Zeitung”, 31.03.1929, s. 1.

KREUTZ Philipp, Pfingsten, „Lodzer Illustriertes Sonntagsblatt. Beilage zur Neuen Lodzer Zeitung", 8.06.1924, s. 5.

KREUTZ Philipp, Totensonntag, „Welt im Bild”, 11.1930, s. 3.

KREUTZ Philipp, Traum und Tag: Gedichte, Braun \& Elble, Weißenburg 1953.

KREUTZ Philipp, Weihnachten, „Lodzer Illustriertes Sonntagsblatt. Beilage zur Neuen Lodzer Zeitung", 27.12.1925, s. 5.

KREUTZ Philipp, Zeit und Ewigkeit: Gedichte, Neue Lodzer Zeitung, Lodz 1937.

Literackie i nieliterackie obrazy miasta. Łódź przełomu wieków oczami niemieckojęzycznego autora - Carla Heinricha Schulza / Nicht nur literarische Bilder einer Stadt. Lodz in den Au- 
gen eines deutschsprachigen Autors - Carl Heinrich Schultz, red. Monika KUCNER, Primum Verbum, Łódź 2011.

LOEBELL Arthur von, Der Weltkrieg 1914/1915. Gesammelte Berichte, Bd. 1: Bis zu den Kämpfen um Lodz, Recklam, Leipzig 1915.

MATYS Karl Gustav, Festschrift zur Feier des 50-jährigen Jubiläums der Lodzer Freiwilligen Feuerwehr: 14. V. 1876-1926, [b.w.], Lodz 1926.

METZNER Friedrich Gottlob, Gesang zur Weihe des neuerbauten Meisterhauses der löblichen Weberinnung zu Lodz am 3ten September 1839, Evangelische Gemeinde, Lodz 1839.

MILKER Aleksander, Konsistorialrat Pastor Rudolf Gundlach, „Illustriertes Sonntagsblatt. Beilage zur Neuen Lodzer Zeitung", 23/1922.10.15, s. 1-2, 4.

MÜLLER August Hermann, Waldblumen, Selbstverlag des Verfassers, Lodz 1902.

PIEL Reinhold, Ne Mütze voll Witze aus Lodz und Pabianice, Grüning, Lodz 1913.

RAYMOND Bruno, Isabella. Motive aus der Komödie der Ehe, Libertas, Lodz 1928.

RAYMOND Bruno, Miłość, student a wojna, Drukarnia Polska Ludomira Mazurkiewicza, Łódź 1933.

RAYMOND Bruno, Ucieczka przez błękit nieba, Dzieje miłości w trzech aktach z epilogiem bez słów, Drukarnia Polska Ludomira Mazurkiewicza, Łódź 1935.

RAYMOND Bruno, W poszukiwaniu ojczyzny, Drukarnia Polska Ludomira Mazurkiewicza, Łódź 1938.

REICKE Ilse, Ein Flüstern über Gräbern, „Illustrierte Sonntagsbeilage zur Neuen Lodzer Zeitung", 29.10.1916, s. 1.

REIMANN Wally, Vorfrühling, „Lodzer Illustriertes Sonntagsblatt. Beilage zur Neuen Lodzer Zeitung", 12.03.1924, s. 4.

RENNER Wilhelm, Feldmarschall von Mackensen; ein Lebens- und Charakterbild, Scherl, Berlin 1915.

SCHULTZ Carl Heinrich, Die Schrecken von Kalisch I, „Neue Lodzer Zeitung”, 24.08./6.09.1914, s. 1; Die Schrecken von Kalisch II, „Neue Lodzer Zeitung”, 26.08./8.09.1914, s. 1.

SCHULTZ Carl Heinrich, Gesangverein „Danysz“: Festschrift anläßlich des 25-jährigen Bestehens des Vereins 1903-1928, [b.w.], Lodz 1928.

SONNENBERG A.W., Festschrift zur 50-jährigen Jubiläumsfeier der Fahnenweihe des Evangelisch-Augsburgischen Kirchen-Gesangvereins zu Pabianice, [b.w.], Pabianice 1917.

Śpiewnik dla Kościoła Ewangelicko-Augsburskiego w Królestwie Polskim, Nakł. Kasy Wdów i Sierot po Pastorach, Warszawa 1899.

TEICHMANN Irma, Herbststimmung, „Illustrierte Sonntagsbeilage zur Neuen Lodzer Zeitung”, 24.09.1916, s. 4.

TEPLITZKA Berta, Lodzer Typen, Drewing, Lodz 1913.

TESCHNER Olenka, Aus dem Skizzenbuch des Karnevals, „Illustriertes Sonntagsblatt der „Neuen Lodzer Zeitung", 2.03.1924, s. 3-4.

THIEM Wally, Faschingswünsche, „Illustrierte Sonntagsbeilage zur Neuen Lodzer Zeitung”, 13.01.1924, s. 3.

TRIEBE Wally, Dämmerstunden, „Illustrierte Sonntagsbeilage zur Neuen Lodzer Zeitung”, 11.08.1918, s. 1.

TRIEBE Wally, Herbst, „Illustrierte Sonntagsbeilage zur Neuen Lodzer Zeitung”, 8.09.1918, s. 144.

WICKEL, Werner, Am Soldaten Friedhof zu Rzgow, „Deutsche Lodzer Zeitung”, 16.09.1917, s. 2.

WIHAN W. [?], Oktobernacht, „Illustrierte Sonntagsbeilage zur Neuen Lodzer Zeitung”, 29.10.1916, s. 4.

WILL Julian, Fern vom Land der Ahnen. Gesammelte Gedichte, Selbstverlag des Verfassers, Lodz 1935.

ZIMMERMANN Heinrich, Auf den Schlachtfeldern in der Umgegend von Lodz, „Neue Lodzer Zeitung", 29.11./12.12.1914, s. 1. 
ZIMMERMANN Heinrich, Aus unvergeßlichen Tagen. Tagebuchaufzeichnungen, „Neue Lodzer Zeitung", 14.11.1915; 16.11.1915; 18.11.1915; 19.11.1915; 21.11.1915; 23.11.1915; 25.11.1915; 28.11.1915; 1.12.1915; 2.12.1915; 5.12.1915; 6.12.1915.

ZIMMERMANN Heinrich, Der sterbende Stadtwald in der Poesie der Lodzer, „Neue Lodzer Zeitung" 25.10./7.11.1914, s. 1.

ZIMMERMANN Heinrich, Die Nacht der Toten, „Neue Lodzer Zeitung”, 30.11./13.12.1914, s. 1. ZIMMERMANN Heinrich, In einer billigen Küche, „Neue Lodzer Zeitung”, 16/29.10.1914, s. 2.

ZIMMERMANN Heinrich, Konstantynow nach der Schlacht, „Neue Lodzer Zeitung”, 27.11./10.12.1914, s. 3.

\section{Literatura przedmiotowa}

ADELUNG Johann Christoph, Grammatisch-kritisches Wörterbuch der hochdeutschen Mundart mit beständiger Vergleichung der übrigen Mundarten, besonders aber des Oberdeutschen. Zweyter Theil, von F-L, Wien 1808.

Atlas miasta Łodzi, red. Stanisław LISZEWSKI, Łódzkie Towarzystwo Naukowe, Łódź 2002.

BANDURKA Mieczysław, Zmiany administracyjne i terytorialne ziem województwa łódzkiego w XIX i XX wieku, PWN, Łódź 1995.

BARANOWSKI Bohdan, Łódź rolnicza , Biblioteka Wiedzy o Łodzi” 1973/3.

BARANOWSKI Bohdan, O dawnej Łodzi, Wydawnictwo Łódzkie, Łódź 1976.

BARANOWSKI Bohdan, FIJAŁEK Jan, Łódź. Dzieje miasta, t. 1, PWN, Warszawa-Łódź 1980.

BARANOWSKI Julian, Organizacja władz administracji ogólnej szczebla wojewódzkiego w Łodzi w lalach 1919-1939-1945, „Rocznik Łódzki” 41/1994.

BARSZCZEWSKA-KRUPA Anna, Rodowód oraz drogi rozwoju kultury i oświaty w Łodzi. Uwagi ogólne, [w:] Łódź. Dzieje miasta, red. Ryszard ROSIN, t. 1: Do roku 1918, red. Bohdan BARANOWSKI, Jan FIJAŁEK, PWN, Łódź-Warszawa 1980, s. 480-486.

BASTIAN Andrea, Der Heimat-Begriff. Eine begriffsgeschichtliche Untersuchung in verschiedenen Funktionsbereichen der deutschen Sprache, Niemeyer, Tübingen 1995.

Bibliografia czasopism religijnych $w$ Polsce 1918-1944, oprac. Zygmunt ZIELIŃSKI, Towarzystwo Naukowe KUL, Lublin 1981.

Bilder-Conversations-Lexikon für das deutsche Volk. Ein Handbuch zur Verbreitung gemeinnütziger Kenntnisse und zur Unterhaltung in vier Bänden, Bd. 2: F-L, mit 368 Abbildungen und 11 Landkarten, Brockhaus, Leipzig 1838.

BRAMWELL Anna, Blut und Boden, [w:] Deutsche Erinnerungsorte, hrsg. v. Etienne FRANCOIS, Hagen SCHULZE, Bd. 3, Beck, München 2003.

BOBBE Sławomir, Wielcy w kiepskim towarzystwie, „Express Bydgoski”, 8.10.2007.

BOGUSZ Andrzej, Dawna Łódź sportowa, Muzeum Miasta Łodzi, Łódź 2007.

BREYER Albert, Deutsche Gaue in Mittelpolen, Wolff, Plauen im Vogtland 1935.

BREYER Albert, Neuerscheinungen im Deutschen Schrifttum Mittelpolens (1925-1930), „Deutsche Blätter in Polen" 8/1931.

BUDZIAREK Marek, Łódzki bedeker wyznaniowy, Muzeum Historii Miasta Łodzi, Łódź 1998.

BUDZIAREK Marek, Skromna wielkość, Rudolf Gustaw Gundlach (1850-1922), [w:] Łodzianie, Wydawnictwo Literatura, Łódź 2000.

BUDZIAREK Marek, SKRZYDŁO Leszek, SZUKALAK Marek, Unsere Stadt Lodz. Łódź nasze miasto, Oficyna Bibliofilów, Łódź 2000.

CYGAŃSKI Mirosław, Mniejszość niemiecka w Polsce w latach 1918-1939, Wydawnictwo Łódzkie, Łódź 1962.

CZECHOWSKA-BŁACHIEWICZ Aleksandra, Der entlehnte deutsche Wortschatz der Sachgruppen ,Textilindustrie', ,Handwerk' und ,Haushalt' im heutigen Polnisch der Einwohner von 
Łódź, [w:] Beiträge zur Deutsch-Polnischen Germanistik 1999-2000, hrsg. v. Peter KÖNIG, Michael KLEES, Frank M. SCHUSTER, Litblockin Verlag, Fernwald 2000.

CZECHOWSKA-BŁACHIEWICZ Aleksandra, HABRAJSKA Grażyna, Deutsche Entlehnungen in der Sprache des Gebiets von Łódź, [w:] Proben. Konferenzbeiträge, hrsg. v. Helmut STETTER, Warszawa 1989.

Dawne Kurkowe Bractwa Strzeleckie w Chojnicach i na Pomorzu, red. Kazimierz LEMAŃCZYK, Muzeum Historyczno-Etnograficzne, Chojnice 2006.

DĄBROWSKA-PARTYKA Maria, Literatura pogranicza. Pogranicze literatury, Wydawnictwo UJ, Kraków 2009.

Deutsches Wörterbuch von J. Grimm und W. Grimm. Vierten Bandes zweite Abtheilung. H. I. J, bearb. V. Moriz HEYNE, Hirzel, Leipzig 1877.

Deutsches Wörterbuch von Jacob und Wilhelm Grimm, 16 Bde. in 32 Teilbänden, Leipzig 18541961, Leipzig 1971.

Deutschtum im Aufbruch, hrsg. v. Adolf KARGEL, Eduard KNEIFEL, Hirzel, Leipzig 1942.

DROŻDŻYŃSKI Aleksander, ZABOROWSKI Jan, Oberländer przez Ostforschung, wywiad i NSDAP do rzq̨du NRF, Wydawnictwo Zachodnie, Poznań-Warszawa 1960.

Dzieje inteligencji polskiej do roku 1918, red. Jerzy JEDLICKI, Neriton, Warszawa 2008.

Dzieje Żydów w Łodzi 1820-1944. Wybrane problemy, red. Wiesław PUŚ, Stanisław LISZEWSKI, Wydawnictwo UŁ, Łódź 1991.

EFENBERGER E., Das Lodzerdeutsch. Die Umgangssprache der Deutschen im Lodzer Raum, Archiv der Deutschen aus Mittelpolen und Wolhynien, Mönchengladbach 2009/2010.

EICHLER Adolf, Deutschtum im Schatten des Ostens, Meinhold Verlagsgesellschaft, Dresden 1942.

FISZBAK Jolanta, Mity „ziemi obiecanej” w regionalnej literaturze Łodzi. Między gra wyobraźni, fikcją literacką a historiq, Wydawnictwo UŁ, Łódź 2013.

GERLACH-DAMASCHKE Renate, Dichtung im Kontext der Geschichte. Zur Literatur der Deutschen in und aus Polen, [w:] Beiträge zur deutsch-polnischen Nachbarschaft, hrsg. v. Csaba János KENEZ, Helmut NEUBACH, Joachim ROGALL, Westkreuz-Verlag, Berlin-Bonn 1992.

GOLEC Janusz, Postawy antywojenne w poezji i publicystyce niemieckiego ekspresjonizmu, [w:] Pierwsza wojna światowa w literaturze polskiej i obcej. Wybrane zagadnienia, red. Eugenia ŁOCH, Krzysztof STĘPNIK, Wydawnictwo UMCS, Lublin 1999.

GREVERUS Ina Maria, Der territoriale Mensch. Ein literaturanthropologischer Versuch zum Heimatphänomen, Athenäum, Frankfurt/Main 1972.

GROCHOWSKA Joanna, Kurkowe Bractwo Strzeleckie w Wejherowie. Historia i współczesność, Kurkowe Bractwo Strzeleckie, Muzeum Piśmiennictwa i Muzyki Kaszubsko-Pomorskiej, Wejherowo 2004.

HEIKE Otto, Das Deutschtum in Polen 1918-1939, Verlag für ganzheitliche Forschung, Bonn 1955.

HEIKE Otto, Die deutsche Minderheit in Polen bis 1939. Ihr Leben und Wirken kulturell, gesellschaftlich, politisch, Selbstverlag des Verfassers, Leverkusen 1985.

HEIKE Otto, Leben im deutsch-polnischen Spannungsfeld: Erinnerungen und Einsichten eines deutschen Journalisten aus Lodz, Hobbing, Essen 1989.

HUMERCZYK Zygmunt, Dzieje bractwa strzeleckiego w Grodzisku Wielkopolskim, 1646-1947 w zarysie, Urząd Miasta i Gminy, Grodzisk Wielkopolski 2000.

HUTNIKIEWICZ Artur, Młoda Polska, Wydawnictwo Naukowe PWN, Warszawa 2000.

JABŁKOWSKA Joanna, „Das gelobte Land“ oder das Elend des Frühkapitalismus? „Heimatliteratur" aus und über Lodz, [w:] Lodz jenseits von „Fabriken, Wildwest und Provinz", hrsg. v. Stefan DYROFF, Krystyna RADZISZEWSKA, Isabel RÖSKAU-RYDEL, Meidenbauer, München 2009.

JAKUBIAK Tadeusz Adam, Kurkowe bractwa strzeleckie w Wielkopolsce, Wydawnictwo Poznańskie, Poznań 1986. 
JANCZAK Julian Karol, Struktura społeczna ludności Łodzi w latach 1820-1918, [w:] Polacy - Niemcy - Żydzi. Sąsiedzi bliscy i dalecy, red. Paweł SAMUŚ, Ibidem, Kurowice 1997.

JAWORSKA Janina, Początki księgarstwa w Łodzi, Łódź 1999.

JAWORSKA Janina, Początki księgarstwa w Łodzi, „Roczniki Biblioteczne” 1-2/1969.

JELONEK-LITEWKA Krystyna, Inwentarz akt Towarzystwa Strzeleckiego (Bractwa Kurkowego) w Krakowie z lat 1591-1939, Archiwum Państwowe, Kraków 2005.

KACZMAREK Roman, Od Jankiela do Cezara, „Głos Robotniczy”, 17/18.09.1960.

KALTSCHMIDT Jakob Heinrich, Kurzgefasstes vollständiges stamm- und sinnverwandtschaftliches Gesamt-Wörterbuch der Deutschen Sprache aus allen ihren Mundarten und mit allen Fremdwörtern. Ein Hausschatz der Muttersprache für alle Stände des Deutschen Volkes worin außer allen einfachen und zusammengesetzten Wörtern der hochdeutschen Sprache, auch alle derselben fehlenden Wörter der norddeutschen, d.h. der westphälischen, bremischen, schwäbischen, hamburgischen, holsteinischen, ditmarsischen, mecklenburgischen, pommerschen, lief- und ebstländlischen, und die Wörter der süddeutschen, d.h. der bayerischen, schwäbischen, schweizerischen und österreichischen Mundarten in schriftgerechter Schreibart verzeichnet und erklärt sind, Tauchnitz, Leipzig 1834.

KAROLAK Czesław, KUNICKI Wojciech, ORŁOWSKI Hubert, Dzieje kultury niemieckiej, Wydawnictwo Naukowe PWN, Warszawa 2007.

KARWACKI Władysław Lech, Związki zawodowe i stowarzyszenia pracodawców $w$ Łodzi (do 1914), Wydawnictwo Łódzkie, Łódź 1972.

KASCHNITZ Karol, Prasa niemiecka w Polsce, „Strażnica Zachodnia” 6/1933.

KASZUBINA Wiesława, Bibliografia prasy łódzkiej, 1863-1944, PWN, Warszawa 1967.

KEMPA Andrzej, Literaci, dziennikarze i publicyści, [w:] Żydzi łódzcy - The Jews of Łódź, red. Andrzej MACHEJEK, Hamal, Łódź 2004.

KESSLER Wolfgang, Doppelte Ausgrenzung. Zu Geschichte und Konzeption der „auslanddeutschen Literatur", [w:] Literatur - Grenzen - Erinnerungsräume, hrsg. v. Bernd NEUMANN u.a., Königshausen \& Neumann, Würzburg 2004.

KLEIN Karl Kurt, Literaturgeschichte des Deutschtums im Ausland, Olms, Leipzig 1939.

KONIECZNA Jadwiga, Kultura książki polskiej w Łodzi 1820-1918, Wydawnictwo UŁ, Łódź 2005.

KOSSMANN Eeugen Oskar, Die Sprache des Lodzer Deutschen, [w:] Das Lodzer Deutsche Gymnasium. Im Spannungsfeld zwischen Schicksal und Erbe1906-1981, hrsg. v. Peter Emil NASARSKI, Westkreuz-Verlag, Berlin-Bonn 1981.

KOSSMANN Eeugen Oskar, Lodz. Eine historisch-geografische Analyse, Holzner-Verlag, Würzburg 1966.

KOSSMANN Eugen Oskar, Lodzer Deutsch - ein Stück der Heimat, [w:] idem, Ein Lodzer Heimatbuch, Hilfskomitee der ev.-luth. Deutschen aus Polen, Hannover 1967.

KOSSMANN Eeugen Oskar, Lodzer Heimatbuch. Geschichte und Geschichten aus Stadt und Land, Hilfskomitee der ev.-luth. Deutschen aus Polen, Nürnberg 1967.

KOTER Marek, KULESZA Mariusz, PUŚ Wiesław, PYTLAS Stefan, Wpływ wielonarodowego dziedzictwa kulturowego na współczesne oblicze miasta, Wydawnictwo UŁ, Łódź 2005.

KOTER Marek, LISZEWSKI Stanisław, SULIBORSKI Andrzej, Łódź i region Polski Środkowej. Podręcznik wiedzy o regionie dla liceów, Łódzkie Towarzystwo Naukowe, Łódź 1999.

KOWALAK Tadeusz, Prasa niemiecka w Polsce 1918-1939, Książka i Wiedza, Warszawa 1971.

KOWALSKA Aniela, Nieznany łódzki utwór sceniczny o „Ziemi obiecanej”, „Prace Polonistyczne” 1966, ser. XXII, s. 3-17.

KRAJEWSKA Janina, Czytelnictwo wśród robotników w Królestwie Polskim 1870-1914, PWN, Warszawa 1979.

KRAKOWIAK Janina, Od Fiszera do „Pegaza” - księgarnie łódzkie okresu międzywojennego, Wydawnictwo Zora, Łódź 2005.

KUCNER Monika, Deutsche Presselandschaft der Zwischenkriegszeit in Lodz, „Acta Universitatis Lodziensis. Folia Germanica" 5/2009, s. 285-301. 
KUCNER Monika, Deutschsprachige Literatur in Lodz bis 1939, [w:] Studia i szkice dedykowane Julianowi Baranowskiemu, red. Ewa WIATR, Piotr ZAWISKI, Archiwum Państwowe w Łodzi, Łódź 2010.

KUCNER Monika, Felieton w prasie łódzkiej w XIX wieku, „Acta Universitatis Lodziensis. Folia Germanica" 7/2011, s. 153-166.

KUCNER Monika, Lodz in den feuilletonistischen Texten von Carl Heinrich Schultz (1882-1940), [w:] Lodz jenseits von „Fabriken, Wildwest und Provinz”, hrsg. v. Stefan DYROFF, Krystyna RADZISZEWSKA, Isabel RÖSKAU-RYDEL, Meidenbauer, München 2009.

KUCNER Monika, I wojna światowa w świetle badań literaturoznawczych: kazania pastora Paula Althausa z lat 1915-1917, [w:] Między wielkq historiq a codziennościq. Łódź i region łódzki w okresie I wojny światowej, red. Krystyna RADZISZEWSKA, Piotr ZAWILSKI, Wydawnictwo UŁ, Łódź 2011, s. 111-127.

KULIGOWSKA Anna, Pierwsze przedstawienia teatralne w Łodzi, „Pamiętnik Teatralny” 2/1972, s. 199-213.

KULIGOWSKA Anna, Trudne poczq̨tki. Teatr łódzki w latach 1844-1863, Zakład Narodowy im. Ossolińskich, Wrocław 1976.

KULIGOWSKA-KORZENIEWSKA Anna, Łódź teatralna: polska, niemiecka i żydowska. Współpraca i rywalizacja, [w:] Polacy - Niemcy - Żydzi w Łodzi w XIX-XX w. Sąsiedzi dalecy i bliscy, red. Paweł SAMUŚ, Ibidem, Łódź 1997, s. 240-259.

KULIGOWSKA-KORZENIEWSKA Anna, Łódzka publiczność teatralna w XIX wieku, [w:] Sto lat stałej sceny polskiej $w$ Łodzi 1888-1988, red. Anna KULIGOWSKA, Towarzystwo Przyjaciół Łodzi, Łódź 1993.

KULIGOWSKA-KORZENIEWSKA Anna, Od Marzantowicza do Zelwerowicza, [w:] Teatr przy ulicy Cegielnianej, red. Stanisław KASZYŃSKI, Wydawnictwo Łódzkie, Łódź 1980, s. 26-73.

KULIGOWSKA-KORZENIEWSKA Anna, Poczq̨tki teatru amatorskiego $w$ Łodzi, „Zeszyty Naukowe Uniwersytetu Łódzkiego. Nauki Humanistyczno-Społeczne. Folia Polonica" 2/1975, ser. I, s. 123-128.

KULIGOWSKA-KORZENIEWSKA Anna, Scena obiecana. Teatr polski w Łodzi 1844-1918, Wydawnictwo Łódzkie, Łódź 1995.

KULIGOWSKA-KORZENIEWSKA Anna, Teatr, [w:] Łódź. Dzieje miasta, t. 1: Do 1918 roku, red. Ryszard ROSIN, Łódź 1980, s. 571-592.

KULIGOWSKA-KORZENIEWSKA Anna, Teatr łódzki w latach 1863-1888, [w:] Dzieje teatru polskiego, red. Tadeusz SIVERT, t. 3, PWN, Warszawa 1982.

KULIGOWSKA-KORZENIEWSKA Anna: Teatr łódzki w latach 1888-1918 [w:] Teatr polski w latach 1890-1918. Zabór rosyjski, red. Tadeusz SIVERT, PWN, Warszawa 1988, s. 362-527.

KULIGOWSKA-KORZENIEWSKA Anna: Zaczęło się od „Małżeństwa Apfel”, [w:] Dwa jubileusze, red. Elżbieta DROZDOWSKA, Teatr im. S. Jaracza, Łódź 1989, s. 5-17.

Kultura Łodzi jako ważny czynnik rozwoju miasta, red. Violetta KRAWCZYK-WASILEWSKA, Monika KUCNER, Emilia ZIMNICA-KUZIOŁA, Wydawnictwo UŁ, Łódź 2012.

KUŹMA Erazm, Literatura regionalna, [w:] Słownik literatury popularnej, red. Tadeusz ŻABSKI, Towarzystwo Przyjaciół Polonistyki Wrocławskiej, Wrocław 1997.

LINDE Samuel Bogumił, Słownik języka polskiego, t. 2, cz. 1: M-O, Drukarnia ks. Pijarów, Warszawa 1809.

LIPIEC Wanda, Kultura i oświata $w$ Łodzi w okresie międzywojennym, Prezydium Komitetu FJN, Łódź 1973.

Lodz - "gelobtes Land“. Von deutscher Tuchmachersiedlung zur Textilmetropole im Osten, hrsg. v. Peter NASARSKI, Westkreuz-Verlag, Berlin-Bonn 1988.

Lodz in derdeutschsprachigen Literatur. Eine Anthologie, hrsg. v. Krzysztof A. KUCZYŃSKI, Elke MEHNERT, Barbara RATECKA, Wydawnictwo UŁ, Łódź 2005.

Łódzkie sceny żydowskie. Studia i materiały, red. Małgorzata LEYKO, Wydawnictwo UŁ, Łódź 2000. 
Łódź - monografia miasta, red. Stanisław LISZEWSKI, Łódzkie Towarzystwo Naukowe, Łódź 2009.

MECKLENBURG Norbert, Erzählte Provinz. Regionalismus und Moderne im Roman, Athenäum, Königstein/Taunus 1982.

MISSALOWA Gryzelda, Studia nad powstaniem łódzkiego okręgu przemysłowego 1815-1870, Wydawnictwo Łódzkie, Łódź 1967.

MROCZKA Ludwik, Dynamika rozwoju i struktura społeczno-zawodowa głównych grup etnicznych $w$ Łodzi w latach 1918-1930, [w:] Polacy - Niemcy - Żydzi. Sąsiedzi bliscy i dalecy, red. Paweł SAMUŚ, Ibidem, Kurowice 1997.

MÜLLER Leo, Das deutsche Theater in Lodz 1867-1939. Ein Zeugnis schicksalhafter deutscher Kulturpflege, Patenschaftsausschuss d. Deutschen aus d. Lodzer Industriegebiet, Mönchengladbach 1968.

NASARSKI Peter Emil, EFFENBERGER Edmund, Lodz-Gelobtes Land, Westkreuz-Verlag, Berlin-Bonn 1988.

Niemcy łódzcy, red. Andrzej MACHEJEK, Hamal, Łódź 2005.

Niemcy $w$ dziejach Łodzi, red. Krzysztof A. KUCZYŃSKI, Barbara RATECKA, Wydawnictwo UŁ, Łódź 2001.

Niemcy w Polsce 1945-1950. Wybór dokumentów, red. Włodzimierz BORODZIEJ, Hans LEMBERG, t. 2, Neriton, Warszawa 2000.

OLSZEWSKA Maria Jolanta, Człowiek w świecie Wielkiej Wojny, Imprint, Warszawa 2004.

PAWLAK Wacław, Na łódzkim bruku 1901-1918, Wydawnictwo Łódzkie, Łódź 1984.

PIESTRZENIEWICZ Marta, Rozrywka łodzian na przełomie XIX i XX w., Ibidem, Łódź 2010.

PELLOWSKI Alfons, Kultura muzyczna Łodzi do roku 1918, Papier-Service, Łódź 1994.

PLESZKUN-OLEJNICZAKOWA Elżbieta, Instytucje literackie $w$ Łodzi międzywojennej i ich rola kulturotwórcza, Wydawnictwo Biblioteka, Łódź 1996.

Polacy - Niemcy - Żydzi w Łodzi w IX-XX wieku, red. Paweł SAMUŚ, Ibidem, Łódź 1997.

Polen, Deutsche und Juden in Lodz 1820-1939. Eine schwierige Nachbarschaft, hrsg. v. Jürgen HENSEL, Fibre, Osnabrück 1999.

PRYKOWSKA-MICHALAK Karolina, Teatr niemiecki $w$ Łodzi. Sceny, wykonawcy, repertuar (1867-1939), Wydawnictwo UŁ, Łódź 2005.

PUŚ Wiesław, Dzieje Łodzi przemysłowej, Muzeum Historii Miasta Łodzi, Łódź 1987.

PUŚ Wiesław, Przemysł Królestwa Polskiego w latach 1870-1914. Problemy struktury i koncentracji, Wydawnictwo UŁ, Łódź 1984.

PUŚ Wiesław, Przemysł włókienniczy w Królestwie Polskim w latach 1870-1900, Wydawnictwo UŁ, Łódź 1976.

PUŚ Wiesław, MISSALOWA Gryzelda, FIJAŁEK Jan, PEŁKA Bolesław, Przemysł włókienniczy, [w:] Uprzemysłowienie ziem polskich w XIX i XX wieku, red. Irena PIETRZAK-PAWŁOWSKA, Zakład Narodowy im. Ossolińskich - Wydawnictwo PAN, Wrocław 1970.

PYTLAS Stefan, Łódzka burżuazja przemysłowa w latach 1864-1914, Wydawnictwo UŁ, Łódź 1994.

RADZISZEWSKA Krystyna, Flaschenpost aus der Hölle. Texte aus dem Lodzer Getto, Lang, Frankfurt/Main 2011.

RIECKE Jörg, Deutsch in Lodz und ,Lodzer Deutsch'Grundzüge einer Geschichte der deutschen Sprache in Lodz im 19. und 20. Jahrhundert, [w:] Deutsch in multilingualen Stadtzentren Mittel- und Osteuropas, hrsg. v. Verena BAUER, Albrecht GREULE, Marek NEKULA, Praesens, Wien 2008.

Rufer des Ostens, hrsg. v. Hubert MÜLLER, Hirt-Reger u. v Schroedel-Siemau, Posen 1941.

RYNKOWSKA Anna, Działalność gospodarcza władz Królestwa Polskiego na terenie Łodzi przemysłowej w latach 1821-1831, Łódzkie Towarzystwo Naukowe, Łódź 1951.

RYNKOWSKA Anna, Zarys historyczny rozwoju Łodzi (1332-1945), Wydawnictwo Łódzkie, Łódź 1964. 
RYNKOWSKA Anna, Poczq̨tki rozwoju kapitalistycznego miasta Łodzi (1820-1864), Książka i Wiedza, Warszawa 1960.

RYNKOWSKA Anna, Ulica Piotrkowska, Wydawnictwo Łódzkie, Łódź 1970.

SADZIŃSKI Roman, Osadnictwo niemieckie $w$ regionie łódzkim $w$ świetle faktów językowych, [w:] Niemcy w dziejach Łodzi, red. Krzysztof A. KUCZYŃSKI, Barbara RATECKA, Wydawnictwo UŁ, Łódź 2001.

SADZIŃSKI Roman, SADZIŃSKI Witold, Die Sprache der Lodzer Deutschen, [w:] Studien und Forschung zur Deutschland- und Österreichkunde in Polen, Beiträge der Internationalen wissenschaftlichen Konferenz des Verbandes Polnischer Germanisten, 2.-4. August 2010, hrsg. v. Lucjan MEISSNER, Grzegorz PAWŁOWSKI, Euro-Edukacja, Warszawa 2011.

SCHLÖGEL Karl, Lodz - Suche nach dem ,Gelobten Land', „Die Zeit”, 13.09.1996; druk również [w:] Karl SCHLÖGEL, Promenade in Jalta und andere Städtebilder, Frankfurt/Main 2003, s. 126-138.

SCHOTTELIUS Justus Georg, Ausführliche Arbeit von der teutschen Haubtsprache, Braunschweig 1663.

Społeczność niemiecka i żydowska w Łodzi po 1945r., red. Andrzej LECH, Krystyna RADZISZEWSKA, Andrzej RYKAŁA Wydawnictwo UŁ, Łódź 2010.

Społeczność polska, niemiecka i żydowska w Europie Środkowej i Wschodniej w XIX i XX wieku: kultura-literatura-język / Polen, Deutsche und Juden in Mittel- und Osteuropa im 19. und 20. Jahrhundert: Kultur-Literatur-Sprache, red. Monika KUCNER, Wydawnictwo UŁ, Łódź 2013.

STOLARZEWICZ Ludwik, Literatura Łodzi w ciągu jej istnienia. Szkic literacki i antologia, Nakładem księgarni Szarlotty Seipeltówny, Łódź 1935.

STRZAŁKOWSKI Jacek, Drukarnie i księgarnie w Łodzi do 1944 roku, nakładem autora, Łódź 1999.

STRZAŁKOWSKI Jacek, Słownik artystów łódzkich, nakładem autora, Łódź 2005.

Teatr niemiecki w Polsce. XVIII-XX wiek, red. Karolina PRYKOWSKA-MICHALAK, Wydawnictwo UŁ, Łódź 2008.

TRABA Robert, Wschodniopruskość. Tożsamość regionalna i narodowa w kulturze politycznej Niemiec, PTPN, Poznań-Warszawa 2005.

TYNECKI Jerzy, Łódzki rynek prasowy w dwudziestoleciu międzywojennym, „Prace Polonistyczne" 1983, ser. XXXIX.

Unter einem Dach. Die Deurschen und ihre polnischen und jüdischen Nachbarn in Lodz im 19. und 20. Jahrhundert, hrsg. v. Krystyna RADZISZEWSKA, Krzysztof WOŹNIAK, Literatura, Łódź 2000.

WALICKI Jacek, Samoorganizacja społeczeństwa Łodzi w obliczu wybuchu wojny i działań wojennych w 1914 roku, [w:] Łódź i region łódzki w czasie I wojny światowej. Między wielka historiq a codziennościq, red. Krystyna RADZISZEWSKA, Piotr ZAWILSKI, Wydawnictwo UŁ, Łódź 2011.

WEIGELT Fritz, Das Lodzer Deutsche Gymnasium. Gedenkschrift zur Gründung des LDG am 29. November 1906 und zur Feier des 50. Jubiläums in Weinheim, Selbstverlag des Kuratoriums für das LDG, Weinheim 1956.

WEIGELT Fritz, Penne, Pauker und Pennäler. Eine Gedenkschrift für die Lodzer deutschen Gymnasien 1866-1945, Selbstverlag des Kuratoriums für das LDG, Wuppertal 1972.

Wizerunek Łodzi w literaturze, kulturze i historii Niemiec i Austrii, hrsg. v. Krzysztof A. KUCZYŃSKI, Elma, Łódź 2005.

WOŹNIAK Krzysztof P., Wystawieni na ciężką próbę. Antagonizmy i zbliżenia, „Kronika Miasta Łodzi" 3/2005. 


\section{Czasopisma}

„Der Deutsche Wegweiser” 1938-1939.

„Deutsche Post” 1915-1918.

„Die Welt im Bilde. Sonntagsbeilage zur Neuen Lodzer Zeitung” 1927-1937.

„Lodzer Freie Presse” 1919-1939.

„Lodzer Informationas- und Hauskalender” 1910-1920.

„Lodzer Tageblatt” 1887, 1888, 1889.

„Lodzer Volkszeitung” 1923-1939.

„Lodzer Zeitung” 1865-1915.

„Łódzkie Ogłoszenia-Łodźer Anzeiger” 1863-1864.

„Illustriertes Sonntagsblatt. Beilage zur Neuen Lodzer Zeitung” 1923.

„Illustriertes Wochenblatt. Beilage zur Neuen Lodzer Zeitung” 1924-1925.

„Illustrierte Sonntagsbeilage. Neue Lodzer Zeitung” 1910-1913.

„Illustrierte Sonntagsbeilage. Neue Lodzer Zeitung. Handels- und Industrieblatt” 1902-1910.

„Illustrierte Sonntagsbeilage zur Neuen Lodzer Zeitung” 1916-1918.

„Neue Lodzer Zeitung” 1902-1939.

„Volksfreund-Kalender für Stadt und Land” 1932, 1939.

\section{Archiwa}

Archiv der Deutschen aus Mittelpolen und Wolhynien, Herne (ADMuW).

Politisches Archiv des Auswärtigen Amtes, Berlin (PA AA). 


\section{INDEKS NAZWISK}

A

Abel Theodore 87, 91, 123, 129-133, 135, $139,199,203,204,270,271,273,274$, 305,315

Adamowicz Józef 128

Adler Jankiel 46, 274, 284

Aldridge Ira 80

Aleksander III 29

Aleksandrowicz Michał 29

Althaus Paul 51, 123, 143, 145-153, 275, 315,321

Angerstein Wilhelm 50, 51, 73, 204, 205

\section{B}

Balle Alois 75

Banek Sigismund 12, 37, 38, 109, 125, 169, $175,176,249,270,271,275,285,315$

Barański Józef 51

Barczyński Henryk 46, 276

Bartkiewicz Zygmunt 41, 121, 218, 276

Behrens Eduard von 77, 276

Berlewi Henryk 46, 276

Bersin Waldemar 128

Biedermann Robert 18, 34

Bierschenk Theodor 78

Blitz Paul 122

Blumenthal Oscar 86, 276

Blumgarten Solomon 81

Blüthgen Klara 86, 277

Bock Alfred 86, 277

Bohrmann-Riegen Heinrich 81

Boksleitner Alfred 81

Braun Bogumił 31

Brauner Ida 46, 277, 278

Brauner Wincenty 46, 277

Braun Mieczysław 42, 44, 45, 277, 286

Bräutigam Robert 33, 91, 123, 126, 129 , $137,270,278,315$
Brayer Richard 12

Brecht Bertold 180, 181

Breyer Albert 11, 12, 78, 125, 169, 178, $179,273,278,279$

Broderson Mojżesz 46, 279

Bulwer Edward George Earle Lytton 35

C

Cleinow Georg 75, 279

Cooper James Fenimore 35

Csokor Franz Theodor 81

Cygański Mirosław 33, 80, 109, 125, 144, 278

Cyps Aleksander Bolesław 26

Czajewski Wiktor 26, 41, 280

\section{D}

Daube Oskar 32

Dehmel Richard 81

Dietrich Julius 50, 200, 205, 315

Dłużniewski Wiktor 9

Döblin Alfred 26

Dostojewski Fiodor 34, 53, 81

Drewing Alexis 31, 32, 47, 70, 72, 126, 193, 269,273

Dumas Aleksander 35

E

Ehrenstein Albert 131, 132

Eichler Adolf 33, 72, 75, 109, 110, 169, 187, $270,273,279,280,285$

Elster Otto Wilhelm Philipp 86, 280

Elzenberg Henryk 40

Ender Franciszka 35

Eser Ingo 72, 124

\section{$\mathbf{F}$}

Federn Karl 86, 280, 281

Feldmann Wilhelm 163, 316 
Finkelstein Samuel 44

Fiodorowna Aleksandra 29

Fiszer Ludwik 34, 35, 281, 290, 292, 296

Flatt Oskar 9, 27, 40, 117-120, 281, 316

Flierl Friedrich $33,72,123,141,142,169$, $270,281,316$

Flukowski Stefan 45

Franke Hans 75

\section{G}

Gawalewicz Marian 88, 121

Gerlach-Damaschke Renate 12

Geyer Ludwik 18, 34, 52

Ginsbert Adam 9

Glisczyński Artur 11, 40, 41, 215, 281

Goeppert Karl-Heinz 219

Goethe Johann Wolfgang von $34,53,57,58$, $81,87,151,310$

Gollnick Ernst 32

Gomoll Wilhelm Conrad 164, 165, 316

Gorczyński Bolesław 41, 282

Gorki Maksym 35, 87

Gorski Stefan 23, 24, 216, 225, 226, 264, 265,270

Gregor Joseph 132, 138

Grohmann Ludwik 34

Grohmann Matylda 35

Grohmann Traugott 18

Grüner Margarete 129, 141, 142, 270, 282, 316

Grzelak Władysław 50

Gundlach Rudolf 50, 90, 114, 269, 282

Gundlach Rudolf Gustaw 269

Gutentag Zofia 46, 282

Guthke Bruno 32

\section{H}

Habermann Eduard 282

Hadrian Paul 73

Hauptmann Gerhard 35

Heike Otto 12, 76, 77, 79, 124, 283, 285, 301, 319

Heinrich August 29

Heinzel Juliusz 19

Hentschel August 51

Hentschel Eberhard 32

Herbst Edward 19

Hertz Mieczysław 127, 283, 289, 291

Herz Mieczysław 42
Heyer Otto 29

Hiller Karol 44, 47, 283, 284

Hirszberg Izaak 44

Hirszfang Ignacy 44

Hitler Adolf 76, 78, 82, 110, 181, 189, 191, 192, 274

Hoefig Aleksander 76, 79, 284

Hoffmann Kamill 133, 316

Höning Richard 261

Horn R. 35

Horzelski Tadeusz 45

Hugo Wieczorek 78

Hugo Wiktor 25, 34, 35, 138

Hulka-Laskowski Paweł 46

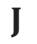

Jabłkowska Joanna 13, 193, 319

Jelenta Cesar 81

Jenske Erwin 193-195, 210

Jess Wilhelm 91, 115, 116, 123, 129, 136,

$137,139,269,270,284,316$

Joachimowicz Abraham 46

Jokai Maurycy 35

Judeich-Werswa J. 122

K

Kamenz Wilhelm 32

Kargel Adolf 76, 77, 110, 125, 135, 169, $187,207,208,270,275,279,284,285$, 299, 316, 319

Karpiński Świętopełk 45

Kaschnitz Karol 60, 63, 71, 73

Kästner Erich 180, 197

Katsczinski Alfred 165, 167, 316

Kindermann Leopold 31, 176

Kindler Oskar 128

Klein Karl Kurt 11, 12, 109, 110, 320

Kobro Katarzyna 47

Kochanowski Jerzy 72, 124

Kołoniecki Roman 45

Kopisch Tytus 18

Kosiakiewicz Wincenty 11, 41, 121, 217, 228, 269, 270, 285

Kościelecki Łucjan 40, 52, 285, 299

Koter Marek 10, 19, 54, 247, 320

Kraszewski Józef Ignacy 34, 35, 41

Kraśniański Aleksander 42, 45, 286

Kremnitz Mite 86, 286

Kreutz Philipp 12, 48, 50, 109, 126, 193, 195-199, 202, 205, 209-212, 270, 316 
Krieger Józef 50

Kriese Hans 75, 77

Kronig Artur 79

Krönig Artur 287

Kühn Gustaw 32, 279

Kuk Ludwik 79

Kulesza Mariusz 10

L

Lange Jan Traugott 18

Laskowski Kazimierz 121, 218, 280, 287

Lejzerowicz Izrael 44

Len Rafał 45, 46

Leonhardt Ernst 31, 33

Liszewski Stanisław 10

Litt Theodor 33, 288

Lobusch Artur H. 81

Loebell Artur von 164, 317

Lubowski Käte 86, 288

Lüdtke Franz 123, 141, 142, 289

Ludwig Max 28, 75, 78, 169, 300

$\mathbf{E}$

Łaganowski Karol 40, 289

Łąpiński Stanisław 42, 116, 121, 218, 289

Łukowska Maria 219

\section{M}

Mackensen August von 166, 167

Malzahn Edith 125, 169, 176, 177, 270

Markgraf Horst 31, 78, 81, 271, 276

Marrené-Morzkowska Waleria 10, 40, 41, 121,252

Matus Dina 46, 289

Mayen Józef 44

May Karl 35

Metzner Friedrich 48, 54, 113, 269, 290

Metzner Friedrich Gottlob 50

Mieszkowski Antoni 40, 215, 290

Mikołaj II 29

Milker Aleksander 47, 70, 72, 90, 203, 204, $273,280,282,290,317$

Miller Jan Nepomucen 46

Mill John Stuart 219, 220

Missalowa Gryzelda 9

Mortimer-Szymczak Hanna 10

Müller August Hermann 12, 48, 50, 115, $269,291,317$
$\mathbf{N}$

Nałkowska Zofia 154

Nahurska Waleria 44

Nałkowska Zofia 46, 47

Nasarski Edmund 78, 229, 261, 291

Neumann Wilhelm 13, 32, 33, 56, 72, 74, 110

$\mathbf{0}$

Olszewska Maria Jolanta 121, 123, 130, 163

Ortmann Reinhold 86, 291

Orzeszkowa Eliza 35, 40, 55, 87

Ostaszewski Jan 45

\section{$\mathbf{P}$}

Pawlak Władysław 128, 138, 154, 166, 246, 291

Petersilge Johann 47, 59, 60, 62, 67-70, 77, 279,291

Pfeiffer Józef 51

Piłsudski Józef 121

Piechal Marian 42, 43, 45, 46

Piel Reinhold 8, 225, 228-232, 242, 262, $269,270,291,317$

Pietrzykowski Feliks 51

Potempa Antoni 50

Poznański Izrael 18, 19, 54, 219, 247

Przedborska Felicja Maria 42, 291

Przeździecki Henryk 128

Przybyszewski Stanisław 35, 50, 81, 88

Puś Wiesław 10, 19, 23, 54, 55, 247, 319, 320,322

Pytlas Stefan 10, 18, 19, 34, 54, 219, 247, $248,320,322$

$\mathbf{R}$

Rabon Izrael 46, 292

Ramisch Alfred 128

Rapke Kurt 78

Raszewski Wincenty 51

Ratecka Barbara 13, 62, 172, 229, 261, 321-323

Ratyński Władysław 42

Rawska-Kon Dora 44

Raymond Bruno 13, 112, 125, 126, 232, $234,235,237-241,243,262,269,270$, 292, 317

Reicke Ilse 136, 317 
Reimann Wally 193, 210, 211, 317

Rennert Alfred 82

Reymont Władysław Stanisław 25, 41, 121, $217,227,235,248,252,269,270$

Richter Cezary 34

Richter Juliusz Cezar 287, 292

Roda Roda Alexander 86, 292

Rosenzweig Berta 292

Rosset Edward 9

Roszkowski Antoni 50

Rowiński Władysław 11, 41, 121, 218, 293

Rozenberg Dawid 44

Rozental Roman 44

Rudnicki Lucjan 37, 43, 293

Rynkowska Anna 10, 22, 282, 322, 323

Rżewski Aleksy 42, 293

\section{$\mathbf{S}$}

Scheibler Karol Wilhelm 19, 34, 35, 128, 207, 259,280

Schettler Paul Aleksander 86, 293

Schmidt Ferdinand 32, 55, 66, 70, 84, 293

Schrickel Ludwig 75

Schultz Carl Heinrich 7, 8, 62, 63, 76, 93, $94,112,123,125,138,154,155,167$, 179-193, 195, 201, 247, 248, 253-267, 269-271, 292-294, 313, 317

Sebastian A.G. 31

Seeliger Ewald Gerhard 86, 294

Seidler Oskar 79, 294

Seiler Edith 193, 210

Sellin Fryderyk 51

Sender Helmuth 122

Serini Karol 38

Silberstein Stanisław 128

Skowronnek Fritz 86, 295

Słobodnik Włodzimierz 45, 46

Smith Adam 219, 220

Stamirowski Antoni 128

Stażewski Henryk 47

Stebielski Kazimierz 128

Stolarzewicz Ludwik 10, 21, 26, 38, 39, 43, 44, 286, 291, 295, 323

Strakun S. 34

Strauch Józef Alfred 35, 296

Strug Andrzej 47,121

Strzemiński Władysław 44, 47

Szajewicz Symcha-Bunim 46, 296

Szeliga Maria 40, 296
Szenbrunowa Regina 44

Szendlerowski Antoni 50

Szpigel Jeszajahu 46, 296

Szpigel Natan 44

Szwarc Marek 44, 46, 296

Szyk Artur 44

\section{T}

Teichmann Irma9 91, 136, 296, 317

Teplitzka Berta 48, 121, 220-223, 225, 232, $242,250,251,269,270,297,315,317$

Teslar Józef Andrzej 133, 134, 296

Texel Józef 297

Thiele August 69, 86, 297

Thieme Friedrich 86, 297

Thiem Heinrich 82

Thiem Wally 126, 193, 194, 199, 210-212, 270,317

Timkovskij-Kostin Ivan 121, 297

Timofiejew Grzegorz 43, 45, 46

Torn Teo von 87, 297

Trakl Georg 131

Treistman Eliezer Lejb 81

Trenkner Henryk 128

Trębacz Maurcy 44

Triebe Wally 81, 135, 317

Tucholski Kurt 180

Tugemann Bruno 74

Tuwim Julian 11, 42, 45-47, 121, 217

Tymieniecki Wincenty 50, 55, 128

$\mathbf{U}$

Ulinower Miriam 46, 298

Utta August 78, 109, 125, 169, 176, 270, 298

W

Wandurski Witold 42, 44, 298

Warrikow Maks 70, 298

Weigelt Karl 31, 32, 271, 276, 279, 300

Weinbaum Abraham 44

Weinsteinówna Ruth 44

Wendisch Christian Friedrich 18, 34

Wever Ernst 31

Wilkens Karl 70, 299

Will Julian 12, 37, 109, 111, 125, 169-175, $181,182,201,202,213,249,270,285$, 299, 317

Winfeld Lenelotte 86, 299 
Wittlin Józef 44, 46

Wolff Ludwig 33, 78, 110, 169, 187, 190, 300

Wolff Otto 78

\section{$\mathbf{Z}$}

Zaar Henryk 128

Zelikowicz Józef 46, 300

Zerbe Armin 79, 84, 300, 301
Zerbe Emil 79, 85, 301

Zerbe Richard 79

Ziegler Rudolf 31

Zielke Albert 32

Zimmermann Heinrich 7, 48, 53, 80, 81, 91, $123,129,138,139,156-163,167,220$, 223-225, 242, 245, 251-253, 269, 270, 301-303, 312, 317, 318

Zirkler Heinrich 31, 33 